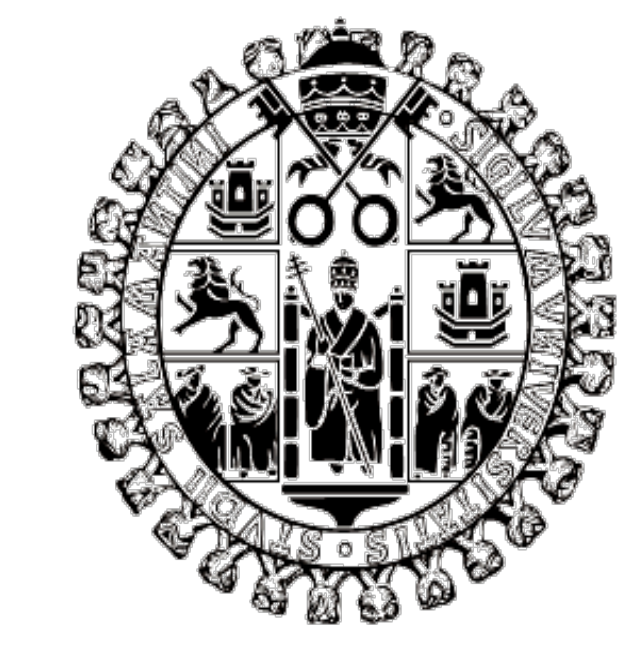

UNIVERSIDAD DE SALAMANCA

DEPARTAMENTO DE DERECHO ADMINISTRATIVO, FINANCIERO Y PROCESAL

\title{
LA PRUEBA EN LOS PROCESOS DE FILIACIÓN
}

\author{
Roberto Wesley ZAPATA DURÁN
}

Directores:

PROF. DR. D. LORENZO M. BUJOSA VADELL Y PROF. ${ }^{a}$ DR. ${ }^{a}$ D. ${ }^{\text {a }}$ MARTA DEL POZO PËREZ

SALAMANCA 


\section{INDICE}

Pág.

INTRODUCCIÓN

\section{SECCIÓN I. La filiación}

\section{Capítulo I. Derechos fundamentales y filiación}

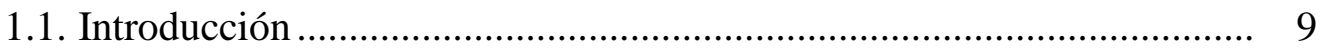

1.2. Marco legal de la filiación ........................................................... 10

1.3. La filiación, la maternidad y la familia como derechos sociales ........... 19

1.3.1. Protección de la persona y familia ..................................... 19

1.3.2. Principio de igualdad en la filiación ................................ 21

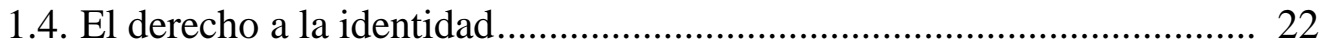

1.4.1. Derecho a la vida personal ............................................... 25

1.4.2. Derecho a la identidad sexual ........................................... 25

1.4.3. Derecho a la identidad genética ....................................... 27

1.4.4. Derecho a la identidad en el marco jurídico mexicano....... 28

1.5. El derecho a la investigación de la paternidad.................................. 30

1.6. El derecho a conocer el propio origen biológico ............................... 33

\section{Capítulo II. La determinación de la filiación}

2.1. La filiación ................................................................................... 37

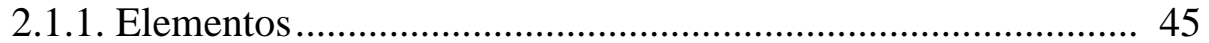

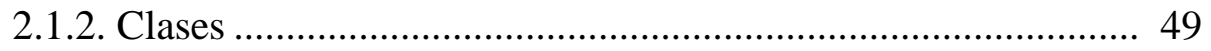

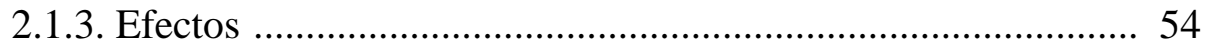

2.2. Determinación de la filiación......................................................... 57 
Pág.

2.3. La declaración judicial del vínculo paterno-filial a través de los procesos de filiación: Las pretensiones de filiación............................ 68

2.3.1. Concepto ................................................................. 69

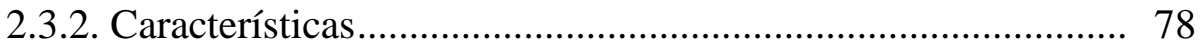

2.3.3. Clases .................................................................... 89

\section{SECCIÓN II. La prueba en los procesos de filiación}

\section{Capítulo III. Consideraciones generales}

3.1. Concepto de prueba ................................................................. 99

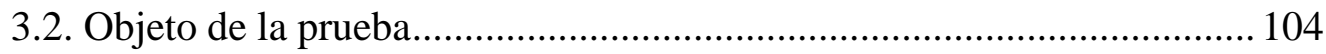

3.2.1. Diferencia entre objeto y fin de la prueba. ............................ 109

3.2.2. El derecho a la prueba ...................................................... 111

3.3. Carga de la prueba: características esenciales ................................... 112

3.4. Fuentes y medios de prueba ........................................................ 116

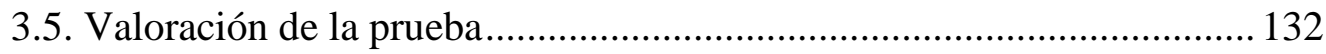

\section{Capítulo IV. La prueba de la filiación}

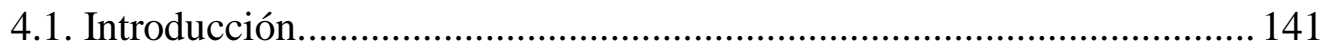

4.2. Declaración judicial del vínculo de paternidad y su investigación ......... 146

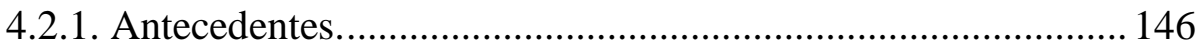

4.2.2. Concepto ...................................................................... 147

4.3. Principio de la prueba de la paternidad ............................................ 148

4.3.1. El principio de prueba como límite al derecho a la tutela judicial efectiva ..................................................... 149 
4.3.2. La legalidad del principio de prueba en defensa de otros valores

4.4. Sistemas de investigación de la paternidad. .151

4.4.1. Sistemas prohibitivos 151

4.4.2. Sistemas permisivos 151

4.4.3. Sistemas mixtos 153

4.5. Medios de prueba y determinación de la paternidad 154

4.5.1. La prueba confesional en los procesos de filiación... 158

4.5.2. La prueba testimonial en los procesos de filiación 167

4.5.3. La prueba de inspección o reconocimiento judicial en los procesos de filiación

4.5.4. La prueba documental en los procesos de filiación

4.5.5. La prueba pericial en los procesos de filiación

4.5.5.1. Las pruebas científicas

4.5.5.2. Avance sobre el valor jurídico de las pruebas científicas en los juicios de investigación de paternidad

4.6. Indicios y presunciones en los procesos de filiación .212

4.6.1. Los indicios

4.6.1.1. Naturaleza jurídica 214

4.6.1.2. Diferencia con las presunciones. .215

4.6.1.3. Clases de indicios. .216

4.6.1.4. Indicios y procesos de filiación. .217

4.6.2. Las presunciones 219

4.6.2.1. Naturaleza jurídica 219

4.6.2.2. Clases

4.6.2.3. Las presunciones en los procesos de filiación

a) Especial consideración de la posesión de estado .223

b) Especial referencia a las presunciones en el caso de las parejas de hecho 
Capítulo V. La prueba biológica en los procesos de filiación

Pág.

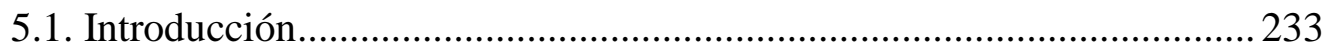

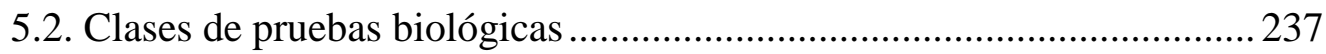

5.2.1. Prueba hematológica .................................................................2 240

5.2.2. Prueba de maduración fetal .......................................................252

5.2.3. Prueba antropológica o heredobiológica ....................................256

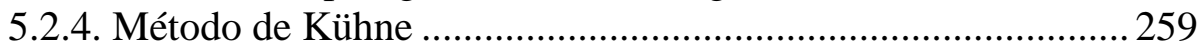

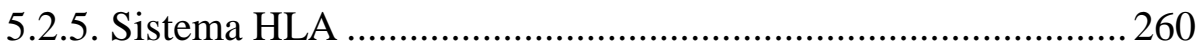

5.2.6. Prueba de compatibilidad inmunogenética.................................264

5.2.7. Prueba de ADN o de la identificación de personas a través del ácido desoxirribonucleico .........................................268

5.3. La prueba biológica como un derecho constitucional ..............................2276

5.3.1. Afectación de derechos fundamentales .....................................2277

5.3.2. Principio de libertad de investigación de la paternidad............2278

5.3.3. Efectividad de la prueba biológica ..............................................2 279

5.4. Naturaleza jurídica de las pruebas biológicas en los procesos de filiación............................................................................ 280

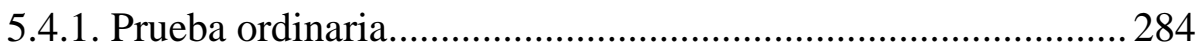

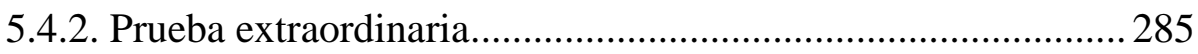

5.5. Admisibilidad de las pruebas biológicas ..................................................... 289

5.6. Las partes y las pruebas biológicas ............................................................293

5.6.1. Teoría de la potestad de la prueba .............................................2 293

5.6.2. Teoría del fin supremo de la justicia ...........................................294

5.6.3. Teoría de los derechos de la persona ...........................................297

5.7. Los terceros y las pruebas biológicas ...................................................... 312

5.8. La negativa a someterse a la prueba biológica ...........................................315

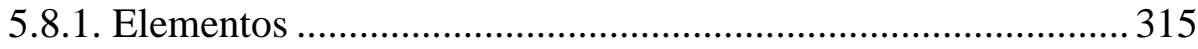

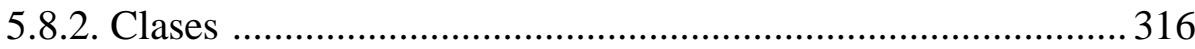

5.8.3. Valoración de la negativa ......................................................... 323

5.8.4. Efectos de la negativa ................................................................ 330 


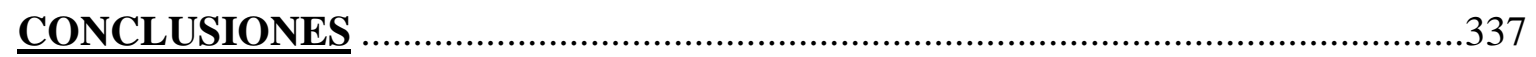

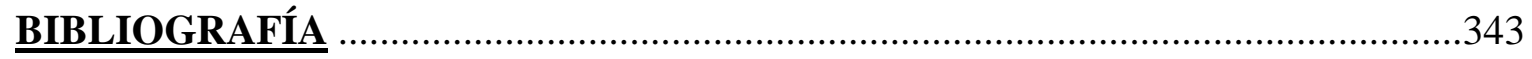

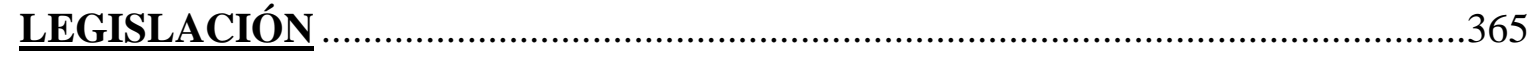

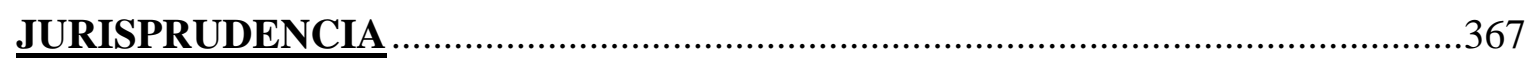

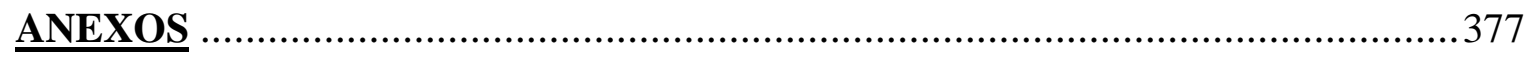




\title{
INTRODUCCIÓN
}

\author{
“El Derecho es una dulce poesía, que mal \\ escuchada puede amargar lo más dulce, \\ pero al fin una poesía constante $e$ \\ incontenible.... Imparable”
}

El avance en la ciencia y en la tecnología, y por ende en la medicina, en los últimos años, han dado grandes pasos, dándonos a conocer progresos tan extraordinarios que en otros tiempos solo podían existir en la mente de los escritores de ciencia ficción, como en las obras de Julio Verne.

El Derecho, como fuente para regular los conflictos sociales, tiene la imperiosa necesidad de evolucionar, de ir modificando las diversas leyes, como es el caso de aquellas que se encargan de regular lo relacionado con la Genética y sobre todo las bases de datos, tema que ha tenido una importante aplicación dentro de la sociedad, pero que por desgracia pocos países han puesto el empeño necesario para contar con una regulación que satisfaga las exigencias de protección social.

Entre las nuevas tecnologías médicas, encontramos aquellas que realizan el manejo del $\mathrm{ADN}$, en específico la identificación humana, y que encuentra su importancia en diversos temas del Derecho, a través de la prueba; tal es el caso del Derecho civil, en lo relativo a la Filiación y Sucesiones; así como en otras materias que sin querer en este momento dejar a un lado, podemos mencionar al Derecho penal, Criminalística, Derecho laboral y hasta el Derecho mercantil. 
Aludiendo al primero de ellos, y específicamente al Derecho de familia, podemos decir que ha sido de regulación universal la protección de esta institución, base fundamental de la sociedad, y por tanto debe contar con normas adecuadas que cumplan las exigencias de la sociedad en su evolución para poder regularla. Desde tiempos muy antiguos, en los grupos sociales ha sido de gran importancia todo lo concerniente al parentesco como una forma de perpetuar el grupo familiar; ya que la familia nos otorga los elementos fundamentales de identificación de personas con vínculo entre sí, fijando como el principal, el parentesco de consanguinidad, el cual lo encontramos entre personas que descienden de una misma raíz o tronco; sin dejar a un lado que en nuestros días ha sido de gran auge el parentesco extramatrimonial, con una protección igual al consanguíneo.

Este tema a raíz de la evolución científica ha retomado una mayor relevancia, por la repercusión que se tiene en la exactitud de los análisis de ADN en la identificación de personas, y en el caso en particular para fijar las relaciones paterno-filiales.

Ahora bien, estas tecnologías tienen en contraposición, la restricción de algunos derechos fundamentales que ostenta el individuo sobre el cual se realizará dicho examen (sujeto pasivo), sobre todo el derecho a la intimidad, ya que de dicho examen, mal utilizado, puede derivarse información de su mapa genético que en determinado momento pueda afectarle; y este choque de intereses debe estudiarse desde el mayor beneficio, o mejor dicho, el mayor respeto al más alto derecho fundamental afectado: el del menor a conocer sus orígenes y con esto determinar las responsabilidades que tenga el presunto padre en relación al mismo; por lo cual, nuestra intención es estudiar el concepto de filiación, teniendo en cuenta la diferenciación de las clases de ésta, y aplicar 
sobre todo la perspectiva del Derecho probatorio, atendiendo especialmente a la ponderación de intereses en conflicto.

La presente investigación se ha realizado metodológicamente pretendiendo una construcción dogmática sobre el tema de las pruebas de ADN en materia de filiación, utilizando una metodología deductiva al momento de abordar diferentes doctrinas en la materia, con una labor investigadora en diversas fuentes legales, jurisprudenciales y bibliográficas, albergadas de igual forma en monografías, revistas y jurisprudencia, con una sistematización sencilla en el Derecho español y pero con escasa doctrina por lo que se refiere al ámbito de México. De esta forma ha sido posible desarrollar un esquema que ha permitido un estudio que esperamos resulte útil a fin de establecer el panorama y las cuestiones que se presentan en la materia. Para ello ha sido fundamental tener muy en cuenta el análisis de las diferentes sentencias emanadas de los altos tribunales de ambos países.

Efectivamente el trabajo tiene entre uno de sus principales objetivos el poder hacer un análisis de diversas sentencias de la jurisprudencia española y de la mexicana en relación con la realización de las pruebas biológicas en materia de filiación; y muy en especial lo relativo a la negativa del sujeto pasivo a practicársela. Hemos considerado necesario enmarcar este punto fundamental de nuestra investigación en un estudio más detenido sobre los diversos medios de prueba, los cuales sirven de complemento para la declaración de la paternidad en caso de negativa del padre al sometimiento a la práctica de alguna prueba biológica. Es imprescindible relacionar estas cuestiones con la afección o no de los derechos fundamentales de los sujetos implicados: por un lado, el demandante que presenta su demanda de filiación y por ello goza de un derecho fundamental a la prueba, aunque por supuesto no ilimitado; pero también, por otro lado, el sujeto pasivo de la prueba, que puede optar por la negativa a ciertas 
prácticas probatorias que puedan afectarle y, por ejemplo también a la adecuada protección de los datos genéticos en el caso de que se practicara dicha prueba.

Se trata de una problemática plenamente vigente, como muestran la legislación y la jurisprudencia actuales. A pesar de no ser un tema de planteamiento reciente, todavía surgen en él elementos nuevos que siguen situándose entre el convencimiento de querer llegar a que se cumpla el fin último de la prueba y el necesario respeto a los derechos fundamentales de las partes del proceso. El tema merece pues nuevos aportes y nuevas reflexiones dirigidos a valorar con atención cómo lograr conocer el origen del menor, respetando a la vez todos los derechos que podríamos considerar afectados para el sujeto pasivo de la prueba. Debemos insistir en que, por lo que se refiere a la perspectiva mexicana existe una bibliografía casi nula y asimismo la regulación es escasa. Es importante pues intentar satisfacer la necesidad de proponer los conceptos, limites y efectos de este tipo de pruebas, y no solo a nivel regional, sino intentando realizar valoraciones con pretendida validez más amplia, y que en nuestra opinión, deberían ser regulados en convenciones internacionales en la que se puedan sentar las bases para una armonización de la materia en un ámbito más amplio.

La Ciencia del Derecho es dinámica, y debe ir avanzando a los grandes pasos en los que la humanidad misma lo hace, y sobre todo al paso de las demás ciencias, como es el caso de la Genética; campo cuyos avances han tenido reflejo legislativo únicamente en los países más desarrollados, no del mismo modo en la mayoría de países de América Latina como el caso de México. En este concreto país temas tan básicos como los relativos a las pruebas biológicas sólo han ido incorporándose como parches legislativos, como ocurrió con la adecuación del artículo 382 del Código Civil Federal de México, en el que aceptada la prueba biológica, o todavía más genéricamente, la proveniente de los 
avances científicos, como medio probatorio idóneo para acreditar el nexo filial. Sin embargo no es suficiente con su reflejo en algún precepto del ordenamiento, si aun los juzgadores y operadores jurídicos no cuentan con los conocimientos y la experiencia en las diversas pruebas de prueba del vínculo filial, las consecuencias inherentes al empleo de las mismas, derivadas de su resultado concluyente, y los problemas que suelen rodean el sometimiento a la práctica de estos medios probatorios, no sólo los antes mencionados sino también otros como los relativos a la creación de laboratorios especializados con personal altamente calificado y sujeto a rigurosas exigencias éticas; o la determinación de procedimientos correctos para la selección y conservación de las muestras de material genético; ya que la incertidumbre del destino final de la información que puede obtenerse puede implicar una violación tajante a los derechos de intimidad de los sujetos ala prueba.

Debemos atender a que uno de los objetivos del Derecho es la búsqueda sin cesar de la verdad, debiendo ser éste capaz de derribar los obstáculos que se le oponen e impiden avanzar, pero sin llevarse por delante las garantías constitucionales esenciales. Así se ha dicho, respecto al tema que en concreto nos ocupa, que el Derecho debe ir avanzando atendiendo al progreso de la genética clásica, la cual ha tenido en la última década una revolución médicobiológica, debiendo ser reguladas sus acciones en el campo del Derecho: en cuestiones como la eugenesia, las células madre, la clonación y, porqué no, en materia penal de los indicios del delito o bien para conocer la responsabilidad penal o no de un inculpado o, en el campo mercantil, las enfermedades que pueda llegar a presentar el solicitante de un seguro de trabajo, o, en el laboral, para conocer si el empleado es apto o no para el puesto solicitado; o, por supuesto, finalmente, en el ámbito civil en la investigación mediante las pruebas biologías para la determinación del nexo filial. 
Por todo ello, hemos entendido necesario estructurar la presente investigación en dos grandes secciones, en las que se agrupan un total de cinco capítulos. En primer lugar, hemos prestado atención a los derechos fundamentales que tiene todo ser humano en relación con el tema de la filiación y cuya protección debe ser muy tenida en cuenta para la investigación de la verdad biológica filial, pero que en la mayoría de los casos pueden, a su vez, llegar a violentar otros derechos fundamentales, en especial de la persona del supuesto padre, debiendo buscar ya bien un equilibrio entre ambos o imponiendo el que debe ocupar una posición predominante sobre el otro.

No menos decisivo para nuestra investigación es el contenido del capítulo segundo, relativo a la filiación y a su determinación. Se centra pues es en el examen de los elementos que configuran una de las figuras jurídicas de mayor relevancia desde la antigüedad hasta nuestras fechas; tan importante que en muchos de los pueblos antiguos la riqueza llego a medirse en la capacidad de tener descendencia que pudiera ir distribuyendo su estirpe. No es necesario dedicar gran esfuerzo para demostrar que, a pesar de las evidentes modificaciones, la determinación fiable del vínculo biológico parental sigue siendo fundamental para cualquier sistema jurídico; y por ende, tiene importantes consecuencias la falta de certeza en estos casos, paliada de algún modo desde hace tiempo con la aplicación de las conocidas presunciones de paternidad, lo cual sin embargo no evita problemas sobre todo en los casos de filiaciones extramatrimoniales o como ocurre en el caso mexicano, en la figura del concubinato, tan socorrida actualmente, pero ayuda de la necesaria seguridad jurídica, en especial respecto a los hijos.

Como se ha dicho unas páginas atrás, en las primeras consideraciones introductorias, el punto central en la actualidad sobre este tema se sitúa en el campo probatorio. Ya hemos adelantado algunas referencias a la problemática 
sobre las pruebas en materia de filiación, y hemos aludido a la necesidad de incorporar los avances científicos a los procesos dirigidos a la determinación de la filiación, utilizando los métodos más modernos para la identificación humana. Pero ello no evita el sistematizar de manera analítica los distintos aspectos que específicamente plantea la prueba en los procesos de filiación, todo ello tras un capítulo de consideraciones generales en las que nos posicionamos respecto a los grandes elementos del Derecho probatorio.

Sin lugar a dudas, la declaración judicial de un vínculo de paternidad y los medios adecuados para adquirir la correspondiente convicción sobre ello se sitúa en el Derecho comparado en una pluralidad de sistemas, cuyos rasgos principales son analizados. Ha sido preciso aludir específicamente a la necesidad de un principio de prueba para iniciar un proceso de determinación de la filiación y a hacer un minucioso repaso acerca de la importancia que pueden tener los diversos medios de prueba tradicionales para el fin que hemos señalado. Además, en este ámbito los indicios y las presunciones han jugado históricamente una función decisiva.

Pero el núcleo central de la investigación se sitúa en el capítulo quinto, con un estudio específico de la prueba biológica, teniendo en cuenta su gran evolución desde la prueba antropológica, hasta la actual, mucho más perfeccionada de las pruebas sobre el ADN, no pudiendo de dejar a un lado los cuadros de marcadores de la determinación filial, pruebas que han estado siempre a la mano del derecho, aunque en esta materia poco utilizados. Estas posibilidades son valoradas atendiendo principalmente al Derecho español y al mexicano, sin dejar pasar el tema fundamental de la negativa a la práctica de las pruebas, y la presunción derivada de tal actitud del sujeto pasivo. 


\section{SECCIÓN I}

\section{LA FILIACIÓN}

\section{CAPITULO I \\ DERECHOS FUNDAMENTALES Y FILIACION}

\subsection{Introducción}

El fundamento de fondo para un análisis sobre la primacía de la protección integral de la niñez, la maternidad, la paternidad y la familia, debe descansar en gran medida en el examen de los vínculos filiales y del parentesco; cuyas características son la certeza y la inalterabilidad. Si bien el procedimiento es de contenido exclusivamente civil, la materia que se aborda y los derecho que en ella se discuten permiten claramente un análisis desde la perspectiva constitucional, tomando en consideración principalmente los siguientes puntos en debate:

- La filiación, como derecho social.

-El derecho a la identidad y su relación con la filiación.

- El derecho a la investigación de la paternidad

-El derecho a conocer el propio origen biológico

- La legalidad constitucional de la aplicación de pruebas biogenéticas para verificar una relación filial y su contraposición con los derechos fundamentales de la persona. 
Sobre la base de las conclusiones obtenidas en estos puntos se desarrollará, más adelante en su lugar oportuno, el análisis de la aplicación de la prueba de ADN en la determinación de la paternidad, problema que ha venido dirimiéndose principalmente en las sentencias emitidas tanto por el Tribunal Constitucional Español STC 7/1994 y la emitida por la Suprema Corte de Justicia de la Nación de México, con referencia número 20018 de la contradicción de tesis 154/2005-PS.

La asimilación de un criterio determinado debe requerir una rápida y necesaria adecuación al sistema legal de cualquier país, a fin de encauzar reformas en relación a la determinación de la paternidad, sobre la base de un sistema abierto de la declaración de la filiación, siendo más ágil y por ende menos burocrático.

\subsection{Marco legal de la filiación}

La filiación, como relación jurídica familiar y primordial, tiene un sustento legal muy rico.

De inicio podemos citar la Declaración de los Derechos del Niño, proclamada por la Asamblea General en su resolución 1386 (XIV), de 20 de noviembre de 1959, y la cual establece de manera genérica en su principio VI, el derecho que tiene el niño a desarrollarse en un ambiente pleno y armonioso con amor y comprensión, al amparo y responsabilidad de sus padres.

Continuando con ello, tenemos el Pacto Internacional de Derechos Civiles y Políticos, aprobado por la Resolución 2200 (XXI), de 16 de diciembre 
de 1966; y el cual proclama en su artículo 24 el derecho que tiene todo niño a las medidas de protección que su condición de menor requiere y otorgadas por su familia, al cual le va seguidos, la sociedad y el Estado.

Este principio de igual forma es recogido por la Convención americana de derechos Humanos firmada en San José de Costa Rica, el 28 de noviembre de 1969, en su artículo 19, y por el Protocolo adicional a dicha Convención en materia de derechos económicos, sociales y culturales, suscrito en el Salvador el 17 de noviembre de 1988.

Además, podemos señalar la Convención sobre los Derechos del Niño adoptada en la convención de Nueva York, EUA, el 20 de noviembre de 1989; la cual, le otorga la protección de la identidad en sus artículos 7.1 y 8; los cuales exigen mediante el compromiso de los Estados partes, a incorporar en sus sistemas legales, el derecho que tiene el menor a ser inscrito en un registro a su nacimiento, tener un nombre, nacionalidad y conocer a sus padres y ser cuidado por ellos, así como -de gran importancia-, el respeto por los Estados al derecho del niño a su identidad -lo cual supone vincularlo a sus padres-, a las relaciones familiares y en caso de ser privados de lesa identidad, a prestar asistencia y protección apropiada para restablecerla.

En el caso europeo, no se puede dejar de mencionar el caso de la Carta europea de Derechos del Niño, aprobada por el Parlamento Europeo el 8 de julio de 1992, en la cual se reconoce en su punto 7.11, la existencia del derecho a la protección de la identidad, partiendo de una concepción básicamente biológica del mismo y estableciendo que todo niño tiene derecho a la protección de su 
identidad, facultándolo a conocer las circunstancias necesarias para saber su origen biológico. ${ }^{1}$

Estas normas internacionales tienen jerarquía constitucional al ser tratados relativos a derechos humanos. Son entonces, normas constitucionales que priman sobre las ordinarias en el sentido de que debe prevalecer el establecimiento de una filiación por sobre cualquier otro interés.

En este sentido aparece, tal y como hemos indicado con anterioridad ,la interpretación del artículo 133 de la Constitución Política de los Estados Unidos Mexicanos y los criterios de la Suprema orden judicial mexicana; y en forma similar por los artículos 94 y 96 de la Constitución Española; así podemos mencionar de igual forma el caso de la Constitución Peruana, la cual indica que los derechos y libertades deben ser interpretados de conformidad con la Declaración Universal de los Derechos humanos y los Tratados y Convenios internacionales de la misma manera que sean ratificados, así tienen una jerarquía constitucional, pero exclusivamente en materia de derechos humanos.

Igual en este contexto hay que mencionar la denominada Ley de Garantías de los Derechos de la Infancia y Adolescencia, de la Comunidad de Madrid, Ley 5/1996; así como en el caso mexicano las leyes derivadas de la Convención de los Derechos del Niño, por un lado la Ley para la Protección de los Derechos de Niñas, Niños y Adolescentes, publicada en el Diario Oficial de la Federación en fecha 20 de mayo de 2000, y por otro lado, esta ley federal ha influido directamente en que cada uno de los 31 estados restantes que conforman el territorio mexicano, adoptaran leyes homólogas en la materia, siendo éstas de observancia obligatoria por el Poder judicial en la resolución de casos de familia

\footnotetext{
${ }^{1}$ Parlamento europeo, Resolución A3.01172/92 de 8 de julio de 1992, sobre una Carta Europea de los derechos del niño, 7.11, DOCE No. C241, de 21 de septiembre de 1992.
} 
donde se tengan que entrever los derechos de los menores, entre los que se encuentran, en concreto en sus artículos 3 punto D, 11 y 22, el derecho al desarrollo en plena identidad y con una familia del menor.

Junto a lo detallado con anterioridad, conviene destacar que a diferencia del caso español, el Derecho mexicano no brinda una regulación cabal y justa en el ámbito filial en beneficio de los hijos, por lo que se contrapone a la Constitución y a los tratados internacionales, por ello consideramos que estas normas deben adecuarse plenamente en cumplimiento del principio de legalidad y de protección de los menores carentes de lazos parentales, que es un sector amplio de la población que exige la defensa de sus derechos, tales como la educación, la alimentación, la identidad y la salud, entre otros.

De esta manera se debe entender el derecho supremo del menor frente al derecho de sus progenitores, aun sabiendo que nos representará un conflicto de intereses, pero debemos aplicar la máxima jurídica de in dubio pro filii (en caso de duda ha de estarse al interés preponderante de los hijos), entendido como un axioma del antiguo in dubio contra libero naturales y el in dubio pro liberis naturalibus, dando como se ha mencionado una protección mayor a los hijos, sea cual fuere su origen, y reconociéndoles el derecho a saber su identidad. Desde la perspectiva procesal debemos recordar, en este sentido, que los jueces no pueden dejar de administrar justicia por defecto o deficiencia de la ley.

Pero ha sido la jurisprudencia francesa la que mayor rigor ha mostrado, pues ésta ha comenzado a hacer patentes casos de inaplicación de normas internas del Derecho de familia con el fundamento de que resultan violatorias de derechos acordados por tratados internacionales; o bien, por lo que se refiere al caso argentino Aída KEMELMAJER ha sustentado su posición en 
los trabajos de GROSMAR y CAMPOS, al indicar que la primacía de las normas internacionales empieza a ser defendida por la doctrina de ese país. ${ }^{2}$

Es necesario aclarar que en este punto la Constitución Política de los Estados Unidos Mexicanos, no contiene una norma expresa que fomente o incentive la investigación de la paternidad ${ }^{3}$, como sí lo hacen otras constituciones tanto de América como europeas, así la Constitución Española que en su artículo 39.2 parte final, posibilita legalmente la investigación de la paternidad; el caso Italiano en su artículo 30 de igual forma lo autoriza, fomentando a la ley la creación de normas y límites de la investigación.

En América podemos señalar las constituciones de Bolivia de 1954, Venezuela de 1961, Panamá 1946 y Cuba de 1992, las cuales han regulado el presente aspecto, orientando su rumbo hacia el descubrimiento de la verdad de la filiación a través de todos los medios probatorios posibles.

El caso de la legislación suprema española es ejemplar, ya que el artículo citado, aunque integrado en su parte programática denominada "Principios rectores de la política social y económica", contiene un mandato legislativo, en términos de posibilitar la investigación de la filiación ${ }^{4}$

La tendencia constitucional española, como podemos observar es loable pues representa el reconocimiento máximo en una materia esencial como

\footnotetext{
${ }^{2}$ KEMELMAJER DE CARLUCCI, Aída; “El derecho constitucional del menor a ser oído” en Revista de Derecho Privado y Comunitario (derecho privado en la reforma constitucional), No. 7 pp. 158 - 159.

${ }^{3}$ Sin embargo como se ha estipulado, si se realiza en las leyes secundarias como serían los Códigos civiles o familiares.

${ }^{4}$ A opinión de DOMINGUEZ PLATAS Jesús, en su artículo: "Las acciones de filiación. Encuadramiento general y funciones de la posesión de estado"; Revista de Derecho y Genoma Humano; Bilbao: Universidad de Deusto, 1995, No. 3, p. 454; investigación que será facilitada aunque sea por vía de interpretación extensiva que hará el juzgador antes de enfrentarse a la amenazante inconstitucionalidad por no posibilitarla.
} 
es la vinculación padre - hijo, que el sistema constitucional no reconoce expresis verbis, al dejarle esta facultad a las leyes secundarias.

\section{Así en la Constitución Política de los Estados Unidos Mexicanos} podemos señalar una deficiencia en la norma, al desatender la indagación filial, ya que aunque pueda realizarse una interpretación indirecta, a partir del artículo 133, que establece la jerarquía normativa e impone que la Constitución Política de los Estados Unidos Mexicanos es la ley suprema, junto con los tratados internacionales ${ }^{5}$, que se ajusten a los requisitos establecidos en la misma, cosa que cumple la Convención sobre los Derechos del Niño adoptada en la convención de Nueva York, EUA, de 20 de noviembre de 1989; la cual ha sido objeto de ratificación por México el 21 de septiembre de 1990, y dada a conocer directamente a los mexicanos mediante Decreto Promulgado y publicado en el Diario Oficial de la Federación de fecha 25 de enero de 1991; y el cual sirve de base para la creación de la Ley para la protección de los derechos del niño ${ }^{6}$.

\footnotetext{
${ }^{5}$ En este punto la Suprema Corte de Justicia de la Nación, en tesis jurisprudencial, ha sostenido que en "una interpretación sistemática del artículo 133 de la Constitución Política de los Estados Unidos Mexicanos permite identificar la existencia de un orden jurídico superior, de carácter nacional, integrado por la Constitución Federal, los tratados internacionales y las leyes generales. Asimismo, a partir de dicha interpretación, armonizada con los principios de derecho internacional dispersos en el texto constitucional, así como con las normas y premisas fundamentales de esa rama del derecho, se concluye que los tratados internacionales se ubican jerárquicamente abajo de la Constitución Federal y por encima de las leyes generales, federales y locales, en la medida en que el Estado Mexicano al suscribirlos, de conformidad con lo dispuesto en la Convención de Viena Sobre el Derecho de los Tratados entre los Estados y Organizaciones Internacionales o entre Organizaciones Internacionales y, además, atendiendo al principio fundamental de derecho internacional consuetudinario "pacta sunt servanda", contrae libremente obligaciones frente a la comunidad internacional que no pueden ser desconocidas invocando normas de derecho interno y cuyo incumplimiento supone, por lo demás, una responsabilidad de carácter internacional”. Registro No. 172650; Localización: Novena Época; Instancia: Pleno; Fuente: Semanario Judicial de la Federación y su Gaceta; XXV, Abril de 2007; Página: 6; Tesis: P. IX/2007; Tesis Aislada; Materia(s): Constitucional

TRATADOS INTERNACIONALES. SON PARTE INTEGRANTE DE LA LEY SUPREMA DE LA UNIÓN Y SE UBICAN JERÁRQUICAMENTE POR ENCIMA DE LAS LEYES GENERALES, FEDERALES Y LOCALES. INTERPRETACIÓN DEL ARTÍCULO 133 CONSTITUCIONAL.

${ }^{6}$ Al respecto la Suprema Corte de Justicia de la Nación al hacer una interpretación del artículo 133 nos refiere que en la Constitución en los artículos 1, 133, 103 fracción I y 107 establecen que todo individuo gozará de las garantías que ella otorga; que las leyes del Congreso de la Unión, que emanen de ella, y los tratados acordes a la misma, serán la Ley Suprema de toda la Unión; que los tribunales de la Federación resolverán toda controversia que se suscite por leyes o actos de la autoridad que violen las garantías individuales; $\mathrm{y}$, las bases, los procedimientos y las formas para la tramitación del juicio de amparo De ahí
} 
Por lo antes citado es que podemos considerar que la investigación de la paternidad es un derecho y a la vez un deber implícitamente reconocido, ya que, aun y que no existe norma expresa, todo individuo tiene derechos fundamentales implícitos, y por lo regular incluidos en un marco constitucional, en un Estado democrático y que contiene derechos representados en un conjunto de principios y valores humanos; así es como el derecho a indagar la filiación, el derecho a la identidad personal y el estado civil de familia, que se conecta íntimamente al anterior, el derecho a integrar una familia y a gozar de su protección, son derechos que deben estar debidamente protegidos a toda persona.

En este punto, es de considerar que la lucha jurídica más difícil y larga ha sido la encaminada a lograr que en el proceso de filiación se permita la libre investigación de la paternidad y de la maternidad en los códigos civiles o familiares, para lo cual, además de otros factores, han servido eficazmente los últimos avances científicos referidos a las pruebas biológicas de la filiación. ${ }^{7}$

Como dice PÉREZ LUÑO, “De esta manera, la aceptación, adecuación o creación de mecanismos legales apropiados para la protección de los derechos humanos ${ }^{8}$ es indispensable, llámeseles como se les llame”. ${ }^{9}$ Esto ha

que si en el amparo es posible conocer de actos o leyes violatorios de garantías individuales establecidas constitucionalmente, también pueden analizarse los actos y leyes contrarios a los tratados internacionales suscritos por México, por formar parte de la Ley Suprema de toda la Unión en el nivel que los ubicó la Corte. Registro No. 169108; Localización: Novena Época; Instancia: Tribunales Colegiados de Circuito; Fuente: Semanario Judicial de la Federación y su Gaceta; XXVIII, Agosto de 2008; Página: 1083; Tesis: I.7o.C.46 K; Tesis Aislada; Materia(s): Común. DERECHOS HUMANOS, LOS TRATADOS INTERNACIONALES SUSCRITOS POR MÉXICO SOBRE LOS. ES POSIBLE INVOCARLOS EN EL JUICIO DE AMPARO AL ANALIZAR LAS VIOLACIONES A LAS GARANTÍAS INDIVIDUALES QUE IMPLIQUEN LA DE AQUÉLLOS

${ }^{7}$ GARCÍA CANTERO, Gabriel; "El derecho a la propia identidad”, en El derecho ante el proyecto de genoma, Madrid; Fundación BBV, vol. IV, 1994, p. 156.

${ }^{8}$ La clasificación actual que se estudia sobre los derechos humanos admitidos unánimemente por la doctrina es en cuatro generaciones a saber: La primera sobre los Derechos de defensa contra el Estado y referidos a la libertad individual como la libertad, la vida, integridad, etc.

La segunda generación que son los derechos de participación o derechos económicos, sociales y culturales referidos a la igualdad, como al trabajo, la vivienda, la salud. 
sucedido con el reconocimiento legal de la libre investigación de la paternidad y de la maternidad, principio que hoy forma parte del jus comune europeum en materia de filiación y que, más que una necesidad particular, es una exigencia social. Esto se ve reflejado en el consenso doctrinal, bastante generalizado, en el sentido de que la persona para asentarse en la sociedad debe estar segura de sus orígenes y conocer a sus progenitores, no sólo en sus características genéticas, teniendo acceso a su genoma, sino comprendiendo su personalidad, como seres de carne y hueso, a quienes amar y admirar, imitar o discrepar.

A fin de salvaguardar la procreación y el establecimiento filial, todo lo expuesto, y en esencia el apoyo y reconocimiento constitucional de la investigación de la paternidad, exige una regulación bajo normas constitucionales expresas y claras pues no es un tema exclusivo del ámbito civil. Para explicarlo mejor y justificarlo, tomaremos la idea de FRANCESCO GALGANO, quien alude a que actualmente se ha producido un vuelco a las constituciones modernas, pues el interés está centrado en proteger al ser humano, en razón de que es el eje de la disciplina jurídica, sea pública o privada. Por su parte JOAQUIN ARCE y FLORES VALDÉS, han denominado a este fenómeno Derecho civil constitucional, en el que se insufla a las constituciones todo lo relativo a la protección al ser humano ${ }^{10}$, donde la determinación de la identidad filial es, sin la menor duda, una parte esencial.

\footnotetext{
La tercera generación que son los derechos al desarrollo, progreso y calidad de vida, en donde refieren la paz, calidad de vida, protección frente a la manipulación genética, medio ambiente, informática, consumo, patrimonio histórico o cultural, y autodeterminación y defensa del patrimonio genético de la humanidad; $\mathrm{y}$

La cuarta y última referidos al derecho a ser diferente, como la homosexualidad, cambio de sexo, aborto, rechazo de tratamientos médicos que llevan a la muerte.

${ }^{9}$ PÉREZ LUÑO, Antonio Enrique, “Las generaciones de derechos humanos", en Revista del Centro de Estudios Constitucionales; no. 10, 1981; pp. 15-19

${ }^{10}$ Cit. MOSSET ITURRASPE, Jorge; "Los nuevos derechos: ¿meras declaraciones o derechos operativos?, en Revista de Derecho Privado y Comunitario (Derecho privado en la reforma constitucional); Santa Fe, Rubinzal Culzoni, No. 7, pp. 87-88
} 
En este orden de ideas, es imprescindible buscar la compatibilización de los tratados sobre derechos humanos, las constituciones, las leyes de protección de los derechos de los niños y adolescentes y códigos civiles o bien familiares, de manera que los ordenamientos legales estén vinculados entre sí reconociendo en una interpretación auténtica el derecho fundamental de toda persona para reclamar la determinación de la filiación sobre la base de la probanza del nexo biológico entre progenitor e hijo; ya que si bien en el desarrollo del trabajo nos centraremos en la filiación del menor; pues cierto es que en la práctica puede no solo ser un menor el titular del derecho, sino cualquier persona, y el hecho de ser mayor de edad no puede ser motivo de que se le prive del derecho fundamental de la identidad y de conocer sus orígenes, ya que este derecho no es ni deberá ser nunca un derecho exclusivo de los menores, pues como hemos referido antes se trata de buscar la filiación auténtica, sus orígenes, y para esto no debe haber un momento determinado para su ejercicio.

Pero el derecho de conocer los orígenes, desde otro punto de vista, puede ser igualmente exigido por los progenitores, quienes por cualquier causa que pudiera originar el alejamiento entre ellos y sus hijos, siempre tendrán el derecho de saber cuál es su descendencia para poder así unificar los lazos filiales que le unan con otros individuos, por tal razón, en materia internacional, los gobiernos de los diversos países tendrían que unificar las formas por las que los ciudadanos podrían llegar a conocer esta verdad filial, como se ha hecho en un primer momento mediante tratados internacionales; pero en un segundo momento, se ha planteado la exigencia de la creación de leyes nacionales que contengan en forma igual a otras, el ejercicio de estos derechos. 


\subsection{Filiación, maternidad y familia como derechos sociales}

Para la realización de estos derechos se requiere la coexistencia o vinculación interpersonal, es decir, son derechos en los cuales forzosamente interactúan vínculos jurídicos entre dos o más sujetos.

En este tipo de relación jurídica, ya no está el sujeto sólo, exigiendo o demandando naturalmente el respeto de sí, o dicho de otra forma, su derecho personalismo, sino que ahora está acompañado, es decir, es un conjunto y no una unidad, quien pide o representa una consideración jurídica de los demás.

Como tales, los derechos sociales son variados y sus características se dan de acuerdo con el origen de la relación jurídica. Es preciso resaltar que os derechos sociales referidos a la familia se sustentan en una serie de principios que seguidamente serán apuntados:

\subsubsection{Protección de la persona y la familia}

Especial interés para las constituciones, en este caso en particular la española y mexicana, lo merece la familia y el matrimonio pues, como derechos sociales de todo ser humano, exigen a su vez el deber de la comunidad y del Estado de brindarle protección ayuda y afianzamiento. Este apoyo y cautela se hace extensivo, de manera directa, a dos estados biológicos de importancia: la maternidad y la niñez.

Este postulado lo encontramos en el artículo 32 de la Constitución Española, y de forma similar, en lo establecido en el artículo 4 de la Constitución Política de los Estados Unidos Mexicanos, al proclamar una plena igualdad 
jurídica para el hombre y la mujer para contraer matrimonio, y en ambos casos, imponiendo al matrimonio la protección de la ley. ${ }^{11}$

Es factible especificar que de este principio surge un nuevo derecho: el de la vida familiar, y que como tal, implica una doble configuración pues está de por medio el interés de la persona y la necesidad de protección de la familia.

La autora Aída KEMELMAJER trató el derecho a ser reconocido por el padre biológico ${ }^{12}$, citando en su obra el caso Kroon donde la Corte Europea de Derechos Humanos declaró que la norma interna que impide al padre biológico reconocer a su hijo mientras esa paternidad no sea impugnada por el marido de la madre, viola el derecho a una vida familiar. Se resume el caso en que cuando el niño nació, la mujer ya no convivía con el marido ni con el padre del niño. Luego del nacimiento, se divorció y tuvo otros tres hijos con ese mismo hombre, aunque no convivían bajo el mismo techo. El padre reconoció a los tres últimos, pero no podía establecer lazos jurídicos con el primero, porque el marido de la madre no había impugnado la paternidad.

Así tenemos que en cada país se le ha dado la importancia diversa a la paternidad; sin embargo pensamos que es absolutamente necesario que las diversas legislaciones en la materia tengan una homogeneidad esencial en materia de filiación, ya que lo que fundamentalmente se está protegiendo es el derecho de ese menor a tener una vida en familia y sobre todo a conocer sus orígenes.

\footnotetext{
${ }^{11}$ En ambos casos, la ley que se encarga de la regulación y protección de la familia, lo son los Códigos civiles, y como se ha mencionado en capítulos anteriores, en los Estados de Hidalgo, Michoacán y Zacatecas, regulado por los nuevos sistemas de Código de Familia, dándole un tratamiento especial a la familia y las implicaciones de la misma.

${ }^{12}$ Tribunal Europeo de Derechos humanos de 27/10/1994, caso Kroon y otros c/Países Bajos, en Revista General de Derecho, año LIII, No. 632, mayo de 1997, p. 5364. Por otra parte se sostiene que igual solución debe ser para el Derecho interno, entendiendo que la norma que niega la legitimación para impugnar la paternidad a la madre y al padre biológico viola la Convención de los Derechos del Niño.
} 


\subsubsection{Principio de igualdad en la filiación}

Este principio se encuentra establecido en la máxima legal en el sentido de que "todos los hijos tienen iguales derechos y deberes", principio que tiene que venir a eliminar en los códigos civiles los grados de hijos, quitándoles definiciones de legítimos e ilegítimos, siendo en la actualidad para todos la denominación de: hijos de sus padres.

Este es un postulado unánime en las legislaciones actuales, ya que la mayoría de normas de nivel internacional y las de nivel constitucional se refieren a la equiparación filial ${ }^{13}$ o igualdad entre los hijos.

Es clara la idea de que cuando el sistema responde a la unidad de todas las filiaciones, por efecto del principio de igualdad, y se tiende a favor de técnicas más avanzadas en la investigación filial, el interés del hijo parece localizarse en el establecimiento de la verdad biológica, aun cuando el éxito de una acción pueda modificar unas realidad sociológica anterior. En este sentido aclara GUZMÁN ZAPATER que en rigor, deben perder importancia las presunciones legales y/o la posesión de estado, a favor de pruebas más exactas, como las biológicas, en la investigación de la paternidad. ${ }^{14}$

\footnotetext{
${ }^{13}$ MÉNDEZ COSTA María Josefa, La Filiación; Rubinzal-Culzoni Editores, Argentina; p. 53; indica que los preceptos constitucionales, programáticos u operativos, coinciden en proclamar la equiparación de las filiaciones, sin incidir en la situación de los progenitores, dejando de lado la protección del matrimonio y la familia fundada en él. Por tanto, se llega al derecho positivo privado interno descendiendo de lo doctrinario a las pautas internacionales y de éstas a las constitucionales, sin superación de la misma problemática de conciliar el respeto por la persona y la defensa de la familia legítimamente constituida.

${ }^{14}$ GUZMÁN ZAPATER Mónica; El Derecho a la investigación de la paternidad; Madrid; Civitas, S.A., 1996 pp 31-32
} 


\subsection{El derecho a la identidad}

Es esencial poder contestar las interrogantes en forma satisfactoria de: ¿quién soy? O bien: ¿quiénes son mis padres? Son interrogantes que angustian a parte de la población no solo de un lugar, sino a nivel mundial. Es un problema cotidiano de hombres y mujeres comunes que al no tener la certeza se han formulado esta cuestión a lo largo de su vida, con la esperanza de poder conocer el punto de partida de su existencia; ya que la identidad desde esta perspectiva, es decir, la psicológica, es una cuestión difícil de definir, pues desarrollar una identidad personal adecuada implica ser consciente de uno mismo como alguien separado y distinto de los demás, en una experiencia de continuidad con el pasado, partiendo de un presente y con una perspectiva firme hacia el futuro, todo ello con una serie de cambios contextuales y de función social que se van dando con el tiempo.

Entre los factores que contribuyen al desarrollo de la identidad de la persona se menciona la calidad de las relaciones del menor con su familia, especialmente las primeras relaciones que entabla y la calidad y estabilidad de los cuidados que le proporcionan las personas responsables de su atención más temprana. La relación con los padres es, por tanto, fundamental para la formación de la identidad de las personas, y el conocimiento del origen biológico puede ser una parte importante del desarrollo de su identidad.

La identidad, según podemos ver, es un fenómeno complejo que comprende diversos elementos de identificación, distintos contenidos para la persona: la identidad individual como un conjunto de elementos que le sirven para distinguirse de los demás; la identidad familiar como pertenencia a la sociedad por ser parte de una familia y la identificación psicológica; aquí, podemos hablar de la trascendencia de los estudios sobre la importancia 
psicológica del conocimiento del origen biológico, ya que establece una conexión del menor con el propio origen familiar, tanto genético como social, lo cual implica una afectación de todas las personas que tiene en su entorno.

El ser humano, como refiere VARSI ROSPIGLOSI ${ }^{15}$, es un todo, en el que convergen valores, actitudes y elementos biológicos, en fin, todo aquello que le permite la vida y la socialización. Toda persona es un ser absolutamente único, singular e irrepetible, con una perfecta unidad de alma y de cuerpo. Dicho cuerpo y su confirmación biogenética lo diferencia de sus semejantes con quienes comparte una misma naturaleza: el ser un humano.

Así, el cuerpo y su configuración son intangibles por ser constitutivos de la persona misma y de su identidad; identidad personal, que, como bien dice Carlos FERNÁNDEZ SESSAREGO, es el conjunto de atributos y características que permiten individualizar a la persona en sociedad, permitiendo que cada cual sea uno mismo y no otro. ${ }^{16}$

De esta manera el sujeto tiene derecho a que se le conozca y defina en su verdad personal, tal cual es, sin alteraciones, desfiguraciones, falseamientos, distorsiones o desnaturalizaciones de sus atributos que lo van distinguiendo de los demás.

DE CUPIS, precursor de este derecho, refiere que "la identidad es el ser sí mismo con sus propios caracteres y acciones constituyendo la misma verdad de la persona” ${ }^{17}$, y pone especial detalle en la identificación filial, paterna

\footnotetext{
${ }^{15}$ VARSI ROSPIGLOSI, Enrique; Filiación, Derecho y manipulación genética; Lima; Universidad de Lima, 1996, p. 111.

${ }^{16}$ FERNÁNDEZ SESSAREGO, Carlos; Derecho a la identidad personal. Buenos Aires; Astrea, 1992, p. 113.

${ }^{17}$ Cit. CIFUENTES, Santos. Derechos Personalísimos. 2ª Edición; Buenos Aires; Astrea, 1995, p. 606.
} 
o materna que le sirve a la persona para posicionarse en la sociedad, contribuyendo fuertemente a su identificación.

Y es que, la identificación filiatoria es la que surge del emplazamiento de una persona en un determinado estado de familia, en relación a quienes aparecen jurídicamente como sus padres. Normalmente, entra en relación con la identidad genética, pero puede no estarlo.

Santos CIFUENTES, muestra una disconformidad al preguntarse cómo puede confundirse esa amplia concepción del estado filiatorio, abstracta, anterior y que presupone derechos del sujeto, con el concreto derecho a la identidad personal, que es, igual que todos, relativamente disponible ${ }^{18}$, a lo cual se responde que la filiación como estado de familia es un atributo de la persona de orden público, irrenunciable, no innato sino derivado de vínculos sanguíneos y sexuales. Como tal es un presupuesto de capacidad de vocación a la titularidad de derechos y que cuando se investiga la paternidad por los medios hematológicos o genéticos, no se procura el ejercicio y la defensa de un derecho personalísimo que es el de conocer su identidad familiar, sino lograr la concreta posición o cualidad de la persona en el seno de la familia a la que pertenece; sin embargo, el status no es el de un derecho personalísimo, si no un atributo y configuración de la persona. Es una cualidad esencial del ser. No hay nada disponible ni renunciable en el estado filial. ${ }^{19}$

El derecho a la identidad, como derecho de contenido complejo, lo podríamos configurar de la siguiente forma:

\footnotetext{
${ }^{18}$ CIFUENTES, Santos; op cit. pp 611 y 621

${ }^{19} \mathrm{Al}$ respecto señala el mismo autor que "la filiación y la identidad por ende biológico - genética, es mucho más que un derecho subjetivo. Es un atributo, cualidad, posición jurídica sustancial para ser, es el elemento del estado de las personas, no teniendo nada de subjetivo, privado no disponible”. En: "Difícil y necesario equilibrio entre los intereses públicos y los derechos personalísimos (la inspectio corporis forzada)" op cit. p. 318
} 


\subsubsection{Derecho a la vida personal}

Referido a los atributos de la persona como elementos que diferencian a una persona de otra, como el nombre, edad, sexo, estado civil, profesión, religión, patrimonio, domicilio, capacidad y nacionalidad, determinando la individualidad propia de cada persona en sociedad y frente al derecho.

Sin embargo, no es posible limitar el derecho a la identidad personal a un conjunto de situaciones o categorías jurídicas, sino que debemos entenderlo de una manera amplia y heterogénea, producto de la bioquímica y de las vivencias del hombre, pues la identidad se presenta como la unidad y el todo del ser humano.

Así, la identidad personal es el resultante de la fuerza expansiva del código genético que es el principio intrínseco de actividad, modificado por los impulsos procedentes del hábitat y, ambos a su vez atemperados o dirigidos por el ejercicio efectivo de la libertad; de allí que el ser humano se halla en la intersección de tres ejes de coordenadas: la herencia, ambiente y su propia libertad personal. ${ }^{20}$

\subsubsection{Derecho a la identidad sexual}

El ser humano como ser inteligente, pensante y con capacidad de procreación, conoce, quiere y se identifica con el sexo y por tanto es esencial averiguar el origen para que se complete el derecho a la filiación.

\footnotetext{
${ }^{20}$ VILA-CORO BARRACHINA, María Dolores; “Los límites de la bioética”, en Biotecnología y futuro del hombre: la respuesta bioética (Madrid, Eduema S.A., diciembre de 1992, p. 76
} 
Así debemos puntualizar al analizar este derecho que el sexo no es sólo el aspecto corporal o anatómico, sino un conjunto variado de elementos y condiciones interrelacionadas que distinguen al hombre de la mujer, es decir, el sexo no se agota en lo físico, ya que el físico no lo es todo, es solo una parte de ese universo.

Esta variedad de elementos nos lleva a referir los cinco tipos de sexo que se tienen, como es el cromosomático manifestado con XX en el hombre y $\mathrm{XY}$ en la mujer; el gonádico, que son los testículos y ovarios; el anatómico representado por el pene y la vagina; el psíquico, que se representa con los sentimientos y el registral manifestado en documentos.

Cuando alguno de estos sexos no coinciden con otro, surge la llamada alteración sexual o conducta sexual disfuncional, permitiéndose, en determinados casos la correspondiente adecuación de sexo. ${ }^{21}$

Podemos decir en concreto, que el derecho a la identidad sexual protege la integridad psicosomática de la persona relacionada con su sexo, de manera tal que se logre la identificación del sexo que tiene con el que psíquicamente siente.

\footnotetext{
${ }^{21}$ Vid. "Bases para una legislación sobre adecuación de sexo en casos de transexualismo y consiguiente modificación de nombre”, en Cuadernos de Derecho, Revista del Centro de Investigación jurídica de la Facultad de Derecho y Ciencias Políticas de la Universidad de Lima, 1992, año 1, No. 1, p. 61
} 


\subsubsection{Derecho a la identidad genética}

El ser humano en su composición biológica, es un conjunto celular y genómico, la información contenida en el núcleo de la célula se conforma a partir de las características de los progenitores.

En el núcleo celular se halla el patrón o huella genética que tiene todo ser viviente. En el caso del ser humano, surge en el momento de la concepción cuando el núcleo del espermatozoide intercambia su información genética con el núcleo del óvulo, esta huella o pauta genética viene a ser el resumen de la información aportada por los progenitores del procreado, de ahí la posibilidad de determinar con certeza el origen biológico de la filiación. De este se deduce que desde la concepción el ser humano tiene una determinada identidad. ${ }^{22}$

Dentro de esta clase de derecho a la identidad se sitúa la posibilidad científica de indagar y afirmar la paternidad o maternidad, a través de las pruebas biogenéticas.

Con estos métodos especiales se busca de la determinación del origen de la huella genética de un sujeto, para poder encontrar la verdadera relación filial que une al menor con sus progenitores.

La huella genética es parte del derecho a la identidad junto con lo referente al genoma, teniendo una estrecha vinculación con el derecho a la integridad, a la dignidad por su correcta aplicación y uso; a la libertad para su determinación de prestar o no su material genético o dicho de otra forma, para practicarse o no la prueba genética, y a la intimidad, es decir, a que la información que se obtenga de dicha prueba sea individual y privada.

${ }^{22}$ FERNÁNDEZ SESSAREGO, Carlos; op cit p. 21 
Este tipo de identidad será entendida en un doble sentido: la identidad genotípica e identidad hábitat (paratipo-ambiente que permite desarrollar unos genes u otros) $)^{23}$

El derecho a la identidad personal se debe desdoblar en dos facultades especiales:

- El derecho a la propia herencia genética, que se vulnera a través de la manipulación genética al variarse la información natural del ser humano; y

- El derecho al propio“hábitat” natural que le proporcionan sus progenitores, que se ve afectado cuando se aísla o aparta al concebido del medio que le es propio, situándolo en otro distinto, sea en la etapa prenatal o posnatal (cesión de material genético -anonimato- o embriones - maternidad subrogada - , fecundación post mortem).

\subsubsection{Derecho a la identidad en el marco jurídico mexicano}

En el caso mexicano el derecho a la identidad se encuentra regulado en una ley federal denominada Código Civil Federal, la cual pretende ser congruente con los tratados internacionales celebrados por este país con relación al tema, derivando de éste la Ley para la Protección de los Derechos de Niñas, Niños y Adolescentes, la cual en su capítulo Sexto lo titula "Del Derecho a la identidad” y dedica un solo punto -el C- de un solo artículo -el número 22- a la

\footnotetext{
23 "El impacto de la biotecnología en el derecho" Comisión 1, en El Derecho privado en la Argentina, II Jornadas Marplatenses de Responsabilidad Civil y Seguros. Tucumán: Universidad Nacional de Tucumán, II parte, diciembre de 1992, p. 72
} 
materia de la filiación. Este precepto, de forma muy vaga sólo proclama el derecho a conocer su filiación y su origen, imponiendo una restricción al continuar diciendo, “salvo en los casos que las leyes lo prohíban”, en una falta clara de técnica legislativa y en cierto punto de manera contradictoria con las normas internacionales. Precisamente teniendo en cuenta las disposiciones de estas últimas debería primar el derecho de la identidad del menor, así como se ha mencionado ya en lo principal el derecho a conocer su origen biológico, añadiendo además, que se debió haber expresado la posibilidad de emplear las pruebas biológicas o científicas para llegar a tal fin, sin embargo, este punto debe ser recogido todavía por los diversos ordenamientos civiles del país.

\section{Breve consideración sobre el derecho a la identidad en los grupos minoritarios en México}

Sin poder dejar a un lado el análisis de este trascendental derecho, nos podemos referir al otorgado a las minorías, en el caso europeo nos referimos al Convenio-marco para la Protección de las Minorías Nacionales no. 157, hecho en Estrasburgo, en el seno del Consejo de Europa, el 1 de febrero de 1995, ratificado por España y en vigor desde el 1 de febrero de $1998^{24}$, y en el cual se protege la vertiente del derecho a la identidad relacionada con la cultura, haciendo referencia en sus artículos 5 y 12 a la necesidad de permitir a las personas pertenecientes a minorías nacionales preservar su religión, lengua, tradiciones y patrimonio cultural, así como el compromiso de los Estados partes de reconocer a estas personas el derecho a utilizar su apellido y nombre de pila en la lengua minoritaria, y a reconocerlos oficialmente según las modalidades previstas en su ordenamiento jurídico.

\footnotetext{
${ }^{24}$ Publicado en el Boletín Oficial Español no. 20, de 23 de enero de 1998
} 
En el caso del Derecho mexicano, se cuenta con la protección constitucional a los grupos minoritarios y, en especial, a los indígenas en el artículo segundo de la Constitución, en el cual se les reconoce que la nación mexicana tiene una composición pluricultural sustentada originalmente en sus pueblos indígenas que son aquellos que descienden de poblaciones que habitaban en el territorio actual del país al iniciarse la colonización y que conservan sus propias instituciones sociales, económicas, culturales y políticas, y de esta forma, se les reconoce el derecho a la libre determinación en el marco constitucional de su autonomía, respetando entre otras cosas su ámbito para preservar y enriquecer sus lenguas, conocimientos y todos los elementos que constituyan su cultura e identidad. ${ }^{25}$

\subsection{El derecho a la investigación de la paternidad}

El legitimo interés faculta a todo sujeto a iniciar las acciones legales a fin de averiguar su nexo filial. Esto quiere decir que la investigación de la paternidad es un derecho inherente a la persona, cuyo objetivo es indagar y establecer la verdad biológica con la relación jurídica de la filiación. Es por ello

\footnotetext{
${ }^{25}$ En este caso, mencionaremos como una protección a la identidad de estos pueblos el caso de los padres de la niña hñähñu D_oni Zänä quien le fue negado el registro con ese nombre por los signos que contiene ya que se estaba incurriendo en la violación a los derechos de la menor, no habiendo aceptado el significado al castellano que es el de Flor de Luna, lo que fue logrado, tras un proceso legal que iniciaron sus padres en 2006 para exigir el reconocimiento a su lengua. Luego de un año y ocho meses y en medio de complicaciones técnicas, la menor, obtuvo su personalidad jurídica que le permitirá tener un nombre oficial, acceder a programas sociales y acudir a la escuela. Habiendo manifestado sus padres que: "Este es un triunfo para la comunidad indígena no sólo de Hidalgo, sino del País, toda vez que demostraron que sí se puede defender su lengua, sus culturas y tradiciones", "Ya nos habían pedido que le pusiéramos otro nombre a nuestra pequeña hija pero no nos parecía justo que a los indígenas se nos discriminara; nosotros recurrimos a todas las instancias nacionales e internacionales para defender este nombre y, cómo íbamos a cambiarlo después de haber avanzado tanto en la ONU y en la propia Corte de Justicia de la Nación". Esta familia hñahñú, procedente de la comunidad de San Ildefonso, logró las modificaciones de los sistemas de cómputo que ahora incluyen guión bajo y diéresis, entre otros signos, que permitirán que el significado de D_oni no cambie, pues la falta de guión bajo significaría Piedra, y entonces el nombre quedaría como Piedra de Luna. Fuente: Diario Reforma.
} 
que, como derecho, protege y encauza el interés privado de la persona por hallar sus orígenes familiares a través de los medios jurisdiccionales correspondientes.

La decisión de hacer uso de este derecho implica iniciar procesos, que por su naturaleza, conllevan realizar actos de libertad pensando, evaluando cuidadosamente, pues lo que se va a discutir y establecer, el entronque familiar, resulta sustancial para la persona. Dados los sujetos intervinientes y las consecuencias jurídicas que genera, es básico establecer quién es el sujeto beneficiario directo y primario de este derecho, en otras palabras, el derecho a la investigación de la paternidad, como tal, debe ser un derecho del hijo o un derecho de los progenitores.

Partiendo del principio del interés superior del niño, reconocido en los ordenamientos jurídicos tanto de España como México; así como en el ámbito internacional, es fácil establecer que se debe poner una especial atención en el menor, por tanto, como un derecho que corresponde en un primer término al hijo.

Por este orden de preferencia, el derecho a la investigación de la filiación es más un derecho vinculado con el derecho a conocer el propio origen biológico que con el derecho a la paternidad.

Una mirada a la doctrina nos hace ver la falta de pronunciamiento acerca de la naturaleza de este derecho, es decir, si es fundamental o no. En el Derecho privado, y especialmente en el civil, el tema ha sido estudiado ampliamente, afirmándose el carácter de derecho fundamental que tiene el conocer el propio origen biológico.

Desde el punto de vista jurisprudencial, es clara la tendencia a favor de entender que la investigación de la paternidad entraña un derecho primigenio 
del hijo frente a otros derechos individualistas ${ }^{26}$. Frecuentemente se afirma esta preponderancia ante las colisiones alegadas entre este derecho y otros como el honor, la intimidad, la integridad o la tutela judicial efectiva, entendiéndose que el derecho a la investigación de la paternidad responde esencialmente a una finalidad protectora ${ }^{27}$, de allí su prevalencia.

Por el momento, el derecho a la investigación de la paternidad no se tutela por sí como un derecho autónomo, sino que depende de la existencia de otros derechos para su configuración, como es el derecho a conocer el propio origen biológico, entre los principales. Es necesario forjar su inmediata autonomía y configuración como derecho fundamental de la persona ${ }^{28}$. Sus objetivos, características y fundamentos así lo exigen.

En cuanto a las características de este derecho es de detallar que son el ser un derecho de la persona, que tiene una finalidad protectora y el establecimiento del estado civil filial y que su objetivo es fijar una correspondencia entre la verdad formal y la verdad biológica.

Decimos que es un derecho de la persona porque quien justamente tiene la capacidad de iniciar un proceso es aquella persona física interesada, el cual siempre tendría que ser el menor o su tutor o bien los que se consideren los padres del menor.

\footnotetext{
${ }^{26}$ Con especial incidencia en el carácter público y de ius cogens que está adquiriendo el derecho de familia, como se ha estipulado en la STS de 15 de marzo de 1989.

${ }^{27}$ Así se ha estipulado en la STS de 12 de noviembre de 1987.

${ }^{28}$ GUZMÁN ZAPATER, Mónica, Op cit pp. 45-46 analiza de manera interesante la posibilidad de recurrir en amparo frente a la violación a este derecho, estableciendo que los recursos de amparo tienen por objeto central la tutela de los derechos fundamentales comprendidos en los artículos 14 a 29 de la Constitución española, referidos a los derechos y libertades. El derecho a al investigación de la paternidad no es un derecho directamente protegible en amparo, no goza de tal garantía, pero la infracción del derecho a la investigación de paternidad, sólo en forma indirecta puede acceder al amparo, y esto es desde el momento en que se ha entendido que, impedir o admitir injustificadamente la investigación de la paternidad, así es susceptible el considerar violado el derecho a la tutela judicial efectiva, al derecho a la intimidad, al honor e incluso a la integridad física.
} 
Al hablar de una finalidad protectora hay que referirse a que lo importante y último fin de este derecho se centra en buscar el entronque de sangre entre el menor y sus padres para que con esto tenga garantizado su derecho a conocer su origen y por ende protegido el mismo, al establecerle el estado filial entre padres e hijos.

Aun esto y el avance dentro del proceso, es complicado poder hablar de buscar una correspondencia entre la apariencia y la verdad biológica, dado que para que esto fuera así sería necesario que a la prueba de ADN se le diera un carácter de obligatoria, ya que con la pura presunción consideramos se tiene una verdad a medias, teniendo así que se pueda dar una suposición errónea.

\subsection{El derecho a conocer el propio origen biológico}

Esta es la facultad propia y natural del ser humano que, sustentada en el principio de la verdad biológica, le permite el ejercicio de iniciar la averiguación de quién es su progenitor, el cual, por distintas causas, puede ser desconocido, estar en discusión o ser debatible.

Este derecho recibió un impulso a consecuencia de los avances de las técnicas de reproducción humana asistida, dado que la aplicación indiscriminada y sin respeto a los principios naturales desencajaron la coherencia biolegal, al utilizar gametos de terceros, prácticas de maternidad subrogada, etcétera. ${ }^{29}$

\footnotetext{
${ }^{29}$ QUEZADA GONZÁLEZ, al citar a NUEUMANN DUESBERG nos dice que "vigente la Grundgesetz, fundamentó este derecho en la analogía existente entre el derecho y al conocimiento de la filiación biológica y el derecho al nombre (12BGB), por ser ambos distintivos individualizadores de la persona": "El derecho (¿constitucional?) a conocer el propio origen biológico", en anuario de derecho civil, Madrid: Ministerio de justicia e interior, tomo XLVII, fasc. II, abril-junio, 1994, p. 241.
} 
En este sentido y tomando como base legal de este derecho el artículo 10 de la Constitución Española, y partiendo del derecho a la dignidad de la persona y el libre desarrollo de la personalidad, se hace posible considerar que el derecho al conocimiento del verdadero origen biológico es uno de los derechos de la personalidad. Es decir, establece que este nuevo derecho forma parte de la dignidad humana y su ejercicio contribuye al libre desarrollo de la personalidad.

En este sentido bajo la opinión de ZANNONI ${ }^{30}$, en el derecho a conocer el propio origen biológico existe una relación entre la identidad personal y la realidad biológica, mediante la cual un sujeto encuentra su pertenencia a una familia y obtiene el emplazamiento de su estado que, de acuerdo con su origen biológico, le corresponde. Esto implica que el derecho a preservar la identidad personal como identidad filiatoria o genética es común a toda persona, y no es exclusivo o sólo privativo de los niños.

Ahora en el Derecho mexicano y como ya se ha expuesto con anterioridad, el derecho a conocer el propio origen biológico no es un derecho expreso en la Constitución, pero siguiendo este criterio, es un derecho que se encuentra reconocido tácitamente, aunque es claro que un ordenamiento jurídico tutela a la persona también en supuestos no típicamente establecidos, así igual como se ha citado antes, este derecho lo encontramos en los Tratados Internacionales, los cuales al ser ratificados por el Congreso de la unión de México, tienen valor de ley y por tanto son de observancia obligatoria en su protección y contenido.

Los fundamentos que determinan la existencia de este derecho están íntimamente relacionados con el derecho a conocer la identidad del progenitor o

\footnotetext{
${ }^{30}$ ZANNONI, Eduardo; "Identidad Personal y pruebas biológicas", en Revista de Derecho Privado y Comunitario; Derecho privado en la reforma constitucional; Santa Fe, Rubinzal y Culzoni, 1997, No. 13
} 
el derecho a conocer a sus padres; ya que éste es un derecho fundamental de todo niño, que para el pleno y armonioso desarrollo de su personalidad, debe crecer en el seno de una familia, siendo un derecho humano vinculado directamente con sus padres, y por tanto, es irrenunciable e imprescriptible. ${ }^{31}$

Su objetivo o ámbito será la investigación de la filiación natural o sanguínea, el derecho a conocer la identidad del progenitor del niño y el derecho a conocer la identidad del cedente de gametos en las técnicas de reproducción.

Dada la trascendencia que el ejercicio de este derecho significa para la persona, es prioritario fomentar su reconocimiento expreso y que sea elevado como derecho de la persona y, más aún, como derecho fundamental con rango constitucional. Esto debe permitir la determinación del origen de la identidad genética, el exigir el cumplimiento de los deberes básicos y asistenciales como el nombre, apellidos, alimentos y herencia entre otros; el libre y pleno desarrollo del ser humano. Este derecho debe representar como algo impostergable e incuestionable, pues su negación implicaría situaciones de clara desigualdad, cuando no de abuso y discriminación.

${ }^{31}$ Como se ha señalado, la Convención sobre los Derechos del Niño, en su artículo 7 manda el derecho del menor a que desde el momento de su nacimiento conozca a sus padres, mandamiento que se va repitiendo en las diversas legislaciones derivadas de esta convención. 


\section{CAPITULO II \\ LA DETERMINACIÓN DE LA FILIACIÓN}

\subsection{La Filiación}

Para poder tratar la determinación de la paternidad a través de las pruebas heredobiológicas, es siempre necesario el tener definido lo concerniente a la filiación, la cual ha sido estudiada desde hace muchos siglos atrás, por la imperiosa necesidad de saber el origen de las personas, así como la continuidad de las familias. Por ello podemos empezar considerando que en la doctrina existen numerosas definiciones de filiación, tomando en consideración los elementos personal, familiar o social.

La filiación es una de las figuras jurídicas que forman parte del Derecho de familia, que como el matrimonio, tiene la característica de ser un hecho natural regulado por el ordenamiento jurídico, inspirado fundamentalmente en la protección del interés del hijo.

No se puede negar entones que la filiación se refiere a un lazo sanguíneo, sin embargo, a los ojos del Derecho consiste en algo más que una relación biológica. Es esencialmente una relación de índole jurídica entre dos personas, padre o madre e hijo e hija, "es una relación de nacimiento elevada a la categoría de jurídica”32, porque para que produzca efectos jurídicos, tiene que ser

${ }^{32}$ CARBAJO GONZÁLEZ, Julio, en SERRANO ALONSO, Eduardo (compilador), Manual de derecho de familia, Edisofer, Madrid, 2000, p. 335 
conocida por el Derecho, es decir, debe cumplir con ciertos presupuestos o requisitos ${ }^{33}$.

De esta forma, y con base en lo anterior podemos decir que la filiación es aquel vínculo que une a una persona con todos sus ascendientes y descendientes, uniendo a los hijos con sus padres en una relación de sangre y derecho entre ellos.

Para los civilitas franceses "es la relación que existe entre dos personas" ${ }^{34}$; de las cuales una es considerada al progenitor, sea padre o madre y la otra el hijo o descendiente de la unión. Para CICU es el estado cuya característica es "que forma parte de una serie de relaciones que unen al hijo, no sólo con sus padres, sino con todos los parientes de sus padres”35; mientras que el tratadista español DIEZ PICAZO Y GULLÓN, nos dice que la filiación “...es aquella que se establece entre personas a quienes el derecho coloca en la condición de padre o madre y también en la de hijos”. ${ }^{36}$

En la misma línea, podemos distinguir igualmente las definiciones dadas por el autor DOMÉNICO BARBERO para quien la "filiación es, ante todo, el hecho de la generación por nacimiento de una persona, llamada hijo, de otras dos personas, a quienes se llama progenitores" ${ }^{37}$. Por su parte, partiendo de que la procreación es obra del padre y de la madre, ESPÍN CÁNOVAS, manifiesta que la filiación es aquella "relación existente entre

\footnotetext{
${ }^{33}$ MORO ALMARAZ y SÁNCHEZ CID, Lecciones de derecho de familia, Universidad de Salamanca y Ed. Colex, Madrid, 2002, p. 186; señalan que el derecho para reconocer efectos a la filiación o procreación, exige ciertos presupuestos o requisitos,

${ }^{34}$ PLANIOL, MARCEL y RIPERT, GEORGES; Tratado de Derecho Civil, Ed. Harla; México; 2005; p. 258

${ }^{35}$ CICU, ANTONIO; La filiación; $1^{\text {a }}$ ed., Ed. Revista de derecho privado; 1930; p. 18

${ }^{36}$ DIEZ-PICAZO, LUIS y GULLÓN; ANTONIO; Sistema de Derecho Civil, Madrid, Ed. Tecnos, Tomo IV; Derecho de Familia; 1992; p. 247; en el mismo sentido EDUARDO ZANNONI, en su obra Derecho de familia, tomo II, P. 283, nos define la filiación como "el conjunto de relaciones jurídicas que determinadas por la paternidad y maternidad, vinculan a los padres con los hijos dentro de la familia".

${ }^{37}$ BARBERO, Doménico: Sistema del Derecho privado, Buenos Aires, EJEA, 1967, t.II, p.105.
} 
una persona de una parte, y otras dos, de las cuales una es el padre y otra la madre de la primera" ${ }^{38}$.

Etimológicamente la palabra filiación, viene de la acepción latina filius filii, lo que significa "hijo". Se han empleado tradicionalmente dos acepciones de filiación, uno en sentido amplio y otra en sentido restringido.

En sentido amplio, podemos decir que es aquella determinada por la secuela del parentesco en línea ascendiente y descendiente de una persona. PLANIOL $^{39}$ señala que este concepto tomado en sentido natural de la palabra, no era otra cosa que una descendencia en línea directa: es decir, incorporaba toda la serie de intermediarios que ligan a una persona determinada con alguno de sus antecesores, así sea sumamente alejado: si se quería tomar desde un punto de partida ascendente se partía de los padres, abuelos, bisabuelos, etcétera, y si se toma el lado contrario, es decir partiendo en línea descendente entonces se podía tomar como punto de relación a los hijos, nietos, bisnietos, etcétera.

Así, en sentido estricto, es el vínculo o nexo que existe entre el engendrado y sus progenitores, es decir, cuando se considera la calidad que una persona tiene de hijo o hija con respecto a otra, que es su padre o madre. PLANIOL y RIPERT en este sentido decían que en el lenguaje del Derecho, la palabra había tomado un sentido estrecho que se reducía exclusivamente a la relación inmediata del padre o la madre con el hijo o hija. Esta relación según sea derivada de la madre o del padre toma también el nombre de paternidad o maternidad.

\footnotetext{
38 ESPIN CANOVAS, Diego: Manual de Derecho civil español, 7a. edición, Madrid, Ed. Revista de Derecho privado, 1982, vol.IV, p.338.

${ }^{39}$ PLANIOL, Marcel y RIPERT, Jorge; Op Cit p. 557
} 
Ahora bien, maternidad y paternidad forman parte de la relación jurídica de la filiación. Por tanto, no pueden considerarse sinónimos paternidad o maternidad y filiación, pero hacen referencia a los sujetos entre los cuales se generan deberes, derechos y obligaciones. Lo que hace que se estudien separadamente es la diferencia que existe en cuanto a la forma de probar cada uno de esos hechos, pero existe un principio común en el sentido que la paternidad y maternidad son indivisibles. Es decir, no es posible ser hijo o hija de una mujer sin serlo del progenitor. ${ }^{40}$

Así, como regla general podemos afirmar que todo ser humano cuenta con una filiación por el solo y único hecho de haber sido engendrado, ésta es la denominada filiación biológica que surge del acto propio de la concepción con relación a los progenitores. De ahí que se diga que "la filiación humana está basada, pues, en la aportación de material genético con el que se produce la fecundación” ${ }^{41}$ Para que surta sus efectos legales debe ser conocida conforme a Derecho, de manera tal que la filiación legal (hecho jurídico) es aquella que la ley determina como la presunción matrimonial de la paternidad o declaración judicial; o bien por la procreacional del ser humano como el reconocimiento, adopción o posesión constante de estado, adquiriéndole la calidad de padre o madre. $^{42}$

\footnotetext{
${ }^{40}$ CHAVEZ ASENCIO, Manuel F., La familia en el derecho. Relaciones jurídicas patyerno filiales. Ed. Porrúa, México, 1987, p. 11

${ }^{41}$ SOTO LA MADRID; MIGUEL ÁNGEL; Biogenética, filiación y delito; Buenos Aires; Astrea; 1990, p. 72

${ }^{42}$ Siguiendo a MARCIAL RUBIO con la teoría de la voluntad procreacional, existen tres formas de producir la relación paterno filial para el derecho: 1. como regla general la consanguinidad; 2. la adopción; y 3. la voluntad del hombre de asumir la paternidad del hijo de su cónyuge que no es hijo suyo, así como la voluntad del padre de declarar ser padre de alguien que no tiene vínculo genético (Las reglas del amor en probetas de laboratorio; Biblioteca de derecho contemporáneo; Perú; Pontificia Universidad Católica del Perú; 1996; vol. 2; pp. 45 y 46
} 
Podemos considerar entonces, que la filiación es la condición necesaria para conocer la situación en que se encuentra una persona como hijo de otra. Es una forma de estado de familia, de esto que implique un triple estado:

Jurídico: La ley asigna a una persona la relación natural de la procreación que la liga con otra.

Social: En cuanto se tiene con respecto a otra u otras personas.

Civil: Implica la situación jurídica del hijo frente a la familia y la sociedad.

La importancia de la determinación del nexo filial ${ }^{43}$ del engendrado y su progenitor es fundamental, ya que de ella surge una vasta gama de derechos, deberes y obligaciones ${ }^{44}$;

Joaquín ESCRICHE, en su diccionario razonado de legislación y jurisprudencia, nos señala que "los términos de paternidad y filiación expresan cualidades correlativas; esto es, aquélla cualidad de padre y ésta la calidad de hijo" ${ }^{45}$. Sin embargo, paternidad y filiación solo son correlativos, ya que uno no puede ser concebido sin el otro, pero la filiación presenta algo más extenso, corresponde no solo a la paternidad, sino de igual forma a la maternidad, ya que el parentesco reposa sobre la filiación.

\footnotetext{
${ }^{43}$ En este nexo causal que se le ha denominado filiación, y en el cual existe la calidad de ser hijo respecto de otras denominadas padre, madre; llamado paternidad o maternidad respectivamente, sin embargo paternidad se ha utilizado como comprensivo de ambos, confundiendo el valor semántico y su naturaleza jurídica.

${ }^{44}$ A este considerando Héctor Lafaille, opina que "esa relación de causa - efecto origina el estado civil de las personas y al mismo tiempo el vínculo que puede ligar a un individuo determinado con el grupo, fuente de todas las ventajas que tal situación comporta, como ser los derechos sucesorios, la prestación de alimentos y otras consecuencias jurídicas" (LAFAILLE, Héctor; Derecho de Familia; Buenos Aires; Biblioteca Jurídica Argentina; 1930; p. 302)

${ }^{45}$ ESCRICHE, Joaquín; Diccionario razonado de legislación y jurisprudencia; París; Librería de Ch. Bouret; 1884. p. 203
} 
En tal virtud, podemos entender la filiación como la relación existente entre dos personas; una de las cuales generalmente desciende de la otra; es una relación que existe entre padre, madre e hijos, y se establece por los lazos de sangre o voluntad declarada, entre el hijo o hija y la madre y entre el hijo o hija y el padre, considerándose como la fuente principal de la familia, comprendiendo un conjunto de derechos y obligaciones que respectivamente se crean entre el padre y el hijo o hija y constituyen también un estado jurídico, entendido como una situación permanente que el derecho reconoce por virtud del hecho jurídico de la procreación, para mantener vínculos constantes entre el padre o la madre y el hijo.

A pesar de las marcadas características de cada uno de estos términos, la corriente jurídica que postuló la igualdad entre los hijos ha realizado toda una diferencia entre paternidad y filiación ${ }^{46}$ a efectos de no determinar el modo, circunstancias, tiempo y forma como ha sido concebida una persona.

De ello se tiene que la filiación es consustancial e innata del ser humano en el sentido de que el status filii es un atributo natural, siendo aceptado y fomentado actualmente que toda persona debe conocer su filiación, o dicho de otra forma, a conocer su propio origen biológico en la medida de lo posible ${ }^{47}$; no sólo para generar consecuencias legales, sino para permitir la concreción y goce de su derecho a la identidad. ${ }^{48}$

\footnotetext{
${ }^{46}$ SILVA Cruz, Pedro; "El derecho de familia y la inseminación artificial -in vitro-“, en Revista de Derecho Privado, Madrid; Ed. Derecho Reunidas, 1987; enero - diciembre, tomo LXXI, p. 326.

${ }^{47}$ Opinión igual reconocida y vertida en el artículo 5 de la Convención de los Derechos del Niño, firmada y ratificada por Asamblea General en resolución 44/25 de 20 de noviembre de 1989; y dentro de la cual como estados firmantes se encuentran entre otros México y España, y en los cuales se deberá preponderar como compromiso asumido dentro de la misma, el derecho innato y supremo del menor a saber su origen, aún frente a otros derechos controvertidos.

${ }^{48}$ SOTO LAMADRID, Miguel Ángel, nos dice que "la filiación, como categoría jurídica, es más que un hecho jurídico, es un acto jurídico familiar, porque el surgimiento de la filiación no existe hasta que haya
} 
Ahora bien, en lo relativo a la conjunción de lo biológico y la parte jurídica en la filiación, se puede aseverar que el hombre y la mujer perpetúan la especie, pero al mismo tiempo satisfacen un instinto natural de perseverar su nombre, tradiciones, costumbres y modos de vida. Jurídicamente la procreación genera un sujeto de derecho al que el ordenamiento social le debe la más amplia protección, siendo la primaria el establecer sus vínculos parentales del que surgen los derechos y deberes de los padres para con los hijos. ${ }^{49}$

La filiación es una determinación conjuntiva de la paternidad y maternidad, ya que el título de adquisición del estado de hijo tiene su causa en la procreación constituyendo ésta el presupuesto biológico fundamental en la relación jurídico filial, sin embargo, en la actualidad igual esta relación puede constituirse sin hecho biológico, sin procreación, sino mediante la figura de la adopción; o bien, mediante una filiación sin procreación como sería el caso de la reproducción asistida. ${ }^{50}$

El problema surge cuando se intenta correlacionar el vínculo biológico con el jurídico, ya que mientras el biológico es natural, ilimitado y reservado en su determinación, el jurídico es creado, limitado y concreto en su establecimiento, por ende contrapuestos. Así, podemos observar que escapa del Derecho la posibilidad de crear un vinculo biológico, sólo lo puede reconocer o impugnar,

una manifestación de voluntad del reconociente, y sólo a falta de tal voluntad, surge la declaración judicial que atribuye, ahora si, las consecuencias de lo biológico”; op cit, pp. 68 y 69

${ }^{49}$ CICU, señalaba en su época en este sentido que "el estado de filiación se da propiamente en la familia legítima, es decir, en la procreación dentro del matrimonio”, La filiación, traducción Faustino Giménez Tejeiro Arnau y José Santacruz Tejeiro, Revista de Derecho Privado, Madrid, 1930, p. 18

50 Cecilia GROSMAN, siguiendo el esquema de la filiación genética dice que: "En el caso de la inseminación artificial, sea mediante semen del marido o de un tercero, ya no es posible hablar de una presunción de paternidad, porque el responsable de la procreación no surge por inferencia de las relaciones sexuales habidas entre el hombre y la mujer durante la época de la concepción, sino por verificación directa del cuál ha sido el semen fecundante. Por lo que no puede aplicarse un esquema ideado para determinado desarrollo histórico - científico, a una situación originada en otra etapa de la evolución de la ciencia” Cfr. Acción de impugnación de la paternidad del marido; Buenos Aires; Ed. Abaco de Rodolfo Depalma; 1982, p. 101 
de allí que se ha afirmado que el vínculo jurídico no es el elemento creador de la filiación, sino que es el elemento calificador y condicionante de ésta.

Al respecto escribe KOZICKI, en un criterio similar, que el padre entonces es un lugar lógico creado por la ley, un juego de presunciones, un montaje de ficciones, una construcción racional... el elemento biológico y que solo resulta relevante si tiene soporte institucional, Vital instituere, decían los romanos, ya que no basta que la sangre nazca, debe ser instituida, "nacer" por segunda vez, a la ley y al poder" ${ }^{\text {. }}$.

Asumiendo esta posición, se derivan dos cuestiones elementales en lo que atañe a la filiación a saber: el hecho biológico de la procreación ${ }^{52}$ y el acto jurídico de la prueba.

Estos dos presupuestos básicos relacionados con la filiación sientan sus bases en las ciencias biológicas, las que tienen como regla evidente el hecho de que cada hijo tiene necesariamente un padre que lo fecundó y una madre que lo concibió; o de los dos porque la procreación es un hecho productor de efectos jurídicos, pero entre éstos no están necesariamente la atribución de un estado de filiación.

Por ende, no siempre existe una correlación exacta entre la paternidad jurídica y la paternidad biológica aun cuando el Derecho trate de apoyar la primera en la segunda, al establecer medios legales para buscar la verdad en relación a la filiación, haciendo un esfuerzo porque ambos conceptos concuer-

\footnotetext{
${ }^{51}$ KOSICKI, Enrique; “La filiación, El HLA, DNA, la ciencia y el derecho” en La Ley, tomo 1990-D, p. 195.

${ }^{52}$ El hecho de la procreación interesa al Derecho solamente en cuanto da lugar a una relación social especial, por la procreación se produce un sujeto de derecho que se relaciona con los demás individuos y con el Estado, pero se origina también una relación especial entre procreantes y procreado, lo cual significa que hay una actividad particular que deriva de tal cualidad que hay deberes y derechos que se refieren a ella" CICU, Antonio, Op Cit. p. 1
} 
den; sin embargo como analizamos en el presente trabajo, sería de gran importancia el que se establezcan reformas en las cuales las pruebas de filiación fueran obligatorias para dar una certeza y protección de saber el origen filial.

\subsubsection{Elementos de la filiación}

Es indudable que en esta institución del Derecho familiar convergen una serie de elementos que hacen de ella una figura jurídica rica y compleja. Con la filiación se tiene una concurrencia de hechos que no siempre se agotan solo en los biológicos para establecer los presupuestos jurídicos que el derecho debe regular, sino que por el contrario a esta figura cada vez más se incorporan elementos de carácter afectivo, espiritual, social, etcétera, que hacen de la filiación una relación paterno filial con complejas consecuencias jurídicas.

a) Dato biológico; El hecho natural es sin duda, el primer elemento considerado. En efecto la relación paterno-filial tiene fundamentalmente una base biológica inexcusable, sobre la que se levanta en principio la institución. Hay un hecho biológico, que se determina por el nacimiento. Es un hecho natural que existe en todos los seres humanos, ya que siempre se es hijo o hija de un padre y de una madre.

Así las cosas, la procreación es una realidad recogida y amparada por el Derecho. Ante esto CICU $^{53}$ ha sostenido que el hecho de la procreación interesa al Derecho solamente en cuanto da lugar a una relación social especial, por la procreación se produce un sujeto de derecho que se relaciona con los demás individuos y con el Estado. Pero se origina también una relación especial

${ }^{53}$ Op cit. P. 16 
entre procreantes y procreados, lo cuál significa que hay una actividad particular que deriva de tal cualidad, que hay deberes y derechos que se refieren a ella. En la vida social esta misión se lleva y se extiende también al campo espiritual y pasa a ser crianza y educación a un tiempo, y, como actividad del espíritu, hace estable y duradera la relación creada, originando un vínculo perpetuo que sobrepasa la vida individual; pero para ello, antes que nada necesita asegurarse la paternidad o maternidad; para reconocer sus efectos jurídicos al hecho de la procreación.

De esta idea deriva la definición de la filiación como relación biológica existente entre padres e hijos, dotada de un contenido jurídico desde el momento que el ordenamiento atribuye derechos y obligaciones entre estos y aquellos $^{54}$; es decir, derivada de la relación biológica que supone la generación, relación que varía según se contemple del lado de los progenitores (paternidad o maternidad) o del lado de los descendientes (filiación).

La maternidad y paternidad son dos elementos en que se basa la relación de filiación desde el punto de vista físico, ya que todo aquel que nace necesariamente tiene un padre y una madre; el problema estriba en que idénticos hechos naturales, no tienen tratamiento jurídico idéntico, en razón de determinadas circunstancias extrínsecas a los mismos, la relación jurídica sólo existe entre el hijo (a) y sus dos progenitores, sin embargo esta relación puede no existir en casos concretos, bien porque resulten totalmente desconocidos o no identificables los progenitores del hijo (a), o uno de ellos, generalmente el hombre, bien porque, aunque se sospeche quién puede ser, falten pruebas. ${ }^{55}$

\footnotetext{
${ }^{54}$ FERNANDEZ GONZÁLEZ, Ma. Begoña; El reconocimiento de los hijos no matrimoniales, Dykinson, Madrid, 1998, p. 37, Derecho de familia, México, p. 356

55 HERRERA CAMPOS, Ramón, La investigación de la paternidad y la filiación no matrimonial, Universidad de Granada, Granada, 1987, p. 29
} 
Sin embargo, tenemos que señalar que aun cuando lo ideal es la coincidencia entre el hecho biológico, para el Derecho resulta intrascendente que haya equivalencia plena entre la relación biológica y la relación jurídica, ya que se dan casos en que existen progenitores que no son padres en el sentido estrictamente jurídico de la palabra, y por el contrario, hay padres para el Derecho que no son progenitores. En principio, la filiación es una relación biológica y jurídica; porque al vínculo de sangre se une la relación jurídica; pero eso no impide que pueda darse una relación biológica, pero no jurídica, o por el contrario conste una filiación jurídica que no sea la biológica.

b) La voluntad: En la filiación la voluntad juega un papel diverso, aun cuando el Derecho de familia se caracteriza por su conjunto de normas imperativas, en esta materia se pueden apreciar sensiblemente disminuidas, ya que cada vez se observa una mayor intervención de la voluntad de los sujetos en cuya relación intervienen, algunas veces por parte de los padres, otras por parte de los hijos, lo que sea necesario para regular los efectos ${ }^{56}$.

El elemento voluntario está presente incluso en el concepto actual de filiación que rebasa a los progenitores otorgando esa connotación a personas ajenas, creando el mismo vínculo jurídico; y su función social es tan relevante que ha dado origen a una categoría de filiación, en la que voluntariamente se prescinde de la relación natural derivada de la reproducción para sustituirla por otra relación no natural o exclusivamente social, ante la incapacidad y/o la negativa de los progenitores naturales para llevarla a cabo. Es el caso de la filiación

\footnotetext{
${ }^{56}$ Ese elemento voluntarista adquiere especial trascendencia, por ejemplo en la filiación fuera del matrimonio, donde el reconocimiento voluntario por parte del padre aparece como medio fundamental para establecer la paternidad en todas las legislaciones; también en el reconocimiento se requiere la voluntad del hijo o hija por reconocer: en la investigación de la paternidad o maternidad hay libertad para indagarlas.
} 
adoptiva, cuyo significado ha ido creciendo hasta el punto de quedar equiparada con la filiación consanguínea ${ }^{57}$.

Así las cosas, la paternidad y la maternidad no son ya un hecho solamente biológico: la adopción ha creado un tipo diferente de paternidad y de maternidad que puede llamarse afectiva o social, lo que nos lleva a que no siempre se pensó en una paternidad legal, y la que puede o no corresponder con la paternidad biológica ${ }^{58}$. Es evidente que no siempre debe existir una identidad biológica para la existencia de una identidad filial legal.

Aunado a lo anterior, también se puede enunciar otro nuevo modo de filiación que requiere ineludiblemente del concurso de la voluntad; que no es otro más que la procreación con el auxilio de los avances científicos, ya que se permite la utilización de las técnicas de reproducción asistida, siempre que se cuente con el consentimiento de los interesados, cuya voluntad permite atribuir la paternidad o maternidad. No hay duda que este elemento es fundamental en la constitución del concepto actual del Derecho de filiación.

De esta manera se establecen unas filiaciones de tipo jurídico que no coinciden con las biológicas o por naturaleza; lo que ha permitido que algunos juristas distingan los conceptos de padre y madre del de progenitor, pues estas figuras jurídicas ya no tienen que coincidir desde el punto de vista legal. ${ }^{59}$

\footnotetext{
${ }^{57}$ BERCOVITZ y RODRÍGUEZ-CANO, Rodrigo; "La filiación inducida y las clasificaciones legales”, II Congreso mundial vasco, La filiación a finales del siglo XX, Problemática planteada por los avances científicos en materia de reproducción humana, Ed. Trivium, S.A., Madrid, 1988, p. 118

58 CASINI, Carlo, "Informe sobe la fecundación artificial in vivo e in vitro" Parlamento Europeo, Problemas éticos y jurídicos de la manipulación genética y de la fecundación humana, Comisión de Asuntos Jurídicos y de Derecho de los Ciudadanos, Oficina de Publicaciones Oficiales de las Comunidades Europeas, Bruselas, 1990, p. 91

59 En este sentido Vicente MONTES PENADES, establece que la "filiación no es necesariamente una situación derivada de un hecho biológico, por lo que padre y progenitor no son sinónimos. Padre tiene una carga de sentido socio-cultural y jurídico de la que carece el término -progenitor-” en: "Las características negociales de las técnicas de reproducción asistida”, Actualidad Civil, Revista Semanal técnica jurídica de derecho privado, 1994-4, Actualidad Editorial, S.A., Madrid, España, 1994; p. 968
} 


\subsubsection{Clases de filiación}

Las clases existentes de filiación son la matrimonial y la extramatrimonial, tienen su antecedente y deben su origen al Derecho romano, “...donde el advenimiento de la prole se consideró como un beneficio de los dioses y su falta como un castigo, lo cual se explicaba porque con la perpetuación de la prole, se procuraba la existencia de seres que rindiesen culto a los antepasados”60

Una de las características del Derecho familiar romano era el distinguir a los hijos en aquellos habidos dentro del matrimonio y los habidos fuera de él, criterio éste que prevaleció hasta nuestros días para efectos de la determinación, más no para la jerarquía filial, la cual ha sido desplazada por el principio de igualdad o bien de unificación de la filiación ${ }^{61}$.

El sistema jurídico que se ha venido estableciendo en México, siguiendo homólogamente al de España, ha sido el de establecer diversas reglas aplicables según se trate de hijos de los cónyuges o de hijos de personas que no se encuentran unidas por algún vínculo jurídico afectivo, pero más que en cualquier otro sentido, se debe apreciar su carácter de medio a probar cada una de las formas de filiación, en base a lo que establece cada una de ellas.

\footnotetext{
${ }^{60}$ BUENO RINCÓN, Enrique Fabio; La Investigación de la filiación y las pruebas biológicas; $2^{\mathrm{a}}$ edición, Santa fé de Bogota, 1996, p. 36

${ }^{61}$ Este principio tiene su origen en la socialización de las relaciones jurídicas, sustentada en forma genérica en el respeto y máxima consideración al ser humano, muy en específico del derecho a la igualdad y dignidad de que goza, estableciéndose que el hecho de la generación de vida es uno solo y que, como tal, la filiación presenta la misma característica, la unidad; por lo que los distingos y diferenciaciones se condicen con la esencia propia de esta relación jurídico - familiar, por ende al referirnos a la filiación como matrimonial o extramatrimonial da un trato desigual o discriminatorio. Es decir, la unidad de la filiación es el trato igualitario y singular en cuanto a los efectos que ésta produce independientemente del estado civil de los progenitores.
} 
La ley mexicana regula este tema en el Código Civil Federal, de aplicación para toda la República mexicana, y la cual no hace distinción del origen de la filiación, no distinguiendo entre hijos nacidos fuera o dentro del matrimonio, lo cierto es que en dicho sistema jurídico la filiación de los hijos y los cónyuges se prueba por vía el acta de nacimiento y de matrimonio de los padres, y la filiación de los hijos fuera de dicho vínculo se prueba, respecto de la madre sólo por el hecho del nacimiento y el reconocimiento; en cambio, respecto del padre por un acto de voluntad como es el reconocimiento, o bien a través de un medio forzoso, como lo es la sentencia que declara la paternidad o maternidad.

En el caso de la legislación civil española, bajo un concepto igual, nos indica una separación entre la filiación de los hijos nacidos dentro y fuera del matrimonio. Para los primeros sigue la formula de comprobación mediante la inscripción del nacimiento junto con la de matrimonio o bien sentencia firme ${ }^{62}$. Ahora bien, para el caso de los hijos nacidos fuera del matrimonio la filiación quedará determinada legalmente ya sea por el reconocimiento ante el encargado del Registro Civil; en testamento o en otro documento público, o bien por resolución recaída en expediente tramitado con arreglo a la legislación del Registro Civil, o por sentencia firme. ${ }^{63}$

Ahora es conveniente especificar que los hijos nacidos dentro de matrimonio son aquellos que son concebidos bien dentro del matrimonio de los padres o en los plazos legales que analizaremos más adelante, y se determina por el parto, más la identidad del hijo (a) para la maternidad. Para el caso de la

\footnotetext{
${ }^{62}$ Artículo 115 del CCE que estipula: "la filiación matrimonial materna y paterna quedará determinada legalmente: 1. Por la inscripción del nacimiento junto con la del matrimonio de los padres; y 2. Por sentencia firme.

${ }^{63}$ Sección Tercera De la determinación de la filiación no matrimonial, artículo 120 del Código Civil Español.
} 
paternidad, como es más difícil e incierta su determinación, hay necesidad de recurrir a la presunción de la paternidad ${ }^{64}$, ya que no se puede conocer en forma directa e inmediata, por la imposibilidad de penetrar en la intimidad de la pareja.

La condición para que se tenga la filiación de hijo o hija de los cónyuges en términos generales, es que la concepción se realice dentro del matrimonio, aunque cada vez la ley se va inclinando para determinar la filiación dentro del matrimonio la fecha de su nacimiento, es decir, que el parto del hijo o hija tenga lugar después de haber contraído matrimonio el padre y la madre, aun cuando su concepción tenga lugar antes de este vínculo. Así se tiene como hijos de los cónyuges a los que han sido concebidos antes de la fecha de su celebración pero que tienen esa categoría, si el marido sabe del embarazo antes del matrimonio, si concurre al levantamiento del acta de nacimiento y la firma, si reconoce expresamente por suyo al hijo o hija de su mujer. Todavía más elocuente es fijar la presunción de paternidad a partir de la celebración del matrimonio, como actualmente se establece en el Código Civil Federal de México y como se estipula en el Código Civil español

La filiación de los hijos que nacen de personas que no están unidas por el matrimonio se establece por el reconocimiento voluntario, como acto jurídico consistente en la afirmación de paternidad o maternidad hecha por el padre o madre respectivamente, que confiere un status filii que lo liga al reconocedor; acto solemne, que se realiza ante el encargado del Registro civil, en testamento o en documento público, por una sentencia que declare la paternidad o de la maternidad y por la misma presunción que establece la ley para los hijos

\footnotetext{
${ }^{64}$ Dicha presunción se funda en los plazos mínimo y máximos de gestación. Es otra colaboración de la Medicina en el Derecho. GIL RODRÍGUEZ, Jacinto, "La reproducción humana asistida como acto médico y el fundamento del anonimato", Boletín de información del ministerio de justicia, año XLV, núm, 1593, Madrid, España, 15 de marzo de 1991, p. 1603
} 
nacidos del matrimonio, pero en este caso a los hijos de concubinato ${ }^{65}$ o bien de una pareja de hecho.

Entre estos dos puntos, queda comprendida la filiación adoptiva, que es aquella equiparada a la filiación por naturaleza, solo que por efecto de una declaración de voluntad, la cual hace indispensable también para el establecimiento de la filiación de un hijo o una hija que son procreados con el auxilio de los avances científicos. En ambos casos tendrán la filiación atendiendo el vínculo jurídico que une a sus padres, que generalmente serán consecuencia del matrimonio.

Aquí sería importante analizar lo expresado por la legislación mexicana $^{66}$, la cual para estos efectos, cuenta con legislaciones en cada uno de los Estados, sin embargo todas ellas se han hecho homólogas, si bien se cuenta con tres Estados con leyes específicas en materia de Derecho familiar y las cuales son Hidalgo, Zacatecas y la más nueva de Michoacán.

En el primero de los casos, en la Ley para la Familia del Estado de Hidalgo, hace en su definición de filiación, una separación dependiendo del lazo al cual sea atribuido al menor, así tenemos que queda conceptualizada como la relación entre dos personas, que se da por el hecho de engendrar o concebir una a la otra, incluyendo dentro de este los actos jurídicos de la adopción y por el reconocimiento; así, se entiende porque a la relación entre padre e hijo se llama paternidad; y entre madre e hijo, maternidad.

\footnotetext{
${ }^{65}$ Es de aclarar que el término de Concubinato se encuentra aún como una figura legal dentro del derecho familiar mexicano y la cual a la fecha se encuentra en total vigencia como una unión de pareja libre de matrimonio.

${ }^{66}$ Los conceptos que se adquieren en las legislaciones especializadas en la materia en México, son tomadas de la Legislación federal en forma idéntica, sin embargo agrupadas en leyes familiares exclusivamente y no genéricas como seria el Código Civil Federal.
} 
Así del mismo modo, hace la premisa de los hijos nacidos fuera del matrimonio, y para lo cual ha señalado que en estos casos la madre y el padre solteros tienen obligación de reconocer a sus hijos, ya que la filiación de los hijos nacidos fuera del matrimonio sólo se establecerá por el reconocimiento voluntario o por una sentencia que declare la paternidad o maternidad en su caso.

Ahora en el Código Familiar para el Estado de Zacatecas, no existe una definición legal de que es lo que se entendería por filiación, sino que pasa directamente a regular la forma de cómo es que se contempla esta figura, haciendo ver que la filiación resulta de las presunciones legales, o del nacimiento, o del reconocimiento o por virtud de una sentencia ejecutoriada que la declare; aumentando a ello que igual es resultado de la adopción.

Desde otro punto de vista el Código Familiar para el Estado de Michoacán, podemos decir que con una falta clara de técnica legislativa, en el apartado donde debería por lo menos introducir a las formas de cómo se establecería la filiación, pasa por completo de ello, sin dar ni un concepto base ni las formas de determinación, sin embargo inmediatamente nos conduce a la presunción de los hijos tanto dentro como fuera del matrimonio.

No obstante aquí podemos resaltar lo estipulado en el Derecho Civil alemán, en su artículo 1591, que hace la distinción legal de la madre y el padre, disponiendo que madre de un niño es la mujer que lo ha alumbrado y que el padre de un niño es el hombre que en el momento del nacimiento, está casado con la madre del niño; que ha reconocido la paternidad o bien cuya paternidad ha sido determinada judicialmente.

Opinamos que del análisis realizado con anterioridad sobre distintas legislaciones, entre ellas mismas existen grandes diferencias entre lo que 
consideran como la filiación, que aunque al final todas inciden en lo mismo es un tema que no puede dejarse a la ligera y al entendimiento, por lo cual dar pasos hacia una armonización sobre el concepto a nivel internacional es un buen punto de inicio para así velar por los intereses de la familia y sus integrantes.

\subsubsection{Efectos de la filiación}

Todos los hijos, independientemente de su origen, siempre que su filiación esté establecida tienen la misma condición y la filiación los mismos efectos. La relación paterno-filial es una de las más ricas en Derecho privado y sus efectos se proyectan en muchas áreas jurídicas, no sólo en el ámbito del Derecho de familia (alimentos, patria potestad, tutela, etcétera) sino también en el Derecho de personas (nacionalidad, domicilio, entre otros) y en el Derecho de las sucesiones; sin embargo no son motivo del presente trabajo de investigación; sino que en este apartado nos referiremos únicamente al apellido, alimentos y sucesiones que queden reglamentados para el caso del reconocimiento de hijos, por ser el tema central de nuestra investigación.

Se debe mencionar que sobre los hijos nacidos fuera del matrimonio, al comprobarse su filiación, si aun fueren menores de edad, ejercerán la patria potestad quienes se les haya atribuido dicha filiación, así como todos los derechos y obligaciones que conlleva la paternidad. Conveniente es decir, que los hijos menores de edad, cualquiera que sea su filiación se someten a la patria potestad de sus padres para el caso del matrimonio y de quien lo haya reconocido en el caso de los hijos nacidos fuera del matrimonio, pues es la institución del Derecho de familia que tiene por objeto la guarda y custodia de la persona del menor y de sus bienes. Lo mismo sucede con la tutela legítima que siendo una institución subsidiaria de la patria potestad tiene por encargo la protección de los 
menores e incapacitados y sus bienes derechos, los cuales para ambas figuras de protección al menor, principalmente serían:

\section{a) Apellido}

Se refiere este efecto a que el niño o la niña tengan el derecho de llevar el apellido de su madre y de su padre. Los hijos del matrimonio, llevarán el nombre o nombres propios que les impongan sus padres, seguidos del apellido del padre y de la madre; y los hijos fuera del matrimonio llevarán el nombre o nombres que les imponga quien o quienes los reconozcan, seguidos del apellido o apellidos de éstos. Se procede de la misma manera cuando se establezca la paternidad o maternidad por sentencia ejecutoriada.

Para el caso de la adopción, se siguen las reglas de los hijos consanguíneos nacidos fuera o dentro del matrimonio. En el caso de la adopción simple, existe la elección del adoptado, de usar el nombre que ya ha adquirido desde su nacimiento, o puede cambiarlo y agregar el apellido del adoptante. En México en el caso de adopción plena, se levantará un acta como si fuera de nacimiento, en los mismos términos que la que se expide para los hijos consanguíneos, conforme establece el artículo 86 del Código Civil del Distrito Federal.

Sin embargo en el Código Civil español, la adopción es plena, por ende tendrá el adoptado los apellidos de los adoptantes; de igual forma es un derecho que se encuentra estipulado por la Convención sobre los Derechos del niño de 2 de septiembre de 1990, en su artículo séptimo, al establecer que “...1. El niño será inscripto inmediatamente después de su nacimiento y tendrá derecho desde que nace a un nombre, a adquirir una nacionalidad y, en la medida de lo posible, a conocer a sus padres y a ser cuidado por ellos.” 


\section{b) Alimentos}

Este derecho puede tener gran relevancia, ya que los hijos tienen derecho a recibir alimentos de sus ascendientes, en una forma de protección a la vulnerabilidad con que cuenta el ser humano desde que nace, considerando la ley la mayoría de edad como el momento propicio para que éste pueda hacerlo por si, y es cuando podemos hablar de la reciprocidad en materia de alimentos, ya que los padres al encontrarse en estado de incapacidad tienen también el mismo derecho a recibir alimentos por parte de sus hijos -es una obligación que la ley impone hasta el cuarto grado en parentesco por consanguinidad-. Lo mismo sucede con la adopción plena.

\section{c) Derecho sucesorio}

Uno de los efectos de la filiación es el derecho que tienen los hijos a heredar; así como a recibir una pensión alimenticia que fija la ley para el caso en que mueran los padres y viceversa, así los hijos filiales, llámense consanguíneos o por adopción, incluso ambos por ser considerados iguales ante la ley, tienen el derecho y obligación plena de la sucesión de sus padres.

\section{d) Parentesco}

La filiación produce un efecto básico, consistente en la creación de un vínculo inicial de parentesco entre el progenitor y su hijo o hija, que se extiende a un amplio conjunto de relaciones jurídicas de muy variada índole, como los 
impedimentos para contraer matrimonio, revocación de las donaciones por supervivencia de hijos, la patria potestad, etcétera ${ }^{67}$

\subsection{Determinación de la filiación}

Al referirnos a la determinación de la filiación, nos referimos a "la afirmación jurídica de una realidad biológica presunta”"68 es decir, "la filiación se determina por naturaleza o de manera formal, la filiación por naturaleza puede ser matrimonial o extramatrimonial; así como la formal, que surge de la adopción o por técnicas de reproducción humana asistida”,69

La filiación se acredita conjuntamente respecto del padre y de la madre. Al demostrar la maternidad se manifiesta, propiamente y siempre, la paternidad del esposo a pesar de que luego pueda ser impugnada. ${ }^{70}$

Esta filiación sienta sus bases en la presunción pater est, la cual se ha mencionado como regulada en los artículos 116 y 324 respectivamente de la CCE y CCFM reafirmando la presunción de la paternidad, ya que le atribuye en

\footnotetext{
${ }^{67}$ GALINDO GARFIAS señala que: "la filiación se relaciona con el concepto jurídico de parentesco consanguíneo, que como s recordará, ya sea en la línea recta o en la línea colateral, queda establecido respecto de las personas que descienden de un tronco común; es decir, de una pareja de progenitores, un varón y una mujer, que son los ancestros del grupo de parientes. La fuente primordial de la familia es la filiación, que es el parentesco más cercano y más importante: el que existe entre los padres y los hijos y que por su particular relevancia, toma el nombre de filiación”, en: GALINDO GARFIAS, Ignacio, Derecho Civil; Primer Curso, Parte General, Personas y familia, Editorial Porrúa ; México, 1993, p. 582

${ }^{68}$ LA CRUZ, ALBADALEJO, José y SANCHO REBULLIDA, Francisco de Asis; Derecho de familia, Barcelona, Bosch, 1982, p. 606

${ }^{69}$ VARSI ROSPIGLIOSI, Enrique. Derecho Genético; Universidad de Lima; Perú; 2006.

${ }^{70}$ En un inicio el principio de protección de la familia no admitía otro supuesto de impugnación que la imposibilidad física del esposo ya sea importancia o infertilidad; Al respecto ALVADALEJO, establece que la afirmación legal de paternidad matrimonial es inatacable, aunque la madre y el marido sean blancos, el hijo mulato, la madre haya sido condenada por adulterio cometido por un negro y, además. La prueba de los grupos sanguíneos demuestre que el ser dado a luz por la mujer no puede ser hijo del marido.
} 
forma automática el vínculo paternal (atribución de paternidad ministerio legis $u$ ope legis)

El establecimiento de la paternidad matrimonial se sustenta en el denominado período de concepción y gestación de manera tal que, legalmente, la gestación tiene una duración mínima de 180 días y máxima de 300, mientras que la concepción se produce dentro de los primeros 121 días de los 300 anteriores al nacimiento. ${ }^{71}$

Esta presunción, si bien dispensa de probar el hecho biológico, no descansa sino en un presupuesto de regularidad social que se traduce en contenidos éticos que dan sentido a la institución del matrimonio mismo, tales como la fidelidad y cohabitación que, como decía MAZZEAUD ${ }^{72}$, son los pilares de la unión monogámica o presunciones vitales, de las que se deriva una presunción negativa de infidelidad y una presunción positiva del contacto.

Sin embargo, la presunción pater est tiene un carácter de historicidad que deberá dar paso a andar a la par con una información técnica pues su carácter histórico desmedra su eficacia y le otorga valor absoluto. ${ }^{73}$

\footnotetext{
${ }^{71}$ Este es lo que se le ha llamado postulado ovni meliore momento, por el cual la ley contempla una etapa de la fecundación y no el momento en que se produce la concepción.

${ }^{72}$ MAZEAUD, Henri; Lecciones de Derecho civil. La familia, Constitución de la familia, Trad. Por Luis Alcalá Zamoda y Castillo, Parte Primera, V. III, Ediciones jurídicas Europa - América, Argentina. P. 85

${ }^{73} \mathrm{Al}$ caso JOSÉ DE JESÚS ÁLVAREZ, en su artículo "El examen de los grupos sanguíneos como medio de prueba jurídica” en Revista de Derecho y Ciencias Política No. 9, p. 163 estima”Lo que hasta aquí fue invulnerable presunción de legitimidad debe dar paso a los hechos de la vida; porque, por razonable que sea esta presunción, después de todo no es más que una apariencia que puede ser destruida por la prueba en contrario. Las presunciones deben ser consideradas, según expresión de un juez norteamericano, como murciélagos de la ley, volando en el crepúsculo, pero desapareciendo bajo el sol de los hechos reales, mientras que el examen de los grupos sanguíneos, rayo de luz en la delicada, difícil de aprehender y engañosa cuestión de paternidad, disuelve aquélla, presunción erigida artificialmente”.
} 


\section{Filiación extramatrimonial.}

Frecuentemente el hijo extramatrimonial goza de hecho de status filii, pero no del status familiae, es decir, que tendrá un nombre, pero no las relaciones familiares completas, al tratarse de los hijos concebidos fuera del matrimonio y a falta de emplazamiento, sea por reconocimiento ${ }^{74}$ o la declaración judicial. Lla filiación materna puede ser acreditada con independencia de la paterna, sin que por establecer la una se induzca la existencia de la otra.

En sentido básico tenemos que los presupuestos de la filiación extramatrimonial son la maternidad y la paternidad de ambos hechos biológicos de los progenitores.

Tradicionalmente, las doctrinas han distinguido la filiación "legitima" de la "ilegítima", determinando para aquélla un trato privilegiado y degradando la última, sus antecedentes los tenemos en el Derecho en la Roma clásica, donde se estimulaba la unión matrimonial dando fijeza, certidumbre y estabilidad a los derechos y obligaciones emergentes de la procreación y a las relaciones parentales derivadas de la unión matrimonial.

La protección a las relaciones matrimoniales trajo como consecuencia la satanización de las uniones sexuales extramatrimoniales, de tal manera que constituían delito la unión sexual de dos personas libres (estupro) o la unión de una persona libre con una que no lo era (contubernio), en estos casos el fruto de la concepción no era considerado ni siquiera como hijo natural.

\footnotetext{
74 Entendiendo al reconocimiento como el acto jurídico de orden familiar por el cual se determina unilateralmente el vínculo filial del padre con el hijo.
} 
Pero el concubinato tuvo un trato especial, ya que el vínculo que derivaba de éste configuraba similar certeza que la del matrimonio, sin embargo este criterio de paridad de la relación vincular que surgía del matrimonio o del concubinato sólo tuvo vigencia hasta que el Derecho canónico afianzó el nexo matrimonial monogámico, basándose en el axioma jurídico: “enfamado es de fecho aquel que non nasce de casamiento derecho",75.

Al no existir en la filiación extramatrimonial un estado legal vinculante con respecto a su descendencia, únicamente la voluntad reproducida en el reconocimiento o la imposición legal, traducida en la declaración judicial, serán los medios de establecerla.

\section{Filiación Materna}

El axioma mater semper certa est etiam si vulgo concepteril ${ }^{76}$, (la madre resulta siempre cierta) tomado por Paulo del Digesto, nos decía que la maternidad era siempre indubitable y que su prueba era sencilla, directa $\mathrm{y}$ demostraba un hecho simple y común: el sólo hecho de ver en estado gestante a una mujer hacía presuponer que el hijo que luego veríamos llevar en sus brazos sería de ella ${ }^{77}$.

El primer alcance legal sobre el tema se dio con la Ley de las XII Tablas, la cual estableció que: “4. Una mujer conocida por su indiscutida honestidad dio a luz en el undécimo mes de la muerte de su marido; y se originó cuestión respecto la concepción, que se reputó posterior a la muerte de aquél,

\footnotetext{
${ }^{75}$ CORNEJO CHÁVEZ, Héctor; Derecho Familiar peruano; 6a edición; Lima; Librería Studium; tomo II, 1987, p. 90

${ }^{76}$ DIGESTO, ley 5, título 4, libro 2

${ }^{77}$ Partus séquitur ventrem, Instituta 2,1,19
} 
pues los decenviros establecieron que los partes legales debían tener lugar dentro del décimo mes, no, del undécimo»,78

En la práctica este sistema ofrece dificultades, pues es justo en los casos en controversia cuando la maternidad no puede presentarse como indubitable, salvo que el juez hubiese asistido al parto, de esta manera los supuestos de simulación de embarazo o de parto, inscripción indebida registral, maternidad disputada, transcurso del tiempo que posibilite el examen de parto entre otras, son casos en los cuales sólo podrá determinarse la maternidad con ayuda de las pruebas heredobiológicas.

Se ha denominado también "filiación legítima". Era la derivada por efectos del matrimonio otorgado a los hijos ex iusto matrimonio, con la condición de libres y por tanto con todos sus derechos civiles y políticos. Esta filiación es una institución que se encuentra unida al matrimonio entre los progenitores, siendo su causa esencial, sin embargo el solo acto matrimonial es insuficiente para establecer la filiación, hecho por el cual han surgido algunas teorías que tratan de determinar qué tipos de hijos son matrimoniales y cuáles no.

\section{a) Teoría de la concepción.}

Considera como hijos matrimoniales los engendrados por los padres casados, sea que nazcan dentro del matrimonio o sean alumbrados después de disuelto o anulado el vínculo. Es decir, en esta teoría los concebidos antes del matrimonio serán extramatrimoniales, aun cuando su nacimiento se verifique después del matrimonio; lo cual en nuestros días se encuentra reconocido por los Códigos Civiles, francés en su artículo 312 e italiano en el artículo 231.

\footnotetext{
${ }^{78}$ VARSI ROSPIGLIOSI, Enrique, “La ley de las XII tablas (su vigencia con el Código Civil Peruano en 1984”, en Revista jurídica del Perú, Trujillo, Ed. Normas Legales S.A., 1997 año XLVII No. 12, p. 75.
} 
Esta teoría establece una diferencia muy marcada entre los hijos de los mismos padres.

\title{
b) Teoría del nacimiento.
}

Serán hijos matrimoniales los nacidos en el momento en que sus padres estén casados, no importando el momento en que hayan sido engendrados, es decir, los concebidos antes de la celebración nupcial serán matrimoniales siempre que nazcan cuando aquéllas ya hayan sido contraídas, por ende, no lo serán los nacidos después de la disolución del acto jurídico del matrimonio, a pesar de que hayan sido procreados durante el mismo, haciendo depender de manera ventajosa la calidad filial de tres hechos:

\author{
1. Celebración del matrimonio \\ 2. Parto \\ 3. Disolución del matrimonio sea por divorcio o nulidad. \\ c) Teoría Mixta
}

También denominada del nacimiento - concepción. En esta es importante la atribución de la paternidad matrimonial tanto al hecho propio de la concepción como del nacimiento, siempre que se respeten los plazos legales determinados por la ley. En este punto se presumen hijos del matrimonio los nacidos después de 180 días de celebrado el matrimonio; los nacidos dentro de los 300 días siguientes a la disolución del matrimonio, en el caso de México; sin embargo para España, el término inicial no existe, imponiéndolo únicamente a los nacidos “después” de la celebración del matrimonio, entendido entonces que serán hijos matrimoniales incluso los nacidos al primer día de celebración del 
mismo. Pero el padre se encuentra facultado por el artículo 117 del Código Civil Federal, de romper la presunción de ser el padre siempre que el hijo haya nacido “dentro” de los 180 días iníciales a la celebración del matrimonio.

Analizado lo anterior, observamos que se encuentra sustentada en varios presupuestos:

- $\quad$ La filiación surge a partir del hecho de la concepción

- $\quad$ El hombre casado con mujer se considera iuris tantum padre de los hijos de esta.

- $\quad$ La facultad del esposo de impugnar la paternidad del hijo de la mujer que le es imputado.

Esta teoría por ende es mucho más amplia, distinguiendo claramente entre:

- Maternidad,: al ser indudable por el hecho de que la madre es quien realiza el parto del hijo.

- Paternidad: el esposo es el padre de los hijos concebidos dentro del matrimonio (Pater est is quem justae nuptia demonstrant, ${ }^{79}$ ) siempre que el hijo nazca dentro de los términos indicados. ${ }^{80}$

En este caso, las legislaciones civiles tanto mexicana como española, siguiendo la misma tradición, tiene como hijos matrimoniales los nacidos dentro de la celebración de éste o bien procreados antes, pero nacidos dentro del matrimonio, o bien procreados dentro del matrimonio y nacidos dentro de los 300 días posteriores.

\footnotetext{
${ }^{79}$ Máxima contenida en el Digesto, ley 2, título 4, libro5.

${ }^{80}$ La concepción durante el matrimonio tropieza con el obstáculo de que el plazo de gestación no es igual siempre, ni puede fijarse con exactitud cada uno, y por ende, no es determinable con precisión la fecha de la concepción con relación a la del parto; así, la paternidad ni siquiera con las investigaciones es cierta; pero cabe establecer que con los actuales medios de prueba es seguro el establecimiento de la paternidad en todos los casos.
} 
Opinamos que si bien todas las teorías tienen gran relevancia y al final plena aplicabilidad dentro de las relaciones filiales, es necesario generar en vía del rompimiento de fronteras criterios iguales a nivel internacional, rompiendo un poco los estigmas e intentando generar principios a favor de la protección de los menores, quienes al final siempre deben tener un mejor derecho sobre sus progenitores.

\section{Filiación paterna}

Como antípoda al criterio pauliano se presenta el pater semper incertus (El padre siempre es incierto), que tiene como base originaria el carácter preciso de las relaciones sexuales y el momento de la fecundación. Así, “el fenómeno de la generación está, en cuanto al padre, rodeado de un misterio casi impenetrable y pocas veces propicio a la justificación mediante prueba directa, razón por la que es preferible establecer situaciones objetivas, solemnes y comprobables fácilmente que, por otra parte, sirvan de base para instaurar una presunción, allí donde no es posible instaurar una demostración”. ${ }^{81}$

Con base a ello desde la normativa romana se establecieron ciertas presunciones para determinar la paternidad, las que han perdurado hasta nuestros días sumiéndonos en un sistema cerrado y socialmente aceptado del concepto de paternidad.

Conforme avanza la ciencia biomédica en las investigaciones para determinar biológicamente la paternidad y en tanto sean debidamente aceptadas por nuestro derecho como pruebas positivas, las presunciones tendrán un lugar

\footnotetext{
${ }^{81}$ FERNÁNDEZ CLÉRIGO, Luis. El derecho de familia en la legislación comparada, México, Ed. Hispano Americana, 1987, p. 179
} 
importante en la declaración del vínculo paterno filial. El carácter de relevancia que tienen en nuestro medio las presunciones de paternidad han relegado el desarrollo científico y la admisibilidad judicial de las pruebas heredobiológicas. ${ }^{82}$

La paternidad jurídica y biológica, como hemos referido en líneas anteriores, es una sola, pero desde la óptica social puede tener varias aristas en su establecimiento; ya que decir que una persona es hija de otra, no necesariamente debe conllevar al vínculo biológico. Esto se sustenta en la realidad de que el ser padre o bien madre, más que el vínculo carnal de la procreación, es un estatus ganado por el actuar con esmero y oficiosamente al cuidado del menor, el ir generando en éste una identidad social y cultural como vínculo de afinidad entre ambos, a lo que se la ha denominado el criar a una persona. Por otro lado, el término de progenitor indica el vínculo únicamente biológico entre ellos.

En este punto María Dolores VILA-CORO, en forma clara precisa las clases o grados de paternidad en el siguiente sentido ${ }^{83}$ :

Paternidad plena: Hablamos de ésta cuando decimos que el padre es aquél que ha engendrado al hijo (padre biológico), pero que además tiene una relación jurídica con la madre (matrimonio o concubinato) ${ }^{84}$, y que le otorga la calidad de "padre legal”, tiene una presencia física en el hogar, en el desarrollo del niño y ejerce los derechos y obligaciones paterno - filiales.

\footnotetext{
${ }^{82}$ Tender a la verdad biológica dejando a un lado la verdad social es ponernos al día legislativamente remozando los conceptos que tradicionalmente han primado en el derecho de familia referido a esta materia. Admitir simplemente las pruebas biológicas no es la solución exacta. Brindarle adecuada regulación jurídica es lo conveniente, reafirmando el principio natural que la filiación tiene su causa iuris en la concepción.

${ }^{83}$ VILA-CORO BORRACHINA, María Dolores; Huérfanos Biológicos; Madrid, San Pablo; 1997; pp. 77-86

${ }^{84}$ Esta relación jurídica puede estar regulada de diversas formas, ya que bien en el caso de España podemos hablar de igual forma de las parejas de hecho, en la cual si bien no existe un matrimonio existe un vínculo jurídico entre la pareja.
} 
Paternidad referencial.- Es el padre cuyo hijo no goza de su presencia física, pero tiene referencias de él que lo ayudan a desarrollarse dentro de los parámetros de una familia con sus antecedentes y estirpes. El hijo conoce la identidad de su padre (rasgos, profesión, calidades, etc.), ésta puede presentarse en dos casos:

- Aquélla que corresponde al hijo de una pareja en la que el marido ha fallecido o está ausente.

- $\quad$ Aquélla que se da por fecundación post mortem, el hijo tendrá conocimiento de la identidad de su padre, pero está privado de los derechos legales.

Esta sirve para establecer la identidad filogenético del hijo.

Paternidad social.- En ésta el padre ha engendrado al hijo pero no convive con él, de manera tal que su relación o tiene efecto legal pero sí contenido emocional, ya que le permite tener a un hombre como imagen de padre

Padre excluido.- Es aquel padre que, producto de una técnica de reproducción, ha cedido su material genético (de manera anónima pues prima la reserva de su identificación) sin compromiso de asumir una paternidad, privando del derecho de conocer su identidad al hijo engendrado con su semen. Por ende éste no cuenta con la persona del padre ni con su presencia referencial, no podrá establecer su identidad filial.

Todo ello nos lleva a afirmar que la paternidad representa una multiplicidad de lazos y variedad de relaciones que, organizadas entre sí, orientan la labor natural del hombre en la familia, como es la interrelación padre - hijo. 
En otras palabras, la paternidad implica consideraciones de orden personal, biológico, social y legal, generando en su conjunto un estado paternal pleno.

\section{Parentesco, filiación y vínculos genéticos}

Podemos decir que el parentesco es la relación existente entre sujetos en virtud de la consanguinidad, afinidad o adopción que conforman una familia, mientras que la filiación como se ha destacado en epígrafes anteriores, es aquella que conlleva el núcleo paterno - materno - filial, es decir, es la relación del hijo con sus progenitores, a lo que igual se le conoce como familia nuclear o estado de familia general. El parentesco reposa esencialmente sobre la filiación, ya que en ésta se fundamentan sus orígenes y lazos entre los individuos.

Lato sensu, al referirnos a que entre dos personas existe ese lazo filial reconocido como parentesco, es porque tienen un antecesor en común, generando entre todos ellos las estirpes.

Stricto sensu, cuando existe una relación de descendencia en línea directa inmediata surge una paternidad o maternidad; lo que implica que la filiación estructurada sobre la base del parentesco. Es aquella relación parental entre dos personas que tienen un parentesco consanguíneo en línea recta ascendente en primer grado (hijo con el padre o la madre).

Las clases de parentesco implican la extensión de sus efectos, el consanguíneo es más fuerte que el afín, la línea recta que la colateral y los grados más cercanos contra los más remotos. Por su parte, la filiación como estado de familia específico, genera efectos erga omnes respecto de quienes gozan de ésta. 
Como forma de vincular a las personas dentro de una familia $y$ tomando en consideración las nuevas formas de individualización e identificación, el parentesco está variando su composición originaria que se sustenta en el método romano basado en la teoría pangenética de la herencia ${ }^{85} \mathrm{y}$ se está orientando hacia sus verdaderos objetivos, encontrar la real vinculación sanguínea entre las personas, es decir, la teoría de la herencia ${ }^{86}$.

Ricardo COKE, siguiendo esta línea nos dice que “... el Derecho romano y los códigos civiles estatuyen que los grados de parentesco de la familia están determinados por las distancias generacionales entre las personas, ascendiendo hasta un antecesor común. Por el contrario la teoría genética estatuye que los grados de parentesco están determinados en proporción de genes idénticos por descendencia”, ${ }^{7}$

2.3. La declaración judicial del vínculo paternofilial a través de los procesos de filiación: Las pretensiones de filiación

La declaración judicial de la filiación opera a falta de reconocimiento voluntario del padre o la madre respecto de un hijo extramatrimonial, ya sea porque desconfían de la certeza del vínculo, por un acto de mala fe, confusión, desconocimiento del procedimiento, costo, existencia de errores que impiden el

\footnotetext{
${ }^{85}$ Los grados de parentesco se determinan por las líneas generacionales entre las personas, ascendientes hacia un antecesor común, teniendo la división en grado, que es el vínculo entre dos individuos que forman una generación; la línea como la serie no interrumpida de grados; y el tronco, como el ascendiente común de dos o más ramas.

${ }^{86}$ En esta el parentesco se especifica de acuerdo con los genes idénticos que en proporción adquieren la descendencia por transmisibilidad, identificando como claves la proporción de genes idénticos a un antecesor común y reservorio común de genes iguales por descendencia, lo que establece el grado de parentesco.

${ }^{87}$ COKE, Ricardo; "Nueva nomenclatura familiar del genoma humano” en El Derecho ante el proyecto genoma humano, Madrid; Fundación BBV, vol. IV, 1994, pp. 147 - 154
} 
reconocimiento, descuido, actitud machista o feminista, etcétera; ${ }^{88}$ sin embargo estas causas no pueden ser motivo suficiente para dejar a un nuevo ser con la incertidumbre de la naturaleza de su propio origen de no saber cuáles son sus lazos y parentesco, ya que es un eslabón que se encontraría roto y sin la existencia de medios legales para conocer la verdad biológica y jurídica sería un hecho que por siempre tendría que ser incompleto, vulnerando claramente el derecho que éste tiene de saber de dónde proviene, tener una familia y sobre todo ser protegido.

Es por ello que el perjudicado con esta ingratitud paternal goza de la facultad de pedir que se practique la investigación correspondiente y que se declare en su momento la relación jurídica familiar pudiendo incluso, con legítimo derecho, exigir la reparación civil por el daño causado por no haber cumplido el padre con la obligación moral de reconocerlo en su momento.

\subsubsection{Concepto}

La presunción se refiere a un hecho en principio desconocido, que se deduce o induce de otros hechos conocidos con los que guarda relación. Así la presunción de paternidad se deduce de hechos conocidos o relación íntima existente entre los padres.

Las pretensiones de filiación están referidas al estado de familia y buscan el establecimiento del verdadero status filii, o calidad de hijo a través de un emplazamiento iniciado por quien carece de dicho status, o un desplazamiento cuando la filiación establecida no coincide con la real.

\footnotetext{
${ }^{88} \mathrm{Al}$ respecto se puede mencionar el programa DEMUNA, realizado por la institución sueca de protección a la niñez RADDA BARMEN, por el cual busca el reconocimiento voluntario de los padres a sus vástagos, a través de un Manual para promover reconocimientos voluntarios, y con la bandera "Si no reconocimos a nuestros hijos en el momento oportuno, estamos a tiempo de hacer la mejor inversión de nuestras vidas, reconocerlos ahora".
} 
El objeto de las pretensiones de filiación es facilitar la adecuación entre la filiación como hecho y la filiación como relación jurídica.

El fundamento de las mismas reside en la prueba de un hecho, la correspondencia entre la verdad biológica (procreación) y el estado filial (situación de hecho), de ahí que sea de la realidad biológica que se establezca por medio de la determinación o bien quede sin efecto a través de la impugnación el vínculo filiativo respecto del hijo y sus progenitores; en otras palabras, las pretensiones de filiación buscan la adecuación entre la verdad formal y la verdad biológica.

Como hemos visto, la ley tanto en México como en España, determina con precisión los días a computar y los momentos para iniciar éste, que como hemos visto es durante la gestación y que tiene una duración mínima de 180 días y máxima de 300, mientras que la concepción se produce dentro de los primeros 121 días de los 300 anteriores al nacimiento.

Sin duda que la más importante contribución del Derecho romano a la teoría y a la historia de la presunción de la paternidad en matrimonio es el célebre pasaje pauliano recogido por los compiladores justinianeos en el Digesto D.2,4,5: "quia semper certa est (mater) atiam si vulgo conceperil: pater vero ist est, quem nuptiae demostrant”, 89

Esta regla romana pater is quem nuptiae demostrant, fue recogida por el Código de Napoleón, y la justificación de su inclusión se regía dada la imposibilidad de demostrar de manera directa el hecho de la paternidad y además

\footnotetext{
89 "El que nace de matrimonio es hijo del marido de la madre"
} 
llevaba consigo la tranquilidad de las familias y la paternidad de la especie dentro de matrimonio. La presunción de paternidad lleva a su vez, como presupuestos: a) que han existido relaciones sexuales entre la mujer casada y su marido; y b) que la mujer casada no ha tenido relaciones sexuales con ningún otro hombre que no fuera su marido ${ }^{90}$. Por su parte, LANFRANCHI, sostiene que la presunción de paternidad tiene como base o fundamento: a) la cohabitación entre los esposos; b) la fidelidad de la mujer; y c) el nacimiento en el tempus legitimus o plazo legal de gestación $^{91}$.

Efectivamente la presunción se desprende únicamente de la naturaleza de las relaciones conyugales, o sexuales, infiriendo que el marido tiene relaciones sexuales con su esposa y que el hijo o hija concebido por ella, es de él. Se le atribuye la paternidad sobre la regla del monopolio sexual recíproco entre los cónyuges. Luego es regla moral, jurídica que la mujer copule solo con el esposo, en tal virtud los hijos pueden nacer sólo como consecuencia de sus relaciones sexuales, por lo que parece razonable atribuir la calidad de padre al marido de la mujer que da a luz al hijo o hija. En este sentido, no se puede negar que la norma que regula la presunción presta solidez y firmeza a las relaciones entre los miembros de la familia, por ello también es razonable impugnar tal paternidad cuando se debe excluir la hipótesis del ayuntamiento fecundo entre marido y mujer; impotentia coeundi y generandi de él, imposibilidad material de relación entre la mujer y el hombre por falta de cohabitación en los tiempos presumibles de la fecundación.

Las presunciones suelen actuar en dos campos, tanto en orden al tiempo de la concepción, fijando un determinado periodo de tiempo en atención a la duración del embarazo, como en orden a la paternidad, en el sentido de

\footnotetext{
${ }^{90}$ SERNA MEROÑO, Encarnación, La reforma de la filiación, Ed. Montecorvo, Madrid, 1985, pp. 39-40

${ }^{91}$ Citado por RIVERO HERNÁNDEZ, La presunción de la paternidad; op. Cit. P. 179
} 
considerar padre al que aparece como marido de la madre, la famosa regla pauliana citada, cuya aplicación no supone únicamente que la concepción, la gestación o el nacimiento del niño o la niña tienen lugar en el matrimonio, sino también implica que la paternidad del marido es muy probable.

El orden jurídico se dirige a otorgar la regulación necesaria de la presunción para resolver sobre todo la impugnación de la paternidad que es el escollo más grande en este tema, ya que la paternidad se atribuye al cónyuge de la madre, por regla general en todos los sistemas jurídicos. El sistema legal mexicano no es la excepción, aunque todos los estados de la República mantengan la incerteza de la paternidad beneficiando al hijo con un favor iuris, el status filii sin que preocupe demasiado si ese lazo jurídico coincide o no con el biológico, la presunción pater is est, actúa ex lege, Durante su vigencia no requiere de ningún acto voluntario por parte de los interesados; la presunción de paternidad se produce únicamente con el nacimiento del hijo de una mujer casada dentro del plazo legal de concepción actúa desde el mismo instante del nacimiento del niño o la niña ${ }^{92}$; praesumptio iuris valida para la legislación española.

La filiación es parte de Derecho común en el caso español, que solo cuenta con un código civil y no representa problema alguno, por tener que ajustarse todas las comunidades al mismo; pero en el caso mexicano, le corresponde a cada entidad federativa legislar sobre la materia, en tal virtud cada uno de los estados y el propio Distrito Federal y el Código Civil Federal tienen regulada la filiación y la forma para resolver el problema de impugnación marital. En términos generales se circunscribe a la paternidad formal para la protección de la familia, es decir, que regulan una presunta paternidad, porque

\footnotetext{
${ }^{92}$ VERDERA SERVER, Rafael, Determinación y acreditación de la filiación, Bosch, Barcelona, 1993, p. 72
} 
priman intereses de tranquilidad y paz familiar, protección al matrimonio, honorabilidad, etcétera, sin que preocupe de si coincide con la biológica. Es por ello que, a excepción de Baja California Sur y el Distrito Federal, se señalan taxativamente los casos, circunstancias y medios con los que se puede impugnar la paternidad. Importa más la verdad sociológica, que la biológica, de modo que resulte más conveniente para la seguridad del estado civil y la estabilidad familiar, que quien ha venido ostentando una filiación determinada, continúe con ella siempre en interés del propio hijo (a). ${ }^{93}$

Baja California Sur y el Distrito Federal eliminaron la casuística para impugnar la paternidad, y por el contrario introducen una norma que permite toda clase de pruebas en la impugnación de la paternidad del marido, en busca de la realidad de los hechos, así cuando el marido no sea el padre del hijo o hija de su mujer, podrá impugnar su paternidad con todos los medios de prueba a su alcance.

Con este precepto tampoco se desconocen valores e intereses como la tranquilidad y paz de las familias, sino que se busca que la paternidad legal coincida con la verdadera. En un plano ideal, lo deseable es que coincidan la paternidad biológica y la paternidad jurídica, esto es, que el hijo o hija siempre que sea posible, esté relacionado jurídicamente con su verdadero padre.

En el caso de la Ley de Familia del Estado de Hidalgo, la presunción tiene un tratamiento especial, restringiendo el desconocimiento de la presunción de hijo del matrimonio, ya que encontramos dentro de la misma, que si un hijo nace después de 180 días de celebrado el matrimonio, o dentro de los 300 días siguientes a la disolución o anulación del mismo, se presume que sus padres son los cónyuges; sin embargo contra esta presunción se admite solo la prueba de

\footnotetext{
${ }^{93}$ FERNANDEZ GONZÁLEZ, Ma. Begoña, op cit. P. 38
} 
haber sido físicamente imposible al marido tener acceso carnal con su mujer, en los primeros 120 días de los 300 anteriores al nacimiento.

Ahora que en caso de adulterio por parte de la esposa, en el Estado de Hidalgo no autoriza al marido para desconocer al hijo de su matrimonio; excepto que el nacimiento se le haya ocultado, o por haberse cometido adulterio en la época de la concepción y así se declara en sentencia ejecutoriada.

Dentro de otra idea, la Ley para la Familia del Estado de Hidalgo igual presume hijos de los cónyuges, los nacidos después de los 300 días siguientes a la separación legal de ellos, pero siempre que éstos se hubieren reunido temporalmente, siendo hasta cierto punto ambiguo, ya que bien pudieron los cónyuges en una hipótesis jamás haberse separado en ese tiempo.

Hablamos de restricciones al desconocimiento, ya que el marido no podrá desconocer que es padre del hijo nacido dentro de los 180 días siguientes a la celebración del matrimonio cuando se pruebe que supo, antes de casarse, del embarazo de su futura esposa; requiriéndose para ello un principio de prueba escrita; si al levantarse el acta de nacimiento, fue firmada por él, si ha reconocido expresamente por suyo, al hijo de su mujer; o bien si el hijo no nació capaz de vivir, caso último en que los efectos de la filiación no tendrían una repercusión aparente a futuro.

En lo que respecta al Código de Familia de Zacatecas, se presume como hijos matrimoniales, tal como hace el Código Civil español, a los nacidos en cualquier momento después de la celebración del matrimonio; o bien, a los nacidos dentro de los trescientos días siguientes a la terminación del matrimonio, ya provenga ésta de la muerte del cónyuge, de la nulidad o de divorcio, siempre y cuando no hubiere contraído nuevo matrimonio la excónyuge. Este término se 
contará en los casos de divorcio o nulidad, después que de hecho quedaren separados físicamente los cónyuges.

Pero como defensa ante esta presunción el padre tiene como prueba la de haber sido físicamente imposible al cónyuge tener relaciones sexuales con su cónyuge, en los primeros ciento veinte días de los trescientos que han precedido al nacimiento, así como aquellas derivadas de las pruebas científicas.

En el caso del adulterio, el cónyuge no podrá desconocer a los hijos, alegando este hecho, salvo prueba en contrario.

Se han planteado diversas teorías acerca de la naturaleza jurídica de la regla pater is est, que intentaremos resumir de la siguiente manera:

1. Teorías que ven la presunción de paternidad como una simple presunción, es decir como una regla de prueba fundamentalmente. Es un medio de probar la paternidad ante la imposibilidad de demostrar de otra forma ese elemento de la relación paterno-filial. De este modo adquiere un significado o trascendencia probatoria, jurídico formal más que sustantiva. ${ }^{94}$

2. Teorías que la consideran una regla de fondo, imperativa, de naturaleza juris-sustantiva.

\footnotetext{
${ }^{94}$ En esta posición, BERNAL DE AFANADOR Y BUITTRAGO, afirman que: "Los doctrinarios han sostenido sobre la naturaleza jurídica de la presunción en el derecho procesal dos tesis encontradas, pues mientras una parte afirma que es un medio probatorio con características propias, otra por el contrario sostiene que constituye un sustituto de la prueba o exención de la misma. Pero la presunción no es un sustituto de la prueba sino es más, está constituida por un conjunto de pruebas de diversos hechos y actos jurídicos que en síntesis podemos concluir, que es una, sino la más compleja de las pruebas. En ella más que una prueba existe un razonamiento lógico, pero también es cierto que en ella se da el indicio, por lo cual también ha sido su esencia como medio de prueba, dicho razonamiento es en el fondo genérico de todos los medios de prueba pues en cada uno de ellos debe existir una relación entre la prueba, el hecho por probar y la conexidad entre ambos” BERNAL DE AFANADOR, Silvia Y BUITRAGO, Margarita, Impugnación de la paternidad legítima, Pontifica Universidad Javeriana, Bogotá, 1988, p. 29
} 
3. Teorías u opiniones intermedias, o de doble naturaleza, procesal y material, superpuesta, o alternativa, según el punto de vista. Estas teorías postulan que hay en esta institución, algo o mucho de sustantivo de regla de fondo y es también una presunción. Regulada para resolver el problema de prueba de la paternidad, cuando no se permiten otros medios directos u ordinarios.

En este último caso, podemos hablar de que entenderla como la norma material no es incompatible con concebirla también como norma procesal. La norma que decreta la paternidad del marido de la madre, presunción legal por reunir los requisitos que la definen, es relevante sin ninguna duda y produce efectos jurídicos fuera y antes de actuar en el proceso: todos los hijos concebidos o nacidos en matrimonio son del marido, en principio, sin necesidad de que esa regla invocada ante los tribunales. Si el legislador ha dictado la presunción de paternidad, es con toda seguridad, pensando más en su efectividad extraprocesal que en caso de litigio sobre la paternidad.

Si formalmente la regla pater is est es una presunción legal, tampoco puede desconocerse su proximidad, su parentesco con el Derecho procesal; pero en un sentido más profundo, en cuanto a su contenido, por su operatividad, por su alcance, la considera regla de fondo o más exactamente, una norma e institución sustantiva, de Derecho material. Ubicada en el límite entre el Derecho procesal y el Derecho material y la dificultad que halla para colocarla en uno u otro campo proviene en gran parte de la propia dificultad en deslindar ambas ramas del Derecho, del que, 
por otro lado, nunca debe perderse de vista su propia e íntima unidad, no sea que su ubicación perjudique a una clara visión del mismo y de sus instituciones, pero sobre todo la debemos considerar dentro del Derecho común.

4. Teoría formalista, para la que la presunción de paternidad no tiene otra función que la de integrar el acta de nacimiento para que ésta tenga el valor de título de estado y afines.

Así lo anterior, consideramos que la teoría a la que más nos apegamos es la formalista, dado que la presunción de la paternidad en nada resuelve los problemas de buscar la verdad si no como su nombre lo indica únicamente dar la presunción de ser el progenitor, lo cual en efectos jurídicos dará una consecuencia posiblemente falsa.

Cuando en la legislación no admite prueba directa, la paternidad se tiene que presumir, en función de las relaciones sexuales que se mantienen entre el marido y la esposa, considerando que el hijo o la hija que dé a luz la esposa es del marido, siempre que se parta de que el nacimiento ocurra después de los ciento ochenta días de celebrado el matrimonio en México o bien como hemos dicho en el caso español, solo después de celebrado el matrimonio, salvo prueba en contrario. Esta presunción se desprende de la naturaleza de las relaciones conyugales.

La presunción dentro del matrimonio, es casi absoluta, ya que sólo se puede destruir cuando exista una prueba que demuestre la imposibilidad de haber tenido relaciones sexuales entre el marido y la esposa en los primeros ciento veinte días de los trescientos anteriores al nacimiento. 
Para el caso de la impugnación, como se verá más adelante, no sólo se podría realizar la impugnación de la paternidad por imposibilidad física de haber mantenido relaciones entre los cónyuges, sino que se admiten también todas las pruebas biológicas o que el avance de los conocimientos científicos pueden ofrecer.

En uno u otro caso, la presunción de paternidad, al contrario que la presunción de concepción, tiene carácter iuris tantum, por su propia naturaleza. Entre las causas que pueden motivar la impugnación se encuentra la ausencia de uno de los cónyuges, el alejamiento físico entre ambos cuando hubiera sido continuado y se efectuase en el tiempo que correspondía a la concepción y la impotencia del marido, que puede ser anterior o posterior al matrimonio.

\subsubsection{Características}

Las pretensiones de filiación tienen como principales características las siguientes:

a) Imprescriptibles: Ya que el paso del tiempo no debería influir en su admisibilidad o requerimiento

b) Inalienables: Los efectos que producen no pueden ser limitados ni restringidos.

c) Personales: Sólo pueden ser utilizadas por un número limitado de personas 
d) Intransmisibles: No pueden ser transferidas bajo ningún título

e) Irrenunciables: El goce natural de estas pretensiones limita la posibilidad de que pueda renunciarse a ellas, no obstante sí podrá renunciarse al derecho a ejercitarlas.

f) Eficacia ergo omnes: sus efectos son generales con respecto a las personas que están vinculadas filiativamente. No cabe el establecimiento de una filiación in diminuto.

Además, para que opere la presunción, debe darse una serie de presupuestos, que a simple vista parecen ser sencillos y fácilmente comprobables, sin embargo en realidad son complejos y no siempre susceptibles de prueba. La falta de alguno de ellos determina la posibilidad de impugnar la paternidad, y si por el contrario concurren todos los presupuestos, legitima al niño o niña, para hacer valer su estado, mediante la pretensión de reclamación del mismo. Según RUGGIERO ${ }^{95}$ son:

\section{a) Matrimonio válido de los padres.}

La celebración del matrimonio entre la madre y la persona a quienes se atribuye la paternidad, es por principio el presupuesto característico que define a los hijos de los cónyuges. Es factor que no deja de ser eminentemente social, pero adquiere un valor sustantivo porque califica el estado de los padres, en cuanto los hace marido y mujer.

\footnotetext{
${ }^{95}$ RUGGERIO, Roberto, Instituciones de derecho civil, trad. Ramón Serrano Suñer y José Santa Cruz Tejeiro, vol. II, Reus, Madrid, 1931, pp. 855. En este mismo sentido ALBALADEJO, op cit. P. 223; LA CRUZ y otros p. 464
} 
Por otro lado, aun cuando se señala que el matrimonio debe ser válido, lo cierto es que también puede tratarse de un matrimonio putativo sin que tenga relevancia que los cónyuges se hayan manifestado con buena o mala fe, cuya protección independientemente que se dirige al cónyuge que lo haya contraído de buena fe, se justifica sobre todo en el interés del hijo (a) y el interés social.

\section{b) Determinación de la maternidad de la esposa.}

La maternidad de la esposa se considera el elemento básico y más ostensible de la relación de filiación; indudablemente que es el único seguro, a primera vista. Es un elemento fundamental al que se superponen los demás, todos relativos y referidos directa o indirectamente a él, así por ejemplo la paternidad es presumida por la ley en función de la maternidad y del matrimonio, y éste es el vínculo que une a la madre con el presunto padre; el establecimiento de esta clase de filiación en sí resulta del juego de todos ellos.

\section{c) Paternidad del esposo.}

Se trata del último de los presupuestos para que opere la presunción de paternidad; cuyo presupuesto junto con la maternidad de la esposa son los verdaderos elementos constituyentes de dicha filiación; porque el matrimonio como se decía antes, actúa en cuanto hace a la mujer esposa y al progenitor esposo. La concepción a marito y la paternidad del marido son el centro de gravedad de la filiación de los hijos de los cónyuges, por ello también TAMBURRINO $^{96}$ señala que no basta que el hijo sea de la madre sino que es necesario que el padre sea el marido de la madre y haya sido concebido durante el matrimonio.

\footnotetext{
${ }^{96}$ TAMBURRINO, Giuseppe, La filiazone, Utet, Torino, 1984, p. 19
} 
Finalmente se puede agregar a lo aseverado un presupuesto más, y es el nacimiento o concepción dentro del matrimonio, toda vez que algunos sistemas pueden tomar como elementos indispensables para que opere la presunción de paternidad: que los hijos hayan sido concebidos durante el matrimonio de los padres o que al menos hayan nacido después de haberse celebrado el vínculo matrimonial.

\section{d) La presunción de concepción}

En atención al tiempo de concepción, se presumen hijos de los cónyuges unos términos que se establecen entre un máximo y un mínimo. Se advierte que, dado que el embarazo no tiene términos exactos, es variable según los casos, se fija una duración entre un máximo de 300 días y un mínimo de 180; en tal virtud se presume que la concepción tiene lugar en cualquiera de los 120 días de diferencia entre ambos periodos de tiempo.

El Código de Napoleón también se hace evidente en la presunción en orden al tiempo de la concepción. En México con la codificación no se alteraron los periodos de tiempo que se había fijado en atención a los dictámenes de especialistas de la época. La finalidad de la figura era evidente ya que los legisladores con su inclusión suprimen cualquier discusión sobre este punto; en tal virtud, las presunciones tienen carácter inatacable y no es posible admitir prueba médica que demuestre que ha sido diferente el tiempo del embarazo. La ley da a esta presunción la condición de iuris et de iure, ya que si bien es evidente que en algunos supuestos estos periodos de tiempo no se ajustan a la realidad, lo es que se producen situaciones injustas. ${ }^{97}$

\footnotetext{
${ }^{97}$ Para SERNA MEROÑO, es incorrecto el planteamiento del periodo de concepción y menos desde el punto de vista de duración del embarazo, ya que el punto de partida no era el día del nacimiento, sino el de la celebración o disolución del matrimonio o separación de los cónyuges. Entendía que el criterio que
} 
La concepción del ser humano es de difícil constatación, aunque se conozca la duración ordinaria de la gestación de la especie humana, por lo que se tiene que deducir de otro hecho, como el nacimiento, cuya constancia es fácil y segura. Es por ello que se tiene que probar a través de una presunción, que tiene una importancia y función primordial toda vez que contribuye a la prueba indirecta, de la paternidad.

En efecto, la duración de la gestación del ser humano no se sabe con exactitud, puede variar de una mujer a otra, y la diferencia puede ser de hasta cuatro meses o más. Incluso la gestación de una misma mujer puede ser distinta de un embarazo a otro. A lo anterior todavía se le une que la fecundación no coincide con el acto sexual, porque también se desconoce el tiempo que puede haber entre cohabitación y concepción.

Sin embargo, la naturaleza sabe dar justificación o explicación a esos hechos, pues con los antecedentes generales, desarrollo y algunos datos específicos del recién nacido como su peso, estatura, salud, etcétera permiten identificar el tiempo de gestación del nuevo individuo, hasta el grado que hoy es posible dictaminar la fecha de concepción con margen de error relativamente pequeño, y desde luego, puede decirse con seguridad que tal o cual recién nacido pudo o no pudo ser concebido en determinada fecha o época.

Al respecto Aníbal GUZMAN ÁVALOS, enumera que existen tres sistemas para determinar el tiempo de la gestación de un ser humano, que responden a una filosofía o concepción de la filiación y de la paternidad ${ }^{98}$ :

se había seguido no era otro que el de al viabilidad del nacido aunque la presunción no tenía valor científico alguno. SERNA MEROÑO, Encarnación; Op cit. P. 38

${ }_{98}$ GUZMAN ÁVALOS, Aníbal; La Filiación en los albores del siglo XXI, Ed. Porrúa, México, 2005, pp 47 y 48 


\section{Sistema judicial}

Consiste en que los tribunales determinen la duración de la gestación en cada caso concreto, a decidir según las circunstancias de hecho e incluso con la ayuda de pruebas periciales. Tiene la ventaja de llegar más probablemente al conocimiento de la filiación biológica, pero tiene el inconveniente de la inseguridad, de ser poco práctico y de cometer abusos, errores y arbitrariedades de los tribunales. Sin embargo, no hay duda que este sistema tiene como finalidad una preocupación y respeto por la paternidad verdadera y en rechazar una paternidad formal. Pero ello no lo exime del riesgo de caer en errores judiciales, errores que no son mayores, ni más frecuentes que los que se pueden consagrar en la ley.

Consideramos que éste es el mejor sistema para determinar el tiempo de gestación ya que los inconvenientes que podríamos encontrar pueden ser fácilmente controlados a través de las regulaciones que en el caso de España existe como es la Ley de Protección de Datos y en el caso de México en próximo estudio para aprobación de la ley.

\section{Sistema legal}

Se basa en fijar legalmente los plazos máximos y mínimos para la gestación, estimando que la concepción tiene lugar en un lapso equivalente a la diferencia entre aquellos plazos, y situando al principio del primero, tiempo denominado "periodo legal de concepción” calculable en cada caso en relación con la fecha del nacimiento, a partir de los cuales se calculan los plazos máximos y mínimos de gestación. Contando, o descontando, hacia atrás. Así las cosas, la concepción y la cohabitación, se presumen legalmente haber ocurrido en dicho 
periodo legal. Este sistema refleja una preocupación por la seguridad jurídica y por evitar los juicios en esta materia, así como también evitar los errores y arbitrariedades de los tribunales. No obstante, hay que conceder que con esta postura, hay también cierta despreocupación por la paternidad biológica en consagración de otras ideas e intereses.

\section{Sistema mixto.}

Este sistema combina, como su nombre indica, las anteriores, tomando como regla general unos plazos, máximo y mínimo, y un periodo legal de concepción, como en el sistema legal, y admite luego que en algunos casos concretos se pueda demostrar judicialmente que la concepción ocurrió fuera de aquellos plazos por haber durado la concepción menos o más (casi siempre más) de lo previsto en la ley. La presunción legal no tiene valor absoluto, ni el periodo legal de concepción carácter indivisible o equivalente; la concepción no se ubicará siempre en el periodo legal en el que resulte más favorable o a elección del hijo, sino en el que corresponda, según las circunstancias y las pruebas practicadas. Este sistema, como el judicial, corre el riesgo de caer en el posible error judicial buscando la paternidad real. ${ }^{99}$ Por ende pensamos que no es tan conveniente ubicar la presunción de paternidad en tiempos legales ya que estos pueden frecuentemente llevar a errores y no sería buscar la verdad de nada y mucho menos se arregla un problema presumiendo la paternidad, ya que si bien pueden encontrarse en matrimonio, lo cierto es que pudo no haber cópula y por ende no por el hecho de encontrarse en una situación legal de matrimonio el menor tenga que ser su hijo, y lo cual es taxativamente difícil desvirtuar si no lo es por la prueba de ADN.

\footnotetext{
${ }^{99}$ RIVERO HERNÁNDEZ; La presunción..., op cit p. 96-98
} 
En los sistemas filiales cerrados la investigación de la paternidad es tolerada siempre que existan elementos básicos (supuestos de hecho) que predeterminen un estado de familia. En otras palabras, un principio de prueba de los hechos en que se funda que permitan la admisibilidad de la demanda.

Dada la posibilidad de probar certeramente la maternidad como la paternidad, se ha seguido el criterio de que sirva lo aparente como indicio para conocer lo inaparente; presunciones en función de los principios de moral social y familiar predominante y del estado de la ciencia biomédica coetánea de la norma. JOSSERAND justificaba este sistema refiriendo que más vale contentarse con lo menos y sacrificar el rigor científico frente a la apariencia del Derecho ${ }^{100}$; estos elementos son presunciones que funcionan como hipótesis o indicios, reflejando casos comunes de la vida social que llevan a suponer que una persona es padre de otra, porque existen hechos ocurridos, conductas asumidas o situaciones por comprobarse, que así lo indican, como sería el rapto, retención violenta, seducción, violación o concubinato o bien denominado como parejas de hecho desde el derecho civil español. Sin embargo no se pueden contemplar todas las posibilidades en que socialmente se pueda atribuir una paternidad, como es el caso del abandono de la mujer embarazada, el noviazgo, abandono con promesa de matrimonio y hasta las relaciones fuera del matrimonio, las cuales no admitían el inicio del juicio de paternidad, ante esto DOMíNGUEZ PLATAS nos dice que: "son incompletos, o no suficientes para fundamentar la filiación que se reclama, si bien en su conjunto pueden convertirse en presumptio hominis, cuando fallan las anteriores, convirtiéndose en presunción de paternidad”. ${ }^{101}$

\footnotetext{
${ }^{100}$ JOSSERAND, Louis; Derecho Civil; Tomo I, Volumen 2;Ediciones Jurídicas Europa-América, Bosch y cía editores; Buenos Aires; 1952; p. 168

${ }^{101}$ DOMÍNGUEZ PLATAS, Jesús; "Las acciones de filiación, Encudramiento general y funciones de la posesión de estado"; en Revista de Derecho Privado, Madrid. Ed. Revista de Derecho Privado, 1996, Tomo LXXX enero - diciembre, p. 462.
} 
Al respecto y bajo el mismo criterio en la vía jurisdiccionales la Sentencia del Tribunal Supremo del 2 de marzo de 1994 en la nota 82 nos dice: “...analizados individualmente y sin conexión no sirven para obtener la declaración pretendida, pero valorados conjuntamente permiten llegar a idéntica convicción (...) lo cual es muy distinto a una apreciación conjunta de la prueba”

Así como la jurisprudencia en el mismo sentido refiere:

“... se admiten dos clases de pruebas acreditativas en la filiación, las directas, entre las que figuran la llamada heredobiológica o antropomórfica, y las indirectas o presuntivas, como indiciarias de la cohabitación sexual necesaria y suficiente para la procreación de las que el citado precepto hace una enumeración abierta o ad exemplum (reconocimiento expreso o tácito, posesión de estado y convivencia con la madre en la época de la concepción), para conceder en su último inciso la facultad de poner en juego lo dispuesto en el artículo 4.1 del Código Civil, en orden a permitir que se tomen en consideración otros hechos de los que se infiera la filiación de manera análoga”102

En el mismo sentido, las resoluciones judiciales del STS que han resuelto en el mismo sentido son: 8 de julio de 1986, 27 de junio y 14 de noviembre de 1987, 20 de julio de 1990, 5 de octubre de 1992 y 29 de marzo de 1993 entre otras.

A contrario sensu, la jurisprudencia mexicana ha dicho que "La presunción legal establecida en la fracción I del artículo 324 del Código Civil, que establece que se presumen hijos de los cónyuges los nacidos después de ciento ochenta días contados desde la celebración del matrimonio, de ninguna

\footnotetext{
${ }^{102}$ Anuario de Derecho Civil, Madrid, Ministerio de Justicia e Interior, abril.junio 1996 tomo XLIX, fasc. II p. 1029.
} 
manera puede destruirse con la simple negativa de la paternidad; tan es así, que el propio legislador ha dispuesto, en el artículo 325 del mismo cuerpo de leyes, que contra esa presunción no se admite otra prueba que la de haber sido físicamente imposible al marido tener acceso carnal con su mujer, en los primeros ciento veinte días de los trescientos que han precedido al nacimiento; prueba que, indudablemente, solo podrá rendirse dentro del juicio contradictorio a que se refieren los artículos 335 y 336” 103

Las presunciones surgen como consecuencia de la imposibilidad biológica de probar el nexo filial. De esta manera se da solución a un problema tomándose como referencia un sistema casuístico de indagación de la paternidad con las limitaciones e inseguridades que éste genera. Solución que es común en los códigos latinoamericanos al buscar a través de la presunción el origen genético de la paternidad. ${ }^{104}$

Como hemos indicado, estas presunciones significan situaciones que permiten la investigación de la prueba y el debate de la paternidad, pero de ningún modo determinarán una declaración de paternidad por sí sola, si no se acredita previamente y de manera debida.

\footnotetext{
103 Registro IUS: 241522; Localización: Séptima Época, Tercera Sala, Semanario Judicial de la Federación, Volumen 73 Cuarta Parte, p. 119, aislada, Civil; Rubro: FILIACION. LA SIMPLE NEGATIVA DE LA PATERNIDAD NO PUEDE DESTRUIR LA PRESUNCION DE QUE SON HIJOS DE LOS CONYUGES.

${ }^{104}$ Francisco RIVERO HERNÁNDEZ ha sostenido que: "los principales problemas para determinar la filiación, tenían su origen en el secreto de las relaciones sexuales causantes del nacimiento, o en la necesidad de determinar cuál, si éstas se realizaron con diferentes varones, fue la que produjo la gestación, ello justificó el juego de presunciones, restricciones probatorias y otros formulismos jurídicos al surgir las pruebas biológicas y poder determinar con precisión creciente cuál es el elemento causal del embarazo hubo de cambiar la normatividad sobre filiación, orientándola al nexo biológico" en "La investigación de la mera relación biológica en la filiación derivada de la fecundación artificial” Ponencia en el II congreso Mundial Vasco, La Filiación a finales del siglo XX, pp. 141-143 y 146-148
} 
Todas y cada una de las presunciones admiten prueba en descargo del demandado, es así que el supuesto padre podrá oponer los medios que le faculta la ley para comprobar su no paternidad.

En resumen, las presunciones:

- No determinan automáticamente la paternidad.

- Son un requisito para indagar la paternidad.

- Deberá ser probado el hecho base.

- Son presunciones iuris tantum.

- Puede debatirse la alegada relación filial

- Pierden su eficacia frente a la demostración por otras vías de los hechos objeto de prueba

- Son desestimadas plenamente si se demuestra biológicamente que el demandado no es el padre, a pesar de haberse probado lo contrario por vías indirectas

Las presunciones de paternidad están siendo desplazadas por las pruebas biológicas, es más, la aplicación de estas "biopruebas” y la negativa de la parte a su sometimiento ha generado el surgimiento de una nueva presunción.

Los hechos inciertos ceden paso a los resultados determinantes. Actualmente, el vínculo filial se sustenta en investigaciones científicas más que en propuestas sociales, ya que si de la "bioprueba” se determina más de un 90\% de paternidad probada es ocioso preguntarse por las circunstancias que permitan inferir una presunción hominis. 


\subsubsection{Clases}

\section{A) Pretensión de reclamación}

Se le conoce como "acción de declaración positiva o vindicación de estado civil”, es decir, se busca establecer una filiación a quien no la tiene. Entre ellas encontramos:

a) Matrimonial.- Se da a falta de una inscripción regular, como en los casos de la inscripción sin mención de los padres, inscripción como hijo extramatrimonial de otras personas, inscripción como hijo matrimonial de otros.

b) Extramatrimonial.- Se sustenta en el principio de la investigación. Se tiene legalmente por haber nacido fuera de matrimonio y sus padres biológicos se niegan a reconocerlo. Lógicamente es exigible al padre o a la madre, teniendo la paternidad y la maternidad acreditadas con los supuestos sociales o la vinculación genética.

\section{B) Pretensión de desconocimiento}

Llamadas “acciones de declaración negativa o de repudio filial”. Es una pretensión de desplazamiento, es decir, busca dejar sin efecto la filiación de quien la goza fuera de los supuestos permitidos por ley.

1. Paternidad matrimonial.

Impugnación.- Denominada desconocimiento riguroso. En este caso el marido ataca la paternidad que tiene con el hijo concebido por 
su mujer durante el matrimonio. En ella está vigente la presunción pater est, existe una verdad biológica probable.

Negación.- Denominada desconocimiento simple o negación ad nutum, en este caso no existe la presunción de paternidad, no hay una verdad biológica probable. Se presume que el hombre no tenía relaciones sexuales con la madre en la época de la concepción.

\section{Maternidad matrimonial}

Impugnación.- Es menos frecuente que el de la paternidad, sin embargo, es más necesaria e importante que otras acciones ya que, si falta el vínculo de la madre, en ocasiones falta el del padre.

Este es un caso relacionado con los delitos de alteración del estado civil, permitiéndose repudiar este tipo de filiación en los casos de parto supuesto o suplantación del hijo.

3. Casos especiales

Impugnación de legitimidad.- Esta acción busca probar que el hijo no es matrimonial. A pesar de que su paternidad legal coincida con la biológica, se presenta el hecho de que el menor ha sido concebido cuando sus padres no estaban casados y este es el motivo de la impugnación, al no tener la seguridad de que el padre o la madre sean los que procrearon al menor; ésta es una pretensión propia de los padres. 
Repudio de filiación legítima.- Busca dejar sin efecto una filiación matrimonial a efectos de declararse hijo extramatrimonial. Es una pretensión propia del hijo.

Este tipo de pretensiones han dejado de tener aplicación, por la unidad de la filiación y el de igualdad entre los hijos.

1. La existencia del concubinato o matrimonio de hecho. Primero analizaremos lo que es el concubinato y los elementos de hecho que generan éste, ya que la primer cuestión que se presenta en las presunciones de filiación concubinaria, es la acreditación de esta institución; así, podemos identificar al concubinato como un acto jurídico unilateral plurisubjetivo de Derecho de familia, por el cual cualquier persona que, libre de matrimonio, sin impedimentos dirimentes no dispensables y con capacidad jurídica para celebrarlo entre sí decide hacer vida en común, de manera seria, no interrumpida, estable y permanente, a fin de constituir una nueva familia o grupo social primario, sin la necesidad de satisfacer determinadas formalidades, ni requisito alguno de inscripción en Registro alguno.

Así, podemos analizar la definición dividiendo los elementos tal como lo hace el tratadista GALVAN RIVERA ${ }^{105}$, y que es de la siguiente forma:

a) Es un acto jurídico unilateral plurisubjetivo; ya que por acto entendemos la manifestación o exteriorización de la voluntad, con la intención de generar consecuencias de Derecho, sancionada por una norma jurídica, resulta claro que el concubinato es un acto jurídico unilateral plurisubjetivo, toda vez que para su existencia se requiere, como elemento sine qua non, la manifestación

${ }^{105}$ GALVAN RIVERA, Flavio; Op Cit. pp 124-127 
de dos voluntades distintas pero coincidentes en su fin, cual es la convivencia para constituir una nueva familia, que recibe la sanción o aprobación del sistema normativo.

b) Se considera acto jurídico del Derecho familiar, ya que sus elementos de existencia y requisitos de validez estarán regulados por esta materia de manera inmediata, directa y exclusiva, ya que el contenido temático del Derecho familiar lo es el origen, organización y disgregación de la familia.

c) Debe ser una unión singular, ya que con independencia de su denominación y naturaleza jurídica y sanción legal, debe satisfacer el requisito fundamental exigido por la regla a la unión matrimonial respecto al país donde se encuentre regulado. Aquí encontramos que hasta hace muy poco tiempo en el caso mexicano -por vía jurisprudencial-, éste podría contraerse únicamente por un hombre con una mujer, no permitiendo las uniones entre parejas del mismo sexo, mientras que en España donde este tema fue superado con las modificaciones al código civil, a pesar de seguir pendiente la resolución de un recurso de inconstitucionalidad.

d) Los concubinos deben estar libres de matrimonio. La simple singularidad de concubinario y concubina no resulta suficiente para que exista jurídicamente el concubinato, porque éste solo se puede dar entre personas libres de matrimonio, ya que si alguno de ellos se encuentra unido jurídicamente con otra u otras personas distintas, en virtud del vínculo matrimonial, la posible vida en común que realicen entre si no será concubinato, antes bien, probablemente sea calificada como ilícita, castigada incluso por algunos ordenamientos jurídicos civiles y penales que se consideren aplicables al caso concreto. 
e) Deben hacer una vida en común, ya que sin la conducta bio-sociojurídica de la concubina y del concubinario, consistente en hacer vida en común, de vivir en el mismo domicilio, es decir, de convivir bajo el mismo lecho, el concubinato sería inexistente, por tanto, es factible afirmar que los concubinos tienen para sí, de manera recíproca, simultánea, permanente, continua y sin excepción, la voluntad al derecho de cohabitar, de hacer vida en común, porque precisamente a partir de esta conducta voluntaria y sólo de esta actuación querida surge el concubinato.

f) Uno de los elementos necesarios y de mayor importancia lo es el trato social y la publicidad, ya que si el concubinato considerado como situación jurídica permanente, que surge de la causa denominada acto jurídico fundante de una familia, constituye un auténtico estado de derecho, similar al que emerge del matrimonio en su calidad de estado civil, resultaría claro que la concubina y el concubinario se deben comportar en su vida diaria, social y jurídica, privada y pública, como genuina pareja que ha asumido la decisión seria y definitiva de formar una nueva familia, una nueva célula social, de tal suerte que los demás miembros de la comunidad tengan el concepto creíble, fundado, razonado y sensato, de que ambos efectivamente integran una pareja estable , que constituye una nueva familia, tanto desde el punto de vista social como jurídico y económico, con independencia de la naturaleza intrínseca y específica del vínculo de derecho que les une.

g) Ahora, dicha unión debe estar libre de formalidades y registros, ya que por regla, para la constitución del concubinato no se exige el cumplimiento de determinadas formalidades y menos aun se requiere como elemento indispensable el registro ante la autoridad registral familiar, el cual, en todo caso, debe ser opcional para los concubinos, ya que para que éste surja al mundo del Derecho, es suficiente el acuerdo de voluntades de ambos sujetos. 
Caso superado para el Derecho español, el cual nos habla sobre las parejas de hecho, para las que la convivencia more uxorio, entendida como una relación a semejanza de la matrimonial sin haber recibido sanción legal, produce o puede producir una serie de efectos que tienen trascendencia jurídica y deben ser resueltos con arreglo al sistema de fuentes del Derecho. La idea es evitar que la relación de hecho pueda producir un perjuicio no tolerable en Derecho en una de las partes, es decir, la protección a la persona que quede perjudicada por una situación de hecho con trascendencia jurídica.

\section{El nacimiento del descendiente después de 180 días contados} desde el inicio del concubinato. Suponiendo que se tiene por acreditado el concubinato, la primera hipótesis y segundo problema a probar lo sería el nacimiento del descendiente teniendo verificación después de los 180 días contados desde el inicio de la figura jurídica del concubinato, y nos hablamos de "problema" porque tampoco puede probarse a través de medios indubitables el momento a partir del cual los concubinos empezaron a hacer una vida en común y con la finalidad de constituir una familia.

No obstante, si ha sido posible probar ese inicio de la vida en común entre los concubinos, el nacimiento del descendiente debe tener lugar como mínimo, después de seis meses contados desde su comienzo, porque éste es el tiempo mínimo de gestación, para que el hijo nazca vivo y viable, salvo las excepciones de acuerdo a los adelantos de la medicina.

\section{El nacimiento del descendiente dentro de los $\mathbf{3 0 0}$ días siguientes} al que cesó la vida en común de los concubinos. Esta presunción implica haber 
acreditado la existencia del concubinato, el momento a partir del cual estuvo vigente esta relación y la fecha en la que terminó la vida en común entre los concubinos, lo cual como en los casos anteriores, representa el tercer problema de las presunciones concubinarias, pues esta última cuestión, sólo podrá probarse a través de medios de prueba indirectos.

En este caso, si ha sido posible comprobar la fecha en que cesó la vida en común entre los concubinos, el descendiente debe nacer dentro de los trescientos días siguientes a la fecha de terminación del concubinato, atendiendo al tiempo máximo de la gestación, presunción que es igual a la filiación matrimonial determinada como hemos analizado en el artículo 324 del Código Civil Federal mexicano, por ende, es necesaria la concepción del descendiente durante el tiempo en el cual sus progenitores hacían vida en común, teniendo verificación su nacimiento después de concluida la relación concubinaria.

Como se ha mencionado, si ya representa un problema la acreditación de la existencia de esta institución familiar a través de medios indubitables de prueba, la situación se agrava más, al no exigir la concepción del descendiente durante su vigencia, ni establecer el término mínimo de la gestación en esta presunción y solo reputar descendiente de ambos concubinos al hijo nacido en el tiempo en el cual estos mantienen una comunidad de vida, porque no puede haber certeza de que la concubina haya tenido únicamente relaciones sexuales con el concubinario, antes del inicio de esa vida en común.

Más aun cuando, ni antes ni después del concubinato, tienen legalmente los deberes de cohabitación y fidelidad ${ }^{106}$, en los cuales se basa la unión matrimonial y aunque es posible su cumplimiento, esto sólo depende del

\footnotetext{
${ }^{106}$ Cfr. Henri MAZEAUD, ET. AL., Trad. Por Luis Alcalá Zamoda y Castillo, Lecciones de Derecho civil. La familia, Constitución de la familia, Parte Primera, V. III, Ediciones jurídicas Europa - América, Argentina, 1959, p. 323.
} 
compromiso generado entre ellos, quieres tienen un libre albedrío para observarlos, por eso es grave, según nuestro parecer, que por disposición de ley se repute al descendiente nacido durante esta relación como producto de ambos, cuando esto no puede asegurarse y sólo contribuye a imputaciones posiblemente falsas de una presunta paternidad.

El análisis realizado respecto de las presunciones de los descendientes habidos en concubinato y su relación con las establecidas para determinar la filiación matrimonial, en la legislación civil mexicana que analizamos denota que los legisladores han pretendido equiparar la institución del matrimonio con el concubinato, lo cual es incorrecto, porque en las nupcias la presunción de paternidad se debe esencialmente a los deberes de cohabitación y fidelidad que se deben los cónyuges entre sí, y aunque es posible la observancia de los mismos en el concubinato, esto sólo depende del compromiso generado entre ellos, quienes tienen un libre arbitrio para observarlos.

Además, si bien es cierto que el concubinato es un acto jurídico bilateral, por el cual dos personas capaces jurídicamente, libres de matrimonio, sin la mediación de impedimentos dirimentes no dispensables para celebrarlo, deciden hacer vida en común, de manera seria, no interrumpida, estable y permanente, con la finalidad de constituir una familia, también debe destacarse la distinta forma como debe acreditarse esta institución respecto del matrimonio, ya que éste último en forma automática se prueba con el acta del registro civil o bien de lo familiar, mientras que el concubinato no puede probarse de manera indubitable, pues la mayor parte de las veces los medios de prueba para ese efecto, sólo son indirectos.

De tal forma, si la misma acreditación de la existencia del concubinato puede ser objetada, lo mismo ocurre con las presunciones de filiación resultantes 
del mismo, sin que sea suficiente el establecimiento de términos mínimo y máximo de la gestación, pues primero se debe acreditar la existencia, su inicio o en su caso su terminación, y luego, el nacimiento de esos descendientes durante el tiempo en el cual tuvo verificación, o bien después de los ciento ochenta días contados desde su inicio, o dentro de los trescientos días siguientes al que cesó la vida en común entre los concubinos.

Así, aun cuando por disposición de la ley se determinen presunciones de filiación iguales para los descendientes habidos en concubinato y para los de matrimonio, en la práctica no pueden ser probadas de la misma forma, por el problema que representa determinar la existencia, inicio o conclusión del concubinato, para acreditar con posterioridad los términos referidos en las mismas, lo cual no ocurre en el matrimonio, porque su existencia, inicio y conclusión se comprueban con las actas del registro civil respectivas.

Podemos decir entonces que el tema de la presunción para acreditar la filiación en las parejas de hecho y el concubinato en México, no es la forma más precisa para poder determinar la relación filial existente entre ascendientes y descendientes ya si bien se ha dicho que a opinión personal la presunción de la relación filial en el matrimonio no da certeza, mucho menos será en el caso del concubinato o de las parejas de hecho en las cuales existe mayor libertad entre los participes. 


\title{
SECCIÓN II
}

\section{LA PRUEBA EN LOS PROCESOS DE FILIACIÓN}

\author{
CAPITULO III \\ CONSIDERACIONES GENERALES
}

\subsection{Concepto de prueba}

El término “prueba” tiene diversos significados tanto en el lenguaje común como en el lenguaje jurídico, por ello, esta es la primer dificultad que se presenta al abordar su estudio. ${ }^{107}$

En un sentido gramatical, la Real Academia de la Lengua Española, ha definido la prueba con varias excepciones, entre los cuales se destaca lo siguiente: “justificación de la verdad de los hechos controvertidos en un juicio, hecha por los medios que autoriza y reconoce por eficaces la ley” 108

Por ende, desde la perspectiva gramatical, el concepto de probar trata de toda aquella actividad realizada para la justificación, manifestación o comprobación, tanto de la verdad de los hechos controvertidos, como de las

${ }^{107}$ CARNELUTTI, Francesco; La Prueba civil Traducido por Niceto Alcala Zamora y Castillo; 2da ed., ediciones Depalma, Argentina; 1982; p. 38

${ }^{108}$ Real Academia de la Lengua Española, Diccionario de la Real Academia Española de la Lengua; 22a . Ed. Editorial Espasa-Calpe; España; 2005; p. 1257 
proposiciones afirmadas en juicio, a través de los medios autorizados y reconocidos por la ley.

En este sentido Francesco CARNELUTTI afirmó que en el lenguaje común la palabra "prueba" se usa como comprobación de la verdad de una proposición, pues sólo se habla de prueba a propósito de alguna cosa que ha sido afirmada, pero en rigor debe diferenciarse del procedimiento empleado para la verificación de esa proposición afirmada. Es decir, de la actividad probatoria, y para hacer palpable esa distinción, se ejemplifica esa noción común de la prueba de la siguiente forma: en una operación aritmética cualquiera, al verificarse su resultado mediante otra operación, surge la prueba, cuyo objetivo es la verificación del resultado afirmativo. Entonces, una cosa es la prueba, es decir, la comprobación del resultado y otra es la actividad mediante la cual se va a conocer el resultado de dicha operación aritmética, porque este conocimiento no es la prueba, pero da la prueba del resultado afirmativo. ${ }^{109}$

Siguiendo la tesis afirmada por este autor, es de señalarse que en el lenguaje común se produce una transposición en el significado del vocablo, en virtud de la cual prueba no designa tan solo la comprobación, sino también el procedimiento o la actividad usada para tal comprobación, y de este modo, es posible que gramaticalmente la prueba no sea únicamente la demostración de la exactitud del resultado de la operación aritmética obtenida mediante otra operación, sino también la actividad mediante la cual se obtuvo dicha demostración. ${ }^{110}$ De esta forma, desde el punto de vista gramatical, "prueba” significa tanto la comprobación de la verdad de una proposición afirmada, como el

\footnotetext{
${ }^{109}$ CARNELUTTI, Francesco; op. cit.; pp. 39 y 40

${ }^{110}$ Idem p. 40
} 
procedimiento o la actividad mediante la cual se comprueba la proposición afirmada. ${ }^{111}$

En un sentido jurídico, Francesco CARNELUTTI decía que "el valor originario del vocablo prueba en el lenguaje corriente, que radica en el concepto de comprobación, se conserva en el campo jurídico, porque casi toda la doctrina en este ámbito conceptúa a la prueba como la demostración de la verdad de un hecho realizada por los medios legales, o más brevemente, la demostración de la verdad legal de un hecho". ${ }^{112}$

De la misma forma, MATEOS ALARCÓN señala que la prueba “...es la demostración legal de la verdad de un hecho”113

En las Siete Partidas del Rey Don Alfonso El Sabio, en la Ley I, del Título XIV, de la Partida tercera, se expresa:

"Que cosa es prueba et quien la puede facer.

Prueba es averiguamiento que se face en juicio en razon de alguna cosa que es dubdosa: et naturalmente pertenece la prueba al demandador quando la otra parte le negare la demanda, ó la cosa ó el fecho sobre que le face la preguntam ca si lo non probase deben dar por quito al demandado de aquella cosa que non fue aprobada contra él, et non es tenuda la parte de probar lo que niega porque non lo podrie facer, bien asi como la cosa que non es, non se puede probar nin mostrar segunt natura; otrosi las cosas que son negadas en juicio non

${ }^{111}$ DEVIS ECHANDIA; Hernando; Teoría General de la Prueba Judicial, T. I, 5a Ed.; Víctor P. de Zavalía editor; Argentina; 1981; p. 29

${ }^{112}$ CARNELUTTI, Francesco; Op Cit pp. 43 y 44

${ }^{113}$ MATEOS ALARCÓN, Manuel; Las Pruebas en Materia Civil, Mercantil y Federal, $3^{\mathrm{a}}$ ed., Cárdenas Editor y Distribuidor, México, 1988, p. 2 
las deben nin las puedes probar aquellos que las niegan sinon en aquella manera que diremos adelante en las leyes deste título”. ${ }^{114}$

En un sentido igual podemos encontrar que DIAZ CABIALE nos dice que no todo acto que va dirigido a convencer psicológicamente al órgano judicial de la verdad acerca de la existencia o inexistencia de un hecho adquiere directamente y sin más la consideración de actividad probatoria, sino que ello ocurre con aquellas actuaciones que hayan sido realizadas en el tiempo y de la manera previamente establecida, pretendiéndose con ello la reafirmación de la seguridad jurídica, al tiempo que se busca dar juego a unos principios que se consideran esenciales. ${ }^{115}$

Por su parte, Hernando DEVIS ECHANDÍA y Antonio DELLEPIANE aportan definiciones más completas del vocablo "prueba", al incorporar en sus conceptos las tres acepciones con las cuales se le pueden definir en el Derecho procesal:

En particular DEVIS ECHANDÍA señala que desde el punto de vista procesal, “... es ineludible reconocer tres aspectos de la noción de prueba, el de vehículo, medio o instrumento; el de contenido esencial o esencia de la prueba (razón o motivos que en esos medios se encuentran a favor de la existencia o inexistencia de los hechos), y el resultado o efecto obtenido en la mente del juez (el convencimiento de que existen o no esos hechos). Una definición general de la prueba debe, pues comprender esos tres aspectos de la noción.” A partir de estos aspectos procesales define y diferencia la actividad de probar del concepto de prueba judicial, señalando que: "Probar es aportar el proceso, por los medios y

\footnotetext{
${ }^{114}$ Rey Don Alfonso X el Sabio; Las Siete Partidas, Suprema Corte de Justicia de la Nación, México, 2003.

${ }^{115}$ DIAZ CABIALLE, J. A.; La admisión y práctica de la prueba en el procesos penal, Cuaderno del CGPJ, Madrid, 1992, pp. 33 y 34
} 
procedimientos aceptados en la ley, los motivos o las razones que produzcan el convencimiento o la certeza del juez sobre los hechos”; mientras que por prueba judicial debe entenderse como todo motivo o razón aportado al proceso por los medios y procedimientos aceptados en la ley, para llevarle al juez el convencimiento o la certeza sobre los hechos” 116

Sobre el mismo tema, Antonio DELLEPIANE, considera que la palabra tiene tres acepciones en el derecho procesal:

1.- En el sentido de medio de prueba con el cual se designan “... los distintos elementos del juicio, producidos por las partes o recogidos por el juez, a fin de establecer la existencia de ciertos hechos en el proceso (prueba de testigos, prueba indiciaria)”.

2.- En el sentido de la acción de probar, derivada de la máxima "actor probat actionem”. Al actor incumbe la prueba de los hechos por él afirmados: “... suministrar los elementos de juicio o producir los medios indispensables para determinar la exactitud de los hechos que alega como base de su acción, sin cuya demostración perderá su pleito”.

3.- En el sentido producido en el juez en los elementos de juicio antes aludidos: “... la convicción, la certeza acerca de la existencia de ciertos hechos sobre los cuales ha de recaer su pronunciamiento". ${ }^{117}$

De las definiciones antes señaladas, se puede concluir que, desde el punto de vista jurídico, la prueba está constituida por los elementos del juicio, motivos o razones aportados por las partes o recogidos por el juez en todo

\footnotetext{
${ }^{116}$ DEVIS ECHANDIA; op cit. p. 36

${ }^{117}$ DELLEPAINE, Antonio; Nueva Teoría de la Prueba; 9a ed., Ed. Themis, Colombia; 2000; pp 7 y 8
} 
proceso; por los medios y procedimientos aceptados en la ley, cuyo objeto, es producir la convicción del juzgador sobre la certeza de los hechos controvertidos, respecto de los cuales ha de recaer su resolución. ${ }^{118}$

Así ajustándonos a la opinión de Isabel HUERTAS MARTÍN, aun y que su conclusión la realiza en el ámbito penal, puede ser aplicada de la misma forma en el proceso civil al indicar que la prueba está constituida por la actividad procesal de las partes y del propio juez o tribunal encaminada a la determinación de la veracidad o no de las afirmaciones que sobre los hechos efectúan las partes, y cuya finalidad no es otra que la de conducir al órgano judicial sentenciador a la convicción psicológica acerca de la existencia o inexistencia de dichos hechos. Añade que debe desarrollarse a través de los cauces legalmente establecidos y de acuerdo con los principios que rigen en este ámbito, fundamentalmente los principios de contradicción, inmediación, oralidad y publicidad ${ }^{119}$

\subsection{El objeto de la prueba}

En este tema procesal se encuentra posiblemente la mayor coincidencia en las opiniones doctrinales, pues casi de manera uniforme se afirma que el objeto de la prueba judicial son los hechos. Así, DEVIS ECHANDIA, por ejemplo, señala: “... que objeto de prueba judicial en general es todo aquello que, siendo de interés para el proceso, puede ser susceptible de

\footnotetext{
${ }^{118}$ Hernando DEVIS ECHANDIA, hace perfectamente la aclaración respecto a lo expuesto al exponer que por "pruebas judiciales se entienden las razones o motivos que sirven para llevarle al juez la certeza sobre los hechos, y por medios de prueba, los elementos o instrumentos (testimonios, documentos, periciales, confesional, etcétera), utilizados por las partes y el juez, que suministran esas razones o esos motivos, (es decir, para obtener la prueba). Puede existir un medio de prueba que no contenga prueba de nada, porque de él no se obtiene ningún motivo de certeza. Pero, en sentido general, se entiende por prueba judicial tanto los medios como las razones o los motivos contenidos en ellos y el resultado de éstos...”, op cit, T1, p. 29

${ }^{119}$ HUERTAS MARTín; M. Isabel; El sujeto Pasivo del Proceso Penal como Objeto de la Prueba; Ed. Bosch; Barcelona; 1999; p. 28
} 
demostración histórica (como algo que existió, existe o puede llegar a existir) y no simplemente lógica (como sería la demostración de un silogismo o de un principio filosófico); es decir, que objeto de la prueba judicial son los hechos presentes, pasados o futuros, y lo que puede asimilarse a éstos (costumbre y ley extranjera)". ${ }^{120}$

De igual forma, otros autores tales como: CARNELUTTI y OVALLE FAVELA entre otros, están de acuerdo en que en cualquier proceso, la prueba tiene por objeto los hechos y, excepcionalmente, las leyes extranjeras y las costumbres. $^{121}$

La opinión de estos tratadistas ${ }^{122}$ es acorde a lo dispuesto por los artículos 86 y 86-bis del Código Federal de Procedimientos Civiles mexicano, al especificar que sólo los hechos estarán sujetos a prueba, así como los usos o costumbres en que se funde el Derecho; siendo el tribunal quien aplicará el Derecho extranjero tal como lo harían los jueces o tribunales del Estado en el que resultare aplicable, sin perjuicio de que las partes puedan alegar la existencia y contenido del Derecho extranjero.

Para informarse del texto, vigencia, sentido y alcance del Derecho extranjero, el tribunal podrá valerse de informes oficiales al respecto, los que

${ }^{120}$ DEVIS ECHANDIA Hernando; op cit TI; p. 155

${ }^{121}$ DE PINA, Rafael; Tratado de las pruebas civiles; $3^{a}$ ed., Ed. Porrúa; México; 1981; pp. 38 у 39; OVALlE FAVELA, José; “Derecho Procesal Civil” 2a ed. Ed. Oxford University Press; México; 2005; CARNELUTTI Francesco; op cit. pp. 38-40

${ }^{122}$ En un mismo sentido, la Ley de Enjuiciamiento Civil española, en su Artículo 281. Objeto y necesidad de la prueba, nos indica que: "1. La prueba tendrá como objeto los hechos que guarden relación con la tutela judicial que se pretenda obtener en el proceso; 2 . También serán objeto de prueba la costumbre y el derecho extranjero. La prueba de la costumbre no será necesaria si las partes estuviesen conformes en su existencia y contenido y sus normas no afectasen al orden público. El derecho extranjero deberá ser probado en lo que respecta a su contenido y vigencia, pudiendo valerse el tribunal de cuantos medios de averiguación estime necesarios para su aplicación”. 
podrá solicitar al Servicio Exterior Mexicano, así como disponer y admitir las diligencias probatorias que considere necesarias o que ofrezcan las partes. ${ }^{123}$

De este modo, el objeto de la prueba puede sentarse en las siguientes reglas:

a) El objeto normal de la prueba son los hechos afirmados por las partes, no obstante dentro de estos, los hechos confesados, los notorios, los que tengan a su favor una presunción legal, los irrelevantes y los imposibles, no requieren ser probados. Respecto a cada uno de ellos me refiero a continuación ${ }^{124}$ :

1. - El que los hechos admitidos como ciertos de manera explícita o implícita por las partes no requieran ser probados, no significa que se trate de hechos excluidos de prueba, sino de hechos que se tienen como "probados" anticipadamente, ya sea en los escritos de demanda o de contestación y conocidos como ficta confessio.

2. - Los hechos notorios no necesitan ser afirmados ni probados por las partes, para que sean apreciados por el juzgador en el proceso, según lo dispuesto en el artículo 286 del Código de Procedimientos Civiles mexicano, por tales hechos, debe entenderse aquellos cuyo conocimiento puede obtener el promedio de los individuos de una sociedad.

\footnotetext{
${ }^{123} \mathrm{Al}$ respecto y en forma homologa la Ley de Enjuiciamiento Civil española, nos refiere en su Artículo 281. El Objeto y necesidad de la prueba, y que versa como sigue:

“1. La prueba tendrá como objeto los hechos que guarden relación con la tutela judicial que se pretenda obtener en el proceso.

2. También serán objeto de prueba la costumbre y el derecho extranjero. La prueba de la costumbre no será necesaria si las partes estuviesen conformes en su existencia y contenido y sus normas no afectasen al orden público. El derecho extranjero deberá ser probado en lo que respecta a su contenido y vigencia, pudiendo valerse el tribunal de cuantos medios de averiguación estime necesarios para su aplicación.

3. Están exentos de prueba los hechos sobre los que exista plena conformidad de las partes, salvo en los casos en que la materia objeto del proceso esté fuera del poder de disposición de los litigantes.

4. No será necesario probar los hechos que gocen de notoriedad absoluta y general”

${ }^{124}$ OVALLE FAVELA, José; op cit, p. 105; en el mismo sentido el procesalista mexicano Rafael DE PINA VARA, en su obra Tratado de las Pruebas Civiles, lo deja asentado en las páginas 40 a 43.
} 
3. En los hechos presumidos es preciso distinguir tres elementos: un hecho conocido, un hecho desconocido y una relación de causalidad entre ambos hechos. Cuando las presunciones legales son absolutas, excluyen la carga de la prueba, pero si son relativas, sólo relevan la carga de la prueba del hecho desconocido, por lo tanto, es necesario probar el hecho del cual parte la presunción, es decir, en el que se fundan.

4. Los hechos irrelevantes son aquellos que no son pertinentes ni trascendentes para la resolución en conflicto, y por eso debe excluírseles del proceso.

5. Con relación a los hechos imposibles o inverosímiles, el artículo 298 del Código de Procedimientos Civiles de México, prohíbe su admisión, claro que respecto de ellos, el juzgador debe ser cauteloso para determinar ésta naturaleza.

b) Los hechos que pueden ser objeto de prueba, son muy amplios y aunque no pueden limitarse a una lista, se señalan demostrativamente los siguientes:

1. Todo lo que puede representar una conducta humana, los sucesos o acontecimientos, hechos o actos humanos voluntarios o involuntarios, individuales o colectivos que sean perceptibles, inclusive las simples palabras pronunciadas, sus circunstancias de tiempo, modo y lugar, así como el juicio o calificación que de ellos se tenga. 
2. Los hechos de la naturaleza en que no interviene actividad

humana.

3. Las cosas o los objetos materiales, cualquier aspecto de la realidad material, sean o no productos del hombre, incluyendo los documentos.

4. La persona física, su existencia y características, estado de salud, estados y hechos síquicos o internos, incluyendo el conocimiento tácito o la conformidad.

c) No es preciso probar el Derecho nacional, porque la aplicación de la norma jurídica es una función procesal del juez y en realidad una presunción, cuyo cumplimiento no puede eludirse por ignorancia y ni siquiera por la inexistencia de un precepto normativo aplicable al caso concreto, pues en tal supuesto debe recurrirse a la analogía o a los principios generales del derecho, como lo dispone el artículo 14 constitucional mexicano. ${ }^{125}$

d) Respecto a las costumbres y las normas de derecho extranjero, no existe propiamente una actividad probatoria en estricto sentido, sino una colaboración a dicha actividad exclusivamente encomendada al juzgador, pues la aplicación de las normas de Derecho es un problema de conocimiento del orden jurídico. ${ }^{126}$

\footnotetext{
${ }^{125}$ Constitución Política de los Estados Unidos Mexicanos, “Artículo 14.- A ninguna ley se dará efecto retroactivo en perjuicio de persona alguna.

Nadie podrá ser privado de la libertad o de sus propiedades, posesiones o derechos, sino mediante juicio seguido ante los tribunales previamente establecidos, en el que se cumplan las formalidades esenciales del procedimiento y conforme a las Leyes expedidas con anterioridad al hecho.

En los juicios del orden criminal queda prohibido imponer, por simple analogía, y aún por mayoría de razón, pena alguna que no esté decretada por una ley exactamente aplicable al delito de que se trata.

En los juicios del orden civil, la sentencia definitiva deberá ser conforme a la letra o a la interpretación jurídica de la ley, y a falta de ésta se fundará en los principios generales del derecho.”

${ }^{126}$ Por ello el juzgador podrá solicitar al Servicio Exterior los informes oficiales necesarios para conocer el texto, vigencia, sentido y alcance legal del derecho extranjero, sin perjuicio de que las partes proporcionen tal información, según lo dispuesto por el artículo 284-bis del CFPC.
} 


\subsubsection{Diferencia entre objeto y el fin de la prueba.}

El objeto de la prueba en general y de la judicial en particular, se resumen en todo aquello sobre lo cual puede recaer o versar la actividad probatoria, pero ¿para qué se prueba en el proceso?, ¿cuál es la intención de proporcionar al juzgador los medios probatorios dentro del proceso? La respuesta a estas interrogantes constituyen lo que debe entenderse por el fin de la prueba judicial. ${ }^{127}$ Así podemos identificar el objeto de la prueba como aquella realidad susceptible de ser probada, sin relación con ningún proceso en particular, es decir de una noción abstracta y objetiva. ${ }^{128}$

En principio, sabido es que en todo proceso contencioso la prueba se convierte en un arma de ataque y de defensa, con la cual las partes buscan obtener sus pretensiones. Sin embargo, ese fin individual y concreto de los contendientes siempre en su favor y para su beneficio, no representa de manera alguna su fin primordial, sino un fin secundario de acuerdo con su interés y egoísmo. Por eso, han sido diversas las teorías desarrolladas respecto al fin de la prueba, encontrándose dentro de ellas las siguientes:

\section{a) Teoría que considera como fin de la prueba judicial el establecer la verdad.}

Esta considera como fin de la prueba judicial, el establecer la verdad, sus máximos exponentes como BENTHAM, BONNIER y DELLEPIANE ${ }^{129}$, están a favor de que el objetivo de los medios probatorios en el proceso, es el

\footnotetext{
${ }^{127}$ DEVIS ECHANDIA; op cit. TI; p. 238

128 PARRA QUIJANO, Jairo; Manual de Derecho Probatorio; 15ª ed., Ed. Librería Ediciones del profesional ltda., Bogota, Colombia; 2006; p. 129

${ }^{129}$ BONNIER, EDUARDO; Tratado Teórico y Práctico de las pruebas en Derecho Civil y en Derecho Penal traducido por José Vicente y Caravantes; Ed. Reus, 1929 pp. 8 y 9; BENTHAM JEREMIAS; op cit. pp. 85 y 86
} 
descubrimiento y la comprobación de la verdad de los hechos controvertidos. Esta teoría podemos considerar que hasta cierto punto es inaceptable, porque en su opinión, el resultado de la prueba puede no corresponder a la verdad, a pesar de llevarle al juez el convencimiento necesario para fallar.

\section{b) Teoría que estima como fin de la prueba judicial producir el convencimiento del juzgador, o llevarle la certeza necesaria para su decisión}

Relativa a que el fin de la prueba judicial es producir el convencimiento del juzgador, o llevarle la certeza necesaria para su decisión, es la más aceptada hoy en día y entre sus partidarios se encuentran LESSONA, ROCCO, FURNO, GUASP y COUTURE, quienes consideran que el fin de la prueba es formar la convicción de los órganos jurisdiccionales sobre la verdad, existencia, falsedad o inexistencia de los hechos controvertidos, a efecto de que los mismos pueden dictar sentencia justa conforme a Derecho. ${ }^{130}$

\section{c) Teoría que sostiene como fin de la prueba judicial fijar los hechos en el proceso}

Esta sostiene como fin de la prueba judicial, fijar los hechos en el proceso, su máximo representante es CARNELLUTI, quien sostiene que el proceso no sirve para conocer los hechos y establecer su verdad, sino únicamente para conseguir una fijación formal de ellos. ${ }^{131}$ Evidentemente, ésta posición contempla un planteamiento incompleto del problema del fin de la prueba,

\footnotetext{
${ }^{130}$ FURNO, Carlo; Teoría de la Prueba Legal, Ed. Obregón y Heredia; 1983; pp. 25 y 26

${ }^{131}$ CARNELUTTI Francesco; op cit. pp. 44 - 46
} 
porque desde la perspectiva de la primera y la segunda tesis, en principio deben fijarse los hechos del proceso, para después comprobar la veracidad o falsedad de los mismos.

Así, de acuerdo con estas teorías relativas al fin de la prueba, la más aceptada por nosotros es aquella en la cual se determina que su objetivo, es producir el convencimiento del juzgador respecto de los hechos controvertidos, llevándole a la certeza necesaria para dictar su decisión con justicia y conforme a derecho.

\subsubsection{El derecho a la prueba.}

Este es de suma importancia para las partes contendientes en todo juicio, así mientras para los actores resulta indispensable en el ejercicio de su acción, también para los demandados lo es, al oponer sus excepciones o defensas. Es claro que sin el derecho de probar, no existiría audiencia bilateral, ni se cumpliría con la exigencia constitucional de condenar a un individuo, sólo cuando haya sido oído y vencido en juicio.

El derecho de probar tiene por objeto concretamente la práctica de los medios probatorios ofrecidos por las partes, es decir, que las pruebas presentadas por ambas, se admitan, se practiquen dentro del procedimiento y se tomen en consideración, al dictar la resolución correspondiente. ${ }^{132}$ Por ello, la naturaleza jurídica del derecho a la prueba es la de un derecho subjetivo procesal, pues el mismo deriva de un acto de voluntad, de una petición de cualquiera de las partes en el proceso, para practicar los medios probatorios con los cuales pretenden deducir sus pretensiones o excepciones. ${ }^{133}$

\footnotetext{
${ }^{132}$ DEVIS ECHANDIA, Hernando; op cit. pp. 36 y 37

${ }^{133}$ Idem p. 35
} 
En este sentido, el sujeto pasivo de ese derecho subjetivo procesal es el juez, quien está vinculado a decretar y practicar las pruebas ofrecidas, con las formalidades legales, siempre y cuando no exista razón para considerarlas inadmisibles por ser inconducentes, impertinentes o simplemente prohibidas por la ley. Si el juzgador no cumpliera con tal deber, su actitud representaría una auténtica denegación de justicia, la cual podría acarrearle responsabilidades civiles o penales.

\subsection{Carga de la prueba: características esenciales}

Al abordar lo relativo a la carga de la prueba es común que los autores pretendan explicar a cuál de las partes en juicio le corresponde probar los hechos controvertidos. Esto en realidad es un error, porque la carga de la prueba únicamente señala quién tiene el interés jurídico en demostrar cada hecho en el proceso, para obtener una decisión favorable en el mismo. ${ }^{134}$

En este sentido, la carga de la prueba indica a quién corresponde evitar que falte la prueba de cierto hecho, es decir, a quién interesa que se produzca cierta prueba, y por lo tanto, afecta en la sentencia la falta de tal prueba, si pretende obtener una decisión favorable basada en ella.

Podemos de igual forma siguiendo este criterio, concebir a la carga de la prueba como una noción procesal que contiene la regla del juicio, por medio de la cual se le indica al juez como debe de fallar cuando no se encuentre en el proceso pruebas que le den certeza sobre los hechos que deben fundamentar su

\footnotetext{
${ }^{134}$ ibídem p. 427
} 
decisión, e indirectamente establece a cuál de las partes le interesa la prueba de tales hechos, para evitarse las consecuencias desfavorables ${ }^{135}$

La regla general en todos los procesos sin distinción de procedimiento o naturaleza de las pretensiones en ellos aducidas, es que al juzgador corresponde decidir a falta de convencimiento sobre los hechos, quién tiene el interés jurídico de probar los hechos controvertidos para obtener sentencia favorable. Esto significa indirectamente una regla de conducta para las partes, al señalarles cuáles son los hechos que a cada una le interesa probar, a efecto de servir de fundamento a sus pretensiones o excepciones.

Dentro de las características esenciales de la prueba podemos mencionar:

a. La carga de la prueba no consiste en fijar quién debe aportar los medios probatorios en el proceso, sino quién asume el riesgo cuando ellos falten.

La carga de la prueba no significa que la parte sobre la cual recae la demostración de un hecho, deba ser necesariamente quien la presente o la solicite, porque en virtud del principio de la comunidad de la prueba, ésta surte todos sus efectos independientemente de quien la haya suministrado o pedido, e inclusive si proviene de la actividad oficiosa del juzgador. Por consiguiente, si el adversario o el juez llevan la prueba del hecho, queda satisfecha a cabalidad la carga exactamente como si la parte gravada con ella la hubiera suministrado.

Así, es incorrecto señalar a cuál de las partes en juicio corresponde probar los hechos controvertidos, pues más bien se trata de determinar quien

${ }^{135}$ PARRA QUIJANO, Jairo; Op cit p. 227 
tiene el interés jurídico en demostrar cada hecho, o bien, evitar que el mismo quede sin prueba y asumir el riesgo de su falta.

b. La carga de la prueba se refiere la actividad desarrollada por los sujetos del litigio judicial, para demostrar sus afirmaciones y conseguir un resultado favorable a su propio interés, protegido por una norma jurídica.

c. La regla general para la distribución de la carga de la prueba. ${ }^{136} \mathrm{~A}$ cada parte incumbe probar los hechos integrantes del supuesto hipotético contenido en la norma jurídica, cuyo presupuesto es aplicado como fundamento de su pretensión. Dicho en otras palabras, la responsabilidad por el resultado del proceso recae sobre las partes, pues cada una de ellas tiene la carga de probar los hechos que constituyan el supuesto de la norma en la cual se amparan.

d. De la máxima romana onus probando incumbit ei qui dicit non qui negat, debe destacarse que la carga de la prueba corresponde a quien asevera los hechos, es decir, al que los afirma no a quien los niega. ${ }^{137}$ Así, mientras el actor tiene la carga de demostrar los hechos constitutivos de su derecho, el demandado debe probar los hechos impeditivos, extintivos y excluyentes, pues si sólo se limita a negar los invocados por el actor no probará nada. ${ }^{138}$

e. Existe una excepción a la regla de que la carga de la prueba la tiene quien afirma un hecho, no quien lo niega, lo cual encontramos en el artículo 82 del Código de Procedimientos Civiles de México, al establecer en su máxima de que el sujeto que niega sólo está obligado a probar en los casos siguiente:

\footnotetext{
${ }^{136}$ Dentro de este punto es importante mencionar que es menester el dar la total aceptación a la carga material de la prueba

${ }^{137}$ GOMEZ DE LIAÑO GONZALEZ, FERNANDO; El Proceso Civil; ed. Forum; Oviedo, España; 1993; pp. 25

${ }_{138}$ Al respecto, el artículo 81 del Código Federal de Procedimientos Civiles mexicano, dispone que las partes asumirán la carga de la prueba de los hechos constitutivos de sus pretensiones.
} 
I. Cuando la negación envuelva la afirmación expresa de un hecho;

II. Cuando se desconozca la presunción legal que tenga a su favor el colitigante, $\mathrm{y}$

III. Cuando se desconozca la capacidad.

El primer supuesto de dicho artículo se refiere a cuando la negación envuelva la afirmación expresa de un hecho, se presenta ante la posibilidad de que al negar un hecho, se afirme expresamente la actuación del mismo, pero de otra forma.

En cuanto a la hipótesis contemplada en la segunda fracción, cabe decir que la misma se refiere a las presunciones relativas, las cuales admiten prueba en contrario y tienen como consecuencia invertir la carga de la prueba, es decir, no corresponderá probar a quien afirma un hecho que la ley presume, sino a quien lo niega.

La fracción tercera nos refiere a cuando se desconozca la capacidad de la contraparte. Esta hipótesis, en realidad puede quedar comprendida en la fracción primera de dicho precepto, pues quien niega la capacidad de una persona, está afirmando implícitamente su incapacidad y por ende está vinculada a probarlo.

f. La carga de la prueba es una medida imprescindible de sanidad jurídica, una condición sine qua non de toda buena administración de justicia. constituye una guía indispensable y fundamental para el juzgador en la solución de los litigios, pues orienta su criterio en la fijación de los hechos que sirven de base a su decisión. 
Si no existieran las reglas fundamentales sobre la carga de la prueba, sería muy frecuente el fracaso del proceso y la consiguiente pérdida de tiempo, trabajo y dinero para el Estado y las partes. La justicia y la función jurisdiccional del Estado resultarían entorpecidas y frustradas en infinidad de ocasiones, al no ser posible la sentencia de mérito por falta de pruebas, a la vez que se fomentaría la incertidumbre jurídica en las relaciones sociales, la repetición indefinida de procesos para el mismo litigio, y de igual manera, se permitiría que quienes tenga interés en esa situación caótica puedan fácilmente burlar los fines de interés público del proceso y la jurisdicción, ocultando las pruebas y entorpeciendo la actividad oficiosa del juez. ${ }^{139}$

\subsection{Fuentes y medios de prueba}

Los medios de prueba, en opinión de DEVIS ECHANDIA ${ }^{140}$, pueden considerarse desde dos puntos de vista: en primer lugar, se entiende por fuente de prueba, aquello de donde las partes en juicio extraen los motivos o argumentos, para lograr la convicción del juzgador sobre los hechos del proceso, es decir, la confesión de la parte, la declaración del testigo, el dictamen del perito, la inspección o percepción del juez ${ }^{141}$, la narración contenida en el documento, la percepción e inducción de la prueba de indicios.

En segundo lugar, se entiende por medio de prueba, los instrumentos y órganos que suministran al juez ese conocimiento y esas fuentes de prueba, a saber: el testigo, el perito, la parte confesante, el documento, la cosa que sirve de indicio, es decir, los elementos personales y materiales de la prueba.

\footnotetext{
${ }^{139}$ PARRA QUIJANO, Jairo; op cit. P. 450

${ }^{140}$ DEVIS ECHANDIA, Hernando; op cit. p551

${ }^{141}$ PARRA QUIJANO, Jairo; Op cit; p. 163
} 
Esta visión según CARNELUTTI, es la misma noción contemplada en la primera perspectiva, pues entre el confesante y la confesión o el testigo y el testimonio, no media más distinción que la del punto de vista, porque el confesante o el testigo es la persona en actividad, mientras la confesión o el testimonio es el acto de la persona. ${ }^{142}$

Podemos entonces decir, que los medios de prueba son aquellos de donde las partes en juicio extraen los motivos o su argumentos, para lograr la convicción del juzgador sobre los hechos del proceso, como los instrumentos y órganos que suministran al juez esas pruebas, lo cual nos parece impreciso, pues aunque la confesional, testimonial, pericial o inspección judicial se realizan a través de una conducta humana, es preciso no confundir estos medios de prueba con los sujetos que los realizan. En este sentido debemos distinguir entre la persona conocida como sujeto de la prueba y la conducta que ésta realiza, que es el medio de prueba. ${ }^{143}$

Así, los testigos y los peritos son sujetos de prueba en tanto que realizan determinadas conductas, tales como formular declaraciones o dictámenes, cuyo objeto es lograr la certeza del juzgador sobre los hechos discutidos en el proceso, por ello, los medios de prueba no son tales personas, sino sus declaraciones o sus dictámenes. De esta forma, los medios de prueba son únicamente aquellos instrumentos mediante los cuales se pretende lograr el convencimiento del juez, sobre los hechos objeto de prueba. ${ }^{144}$

La fijación de los medios de prueba es diferente en cada sistema jurídico, por ello es necesario destacar la existencia de tres de ellos para su determinación:

\footnotetext{
${ }^{142}$ CARNELUTTI, Francesco; op cit. pp. 197 y 198

143 GÓMEZ DE LIAÑO GONZẦLEZ, Fernando; op cit p. 128

${ }^{144}$ MATEOS ALARCÓN, Manuel; op cit. p. 14
} 
1. El sistema de la prueba libre.- Éste deja a las partes en absoluta libertad para proponer los medios de prueba, con los cuales pretenden acreditar sus pretensiones en juicio, y al mismo tiempo, el juez tiene la libertad para admitir dichos medios u ordenar otros que considere aptos para la formación de su convencimiento.

2. El sistema de pruebas legales, el cual consiste en una regulación taxativa de los medios de prueba, es decir, la misma legislación señala cuales son, y tanto las partes como el juez están limitados a los mismos, e impedidos para desconocerlos.

3. El sistema mixto, en el que se enumeran los medios de prueba que las partes y el juez no pueden desconocer, otorgándoles asimismo a las partes la libertad de aportar otros medios para acreditar sus pretensiones en juicio, y la facultad al juzgador de admitirlos u ordenar otros que estime útiles para la formación de su convencimiento. ${ }^{145}$

De estos sistemas de fijación de los medios de prueba, el mejor es el sistema mixto, ya que lleva implícito el sistema de la prueba libre, y no es incompatible con la determinación legal previa de los medios admisibles en la mayoría de los códigos procesales, ni con la exigencia de determinados medios formales para la validez de ciertos actos jurídicos materiales, sino por el contrario, coincide perfectamente con estas exigencias. ${ }^{146}$

El sistema de la prueba libre implícito en el sistema mixto es ideal en la moderna concepción del proceso, por múltiples motivos, entre ellos, porque

\footnotetext{
145 DEVIS ECHANDIA; Hernando; op cit. p. 553

146 İdem, pp. 553 - 557.
} 
dicha libertad únicamente encuentra límites en las formalidades procesales para la proposición, ordenación y práctica de los medios de prueba, por ser necesaria para garantizar la debida contradicción y la lealtad en el debate probatorio, y porque no hay razón lógica para impedirle al juzgador, la admisión de los posibles medios de prueba provenientes del progreso científico, con el sólo argumento de que no están contemplados en alguno de los enumerados muchos años antes de los códigos de procedimientos civiles.

En este sentido, es razonable permitirle al juzgador la formación de su convencimiento y la investigación de la realidad de los hechos, por todos los medios que de cualquier manera sirven para ese propósito, y otorgarle libertad para apreciar su mérito, según los principios de la lógica, la psicología judicial, la sana crítica y las reglas de la experiencia.

El sistema contemplado en los Códigos de Procedimientos Civiles ${ }^{147}$ tanto de México como España, es un sistema mixto, pues aun cuando dichas leyes regulan los medios de prueba clásicos, determinan que son admisibles como medios de prueba, los elementos que puedan producir convicción en el ánimo del juzgador acerca de los hechos controvertidos o dudosos. ${ }^{148}$

\footnotetext{
${ }^{147}$ Al tanto, el artículo 69 del Código Federal de Procedimientos Civiles mexicano, nos estipula que para conocer la verdad de los puntos controvertidos, el juzgador puede valerse de cualquier persona, parte o tercero y de cualquier documento o cosa, siempre que no estén prohibidas por la ley ni sean contrarias a la moral.

148 Esto lo encontramos sustentado en virtud de que tanto la Ley de Ejecución Civil española como el Código Federal de Procedimientos Civiles mexicano en su artículo 93, disponen como medios de prueba los siguientes: Artículo 299. Medios de prueba

1. Los medios de prueba comparados entre el Derecho español y mexicano entre paréntesis, de que se podrá hacer uso en juicio son:

España
$1^{\mathrm{o}}$ Interrogatorio de las partes.
$2^{\mathrm{o}}$ Documentos públicos.
$3^{\mathrm{o}}$ Documentos privados.
$4^{\mathrm{o}}$ Dictamen de peritos.
$5^{\mathrm{o}}$ Reconocimiento judicial.
$6^{\mathrm{o}}$ Interrogatorio de testigos.

México

(confesión)

Documentos públicos.

Documentos privados

(dictámenes periciales)

(reconocimiento e inspección judicial)

(los testigos)

2. También se admitirán, conforme a lo dispuesto en esta Ley, los medios de reproducción de la palabra, el sonido y la imagen, así como los instrumentos que permiten archivar y conocer o reproducir palabras,
} 


\section{a) Prueba confesional}

La prueba confesional ha sido considerada como la reina de las pruebas; y definida de diversas formas. Para CARNELUTTI, la confesión es el testimonio de la parte, cuyo objeto es un hecho contrario a su interés. ${ }^{149}$

Para DELLEPIANE, "La confesión es el reconocimiento de una obligación, o de la intervención de un delito, en calidad de autor, cómplice o encubridor, que hacen, bien sea el deudor de la obligación, o bien, el implicado en el delito, según el caso". ${ }^{150}$

MATEOS ALARCÓN, opina que “... la confesión es la declaración judicial o extrajudicial (espontaneidad provocada), con la cual una parte, capaz de obligarse, con el ánimo de suministrar a la otra una prueba con el perjuicio suyo, reconoce total o parcialmente la verdad de una obligación o de un hecho, que es susceptible de efectos jurídicos. ${ }^{151}$

Estas definiciones doctrinales se encuentran disociadas de la realidad práctica de la actividad procesal, porque en la mayoría de las ocasiones la confesión sólo es la versión del absolvente sobre los puntos controvertidos, en la que inevitablemente procura no perjudicarse, aun cuando esté protestado de decir verdad, y en todas ellas es posible observar como elemento en común, el que el autor de la confesión declara hechos propios en su perjuicio, y solamente DEVIS ECHANDIA, acepta también como otros hechos de esa declaración, aquellos simplemente favorables a la contraparte en el proceso.

\footnotetext{
datos, cifras y operaciones matemáticas llevadas a cabo con fines contables o de otra clase, relevantes para el proceso."

${ }^{149}$ CARNELUTTI Francesco, op cit p. 225

${ }^{150}$ DELLEPAINE Antonio, op cit p. 118

${ }^{151}$ MATEOS ALARCÓN, Manuel; op cit p. 60
} 
Así mismo, en la definición sostenida por DEVIS ECHANDIA, son evidentes otras imprecisiones, pues dicho autor señala que la confesional consiste en una declaración de ciencia, lo cual no es correcto, porque es un requisito indispensable para la validez de la confesión que la declaración recaiga sobre hechos personales del confesante. ${ }^{152}$

De igual forma, lo sostenido por este autor en cuanto a que se trata de una declaración consistente, terminante, voluntaria y sin coacciones, constituye otra disociación con la realidad, porque no siempre dicha declaración es de esa forma, al poder ocurrir situaciones en las cuales el confesante reconoce un hecho, porque no lo entendió bien o se confundió, o porque su creencia era equivocada, y en esos casos esa declaración no es concluyente frente a otros hechos que consten racionalmente por otros medios de prueba. Además, también es común que no se trate de una declaración de voluntad sin coacción, más aun cuando el confesante está protestado de decir verdad y mediante su declaración procura perjudicarse.

Por eso, la confesional es un medio probatorio consistente en la declaración efectuada durante el proceso ante un funcionario competente para dirimir la controversia, que sobre la versión de hechos propios realiza una de las partes del juicio - tanto personas físicas de modo personal cuando así lo exija quien la aduzca en el proceso, como personas morales a través de un mandatario o representante -, conforme al interrogatorio contenido ya en un pliego de posiciones exhibido por el oferente ${ }^{153}$, así como de acuerdo a las posiciones que el mismo juzgador o su oferente le articulen de manera directa al confesante.

\footnotetext{
152 DEVIS ECHANDIA, Hernando; op cit. p. 667

${ }^{153}$ En el caso mexicano, siempre tendrá que existir en materia civil un pliego de posiciones previo a la audiencia, ya que en caso de que bajo el apercibimiento de ley el absolvente no se presentaré únicamente se le podrá tomar como confeso de las posiciones contenidas en el pliego depositado previamente.
} 


\section{b) Prueba testimonial}

Para Francesco CARNELUTTI, la prueba testimonial es definida como "un acto humano dirigido a representar un hecho no presente, es decir, acaecido antes del acto mismo”. 154

Eduardo BONNIER, nos dice que “... hay testimonio siempre que se trate de declaración sobre hechos pasados, de terceros desinteresados”. ${ }^{155}$

Ahora, GÓMEZ DE LLAÑO, en su obra, comenta que "la prueba por testigos, también denominada prueba testifical, es la que proporcionan personas que son ajenas al proceso, conocedores de los hechos directa o indirectamente, contestando ante el juez al interrogatorio formulado por las partes”. ${ }^{156}$

Para ECHANDIA, la prueba testimonial tiene dos puntos de vista, uno en sentido estricto, el testimonio es un medio de prueba que consiste en la declaración representativa que una persona, que no es parte en el proceso en que se dice, hace un juez, con fines procesales, sobre lo que sabe respecto a un hecho de cualquier naturaleza; y el segundo en sentido amplio, es testimonio también esa declaración, cuando proviene de quien es parte en el proceso en que se aduce como prueba, siempre que no perjudique su situación jurídica en ese proceso porque entonces sería confesión. ${ }^{157}$

El concepto de testimonio proporcionado está adecuado a la noción de testigos aportada por Francesco CARNELUTTI y Jeremias BENTHAM, pues ambos autores también distinguen al sujeto del testimonio mediante dos

\footnotetext{
${ }^{154}$ CARNELUTTI, FRANCESCO, op cit p. 121

${ }^{155}$ BONNIER, Eduardo; op cit p. 218

${ }^{156}$ GOMEZ DE LIANO GONZÀLEZ, Fernando; op cit; p. 155

${ }^{157}$ DEVIS ECHANDIA; Hernando; Teoría General de la Prueba Judicial Tomo II; $5^{\mathrm{a}}$ ed., Argentina; p. 33
} 
acepciones. En sentido amplio, el testigo abarca tanto a la parte en el proceso como al tercero ajeno a él, mientras en sentido estricto, el testigo sólo es el tercero ajeno al proceso. ${ }^{158}$

El concepto de testimonio aportado por CARNELUTTI comprende sin duda estas dos acepciones de testigos, pues dicho autor define de manera genérica este medio probatorio, como un acto humano dirigido a representar un hecho no presente, es decir, un hecho acaecido antes de la declaración testimonial, lo cual significa que el testimonio es siempre una declaración representativa o un medio de representación personal o subjetiva de algún hecho. Sin embargo, es importante destacar que no necesariamente un testimonio versa siempre sobre hechos acaecidos en el pasado, como también se puede señalar que ocasionalmente esos hechos subsisten en el momento de la declaración, e incluso con posterioridad a ella, aunque su existencia haya comenzado antes.

Las definiciones doctrinales referidas reflejan la inexistencia de un concepto uniforme de prueba testimonial, y que dicho medio probatorio puede definirse mediante dos acepciones, dependiendo de quien rinda la declaración, así en sentido lato pueden ser sujetos del testimonio, la parte y el tercero, mientras en sentido estricto sólo es sujeto de la misma, el tercero.

\section{b) Inspección o Reconocimiento Judicial}

Doctrinalmente, la inspección o reconocimiento judicial, se ha definido por diversos autores como MATEOS ALARCÓN, para quien es “... el

\footnotetext{
${ }^{158}$ De las definiciones anteriores, la concordancia de los conceptos de BONNIER, GÓMEZ DE LIAÑO y DEVIS ECHANDÍA, en cuanto a que la prueba testimonial es una declaración proporcionada por quien conoce ciertos hechos, que es una persona ajena al proceso, sin embargo ECHANDIA considera los sujetos del testimonio dependiendo de la aceptación con la cual se le defina, así en sentido restringido, será siempre un acto procesal de terceros, incluyendo en sentido genérico, tanto a las personas ajenas al proceso como a las partes del mismo, con la peculiaridad de que el declarante no debe perjudicar su situación jurídica, pues de lo contrario sería una confesión.
} 
examen que el juez hace en personas y con arreglo a derecho, de las cosas que son objeto de la contienda"159.

En esta misma linea, Enrique PAILLAS ${ }^{160}$, la define como: “una prueba directa pues el juez capta con sus propios sentidos, de visu el de auditu, vel facta probando".

Erich DÖHRING, denomina a esta prueba como “... el acto por el cual el averiguador, en vez de hacerse informar por otros, toma personalmente conocimiento de un objeto concreto con fines de esclarecimiento»161

Aun cuando este autor define a la inspección o reconocimiento judicial con la expresión “inspección ocular”, señala que ese vocablo no alude únicamente a las percepciones obtenidas en el sentido de la vista, sino a observaciones de toda índole, cuya percepción sea transmitida por el oído, el olfato o el tacto, es decir, por cualquiera de los sentidos, como podría ocurrir cuando al juzgador le corresponda determinar la intensidad de los ruidos, el humo o los olores desagradables producidos por un establecimiento industrial.

Para DEVIS ECHANDIA, al referirse a esta probanza, la define como: “... una diligencia procesal, practicada por un funcionario judicial, con el objeto de obtener argumentos de prueba para la formación de su convicción, mediante el examen y la observación con sus propios sentidos, de hechos ocurridos durante la diligencia o antes pero que subsisten o de rastros o huellas de hechos pasados y en ocasiones de su reconstrucción”. ${ }^{162}$

\footnotetext{
${ }^{159}$ MATEOS ALARCÓN, op cit. p. 215

160 PAILLAS, Enrique; La Prueba en el Derecho Penal; 2a ed., Ed. Cardenas Editor y Distribuidor, México, 2002, p. 93

${ }^{161}$ DÖHRING, Erich; op cit; p. 297.

162 DEVIS ECHANDIA, Hernando; op cit. T. II p. 415
} 
De acuerdo a estas definiciones, podemos decir que la inspección o reconocimiento judicial es la diligencia procesal mediante la cual el juez conoce personalmente, a través de sus sentidos, cualquier cuestión controvertida en juicio, con el objeto de formar su propia convicción y obtener los argumentos de prueba necesarios para resolver sobre la misma. ${ }^{163}$

\section{d) Prueba documental}

Doctrinalmente, esta probanza ha sido definida por diversos autores, dentro de los cuales en forma principal encontramos a los siguientes:

Erich DÖHRING, nos dice que es “... la manifestación de un pensamiento que ha tomado cuerpo en caracteres de escritura" ${ }^{164}$; el documento es un objeto inanimado y por ende una cosa.

Francesco CARNELUTTI, al hacer referencia a esta prueba nos dice que "el documento no es sólo una cosa, sino una cosa representativa, o sea, capaz de representar un hecho”. ${ }^{165}$

Para GÓMEZ DE LIAÑO, nos representa que el “documento, es fundamentalmente un escrito que contiene una declaración de voluntad o de conocimiento, o simplemente una expresión de pensamiento". ${ }^{166}$

\footnotetext{
${ }^{163}$ De lo expuesto, se considera más adecuada la de DEVIS ECHANDIA, al dejar cubierta la práctica de la inspección o reconocimiento judicial, con una expresión más genérica como es la de funcionario judicial, a limitarla con la sola referencia de que corresponde al juez, porque comúnmente dichas diligencias procesales también son llevadas a cabo por los secretarios de acuerdos de los juzgados, quienes tienen fe pública.

En cuanto a la expresión de inspección ocular realizada por DÖHRING: él mismo aclara que no sólo puede tratarse de percepciones adquiridas por el sentido de vista, si no también de las obtenidas por cualquiera de los sentidos.

${ }^{164}$ DÖHRING, Erich; op cit. p. 275

${ }^{165}$ CARNELUTTI, Francesco; op cit. p. 156

${ }^{166}$ GÓMEZ DE LIAÑO GONZÁLEZ, Fernando; op cit. p. 139
} 
DEVIS ECHANDÍA nos señala que: “... documento es toda cosa que sea producto de un acto humano, perceptible con los sentidos de la vista y el tacto, que sirve de prueba histórica indirecta y representativa de un hecho cualquiera”. ${ }^{167}$

Los primeros autores nos restringen la manifestación del documento a la forma escrita, mientras que el último de ellos cambia su postura, ampliando su concepto a cualquier cosa producto de un acto humano, ya que, también puede tratarse de algo únicamente representativo, cuando no contiene ninguna declaración, como ocurre en el caso de los planos, cuadros, fotografías o discos fonográficos.

Asimismo, en cuanto al contenido del documento, DÖHRING lo representa como la manifestación del pensamiento, mientras que GÓMEZ DE LIAÑO, lo representa como la declaración de la voluntad o de conocimiento, y ECHANDIA, explica el carácter representativo del documento a partir de su etimología, porque la voz documento deriva de docere, cuyo significado es enseñar, dar a conocer. ${ }^{168}$

Así, concluyendo este punto, el documento no puede limitarse únicamente a lo escrito, sino a todo aquello cuya función sea representar una idea o un hecho. Por ello, es preciso distinguir entre documentos materiales y literales: los primeros tienen lugar cuando la representación no se hace a través de la escritura, tal como sucede con las fotografías, dibujos, cuadros, planos, discos fonográficos o cintas cinematográficas, entre otros. Los literales son aquellos que cumplen su función representativa mediante la escritura.

\footnotetext{
${ }^{167}$ DEVIS ECHANDIA; op cit. T. II; p. 486

${ }^{168}$ Ídem; P. 514
} 


\section{e) Indicios.}

El término "indicios" proviene de la voz latina indicium, que es una derivación de indicere, y cuyo significado es indicar, hacer conocer algo, siguiendo esto, DEVIS ECHADIA, al definir esta probanza, nos dice que es: “... un hecho conocido del cual se induce otro hecho desconocido, mediante un argumento probatorio que de aquél se obtiene, en virtud de una operación lógica - crítica basada en normas generales de la experiencia o en principios científicos o técnicos”. ${ }^{169}$

En esta orden de ideas, DELLEPIANE nos dice que el indicio "es todo rastro, vestigio, huella, circunstancia y en general, todo hecho conocido o mejor dicho, debidamente comprobado, susceptible de llevarnos, por vía de inferencia, al conocimiento de otro hecho desconocido". ${ }^{170}$

Para CARNELUTTI, "es una fuente de pruebas, porque no se trata en sí de un hecho, más bien, se convierte en tal, cuando una regla de la experiencia lo vincula con el hecho a probar, en una relación lógica que permita deducir la existencia o inexistencia de éste, por ello, su función probatoria es meramente accidental y surge por la eventualidad de esa relación con el hecho de probar.”171

Es preciso entonces, considerar que el indicio es una fuente de prueba siguiendo a CARNELUTTI, como un medio probatorio derivado de una relación lógica existente entre un hecho conocido y otro cuya pretensión es probar, mediante una operación mental estrictamente lógica y crítica para quien lo

\footnotetext{
169 DEVIS ECHANDIA, Hernando; op cit; T. II p. 601

${ }^{170}$ DELLEPAINE, Antonio; op cit. p. 57

${ }^{171}$ CARNELUTTI, Francesco; op cit. pp. 191 y 192
} 
valora, ya que se encuentra basado en normas generales de la experiencia o en principios científicos o técnicos.

La diferencia esencial entre el indicio y la presunción parte en principio de su distinto significado gramatical, pues de acuerdo a las definiciones contenidas de ambos y remitiéndonos a lo expuesto por la Real Academia de la Lengua Española, nos dice que un indicio es: "Fenómeno que permite conocer o inferir la existencia de otro no percibido", y presunción la "acción y efecto de presumir”, entendiendo este último como “sospechar, juzgar o conjeturar algo por tener indicios o señales para ello”. ${ }^{172}$

Por ende, el indicio parte de una señal o hecho que da a conocer otro hecho oculto, mientras que la presunción es la acción consistente en juzgar ese hecho a partir de los indicios o las señales obtenidas para tal efecto, entonces primero debe existir el indicio, para luego presumir el hecho por esos indicios obtenidos. $^{173}$

De la diferenciación otorgada en forma principal por DEVIS ECHANDIA que nos dice que: "El indicio es el hecho conocido, del cual se obtiene, mediante una operación lógica crítica, un argumento probatorio que permite inducir de aquél, otro hecho desconocido” y por otra parte la presunción “... es un principio lógico, basado en las máximas generales de la experiencia o en conocimientos especializados, que le sirven al juez para determinar el valor probatorio del indicio o de otra prueba cualquiera”. ${ }^{174}$

\footnotetext{
${ }^{172}$ Real Academia de la Lengua Española; op cit. p. 858 y 1241

173 Doctrinalmente, la distinción entre el indicio y la presunción ha constituido uno de los temas más discutidos entre los juristas procesalistas, porque mientras algunos como PLANIOL, RIPERT, PAILLAS, GÓMEZ DE LIAÑO, RAFAEL DE PINA; señalan la identidad de ambas figuras, otros como DELLEPAINE, DOHRING, ECHADIA Y MELLENDO, son defensores de que deben distinguirse radicalmente los indicios de las presunciones.

${ }^{174}$ DEVIS ECHANDIA; Hernando; op cit. T. II; p. 613
} 
Por ende, podemos deducir que dicha distinción consiste en que el indicio es un hecho probado, que sirve de base para la inferencia lógica que lleva a la certeza sobre el hecho presumido, por ende no es un medio de prueba, mientras la presunción es la aplicación de las reglas de la experiencia del juzgador, o bien, de las reglas técnicas suministradas a éste por los peritos, para una correcta apreciación del mérito o eficacia probatoria de cualquier prueba.

\section{f) Presunciones}

Esta prueba tiene su origen en su etimología misma, la cual proviene de la raíz latina praesumere, y la cual significa suponer como cierta una cosa sin que esté probada, y sin haber adquirido constancia de ella.

En cuanto al concepto jurídico se puede partir de las fuentes de la ley y la doctrina, en la primera no se encuentra definida de una manera satisfactoria, ya que en el artículo 190 del Código Federal de Procedimientos Civiles mexicano únicamente nos da un punto enumerativo de las presunciones considerando como tales las siguientes:

I.- Las que establece expresamente la ley, $\mathrm{y}$

II.- Las que se deducen de hechos comprobados

\section{g) Prueba pericial}

Esta prueba como todas las anteriormente enunciadas, ha sido definida de diversas formas por la doctrina, dado entonces Rodolfo WITHAUS, ha dicho que "La prueba pericial es la opinión fundada de una persona especializada o 
informada en ramas del conocimiento que el juez no está obligado a dominar. La persona dotada de tales conocimientos es el perito y su opinión fundada, el dictamen”. 175

Por otro lado DEVIS ECHANDIA, nos menciona al respecto que: "la peritación es una actividad procesal desarrollada, en virtud de encargo judicial, por personas distintas de las partes del proceso, especialmente calificadas por sus conocimientos técnicos, artísticos o científicos, mediante la cual se suministra al juez argumentos o razones para la formación de su convencimiento respecto de ciertos hechos cuya percepción o cuyo entendimiento escapa de las aptitudes del común de la gente”. ${ }^{176}$

Partiendo de estas definiciones, se puede decir que la prueba pericial es la actividad procesal mediante la cual un experto en alguna ciencia, técnica o arte, proporciona al juzgador su dictamen sobre algún hecho ajeno al Derecho y debatido en juicio, basándose en sus conocimientos especializados, con el objeto de facilitarle a aquél, los elementos necesarios para la justa evaluación y resolución de una controversia jurídica. ${ }^{177}$

La exigencia de la prueba pericial siempre está relacionada con la complejidad de los juicios ventilados ante los tribunales, ajenos muchas veces a la formación profesional de los juzgadores, quienes como técnicos en Derecho, carecen generalmente de conocimientos sobre otras ciencias y cuestiones técnicas

\footnotetext{
${ }^{175}$ WITTHAUS, Rodolfo; Prueba Pericial; Ed. Universidad, Argentina; 1991, p. 17

${ }^{176}$ DEVIS ECHANDIA, Hernando; op cit pp. 267 y 268

${ }^{177} \mathrm{Al}$ respecto el jurista MATEOS ALARCÓN, define la prueba pericial siguiendo a los autores tratados, como “.. el dictamen de las personas versadas en una ciencia, en un arte, en un oficio con el objeto de ilustrar a los tribunales sobre un hecho cuya existencia no pudo ser demostrada ni apreciada sino por medio de conocimientos científicos o técnicos; o bien, un medio de descubrir la verdad de un hecho, y la forma especial de su demostración deducida de los fenómenos visibles de él o de sus efectos”, de esta conceptualización podemos observar que existe una uniformidad sustancial entre los tratadistas sobre el concepto de lo que es el medio de prueba pericial, sin embargo, aquí es tratada diferenciando en una forma clara entre la parte subjetiva y objetiva de la prueba, entendida respectivamente como la actividad pericial y el dictamen.
} 
o artísticas, y no obstante, están vinculados a resolver las controversias jurídicas que se susciten, sin importar el grado de especialidad requerido para ello.

Por eso, a través de la prueba pericial, el experto en la ciencia, técnica o arte correspondiente, deberá proporcionar al juzgador los elementos de juicio necesarios para la correcta apreciación y evaluación de cuestiones ajenas al Derecho, sobre todo cuando éstas revistan especial importancia en el proceso, e inclusive, sean determinantes para la solución de una controversia. Precisamente por este motivo, es aconsejable la colaboración de esos expertos con el juzgador, pues ello radicará en una mayor seguridad y confianza social en la decisión judicial que se adopte.

Como el de la prueba en general, la finalidad de esta prueba son los hechos controvertidos, para cuya apreciación en este medio probatorio en particular, se requieren de conocimientos especiales en alguna ciencia, arte, industria o técnica, y como tal pueden referirse a hechos, cosas y personas. ${ }^{178}$ Así, son objeto de peritación, los hechos físicos, psíquicos, sucesos naturales, productos de la naturaleza, aspectos de la realidad material, cosas u objetos creados por el ser humano, la persona física, su conducta, identidad, condiciones físicas y mentales, es decir, todos aquellos hechos, circunstancias, cualidades y valores que por sus características técnicas, artísticas o científicas, exijan para su adecuada percepción y valoración especiales conocimientos de la misma naturaleza. ${ }^{179}$

La prueba pericial, no puede versar sobre cuestiones de Derecho, ni tampoco sobre los efectos jurídicos de los hechos investigados, verificados o

\footnotetext{
${ }^{178}$ WITTHAUS, Rodolfo; op cit p. 20

${ }^{179}$ DEVIS ECHANDIA, Hernando; op cit, T. II; pp, 299 y 332
} 
calificados por los peritos, únicamente debe tratarse de hechos cuyas características requieran necesariamente la investigación, verificación y/o calificación técnica, artística o científica, para la adecuada percepción y valoración de los mismos por parte del juzgador, para la resolución de los procesos judiciales. $^{180}$

\subsection{Valoración de la Prueba}

La valoración o apreciación de la prueba judicial constituye la etapa final y decisiva del material probatorio aportado en un juicio, se trata de una actividad procesal exclusiva del juzgador, quien a través del estudio crítico del conjunto de probanzas ofrecidas por las partes, deducirá el merito o valor de convicción de las mismas. ${ }^{181}$

Aun cuando, cada medio de prueba es susceptible de apreciación individual y en ocasiones puede bastar uno para formar la convicción del juez, opinamos que lo idóneo en la valoración de la prueba, es que el material probatorio sea analizado críticamente en su conjunto, para llegar a la certeza sobre los hechos discutidos, y no basarse en la individualidad, sino siempre en el conjunto para una autentica interpretación de los hechos

Podemos decir que los sistemas de apreciación de la prueba, se basan básicamente en dos: el de la tarifa legal y el de la libre apreciación por el juez; pues en realidad no existe un sistema mixto, ya que, cuando subsiste la tarifa legal atenuada o cuando se otorgan ciertas facultades al juzgador para apreciar determinados medios de prueba.

\footnotetext{
${ }^{180}$ Ídem p. 300

${ }^{181}$ DÖHRING, Erich; op cit. p. 406
} 
El sistema de la tarifa legal suele confundirse a menudo con el de la prueba legal, es decir, con la fijación legal de los medios probatorios admisibles en el proceso, lo cual es incorrecto, pues el objeto de aquél es la regulación del valor de convicción de cada uno de ellos. Por su parte, el sistema de la libre apreciación el cual consiste en la valoración crítica y razonada de las pruebas, conforme a las reglas de la lógica, la experiencia, la psicología y la sana crítica. ${ }^{182}$

De estos sistemas, el menos admitido en la actualidad es el de la tarifa legal, ya que su objeto es fijar precisamente la valoración legal de los medios probatorios, y si bien fue muy importante tiempo atrás, porque suplía la ignorancia o la falta de experiencia de los jueces orientándolos para la averiguación de la verdad y evitando la sobreestimación peligrosa o el rechazo injustificado de los medios de prueba aportados al proceso, en virtud de la escasez de profesionales del Derecho, por el poco desarrollo de las enseñanzas doctrinales y jurisprudenciales. ${ }^{183}$

Dentro de los puntos negativos del sistema de la tarifa legal, podemos enunciar los siguientes:

1. Mecaniza la función del juez en la valoración de las pruebas, porque lo obstaculiza para formarse un criterio personal, y lo vincula a aceptar soluciones en contra de su convencimiento lógico razonado.

2. Conduce con frecuencia a declarar como verdades, las simples apariencias formales.

\footnotetext{
${ }^{182}$ DEVIS ECHANDIA, Hernando; op cit. TI. Pp. 99, 102 y 105

${ }^{183}$ PARRA QUIJANO, Jairo; Op cit ; p. 655
} 
3. Como consecuencia de ello, se produce un distanciamiento entre la justicia y la sentencia, ya que las normas legales probatorias aplicadas al proceso, señalan tipos abstractos de verdad, frecuentemente aisladas o reñidas con la realidad de los hechos.

Con la aplicación de la tarifa legal, los fines naturales del proceso suelen sacrificarse por el respeto a fórmulas abstractas, olvidándose que el Derecho tiene como función primordial la obtención de la armonía social, para lo cual es indispensable que el proceso responda a la realidad y a la justicia.

En este sentido, es de considerarse que lo más conveniente es que la prueba tenga una reglamentación en cuanto a su ofrecimiento, admisibilidad y desahogo, pues dichas cuestiones son de interés público. Sin embargo, en lo relativo a su eficacia demostrativa, es criticable, porque ello sería tanto como prever con carácter imperativo la solución de los casos concretos, lo cual además es una meta imposible de alcanzar por la infinita variedad actualizada en la realidad. ${ }^{184}$

Ante esto y con el objeto de obtener el fin de interés público del proceso, resulta indispensable la implementación de dos cuestiones: la primera es la aplicación del sistema de libre apreciación de las pruebas, en virtud de que en el mismo, el juzgador debe orientar su criterio basándose en las reglas de la sana crítica, es decir, en las de la lógica, la psicología judicial, la experiencia y la equidad; la segunda, consiste en conferir al juzgador facultades inquisitivas para practicar las que a su leal saber y entender considere convenientes, a efecto de esclarecer los hechos afirmados por las partes; este hecho claro debería ser con los límites que la misma ley le imponga y que por lógica, no tendría que ir en

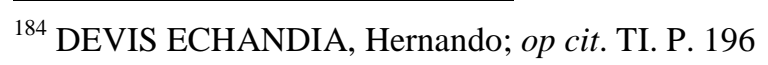


detrimento a los derechos fundamentales de las partes o bien de terceros, así como siempre en la etapa de desahogo de pruebas.

Sólo con estas dos medidas, sería posible obtener la igualdad de las partes en el proceso. Por ello, importa destacar al respecto que en México no hay una justificación para evitar concretar tales objetivos, pues esto se encuentra fundamentado en los artículos 79 y 80 del Código de Procedimientos Civiles mexicano, y en el cual se ha permitido que el juzgador para conocer la verdad, puede valerse de cualquier persona, sea parte o tercero, y de cualquier cosa o documento, ya sea que pertenezca a las partes o a un tercero, sin más limitaciones que las de que las pruebas estén reconocidas por la ley y tengan relación inmediata con los hechos controvertidos.

Los tribunales legalmente no tienen límites temporales para ordenar la aportación de las pruebas que juzguen indispensables para formar su convicción respecto del contenido de la litis, ni rigen para ellos las limitaciones y prohibiciones, en materia de prueba, establecidas en relación con las partes; pudiendo decretar, en todo tiempo, sea cual fuere la naturaleza del negocio, la práctica, repetición o ampliación de cualquier diligencia probatoria, siempre que se estime necesaria y sea conducente para el conocimiento de la verdad sobre los puntos controvertidos. En la práctica de esas diligencias, obrarán como lo estimen procedente, para obtener el mejor resultado de ellas, sin lesionar los derechos de las partes, y procurando en todo su igualdad; sin embargo, es solo una hipótesis normativa, pero la cual en la práctica no es utilizada, ya que la actividad del juzgador se ha concretado a admitir o no las pruebas, sin ordenar la práctica de otras que no hayan sido ofrecidas por las partes, con el fin de no vulnerar derechos fundamentales ni de los litigantes ni de terceros. 
De conformidad con lo anterior, es evidente que en estos órdenes jurídicos, los jueces tienen tanto el deber de aplicar el sistema de la libre apreciación de la prueba, para valorar en su conjunto los medios probatorios aportados y admitidos en el proceso, de acuerdo a las reglas de la lógica y la experiencia, como la facultad para ordenar en todo tiempo sea cual sea la naturaleza del negocio, la práctica o ampliación de cualquier diligencia probatoria, cuando la misma sea conducente para el conocimiento de la verdad sobre los puntos cuestionados.

El proceso de valoración o apreciación de la prueba a pesar de ser complejo y variable en cada caso, comprende comúnmente tres aspectos básicos: la percepción, la representación o reconstrucción y el razonamiento deductivo e inductivo. A continuación se explica cada una de las etapas, aun cuando las mismas son básicamente simultáneas.

La percepción necesariamente se encuentra al comienzo del camino, porque sólo mediante esta operación sensorial, a través de la cual se puede ver, oír, palpar, oler y en casos excepcionales gustar, el juzgador entra en contacto ya sea de forma directa o indirecta con los hechos materia de la litis, pues es imposible apreciar el contenido o la fuerza de convicción de una prueba, si antes no se le ha percibido u observado.

El segundo aspecto indispensable para la apreciación y valoración de la prueba, una vez percibidos aisladamente los hechos a través de sus medios de prueba, es la representación o reconstrucción histórica del conjunto de ellos. En esta fase es indispensable la correcta y compleja representación de cada uno, evitando omitir alguno de ellos por accesorio que parezca, y más bien, coordinarlos todos y colocarlos en el sitio adecuado, para luego clasificarlos con 
arreglo a su naturaleza, al tiempo y circunstancias de la realidad histórica, cuyo objetivo es reconstruir. ${ }^{185}$

La tercera fase del proceso de valoración es el razonamiento deductivo e inductivo, en el cual sin duda alguna, la lógica juega un papel indispensable, ya que sin ella no puede existir valoración de la prueba. En esta etapa, el objeto es razonar sobre todos y cada uno de los aspectos de la prueba, tanto a través de la inducción como de la deducción, porque así como el juzgador realiza inferencias de los hechos, cosas o personas observados, gracias a la inducción, también califica los casos particulares, de acuerdo con deducciones de las reglas de la experiencia.

La actividad lógica llevada a cabo por el juzgador dentro de esta tercera fase de razonamiento, tiene la peculiaridad de basarse siempre en un razonamiento silogístico, porque a partir de datos concretos, el mismo realiza juicios analíticos y sintéticos, basados en las reglas de la lógica y la experiencia, e infiere o deduce la conclusión del conjunto de los medios probatorios aportados al proceso.

Como regla general, puede decirse que la valoración o apreciación de la prueba, se presenta en el momento en el cual debe adoptarse alguna decisión sobre los hechos de la causa o de ciertos problemas incidentales, es decir, cuando se va a dictar la resolución judicial. ${ }^{186}$

La valoración del conjunto de los medios probatorios aportados al proceso por las partes, traerá como resultado que el juez obtenga la certeza

\footnotetext{
${ }^{185}$ Ídem p. 291

${ }^{186}$ Ibídem, pp. 303-304
} 
judicial respecto de las pretensiones controvertidas por las partes en juicio, lo cual es una cuestión indispensable, porque el juzgador debe emitir su decisión con fundamento en las pruebas aportadas por las mismas. ${ }^{187}$

Para ello y a efecto de emitir su decisión, es indispensable que el juez esté convencido de la certeza de los hechos demostrados por las pruebas, pues si los medios probatorios no son suficientes para producirle esa convicción, por ser inexistentes o porque los mismos pesan en su razón por igual, tanto a favor como en contra, sin despejar completamente sus dudas, le está vedado apoyarse en ellos para resolver la controversia; Aún esto, como dentro de sus deberes jurídicos se encuentran la de resolver toda contienda sometida a su conocimiento, en el caso del proceso penal, necesariamente deberá absolver al procesado, mientras en el proceso civil, deberá recurrir a las reglas de la carga de la prueba, a través de las cuales decidirá la controversia tomando en cuenta, quien tiene el interés jurídico en demostrar los hechos materia de la litis, para obtener una sentencia favorable.

En el proceso civil, las reglas sobre la carga de la prueba son una medida imprescindible de sanidad jurídica, una condición sine qua non de toda buena administración de justicia, al constituir una guía indispensable y fundamental para el juzgador en la solución de los litigios, porque orientan su criterio en la fijación de los hechos que sirven de base a su decisión.

Si no existieran dichas reglas fundamentales sobre la carga de la prueba, sería muy frecuente el fracaso del proceso y la consiguiente pérdida del tiempo, trabajo y dinero para el Estado y las partes.

${ }^{187}$ Ibídem p. 321 
Asimismo, la justicia y la función jurisdiccional del Estado resultarían entorpecidas y frustradas en infinidad de ocasiones, al no ser posible la sentencia de mérito por falta de pruebas, a la vez que se fomentaría la incertidumbre jurídica en las relaciones sociales, la repetición indefinida de procesos para el mismo litigio, y se permitiría que quienes tengan interés en esa situación caótica, puedan fácilmente burlar los fines de interés público del proceso $\mathrm{y}$, la jurisdicción, ocultando las pruebas y entorpeciendo la actividad del juez; ${ }^{188} \mathrm{y}$ para evitar todos estos inconvenientes, las reglas de la carga de la prueba dentro del proceso civil, indican que ante la falta de convencimiento judicial sobre los hechos controvertidos, corresponde al juzgador decidir cuáles son los hechos que a cada parte le interesa probar, a efecto de servir de fundamento a sus pretensiones o excepciones, pues a cada una le incumbe probar los hechos integrantes del supuesto hipotético contenido en la norma jurídica, cuyo presupuesto es aplicado como fundamento de su pretensión, con lo que la responsabilidad por el resultado del proceso recae sobre las partes, porque a cada una de ellas corresponde la carga de probar los hechos que constituyan el supuesto de la norma en la cual se amparan. ${ }^{189}$

\footnotetext{
${ }^{188}$ DEVIS ECHANDIA, Hernando; op cit TI; p. 450

189 Debe destacarse que la carga de la prueba corresponde a quien asevera los hechos, es decir, al que los afirma no a quien los niega; es decir, mientras el actor tiene la carga de demostrar los hechos constitutivos de su derecho, el demandado debe probar los hechos impeditivos, extintivos y excluyentes, pues si sólo se limita a negar los invocados por el actor no probará nada, la única excepción a esta regla es cuando se desconozca la presunción legal que tenga a su favor el colitigante.
} 


\section{CAPITULO IV \\ LA PRUEBA DE LA FILIACIÓN}

\subsection{Introducción}

Como se ha indicado en capítulos anteriores, al hablar de filiación, necesariamente es necesario dividirla en: filiación materna y filiación paterna, matrimonial y extramatrimonial; y la que será objeto de estudio en este capitulo será la filiación paterna extramatrimonial, ya que la primera de ellas, es decir la materna, no causa un mayor conflicto ${ }^{190}$, dado que evidentemente es en la madre donde se desarrolla el nasciturus, y ella es quien finalmente dará a luz, y, por su parte, la filiación matrimonial se constituye por una presunción. Sin embargo, en el caso paterno es diferente, pudiendo el padre negar el vínculo de la filiación que lo une con ese nuevo ser, por lo cual ha sido necesario formular normas jurídicas por las cuales el legislador establezca determinadas reglas de prueba de dicha paternidad.

\footnotetext{
${ }^{190} \mathrm{Al}$ respecto, podemos decir que la maternidad siempre es más fácil probarla, pues se trata de un hecho biológico comprobable, y por lo cual podemos señalar las siguientes:

1. El parto. Es una prueba directa, por su propia naturaleza puede probar con una relativa facilidad, ya que el embarazo con su periodo de duración es difícil de ocultar, por la participación de otras personas y que deja huellas en la propia madre y que se puede demostrar con facilidad, además del registro del nacimiento es evidentemente una prueba del parto.

2.- Identidad del hijo. Este se puede probar por varios medios como lo es la partida de nacimiento que es la prueba más típica e idónea, ya que sus datos individualizan la situación de filiación respecto de los sujetos que intervienen; sin embargo igual existe la parte negativa como que no demuestra que la persona que presenta una partida de nacimiento es aquella cuyo nacimiento ha sido registrado por la misma, o bien, ocupar la partida de nacimiento de otro, sin embargo podemos decir que ésta se complementa con la posesión constante de estado, reconociendo al hijo en el entorno familiar y en la sociedad como se establece dicha identidad; por ende se puede afirmar que la maternidad de la esposa es el hecho verdaderamente documentado en la partida de nacimiento.
} 
Comprobada la maternidad por filiación matrimonial, se demuestra casi en forma simultánea la filiación paterna, pues entra en juego la presunción y se atribuye la paternidad al esposo de la madre. En efecto, la filiación en relación al padre, sólo se puede probar mediante la presunción que la ley establece como iuris tantum. Así, el hijo o la hija está dispensado de rendir una prueba directa de su filiación, cosa que difícilmente tendría a su alcance.

La maternidad es susceptible de prueba directa mientras que la paternidad, salvo que se admitan las pruebas que el avance de los conocimientos científicos ofrecen, como bien se encuentra regulado tanto en el Código Federal de Procedimientos Civiles mexicano como en la Ley de Enjuiciamiento Civil española, únicamente pueden probarse en atención a las declaraciones o comportamiento del presunto padre, basado en el monopolio sexual recíproco entre los cónyuges, tal como pasa en la mayoría de las legislaciones americanas como la de Colombia, Perú, Argentina, etcétera; así como la alemana y francesa.

Así tenemos que para determinar la paternidad rige la máxima legal de que la filiación de los hijos nacidos del matrimonio se prueba con la partida de nacimiento del hijo y con el acta de matrimonio de los padres ${ }^{191}$, tal como se ha estudiando en el capitulo anterior; así esta será la mejor forma de probar la paternidad en el caso de la filiación matrimonial.

De otra forma, podemos decir que el estado familiar de las personas solo se comprueba con las constancias relativas del Registro Civil y con esas dos

\footnotetext{
${ }^{191}$ En el caso español, la prueba de la paternidad en la filiación matrimonial , de igual forma se realiza con la inscripción del nacimiento y la del matrimonio de los padres, sin embargo en el artículo 115 del Código Civil, en su segundo párrafo establece de igual forma como manera de prueba la sentencia firme, cosa que indirectamente se encuentra regulada en la legislación mexicana, ya que si bien no es contemplada de hecho, de facto se realiza la inscripción en la partida original, en la cual constará la paternidad obtenida mediante el juicio respecto de reconocimiento.
} 
partidas (actas) se justifica en un primer término que los padres están o estuvieron casados y, segundo, que el hijo ha sido concebido durante el matrimonio o los plazos legales determinados en la ley, pues en el acta de nacimiento consta el día del parto. ${ }^{192} \mathrm{Y}$ por ende este tipo de documentos son oponibles a los padres o a cualquier tercero, siendo una prueba erga omnes.

El hablar del acta o partida de matrimonio como exigencia es lógico, ya que se trata de probar la filiación de los hijos de los cónyuges, y por tanto, requiere antes la prueba del matrimonio de los padres, pues el testimonio de la partida de nacimiento sólo acredita este hecho natural, aun cuando en ella se transcriban los nombres de los padres y abuelos, razón por el cual debe completarse con el acta de matrimonio de los padres para tener el hijo como nacido de matrimonio, ya que como se ha dicho, con éste probaremos que los padres están o estuvieron casados y por ende el menor ha sido concebido durante este matrimonio o sus plazos legales. ${ }^{193}$

El matrimonio que ha sido anulado por cualquier causa e independientemente de la buena o mala fe de los contrayentes, produce todos los efectos civiles en todo tiempo a favor de los hijos nacidos antes de la celebración del matrimonio, durante él y trescientos días después de la declaración de nulidad, si no se hubieren separado los consortes, o desde su separación en caso contrario; sin embargo la declaración de nulidad del matrimonio no tiene porqué

\footnotetext{
${ }^{192}$ ROJINA VILLEGAS, Rafael, op cit. p. 647, en este mismo sentido nos indica que este tipo de actas nos prueban "El matrimonio de los padres y que el hijo es de ambos cónyuges".

${ }^{193}$ Es importante mencionar, que el que un menor nazca o no de un matrimonio, en su partida no tendrá mayor anotación, dado que en las legislaciones no se contempla el estipular dentro de su partida, si es o no hijo de matrimonio; ya que anteriormente se enunciaba dicha diferencia al poner en las mismas los textos de "hijo natural" para los hijos fuera del matrimonio e "hijo legal" para los nacidos de matrimonio.
} 
afectar a la filiación de los hijos ${ }^{194}$, ya que éstos deberán ser reconocidos como hijos de los supuestos cónyuges ${ }^{195}$

Ahora bien, en el caso de la partida de nacimiento, probamos la fecha en que ocurrió el parto como ya se ha dicho, fecha que resulta de gran interés pues de ella se desprende también la fecha en que ocurrió la concepción, haciendo el cómputo que el hijo haya nacido -en el caso mexicano- dentro de los ciento ochenta días de los trescientos que le preceden al nacimiento y que nace después de los ciento ochenta días de celebrado el matrimonio. En España como hemos indicado este último período temporal no existe; dentro de estos plazos debe encontrarse el nacimiento del hijo para presumir la concepción. Así cuando se trata del primer hijo que nazca de los cónyuges, para establecer su filiación habrá de computar la fecha en que haya nacido retrotrayéndola hacia la fecha en que ocurrió la celebración del matrimonio en el caso de México; en el caso español, si el padre no se siente ser quien concibió al menor tiene la opción de impugnar la paternidad; ya que se insiste se le presume iuris tantum el padre del menor nacido aun inmediatamente después de celebrado el matrimonio, por tanto en este punto es innecesario realizar el computo de la concepción-gestación con el nacimiento.

Lo que sí tiene sentido en ambas legislaciones es que con la partida de nacimiento se hace también el cómputo del periodo máximo de gestación que es de 300 días, y se tiene que tener en cuenta dicho límite para aquellos casos en que nazca después de la separación judicial en los juicios de divorcio o nulidad; o bien su caso, de ocurrido el deceso del marido. Es decir, basta con que se retrotraiga la fecha en que ocurrió la separación judicial o la disolución del

\footnotetext{
${ }^{194}$ El artículo 79 del Código Civil Español nos ha señalado en un supuesto igual, el reconocimiento de los efectos producidos respecto de los hijos y del contrayente o contrayentes de buena fe.

${ }^{195}$ En este caso como excepción el hijo no necesitará del requisito de validez del matrimonio de sus padres para ostentar una categoría de filiación basado en ese vínculo, es decir, que dado que ya no existe ninguna diferencia entre un status de hijo, este tendrá determinada su paternidad y su maternidad.
} 
vínculo matrimonial o la muerte del marido a la fecha en que ocurrió el nacimiento y si se encuentra dentro del término de trescientos días, el hijo de facto es de los cónyuges.

La partida de nacimiento es una prueba documental pública, aún cuando el parto es un hecho susceptible de probarse por cualquiera de los medios de prueba, la ley expresamente confiere a la partida de nacimiento como la fórmula específica para probar ese hecho, reconociéndole una gran importancia en cuanto a la filiación de los hijos nacidos dentro del matrimonio ${ }^{196}$; sin embargo es importante decir, que el encargado del registro de lo civil, lo único que hace es dar fe de la presentación del nacido ante él, dando credibilidad a la posesión de hecho, y a la declaración social, realizada por los testigos, y confiriendo total valor al aviso de nacimiento del hospital, dado que a él en realidad no le puede constar que el nacido es hijo de quien lo presenta, ya que para esta situación él debió haber estado presente al momento del parto ${ }^{197}$.

\footnotetext{
${ }^{196}$ PLANIOL, Marcel, Op cit. P. 643, por el contrario ha señalado que el acta de nacimiento no prueba la filiación, que es un error de las disposiciones legales que así lo establecen, pues lo único que hacen las actas es dar fe, lo que es muy diferente del hecho de la maternidad, es decir del parto. Pues siendo éste un hecho debería ser susceptible de probarse por todos los medios posibles, pero a causa de la importancia extrema de los efectos de la filiación matrimonial, y para evitar sorpresas, el ordenamiento dispone de este medio de prueba particular; el acta de nacimiento es para la ley la prueba regular y normal a la que tiene que recurrirse.

${ }^{197}$ En este mismo sentido, MAGALLÓN IBARRA sostiene que el encargado del Registro Civil de lo que da fe es de la declaración del nacimiento y de la presentación del niño ante él, ya sea en su oficina o en el lugar en que hubiere nacido, de lo contrario tendría que estar este funcionario presente en el parto para dar fe del alumbramiento, por lo que concluye que la declaración constituye el aviso o el informe del nacimiento de lo que resulta el acta que se levanta en los términos que señala la ley. MAGALLÓN IBARRA; op cit. P. 438
} 


\subsection{Declaración judicial del vínculo de la paternidad y su}

\section{investigación}

\subsubsection{Antecedentes}

Por regla general, la investigación de la paternidad fue prohibida tomándose como argumento el chantaje contra los supuestos padres y la vulneración de la paz, intimidad e integridad de la familia legítima constituida por éste,. Es decir, en aras de la protección de la familia el sistema jurídico actuó como cómplice del padre ocultándolo, desprotegiendo por ende a la madre y a los hijos extramatrimoniales. Dentro de este sistema conforme a este criterio jugó un rol muy importante en el sentido de que de dos males se ha de preferir siempre el menor, así la consecuencia mínima será el que alguien se quede sin padre en vez de promoverse procesos escandalosos. ${ }^{198}$

La investigación de la paternidad fue rechazada en casi todas las legislaciones del siglo XX excepto en Austria, Dinamarca, España, Noruega, Prusia y Suecia; inmediatamente después de la conclusión de la primera guerra mundial se presentaron los primeros visos de adecuación de este criterio, siendo difundido por los movimientos feministas, llegándose a definir a nivel legislativo por los organismos internacionales después de la Segunda guerra mundial, etapa

\footnotetext{
${ }^{198}$ Con este criterio MIRÓ QUESADA sustenta su posición contraria a la investigación de la paternidad, basándose además en: "la imposibilidad material de acreditar la paternidad, dado el carácter misterioso de la generación y alegando las perturbaciones de los derechos de familia, los escándalos sociales y los inconvenientes prácticos de todo género que origina aquel sistema cuando es sancionado por la ley positiva, combate abiertamente la investigación, principio que considera opuesto a la justicia y a la moral" [MIRÓ QUESADA, Antonio; “La investigación de la paternidad”, en Anales de la Universidad Mayor de San Marcos de Lima, Lima, Imprenta Liberal, 1898, tomo XXV, p. 130] En un tenor parecido en el sistema francés Georges RIPERT, señala que "pareció entenderse que como la relación de filiación comporta derechos y obligaciones, esos derechos y obligaciones sólo podían tener origen en una manifestación de voluntad del padre y de la madre, como resultado de este razonamiento se arribó a la prohibición de investigar la filiación pero, en concesión a la tradición sólo se vedó la investigación de la paternidad y no de la maternidad". MÉNDEZ COSTA, María Josefa, citando a RIPERT, Georges y BOULANGER, Jean, Tratado de Derecho Civil, trad. García Daireaux, Buenos Aires; Ed. La Ley, 1963, tomo III No. 1757
} 
en la que surge un nuevo Derecho de familia, y en especial una estructura de la filiación liberal.

Este tema es una de las conquistas del Derecho moderno, pero no por ello deja de ser aun sombrío por la dificultad frecuente de la probanza, su admisibilidad y por estar arraigada, esencialmente, en supuestos legales de paternidad.

En nuestros días el legislador no puede evitar o prohibir la investigación de la paternidad, pero sí pude limitarla máxime si se admite radicalmente que sobre un proceso de esta naturaleza están de por medio derechos fundamentales de la persona. ${ }^{199}$

\subsubsection{Concepto}

Es la indagación realizada en un proceso judicial de dos situaciones contrapuestas naturalmente y que son:

- Quién es el padre de determinada persona: en este caso la acción interesa primordialmente al hijo, aunque puede ocurrir una situación inversa, es decir, promoverse la investigación a iniciativa de quien haya engendrado a fin de determinar quién es su hijo.

- Que no se es el padre de otro que así se suponía o que fuera declarado, en principio, como tal por la ley.

\footnotetext{
${ }^{199}$ En este sentido, las legislaciones civiles o bien familiares, han acudido a tener como criterio general el dar protección en un primer momento a la integridad de la familia, por lo cual no es posible realizarse la prueba de investigación de la paternidad por un tercero, en los casos en que el esposo de la madre lo haya reconocido previamente como suyo, es decir, no haya negado su paternidad.
} 
Por ello es que la identificación de los intereses privados es compleja: como es obvio, en la investigación de la paternidad están llamados a coexistir intereses forzosamente contrapuestos:

1. El del hijo, dirigido a conocer su verdadera filiación, su origen biológico.

2. El de la madre, que su hijo cuente con una filiación establecida y una manutención segura.

3. El del presunto progenitor, casi siempre opuesto a los anteriores, pues de haber sido favorable habría accedido al reconocimiento.

Esto nos lleva a considerar que la investigación de la paternidad permite el ejercicio de una facultad inherente de la persona, conocer su ascendencia o descendencia, sentido por el cual algunos sectores doctrinarios argumentan que su naturaleza jurídica le otorga la calidad de ser un derecho de la persona el derecho a la investigación de la paternidad.

\subsection{Principio de la prueba de la paternidad}

CHIOVENDA $^{200}$ decía acerca del principio de la prueba que es un hecho indirecto del que se extrae una razón cierta; en materia de indagación filial, es aplicable plenamente este principio, al ser una especie de intermedio entre lo ocurrido y las probables consecuencias que se valoran para atribuir o desvirtuar

${ }^{200}$ Op cit. p. 235 
un estado filial dada la imposibilidad para un establecimiento inmediato o directo.

Esta formulación restrictiva para la investigación de paternidad ha llevado a plantear en el sistema español dos tendencias teóricas definidas en pro o en contra de un sustento preliminar o principio de prueba para demandar la indagación filial, siendo estas las siguientes:

\subsubsection{El principio de la prueba como límite del derecho a la tutela} judicial efectiva

Al entrar en el estudio de los supuestos de paternidad mencionados en el Código Civil Español, en su artículo 116 el cual es homologo al Código Civil Federal de México en su artículo 324 ya mencionado hay que cuestionarse si ambos preceptos llegan a ser taxativos o simplemente enunciativos, es decir, sólo es procedente la demanda cuando se sustenta necesariamente en alguno de los indicados en la ley o cabe la posibilidad de fundamentar una futura pretensión en un supuesto no contemplado en forma por demás expresa en dichos ordenamientos.

En caso de hablar de taxatividad, se estaría consolidando exclusivamente una verdad formal, amparando sólo aquellos hechos que se alinean con la ley, si fuera lo segundo, en base a lo enunciativo, se tiende al establecimiento de una verdad real, y en éstas posibilidades para accionar en paternidad no están parametradas, es labor de interpretación y probanza que aproxime a lo biológico. ${ }^{201}$

\footnotetext{
${ }^{201}$ Al respecto, GUZMÁN ZAPATER ha esbozado que: “... la eventual inconstitucionalidad del artículo 127 del Código Civil que, al desarrollarse el principio de investigación de la paternidad... condiciona la
} 
Este requisito ha sido señalado por diversos autores de entre los cuales podemos mencionar a ÁLVAREZ GONZÁLEZ, al desarrollar el tema de la filiación hispanosuiza, radica la preocupación en el Código Civil Español, así como las legislaciones homólogas, al ser tajante el considerar la viabilidad de las demandas de paternidad sustentadas en un principio de prueba ${ }^{202}$.

\subsubsection{La legalidad del principio de prueba en defensa de otros}

\section{valores}

Otra corriente sostiene que si bien la exigencia de un principio de prueba responde a una previsión legal, a fin de tutelar otros valores constitucionales, estableciendo casos que admiten a debate la relación filial, este prerrequisito u obstáculo satisface esta exigencia - en parte puede decirse que es justificado -, lo que conlleva a que la actitud del juez requiriendo el principio de prueba no podrá ser catalogada de arbitraria.

Más aún, si es claro que en los procesos de filiación se ha interpretado esta exigencia con cierta flexibilidad, admitiendo pruebas de por sí indirectas como la tipología sanguínea, fotografías, afinidades personales, etcétera, en aras de ampliar las posibilidades de su investigación.

admisibilidad de la demanda a la existencia de un principio de prueba, la falta del mismo o su insuficiencia, a juicio del juzgador, puede comportar una infracción del derecho a la tutela judicial efectiva... desde el momento en que la inadmisibilidad de la demandada desemboque en un supuesto de denegación de justicia”. "Se detecta pues una contradicción valorativa: ... la Constitución pretende el establecimiento de la verdad biológica; de otra, el artículo 127 del Código Civil rigurosamente aplicado, puede llegar a impedir el ejercicio del derecho de acceso a la jurisprudencia en estas acciones”. GUZMÁN ZAPATER, Mónica; El derecho a la investigación de la paternidad (en el proceso con elemento extranjero) Madrid, Ed. Civitas, S.A., 1996 pp. 49-50

202 Art. 127.- "En los juicios sobre filiación será admisible la investigación de la paternidad y de la maternidad mediante toda clase de pruebas, incluidas las biológicas.

El juez no admitirá la demanda si con ella no se presenta un principio de prueba en que se funde”. 


\subsection{Sistemas de investigación de la paternidad}

\subsubsection{Sistemas prohibitivos}

En estos sistemas se reconoce el carácter absoluto de la familia y restringido de la paternidad, limitando su indagación. En este tipo de sistema la Ley establece prohibiciones atendiendo a postulados éticos, religiosos ${ }^{203}$, morales y a la organización social por el daño que podría ocasionar en la paz familiar y, lógicamente, por la dificultad de su prueba.

Es así, que la prueba del vínculo parental se tornó materialmente imposible, encontrando una en las presunciones de paternidad; así podemos observar que en el Código de Napoleón ${ }^{204}$ prohibió la investigación de la paternidad $^{205}$.

\subsubsection{Sistemas permisivos}

Frente a las legislaciones que limitan la declaración o investigación de la paternidad se muestran aquellas otras que la admiten a fin de tender al esclarecimiento de la relación familiar, incluso desde la concepción ${ }^{206}$. En este sistema se tienen algunas derivaciones:

\footnotetext{
${ }^{203}$ En el caso de la religión musulmana, se ha prohibido la investigación de la paternidad.

${ }^{204}$ Al respecto TORIBIO PACHECO nos refiere que: "Se conoce que la ley francesa, rindiendo el debido homenaje a la moralidad pública y privada, ha tratado de cubrir con un velo impenetrable las faltas que contra ella se hubieren cometido. Mientras que la ley peruana se muestra esencialmente inmoral permitiendo la indagación no sólo de la maternidad, sino también de la paternidad a toda clase de hijos, aún a los que son fruto de un dañoso y punible ayuntamiento, como los incestuosos, adulterinos y sacrílegos” en su obra Tratado de Derecho Civil; Imprenta de Estado; 2a edición, Lima; 1872, p. 257

${ }^{205}$ La recherche de la paternité est interdite.

${ }^{206}$ Panamá en su Código de Familia, en su artículo 272, permite la libre investigación de la paternidad desde la concepción, al referir que: "El hijo o hija que no haya sido reconocido por su padre, tiene
} 


\section{a) Sistema abierto o biológico}

Postula la investigación amplia de la paternidad por medio de toda clase de pruebas. Se basa en la determinación de la filiación biológica tomando como ayuda la medicina, biología, antropología y últimamente, y de manera revolucionaria, la genética. Estas ciencias trabajan incesantemente para obtener y perfeccionar las pruebas de paternidad. Es digna de elogio esta tendencia ya que muestra preceptos legislativos flexibles y preparados para acoger los avances biomédicos en materia de investigación parental. Tiende al establecimiento del vínculo biológico (principio de verdad natural).

El postulado principal es que todo ser humano tiene de derecho a identificarse y vincularse con sus padres genéticos en todo momento de la vida y a través de cualquier medio de prueba. ${ }^{207}$

\section{b) Sistema cerrado o social}

En este tipo de sistemas la ley señala casos taxativos y expresos (numerus clausus, no numerus apertus) en los que procede la investigación precisando mediante supuestos los elementos constitutivos que presumen una relación parental y que deberán ser demostrados en el proceso incoado, como el caso de Chile y regulado en su Código civil.

derecho a exigir judicialmente el reconocimiento de la paternidad. Se permite la libre investigación de la paternidad desde la concepción”.

${ }^{207}$ Dentro de este tipo de sistemas tenemos las legislaciones de Argentina, Alemania, Honduras, Québec, entre otras. 


\section{c) Sistema cerradísimo u obtuso}

Reduce a un solo caso o supuesto la investigación de la paternidad y establece un exacerbado proteccionismo a la familia matrimonial de manera tal que el hombre no puede ser reclamado en paternidad por una mujer distinta a su cónyuge. Este criterio en la actualidad ya no tiene aplicación.

\subsubsection{Sistemas mixtos}

Permite la investigación de la filiación amplia y otra restringida pues la circunscribe a casos taxativamente enumerados por la ley, así tenemos que los códigos civiles tanto mexicano como español se encuentran en este punto; situando de igual forma los códigos de Bélgica, Colombia y Costa Rica entre otros.

El caso peruano en el Código Civil actual establece que el sistema de filiación mantiene esta característica pues considera los resultados de las pruebas genéticas como un supuesto adicional a los consagrados en la misma ley.

El Derecho y la ley deben reconocer la facultad inherente que tiene el hijo de reclamar el estado filiativo y exigir a sus padres que cumplan con los deberes y obligaciones naturales que tienen respecto de él; y es que la filiación, como relación biojurídica que tienen los padres con sus hijos, ha sido estudiada por mucho tiempo desde un ángulo romántico, una óptica espiritual, ocasionando el aumento de madres solteras, hijos extramatrimoniales y atribuciones de paternidad antojadizas en el Registro Civil, todo como consecuencia de criterios poco claros en lo referente a la responsabilidad procreacional. 
Entendemos que el Estado tiene interés en que ni la sombra ni la confusión se proyecten a tan trascendental relación debiendo dictar medidas de protección para asegurar el cumplimiento de la filiación y de los deberes familiares.

Sin embargo, la relación paterno-filial y su connotación universal ha determinado que el Estado no sólo haya de tomar medidas legales para remediar los problemas suscitados, sino que ha tenido que valerse de alternativas médicas, como las más adecuadas para resolver el problema de la relación filial, a ello se suman los programas de planificación familiar que han servido para la disminución de las tasas de natalidad en el caso de América.

La ética y la religión han influido sobre el interés jurídico por la protección de la estabilidad de las familias y ha incrementado el interés supremo y prevalente por la protección de los hijos, ya sean éstos matrimoniales o extramatrimoniales.

Este cambio esencial y necesario del Derecho se ve reflejado en temas como la igualdad de los hijos, la permisibilidad en la investigación de la paternidad, la admisibilidad de las pruebas heredobiológicas en la investigación de la filiación paternal y el amparo a la paternidad responsable.

\subsection{Medios de Prueba y determinación de la paternidad}

La tendencia legislativa de la investigación de la paternidad ha sido fomentarla pensando en el interés social, a la vez que extiende su protección hacia aquéllos que fueron traídos al mundo por efecto de un romance ocasional, 
desvarío amoroso o incalculado, pero que su progenitor por irresponsabilidad pero sobre todo por cobardía no admitió.

La investigación de la paternidad involucra una indagación de alta escuela y necesita de un cuidadoso análisis del juzgador ${ }^{208}$. Esta facultad de actuar en beneficio del hijo tiene una acentuada repercusión económica, social y moral que exigirá de una prueba vigorosa, sólida y convincente que no sólo represente el interés del propio demandante o beneficiario, sino también de la justicia y la sociedad.

Jean CARBONNIER ${ }^{209}$, al estudiar el aspecto de la prueba en materia de filiación, trata de determinar el fin de la misma, pero se encuentra con dos corrientes existentes:

- La que considera la prueba de filiación como esclarecedora de la verdad biológica (verdad biológica)

- Aquéllas que sostienen que es la demostración de las circunstancias psicológicas y sociales que dotan de verosimilitud al hecho indagado (sistema legal)

Lógicamente, la primera tiene en nuestros días una connotación mucho mayor, en razón de los avances de la ciencia en el campo de la determinación de la paternidad. Por ello actualmente se habla del principio de la

\footnotetext{
${ }^{208}$ ZICARELLI, Filho, “La prueba en la acción de la investigación de paternidad”, en Revista Mexicana de Derecho Penal; México, mayo - junio 1970 No. 3 p. 85

${ }^{209}$ CARBONNIER, Jean; Derecho Civil, Barcelona, Ed. Bosch, 1961, p. 385
} 
verdad biológica en el que la esencia de la filiación es el vínculo biológico, a través del cual nos identificamos con nuestros descendientes ${ }^{210}$

Si bien dentro del plano de la probanza judicial poco se ha resuelto en materia de biopruebas de filiación, es importante esquematizar y clasificar las pruebas de investigación de paternidad; estas se encuentran enumeradas y reguladas como pruebas directas por el Código Civil Federal de México, así como en la Ley de Enjuiciamiento Civil española, siendo las siguientes:

1. El título, consistente en la partida de nacimiento (Prueba documental)

2. Posesión de estado (nomen, tractus y famma)

3. Presunción Pater est

4. Reconocimiento

5. Relación sexual durante la época de concepción

6. Pruebas biológicas a través de la pericial

7. Prueba testimonial

Esta última, como se verá más adelante no es válida por si sola como prueba, teniendo que ser coadyuvada con otra que impere su valor probatorio.

Se puede probar la filiación de los hijos de los cónyuges cuando no existen actas, ni posesión de estado, por todos los medios de prueba que la ley autoriza.

En el terreno de la prueba, hay que fijar en primer lugar, cual sea el objeto que se pretenda probar, porque en función de dicho objeto se tiene que establecer posteriormente cuál es el medio más adecuado. Puede argumentarse

${ }^{210}$ SOTO LA MADRID, Miguel Ángel, Op Cit., p. 46 
que en un juicio sobre filiación lo que hay qué acreditar es la filiación sin más y por lo tanto sobre todo tipo de consideraciones sobre el objeto de la prueba, que está perfectamente identificado en la misma denominación de la acción. Sin embargo esta consideración no es exacta, porque la filiación la podemos entender tomando como punto de partida el concepto de filiación entendida como vínculo jurídico que media ente el padre e hijo y que se fundamenta en un previo lazo biológico o sanguíneo existente entre los mismos. Qué duda cabe que un proceso de reclamación la actividad probatoria de la parte actora irá encaminada preferentemente a probar ese nexo biológico o carnal, porque, confirmándolo satisfactoriamente, logrará obtener del juzgador una resolución judicial favorable a su pretensión. ${ }^{211}$

Cuando faltan las actas de matrimonio y de nacimiento, cuando no haya posesión de estado del menor nacido dentro de matrimonio, se permite demostrar la filiación por cualquier otro medio de prueba. Esos medios de prueba pueden ser documentales, testimoniales, periciales, etcétera; sin embargo, la testimonial no es admisible si no hubiere un principio de prueba por escrito o indicios o presunciones resultantes de hechos ciertos que se consideren bastante sólidos para determinar su admisión.

Así la jurisprudencia mexicana ha sostenido que fundada la petición de investigación de la paternidad en lo dispuesto por el artículo 382, fracción IV, del Código Civil, que contempla el caso de que el hijo tenga a su favor un principio de prueba contra el pretendido padre, ello se surte por medio de fotografías que revelan, apreciadas con sentido humano, que el comportamiento del demandado con la madre del menor y con este mismo, no es el que corresponde a lazos de amistad y compañerismo en el trabajo respecto a aquéllos,

${ }^{211}$ CARBAJO GONZÁLEZ, Julio; Las acciones de reclamación de la filiación, Ed. Bosch, Barcelona, 1989, p. 115 
sino a situaciones concordantes con los hechos en que se apoya la existencia del lazo de consanguinidad entre dicho menor y su pretendido ascendiente; y si a dicha prueba se aúnan determinados hechos aducidos por la actora y no desmentidos por el demandado, que son concordantes, dentro de lo posible, con la fecha del nacimiento del menor interesado, en su conjunto engendran la presunción humana sobre la certeza de la paternidad que se investiga. ${ }^{212}$

\subsubsection{La prueba confesional en los procesos de filiación}

La confesional, como se ha dicho en el capítulo anterior, se ha considerado desde siempre como "la reina de las pruebas"; sin embargo, en la actualidad ha ido perdiendo ese prestigio por varios motivos, entre ellos, porque el juramento o la protesta de decir verdad como hoy en día se le denomina, ha decaído de su antigua respetabilidad ante la consignación del derecho de profesar todo género de creencias, ya que al principio era jurado por Dios el conducirse con verdad, tal como se sigue realizando en el Derecho anglosajón; ante la inexistencia de cualquier tipo de coacción religiosa o moral, es común que en la práctica los confesantes empleen toda clase de habilidades y engaños con la finalidad de no perjudicarse.

En la misma doctrina, son palpables las reservas que se tienen respecto al valor probatorio de la confesional, como lo ha opinado

\footnotetext{
212 Registro No. 204077; Localización: Novena Época; Instancia: Tribunales Colegiados de Circuito; Fuente: Semanario Judicial de la Federación y su Gaceta II, Octubre de 1995; Página: 590; Tesis: I.3o.C.50 C; Tesis Aislada; Materia(s): Civil PATERNIDAD INVESTIGACION DE LA. PRUEBAS APTAS EN EL EJERCICIO DE ESA ACCION. TERCER TRIBUNAL COLEGIADO EN MATERIA CIVIL DEL PRIMER CIRCUITO; Amparo directo 4703/95. Roxana Romero Rodríguez. 14 de septiembre de 1995. Unanimidad de votos. Ponente: José Becerra Santiago. Secretario: Gustavo Sosa Ortiz.
} 
VALVERDE $^{213}$. Para que la confesión pueda ser un medio práctico de prueba se requiere una nobleza, una gran dosis de buena fe y un espíritu de rectitud en quien hace la declaración, pues de otro modo es inútil o de escasa utilidad. ${ }^{214}$

\section{a) Clases de confesiones}

1. Judicial o extrajudicial.- Es judicial la confesión que se hace ante un juez en ejercicio de sus funciones, en el curso del proceso, al cohonestar la demanda, al absolver posiciones o en otras diligencias durante el proceso, y es extrajudicial, la confesión hecha en otra oportunidad distinta al proceso o ante personas distintas al juzgador.

2. Espontáneas y provocadas.- La confesión es espontánea, cuando surge voluntariamente por iniciativa del confesante, y es provocada, cuando se obtiene a partir de la absolución de posiciones articuladas por el oferente o el juzgador al confesante.

3. Escritas u orales.- Según el medio de expresión utilizado, es escrita, la confesión aportada en un documento dirigido al juez del proceso, y será oral, la emitida de manera verbal ante el juzgador competente.

4. Preconstituidas o por constituir.- Este criterio de clasificación se determina según exista o no la confesión antes del proceso en el cual se

${ }^{213}$ VALVERDE Y VALVERDE, Calixto; Tratado de Derecho civil Español, Derecho de Familia, $3^{\circ}$ ed., Publicaciones de los Talleres Tipográficos Cuesta, España, 1926, p. 548

${ }^{214} \mathrm{Al}$ respecto Antonio DELLEPIANE, señala que: "La observación de la realidad ha demostrado, sin embargo, que ésta suposición o presunción de verdad de lo confesado no es exacta en múltiples casos, que existen confesiones que, o no son sinceras o revisten carácter patológico. No es posible, pues acordar fe completa a la confesión en estado bruto, diremos, en presencia de una confesión cualquiera, no hay, a lo sumo, sino una simple sospecha, o presunción de verdad, sospecha o presunción que sólo podrá convertirse en certeza después de un estudio analítico y de una crítica severa que lleven al ánimo la convicción de que la confesión es sincera y cuerda”. Op. cit. p. 119 
aducen como prueba. Así, como preconstituidas, las confesionales existentes previamente al proceso, y son confesionales por constituir, aquellas realizadas sólo durante y con motivo del proceso. Puede preconstituirse una confesión oral judicial, obteniendo copia del acta de la diligencia en la cual fue recibida en otro proceso, o bien, puede preconstituirse una confesión extrajudicial, mediante declaraciones previas de las personas que la presenciaron u oyeron.

5. Documentales o indocumentales.- Este criterio de clasificación se basa en la forma como constan. Así, las primeras son aquellas que se contienen en documentos públicos o privados, en cuyo caso pierden su naturaleza propia de confesión y adquieren la de prueba documental, mientras las segundas son aquellas que no obran en ningún documento público o privado.

6. Expresa o tácita (ficta).- Es expresa, la realizada con señales o con palabras a través de las cuales se señala clara y manifiestamente lo que se dice, como respuesta a las posiciones articuladas por la contraparte o el juez, y es tácita la inferida de algún hecho o la presumida por la ley. ${ }^{215}$

Respecto a la confesión tácita o ficta, el Código Federal de Procedimientos Civiles mexicano, señala que la misma se actualiza cuando quien ha sido citado para confesar, se coloque en los supuestos determinados por los artículos 329 y 124 de este cuerpo normativo y para lo cual, la demanda deberá contestarse negándola, confesándola u oponiendo excepciones.

${ }^{215}$ MATEOS ALARCÓN, Manuel; op cit. p. 669.

Al respecto DEVIS ECHANDIA y OVALLE FAVELA, José; en sus libros citados con anterioridad contemplan lo mismo que MATEOS ALARCÓN y que para su consulta, se tienen integrados en las páginas 669 y 121 de sus respectivas obras. 
El demandado deberá referirse a todos y cada uno de los hechos comprendidos en la demanda, afirmándolos, negándolos, expresando los que ignore por no ser propios, o refiriéndolos como crea que tuvieron lugar.

Se tendrán por admitidos los hechos sobre los que el demandado no suscitare explícitamente controversia, sin admitírsele prueba en contrario. La negación pura y simple del derecho importa la confesión de los hechos; la confesión de éstos no entraña la confesión del derecho.

Ahora bien, con referencia al artículo 124 del Código de Procedimientos Civiles de México, es de destacarse que ordena que la parte que haya sido legalmente citada a absolver posiciones se tenga por confesa en las preguntas sobre hechos propios que se le formulen en los siguientes casos:

I. Cuando sin justa causa no comparezca;

II. Cuando insista en negarse a declarar;

III. Cuando, al declarar, insista en no responder afirmativa o negativamente, o en manifestar que ignora los hechos, y

IV. Cuando obre en los términos previstos en las dos fracciones que anteceden, respecto a las preguntas que le formule el tribunal...

Así, en una forma similar, el Artículo 304 de la Ley de Ejecución Civil en su capítulo titulado "Incomparecencia y admisión tácita de los hechos", hace referencia a que si la parte citada para el interrogatorio no compareciere al juicio, el tribunal podrá considerar reconocidos los hechos en que dicha parte hubiese intervenido personalmente y cuya fijación como ciertos le sea enteramente perjudicial. 


\section{b) Sujetos del Acto Confesorio}

Es sujeto activo de la confesión la persona que la realiza, quien además debe ser parte en el proceso en el cual es aducida como prueba, precisamente porque es un requisito para la existencia de la confesión, que la misma emane de una de las partes en dicho proceso. Así, son sujetos activos de este medio de prueba, el demandante, el demandado, un interviniente principal o un simple coadyuvante, y en los casos de incidente, cualquiera de las partes de ellos. $^{216}$

Por otro lado, es sujeto promotor de esta prueba quien la provoca mediante interrogatorio, ya sea cualquiera de las partes en el juicio o el mismo juez. En este sentido, cualquiera de las partes puede promover la confesional, porque cuando la confesión es espontánea, el mismo confesante se constituye en promotor de la prueba y por otro lado, en sujeto activo desde este punto de vista, aunque también en ocasiones, el confesante suele ser sujeto contradictor de esa prueba, al sufrir las consecuencias desfavorable, y por consiguiente, tener interés jurídico en discutir su validez y eficacia probatoria. ${ }^{217}$

En cuanto al juez, además de ser sujeto ordenador de la confesional en aquellos casos en los cuales ordena su desahogo y formula las posiciones que la producen, también se constituyen en su persona otras calidades, como el de admitente, receptor o destinatario y valuador de la misma; lo primero, porque es él quien debe de juzgar la oportunidad de admitirla e incorporarla al proceso, lo segundo, porque a él va dirigida, y en el último caso, porque es la persona encargada de asumirla y valorarla.

\footnotetext{
${ }^{216}$ DEVIS ECHANDIA, Hernando; op cit. pp 669 y 700

${ }^{217}$ idem; pp 670 y 671
} 
Propiamente no existen sujetos pasivos de la confesión ni de la prueba en general, porque en uno u otro sentido todos son sujetos activos de ellas.

\section{c) Formalidades procesales}

La prueba confesional deberá desahogarse por la parte absolvente ante el juez competente. En este sentido, las personas físicas que sean parte en el juicio sólo están vinculadas a absolver posiciones personalmente, cuando así lo exija quien las articula, y esta petición se hubiere realizado desde el ofrecimiento de la prueba, argumentando la necesidad de esa absolución de modo estrictamente personal, por la existencia de hechos concretos en la demanda o personal, por la existencia de hechos concretos en la demanda o contestación que justifiquen dicha exigencia, la cual será calificada por el juzgador para así ordenar su recepción.

En el supuesto en el cual el promovente hubiere omitido pedir al juzgador el desahogo de la confesional de modo estrictamente personal, las posiciones podrán ser absueltas por el mandatario o representante del absolvente, siempre y cuando comparezca acreditando su personalidad mediante poder con cláusula especial para tal efecto y conozca de todos los hechos controvertidos propios de su mandante o representado, pues no podrá manifestar desconocer los hechos propios de aquél, ni tampoco argumentar su ignorancia respecto de la respuesta o contestar con evasivas, ni mucho menos negarse a contestar o abstenerse de responder de modo categórico en forma afirmativa o negativa, porque de hacerlo así, se le declarará confeso de las posiciones que calificadas de legales se le formulen. 
Tratándose de personas jurídicas es evidente que la absolución de posiciones siempre se llevará a cabo, mediante apoderado o representante con facultades para absolver, cuestión derivada del poder con cláusula especial para tal efecto. Pero, para dicha absolución no se podrá exigir la comparecencia de algún apoderado o representante específico, y en todo caso, se seguirán las reglas referidas con anterioridad.

Así, habiendo señalado la forma como pueden comparecer quienes deben absolver posiciones, es decir, personalmente, o a través de mandatario o representante, cabe decir que aunque la Ley dispone que el desahogo de este medio probatorio será ante el juez competente, en la práctica en el Derecho mexicano este desahogo se efectúa ante el secretario de acuerdos del juzgado, pues es este el encargado de llevar en la práctica las audiencias de los distintos procesos ventilados en los órganos jurisdiccionales.

Por ello, antes de procederse a la articulación de las posiciones, el secretario de acuerdos en representación del juez, tomará la protesta de decir verdad, el absolvente o absolventes, pues si fueran varios los citados para absolver posiciones al tenor de un mismo interrogatorio, la absolución de las mismas se practicarán por separado, pero en la misma audiencia, evitando que quienes absuelvan primero se comuniquen con los que han de absolver con posterioridad, ordenándose se asienten en el acta respectiva de la audiencia, los datos generales de todos los confesantes.

Posteriormente, en el caso de México, se abrirá en caso de haber sido depositado, el sobre cerrado en el cual se contienen las posiciones, a efecto de calificarlas y aprobarlas. 
Estas formalidades jurídicas exigen que las posiciones se concreten a hechos objeto del debate, se articulen en términos precisos y claros, contengan cada una un solo hecho propio de la parte absolvente, aunque también pueden contemplar un hecho complejo compuesto de dos o más hechos, cuando entre ellos exista íntima relación y no pueda afirmarse o negarse uno sin afirmar o negar el otro, y que no sean insidiosas, es decir, aquellas dirigidas a ofuscar la inteligencia del absolvente, con el objeto de inducirlo al error y obtener una confesión contraria a la verdad. Por último podemos decir que si se refieren a hechos negativos que envuelven una abstención o impliquen un hecho o consecuencia de carácter positivo deberán formularse de tal forma que no den lugar a respuestas confusas.

Posteriormente a la calificación de las posiciones, el absolvente deberá firmar el pliego de posiciones en el que aquellas se contengan, y se procederá al interrogatorio, el cual tradicionalmente se inicia con la frase: "Diga si es cierto como lo es...” seguido de la pregunta respectiva. El absolvente deberá contestar de forma categórica en sentido afirmativo o negativo, pudiendo agregar las explicaciones que estime convenientes o las que el juez le pida.

La parte absolvente al responder las posiciones no podrá estar asistida por su abogado o procurador, ni por ninguna otra persona a menos que sea extranjero, en cuyo caso dicha asistencia será de un intérprete designado por el juez.

Terminado que sea el desahogo del pliego de posiciones, el promovente en forma personal, o bien, el mandatario, puede articular más posiciones en forma oral, las cuales una vez calificadas de legales deberán ser contestadas por el absolvente. 
Una vez absueltas las posiciones, en ese mismo acto el absolvente tiene derecho a su vez a formular posiciones al articulante, si hubiera asistido, y en todo caso, el tribunal puede libremente interrogar a las partes sobre los hechos y circunstancias conducentes para la averiguación de la verdad. De las declaraciones del absolvente, así como del interrogatorio formulado por el juzgador, se levantará acta en la cual se harán constar las contestaciones de las partes, implicando las preguntas, iniciándose como ya se decía con la protesta de decir verdad y de los datos generales de los confesantes.

El acta en la cual se contengan las declaraciones deberá ser firmada al pie de la última hoja y en el margen de las demás, después de que el o los confesantes las hayan leído por sï mismos o les sean leídas por el secretario de acuerdos. Si no supieren firmar se hará constar esta circunstancia, debiendo asentar su huella digital también en todas las hojas. Cuando el absolvente no esté conforme con los términos en los cuales fue asentada su declaración, el juzgador decidirá la forma como deberán hacerse las rectificaciones, pues una vez firmada el acta en la que se contienen, no pueden variarse ni en la sustancia ni en la redacción.

Generalmente, el desahogo de la prueba confesional se lleva a cabo en las instalaciones del juzgado competente. Sin embargo se prevé que en caso de enfermedad legalmente comprobada de quien debe absolver posiciones, el tribunal se trasladará al domicilio de aquel, donde se efectuará la diligencia en presencia de la otra parte si asistiere.

En el caso particular de los juicios de filiación, es evidente que éstos no serán necesarios si existiera la buena fe, la rectitud y la ética de los progenitores o de alguno de ellos para reconocer a sus descendientes, o para no encubrir la certeza de la filiación, pues precisamente el objeto de estas 
controversias es la imputación o el rechazo de la paternidad, de la maternidad o de ambas. Entonces, si por voluntad propia las partes o algún de ellas, evitaron o encubrieron la certeza del nexo paterno o materno filial, no sería extraño que persistieran en el empleo de toda clase de habilidades y engaños ante la coraza de su interés personal. Por eso, sus declaraciones deben ser valoradas en conjunto con otros medios probatorios.

\subsubsection{La prueba testimonial en los procesos de filiación}

Existe resistencia para admitir la prueba de testigos si no hay una prueba documental, ya que se estima peligrosa por ser la más falaz, artificial e insegura, porque los testigos por lo regular no temen a la sanción penal por el falso testimonio y existe en ciertos lugares la desgraciada costumbre de sobornar testigos o de presentar testigos falsos o aleccionados con las controversias de contenido económico, como cuando la calidad de hijo o hija pudiere depender de una herencia cuantiosa. CHÁVEZ ASENCIO ${ }^{218}$ señala que la presentación de testigos falsos es bastante común en los tribunales de México.

Es por eso que la ley exige que la prueba testimonial se complemente con principios de prueba por escrito o por indicios, como son documentos emanados de las personas a las que hay que relacionar en filiación, es decir a los progenitores o sus representantes y al hijo o hija, que contengan datos relacionados con su estado de familia.

Al respecto, PLANIOL y RIPERT han señalado que aun cuando la prueba testifical es forzosa ante la imposibilidad de acreditar el nexo filial, con el acta de nacimiento o con la posesión de estado, la ley desconfía de los testigos,

${ }^{218}$ Op cit p. 104 
por lo cual, el objeto de su admisión radica en apoyar algún principio de prueba por escrito o indicios, los cuales por sí solos no pueden suprimir toda duda y producir la convicción en los jueces, debiendo entonces completarse con las declaraciones de los testigos. ${ }^{219}$

Esa desconfianza a los testigos manifestada por estos autores, está basada en casos comúnmente actualizados en la práctica, a través de declaraciones testimoniales, cuya finalidad ha sido formar una convicción errónea en el ánimo del juzgador, acerca de la existencia o inexistencia de hechos o circunstancias determinadas, con el propósito de favorecer a una de las partes, demostrando con ello ser el medio de prueba más falible, lo cual ha conducido a los legisladores a darle un valor de prueba relativo, como una prueba meramente complementaria en los juicios de filiación. ${ }^{220}$

Así podemos decir, igual que en este tipo de juicios en particular, la eficacia de la prueba depende de múltiples motivos, particularmente en aquellos casos en los cuales existen defectos de sentidos, de la memoria, y de la expresión en los mismos testigos, produciéndose esto, en el defecto del sentido al momento deducen hechos ajenos a la realidad, de la memoria, cuando declaran mucho tiempo después de ocurridos los hechos y aunque se haga de buena fe, no mantiene intactos todos los elementos que se registraron en su momento, y de la expresión, porque en ocasiones no son hábiles en el uso del idioma, o en la explicación mediante los términos más adecuados.

\footnotetext{
${ }^{219}$ PLANIOL Marcel y RIPERT Georges, op. cit. p. 597

${ }^{220}$ Idem.
} 


\section{a) Objeto del testimonio.}

Para CARNELUTTI ${ }^{221}$ son objeto de la prueba testimonial, tanto los hechos percibidos por los testigos, como los hechos deducidos, los juicios $\mathrm{u}$ opiniones que sobre esos hechos percibidos, el testigo transmita al juzgador, e incluso, también señala dentro del objeto de esta prueba, los hechos realizados por el mismo declarante. ${ }^{222}$

Por otra parte, con relación al testimonio de oídas, el cual consiste en la narración del relato de terceros, como no existe una representación directa e inmediata, sino indirecta o mediante del hecho por probar, el objeto de este tipo de testimonio es el hecho percibido de la narración oída, y no el hecho narrado por esos terceros.

Cabe destacar que en la noción de hechos se incluyen todos aquellos que en general pueden ser objeto de prueba, como son: las conductas humanas, hechos de la naturaleza, cosas u objetos materiales, aspectos de la realidad material, la persona física, estados o hechos síquicos o internos del hombre, los cuales pueden ser anteriores a la declaración, subsistente en el momento de la declaración, e incluso con posterioridad a ella, aunque su existencia haya comenzado antes.

\footnotetext{
${ }^{221}$ Lo señalado por tal autor se basa en que al ser el testimonio la declaración representativa de un hecho, no es posible la separación entre el hecho percibido y el juicio que el testigo se haya formado sobre el mismo, el cual necesariamente es parte integrante de su narración, como cuando alguien declara que una persona tenía un fusil cargado, no porque lo hubiera visto, sino porque disparó sin haberlo cargado antes. De igual forma, en cuanto a la posibilidad del testigo para narrar al juez hechos por él realizados.

${ }^{222}$ CARNELUTTI, Francesco; op cit pp. 122-124
} 


\section{b) Sujetos del Testimonio}

El sujeto activo de la prueba testimonial en sentido estricto es el tercero declarante, es decir, la persona llamada a rendir declaración en un proceso en el cual no es parte, y a quien comúnmente se le denomina testigo. La palabra testigo proviene de dos raíces latinas, de testis ${ }^{223}$ cuyo significado es persona que da fe, así como de testando que quiere decir narrando o refiriendo. ${ }^{224}$

En cuanto al sujeto pasivo de la prueba testimonial, cabe decir que propiamente no lo hay, porque en realidad no existen verdaderos sujetos pasivos de la actividad probatoria. Por ello, lo correcto es señalar únicamente como sujeto de este medio de prueba al declarante, quien como se ha dicho es un sujeto activo, y al juez, el cual es el sujeto destinatario del testimonio, pues dentro del marco del proceso toda prueba tiene por destinatario exclusivo al juzgador, cuyo convencimiento se trata de formar con ella. ${ }^{225}$

\section{c) Clases de testimonios y de testigos}

1.- Según el destinatario de la prueba testimonial, el testimonio puede ser judicial y extrajudicial, es judicial, cuando la declaración se emite ante el juzgador, quien es el sujeto destinatario de este medio de prueba, y es

\footnotetext{
${ }^{223}$ Igual conceptualizado como testis, que era la persona que puede dar cuenta de un hecho que presencia, para el Derecho Romano, para ser testigo se necesitaba tener capacidad natural y civil, la primera presupone discernimiento intelectual y tener expeditos los sentidos de percepción para lo cual es necesaria la facultad de expresión, o sea, el uso de la palabra. Por lo tanto carecían de capacidad para ser testigos los que no habían llegado al uso de la razón, los locos u los imbéciles, los sordos, los ciegos y sordomudos; por la segunda, se requería estar libre de antecedentes criminales o injuriantes, por lo que no podían ser testigos los esclavos, los malvados, los indignos, los infames y los condenados por delitos de concusión y adulterio [JIMÉNEZ SANTIAGO TIANA SÓCRATES; Diccionario de Derecho Romano; Ed. Sista; México; 2006.

${ }^{224}$ DEVIS ECHANDIA; Hernando; op. cit. TI; p. 42

${ }^{225}$ Idem, pp. 64 y 65
} 
extrajudicial, en aquellos casos en los cuales la declaración se realiza ante los particulares, ya sean terceros o partes en el futuro proceso. ${ }^{226}$

Para ECHANDIA, los testimonios extrajudiciales no son verdaderos testimonios, ni tampoco sus autores verdaderos testigos en sentido procesal, porque no se trata de actos procesales al haberse producido fuera del proceso o en diligencias procesales previas. No obstante, admite que tales testimonios pueden llegar a producir efectos probatorios relativos, en el caso de actualizarse el proceso y cuando sean narrados en él por un testigo (testimonios de oídas). ${ }^{227}$

Por su parte, CARNELUTTI señala que estructuralmente los testimonios judiciales y los extrajudiciales son idénticos, y critica la tendencia tanto de privar del carácter de testimonios como de excluir todo valor probatorio a los testimonios como de excluir todo valor probatorio a los testimonios privados, pues considera que en ocasiones pueden ser eficaces. ${ }^{228}$

2.- Según el medio utilizado para rendirlo, el testimonio puede ser oral y escrito, e inclusive también es posible su emisión mediante signos distintos del sonido y la escritura, como son los gestos o señas, tal como ocurre en el caso de los sordomudos, en aquellos supuestos en los cuales no puedan darse a entender por escrito, o bien cuando las personas ocasionalmente se encuentren imposibilitadas para hablar o escribir.

3.- Según la fuente de percepción del hecho por probar; si es propia o es ajena, los testimonios pueden ser originales o indirectos. los primeros son cuando quien los emite es un testigo presencial, es decir, una persona que ha visto, oído o conocido con sus sentidos un hecho sobre el cual puede dar

\footnotetext{
${ }^{226}$ CARNELUTI, Francesco; op cit. p. 151

${ }^{227}$ DEVIS ECHANDIA; Hernando; op cit. TII; p. 41

${ }^{228}$ CARNELUTTI, Francesco; op cit, p. 151
} 
información, si es interrogado. Asimismo son indirectos los testimonios realizados por un testigo de referencia o de oídas, es decir, una persona que expone las informaciones adquiridas de otras personas, esto es, por el relato de terceros. $^{229}$

4.- Según la capacidad para rendir el testimonio, los testigos pueden ser hábiles o inhábiles: son hábiles, los que tienen capacidad física e intelectual, los segundos, quienes tienen ciertas incapacidades ya sean absolutas o relativas; las absolutas excluyen en general la recepción del testimonio de una persona en toda clase de procesos, y el juez no puede admitirlo como prueba en ningún caso; las incapacidades relativas se refieren a ciertos motivos que impiden en un proceso determinado la recepción del testimonio, así un testigo puede ser hábil, y no obstante, estar impedido en el proceso al cual se le cita. ${ }^{230}$

\section{5.- Según los testimonios sean o no los medios de prueba idóneos para} demostrar el hecho sobre el cual versan, es decir, de acuerdo a su utilidad o

\footnotetext{
${ }^{229}$ BENTHAM Jeremías; op cit; pp. 177 y 178

${ }^{230}$ En atención a este sentido, el Código Federal de Procedimientos Civiles mexicano, no establece limitaciones para la admisión de los testigos en razón de su edad, capacidad e interés, pues establece que: "Todos los que tengan conocimiento de los hechos que las partes deben de probar, están obligados a declarar como testigos" [artículo 165]; ordenamiento que se encuentra correlacionado con el artículo 90 del mismo ordenamiento legal [Los terceros están obligados, en todo tiempo, a prestar auxilio a los tribunales, en las averiguaciones de la verdad. Deben, sin demora, exhibir documentos y cosas que tengan en su poder, cuando para ello fueren requeridos.

Los tribunales tienen la facultad y el deber de compeler a los terceros, por los medios de apremio más eficaces, para que cumplan con esta obligación; pero, en caso de oposición, oirán las razones en que la funden, y resolverán sin ulterior recurso.

De la mencionada obligación están exentos los ascendientes, descendientes, cónyuges y personas que deban guardar secreto profesional, en los casos en que se trate de probar contra la parte con la que estén relacionados.

Atendiendo a lo anterior, puede decirse que la declaración de los testigos es un deber, pues su incumplimiento puede ser sancionado a través de cualquiera de los medios de apremio establecidos en el Código Federal de Procedimientos Civiles mexicano; no obstante, están excluidos de ese deber los ascendientes, descendientes, cónyuges y personas que deben guardar secreto profesional, en aquellos casos en los cuales se trate de probar contra la parte con quien las personas enunciadas están relacionadas. Sin embargo, aun cuando el ordenamiento en cita no señala limitaciones para la admisión de los testigos por razón de su edad, capacidad e interés, el artículo 371 del mismo, determina que dentro de los tres días siguientes al acto del examen de un testigo, las partes pueden atacar el dicho de este, es decir, podrán promover la tacha de testigos, con el objeto de probar la existencia de circunstancias que afectan su credibilidad, cuando la circunstancia en la cual se basen no haya sido expresada en sus declaraciones.
} 
relación con las cuestiones debatidas en el proceso, pueden distinguirse en conducentes o pertinentes, e inconducentes o impertinentes. ${ }^{231}$

6.- Los testimonios plurales se distinguen además, en contestantes o concordantes y contradictorios o discordantes. Esto en virtud de que el contenido de las declaraciones de los mismos, concuerden o estén en contradicción consigo o con otras. ${ }^{232}$

\subsubsection{La prueba de inspección o reconocimiento judicial en los procesos de filiación}

a) Objeto de la inspección o reconocimiento judicial

El objeto de la inspección o reconocimiento judicial como el de toda prueba, es la verificación de hechos materiales de toda clase, que el funcionario judicial puede examinar y reconocer a través de sus propios sentidos, para adquirir datos útiles con la finalidad de esclarecer la cuestión controvertida. ${ }^{233}$

Así, pueden ser objeto de esta prueba, los objetos y cosas de todo tipo, inclusive documentos, archivos y expedientes o procesos; los bienes muebles en general; los animales, los bienes inmuebles, para identificarlos, establecer sus características, estado actual, extensión, construcciones u obras de otra clase; los hechos producidos en el momento mismo de la diligencia, como podría ser la actualización de un derrumbe en el acto en el cual se está inspeccionando un inmueble; los hechos ocurridos antes, siempre y cuando subsistan total o

${ }^{231}$ DEVIS ECHANDIA; op cit. IT. II p. 82

${ }^{232}$ Ídem

${ }^{233}$ DÖHRING, ERICH; op cit. p. 297. 
parcialmente; la reconstrucción de hechos, cuando la finalidad sea verificar la forma como se exteriorizó una determinada conducta humana en un lugar específico.

Asimismo, pueden ser objeto de esta diligencia las personas, tanto en su entidad física, cuando la finalidad sea verificar su estado físico, heridas o lesiones, como en su cadáver. Sin embargo, escapan de la inspección judicial, los hechos síquicos e internos del ser humano, aunque pueden serlo los síntomas físicos y la conducta comportamiento del sujeto afectado de una anomalía síquica, pero no está en sí misma. ${ }^{234}$

Igualmente, quedan fuera del campo de acción de este medio probatorio, los hechos pasados y los futuros, porque el funcionario judicial no puede percibirlos, aunque en algunas ocasiones respecto de los hechos pasados, es posible examinar las huellas o rastros que se dejaron, y de los futuros, es factible inspeccionar los hechos presentes que pueden servir de causa a aquellos.

Tampoco pueden ser objeto de esta prueba, las deducciones o suposiciones que de los hechos observados en la diligencia formule el secretario de acuerdos o bien, en el caso de España, el secretario judicial, puesto que en el acta respectiva que se levante únicamente debe hacerse constar las observaciones sobre los hechos percibidos y no sus deducciones o suposiciones, las cuales deben ser materia en todo caso de la valoración probatoria de la inspección judicial practicada. $^{235}$

\footnotetext{
${ }^{234}$ DEVIS ECHANDIA, Hernando; op cit. T. II p. 430

${ }^{235}$ Ídem
} 


\section{b) Características generales de la inspección o reconocimiento judicial}

1.- Su naturaleza jurídica es la de la prueba, incluso SENTIS MELENDO la califica como la prueba por excelencia, porque es el único medio probatorio directo, sin embargo, GÓMEZ DE LIAÑO propone un cambio de terminología para expresar mejor su naturaleza, señalando que se trata de una percepción judicial inmediata, porque es una actividad intelectual del juez de carácter perceptivo y estimado. ${ }^{236}$

2.- Es una diligencia procesal, cuyo objetivo es la verificación directa de ciertos hechos controvertidos en juicio.

3.- Esa actividad debe ser realizada por un funcionario judicial, ya que, debe hacerlo el juez personalmente junto con su secretario de acuerdos, quien tiene fe pública.

4.- Es una prueba directa del hecho inspeccionado o examinado, porque el Juez debe conocer personalmente de éste a través de sus sentidos, para obtener los argumentos de prueba necesarios, y poder así resolver la cuestión controvertida.

5.- Es una prueba personal, porque se incorpora al proceso mediante un acto humano, como es la actividad de verificación efectuada por el Juez.

6.- Es una prueba crítica y lógica, porque no es la representación de la cosa o del hecho inspeccionado, pues el funcionario judicial lo asume de manera

${ }^{236}$ GÓMEZ DE LIAÑO GONZÁLEZ, Fernando; op cit p. 163 
directa con sus sentidos y lo verifica a través de un proceso mental, existiendo siempre un juicio crítico por sencillo que este sea.

7.- Puede ser tanto una prueba simple como plena o completa del hecho observado. Así, será simple, cuando por sí sola demuestre el hecho. Por el contrario, será plena o completa, en aquellos casos en que el hecho requiera ser identificado o apreciado mediante conocimientos técnicos, pues en esos supuestos deberá ser complementada con un dictamen pericial.

\section{c) Distintas clases de inspección o reconocimiento judicial}

De acuerdo a la forma como puede practicarse la prueba de inspección o reconocimiento judicial, dicho medio probatorio se clasifica en dos modalidades: a petición de parte y de oficio.

La inspección judicial a petición de parte, tiene su fundamento en los artículos 93 fracción V y el 87 primer párrafo del Código Federal de Procedimientos Civiles de México, el primero de éstos contempla a la inspección judicial como un medio de prueba; mientras que el segundo nos establece el deber del tribunal de recibir las pruebas que le presenten las partes, siempre que estén reconocidas por la ley; y como hemos visto, la inspección se encuentra reconocida en la ley; ${ }^{237}$ éstos artículos son homologo a los artículos 299 de la Ley de Enjuiciamiento Civil Española al enumerar los medios de prueba que podrán ser usados en juicio y al mencionar en su punto quinto, al reconocimiento judicial.

\footnotetext{
${ }^{237}$ Atendiendo a estos preceptos, es necesario en principio que toda prueba ofrecida por cualquiera de las partes durante el proceso, esté permitida por la ley y se relacione con los hechos controvertidos, a efecto de poder producir convicción en el ánimo del juzgador.
} 
En el supuesto particular de la inspección o reconocimiento judicial, dicho medio probatorio no sólo está permitido en la ley, sino que cabe también a petición de parte, cuando cualquiera de los litigantes en juicio la solicite al proceso, con el objeto de probar uno o más hechos controvertidos, teniendo el juzgador el ineludible deber de admitirla, siempre que dicha prueba esté relacionada con los puntos cuestionados, y que tenga verdadera utilidad con la resolución de la litis.

Por otra parte, la inspección judicial de oficio tiene su principal fundamento en lo dispuesto por el artículo 80 de la ley mexicana que comentamos, ya que los tribunales pueden decretar, en todo tiempo, sea cual fuere la naturaleza del negocio, la práctica, repetición o ampliación de cualquier diligencia probatoria, siempre que se estime necesaria y sea conducente para el conocimiento de la verdad sobre los puntos controvertidos. En la práctica de esas diligencias, obrarán como lo estimen procedente, para obtener el mejor resultado de ellas, sin lesionar los derechos de las partes, y procurando en todo su igualdad.

De este modo, la inspección judicial de oficio es la diligencia procesal, cuya práctica es ordenada por el mismo juzgador, cuando así lo estime conveniente, para obtener mayores argumentos de prueba sobre alguna de las cuestiones controvertidas en juicio, permitiéndole ello formar su criterio, para poder fallar con pleno conocimiento de causa.

La única diferencia entre una y otra modalidad de la inspección judicial, radica en que la primera se práctica a instancia de cualquiera de las partes contendientes, y la segunda, por orden del juzgador, pues en ambos casos, su desahogo se lleva a cabo de la misma manera. 


\section{d) Conclusión respecto a los procesos de filiación}

Este medio de prueba, al ser una diligencia procesal mediante la cual un funcionario judicial conoce personalmente, a través de sus sentidos, cualquier objeto o lugar relacionado con la cuestión controvertida en juicio, con el fin de formar su propia convicción y obtener los argumentos de prueba necesarios para resolver sobre la misma, dicho medio probatorio no tiene en sí aplicación práctica en los juicios de filiación. Sobre todo, porque su objeto es la verificación de hechos materiales que el funcionario judicial debe examinar y reconocer a través de sus propios sentidos, para adquirir datos útiles, con la finalidad de esclarecer la cuestión controvertida. Y aun cuando también pueden ser objeto de ésta diligencia las personas en su entidad física, escapan de la inspección judicial los hechos síquicos e internos del ser humano, pues ellos exceden la cultura normal de los juzgadores y requieren de un conocimiento especial de carácter técnico o científico.

Por tanto, sería absurdo que el juzgador, a través de sus sentidos, pudiera verificar la filiación controvertida, argumentando únicamente el gran parecido físico del descendiente, cuyo vínculo filial es discutido con el progenitor a quien se pretende imputar la paternidad o maternidad, pues esa consideración estaría plagado de subjetividad y falta de seriedad y falta de seriedad, más aun cuando en la actualidad existen medios probatorios científicos, a través de los cuales es posible determinar biológicamente con un mínimo de error tal relación jurídica. 


\subsubsection{La prueba documental en los procesos de filiación}

Esta es considerada muy importante al igual que la pericial, al determinar las legislaciones civiles tanto mexicana como española, que la filiación de los descendientes se prueba con el acta de nacimiento, cuya naturaleza jurídica es la de documento público. Evidentemente, este aspecto determina también la importancia de los Registros, así ante el funcionario de dicha institución pública, deberán declarase los nacimientos y realizar los reconocimientos, haciendo una distinción de estos, al ser cuestiones distintas, dado que la declaración de nacimiento, sólo tiene por objeto hacer del conocimiento del registrador el nacimiento de un menor; mientras que el reconocimiento tiene como objetivo, la determinación voluntaria de una filiación ya bien paterna o materna o ambas, en un tiempo posterior al que ha sido inicialmente inscrito.

La presentación de un certificado o aviso de nacimiento ante el Registro de lo civil reviste especial importancia, porque el mismo hace prueba del día, hora y lugar de nacimiento, sexo del nacido y la maternidad, aunque si no se cuenta con él, el declarante deberá presentar constancia del parto, pero, si quienes declaran el nacimiento, omiten presentar tanto el certificado de nacimiento como la constancia del parto, entonces no habría prueba documental que avale la filiación.

\section{a) Objeto del documento y su contenido}

En su más amplia aceptación, el documento tiene por objeto la representación de hechos. Dichos hechos pueden ser: pasados, presentes o 
futuros, simples acontecimientos naturales, o actos humanos de quien lo crea u otorga, o de otras personas, estados psíquicos, sentimientos humanos, simples deseos o pensamientos y conceptos. Todos esos actos humanos representados por el documento, determinan su contenido y permiten clasificarlo por su objeto en las siguientes clases:

1. Dispositivos o constitutivos.- Estos son aquellos donde se plasman actos de voluntad, con el propósito de producir determinados efectos jurídicos.

2. Declarativos.- Los que consisten en la representación de lo que se sabe o conoce respecto de algún hecho. En este caso, pueden consistir en testimonios o confesiones.

3. Simplemente narrativos.- Cuando se trata de una narración imaginativa, como sería el caso de una novela o un poema, con los cuales puede probarse la capacidad y calidad intelectual de su autor.

4. Acciones o situaciones no declarativas.- Estos son documentos materiales en los cuales se plasman hechos puramente representativos y no declarativos, mediante fotografías, dibujos, cuadros, películas, etc.

5. Declaraciones de derecho.- Cuando las partes hacen constar por escrito, la interpretación jurídica que le dan a un acto jurídico pasado, presente o aquel, cuya celebración esté pensada para el futuro.

6. Exteriorización del pensamiento.- En esta se incluyen los deseos, sentimientos humanos, narraciones imaginativas o de recuerdos, en todos los casos, el objeto del documento es propiamente la exteriorización del 
pensamiento, y no los hechos pensados o imaginados porque éstos son a su vez, el objeto de ese pensamiento. ${ }^{238}$

\section{b) Sujetos de la prueba documental}

Considerando al documento como un medio de prueba, esto es, desde el punto de vista procesal, pueden distinguirse dos sujetos: el autor y el destinatario.

El autor debe ser entendido en sentido jurídico y no material, pues como advierte Francesco CARNELUTTI, éste no siempre es la persona que materialmente lo crea, es decir, su elaborador, sino la persona a quien jurídicamente se le atribuye, como ocurre en el caso de las escrituras públicas, porque el notario al documentar un contrato, sólo hace constar la comparecencia de las partes, sus declaraciones, el lugar, la fecha en la cual concurrieron, dando fe de todo ello, pero las partes son en realidad los autores intelectuales del documento y los sujetos del mismo; por eso, es que interesa el saber por quién fue elaborado el documento, permitiendo esto clasificarlo en autógrafos y heterógrafos. Los primeros son aquellos escritos de propia mano del autor; siguiendo la opinión de CARNELUTTI, la escritura posee una función comunicativa, mientras el pensamiento posee una función certificativa, entonces cuando a la vez se conjugan en una persona ambas funciones, y al mismo tiempo que se manifiesta el pensamiento, se forma el documento, se está ante la presencia de un documento autógrafo. ${ }^{239}$

Los documentos heterógrafos son aquellos que son obra de un tercero, es decir, son documentos cuya nota esencial consiste en no haber sido formados

\footnotetext{
${ }^{238}$ DEVIS ECHANDIA; Hernando; op cit. T. II; pp. 514 y 515

${ }^{239}$ CARNELUTTI, Francesco; op cit. 161 y 162
} 
por quien realiza el hecho documentado, tal como ocurre en el caso de los documentos notariales. ${ }^{240}$ Este aspecto plantea la cuestión de determinar quiénes son los sujetos del documento y tiene mucha importancia, porque se encuentra directamente relacionada con los efectos probatorios de los mismos.

Por otra parte, en cuanto al destinatario del documento, es preciso distinguir dos situaciones, pues mientras el documento cumpla su función extraprocesal, como por ejemplo, servir de título para el cobro de una suma de dinero, o para la justificación de una situación jurídica. Su destinatario es la persona a quien está dirigido o ante quien se hace valer.

Pero, cuando el documento es aducido como prueba en un proceso, su destinatario, como en el caso de todas las pruebas aportadas al proceso, es el juez, quien deberá valorarlo y otorgarle el mérito probatorio que considere, de acuerdo con las reglas de la lógica y la experiencia. Por tanto, el único sujeto destinatario procesal de toda clase de documentos es el juez, aunque puedan existir diversos destinatarios extraprocesales. ${ }^{241}$

Por último, extraprocesalmente puede hablarse de sujeto pasivo del documento para referirse a la persona vinculada por él, en cambio procesalmente es más exacto hablar de sujeto contradictor del documento, para señalar a la parte contra la cual se aduce como prueba, en vez de sujeto pasivo, porque toda prueba esta dirigida al juzgador, y el contradictor en realidad es un sujeto activo, quien además de desplegar una actividad probatoria en juicio, tiene la aptitud a través del derecho de defensa que le asiste, de impugnar cualquier documento aducido en su contra.

\footnotetext{
${ }^{240}$ Ibídem p. 164

${ }^{241}$ DEVIS ECHANDIA, Hernando; op cit. T. II; p. 517
} 


\section{c) Clases de documentos}

La forma principal de la clasificación de esta probanza es la de documentos públicos y privados. Dicha referencia atiende a la naturaleza de las personas que intervienen en los mismos, pues ello les confiere un diferente tratamiento, y sobre todo, una eficacia probatoria también distinta.

1.- Documentos Públicos.- Por estos podemos entender, siguiendo la opinión del jurista mexicano Rafael de PINA VARA “... los otorgados por autoridades o funcionarios públicos dentro de los límites de sus atribuciones o por personas investidas de fe pública dentro del ámbito de su competencia en forma legal”242

Legalmente, éstos se encuentran regulados en los artículos 129 y 130 del Código Federal de Procedimientos Civiles mexicano, similares al artículo 317 de la Ley de Enjuiciamiento Civil, al determinar que son documentos públicos aquellos cuya formación está encomendada por la ley, dentro de los límites de su competencia, a un funcionario público revestido de la fe pública, y los expedidos por funcionarios públicos, en el ejercicio de sus funciones.

La calidad de públicos se demuestra por la existencia regular, sobre los documentos, de los sellos, firmas u otros signos exteriores que, en su caso, prevengan las leyes.

De igual forma los documentos públicos mexicanos expedidos por autoridades de la Federación, de los Estados, del Distrito Federal y Territorios o de los Municipios, harán fe en el juicio, sin necesidad de legalización.

${ }^{242}$ DE PINA VARA, Rafael; op cit. p. 170 
Así, como anteriormente se ha mencionado, en el caso español la Ley de Enjuiciamiento Civil, considera documentos públicos los siguientes:

a. Las resoluciones y diligencias de actuaciones judiciales de toda especie y los testimonios que de las mismas expidan los Secretarios Judiciales.

b. Los autorizados por notario con arreglo a derecho.

c. Los intervenidos, en el caso mexicano, por Corredores de Comercio Colegiados y las certificaciones de las operaciones en que hubiesen intervenido, expedidas por ellos con referencia al Libro Registro que deben llevar conforme a derecho. ${ }^{243}$

d. Las certificaciones que expidan los Registradores de la Propiedad y Mercantiles de los asientos registrales.

e. Los expedidos por funcionarios públicos legalmente facultados para dar fe en lo que se refiere al ejercicio de sus funciones.

f. Los que, con referencia a archivos y registros de órganos del Estado, de las Administraciones públicas o de otras entidades de Derecho público, sean expedidos por funcionarios facultados para dar fe de disposiciones y actuaciones de aquellos órganos, Administraciones o entidades.

De acuerdo a lo anterior, podemos decir que los documentos públicos pueden agruparse en cuatro subespecies: los notariales, expedidos y autorizados por notario público; administrativos, expedidos por funcionarios públicos de

\footnotetext{
${ }^{243}$ En el caso de España, los corredores actualmente ya no existen, al haberse integrado al Cuerpo de notarios.
} 
alguna Administración pública en el ejercicio de su cargo y dentro del límite de sus atribuciones legales; judiciales, aquellos derivados del ejercicio de la función judicial, y registrales, aquellos expedidos por las dependencias encargadas de llevar el registro de determinados actos o hechos jurídicos.

Documentos Notariales.- Estos son aquellos expedidos y autorizados por un notario público, y han sido clasificados en escrituras y actas; ya que conforme al artículo 100 y 125 de la Ley del Notariado mexicana; la escritura es el instrumento original que el notario asienta en los folios, para hacer constar uno o más actos jurídicos y que firmado por los comparecientes, autoriza con su sello y firma

Documentos administrativos.- Los documentos administrativos son aquellos expedidos por funcionarios públicos del orden administrativo, en el ejercicio de su cargo y dentro del límite de sus atribuciones legales, éstos sólo serán considerados como públicos cuando sean expedidos como se ha dicho anteriormente, exclusivamente por funcionarios públicos del orden administrativo en ejercicio de sus atribuciones legales, ya que no basta la expedición por ellos sobre asuntos que pudieran llegar a ser ajenos a su cargo o función, en este caso además de estar afectados de nulidad, no serán considerados como documentos públicos, y como consecuencia no tendrán pleno valor probatorio en juicio. ${ }^{244}$

Actuaciones judiciales.- Estas comprenden todos los actos jurídicos realizados por cualquier tribunal, dentro de un procedimiento judicial y respecto de los cuales queda constancia en el expediente respectivo, es preciso el no caer en la confusión de las actuaciones judiciales con el expediente del proceso, pues aquellas sólo se integran por los actos jurídicos en los cuales interviene el

${ }^{244}$ OVALLE FAVELA, José; op cit. p. 130 
tribunal, conocidos como actos, diligencias y resoluciones. En este punto, podemos remitirnos al artículo 296 del Código Procesal Civil mexicano, la cual llega a determinar que las constancias de autos del mismo juicio se tomarán como prueba, aunque no se ofrezcan como tal.

Constancias registrales.- Estos son aquellos documentos expedidos por las dependencias encargadas de llevar un registro de determinados actos o hechos jurídicos, como sería en este caso el Registro Público de la Propiedad y del Comercio, o bien aquellas dependencias que dentro de sus facultades se encuentre la expedición de constancias o certificados de los registro que realiza, como igual se puede ejemplificar el Registro del Estado Civil.

Los documentos públicos a que se ha hecho referencia, de acuerdo a lo dispuesto por el artículo 202 del Código Federal de Procedimientos Civiles mexicano $^{245}$, homologo a los artículos 318 y 319 de la Ley de Enjuiciamiento Civil española ${ }^{246}$, nos determina que por regla general, tendrán pleno valor probatorio, salvo que se demuestre su falsedad por otros medios probatorios.

2.- Documentos privados.- éstos han sido definidos de la manera siguiente:

\footnotetext{
${ }^{245}$ Artículo 202.- "Los documentos públicos hacen prueba plena de los hechos legalmente afirmados por la autoridad de que aquéllos procedan; pero, si en ellos se contienen declaraciones de verdad o manifestaciones de hechos de particulares, los documentos sólo prueban plenamente que, ante la autoridad que los expidió, se hicieron tales declaraciones o manifestaciones; pero no prueban la verdad de lo declarado o manifestado."

${ }^{246}$ Artículo 318. "Modo de producción de la prueba por documentos públicos. Los documentos públicos tendrán la fuerza probatoria establecida en el art. 319 si se aportaren al proceso en original o por copia o certificación fehaciente o si, habiendo sido aportado por copia simple conforme a lo previsto en el art. 267, no se hubiere impugnado su autenticidad.”

Artículo 319. "Fuerza probatoria de los documentos públicos.

1. Con los requisitos y en los casos de los artículos siguientes, los documentos públicos comprendidos en los números $1^{\circ}$ a $6^{\circ}$ del art. 317 harán prueba plena del hecho, acto o estado de cosas que documenten, de la fecha en que se produce esa documentación y de la identidad de los fedatarios y demás personas que, en su caso, intervengan en ella.”
} 
Para DEVIS ECHANDIA, es un "documento privado el que no tiene carácter de público...”247; GÓMEZ DE LIAÑO, nos dice que: "Son los que se formalizan entre particulares, sin la intervención de funcionario público, así como las escrituras defectuosas por incompetencia del notario o por otra falta de forma si estuviese firmada por los otorgantes”248.

Legislativamente el artículo 133 del Código Federal de Procedimientos Civiles mexicano, los define como: "los que no reúnen las condiciones previstas en el artículo 129” ( del mismo Código Federal de Procedimientos Civiles mexicano), el cual ha sido comentado anteriormente. ${ }^{249}$

A su vez el artículo 324 de la Ley de Enjuiciamiento Civil española, determina que por documentos privados a efectos de prueba en el proceso, serán por exclusión, aquellos que no se hallen en ninguno de los casos del art. 317 del mismo ordenamiento

Los documentos privados a diferencia de los públicos que tiene valor probatorio pleno, deben haber sido reconocidos como auténticos por la contraparte, ya sea en forma plena o tácita y con esto se les darán eficacia probatoria.

El reconocimiento expreso del documento privado puede exigirse a petición de la parte interesada o requerimiento del juzgador y sólo puede hacerlo el que lo firma, lo mandó extender o su legítimo representante con cláusula o poder especial; dicho reconocimiento se hará siguiendo las reglas de la prueba

\footnotetext{
${ }^{247}$ DEVIS ECHADIA; Hernando; op cit; T. II; p. 551

${ }^{248}$ GÓMEZ DE LIAÑO GONZÁLEZ; Fernando; op cit p. 141

${ }^{249}$ El Código de Procedimientos Civiles para el Distrito Federal realiza una explicación más detallada, sin dejar tanto a la exclusión por regla general de los documentos privados y el cual nos indica que: "Son documentos privados, los vales, pagarés, libros de cuenta, cartas y demás escritos firmados o formados por las partes o de su orden y que no estén autorizados por escribanos o funcionario competente".
} 
confesional, debiendo mostrarlo a quien deba reconocerlo, en todo su contenido y no sólo en la firma.

El reconocimiento tácito del documento privado, tiene lugar cuando en el juicio se presenta por vía de prueba y la parte contraria no lo objeta, en cuyo caso, se tendrá por admitido y surtirá sus efectos como si hubiera sido reconocido expresamente.

La objeción de los documentos en cuanto a su alcance y valor probatorio, deberá promoverse por las partes dentro de los 3 días siguientes a aquel en que surta efectos la notificación del auto en el cual se ordene su recepción.

\section{d) Impugnación de la prueba documental.}

Tanto los documentos públicos como los privados pueden ser impugnados por inexactitud o falsedad, pero dependiendo del tipo de documento de que se trate, los efectos serán distintos en cuanto a la carga de la prueba y al valor probatorio.

En lo relativo a los públicos, en caso de que a quien perjudiquen decida impugnarlos por inexactitud o falsedad necesariamente deberá indicar los motivos y las pruebas con las cuales pretenda probar dicha impugnación.

En el caso de los documentos privados, como se dijo en párrafos anteriores; éstos solo tienen valor probatorio cuando son reconocidos expresa o tácitamente, por tanto en caso de ser objetados, deberá indica expresamente los motivos específicos en los cuales basa su objeción, y por ende corresponderá la carga de la prueba en contrario al oferente del documento privado. 


\subsubsection{La prueba pericial en los procesos de filiación}

La aplicación de la prueba pericial a los juicios de filiación reviste especial importancia en esta investigación y es en suma, el tema central de este trabajo, en el ámbito de la ciencia jurídica, y como se ha visto la filiación biológica ha constituido un serio dilema para la humanidad, y ha pretendido ser resuelta desde los primeros sistemas legales como el romano, a través de presunciones legales, las cuales aun cuando hoy en día siguen siendo útiles en múltiples casos, dicha utilidad no puede generalizarse a toda la gama de posibilidades que se actualizan en la realidad.

Dentro de las pruebas periciales se debe incluir las pruebas genéticas y biológicas que determinan la paternidad y maternidad que aun cuando no se han admitido en forma expresa en toda la legislación mexicana con un tratamiento especial, bien pueden utilizarse como pruebas periciales. Así desde el mes de mayo del 2000 en la legislación mexicana, se ha admitido la prueba biológica o bien la proveniente de los avances científicos para probar el nexo filial de los descendientes, ya sea, por su padre o con su madre y o tal vez como una prueba para mejor proveer a instancia del propio juez, amén que el Segundo Tribunal Colegiado en Materia civil del Segundo Circuito ha sustentado tesis jurisprudencial, al determinar que cuando se reclame el reconocimiento de la paternidad de un menor, así como sus consecuencias inherentes, la pericial en materia de genética es la prueba idónea para demostrarla, previo análisis de las

muestras de sangre correspondientes, con el propósito de esclarecer jurídicamente el problema planteado, máxime si fue previa y debidamente admitida... pues una vez desahogada debidamente permitirá al Juez decidir justamente, al contar con los elementos esenciales y convincentes indispensables 
para dirimir la litis planteada, ya que la pericial es la prueba científica y biológicamente idónea para tener o no por cierta y corroborada la filiación. ${ }^{250}$

Así, la admisión de la prueba biológica o bien la proveniente de los avances de los conocimientos científicos, para probar el nexo filial de los descendientes con cualquiera de sus progenitores, tanto en la ley civil federal como en la tesis transcrita, así como en el caso similar del ya citado artículo 127 del Código Civil Español y reiterado por las sentencias de 30 de octubre de 1993 que ha estipulado que "ha introducido en nuestro ordenamiento jurídico el principio de libre investigación de la paternidad siendo admisibles en los juicios sobre filiación toda clase de pruebas, incluidas las biológicas”; siendo éstas el medio idóneo para probar el nexo biológico de la paternidad y por tanto la filiación, atendiendo a que en la actualidad éstos son los medios probatorios más concluyentes para la comprobación del nexo filial, al obtenerse resultados con un mínimo de error.

En conclusión, podemos ver que las pruebas biológicas tienen el carácter de auténticas pruebas periciales, por lo tanto deben estar sometidas a la regulación que para las mismas establece el Código de procedimientos civiles y tienen por objeto la demostración o no de la paternidad y maternidad de una persona con respecto a otras a través de un estudio biológico. Es la genuina prueba directa de investigación de la paternidad.

Sin embargo, la parte que vaya a ofrecer la prueba deberá expresar claramente el objeto de la misma, desde la presentación de la demanda, requiriendo la presentación del demandado para su práctica, con advertencia de

\footnotetext{
250 Registro No. 195964; Localización: Novena Época; Instancia: Tribunales Colegiados de Circuito; Fuente: Semanario Judicial de la Federación y su Gaceta; VIII, Julio de 1998; Página: 381 PERICIAL EN GENÉTICA. ES LA PRUEBA IDÓNEA PARA DEMOSTRAR CIENTÍFICA Y BIOLÓGICAMENTE LA PATERNIDAD Y FILIACIÓN.
} 
las consecuencias de su negativa. La prueba puede ser ofrecida por cualquier parte o inclusive por el mismo juez como diligencia para mejor proveer.

\section{a) Características generales de la prueba pericial}

1. Dentro de las características de la prueba pericial, lo primero es determinar si se trata de un medio de prueba o no; al respecto, hay opiniones divididas, para EISNER, la pericia no es propiamente un medio de prueba, porque aun cuando contribuye a formar la convicción del juez, en realidad es una fase del proceso intelectual desarrollado por el juzgador al dictar sentencia, pues sólo consiste en la ilustración o ayuda que le presta un experto para valorar los hechos, ante la imposibilidad de explicarlos por sus propios sentidos o su saber. $^{251}$

A diferencia de este autor, CARNELUTTI y DEVIS ECHANDIA, sí confieren el carácter de medio de prueba a la peritación, porque el dictamen pericial tiene por objeto la investigación, verificación y/o calificación de los hechos controvertidos de carácter técnico, artístico o científico, suministrándole al juzgador la explicación de los mismos, en cuanto a sus características, causas y efectos, en ámbitos ajenos a su preparación fundamentalmente jurídica. ${ }^{252}$

2. Es una actividad humana especialmente calificada, porque consiste en la intervención transitoria en el proceso de personas expertas en alguna ciencia, técnica o arte, quienes deben investigar, verificar y/o calificar ciertos hechos, para rendir posteriormente un dictamen respecto de los mismos.

\footnotetext{
${ }^{251}$ EISNER, Isidoro; La prueba en el proceso civil; $2^{\mathrm{a}}$ ed, Ed. Abeledo - Perrot; Argentina; 1992; pp. 91 y 92

${ }^{252}$ CARNELUTTI; Francesco; op cit. pp. 73-75; DEVIS ECHANDIA op cit; T. II., p. 315
} 
3. Es una actividad procesal, porque debe ocurrir en el curso de un proceso, ya sea durante el periodo probatorio, o bien, en diligencias posteriores y complementarias.

4. Debe versar sobre hechos y no sobre cuestiones jurídicas, ni tampoco sobre exposiciones abstractas que no incidan en la verificación, calificación o investigación de los hechos del proceso. ${ }^{253}$

5. La prueba pericial debe versar sobre hechos especiales, es decir, sobre aquellos que requieran tanto conocimientos como una experiencia específica, ya sea técnica, artística o científica, y cuya verificación, calificación e investigación, no sea posible con los conocimientos ordinarios de personas medianamente cultas, ni tampoco con la preparación de los jueces, la cual es fundamentalmente jurídica.

6. La prueba pericial es una declaración de ciencia, porque el perito expone a través de su dictamen las causas y los efectos de los hechos objeto del peritaje, basándose en sus conocimientos y experiencia técnica, artística o científica, sin pretender ningún efecto jurídico concreto con su exposición: además, es declaración emitida por el perito, es una operación valorativa, porque su dictamen no constituye la simple narración de sus percepciones, sino la explicación de la existencia, característica y apreciación del hecho, de sus causas y sus efectos. ${ }^{254}$

\footnotetext{
${ }^{253}$ DEVIS ECHANDIA, Hernando; op cit. p. 304
}

${ }^{254}$ DE PINA, Rafael; op cit. pp. 180 y 181 


\section{c) Clases de periciales y peritos}

La peritación más común en los procesos civiles y penales es aquella que tiene por objeto verificar la existencia o las características de los hechos técnicos, científicos o artísticos. En este tipo de prueba pericial, el perito se denomina perito percipiendi, y por ello su dictamen es indubitablemente un medio para la comprobación de los hechos controvertidos. ${ }^{255}$

La peritación tiene la finalidad de aplicar las reglas técnicas, artísticas o científicas de la experiencia especializada de los expertos, a los hechos verificados en el proceso por cualquier otro medio de prueba, para decidir de ellos las consecuencias, causas, calidades o valores que se investigan. En esta clase de pericial, el perito se denomina perito deducendi y su actividad consiste en la realización de dos operaciones; la primera, es enunciar las reglas de la experiencia técnica pertinente a los hechos probados en el proceso por cualquier otro medio de prueba, y la segunda es formular las deducciones correspondientes a esos hechos ya probados en el proceso. ${ }^{256}$

Las periciales forzosas y potestativas o discrecionales, según la ley exija o no su práctica para el caso concreto. Así, son forzosas, en aquellos supuestos en los que la ley determina la necesidad de su práctica para comprobar los hechos controvertidos. A diferencia de éstas, las potestativas se actualizan, cuando a instancia de alguna de las partes se ofrecen como prueba, o es el mismo Juzgado, quien exige su práctica con el objeto de comprobar los hechos controvertidos. $^{257}$

\footnotetext{
${ }^{255}$ DEVIS ECHANDIA, Hernando; op cit. p. 305

${ }^{256}$ Ídem

${ }^{257}$ Ibídem, p. 307
} 
Las periciales judiciales y prejudiciales, según vayan ocurriendo en el curso del proceso o en diligencia procesal previa. Así, serán judiciales, aquellas que se realizan en el curso del proceso y surten de inmediato sus efectos probatorios, mientras las prejudiciales se producen anticipadamente en vista del proceso en el cual se aducirán como prueba. ${ }^{258}$

Las periciales individuales y colegiadas, según sean realizadas por uno o más peritos. Si solamente emite el dictamen un perito se considera individual, mientras si el mismo es emitido por un colegio, academia, cámara o corporación de profesionales, sería colegiado, al ser producto del trabajo de un equipo. ${ }^{259}$

En cuanto a las distintas clases de peritos, además de los enunciados con anterioridad, puede hablarse de peritos esporádicos o accidentales, así como de peritos continuos o permanentes, los primeros adquieren esa condición en virtud del nombramiento especial del juez para el caso concreto, mientras los segundos desempeñan ese encargo como parte de sus funciones, encontrándose en este supuesto los médicos legistas o forenses, pues dentro de sus actividades normales en los procesos penales, está la de dictaminar cuestiones tales como: las causas y el momento de la muerte de un individuo, o bien sobre las consecuencias de las heridas producidas a cierta persona. ${ }^{260}$

\section{c) El Perito}

Puede definirse al perito como un "auxiliar del juez", atendiendo a que el mismo sólo se constituye durante el proceso en un colaborador técnico del juzgador, a quien debe ilustrar y suministrar de manera imparcial elementos

\footnotetext{
${ }^{258}$ MATEOS ALARCÓN; op cit. p. 185

${ }^{259}$ DE PINA; Rafael; op cit. p. 185

${ }^{260}$ DEVIS ECHANDIA, Hernando; op cit. T.II; pp. 307 y 308
} 
útiles para pronunciar su decisión, sobre aquellas cuestiones controvertidas en juicio, respecto de las cuales requiere de conocimientos especiales diferentes al Derecho.

En este sentido, cabe resaltar que al constituirse el perito en auxiliar o colaborador del juzgador, su opinión técnica no liga imperativamente a aquél, ni tampoco lo dispensa del deber crítico inherente y esencial de su labor, más aun cuando dispone de otros medios de investigación adicionales a los del perito, y contempla la controversia judicial de manera global, a pesar de no poseer esos conocimientos artísticos, técnicos o científicos especializados. ${ }^{261}$

Así mismo, el cumplimiento de la tarea encomendada por el juzgador al perito, parte de un ángulo visual estrecho y únicamente en la esfera de su experiencia profesional, por ello, su labor no puede tener un significado definitivo en la solución de la controversia, sobre todo porque no deben ignorarse aquellos casos comúnmente actualizados en la práctica, a través de los cuales el perito por una tendencia humana y explicable, emite su dictamen favoreciendo a su promovente.

\section{d) El dictamen pericial}

Este es una opinión fundada del perito respecto de las cuestiones controvertidas en juicio, de carácter científico, técnico o artístico, sobre las cuales versó la prueba pericial. Por ello, necesariamente dicha opinión debe suministrar al juzgador los principios científicos en los que se funda, así como la explicación detallada de la operaciones técnicas, artísticas o científicas

${ }^{261}$ DÖHRING, Erich; La Prueba, su práctica y apreciación; trad. Por Tomás A. Banzhaf, Ediciones jurídicas Europa - América; Argentina, 1986; p. 244 
realizadas, a efectos de la correcta valoración de las conclusiones obtenidas, de lo contrario carece de valor probatorio. ${ }^{262}$

El dictamen pericial puede existir jurídicamente y no obstante adolecer de nulidad, pero para evitar que esto ocurra, es necesaria la actualización de ciertos requisitos de validez, entre los cuales se pueden citar:

1. La ordenación de la prueba en forma legal.

2. La capacidad jurídica del perito para desempeñar el cargo.

3. La debida aceptación y protesta del cargo de perito

4. La presentación del dictamen por escrito debidamente firmado.

5. Que el dictamen sea un acto consciente, libre de coacción, violencia, dolo o cohecho.

6. Que no exista una disposición jurídica en la cual se prohíba la práctica de la prueba pericial al caso concreto.

7. Que los estudios básicos del dictamen hayan sido realizados personalmente por el perito

8. Que el perito no haya utilizado medios ilícitos para la realización del dictamen.

9. Que no exista una causa de nulidad general del proceso que también anule la peritación.

Así mismo, para que el dictamen tenga eficacia probatoria, no basta su existencia jurídica, ni tampoco que no adolezca de nulidad, pues también es necesaria la concurrencia de los siguientes requisitos de fondo y forma:

1. Que sea un medio probatorio conducente respecto al hecho por probar.

${ }^{262}$ WITTHAUS, Rodolfo; op cit p. 53 
Este aspecto está relacionado con el objeto de la prueba parcial en sí, lo cual significa que el hecho, las circunstancias, cualidades o valores del mismo, deben requerir la calificación técnica, artística o científica, para su adecuada percepción y valoración por parte del juzgador en la solución del proceso judicial respectivo. $^{263}$

2. Que el hecho objeto del dictamen sea pertinente.

Esto significa que el hecho objeto de la pericial, debe ser indispensable para resolver la controversia en la cual se promueva, de lo contrario resultará inútil en ese proceso. ${ }^{264}$

3. Que el perito sea experto y competente para el desempeño de su encargo.

En este sentido, importa señalar que en un proceso, cualquier persona puede ser testigo, pero pocas pueden actuar en calidad de peritos, pues no se trata de narrarle al juzgador las percepciones ordinarias de ciertos hechos, sino de emitir conceptos de valor técnico, artístico o científico ajenos al común de las personas. ${ }^{265}$

La eficacia probatoria del dictamen depende fundamentalmente de la competencia del perito para cada caso, y obviamente, su designación debe atender tanto a sus conocimientos como a su experiencia, para poder suministrarle al juzgador algún argumento de prueba. Por tanto, el artículo 347 fracción III del Código Federal de Procedimientos Civiles mexicano, similar al

\footnotetext{
${ }^{263}$ Ídem p. 332

${ }^{264}$ DEVIS ECHANDIA, Hernando; Op cit. T II; pp. 324

${ }^{265}$ DÖHRING, Erich; op cit. pp. 225 y 256
} 
artículo 340 de la Ley de Enjuiciamiento Civil española, exige al perito anexar en el documento de aceptar y protestar su cargo, la copia de su cédula profesional o de los documentos con los cuales acredite su calidad de perito en el arte, técnica o industria en la que se le designe.

Aunque para la ley, el requisito de título profesional sea garantía o por lo menos presunción de idoneidad del perito, es preciso reconocer que en ocasiones y concretamente en el caso de la ingeniería o de la ciencia médica, dicho título es insuficiente para dictaminar cuestiones muy especializadas, aun cuando comprenda en su generalidad la materia de la pericia, pues en estas áreas existen diversas especialidades en las cuales se demandan años de estudio específicos, y en esos supuestos, los promoventes de la peritación pueden exigir mayor grado de especialidad del perito.

Por otra parte, en cuanto a la competencia del perito, también debe incluirse la ausencia de perturbaciones psicológicas o de cualquier otro orden, que aun cuando no produzcan su incapacidad mental ni física, puedan afectar al adecuado desempeño de dicho cargo, repercutiendo en la fidelidad de sus percepciones y la exactitud de sus juicios o inferencias. ${ }^{266}$

De igual forma, en aquellos casos en los que intervenga en calidad de perito, una persona considerada autoridad en la materia sobre la cual debe emitirse la peritación, el juzgador deberá valorar de manera crítica sus explicaciones y la solidez de los argumentos expuestos, pues la reputación de ese experto no es suficiente por sí sola, para despertar confianza en su pericia, y tal prestigio no debe llevar a la aceptación automática de su dictamen.

\footnotetext{
${ }^{266}$ PARRA QUIJANO, Jairo; Op cit p. 636
} 
4. Que no exista motivo para dudar del desinterés, imparcialidad y sinceridad del perito.

Porque al actualizarse de estos supuestos, evidentemente se estaría poniendo en tela de juicio el contenido y resultados del dictamen pericial, dando lugar incluso, a la recusación del perito y a su responsabilidad penal.

Es importante hacer énfasis en la responsabilidad penal del perito, porque los preceptos jurídicos establecidos al respecto en los Códigos penales y que referirían en lo específico al tipo penal de falsedad de declaración ante las autoridades; de acuerdo con estos preceptos jurídicos, el perito es responsable penalmente, cuando dolosamente declara con falsedad en su dictamen, actualizándose tal conducta de concurrir ciertas circunstancias o calidades: ocultar hechos o circunstancias mediante las cuales se modificarían sus conclusiones; el asegurar haber verificado los hechos circunstanciales o calidades del objeto de la peritación con determinados experimentos, sin ser esto cierto; afirmar una conclusión sin tener certeza de ella; señalar en su dictamen un concepto contrario a la realidad, por interés o sentimientos de amistad o enemistad con alguna de las partes o sus litigantes.

5. Que el dictamen esté debidamente fundamentado.

Este aspecto reviste suma importancia y se traduce en la llamada “razón de la ciencia del dicho”, pues el perito no sólo debe constreñirse a emitir su concepto técnico, artístico o científico, sino que también debe explicar las razones que lo condujeron a las conclusiones manifestadas en el dictamen. ${ }^{267}$

En este sentido, será común que en la mayor parte de las ocasiones, el juez esté imposibilitado para saber si las explicaciones técnicas, científicas o

${ }^{267}$ DÖHRING, Erich; op cit. pp. 252 
artísticas, emitidas por el perito en el dictamen adolecen o no de error, a menos que sea obvia la falta de lógica, oscuridad o deficiencia de sus argumentos. No obstante, es posible la actualización de casos en los cuales, el juzgador al informarse en literatura especializada pueda apreciar el valor de esos fundamentos y rechazarlos, o bien, cuando los mismos contradigan normas generales de la experiencia, hechos notorios o conocimientos personales sobre la materia.

6. Que las conclusiones del dictamen sean claras, firmes y consecuencia lógica de sus fundamentos.

Este requisito es consecuencia del anterior, pues el perito además de tener el deber de explicar las razones que lo condujeron a las conclusiones manifestadas en su dictamen, está vinculado a emitir esas conclusiones con claridad, firmeza y una lógica relación entre ellas y los fundamentos con los cuales se respaldan, a fin de ser convincentes. ${ }^{268}$

El dictamen pericial no puede tener eficacia probatoria, si unos buenos fundamentos van acompañados de unas malas conclusiones, o si no existe armonía entre los fundamentos y las conclusiones, o bien, si el perito no expresa con seguridad y contundencia sus conceptos técnicos, artísticos o científicos.

Tampoco basta, que las conclusiones sean claras, firmes y consecuencia lógica de sus fundamentos o motivaciones, pues puede presentarse el supuesto en el cual el perito exponga con claridad, firmeza y lógica tesis equivocadas, en cuyo caso, si el juez considera improbables esas conclusiones,

${ }^{268}$ DEVIS ECHANDIA, Hernando; op cit. p. 336 
de acuerdo con las reglas de la experiencia y con la crítica lógica del dictamen, estará imposibilitado para otorgar valor probatorio a la prueba pericial. ${ }^{269}$

7. Que no existan otras pruebas que desvirtúen el dictamen o lo hagan dudoso o incierto.

Si en el proceso aparecen otros medios probatorios, a través de los cuales se desvirtúen las conclusiones del dictamen, o dejen al juzgador en situación de incertidumbre sobre su mérito probatorio, después de una crítica conjunta y razonada, aquél no puede tener plena eficacia probatoria.

8. Que no haya rectificación o retractación del perito.

Cuando el perito rectifique o se retracte total o parcialmente de su dictamen, ese cambio de conceptos impedirá al juzgador otorgarle eficacia probatoria a las nuevas conclusiones presentadas, deduciéndose su falta de firmeza y claridad, pues si el mismo perito no tuvo seguridad en sus conclusiones, menos puede producirla en el ánimo del juez, y en este caso, lo procedente sería ordenar oficiosamente o para mejor proveer, otro dictamen con distintos peritos.

9. Que no se haya violado el derecho de defensa de la parte perjudicada con el dictamen o su debida contradicción.

Este requisito está relacionado con el carácter de medio de prueba reconocido a la peritación, porque es una exigencia propia de la disciplina probatoria, conceder a las partes la oportunidad de alegar lo que a su derecho

${ }^{269}$ OVALLE FAVELA, José; op cit. p. 337 
convenga respecto a las pruebas ofrecidas, admitidas y desahogadas en el proceso.

En particular, el ejercicio de ese derecho de defensa de las partes respecto a la prueba pericial, les asiste desde la debida ordenación de la peritación en el proceso; la notificación de las mismas, en la cual se haga de su conocimiento la ordenación de su práctica, a efecto de que manifieste lo relativo a su pertinencia; los puntos sobre los cuales deberá versar, las pretendidas cuestiones a resolver a través de dicha probanza, la solicitud de tener en cuenta otros hechos o pruebas relacionadas con el objeto del dictamen; la designación de los peritos, y en su caso, lo relacionado a la recusación de éstos.

Así, es indispensable para las partes en el proceso conocer y tener la oportunidad, tanto de solicitar las aclaraciones, como de formular las objeciones pertinentes al dictamen procesal que les perjudiquen, porque de lo contrario, se les estaría violando su derecho constitucional de defensa, y el juzgador estaría imposibilitado para reconocer al mismo, eficacia probatoria. ${ }^{270}$

10. Que los peritos no excedan los límites de su encargo.

El dictamen debe limitarse a los puntos propuestos por las partes y autorizados por el juzgador para la práctica de la prueba pericial, porque de versar sobre puntos distintos carecerá de eficacia probatoria.

\footnotetext{
${ }^{270}$ DEVIS ECHANDIA, Hernando; op cit; T II; p. 344
} 


\section{e) Valoración}

Si la prueba es positiva deberá declararse la paternidad o maternidad, toda vez que como se ha dicho, la importancia científica de esta prueba pericial y el grado de certidumbre que ofrece la vuelve la reina de las pruebas de la filiación que será apreciada por los tribunales al momento de resolver una pretensión.

Si no se practica la prueba por causas ajenas a la voluntad del demandado, es decir, sin imputarse a una negativa injustificada del demandado, el juez tiene que resolver la pretensión con apoyo en las demás pruebas científicas que no son las únicas posibles. No es la única prueba que puede rendirse en el juicio, sino que tendrá que valorarse otras pruebas como las mismas presunciones, posesión de estado, etcétera.

\section{f) La ficta confessio como resultado de la negativa a someterse} a la prueba genética

Es de suma importancia que en la nueva regulación del Derecho de filiación, se dispone una presunción de paternidad y de maternidad si se niegan a proporcionar la muestra necesaria para el análisis respectivo, consignando que dicha paternidad y maternidad pueden probarse por cualquier medio ordinario, y que si se propone la prueba biológica o proveniente del avance de los conocimientos científicos negándose el presunto progenitor a proporcionar la prueba necesaria, se presumirá, salvo prueba en contrario como el padre o madre del hijo o hija. ${ }^{271}$

\footnotetext{
${ }^{271}$ Artículo 382 del Código Civil Federal mexicano; sin embargo, el artículo 398 del código Civil de Baja California Sur, ha consignado que: "El demandado que, sin causa justificada, se niegue a someterse a las
} 
Estos preceptos como se ha dicho, establecen una presunción legal iuris tantum, toda vez que el legislador presupone probada la paternidad o maternidad por la simple negación o proporcionar la muestra necesaria para la realización de la prueba genética. En tal virtud, la negativa injustificada de la parte demandada a someterse a esta prueba, salvo prueba en contrario, hará presumir que la presunta madre o presunto padre es el verdadero, es decir, que la negativa injustificada se puede reputar por sí misma una ficta confessio, y por ende el resultado del litigio puede depender de tal negativa sin importar otras pruebas de cualquier clase, aunque no se trate de una presunción que haga prueba plena, por admitir prueba en contrario.

Como se dijo anteriormente, quien ofrezca la probanza deberá expresar claramente su objetivo, requiriendo la presentación del demandado para su práctica, con advertencia de las consecuencias de su negativa. Lo anterior hace evidente que ante dicha situación va a ser necesario que esa negativa conste de forma clara, indubitada y fehacientemente.

Por último, dada la voluntad de los legisladores en establecer como presunción legal para probar la paternidad o maternidad, la negativa a someterse a las pruebas biológicas, resulta contundentemente para alguna de las partes como carga procesal, ya que obligará al juez a pronunciar una sentencia contraria a la parte que no cumplió con dicha carga, toda vez que no existe una disposición que imponga la extracción de la sangre por medio de la fuerza.

Sin embargo, la postura del legislador federal llega a superponerse ya que aun cuando no se violenten garantías individuales, la simple negativa de una

pruebas biológicas ordenadas por el juez o el tribunal, será tenido por confeso de lo que se pretende demostrar con dichas pruebas, por vía de presunción en su perjuicio” 
de las partes en un juicio de filiación de someterse a las prácticas de pruebas biológicas o proveniente del conocimiento de los avances científicos, no es un hecho encaminado a probar la paternidad o maternidad, porque esa simple negativa injustificada se puede valorar de una forma desmesurada y no supone una regla lógica que pruebe la filiación, es solamente un indicio que tendrá que valorarse en su momento con el resto de las demás pruebas practicadas que dejen constancia de que hubo entre la partes en litigio relaciones sexuales que supongan la fecundación del hijo o hija que reclaman la filiación, de lo contrario se pueden desencadenar una serie de procesos de investigación de la paternidad sin que existan lazos genéticos entre el actor y el demandado y por la simple negativa a la práctica de las pruebas, se le atribuya la paternidad.

Se ha señalado igual que cuando no haya otra prueba más que la negativa a someterse a la heredobiológica, debe hacerse a la acción porque se trata de una acción de estado, en la que toda la comunidad está interesada y porque cada persona tiene derecho a conocer su identidad, tal y como lo postula la Convención sobre los Derechos del Niño, a conocer a sus padres y los estados firmantes a prestar la asistencia y protección para establecer la filiación. Postulan que ante la colisión de derechos entre las partes "negativa paterna y derecho a la identidad” debe prevalecer el interés social en juego: por lo que la simple negativa a someterse a las pruebas genéticas es suficiente para declarar la filiación reclamada; con base en que con dicha negativa frustra una posibilidad real y concreta de conocer la verdad biológica y que se priva al más débil de la prueba más contundente que se encuentra fuera de su alcance y dependiendo solamente de la voluntad de la otra parte. 


\subsubsection{Las pruebas científicas}

En el Derecho de filiación en México, una de las innovaciones más destacadas que marcan una postura del conocimiento real de la paternidad y maternidad es la inclusión de manera expresa de las innovaciones científicas para probar la filiación.

Existe el principio procesal de quien afirma está obligado a probar, por tanto en materia de filiación quien alega la paternidad y/o maternidad tiene que probar los hechos, esencialmente el de la procreación, sin embargo el Derecho federal mexicano ahora es más abierto que el anterior, y que en resumen sólo pedía la falta de cohabitación entre los cónyuges, actualmente se puede utilizar pruebas directas que el avance de los conocimientos científicos pone a disposición tal y como lo prescribe el Código civil; y que en este caso son los artículos 341, 352, 382 y 385.

La paternidad se podrá demostrar no sólo ofreciendo las pruebas tradicionales en la filiación (impotencia coeundi o generandi, o por haber estado alejados físicamente de la mujer), sino por otros novedosos, que el avance de los conocimientos científicos pueden ofrecer; cuya importancia en el proceso de filiación, consiste en demostrar o no la paternidad y/o maternidad, que otros medios de prueba ordinarios no alcanzan plenamente. ${ }^{272}$ A este resultado se ha llegado con el conocimiento del código genético que permite identificar plenamente a un descendiente con su ascendiente.

Precisamente, por esa influencia del Derecho Canónico en los antecedentes de la legislación civil mexicana, el concubinato no fue reconocido,

\footnotetext{
${ }^{272}$ MASSIP, Jacques, “La preuve scientifique de la filiation et la practique judiciare”, en Droit de la filiation et progres scientifiques, Económica, París, 1982, p. 54.
} 
sino hasta el Código Civil para el Distrito Federal en materia común y para toda la República en materia federal de 1928, como una forma peculiar de formar la familia, lo que trajo como consecuencia la determinación de efectos jurídicos a favor de los concubinarios y sus descendientes, así como el establecimiento de las presunciones de filiación de los descendientes habidos dentro de esta institución, y lo cual se ordeno considerando como presunción de hijos resultados del concubinato en forma homologa a los del matrimonio, es decir, los hijos nacidos después de los ciento ochenta días contados a partir del inicio del concubinato o bien los nacidos dentro de los trescientos días siguientes al que cesó la vida en común entre los concubinos.

\subsubsection{Avance sobre el valor jurídico de las pruebas científicas en}

\section{los juicios de investigación de paternidad}

Joaquin ESCRICHE nos decía que cuando para la decisión de un asunto litigioso se necesitan conocimientos facultativos, las partes deben nombrar a dos peritos que hagan el examen o reconocimiento, y que rindan su declaración. ${ }^{273}$ Entendido esto, podemos ver que la pericia no es otra cosa sino un medio de prueba que consta de la opinión, deducción y actividad de personas entendidas en una ciencia o arte, que pueden aportar al juez elementos de convicción y entendimiento especiales ${ }^{274}$ para resolver la materia controvertida. ${ }^{275}$

\footnotetext{
${ }^{273}$ ESCRICHE, Joaquín, Diccionario razonado de legislación y jurisprudencia, Ed. Porrúa, México, p. 1344

${ }^{274}$ Dichos conocimientos no son jurídicos, debiendo ser interpretados por expertos en alguna ciencia arte u oficio

${ }^{275}$ CARNELUTI; La prueba civil; op cit. no la consideraba como una prueba en sí, sino como un medio para obtener una prueba, en el mismo sentido se establece que la prueba es el hecho, los peritos lo aprecian y explican, distinción que es aplicable por extensión a todos los medios probatorios, por ejemplo la declaración de parte no es prueba sino un medio probatorio a través del cual se puede obtener la afirmación o negación de un hecho.
} 
A la pericia igual se le denomina peritación o juicio pericial ${ }^{276}$, siendo un sinónimo práctico de habilidad, destreza, conocimiento. ${ }^{277}$ Ontológicamente la pericia se sustenta, desde sus orígenes, en que el magistrado no puede conocer todas las ramas del saber humano, y menos aún las científicas, por lo que la pericia, desde el punto de vista práctico, es una colaboración especializada en pro de la correcta decisión judicial. También es un medio de prueba de evidencia indirecta cuyo fin es permitir al juez superar las dificultades que se oponen al conocimiento directo de la causa. En pocas palabras, la pericia como medio de prueba es un auxilio que la justicia procesal otorga al juzgador para su mejor resolver. $^{278}$

La pericia como medio de prueba fue creada con el objeto de examinar cuestiones que si bien merecen conocimientos especializados, sólo servirían como hemos dicho para otorgar al juez elementos de mera convicción, es decir, permitan comprobar a través de elementos científicos, artísticos o industriales, cuál es la relación existente entre los hechos controvertidos y el derecho de los justiciables, a fin de obtener una correcta solución a su pretensión.

En definitiva, la pericia sirve para ayudar y colaborar con los conocimientos del juez, dejando en claro que no determinan probatoriamente

\footnotetext{
${ }^{276}$ Concepto que es utilizado por BONNIER, Eduardo en su obra Tratatado teórico y práctico de las pruebas en el derecho civil y en derecho penal. Madrid, Reus Editores, 1913, tomo I, p. 155

${ }^{277}$ Respecto de estas denominaciones, SENTIS MELENDO en su libro de La prueba, hace referencia a la opinión de CLARIA OLMEDO, quien señala que "no obstante entender que gramaticalmente es preferible hablar de peritación, en adelante utilizaremos como sinónimos ambos vocablos por estimarlos técnicamente adecuados para caracterizar este medio probatorio".

${ }^{278}$ SENTIS MELENDO, La prueba, los grandes temas del Derecho probatorio; Ediciones jurídicas Europa - América; Argentina; 1979; comentando su posición doctrinal, establece: "Me parece fuera de lugar el planteamiento de la cuestión de si el perito es fuente de prueba auxiliar del juez". (Carnelutti en La Prueba Civil, p. 84), también hace una interesante distinción con respecto a la pericia como prueba y el objeto de ésta como fuente de prueba, así: "La pericia o peritación es una prueba que se realiza interviniendo el perito como auxiliar del juez, por faltarle, o poderle faltar, a éste las posibilidades técnicas de realizarla eficazmente, la fuente de prueba la constituye el objeto de la peritación una cosa o una persona); el medio es la prueba, el examen y las operaciones que el perito lleva a cabo y que se reflejan en su dictamen...” ibidem.
} 
nada, sólo fijan futuras pautas a seguir para permitir una adecuada decisión judicial.

Hoy en día los avances de la ciencia han sido considerables, a pesar de ello las legislaciones son tornan inadecuadas para la regulación de los progresos científicos que, desde el ángulo procesal en especial probatorio, deben ser regulados por las reglas de la pericia. Conforme ha sido siempre entendido, como tal, este medio de prueba es insuficiente para permitir una decisión acertada, correcta y determinante en casos especiales.

Efectivamente en nuestros días y a causa del avance acelerado de la ciencia, tantos los procedimientos como las reglas que norman procesalmente la pericia resultan inapropiadas a muchos métodos y aplicaciones científicas que pueden per se o con absoluta certeza, resolver la materia controvertida.

Tanto la falta de seguridad, la poca importancia que se da en muchas de las ocasiones a la profesionalización de los peritos, los términos para la actuación y presentación del dictamen, la ausencia de responsabilidad por errores o faltas graves en la ejecución del examen pericial y la valoración subjetiva ${ }^{279}$ de éste, convierten la pericia entre otras causas, más que en una tarea de especialistas, en una simple versión sin valor alguno que no se acoge ni contribuye procesalmente a su importancia científica real.

Aunado a esto y acorde a nuestra época, al nutrirse los descubrimientos de la ciencia para poder resolver las causas controvertidas, sino que se mostrara idónea y se configurara jurídica y socialmente con el desarrollo

\footnotetext{
${ }^{279}$ El valor o fuerza probatoria del dictamen pericial será estimada por el juez, teniendo en consideración: la competencia y habilidad de los peritos, la uniformidad o disconformidad de sus opiniones, los principios científicos en que se funda, la concordancia de su aplicación con las leyes y demás pruebas y, sobre todo, los elementos de convicción que la causa ofrezca. Todo esto vinculado dentro de las reglas de la crítica, esto es lógica jurídica, sentido común, perspicacia y experiencia del juzgador.
} 
científico, a fin de lograr una colaboración más directa entre las disciplinas técnicas y el Derecho. ${ }^{280}$

Lo cierto es que cada vez se pueden obtener mayores y mejores resultados probatorios a través de los medios indirectos pero, para su aplicación y ejecución, carecen de un marco jurídico lógico y congruente que le otorguen máxima seguridad en la aplicación de resultados; la situación entonces, es crear un esquema jurídico adecuado para aplicar satisfactoriamente los resultados obtenidos.

Este nuevo medio de prueba podría llamársele como se hace en Venezuela en su Código civil como “técnica o experticia” en su artículo $210^{281}$, caracterizado por testificar un hecho científico controvertido, irrebatible y evidente, basado esencialmente en leyes naturales, científicas o técnicas, las que no sólo coadyuvarán con elementos prácticos a la decisión subjetiva del juzgador sino que le otorgarán, además, elementos determinantes para sentenciar objetivamente en base a los mismos.

De lo anteriormente expuesto, se clarifica que la valoración probatoria de estas técnicas (que no son otra cosa que una pericia sui géneris) será de carácter mixto, considerando el juzgador, necesariamente, su validez científica y valorando las demás pruebas actuadas en el juicio.

Esta valoración se da en razón de que el juez no puede sustituir al especialista y entrar a incursionar en campos técnicos o científicos totalmente

\footnotetext{
${ }^{280}$ No deberíamos aplicar un medio de prueba regulado tan anacrónicamente como la pericia a situaciones técnicas actuales, ya que datan de más de 2.000 años atrás aproximadamente y perfeccionada jurídicamente a principios del siglo XIX.

${ }^{281}$ El artículo 210 en mención especifica que a falta de reconocimiento voluntario, la filiación del hijo concebido y nacido fuera del matrimonio puede ser establecida judicialmente con todo género de pruebas, incluidos los exámenes o las EXPERTICIAS hematológicas y heredobiológicas que hayan sido consentidos por el demandado
} 
vedados para la norma. En estos casos no podemos decir que la palabra del especialista o técnico deba ser considerada determinante ${ }^{282}$, pero tampoco podemos negarle que en gran medida lo sea. ${ }^{283}$

La aplicación de la experticia será en razón de la necesidad extrema de una regulación jurídica apropiada a los avances de la ciencia, y su justificación se dará en la medida en que es preciso contar con dispositivos procesales modernos, coherente con nuestra realidad y, sobre todo, comprometidos con los avances técnicos.

Está por demás decir que muchos medios de prueba modernos carecen hoy de una adecuada aplicación jurídica y práctica, lo cual ha querido ser subsanado por el sistema de asimilación, proponiendo que los medios de prueba no previstos legalmente sean ofrecidos, y por ende deberán ser admitidos y actuados a través de los taxativamente regulados por la ley. Pero esto tampoco es lo correcto, ya que desnaturalizamos los principios esenciales del sistema probatorio que se sustenta en otorgar la máxima la seguridad a cada una de las pruebas presentadas, tomando en consideración sus características esenciales y su relación técnica.

Con este comentario, se pretendió esbozar las limitaciones del sistema pericial y sus incongruencias, dando una alternativa para el establecimiento de un medio de prueba más específico y profesional (con reglas procesales propias) que determine las causas u los casos concretos por el hecho incuestionable de la validez de sus resultados, los que de conformidad con las tradicionales normas

\footnotetext{
${ }^{282}$ Esto en virtud de que la naturaleza del informe técnico que recae a la prueba pericial en genética y determina la paternidad no puede ser apreciado ni rebatido subjetivamente por el juzgador, por el hecho tajante de que éste tiene una certeza absoluta.

${ }^{283}$ Atilio Aníbal ALTERINI dice que "En esto, claro está, no se trata de abdicar en beneficio de los peritos la función jurisdiccional de fallar, sino de acatar las evidencias científicas cuando éstas existan, sin ingenuidad, pero también sin misoneísmo"; en "Cuerpo humano, persona y familia” en Libro homenaje a la doctora María Josefa Méndez Costa, Santa Fe, 1990, p. 308,
} 
procesales y costumbres procedimentales no contaban, ni cuentan en la actualidad, con un medio de prueba capaz de otorgarle seguridad jurídica que merecen, tanto para su ofrecimiento y aplicación como para su correcta valoración técnica.

Lo aquí expuesto, se sustenta en un análisis lógico jurídico sin dejar a un lado lo doctrinal, basado en la necesidad exclusiva de renovación y actualización de nuestro sistema probatorio en lo referente a la prueba de evidencia indirecta denominada pericial; así como que es importante aclarar que muchas de las disposiciones procedimentales en esta materia no cautelan ni resguardan la correcta aplicación ni valoración de la probanza, sino que mantienen casi la misma actividad legislativa.

\subsection{Indicios y presunciones en los procesos de filiación}

\subsubsection{Los indicios}

Aquí podemos recordar que la falta de documento público que sirva de título de determinación legal de la filiación, no producirá ningún efecto, pero podrá ser utilizado como indicio en los juicios de investigación de paternidad o maternidad, o aun cuando existiera dicho título, si fuera defectuoso, incompleto o falso, hará necesario probar la filiación, mediante la posesión constante de estado de hijo o hija, sirviendo para tal efecto, todos los medios de prueba autorizados por la ley. Sin embargo, si no existiera un principio de prueba por escrito, indicio o presunción resultante de hechos ciertos considerados lo bastantes graves para determinar su admisión, no estaríamos en la posición de hablar de filiación por el momento. 
De ahí precisamente la importancia y utilidad práctica de la prueba indiciaria en los juicios de filiación, pues así como cualquier hecho conocido puede servir al juzgador de indicio, para conocer otro hecho desconocido, sobre el cual se esté investigando en los procesos relativos a la investigación de la paternidad o maternidad, también es útil para probar la posesión constante de estado de hijo o hija, e incluso, la misma legislación civil condiciona a la misma prueba testimonial , la existencia de indicios resultantes de hechos ciertos, considerados lo bastante graves para determinar su admisión.

PLANIOL y RIPERT ${ }^{284}$, han destacado el principio de prueba por escrito como otro importante indicio de la filiación discutida en un juicio, cuando el mismo se constituye en registros y papeles domésticos del padre y de la madre, o en cartas o documentos privados de ellos o de otros familiares.

Así la jurisprudencia mexicana ha estipulado en dos relevantes criterios que la investigación de la paternidad de los hijos nacidos fuera de matrimonio esta permitida cuando el hijo tenga a su favor un principio de prueba escrita contra el pretendido padre. Instituye un sistema rígido para la demostración del extremo en que descansa la hipótesis legal, pues exige que el referido principio de prueba sea por escrito y proveniente del presunto padre, en el que de manera directa o indirecta haga reconocimiento de la paternidad, a diferencia de otros ordenamientos como el del Distrito y Territorios Federales,

\footnotetext{
${ }^{284}$ Así, PLANIOL Y RIPERT, han dicho en su obra que: “... todos los hechos que hagan verosímil la filiación, y corroboren las declaraciones de los testigos. Debe, por tanto, tomarse en consideración la actitud adoptada hacia el niño por los pretendidos padres y los demás miembros de la familia. Se puede también citar como ejemplo de indicios el parecido personal, o cualquier otro fenómeno de herencia física, las circunstancias en las cuales el niño resultó abandonado, la marca de la ropa que llevaba cuando fue encontrado, etcétera... La ley quiere solamente que los indicios sean graves y constantes, es decir, que no sean dudosos. Serían, por ejemplo, rechazados como insuficientes los hechos siguientes: la identidad de los nombres y edad de la pretendida madre y del padre que indica en el acta de nacimiento; un certificado de la comadrona atestiguando que la pretendida madre tuvo un parto en la fecha de nacimiento del niño; la confesión de la madre, cuando es ella actora en el pleito, y la circunstancia de que el nacimiento haya tenido lugar en el transcurso del matrimonio de ésta” Op cit. pp. 598, 599 y 600
} 
que solamente exige un principio de prueba, o sea que permite un sistema flexible que da cabida a cualquier medio probatorio, aun presunciones graves que autoricen al juzgador a establecer la paternidad ${ }^{285}$. Así como en otro criterio en el cual se establece que la investigación de la paternidad de los hijos nacidos fuera de matrimonio está permitida cuando el hijo tenga a su favor un principio de prueba contra el pretendido padre, conclusión a la que se llega a través de la prueba presuntiva integrada por dos reglas fundamentales: primero, que se encuentren probados los hechos de los cuales se derivan las presunciones; y segundo, que exista un enlace natural más o menos necesario entre la verdad conocida y la que se busca. Esto es así porque la paternidad es un hecho que no puede comprobarse objetivamente como la maternidad mediante el parto y la identidad del hijo, razón por la cual es factible presumirse, entre otros datos, a través de determinar si coincide la fecha de las relaciones sexuales con la fecha probable de la concepción ${ }^{286}$

\subsubsection{Naturaleza jurídica}

Esta prueba tiene la peculiaridad de que a través de operaciones mentales, el juzgador deduce un hecho desconocido de otro conocido, lo cual ha repercutido algunas ocasiones en su reconocimiento como medio probatorio, sobre todo porque es difícil ubicarla dentro del sistema de pruebas tradicional.

\footnotetext{
285 Registro No. 269128; Localización: Sexta Época, Instancia: Tercera Sala, Fuente: Semanario Judicial de la Federación, Cuarta Parte, CXXXVII; Página: 121; Tesis Aislada; Materia(s): Civil; PATERNIDAD, INVESTIGACION DE LA. REQUIERE UN PRINCIPIO DE PRUEBA ESCRITA (LEGISLACION DEL ESTADO DE JALISCO). Amparo directo 4727/68. Guillermina Tinajero González. 28 de noviembre de 1968. Cinco votos. Ponente: Mariano Azuela.

${ }^{286}$ Registro No. 240513; Localización: Séptima Época; Instancia: Tercera Sala; Fuente: Semanario Judicial de la Federación; 163-168 Cuarta Parte; Página: 107; Tesis Aislada; Materia(s): Civil; PATERNIDAD, INVESTIGACION DE LA. VALOR DE LA PRUEBA PRESUNCIONAL (LEGISLACION DEL ESTADO DE HIDALGO).Amparo directo 2353/81. María del Carmen Pérez Lozano. 5 de julio de 1982. Unanimidad de cuatro votos. Ponente: Raúl Lozano Ramírez. Secretario: Teodoro Camacho Pelayo.
} 
Entre quienes admiten el carácter de la prueba de los indicios, se encuentran DÖHRING y DEVIS ECHANDIA; el primero de ellos, sostiene que la prueba indiciaria no es un medio de prueba porque si no merece la alabanza incondicional, tampoco la excomunión mayor. Además, critica a todos aquellos cuya pretensión es reducir su valor probatorio por considerarla una prueba indirecta, ya que está en desacuerdo con la visión de la plenitud y el carácter directo de los elementos probatorios. ${ }^{287}$

En la práctica en el caso mexicano el indicio tiene gran relevancia en materia penal, sin embargo en el caso civil se le ha restado, cosa que por los excesos de trabajo el juez se ha visto imposibilitado de razonar caso por caso cada uno de las pruebas y por ende su proyectista razona la supuesta verdad en relación únicamente apegada a las pruebas existentes, no realizando la deducción de hechos.

\subsubsection{Diferencia con las presunciones}

Muchas de las veces se suele englobar a las presunciones dentro de los indicios, al dársele un tratamiento igual; es más, en la práctica podemos decir que vendría siendo lo mismo, sin embargo, tienen un tratamiento distinto, en el presente trabajo se le dedicará un pequeño espacio, no sin antes decir, que en el

\footnotetext{
${ }^{287}$ Para DÖHRING, la prueba indiciaria es un medio probatorio especial de determinación de la verdad, a la cual se le ha reconocido poca importancia dentro del proceso civil, porque los juzgadores ni siquiera se percatan de la frecuencia y la facilidad con la que se sirven de la deducción por indicios, para sondear aspectos tales como: la voluntad de las partes en cuanto ésta sea dudosa; la agilidad para negociar, el genio artístico; el temperamento flemático, de la persona implicada; y muchos otros elementos fácticos, generalmente determinados sobre la base de los indicios.

Por otro lado DEVIS ECHANDIA, califica a la prueba indiciaria como un medio probatorio crítico o lógico e indirecto por excelencia, ya que su función probatoria consiste en suministrarle al juzgador un hecho, del cual pueda inducir indirectamente y mediante razonamientos crítico - lógicos, fundados en normas generales de la experiencia o en conocimientos científicos o técnicos especializados, otro hecho desconocido cuya existencia se esté investigando.
} 
caso mexicano, los indicios se han ocupado en materia penal, mientras las presunciones en la civil.

A pesar de las distinciones señaladas de la presunción y el indicio, no debemos separarles, dado que existe una gran e intima vinculación entre ambos, porque bien es sabido que el indicio como hecho material nada prueba, por tanto no puede escindirse de la operación lógica y del argumento probatorio, es decir, está vinculado a la regla de experiencia del juzgador, mediante la presunción humana, llegando a un argumento de prueba necesariamente crítico - lógico.

\subsubsection{Clases de indicios}

No es posible en la práctica hablar de una clasificación de indicios, pues por estos se entiende todo hecho o toda circunstancia de hecho que sirva, por sí misma o junto con otros, para inducir la existencia o inexistencia de otro hecho o de otra situación, en virtud de la conexión lógica que entre aquél y éste encuentre el juzgador, basado en los principios o las nociones comunes de su cultura o las cuestiones técnicas proporcionadas por el dictamen pericial respectivo; por tal cuestión su número sería ilimitado, pero de manera general, intentando realizar una clasificación aproximada:

1. Indicios anteriores, concomitantes y posteriores al hecho desconocido que se trata de verificar.

2. Indicios personales o subjetivos y reales o materiales. Los primeros son los que se refieren a condiciones y modos de ser de una persona, como la capacidad intelectual, física o bien hasta moral; 
mientras los segundos son aquellos relativos a las características de las cosas, huellas, rastros o similares.

3. Indicios necesarios, según que uno sólo baste para producir el convencimiento, en razón de ser indispensables para conocer el hecho indicado, o bien, porque corresponden a una ley física inmutable de causalidad necesaria o contingente.

4. Indicios positivos y negativos, esto según concurran a indicar la existencia o inexistencia del hecho investigado, o de la responsabilidad del imputado.

5. Indicios causales y de efecto, según concurran al acaecimiento del hecho investigado, o signifiquen efectos del mismo. ${ }^{288}$

\subsubsection{Indicios y procesos de filiación}

La importancia que ha tenido esta prueba ha sido objeto de diversas opiniones, ya que se consideró como un instrumento de averiguación sumamente inseguro e inferior, recuperado la importancia de la probanza del indicio, colocándola como una prueba principal, al reconocerse su utilidad en todo tipo de procesos, gracias a la libertad del juzgador en su valoración conforme a las reglas psicológicas, de la lógica y experiencia, para formar por sí una sola convicción o certeza necesaria sobre los hechos investigados. ${ }^{289}$

\footnotetext{
${ }^{288}$ DEVIS ECHANDIA; Hernando; op cit pp. 616 y 617

${ }^{289}$ DÖHRING, Erich; op cit. p. 311
} 
Está cierto se trata de elementos de difícil valoración, lo que nos viene a implicar riesgos, y por tanto haciendo necesaria la aplicación de un rigor crítico máximo; ahora, bien manejada, esta prueba nos permiten alcanzar no solo una verosimilitud más o menos cuestionable, sino una certeza plena respecto de puntos determinados y precisos. Por ende su necesaria aplicación en todos los procesos, como enunciativamente mencionamos los civiles y muy en especial los penales.

En el proceso penal se le considera una prueba fundamental e indispensable en mchos casos, porque sin ella quedarían impunes innumerables delitos. Sin embargo, en los procesos civiles se ha pretendido reducir su importancia, aunque su aplicación sea también decisiva en muchos procedimientos, como la posesión del estado civil, conocimiento e ignorancia de la ley, simulación de actos jurídicos o bien posesión de bienes. ${ }^{290}$

En nuestros días y ante el avance de las técnicas modernas de investigación de huellas; rastros, tipos de sangre y escrituras, de identificación de materiales utilizados en vestidos y armas, comparación de cabello, armas de fuego, etcétera, se considera importante su empleo, pues estos dictámenes técnicos prestan un valioso auxilio a la prueba indiciaria, considerándosele como una de las principales y no solo en materia penal, sino ahora en materia civil, en su utilización como fundamental en los juicios de filiación, precisamente a través de las periciales científicas. ${ }^{291}$

\footnotetext{
${ }^{290}$ Ídem.

${ }^{291}$ DELLEPAINE, Antonio; op cit. pp. 55 y 56;
} 


\subsubsection{La Presunciones}

\subsubsection{Naturaleza jurídica}

A partir de los tipos de presunciones existentes y sus características, podremos encontrar la explicación sobre si se trata de un medio de prueba o no.

Así, respecto de las presunciones denominadas humanas o simples, al ser resultado de los razonamientos e inferencias realizadas por el juzgador, de acuerdo a máximas de la experiencia, a través de las cuales valorará conclusivamente el mérito o eficacia de las pruebas suministradas por las partes, puede decirse que en realidad no constituyen medios de prueba, porque simplemente son la manera de razonar el juzgador, para calificar el mérito o la eficacia probatoria de las pruebas presentadas en juicio. ${ }^{292}$

En cuanto a las presunciones legales, al ser reglas jurídicas sustanciales, para la aplicación del Derecho objetivo a un caso determinado, cuyos efectos se producen fuera del proceso y son reconocidos en éste, donde además influyen en la carga de la prueba, su naturaleza tampoco es la de un medio probatorio, independientemente de que sean iuris tantum y presuman como cierto un hecho, mientras no se desvirtúe como prueba plena, o bien, se trate de presunciones iuris et de iure $\mathrm{y}$ otorguen una certeza definitiva $\mathrm{e}$ indiscutible. $^{293}$

\footnotetext{
${ }^{292}$ Ídem p. 298

293 DEVIS ECHANDIA, Hernando; op cit. pp. 697 - 699; en este punto es necesario precisar que la prueba pericial no siempre se desarrolla en virtud de encargo judicial, pues aun cuando el juzgador puede decretar en todo tiempo la práctica o ampliación de cualquier diligencia probatoria conducente para el conocimiento de la verdad sobre los puntos cuestionados, también puede promoverse a pericial a iniciativa de las partes.
} 
Por tanto, podemos concluir que la naturaleza jurídica de las presunciones humanas es la de una fuente de prueba o en opinión de CARNELUTTI "los razonamientos inferidos por el juzgador a través de una operación lógica - jurídica, para valorar el mérito o la eficacia probatoria de las pruebas presentadas en juicio”. ${ }^{294}$

\subsubsection{Clases}

Legalmente, las leyes procesales los dividen en: humanas y legales.

1.- Presunciones humanas, denominadas también como presunciones simples, de los hombres o judiciales, son el resultado de los razonamientos e inferencias realizadas por el juzgador, de acuerdo a máximas de la experiencia, que le permiten valorar conclusivamente el mérito o eficacia de las pruebas suministradas por las partes. ${ }^{295}$

Dentro de estas presunciones, el aspecto más importante, es que a través de ellas, el juzgador emite sus razonamientos e inferencias para valorar el mérito o eficacia de las pruebas aportadas en el juicio, afectando directamente el momento de la valoración de todos aquellos medios probatorios desahogados en el proceso.

En lo relativo a la regla de la experiencia DÖHRING señala que la misma parte de vivencias iguales o similares, habidas en ocasión del juicio ventilado en ese momento, sino de otros anteriores, los cuales han condensado en el juzgador, ya sea en mayor o menor medida, determinados conocimientos tanto

\footnotetext{
${ }^{294}$ CARNELUTTI, Francesco; op cit. pp. 90, 91, 200, 201 y 254

${ }^{295}$ DEVIS ECHANDIA, Hernando; op cit; T II; p. 696
} 
de la experiencia, lógica y del mismo sentido común, para deducir la configuración fáctica del caso en estudio, aún no esclarecido. ${ }^{296}$

Esto nos denota que las reglas de la experiencia son el producto de todos aquellos casos vivenciados, por quienes están encargados de impartir justicia, porque de cada uno de ellos, los juzgadores obtienen observaciones coincidentes entre los hechos y sus resultados, formándose un criterio, cuya aplicación pretende ser válida en casos posteriores similares. ${ }^{297}$

2.- Las presunciones legales.- Son aquellas establecidas expresamente por la propia ley, y a las cuales CARNELUTTI las identifica como reglas jurídicas sustanciales para la aplicación del Derecho objetivo a un caso determinado, cuyos efectos se producen fuera del proceso y son reconocidos en éste, donde además influyen en la carga de la prueba. ${ }^{298}$

Las presunciones legales se han distinguido por los jurisconsultos en dos categorías: las relativas y las absolutas, según admitan o no prueba en contrario; las relativas, también designadas por el nombre de iuris tantum, se tienen como verdad, mientras no se pruebe lo contrario, porque se fundan en simples probabilidades, las cuales deben ceder ante la evidencia de la verdad, mientras las absolutas, igualmente denominadas presunciones iuris et de iure, son aquellas que no admiten prueba en contrario. ${ }^{299}$

\footnotetext{
${ }^{296}$ DÖHRING, Erich; op cit pp. 323 y 324

${ }^{297}$ Ibídem, p. 324

${ }^{298}$ CARNELUTTI, Francesco; op cit. p. 254

${ }^{299}$ MATEOS ALARCÓN, Manuel; op cit. pp. 205 y 206
} 


\subsubsection{Las presunciones en los procesos de filiación}

Las presunciones han sido fundamentales en los procesos de filiación, ya que como podemos observar en el artículo 382 del Código Civil Federal mexicano, que la paternidad y maternidad pueden probarse por cualquiera de los medios ordinarios, pero si se propusiera cualquier prueba biológica o de avance de los conocimientos científicos, y el presunto progenitor se negara a proporcionar la muestra necesaria, se presumirá, salvo prueba en contrario que es el padre o la madre. Como es notorio, se tiene un sistema de libertad probatoria de la filiación, al manifestarse que la maternidad o paternidad podrán acreditarse por cualquier medio ordinario de prueba, haciendo una referencia específica a las biológicas o de avance científico, tal y como se recoge en el primer párrafo del artículo 127 del Código Civil Español; pero adiciona el caso de que el sujeto pasivo de la prueba se negare a proporcionar las muestras necesarias para llevar a cabo la prueba científica y en tal caso debe presumirse salvo prueba en contrario como padre o madre, lo cual es de considerarse grave, que mediante una simple presunción legal se pretenda imputar la paternidad o maternidad , por la negativa del progenitor para aportar las muestras de material genético necesario para la práctica de la prueba pericial científica, pues dicha presunción constituye simplemente una prueba artificial, que de ninguna manera puede ser autónoma, ni hacer prueba plena de una cuestión tan delicada, como es el vínculo filial controvertido.

Es bien sabido que toda presunción debe ser necesariamente consecuencia de dos hechos: uno comprobado y el otro no manifiesto, aunque el mismo se trate de demostrar para derivar una conclusión. Por tanto, primero, debe acreditarse la paternidad o maternidad mediante otras pruebas, para que la presunción resulte del complemento de dicha privanza, que confirmen o rechacen 
la existencia del vínculo filial controvertido, de lo contrario, se estarían violando normas esenciales del procedimiento.

\section{a) Especial consideración a la posesión de estado}

La posesión de estado de hijo es un estado de hecho, que por sí solo carece de legitimidad jurídica, pero por actos directos de los presuntos padre, madre o familia de estos, tales como el trato, fama y nombre demostrativos de una filiación que acredita la relación entre el ascendiente y el descendiente.

En este aspecto PLANIOL dice que la "Ley presume que quien pasa por hijo lo es realmente porque en la mayoría de los casos, los hechos se hallan de acuerdo con el derecho”300. Ya que cuando dos personas realmente están casadas y cuyo matrimonio se encuentre probado, educan y cuidan a un menor como hijo suyo, que es conocido y aceptado como tal, por todos aquellos que se encuentran relacionados con él, se debe a que dicho menor realmente es hijo del matrimonio. Las posibilidades de error, realmente son débiles y por el contrario la presunción de la ley que admite la posesión de estado es absolutamente racional. Ninguna contradicción existe entre esta disposición y la que rechaza la posesión de estado como prueba del matrimonio: la posesión del hijo no es sospechosa, porque no es él quien se la ha dado; por otra parte, se funda en un primer título: la prueba regular de un matrimonio valido entre sus padres.

En la legislación mexicana se regula el hecho de que algún individuo haya sido reconocido constantemente como hijo del matrimonio, por la familia del marido o de la esposa frente a la sociedad, incluyendo además como requisito el que el hijo use constantemente el apellido de los padres, o bien los padres le

${ }^{300}$ PLANIOL, Marcel, op cit. . 670 
hayan proporcionado subsistencia, educación y establecimiento, pero siempre que los padres tengan la mayoría de edad, es decir en el caso mexicano o español los 18 años cumplidos, sumándole a ésta la edad del hijo que se presume por posesión de estado. ${ }^{301}$

Los elementos de la posesión de estado son el trato (tractatus), nombre (nomen), fama (fama) y edad.

El nombre significa que el hijo lleva el apellido de los presuntos padres que lo usa en forma constante con el consentimiento de ellos, pero no cuenta con la partida de nacimiento, por lo que deberá acreditar este hecho.

Al hablar del trato, nos referimos a que el hijo ha sido considerado como tal, nacido dentro del matrimonio, proveyendo los padres a su subsistencia, educación y establecimiento.

La fama, es que el hijo sea reconocido constantemente como tal del matrimonio, en la familia del padre y de la madre, así como en el círculo social al cual pertenezcan, este es el elemento primordial de la posesión de estado, pues el hijo debe gozar de ese carácter públicamente sobre todo dentro de las familias del padre y la madre, que son quienes conocerán más de cerca el caso, y quienes tengan los datos precisos de que se trata de un hijo nacido dentro del matrimonio.

La edad, significa que el padre o la madre tengan la edad requerida para contraer matrimonio, más la edad del hijo o hija, es decir aproximadamente una diferencia de dieciséis años entre los padres y el hijo al que se pretende probar la posesión de estado.

\footnotetext{
${ }^{301}$ Este caso puede llegar a ser un poco fuera de lo normal, ya que bien en la actualidad los padres en un porcentaje, procrean antes de la mayoría de edad, existiendo casos en los cuales desde los 15 o 16 años ya son padres o bien madres.
} 
No se requiere el concurso de todos los elementos para probar la posesión de estado, como señala CICU al interpretar el Código Civil Italiano. En el sistema jurídico mexicano, como se desprende específicamente de la disposición del Código Civil Federal, sólo exige que a ese reconocimiento constante de hijo o hija de matrimonio, se adicione uno más, es decir a la fama, se agregue el nombre o bien el trato que son los tres elementos clásicos constitutivos de esta institución.

Además es de comentarse que se puede probar la posesión de estado con este nuevo elemento que es la edad, cuya exigencia es el hecho de que los padres tengan la edad que se encuentre establecida para contraer matrimonio, en casi todos los casos; siendo entonces la mayoría de edad aumentando a esta la edad que tenga el hijo presunto en posesión. ${ }^{302}$

Este nuevo requisito es objeto de discusión, ya que se puede ver una redacción notoriamente impropia y que existe un error indiscutible en la ley, pues no puede ser posible que se pruebe la posesión de estado con la fama de hijo nacido dentro de matrimonio más la edad del presunto padre o madre, porque faltaría el concurso de alguno de los otros elementos que son importantes para esclarecer la institución, es decir, faltaría que el hijo llevara el nombre de los padres o que fuera tratado como hijo nacido en matrimonio y la ausencia de estos elementos pondría en duda la posesión de estado, por ende no significa la existencia de relación familiar alguna, ni que sea elemento considerable para que junto con la fama se atribuya a una persona la posesión de estado, pues se trata

\footnotetext{
${ }^{302}$ En referencia a este punto, sería mucho más adecuado el poder exigir que se tenga una edad fértil más que decir una edad para contraer matrimonio, ya que como se ha mencionado, existen muchos casos en los cuales se procrea mucho antes de la edad permitida para contraer matrimonio, estando en un vacío jurídico al presentarse esta hipótesis en un caso dado.
} 
únicamente de un elemento biológico que indica que una persona puede ser hijo de otra. ${ }^{303}$

Las posturas llegan a ser consiguientemente concordantes con la ley, ya que se expresa en el Código civil en su artículo 274 que si un individuo posee la fama de ser hijo o hija de matrimonio, queda probado el presupuesto de la posesión de ser hijo o hija de matrimonio, queda probada la posesión de estado; si además concurre alguna de las circunstancias indicadas anteriormente, lo que significa que a la fama, elemento indispensable, se le debe conjugar o bien al trato, el nombre o la edad. No se requiere el concurso de todos los elementos clásicos como señala $\mathrm{CICU}^{304}$, que considera que si falta algún elemento no puede ser reconocida la posesión de estado, ya que no puede probarse si se prescinde del nombre que el hijo lleva y de la prueba relativa al trato de la presunta madre o del presunto padre. En el ordenamiento jurídico vigente como se ha señalado solo basta con la concurrencia de dos elementos, requiriéndose siempre la fama, aunque con el concurso de la edad no se demuestre el status familae que es el espíritu de la posesión de estado; sin embargo, para la ley mexicana ese elemento es suficiente.

La posesión de estado en el sistema jurídico, abarca tanto a los hijos nacidos fuera del matrimonio, como de igual forma a los que nacen dentro de

\footnotetext{
${ }^{303}$ El tratadista mexicano Rafael ROJINA VILLEGAS critica la disposición por tener una "redacción notoriamente impropia”, y existe un error indiscutible en la ley, pues no puede ser posible que se pruebe la posesión de estado con la fama de hijo nacido dentro de matrimonio más la edad de los presuntos padres, porque faltaría el concurso de alguno de los otros elementos que son importantes para establecer la institución, es decir, faltaría que el hijo llevara el nombre de los padres o que fuera tratado como hijo nacido en matrimonio y la ausencia de estos elementos pondría en duda la posesión de estado, pues es posible que el menor ya llevase otros apellidos (op. cit. P. 655). Al respecto CHÁVEZ ASENCIO señala en el mismo sentido que: " la edad no significa la existencia de relación familiar alguna”, ni que sea un elemento considerable para que junto con la fama se atribuya a una persona la posesión de estado, pues se trata únicamente de un elemento biológico que indica que una persona puede ser hijo de otra”, op cit. Pp. 31 y 32, teoría a la cual me acojo, dado que como requisito único de la edad no es forma de probar el estado de los hijos, faltando entonces el comprobar uno de los elementos principales, y este requisito solo es accesorio de una forma de proteger al menor.

${ }^{304}$ Op Cit. p. 31 y 32
} 
éste, solo que para el último caso además de probar los elementos de la posesión de estado de hijo nacido fuera del matrimonio, tendremos que probar previamente que existe un matrimonio de los padres; en cambio, en relación a la filiación extramatrimonial, la prueba se refiere principalmente al padre y sólo se exige que se justifique por los medios ordinarios de prueba, que el hijo ha sido tratado por los presuntos padres y familia como miembro de su estirpe y que han proveído a su subsistencia, educación y establecimiento; es decir ya no se requiere que lleve el nombre, tampoco se exige la fama respecto a la sociedad, aunque esta clasificación se ha ido eliminando para únicamente regular la posesión de estado de hijos cualquiera que sea su origen.

La posesión de estado prueba la filiación del hijo, puesto que sustituye al acta de nacimiento; para él, vale como un titulo y puede obtener de ella un provecho, así como todas las consecuencias jurídicas del carácter que pretende tener.

Para que la posesión de estado tenga un valor pleno, no debe existir un acta de nacimiento que la contradiga, en efecto, la posesión de estado no puede prevalecer sobre el acta de nacimiento. Al respecto el Código Civil Federal mexicano refiere que a falta de actas o si estas fueren defectuosas incompletas o falsas, se probará con la posesión constante de estado de hijo nacido de matrimonio, concediendo únicamente un papel subsidiario en relación al acta de nacimiento.

Este carácter subsidiario se entiende bien cuando se distingue la prueba de alumbramiento y la prueba de identidad. Por lo que hace a la prueba de alumbramiento, el acta de nacimiento y la posesión de edad constituyen un modo de prueba de que la mujer dio a luz. Si estos elementos concuerdan, no hay ningún problema, sin embargo, se complica la situación si el acta de nacimiento 
establece una filiación diferente de la que resulta de la posesión de estado de hijos nacidos dentro de matrimonio, por más que se demuestre que se trata de una posesión constante, cierta y establecida, no destruirá el valor que tiene el acta de nacimiento; por el contrario, ésta siempre probará por encima de aquélla, salvo que sea tachada de falsa.

Es conveniente resaltar que la posesión de estado establece el parto y la identidad, en efecto, si el alumbramiento de una persona se establece por el acta de nacimiento, que únicamente prueba que la mujer dio a luz, la posesión de estado no sólo establece el parto, sino también la identidad de hijo, porque además del trato, recibe el apellido y la opinión de la familia y de todas las personas que lo rodean. El comportamiento de la madre respecto del hijo o hija es importante porque prueba que el hijo goza de una posesión de estado dentro de matrimonio, que lo ha concebido una mujer casada y a la vez que se prueba que lo dio a luz, igualmente se prueba que ése es el hijo que ella alumbró.

El acta de nacimiento prueba al mismo tiempo la maternidad y la paternidad dentro del matrimonio, a partir del momento en que el nombre de la madre se inscribe en el acta; en cambio para que se prueba la posesión de estado dentro de matrimonio, es indispensable que se ligue al niño con sus dos padres, ahora bien, puede darse el caso de que el hijo pruebe únicamente que ha sido tratado y considerado como hijo de uno sólo de los cónyuges; en tal caso no tiene la apariencia de hijo dentro de matrimonio; su posesión de estado lejos de presumir que es hijo de dos esposos deja prever una muy seria duda sobre su filiación paterna, por el contrario, el acta de nacimiento prueba a la vez la maternidad y paternidad matrimonial a partir del momento en que el nombre de la madre se inscribe en el acta. 
El catedrático $\mathrm{CICU}^{305}$ sostiene que es equivocada la idea de equiparar la posesión de estado con la posesión de las cosas, aun cuando la mayoría de los doctrinarios civilistas lo hacen así; porque en la posesión de las cosas, el derecho lo que protege es un interés patrimonial a favor de la persona que se conduce como dueño, que ejecuta actos de uso, goce o de disposición de una cosa, por lo tanto, con ese carácter se ostenta ante los demás, aunque de derecho no lo sea. Es más, se protege al poseedor frente al propietario que abandonó la cosa, que no ha tenido interés en un largo tiempo de vigilar la propiedad, en cuidarla, en permitir que entren en ella sujetos que no tienen derecho alguno y que a través de ese largo tiempo consoliden esa propiedad ostentándose como si fuesen dueños de la misma.

Asevera este autor que con el abandono de la cosa hay una renuncia tácita del derecho de propiedad del dueño que hace que el poseedor en forma pacífica, continua, pública y con el animus domini, llegue a convertirse en dueño por el transcurso del tiempo, si no es interrumpida por el propietario para evitar que el poseedor se convierta en dueño.

En cambio en la posesión de estado de hijo, aun cuando se sostiene que se protege por ser una situación de hecho que se manifiesta a través del comportamiento que el hijo tiene como tal, frente a la sociedad, el presunto padre y a su familia, no se trata de una función de intereses privados, como sucede en la posesión patrimonial, no es así como debe de proteger la posesión de estado, sino tomando en cuenta los intereses superiores de la familia, es por ello que las relaciones no se reserven únicamente entre el padre y el hijo y que no se haga depender esa situación sólo de la voluntad que entre dos personas pudiere existir, una para darle a la otra el tratamiento de hijo y a su vez, el hijo, considerar como padre al que se conduce con tal carácter, porque se dejarían verdaderos estados

${ }^{305}$ Op cit., pp. 35 y 36 
familiares. Lo importante y lo que interesa es la fama pública y la que se tenga en la familia del padre, que ya contempla la situación con un interés general para la unidad familiar, para darle el trato de hijo al que en realidad tenga derecho para ostentarse como tal y que por haber omitido su registro, no sea perjudicado.

Así, ambas situaciones coinciden en ser estados de hecho, porque les falta el título, es decir, al hijo le falta el acta de nacimiento para ostentarse de manera indiscutible y frente a todo el mundo como hijo de matrimonio y al poseedor le falta el título de propiedad; pero es conveniente decir que es una figura que aunque se encuentra legislada, esta en decadencia, habiendo tenido gran utilidad cuando los registros civiles no funcionaban correctamente, pero ahora es de escasa aplicación.

La posesión de estado tiene las siguientes características:

1.- Imprescriptible, significa que la posesión de estado, ni se adquiere ni se extingue por el transcurso del tiempo.

2.- Inalienable, porque la posesión de estado no se encuentra dentro del comercio.

3.- Indisponible, no se puede transmitir por un acto de voluntad a otra persona y por ello no puede ser objeto de transacción o compromiso.

4.- Indivisible, significa por una parte, que cada persona no tiene sino un edad civil y todo estado excluye cualquier otro contrario a él respecto de una misma persona. 
b) Especial referencia a las presunciones en el caso de parejas de hecho

En las sociedades del pasado usualmente se ha establecido que la forma moral de iniciar la familia es el matrimonio, haciendo de éste la base de la misma, sin embargo, es este un criterio muy limitativo, ya que no es la única forma lícita de constituirla, pues la misma se puede fundar en el concubinato o bien en una pareja de hecho como se denomina y se encuentra regulada en el Derecho español.

El concubinato como palabra proviene de la raíz latina concubinatus y cuyo significado ha sido el de trato, vida marital de un hombre con una mujer, y debe su nombre a la Lex Iulia dictada por el emperador Augusto en el año nueve de la era cristiana. En cambio, su amplia normativa jurídica se debe tanto a este ordenamiento imperial como a la diversa Lex Papia Poppeace, también dictada en el año nueve de la era cristiana, así como a la posterior compilación del emperador Justiniano, que, bajo el título “de concubinis” la reguló minuciosamente. ${ }^{306}$

El concubinato es una institución familiar muy antigua. En Roma aunque fue considerado un matrimonio de categoría inferior, no era deshonroso para los concubinarios ni para sus descendientes, quienes tenían un padre conocido, pues implicaba una unión estable, duradera, reconocida por la ley, distinta de las relaciones pasajeras consideradas ilícitas. No obstante, la influencia de la iglesia determinó el que fuera juzgado como un estado de vida 306 GALVAN RIVERA, Flavio; El concubinato en el vigente Derecho Mexicano; Ed. Porrúa; México;
2003. 
pecaminoso e ilícito, al reputar sacramento al matrimonio y tenerlo por la única unión lícita. ${ }^{307}$

Obviamente, las particulares características de este tipo de uniones y la ausencia o limitaciones en cuanto a su inscripción hacen que las presunciones deban de aplicarse de manera parcialmente particular, adaptando las consideraciones antes expresadas a las circunstancias fácticas de estas relaciones informales entre los que van a ser presumidos como padres.

${ }^{307}$ ESTRADA ALONSO Eduardo; Las Uniones Extramatrimoniales en el Derecho Civil Español; 2a. Ed., Ed. Civitas; España; 1991, p. 27 


\section{CAPITULO V \\ LA PRUEBA BIOLÓGICA EN LOS PROCESOS DE FILIACIÓN}

\subsection{Introducción}

Todo progenitor transmite a sus descendientes partículas o genes que permiten determinar los caracteres hereditarios. Dichos genes los recibe cada niño o niña de su padre o madre, por lo tanto su ausencia o su presencia son indispensables para determinar una verdad biológica o bien para cumplir una función, no sólo de designación, sino también de exclusión de la filiación, con ello se pretende que quien aparezca como padre o madre, realmente lo sean desde el punto de vista del lazo de sangre.

Esos genes son transmitidos a través de las células, por la madre en el óvulo y por el padre en el espermatozoide; constituyendo lo que se denomina patrimonio hereditario o código genético, cuyo equivalente morfológico son los cromosomas, los cuales están por parejas y en forma de hilos en el núcleo de cada célula. Los cromosomas humanos son 23 pares, numerados del uno al veintidós, a los que se llama autosómicos, cromosomas que son similares en forma y tamaño y el par 23 de cromosomas sexuales, que son desiguales y determinantes del sexo; en conclusión se tiene un total de 46 cromosomas. ${ }^{308}$

La herencia biológica es exacta y poco cambia con la interacción del ambiente, por lo que resulta indiscutible, el conocimiento de la verdad biológica en la actualidad, pues se puede llegar a ella, con el estudio de grupos sanguíneos,

\footnotetext{
${ }^{308}$ ACERO GALLEGO, Beatriz Helena y GARCÍA BERNAL Juan Carlos; La prueba en la filiación, Pontifica Universidad Javeriana, Bogotá, 1984, pp. 112 y ss.
} 
que hoy día son más exactos que otro tipo de estudios, como el de caracteres antropológicos; que se refieren al largo y forma de la nariz, de la oreja, de la cabeza por ejemplo, que aun cuando es cierto que existe un parecido morfológico entre padres e hijos, también es cierto que la genética del parecido, todavía es desconocida.

La aplicación de este tipo de probanza debe realizarse forzosamente vía prueba pericial, teniendo una importancia mayúscula para el mejor discernimiento de los casos expuestos al juez, muy en especial en el caso de los juicios de filiación, dado que el establecimiento concreto sobre la filiación biológica ha constituido un serio dilema para la humanidad. En el ámbito de la Ciencia jurídica, esta problemática ha pretendido ser resuelta desde los primeros sistemas legales como el caso del romano; y a través de presunciones legales, las cuales aun cuando hoy en día siguen siendo útiles en múltiples casos, dicha utilidad no puede generalizarse a todas las posibilidades que se actualizan en la realidad.

Los problemas, esencialmente en el tema de la filiación, son de Derecho probatorio, sobre todo si la pretensión es la imputación de la paternidad, pues en el caso de la maternidad, sólo deben probarse el parto y la identidad del hijo (a); los cuales son hechos generalmente conocidos, salvo en supuestos realmente excepcionales.

La admisión de la prueba biológica o la proveniente de los avances de los conocimientos científicos, para probar el nexo filial, así como la probable participación de un sujeto en la comisión de algún delito, debe realizarse particularmente por la prueba pericial en genética como prueba idónea, 
atendiendo que en la actualidad estos son los medios probatorios más concluyentes, al obtenerse resultados con un mínimo de error.

La realización de esta prueba, ha requerido desde tiempos ancestrales toda una evolución en el campo médico biológico, de estudios y experimentos científicos: Los indicios más remotos datan de los tiempos de PLATÓN y ARISTÓTELES, cuando "los animalistas” sostuvieron el origen de la vida en un principio vital anímico, el cual era transmitido de generación en generación; de la misma forma HIPÓCRATES sustentándose en su teoría del humor seminal, señaló que el hombre mediante este fluido transmitía a sus descendientes, sus propios caracteres. $^{309}$

No obstante, al descubrimiento de las leyes biológicas básicas de la herencia se atribuye a Juan Gregorio MENDEL, quien realizó investigaciones en $\operatorname{arvejas}^{310}$ de varios tipos a las cuales cruzó entre sí durante dos generaciones, concluyendo que cada nueva especie obtenida presentaba en su descendencia, las características de las especies utilizadas para llevar a cabo ese cruzamiento. ${ }^{311}$

Esta conclusión llevo a MENDEL a su vez a sostener, el punto medular de su teoría, basada en que cada carácter hereditario puede ser dominante o recesivo, y constituye siempre una unidad independiente. A pesar de este gran descubrimiento, los resultados de sus investigaciones, pasaron inadvertidos en los medios científicos, hasta que en 1900 los biólogos CORENZ, TSCHERMACK y Hugo DE VRIES, reconocieron el merito de sus experimentos

\footnotetext{
${ }^{309}$ ROMO PIZARRO, Osvaldo; Medicina Legal. Elementos de Ciencias Forenses; Ed. Jurídica Chile; Chile; 1998; p. 170

${ }^{310}$ Especie de árbol originario de oriente, pertenece a la familia de las papilionáceas

311 PRIMAROSA, CHIERI Y ZANNONI, Eduardo; La prueba de ADN; Ed. Astrea; Argentina; 1999, p. 81
} 
al haber obtenido casi al mismo tiempo, pero de forma independiente iguales resultados. $^{312}$

Sin embargo, la primera aplicación de las leyes de la herencia de MENDEL, en el ser humano fue realizada en 1902, conjuntamente por los científicos de apellidos GARROD y GALTON, quienes han sido considerados los padres de la genética médica. A partir de entonces y hasta hoy, las subsecuentes investigaciones y los progresos en el ámbito de la genética clásica y molecular, han desencadenado una verdadera revolución tanto en la biología como en la medicina, extendiendo sus fronteras y aplicaciones al campo de la medicina legal. ${ }^{313}$

Desde su descubrimiento, son diversas las pruebas biológicas que se han empleado: al principio la determinación de las diferencias entre persona y persona se fundamentó en los clásicos estudios de los grupos sanguíneos ABO. Posteriormente y al irse perfeccionando, se implementaron marcadores cada vez más informativos, tales como: los subgrupos sanguíneos, los morfológicos o heredobiológicos, las proteínas séricas, los antígenos de histocompatibilidad HLA y finalmente las pruebas para tipificar el ADN. ${ }^{314}$

Por ello y siguiendo el orden de estos marcadores hereditarios que se transmiten genéticamente, las pruebas biológicas a las cuales se hace referencia son: la prueba hematológica; la prueba de maduración fetal, la antropológica o heredobiológica; el método de Kühne o prueba morfológica de la columna vertebral; el sistema HLA (human leukocyte antigen); la prueba de compatibilidad inmunogenética y la prueba de ADN o de la identificación de personas a través del ácido desoxirribonucléico.

\footnotetext{
${ }^{312}$ ROMO PIZARRO, Oswaldo; op cit; P. 171

${ }^{313}$ PRIMAROSA, CHIERI Y ZANNONI; Eduardo; op cit; p. 81

314 Ídem pp. 81 y 82
} 
Aun cuando estos métodos, contribuyen a la Ciencia jurídica en el conocimiento del nexo biológico y la identificación humana, este objetivo lo cumplen en distinta proporción.

\subsection{Clases de pruebas biológicas}

A manera únicamente enunciativa, ya que este trabajo pretende ser jurídico, seguimos en este punto la opinión de FABREGAS RUIZ, quien ha señalado que las pruebas de investigación de la paternidad se pueden agrupar en a) Investigación bioantropológica, que se utiliza sólo como estudios de carácter preliminar para excluir la relación y/o embarazo (duración del embarazo, alteraciones ginecológicas en la mujer; impotencia, esterilidad, herencia de determinados caracteres físicos o enfermedades en el hombre). Afirma que hoy en día son poco aceptadas debido a la fuerte carga de subjetivismo que comportan; sin embargo por la gran cantidad de caracteres que estudian (casi 300) hacen que tengan utilidad como pruebas de carácter complementario; b) investigación inmunohematológica, los llamamos antígenos y enzimas eritrocitarios y los antígenos leucocitarios representados por el sistema HLA tienen una gran potencia identificadora superior al 98.62\% de probabilidad consistente en la identificación de las marcas genéticas que llevan los glóbulos blancos y que, codificado en el cromosoma 6 de cada persona, tienen una alta fiabilidad tanto en la exclusión como en la atribución de la paternidad, sólo que tienen una gran desventaja que requiere de laboratorios altamente especializados y por consecuencia tienen un costo muy alto. ${ }^{315}$

\footnotetext{
${ }^{315}$ FÁBREGAS RUIZ, Cristóbal Francisco; Biología y filiación. Aproximación al estudio jurídico de las pruebas biológicas de la paternidad y de las técnicas de reproducción asistida, Ed. Comares, Granada, 1999, p. 7
} 
Las técnicas de ADN (ácido desoxirribonucleico, sustancia ubicada en el interior del núcleo de la célula y que contiene la información genética). Este ácido conforma los cromosomas, y procede de la mitad del padre y mitad de la madre. Las características del ser humano son el resultado de una mezcla o combinación de la información genética aportada por el óvulo y espermatozoide. Se trata de una sustancia fuertemente identificadora que se extrae de cualquier fluido o resto de la persona y del que se puede estudiar su carátula genética; ya que una vez realizados los pasos técnicos precisos, da lugar a la determinación de una especie de “código de barras” que se comparan para observar la posible compatibilidad genética. Se trata de un procedimiento sencillo y permite determinar la paternidad en forma absoluta.

Las pruebas biológicas, como se ha señalado, constituyen un medio científico de un importante valor por su fiabilidad, con la cual se puede excluir totalmente la paternidad, o afirmarse la misma con un porcentaje de acierto de casi el 100\%, dependiendo de los marcadores genéticos utilizados y del número de los mismos.

Hay que señalar que en los procesos de filiación en donde se admitan pruebas científicas, no siempre habrá una prueba directa de la paternidad y éstas podrán declararse de los demás medios de prueba de filiación que hasta hoy se han utilizado; tales como el reconocimiento, la posesión de estado, la presunción, etcétera; probando directamente un hecho y, de forma indirecta, la filiación. Toda vez que como los ordenamientos legales prescriben, sólo se trata de una presunción que será valorada en el proceso. 


\section{a) Pruebas médicas}

En el presente punto es conveniente decir que la clasificación de las pruebas biológicas de paternidad es más un criterio de medicina forense genética $^{316}$, y las cuales son:

1. Pruebas no relativas a la herencia o elementos de diagnóstico retrospectivos y correlativos:

a) Época de la concepción

b) Duración legal del embarazo

c) Estado clínico de los presuntos progenitores al tiempo de la relación

d) Estado clínico de los presuntos progenitores al tiempo del juicio de filiación y correlación del diagnóstico retrospectivo.

Estas pruebas se sustentan en el estudio del hombre (análisis andrológico), de la madre (examen ginecológico) o del hijo (prueba de madurez)

2. Pruebas relativas a la herencia o heredobiológicas

a) Pruebas de paternidad basadas en los elementos de diagnóstico no grupales.

1) Antropomórficas

${ }^{316}$ VARSI ROSPLIGUIOSI, Enrique; Filiación, Derecho y Genética; Universidad de Lima, 2005 p. 70 
2) Antropoquinéticas

3) Patológicas

4) Fisiológicas

5) Psicológicas

b) Pruebas de paternidad basadas en los elementos de diagnóstico grupales

1) Grupos Sanguíneos

c) Pruebas genéticas

1) Marcadores genéticos séricos

2) Sistema de histocompatibilidad de Polimorfismos cromosómicos

3) Perfil del ADN

\subsubsection{Prueba Hematológica}

También denominada prueba de los grupos sanguíneos, cuyo incipiente origen según el tratado Sen-en-roku estaría en la China antigua del año 1247, donde su práctica para determinar la paternidad consistió, en verter la sangre del padre y del hijo gota a gota en una vasija llena de agua, en la que si el líquido sanguíneo de ambos se incorporaba, indicaba la existencia del nexo filial entre ellos, pero si por el contrario se repelía, era indicativo de su ausencia. ${ }^{317}$

\footnotetext{
317 TEJEDA, José Francisco; “Nuevos medios de prueba de la paternidad” en: Boletín Mexicano de Derecho Comparado, Publicado por el Instituto de Investigaciones Jurídicas de la Universidad Nacional Autónoma de México; publicación semestral, Año XI, No. 31 y 32; Enero - Agosto de 1978 p. 94, en el mismo sentido escribe ZICARELLI FILHO; "La prueba en la acción de investigación de la paternidad”
} 
Aunque es evidente la imprecisión de esa técnica aplicada por los chinos, es importante su mención, porque constituye el primer antecedente de la prueba de los grupos sanguíneos descubierta en 1920, por el biólogo Kart LANDSTEINER, quien por ese hecho fue galardonado por el Premio Nobel de Medicina de $1930 .{ }^{318}$

El descubrimiento de LANDSTEINER partió del análisis de los casos de transfusiones sanguíneas accidentales, realizadas hasta ese momento y respecto de los cuales pudo comprobar que se había producido como resultado de la mezcla de líquidos sanguíneos contrapuestos, provocando la coagulación de uno de ellos hacia el otro, por la diferente composición entre la sangre del donante y el receptor. De ahí precisamente, obtuvo dos conclusiones iniciales: la existencia de distintos tipos de sangre humana y la consiguiente incompatibilidad de las mismas.

A raíz de sus conclusiones iniciales, LANDSTEINER explicó el fenómeno de la distinta composición de la sangre humana, a través de la existencia de ciertas sustancias específicas, denominadas antígenos o factores de grupo en los glóbulos rojos o eritrocitos del líquido sanguíneo. Además, a dichos antígenos o factores de grupo, los diferenció mediante la creación del sistema ABO, designándolos con las letras $\mathrm{A}, \mathrm{B}, \mathrm{AB}, \mathrm{y} \mathrm{O},{ }^{319}$ significando ello, la división de la especie humana en cuatro grupos sanguíneos. ${ }^{320}$

Revista Mexicana de Derecho Penal, México, publicado por la Procuraduría General de Justicia del Distrito Federal, Publicación bimestral, tercera época No. 3, mayo - junio, 1965; p. 67

${ }^{318}$ GIRALDO; Cesar Augusto; Medicina Forense; 6 ${ }^{a}$ ed; Ed. Publicación de la Universidad de Antioquia, Colombia, 1991; p. 154

${ }^{319}$ Así, los grupos sanguíneos A, B, AB y O, indicarían el A la presencia del antígeno A en la sangre, el B la presencia del antígeno $\mathrm{B}$, el $\mathrm{AB}$ la presencian de ambos antígenos y el $\mathrm{O}$ la ausencia de ambos. La división de la especie humana en estos cuatro grupos representativos de los antígenos mencionados, se debe a la diferente estructura química de cada uno, lo cual provoca que difieran de una persona a otra, y por ello no en todos los casos pueden ser intercambiables.

${ }^{320}$ Ídem, p. 154 
Pero los descubrimientos de LANDSTEINER no se limitaron sólo al sistema sanguíneo ABO, pues sus investigaciones siguieron con la pretensión de encontrar un mayor número de antígenos en la sangre. De tal forma, junto con LEVINE, descubrió otras propiedades diferentes e independientes de los antígenos $\mathrm{ABO}$, a las cuales denominó $\mathrm{MN}^{321}$, con posterioridad junto con WEINER, descubre el factor Rh de la sangre ${ }^{322}$

El hallazgo del sistema MN fue producto de una serie de investigaciones de inmunización, cuya culminación tuvo lugar con el descubrimiento de dos anticuerpos, designados con las letras $\mathrm{M}$ y $\mathrm{N}$, respecto de ellos pudo determinarse que uno y otro se encuentran invariablemente en el líquido sanguíneo del ser humano.

En cuanto al factor Rh su descubrimiento se debió a los experimentos practicados en la sangre del macacus rhesus, presente también en un gran porcentaje de seres humanos, lo cual los condujo a plantear una nueva clasificación en dos grupos: $\mathrm{Rh}+$ y Rh -, según estuviera presente o ausente este factor en la sangre.

La aplicación médico legal de los distintos sistemas sanguíneos en los juicios, requiere en primer lugar la determinación del grupo sanguíneo muy en especial en los juicios de filiación, ya que es necesario en estos casos la de los progenitores o uno de ellos y la del descendiente, para después poder establecer si por la combinación de líquidos sanguíneos de ambos, fue o no posible que engendraran al descendiente reputado de la unión.

\footnotetext{
${ }^{321}$ Descubrimiento realizado en la inmunización de conejos, con el fin de obtener sueros contra el hombre, lograron ubicar dos nuevos factores sanguíneos que no tenían ninguna relación con el sistema ABO, a ellos se les denominó M y N, permitiendo la clasificación de los tipos sanguíneos $\mathrm{M}, \mathrm{N}$ y MN ${ }^{322}$ MARTÍNEZ TRUJILLO, Salvador; Medicina Lega”, 16ª ed; Méndez editores, México; 1998, pp. 183 y 184.
} 
En estos casos, es muy importante la obtención de muestras de sangre de ambos progenitores, pues la falta de alguna de ellas impedirá que se pueda excluir la paternidad o maternidad. Además, es preferible la realización de la prueba hematológica después del primer año de vida del descendiente, porque en algunos casos antes de ese tiempo, las isoaglutininas de la sangre no se encuentran totalmente desarrolladas, y no pueden proporcionar resultados claros, haciendo necesaria la repetición de dicha probanza cuando el descendiente tenga más edad.

Las posibles combinaciones de los grupos sanguíneos de los progenitores se describen a continuación, siguiendo la propuesta de César Augusto GIRALDO: ${ }^{323}$

\section{SISTEMA SANGUÍNEO ABO}

\begin{tabular}{ccc}
\hline GRUPOS & GRUPOS & GRUPOS \\
SANGUÍNEOS DE LOS & SANGUÍNEOS & SANGUÍNEOS NO \\
PROGENITORES & POSIBLES EN EL & POSIBLES EN EL \\
& DESCENDIENTE & DESCENDIENTE \\
\hline OxO & O & A, B, AB \\
OxA & O,A & B, AB \\
OxB & O,B & A, AB \\
AxA & O,A & B, AB \\
AxB & Todos & Ninguno \\
\cline { 3 - 4 }
\end{tabular}

${ }^{323}$ GIRALDO, César Augusto; op cit. p. 155 


\begin{tabular}{ccc}
\hline BxB & O,B & A, AB \\
OxAB & AB & A, AB \\
AxAB & A, B, AB & O \\
BxAB & A, B, AB & $\mathbf{O}$ \\
\hline ABxAB & A, B, AB & $\mathbf{O}$ \\
\hline
\end{tabular}

Primera ley: El aglutinógeno A1 no puede aparecer en un niño si no está presente por lo menos en uno de los padres.

Segunda ley: La combinación A1B (padres) y A2 (niño) es imposible, al igual que $\mathrm{O}$ (padres) y A1B (Niño)

Tercera ley: La combinación A2B (padres) y A1 (niño) es imposible, en caso de darse excluirá la paternidad del presunto progenitor.

El profesor SIMONÍN logró confeccionar un cuadro de incompatibilidades sanguíneas de filiación a los subgrupos A1, A2, A1B, A2B que han sido los más estudiados. ${ }^{324}$

De igual forma se logro confeccionar una tabla de combinaciones en la que se puede excluir la paternidad teniendo como estudios preliminares la sangre del niño y de la madre:

${ }^{324}$ SIMONIN, Medicina legal judicial; Ed. Jims; Barcelona; 1962; p. 496 
PROBABILIDADES EN RELACIÓN A LA MATERNIDAD Y AL HIJO PARA EXCLUIR LA PATERNIDAD

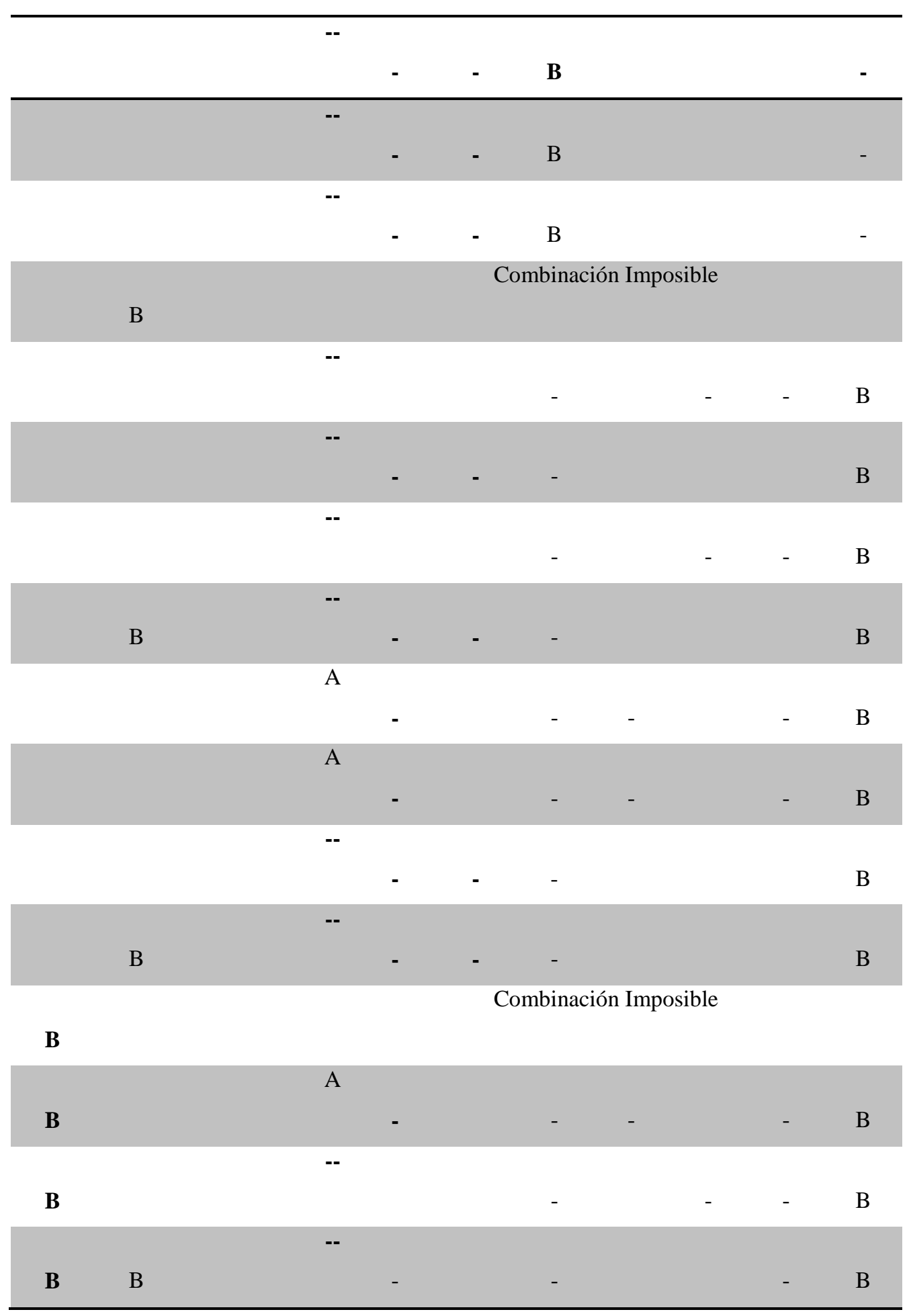


TABLA DE PROBABILIDADES DE PATERNIDAD EN RELACIÓN A LOS SUBGRUPOS A1, A2 Y SU PORCENTAJE DE EXCLUSIÓN

\begin{tabular}{cccccc}
\hline \multicolumn{5}{c}{ Progenitor } & $\begin{array}{c}\text { \% posible de } \\
\text { exclusión }\end{array}$ \\
\cline { 1 - 3 } Niño & madre & Posibles & Excluidos & 0 \\
\hline A1 & A1 & A1,A2,O,B,A1B,A2B & sin exclusión & 61 \\
\hline A1 & A2 & A1 o A1B & O, A2, A2B, B & 61 \\
\hline A1 & B & A1 o A1B & O, A2, A2B, B & 0 \\
\hline A1 & A1B & A1,A2,O,B,A1B,A2B & sin exclusión & 61 \\
\hline A1 & A2B & A1 o A1B & O, A2, A2B, B & 61 \\
\hline A1 & O & A1 o A1B & O, A2, A2B, B & 2 \\
\hline A2 & A1 & A1,A2,O,B,A2B & A1B & 2 \\
\hline A2 & A2 & A1,A2,O,B,A2B & A1B & 54 \\
\hline A2 & B & A1,A2,A2B & O, A1B,B & \\
\hline A2 & A1B & Imposible & -- & 54 \\
\hline A2 & O & A1,A2,A2B & O, A1B,B & 87 \\
\hline B & A1 & B, A1B, A2B & O, A1, A2 & 87 \\
\hline B & A2 & B, A1B, A2B & O, A1, A2 & 0 \\
\hline B & B & A1,A2,O,B,A1B,A2B & sin exclusión & 0 \\
\hline B & A1B & A1,A2,O,B,A1B,A2B & sin exclusión & 0 \\
\hline B & A2B & A1,A2,O,B,A1B,A2B & sin exclusión & 0 \\
\hline B & O & B, A1B, A2B & O, A1, A2 & 87 \\
\hline A1B & A1 & B, A1B, A2B & O, A1, A2 & 87 \\
\hline A1B & A2 & Imposible & -- & \\
\hline A1B & B & A1, A1B & O, B, A2, A2B & 61 \\
\hline A1B & A1B & A1, A1B,2AB,B & O, A2 & 51 \\
\hline A1B & A2B & A1, A1B & O, B, A2, A2B & 61 \\
\hline & & & & \\
\hline
\end{tabular}




\begin{tabular}{ccccc}
\hline A1B & O & Imposible & -- & \\
A2B & A1 & A1, B, 2AB, B & A1,A2,O & 87 \\
A2B & A2 & A1, B, 2AB, B & A1,A2,O & 87 \\
A2B & B & A1, B, 2AB, B & O,B,A1B & 54 \\
A2B & A1B & A1, B, 2AB, B & O,B,A1B & 54 \\
A2B & A2B & A1,A2,A1B,2AB,B & O & 42 \\
A2B & O & Imposible & -- & \\
O & A1 & O,A1,A2,B & A1B,2AB & 3 \\
O & A2 & O,A1,A2,B & A1B,2AB & 3 \\
O & B & O,A1,A2,B & A1B,2AB & 3 \\
O & A1B & Imposible & -- & \\
O & A2B & Imposible & -- & \\
O & O & O,A1,A2,B & A1B,2AB & 3 \\
\hline
\end{tabular}

Tanto URIBE CUALLA, TEJEDA como JIMÉNEZ DÍAZ elaboraron otro cuadro de indagación de la filiación estudiando la unión de los padres, pudiendo determinar los hijos que se podían engendrar.

COMBINACIÓN SANGUÍNEA DE LOS PADRES E HIJOS PROBABLES.

\begin{tabular}{ccc}
\hline Padres & Hijos posibles & Hijos no posibles \\
\hline O*O & O & A1,A2,B,A1B,A2B \\
O*A & O, A1,A2 & B,A1B,A2B \\
O*A2 & O,A2 & A1,B,A1B,A2B \\
O*A1B & A1,B & O,A2,A1B,A2B \\
O*A2B & A2,B & O,A2,A1B,A2B \\
O*B & O,B & A1,A2,A1B,A2B \\
\hline
\end{tabular}




\begin{tabular}{ccc}
\hline A*A & O, A1,A2 & B,A1B,A2B \\
\hline A1*A2 & O, A1,A2 & B,A1B,A2B \\
A1*B & A1,A2,B,A1B,A2B & ----------- \\
\hline A1*A1B & A1,B,A1B,A2B & O,A2B \\
\hline A2* A2 & O,A2 & A1,B,A1B,A2B \\
\hline A2*A1B & A1,A2B & A1,A2B \\
A2*B & O,A2,B,A2B & O,A1,A2B \\
\hline A2*A2B & A2,B,A2B & A1,A1B \\
B*B & O,B & O, A1,A1B \\
B*A2B & A2,B,A2B & A1,A2,A1B,A2B \\
B*A1 & A1,B,A1B & O, A2,A1B \\
A1B* A1B & A1,B,A1B & O, A2,A2B \\
A1B* A2B & A1,B,A1B,A2B & O,A2 \\
A2B* A2B & A2,B,A2B & O,A1,A1B \\
\hline
\end{tabular}

\section{SISTEMA SANGUÍNEO MN}

Los sujetos son portadores siempre de $\mathrm{M}, \mathrm{N}$ o Mn ocasionando los siguientes $\operatorname{casos}^{325}$ :

$\begin{array}{llll}\text { Genotipos: } & \text { MM } & \text { NM } & \text { MN } \\ \text { Fenotipos: } & \text { M } & \text { N } & \text { MN }\end{array}$

Primera ley: Las propiedades M y N no pueden aparecer en los hijos si no existen en los padres, y son dominantes (Landsteiner - Levine)

${ }^{325}$ SIMONIN; op cit p. 498 
Segunda ley: El padre o la madre M no pueden tener un hijo N, ni el padre o madre N podrán tener hijos M (Landsteiner - Levine)

Tercera ley: Los MN que son híbridos, pueden transmitir a sus hijos cualquier característica, sea M, N o MN

\begin{tabular}{ccc}
\hline GRUPOS & GRUPOS & GRUPOS \\
SANGUÍNEOS DE LOS & SANGUÍNEOS & SANGUÍNEOS NO \\
PROGENITORES & POSIBLES EN EL & POSIBLES EN EL \\
& DESCENDIENTE & DESCENDIENTE \\
\hline MN x MN & $\mathrm{M}, \mathrm{N}, \mathrm{MN}$ & Ninguno \\
MN x N & $\mathrm{N}, \mathrm{MN}$ & $\mathrm{M}$ \\
MN x M & $\mathrm{M}, \mathrm{MN}$ & $\mathrm{N}$ \\
$\mathrm{M} \times \mathbf{N}$ & $\mathrm{MN}$ & $\mathrm{M}, \mathbf{N}$ \\
$\mathrm{N} \times \mathbf{M}$ & $\mathrm{MN}-(\mathrm{MN})$ & $\mathrm{M}-\mathbf{N}$ \\
\hline $\mathrm{M} \times \mathbf{M}$ & $\mathrm{M}$ & $\mathrm{MN}, \mathbf{N}$ \\
\hline
\end{tabular}

En cuanto al antígeno $\mathrm{Rh}$, éste se transmite de progenitores a descendientes, siguiendo rigurosamente las leyes de MENDEL, así cada hijo o hija reciben un gen $\mathrm{Rh}$ del padre y otro de la madre, los genes $\mathrm{Rh}$ no forman parte de los mismos cromosomas de los factores A, B, O, M, y N, por eso, su transmisión hereditaria es independiente de dichos antígenos.

Las estadísticas de la herencia del factor Rh han permitido establecer la relación entre su transmisión y los grupos raciales. Así, se ha determinado la presencia del antígeno $\mathrm{Rh}+$, comúnmente entre las personas de raza negra, los indígenas de América, Asía y las poblaciones mestizas de estos dos continentes, más que en las poblaciones blancas. No obstante, dentro de las personas de raza 
blanca, el $85 \%$ suelen ser $\mathrm{Rh}+$ y sólo el 15\% Rh-. La mayor abundancia de Rhse ha observado particularmente entre individuos de origen vasco en un 35\%. En el caso de México este factor es muy raro, pues solo se calcula su presencia en el $4,5 \%$ de la población. ${ }^{326}$

COMBINACIÓN SANGUÍNEA DE LOS PADRES E HIJOS PROBABLES

\section{SISTEMA RH}

\begin{tabular}{|c|c|c|}
\hline FACTORES & FACTORES & FACTORES \\
SANGUÍNEOS DE LOS & SANGUÍNEOS & SANGUÍNEOS NO \\
PROGENITORES & POSIBLES EN EL & POSIBLES EN EL \\
& DESCENDIENTE & DESCENDIENTE \\
\hline $\mathrm{Rh}+\mathrm{X} \mathrm{Rh}+$ & $\mathrm{Rh}+, \mathrm{Rh}-$ & Ninguno \\
\hline $\mathrm{Rh}+\mathrm{X} \mathrm{Rh}-$ & $\mathrm{Rh}+, \mathrm{Rh}-$ & Ninguno \\
\hline $\mathrm{Rh}-\mathrm{X} \mathrm{Rh}-$ & $\mathrm{Rh}-$ & $\mathrm{Rh}+$ \\
\hline
\end{tabular}

Primera ley: El Rh+ es de carácter dominante, su presencia obedece a la transmisión de uno de los progenitores.

Segunda ley: El Rh-, siendo de carácter recesivo, puede aparecer en el niño aun cuando no exista en los padres.

Los antígenos y los grupos sanguíneos referidos con anterioridad son sólo algunos de los muchos conocidos en la actualidad, pues hoy en día se ha

\footnotetext{
${ }^{326}$ BUENO RINCÓN, Fabio Enrique; La investigación de la filiación y las pruebas biológicas, $2^{\mathrm{a}}$ ed.; Ediciones jurídicas Gustavo Ibáñez; Colombia; 1996, p. 74
} 
corroborado la existencia de 100 antígenos diferentes, agrupados en 14 sistemas sanguíneos, los cuales funcionan de forma independiente, sin que exista relación entre ellos, porque se transmiten por genes distintos.

Así, el éxito de la prueba hematológica depende del número y la calidad de los antígenos utilizados, aunque en principio, el único posible resultado que se obtendrá a través de la misma, será siempre negativo, es decir, sólo servirá para excluir o descartar la paternidad o la maternidad, pero no para probarlas. Además, ese resultado de exclusión de cualquiera de estos nexos filiales es mínimo. ${ }^{327}$

Por eso aun y cuando la prueba hematológica sólo conduce a un primer resultado, consistente en excluir, o descartar la paternidad o maternidad, su importancia radica en que la misma puede servir para mejorar ese índice de filiación obtenido, si se utilizan otros marcadores genéticos, como por ejemplo el sistema HLA de histocompatibilidad, pues como decía, frente a cada examen basado en otro marcador genético, se obtendrá un nuevo valor de probabilidad de nexo filial con relación al padre o la madre.

La práctica de la prueba hematológica no es reciente, desde 1931 es posible constatar su aplicación en Alemania y con posterioridad en Suiza y Estados Unidos, particularmente en estos países se ha admitido su utilidad en los juicios de impugnación de la paternidad, porque la misma se limita a la exclusión del nexo filial, y en este tipo de controversias, el presunto padre tiene la carga de la prueba y debe acreditar que no es el padre de un supuesto descendiente. ${ }^{328}$

\footnotetext{
${ }^{327}$ CHIERI PRIMAROSA y ZANNONI, Eduardo; op cit. p. 82

${ }^{328}$ TEJEDA, José Francisco; op cit; p. 124
} 
Aunque también en estos juicios de impugnación de la paternidad, ha ocurrido que después de haber practicado la prueba hematológica, mediante el empleo de varios sistemas sanguíneos, resulta la existencia de cierta compatibilidad entre el presunto ascendiente varón y su supuesto descendiente, significando ello una posibilidad del nexo filial entre ambos, en cuyo caso, esta probanza ha sido complementada con otros medios probatorios científicos, a través de los cuales es posible determinar dicho nexo filial con un mínimo de error. $^{329}$

Como puede observarse tiene gran importancia y utilidad la verificación de los grupos sanguíneos en la actualidad. El descubrimiento de las propiedades serológicas proporcionó un inagotable material de investigación que ha sido utilizado en el estudio del origen y evolución de las especies del hombre así como la determinación hematológica de la paternidad.

Como ha dicho HIRSZFELD, el descubrimiento de las propiedades grupales: “... ha desvelado a los biólogos el secreto de la herencia, ha permitido a los médicos la aplicación de la transfusión sanguínea, ha hecho posible a los juristas la búsqueda de la paternidad y ha permitido a los antropólogos seguir las vías de las migraciones de los pueblos”. ${ }^{330}$

\subsubsection{Prueba de maduración fetal}

Científicamente, se ha comprobado una íntima relación tanto entre los distintos periodos de la gestación y la maduración del feto, como entre la duración del embarazo y el grado de desarrollo del recién nacido. Esta

\footnotetext{
${ }^{329}$ GROSMAN, Cecilia; op cit p. 172

${ }^{330}$ HIRSZFELD, Luwik; Les groupes sanguins. Leer aplication a la biologie, a la medicine et au droit, París, 1938.
} 
vinculación precisamente, ha permitido la elaboración de tablas en las que se especifican ciertas medidas como: la talla, el peso, los diámetros y perímetros craneales del feto o del recién nacido, para determinar el tiempo exacto de su gestación o de su nacimiento.

Por eso el diagnóstico de la maduración fetal es la prueba científica de la filiación cuya práctica se realiza en dos casos específicos: a la madre embarazada antes del nacimiento del feto, o al hijo después de su nacimiento.

En el primer supuesto, es imprescindible cerciorarse del estado de gravidez de la madre, lo cual puede verificarse mediante la aplicación de técnicas ecográficas $^{331}$, la ecocardiografía ${ }^{332}$, la percepción de movimientos fetales activos por parte del examinador; o bien, mediante ultrasonidos, tomografía computarizada o radiológicamente, a través de la típica radiografía abdominal, pero en este caso, sólo será posible tomarla en la segunda mitad del embarazo, es decir, después del cuarto mes de gestación, por el consecuente riesgo de irradiación al feto. ${ }^{333}$

Comprobada la certeza del embarazo, deberá determinarse el tiempo exacto de la gestación, tomando en cuenta para ello dos cuestiones fundamentales: primero, las transformaciones anatómicas y fisiológicas experimentadas en el cuerpo de la madre a partir del momento de la concepción, tales como: el crecimiento del abdomen y los senos, y los cambios de tamaño, forma y consistencia del útero. En segundo lugar, por el tamaño del cuerpo fetal, para lo cual se deberá medir el diámetro biparietal del feto, puesto que se encuentra estrechamente relacionado con la edad de gestación. La técnica utilizada para determinar la edad fetal, el tiempo del embarazo, y por ende, la

\footnotetext{
${ }^{331}$ Reconocimiento del embrión o feto en cualquier momento del embarazo

${ }^{332}$ Identificación de la actividad cardiaca fetal por auscultación

${ }^{333}$ PATITO, José Ángel; Medicina Legal; 2ª ed; Ediciones Centro y Norte; Argentina; 2001. p. 297
} 
fecha más probable de la fecundación, se basa tanto en la formula de BALTHAZARD - DERVIEUX como en el procedimiento matemático de HAASE. ${ }^{334}$

Por otra parte, en el segundo supuesto relativo a la práctica de la prueba de maduración fetal en el descendiente recién nacido, es necesaria la medición de parámetros tales como: el peso, la talla y los perímetros craneales del mismo, pues con estos datos es posible fijar con precisión el tiempo que tiene de nacido, la duración de su gestación y en consecuencia, la fecha más probable de la fecundación, datos todos ellos calculados mediante tablas preestablecidas. $^{335}$

Ahora bien, una vez que en ambos casos haya sido posible determinar la fecha más probable de la concepción, es decir, la de la fecundación del óvulo, será necesario relacionar dicha fecha con la presunciones de paternidad matrimonial y de parejas de hecho respectivamente; así, la imputación de la paternidad a través de esta probanza, deriva de la coincidencia entre la fecha probable de la fecundación del óvulo ${ }^{336}$ con el periodo legal de la presunción de la concepción, ${ }^{337}$ lo cual significa la necesaria ubicación de esa fecha dentro de los primeros 120 días totales de los 300 que como máximo pudo durar el embarazo. $^{338}$

\footnotetext{
${ }^{334}$ SERNA MEROÑO, Encarnación; La Reforma de la filiación; Ed. Montecorvo; España; 1985, p. 52

335 Ìdem, p. 52

${ }^{336}$ Que será determinada por esta clase de pericial en maduración de óvulo.

${ }^{337}$ El Artículo 324 del Código Civil Federal mexicano determina como periodo de concepción para presumir hijo del matrimonio al feto nacido después de los ciento ochenta días de celebrado el matrimonio o bien dentro de los trescientos días después de la disolución del mismo, lo cual en cuestiones parecidas se encuentra determinado por el artículo 116 del Código Civil Español, con la salvedad que se considera hijos del matrimonio por presunción legal a los nacidos después de la celebración del matrimonio sin especificar tiempos mínimos, pero el artículo 117 concede a favor del presunto padre la oportunidad de destruir la presunción del hijo nacido dentro de los 180 días de la celebración del mismo.

${ }^{338}$ Este aspecto debe destacarse, ya que de acuerdo al artículo 325 del Código Civil Federal, contra las presunciones de paternidad matrimonial, establecida en el artículo 324 del mismo ordenamiento, únicamente se admite como prueba la de haber sido físicamente imposible al marido tener acceso carnal con su mujer, en los primeros ciento veinte días de los trescientos que han precedido al nacimiento; en
} 
De este modo, si mediante el diagnóstico de la maduración fetal puede concluirse la concordancia entre la fecha científica probable de la concepción y el periodo legal de la misma, y por ende, el nexo filial del descendiente con el padre, tanto en el matrimonio como en el caso de las parejas de hecho, se estaría frente a un medio probatorio de inclusión de la paternidad, cuyo empleo correspondería a la madre y al hijo (a), de lo contrario, sería el padre quien estaría en la posibilidad de emplearlo a su favor como prueba de exclusión del nexo filial con el presunto descendiente.

Pero la cuestión que comentamos se complica de comprobarse que la madre ha cohabitado al mismo tiempo con su cónyuge o pareja de hecho y con otro individuo en un periodo no muy distante, comprendido en un espacio de cuatro semanas, porque de ocurrir un supuesto así, sería indispensable la voluntad de ambos sujetos para concurrir a juicio, con el objeto de aportar las fechas de las relaciones sexuales mantenidas con la madre, pues sólo con esos datos se podría determinar en el dictamen pericial, la respectiva probabilidad de paternidad. Sin embargo, esa simple probabilidad de paternidad del descendiente cuya filiación es discutida, resultaría insuficiente y haría necesario reforzar el índice de inclusión de dicho nexo filial, con la práctica de otros medios probatorios científicos, a través de los cuales fuera posible determinarlo con un mínimo de error.

Ante estas circunstancias, es posible concluir que la eficacia jurídica de la prueba de maduración fetal es relativa, y en la actualidad podríamos decirlo totalmente insuficiente, dado que no da certeza jurídica ni a las partes ni al juzgador para poder determinar el nexo filial, ya que como se ha dicho líneas

este mismo sentido, debemos destacar que el mismo Código Civil Federal, no determina la admisión de prueba en contrario en los casos de las presunciones de paternidad concubinaria, establecidas en el artículo 383. 
atrás simplemente nos encontramos con una presunción, sin haber una imputación de certeza directa respecto de la paternidad, y lo cual en nuestros días, sería mucho más efectiva la prueba de ADN.

\subsubsection{Prueba antropológica o heredobiológica}

La herencia, en el sentido que lo utilizamos en este apartado, es el fenómeno biológico por el que se transmiten genéticamente de ascendientes a descendientes, ciertos caracteres portados por los progenitores, dichos caracteres hereditarios son: morfológicos, cromáticos, fisiológicos, sanguíneos, psíquicos y algunas veces patológicos. Todos ellos se clasifican dentro de los factores endógenos, porque se deben a la transmisión hereditaria, a diferencia de los factores exógenos, los cuales son adquiridos por cada individuo en el medio ambiente donde vive y se desarrolla. ${ }^{339}$

Precisamente por eso, los factores endógenos constituyen el objeto central de las leyes de la herencia, predominando en ellas el estudio de los caracteres físicos sobre los de orden psíquico, pues normalmente la transmisión hereditaria de aquellos se remonta hasta los abuelos o ascendientes todavía más remotos, dado que las características de un individuo provienen por partes iguales de los respectivos ascendientes de la primera generación (progenitores); por una cuarta parte de la segunda (abuelos); por una octava de los de la tercera (bisabuelos); y por una decimosexta de los de la cuarta (tatarabuelos), y así sucesivamente. $^{340}$

\footnotetext{
${ }^{339}$ TEJEDA, J.F.; op cit. p. 93

${ }^{340}$ ROMO PIZARRO; O., op cit. pp. 169 y 170
} 
Cada ser humano es el producto de la unión de un óvulo y un espermatozoide, procreadores del huevo, en el cual se reúnen los elementos armoniosos de los individuos masculino y femenino. Las propiedades antagónicas de los progenitores no pueden existir conjuntamente, de ahí la predominancia de una u otra característica en el individuo procreado, o bien, de un elemento intermedio; así, por ejemplo, cuando dos individuos de distinto grupo racial tienen un descendiente, como podría ser en el caso una persona de raza negra con otra de raza blanca, se presentan tres posibilidades de heredabilidad racial en aquél, la de cada uno de sus progenitores y una intermedia, suscitándose entonces el mestizaje o hibridación. En los dos primeros casos, la heredabilidad es unilateral, mientras en el último es bilateral. ${ }^{341}$

A partir de los antecedentes de MENDEL, DARWIN y WEISSMAN, se encuentra el fundamento de la prueba antropológica o heredobiológica de la filiación, pues la misma se basa en el estudio de los principales caracteres morfológicos, cuya herencia es transmitida por los progenitores al descendiente según las leyes mendelianas. ${ }^{342}$

Así, la prueba antropológica o heredobiológica consiste en el examen comparativo de 260 a 300 caracteres distintos en el descendiente, con relación a su madre y al presunto padre o viceversa normalmente, entre los caracteres que deben compararse mediante dichos estudio, se encuentran: la nariz, forma y color

\footnotetext{
${ }^{341}$ ZICARELLI, F., op cit. pp. 85 - 87 A este respecto, importa citar las tesis de la herencia sustentadas por MENDEL, DARWIN y WEISSMAN, el primero como hemos mencionado descubridor de las leyes de la herencia en 1865, sostuvo que cada factor hereditario constituye siempre una unidad independiente, ya sea dominante o recesiva, de acuerdo a la predominancia o no de una u otra característica en el individuo procreado; mientras que el segundo de ellos nos dice que la herencia se efectúa a través de la acción de los genes, pues en el huevo (producto de la unión del óvulo con el espermatozoide), existen genes transmisores de las características tanto del padre como de la madre, y según se vaya desarrollando dicho huevo, los genes y las células del nuevo organismo se van multiplicando con restricciones a semejanza de los progenitores. Por su parte, WEISSMAN, explica la teoría de la herencia, mediante la existencia de biósforos, que vendrían a ser los genes de DARWIN, es decir, minúsculas partículas representativas de las características de los progenitores y transmisibles a los descendientes.
}

${ }^{342}$ TEJEDA, J.F.; op cit. p. 90 
de los ojos, el pabellón de la oreja, los diámetros craneales, el color y la estructura del cabello, los labios, la forma del paladar, la columna vertebral, las manos, los dibujos papilares y las huellas dactilares, entre otros.

El examen comparativo de todos estos caracteres se realiza conforme al método antropobiométrico, y el perito deberá analizar cada uno de ellos en cuanto a sus semejanzas o diferencias morfológicas, para aportar los índices de probabilidad positiva o negativa del nexo filial controvertido. El procedimiento aplicado para este efecto consiste en asignar a cada carácter analizando un índice de compatibilidad, lo cual se hace mediante un logaritmo calculado en tablas preestablecidas, y como a cada carácter corresponde un logaritmo diferente, se sumarán algebraicamente para obtener un resultado numérico, que representará el grado de exclusión o inclusión del nexo filial discutido. ${ }^{343}$

Aun cuando, a través de la prueba antropológica o heredobiológica es posible determinar el grado de exclusión o inclusión de la paternidad o maternidad, su empleo en los juicios de filiación no es muy aconsejable, porque en la práctica presenta varios inconvenientes; el primero, es en cuanto a la recolección de los datos para llevarla a cabo, pues la transmisión de los caracteres morfológicos, depende de múltiples factores hereditarios, y es común la ausencia de muchos de ellos en el descendiente recién nacido, ya que, normalmente dichos caracteres se definen en los individuos a los tres años de edad, provocando desde el punto de vista procesal, el estancamiento del juicio entablado hasta que el menor cumpla la edad requerida para poder practicarla.

En segundo lugar, uno de los mayores peligros de esta prueba radica en el subjetivismo pericial, porque el perito de acuerdo con sus apreciaciones personales tiene un amplio campo de discrecionalidad, para atribuir a los

\footnotetext{
${ }^{343}$ HERRERA CAMPOS, Ramòn; op cit. p. 149
} 
distintos caracteres morfológicos analizados, los respectivos índices de compatibilidad. Aún cuando, se ha pretendido objetivizar los resultados de dicha probanza con el empleo de métodos antropobiométricos, basado en cálculos matemáticos y estadísticos. ${ }^{344}$

Por ello, si a pesar de estas circunstancias que restringen la certeza de resultados de la prueba antropológica o heredobiológica en los juicios de filiación, los litigantes insisten en su práctica, la misma sólo podrá aportar al proceso un primer resultado de exclusión o inclusión del nexo filial controvertido, debiéndose corroborar éste con otros medios probatorios científicos más concluyentes, como es el caso de la prueba de ADN.

\subsubsection{Método de Kühne}

Una variedad de la prueba antropológica o heredobiológica es la llamada prueba morfológica de la columna vertebral o método de Kühne, la cual se funda en la transmisión hereditaria de ciertos caracteres morfobiológicos de la columna vertebral. Por ello, este método consiste en el estudio comparativo de la conformación de la columna vertebral de los progenitores y del descendiente, en virtud de que los caracteres morfológicos de ambos son transmitidos a este último, de acuerdo con las leyes mendelianas de la herencia. ${ }^{345}$

Para llevar a cabo este estudio comparativo, se debe tener en cuenta que las vértebras de la columna vertebral, se dividen en cinco regiones: 7 cervicales, 12 dorsales, 5 lumbares, 5 sacras y de 3 a 6 coccígeas. Sin embargo, en algunos casos, la séptima vértebra cervical parece más bien dorsal o la

\footnotetext{
344 SERNA MEROÑO, Encarnación; op cit. pp. 37 y 55;

${ }^{345}$ LLEDO YAGUE, Francisco; “Acciones de Filiación”; Ed. La Ley; España; p. 291
} 
primera dorsal parece cervical, de igual forma, es común en cada vértebra la tendencia a inclinarse, ya sea hacia el cráneo, es decir, hacia arriba o bien, hacia abajo, de esas desviaciones son trascendentes las craneales, porque son dominantes.

Según KÜHNE, todos estos aspectos son muy importantes, porque tanto la imprecisa conformación de la columna vertebral, como su diversa inclinación, constituyen variaciones hereditarias de progenitores a descendientes, permitiendo en algunos casos excluir el nexo filial, siendo éste el único posible resultado que se puede obtener de esta prueba en los juicios de filiación.

Como la prueba morfológica de la columna vertebral, es sólo una variedad de la prueba antropológica o heredobiológica, es obvio que en la práctica presenta los mismos inconvenientes de ésta, al estar restringida al subjetivismo pericial, y únicamente poderse aplicar a los menores a partir de tres años de edad. Por eso, su certeza en los juicios de filiación es mínima y necesariamente debe complementarse con otros medios probatorios científicos. ${ }^{346}$

\subsubsection{Sistema HLA}

El actual empleo del sistema tisular HLA ${ }^{347}$ en los juicios de filiación, deriva de su anterior aprovechamiento en la técnica de los implantes de órganos, cuyo descubrimiento se atribuye al científico francés Jean DAUSSET, y por tal investigación, le otorgan el Premio Nobel de medicina de $1980 .{ }^{348}$

\footnotetext{
${ }^{346}$ HERRERA CAMPOS, R; op cit. pp. 149-150

${ }^{347}$ Human leukocyte antigen

${ }^{348}$ VERRUNO, Luis y otros; “Manual para la investigación de la filiación actualización médico legal”; Ed. Ebeledo - Perrot, Argentina, 1985; pp. 26 y 27
} 
La técnica de los implantes de órganos ha sido determinante para concluir lo relativo a las compatibilidades e incompatibilidades entre seres humanos, así se ha comprobado que la incompatibilidad en el implante de tejidos de un individuo a otro se presenta cuando el organismo elabora anticuerpos contra todos aquellos antígenos ajenos, causando el rechazo sistemático de los mismos. Consecuentemente, el éxito de todo implante depende de la similitud de sustancias anfígenas entre las células del dador y las del receptor, sustancias éstas heredadas, de acuerdo con las leyes mendelianas.

Por este motivo, la comunidad científica dispuso que si el sistema HLA es aplicado con éxito en otras áreas de identificación humana, como son los implantes de órganos en los que está de por medio una vida, con mayor razón puede ser empleado con completa seguridad para hacer una correcta determinación de la ausencia o existencia del vínculo filial de cualquier individuo con su padre o madre.

El sistema HLA constituye básicamente una nueva prueba hematológica, cuya práctica requiere una simple extracción de sangre venosa, para determinar los antígenos HLA en los linfocitos (variedad de leucocito) de la sangre, esto es, la identificación de las marcas genéticas heredadas en las células blancas del líquido sanguíneo.

Particularmente, la información genética codificada por el sistema HLA, se encuentra en el sexto par cromosómico del ser humano, ubicado en la membrana citoplásmica de todas las células y portadora del 6\% del material genético total del organismo. ${ }^{349}$

349 Ídem p. 110 
El hecho de que el sistema HLA constituya una nueva prueba hematológica, conduce precisamente a recordar su íntima relación con la prueba hematológica clásica, la cual sólo permite la obtención de un primer resultado, consistente en excluir o descartar la paternidad o maternidad, y como se sabe, su importancia radica en que el índice de filiación obtenido a través de la misma, puede mejorarse si se utilizan otros marcadores genéticos, como es el caso del sistema HLA de histocompatibilidad, pues frente a cada examen basado en otro marcador genético, se obtendrá un nuevo valor de probabilidad del nexo filial de un individuo con relación al padre o a la madre; por otra parte, cabe destacar dentro de las principales características del sistema HLA, en su aplicación a los procedimientos para identificar la ausencia o existencia del vínculo filial controvertido, las siguientes:

1. Es un sistema multialélico que permite gran cantidad de combinaciones. Los alelos son las formas alternativas de un mismo gen, y el sistema HLA tiene por objeto verificar las posibles combinaciones entre más de 100 alelos.

2. Los alelos son siempre condominantes, es decir, se expresan todos en la descendencia, tanto los paternos como los maternos;

3. Los antígenos HLA se expresan completamente desde antes del nacimiento en el feto y se mantienen constantes y estables toda la vida:

4. Las técnicas para la identificación de los antígenos HLA se realizan con los más rigurosos controles de calidad.

5. Los índices de exclusión e inclusión obtenidos son lo suficientemente seguros para efectuar el diagnóstico de la paternidad o de la maternidad, 
pues su capacidad de exclusión es de aproximadamente $90 \%$ y el de inclusión cercano al $100 \%$

Estas características del sistema HLA y sobre todo, el hecho de que su teoría genética no corresponda al campo experimental, han sido determinantes para su creciente aceptación por la comunidad científica, considerándoseles hoy en día como uno de los métodos más seguros para proveer a la información científica de la filiación, en virtud de los altos porcentajes de exclusión e inclusión de la paternidad o maternidad. ${ }^{350}$

Sin embargo, es menester señalar que su empleo en los juicios de filiación presenta ciertos inconvenientes, no siempre subsanables, porque la complejidad de su práctica hace ineludible recurrir a peritos y laboratorios altamente especializados. Además, no debe olvidarse el aspecto económico, pues es un método costoso cuya técnica requiere el uso de sueros, antisueros y reactivos, también especiales y de elevada cuantía, los cuales son utilizados por duplicado o triplicado, siendo muchas veces difíciles de obtener; ante estas circunstancias, resulta necesario difundir su utilidad en los juicios de filiación, promoviendo a la vez su práctica en instituciones públicas de salud del país, mediante la adquisición del equipo específico para llevarla a cabo y la capacitación de personal especializado, pues de eso dependerá su accesibilidad a la generalidad de la población por un bajo costo y no sólo a determinadas personas de acuerdo con sus recursos económicos.

${ }^{350}$ VERRUNO, Luis; op cit 110 y 111 


\subsubsection{Prueba de compatibilidad inmunogenética}

La práctica de esta prueba científica tiene lugar en el campo de la inmunogenética, en cuyo ámbito se han desarrollado los adelantos más importantes de las últimas décadas. Por ello, la aplicación de su tecnología en lo relativo a la identificación humana, se ha hecho extensiva a todo tipo de controversias jurídicas relacionadas con la filiación, como por ejemplo: en los casos de violación para determinar la posible paternidad del demandado, aun durante la gestación; en los supuestos de cambios de menores verificados en los hospitales; en los juicios de derecho sucesorio mortis causa luego del fallecimiento del de cujus; para determinar el posible vínculo filial de aquellos supuestos descendientes que argumentan haber nacido a través de cualquier técnica de fecundación asistida. ${ }^{351}$

La utilidad de la prueba de compatibilidad inmunogenética en todos esos procedimientos se debe a su complejidad, porque su práctica aglutina los métodos de laboratorio más modernos y complejos para la identificación de personas. En este sentido, cabe destacar que se compone de cuatro partes fundamentales:

A. Determinación de los grupos sanguíneos eritrocitarios y los subgrupos (prueba hematológica clásica)

B. Determinación de los antígenos humanos, leucocitarios o antígenos del sistema HLA.

\footnotetext{
${ }^{351}$ VERUNO, L; y HAAS EMILIO; op cit. p. 10
} 
C. Determinación de las proteínas del suero sanguíneo, es decir, de las proteínas séricas, como por ejemplo: las inmunoglobinas, transferinas, haptoglobinas, entre otras;

D. Determinación de los alelos de las enzimas, también ubicadas en el suero sanguíneo o dentro de las células, como la glioxalasa y la fosfoglucomutasa. ${ }^{352}$

Cada una de estas cuatro partes de que se compone la prueba de compatibilidad inmunogenética, es desarrollada en forma separada haciendo especial referencia a la exclusión o inclusión del nexo filial controvertido. En particular, el mayor peso de esta pericia, se encuentra en su segundo apartado relativo a la determinación de los antígenos HLA, porque estos tienen por sí mismos un poder de exclusión de aproximadamente el 90\% y de inclusión cercano al $100 \%{ }^{353}$

La certeza de la prueba de compatibilidad inmunogenética está relacionada con el hecho de que cada marcador genético, es analizado bajo la óptica de alguna de las cuatro partes integrantes de la misma, evitando la duplicidad de errores.

En la actualidad, la comunidad científica admite dentro de los medios probatorios más concluyentes para el diagnóstico del vínculo filial de un individuo con cualquiera de sus progenitores, las pruebas de compatibilidad inmunogenética, el sistema HLA, el cual a su vez forma parte de aquella; y la del ADN o de la identificación de personas a través del ácido desoxirribonucleico. ${ }^{354}$

\footnotetext{
352 Ídem p. 17

353 Ibídem pp. 17 y 26

${ }^{354}$ PATITO; José Antonio; op cit. p. 14
} 
Sin embargo, la misma comunidad científica ha destacado que ocasionalmente debe preferirse la prueba de compatibilidad inmunogenética, porque aun cuando raras veces se ha evidenciado, existen ciertas alteraciones o particularidades morfológicas de los cromosomas, que no siempre se transmiten verticalmente de progenitores a descendientes, obstaculizando este hecho la conclusión con certeza del vínculo filial controvertido, a través del estudio del ADN. En estos casos, las circunstancias descritas no son relevantes para la prueba de compatibilidad inmunogenética, pues ésta aunque no toma en cuenta el número, la morfología, ni las características cromosómicas del individuo, puede aportar resultados conclusivos respecto de ese vínculo filial controvertido.

Por otra parte, cabe destacar que la prueba de compatibilidad inmunogenética, sólo requiere de una simple extracción de sangre equivalente a cualquier extracción indicada para los análisis comunes de laboratorio bioquímico, es decir, una muestra inocua, indolora, no invasora y no traumática. Esto es, se trata de una nueva prueba hematológica, cuyo objeto es determinar la mayor cantidad posible de marcadores biológicos, para llegar a un diagnóstico de asignación de la filiación con una certeza aproximada del 98 o 99\%.

Su práctica evidentemente se lleva a cabo a través de los procedimientos de laboratorio altamente sofisticados, que como ya señalé, tiene por objeto determinar la mayor cantidad posible de marcadores biológicos. Una vez logrados éstos, se inicia el proceso de manejo de información para obtener los valores matemáticos, con los cuales se podrá precisar si el individuo queda o no excluido del vínculo biológico analizado. En el caso de deducirse la no exclusión, deberá precisarse también de manera porcentual, el grado de inclusión de dicho vínculo biológico. ${ }^{355}$

\footnotetext{
${ }^{355}$ CHIERI PRIMAROSA y ZANNONI, Eduardo; op cit p. 86. En el mismo sentido VERRUNO, Luis y
} ZANNONI, Eduardo, op cit. 13 y 45 
La inclusión del vínculo biológico es precisamente el aspecto más relevante de la prueba de compatibilidad inmunogenética, ya que este resultado como se veía, no puede ser obtenido con certeza absoluta a través de otros medios probatorios ya analizados; como la prueba hematológica, la maduración fetal, la antropológica o heredobiológica, método de Kühne o prueba morfológica de la columna vertebral, pues todas ellas necesariamente deben complementarse con otros medios probatorios científicos más concluyentes, como son: el sistema HLA, la prueba de compatibilidad inmunogenética o la prueba de ADN o de la identificación de personas a través del ácido desoxirribonucléico,

En particular, la inclusión del vínculo filial analizado en la prueba de compatibilidad inmunogenética es un fenómeno que dependerá de dos factores, primero, de la no exclusión de una persona como padre o madre biológica del descendiente en cuestión, y en segundo lugar, de los valores acumulados en cada grupo de marcadores genéticos estudiados. Así, a partir de esos dos aspectos, será posible determinar la inclusión, pero siempre y cuando el índice de paternidad o maternidad sea del $95 \%$ o mayor. ${ }^{356}$

En otro orden de ideas, es preciso destacar que aun cuando la aceptación científica de la prueba de compatibilidad inmunogenética está determinado por su teoría genética y por la aportación de los altos porcentajes de exclusión e inclusión del nexo filial controvertido, su aplicación práctica no deja de presentar los mismos inconvenientes señalados en el caso del sistema HLA, es decir, la ineludible necesidad de recurrir a peritos y laboratorios altamente especializados, y en el aspecto económico, su elevada cuantía, por el uso de sueros, antisueros y reactivos especiales, difíciles de obtener y normalmente utilizados por duplicado o triplicado.

356 Ídem p. 66 


\subsubsection{Prueba de ADN o de la Identificación de personas a través} del ácido desoxirribonucleico

Desde hace varios años las pruebas de ADN han representado el método más revolucionario de identificación de personas

en el ámbito del Derecho penal para los casos de homicidios, violaciones y otras acciones delictivas. En la actualidad, su aceptación no se restringe únicamente a ese campo, pues su aplicación también tiene lugar en los juicios de filiación, cuyo objetivo es el esclarecimiento del vínculo biológico controvertido entre progenitores y descendientes. ${ }^{357}$

Para poder entender qué es el ácido desoxirribonucleico, y por ende, la prueba de $\mathrm{ADN}$ o de la identificación de personas a través del ácido desoxirribonucleico, es esencial abordar algunas cuestiones médicas. Por ello, se iniciará la exposición de este medio probatorio con una explicación simple del sistema celular humano.

La célula ha sido considerada la más pequeña unidad estructural y funcional de cualquier organismo vivo, pues según el postulado de la teoría celular enunciada por VIRGHOW en 1855, “toda célula procede de otra célula”, en el caso del ser humano, todas las células surgen de una inicial denominada cigoto, el cual se forma a partir de la unión del óvulo de la madre y el espermatozoide del padre. De esta fusión, precisamente se conforma la información genética única de cada individuo, porque el óvulo y el espermatozoide aportan la mitad al nuevo ser, las informaciones genéticas de cada uno de los progenitores. ${ }^{358}$

\footnotetext{
${ }^{357}$ METER, TAK; "Le test ADN et la procédure pénale en Europe”. Revue de Science Criminelle et de Droit Pénal Comparé, France, Ed Virrey No. 4, Trimestrielle, Octubre - Décembre, 1993 p. 681.

${ }^{358}$ CHERI PRIMAROSA y ZANNONI Eduardo; op cit pp. 1 y 4
} 
A su vez, la información genética contenida en la primera célula o cigoto, es heredada a cada una de las células que se van desarrollando en el nuevo individuo, conformándose todo el sistema celular del feto con el mismo material genético. En particular, esa información genética, se encuentra en el ácido desoxirribonucleico (ADN) de los cromosomas de cada célula del organismo. $^{359}$

A este respecto, cabe destacar que cada ser humano posee en cada una de sus células nucleadas 46 cromosomas, los cromosomas contienen en su estructura la sustancia química de alto peso molecular, denominada ácido desoxirribonucleico (ADN), en la cual como ya dije se contiene toda la información genética transmitida por los progenitores. De los 46 cromosomas, 44 son llamados autosómicos o somáticos, y se encargan de todas las funciones no sexuales del individuo, los cromosomas restantes $\mathrm{X}$ e $\mathrm{Y}$ son los cromosomas sexuales, y diferencian a mujeres $(\mathrm{XX})$ de hombres $(\mathrm{XY}) .{ }^{360}$

Así mismo, el conjunto de cromosomas de cada célula (46) se denomina cariotipo, es decir, las características genéticas heredadas de progenitores a descendientes siguiendo las leyes de MENDEL, pues dichos cromosomas conforman 23 pares, su ordenamiento en pares se debe al origen paterno y materno de cada par. Hasta este momento, es posible comprender la prueba de exclusión de la filiación: Todo material genético de un descendiente que no esté representado en uno de los progenitores, deberá estar obligatoriamente presente en el otro. ${ }^{361}$

Por otra parte, la porción de la molécula de ADN del cromosoma que codifica un determinado carácter, como por ejemplo el grupo sanguíneo A o la

\footnotetext{
359 îdem pp. 4 y 5

${ }^{360}$ CHIERI PRIMAROSA y ZANNONI Eduardo; op cit P. 14

${ }^{361}$ VERUNO Luis y HAAS Emilio; op. cit. p. 14
} 
producción de una determinada proteína, se denomina gen. Cada cromosoma contiene aproximadamente 60,000 genes, y que existen tantos genes como características genéticas. El conjunto de genes de un individuo se denomina genotipo. A su vez, el genotipo se divide en dos partes llamadas haplotipos, es decir, de dos mitades, una paterna y una materna, pues todo individuo se compone de un haplotipo paterno y otro materno. ${ }^{362}$

Sin embargo, como la herencia es doble, no siempre el producto directo del gen es visible, por ejemplo, si un grupo de genes paternos codifica el color de los ojos indicando “ojos negros”, y un tipo de genes maternos indica “ojos verdes”, no es frecuente tener un ojo de cada color, el resultado de la combinación de ambos grupos de genes, puede dar lugar a ojos marrones en el individuo. Por lo tanto "color negro” y “color verde” son las características del genotipo, pero “ojos marrones” es la expresión visible de la combinación de ambos grupos de genes, es el llamado fenotipo, es decir, la expresión de caracteres aparentes de tipo morfológico, bioquímico o funcional del genotipo, que permiten reconocer a un individuo. ${ }^{363}$

Los genes se expresan en el fenotipo de tres formas, como genes dominantes, recesivos y condominantes. Estos últimos, son los que especialmente interesan en las pruebas científicas de la filiación, porque son los genes aportados por cada uno de los progenitores y expresados ambos en el fenotipo, es decir, son genes específicos de cada individuo heredados por sus ascendientes.

En el caso particular de la prueba de $\mathrm{ADN}$, la materia genética está codificada aproximadamente en tres mil millones de pares básicos de ADN, los

\footnotetext{
362 Ibìdem pp. 15

${ }^{363}$ Ibìdem pp. 22 y 220
} 
cuales son iguales de individuo a individuo, por eso tenemos dos orejas, una nariz, dos ojos, es decir, son las características comunes entre todos los seres humanos. Esos pares básicos que compartimos se denominan monomórficos, el resto del ADN calculado en aproximadamente tres millones de pares básicos, son significativamente distintos de un individuo a otro $y$ se conocen como polimórficos. $^{364}$

Por eso la prueba de ADN consistirá exclusivamente en el análisis de los fragmentos polimórficos del ADN, a través de complejos procedimientos de laboratorio, en los cuales primero se rompe el núcleo celular para extraer la molécula del ADN, una vez extraída se separa en dos barras paralelas, y se corta selectivamente con el uso de unas sustancias conocidas como enzimas de restricción. Los fragmentos así obtenidos se colocan en una base gelatinosa a la que se aplican corrientes eléctricas, después se les transfiere a una membrana de nylon o nitrocelulosa para el procedimiento de hibridación. ${ }^{365}$

Enseguida, la membrana de nylon se coloca contra la película de rayos $\mathrm{X}$ para la toma de la radiografía respectiva, a la cual se le conoce con el nombre de autoradiografía. En ella deben aparecer mediante bandas negras el patrón de los marcadores polimórficos del ADN analizados. Este procedimiento, debe realizarse a cada uno de los progenitores y al descendiente, a efecto de comparar las distintas autoradiografías.

Como cada una de las autoradiografìas contiene el análisis de los fragmentos polimórficos del ADN, de cada una de las personas a quienes se les practicó la prueba, dichas autoradiografías constituyen la huella personal de esos

\footnotetext{
364 COSTAS LUGO Carolyn; "Las pruebas del ADN y su justo valor probatorio”; Revista de Derecho Puertorriqueño; Puerto Rico, Publicación de la Facultad de Derecho de la Pontificia Universidad Católica de Puerto Rico; Vol. 37 No. 2 y 3, mayo - diciembre de 1998, p. 382

${ }^{365}$ PATITO, José Ángel; op cit. p. 286
} 
individuos, y por eso la comparación de las mismas tiene por objeto determinar los emparejamientos de las bandas negras en ellas contenidas, de acuerdo con las leyes mendelianas de la herencia, partiendo de que todo marcador genético presente en el hijo (a), si no proviene de la madre obligatoriamente debe provenir del padre. ${ }^{366}$

Normalmente, primero se compara la autoradiografía del descendiente con la madre, para determinar las bandas comunes entre ellos, las cuales se denominarán bandas maternas, las restantes serán bandas paternas y deberán compararse con la autoradiografìa del padre. Si de la comparación resulta el emparejamiento entre ellas, no se reputará automáticamente la paternidad, pues deberá calcularse la frecuencia de ese emparejamiento, utilizando para ello tablas preestablecidas, mediante las que se precisará el porcentaje de correlación de los alelos entre el progenitor y el descendiente.

Del emparejamiento de cada alelo provee una evidencia estadística independiente, por eso deberán calcularse la cantidad y frecuencia de los alelos emparejados, pues mientras más correlación de estos exista entre el descendiente y el progenitor, cuyo vínculo filial con aquél sea controvertido, mayor es la probabilidad del vínculo filiatorio. ${ }^{367}$

La contundencia de los resultados de la tecnología del ADN, estriba en dos cuestiones fundamentales: la primera, es la forma como la misma hace posible invididualizar a los seres humanos con gran precisión, basándose en la identificación de la cadena compuesta por cuatro pares de bloques químicos, como son: la adenina, timina, citosina y guanina, cuya unión da lugar a largas secuencias con combinaciones y localizaciones variables para cada persona,

\footnotetext{
${ }^{366}$ CHIERI PRIMAROSA y ZANNONI Eduardo; op cit p. 74

${ }^{367}$ İdem op cit. p. 91
} 
permitiendo con ello determinar la huella dactilar química, denominada comúnmente genetic fingerprint ${ }^{368}$

La segunda es la manera como se determina la inclusión del vínculo filial controvertido, porque éste se diagnostica a través de la comparación de las autoradiografías de los ascendientes y descendientes, según las leyes mendelianas de la herencia, permitiendo dicho diagnóstico la obtención de dos resultados: cuando del examen genético se deduce una probabilidad de paternidad de 95 a 97.9\%, el nexo filial analizado no será considerado contundente, mientras si la probabilidad de paternidad es del $98 \%$ en adelante, se considerará irrefutable.

Sin embargo, su valor médico legal está condicionado a varios aspectos, como son: la selección y conservación de las muestras; la implementación metodológica del estudio de los polimorfismos; y la interpretación de los resultados. ${ }^{369}$

La selección y conservación de las muestras es una de las cuestiones más relevantes y ventajosas de esta prueba en el ámbito de la medicina legal, pues como la molécula del ADN es muy estable, permite rastrear sus polimorfismos en casi cualquier tipo de muestra biológica, en la que se contenga material genético medianamente conservado, porque comúnmente las muestras sobre las cuales se debe investigar en esta disciplina, son de muy diversa procedencia, y no siempre suelen ser las de mejor calidad, sino las posibles, e incluso, las únicas.

\footnotetext{
${ }^{368}$ ALVA RODRÍGUEZ, Mario; "El ADN su caracterización y utilidad en la investigación Criminalística y médico forense”. Criminalia; México; Ed. Porrúa Año LVII, No. 1-12 Enero - diciembre de 1991. ${ }^{369}$ PATITO, José Ángel; op cit. p. 389
} 
Así, las muestras para practicar la prueba del ADN pueden provenir de material cadavérico, extracción de sangre, orina, hisopados de cavidades vaginal, rectal o bucal, manchas orgánicas de sangre o semen en prendas, telas, tapizados, papeles u otras superficies. En el caso particular de los juicios de filiación, normalmente las muestras aportadas al perito suelen ser la sangre o los hisopados bucales. $^{370}$

Cuando las muestras aportadas consisten en sangre, es preciso la punción venosa de aproximadamente $10 \mathrm{ml}$ de líquido sanguíneo, a cada una de las personas a quienes se debe practicar la prueba, es decir, a ambos progenitores y al descendiente, aunque si éste es mejor esa cantidad puede ser reducida. Además, la sangre extraída necesariamente debe ser anticoagulada con un anticoagulante especial denominado EDTA, el cual deberá suministrarse a la muestra en un 5\%. En cuanto a los hisopados bucales, estos constituyen hoy en día la muestra más frecuente y aceptada para la práctica de la prueba de ADN en los juicios de filiación. Su objetivo es la obtención de miles de células de la mucosa bucal, en cuyo contenido se encuentra la cantidad necesaria de ADN, para la determinación de un vínculo filiatorio controvertido, o la identificación de un individuo, con el mismo grado de certeza que el de la sangre. ${ }^{371}$

La recolección de la muestra de la mucosa bucal consiste en la extracción de la mayor cantidad posible de exudado de la cavidad bucal a través de simples hisopos de algodón. Una vez tomada la muestra, es preferible dejar secar al aire los hisopos, antes de introducirlos en el tubo de ensayo correspondiente, previniendo con ello su degradación, pues su preservación es un punto crucial para la práctica de la prueba. ${ }^{372}$

\footnotetext{
${ }^{370}$ CHIERI PRIMAROSA y ZANNONI, Eduardo; op cit; pp. 26 y 207

${ }^{371}$ Ìdem p. 207

${ }^{372}$ PATITO, José Ángel; op cit. p. 283
} 
La especial aceptación de las muestras de los hisopados bucales en los juicios de filiación se debe a que su recolección es fácil y simple, pues sólo toma unos minutos la obtención del exudado bucal requerido, a través de un suave raspado de la parte interna de la mejilla, debiendo utilizarse en ese procedimiento un total de cuatro a ocho hisopos por persona. Además, no se trata de un método invasivo, porque no es necesario la punción de la piel con agujas, evitando traumatismos e infecciones, particularmente en los recién nacidos.

Pero como ya había señalado, además de esta selección y conservación de las muestras, el valor médico legal de la prueba del ADN esta condicionado también a otros dos aspectos: la implementación metodológica del estudio de los polimorfismos y la interpretación de los resultados obtenidos a través de su práctica.

Evidentemente ambos aspectos, están íntimamente relacionados con la especialización de los laboratorios y la idoneidad de los profesionales que la llevan a cabo. Por eso, es necesaria la evaluación judicial de ambas cuestiones, mediante el mismo dictamen pericial y la debida actualización de los jueces en esta materia de las pruebas científicas de la filiación.

Este medio probatorio, constituye hoy en día, uno de los más seguros y relativamente sencillos para la determinación científica de la filiación, porque partiendo de la comparación del ADN de las células del descendiente y de los presuntos ascendientes, puede saberse con absoluta seguridad, si existe o no la relación consanguínea de parentesco, pues la posibilidad de que dos seres humanos tengan la misma huella dactilar del ADN es de 1 en 3 billones ${ }^{373}$

${ }^{373}$ QUIROZ CUARON, Alfonso; Medicina forense, 8ª ed.; Ed. Porrúa, México; 2006, p. 656 


\subsection{La prueba biológica como un derecho constitucional}

La genética como un área científica actual, viene a prestar una gran ayuda al Derecho en nuestras épocas, y muy en particular en la identificación personal la cual es determinante y sin precedentes ${ }^{374}$

La identificación de las personas mediante técnicas genéticas no es utilizada sólo en el Derecho procesal civil para los procesos de filiación sino en otras ámbitos del Derecho, con en el caso del Derecho procesal penal, en la determinación del autor de algún delito o la revisión de algún delito que permita la liberación de condenados ${ }^{375}$; el Derecho mercantil, en los casos de seguros de enfermedad y muerte; el Derecho internacional en los procedimientos de inmigración.

Asimismo, como refiere Aída KEMELMAJER, “el derecho constitucional no es ajeno a la cuestión porque están involucrados el derecho a la identidad personal, a la intimidad, a la disposición del propio cuerpo, etcétera” ${ }^{376}$. De acuerdo a esto, podemos establecer la relación o implicación jurídica de las pruebas genéticas con la Constitución.

\footnotetext{
${ }^{374}$ El ADN es "el elemento de prueba forense más poderoso y preciso que jamás se haya creado" (William SESSIONS, Director de la Brigada de investigación Criminal del FBI, 20 de febrero de 1989) Cit. STEPHAN, Robert Y. “Genética y culpabilidad: ¿quién paga el precio?” en El derecho ante el proyecto de genoma. p. 231

${ }^{375}$ Un informe sobre la pena de muerte en Estados unidos, indica que las pruebas de ADN han revelado errores en el caso de 69 condenados a la pena capital, que han tenido que ser puestos en libertad al habérseles atribuido erróneamente una responsabilidad penal. Tal es el caso de Ronald Jones, condenado en 1989 por violación y asesinato, habiendo revelado un análisis de ADN que el semen encontrado en el cuerpo de la víctima no correspondía en nada al próximo ejecutado; las pruebas genéticas prueban que hay muchos inocentes en espera de ser ejecutados. Cfr. "ADN prueba que hay inocentes que esperan ejecución en los EE UU”, en El Comercio, Lima, 17 de julio de 1997, sección B, p.1.

${ }^{376}$ KEMELMAJER DE CARLUCCI, Aída; “El valor de la prueba genética en el derecho argentino”, p. 173.
} 


\subsubsection{Afectación de los derechos fundamentales}

El hecho de requerirse la voluntad aquiescente para la práctica de las pruebas biológicas plantea un conflicto que puede afectar, como se verá en el último capitulo, los derechos fundamentales de la persona si no existe una voluntad o se niega su práctica. De ahí que se haya cuestionado, e incluso negado, la constitucionalidad de las pruebas. ${ }^{377}$

En efecto, la aplicación de las pruebas biogenéticas puede determinar una vulneración a los derechos personales del analizado, constituyendo una duda acerca de su legalidad constitucional.

Linda LIESEN nos dice que los dilemas básicos en cuanto a la aplicación de estas pruebas son:

\section{Protección de:}

Autonomía

Dignidad humana

Intimidad

Equidad

Justicia

\section{Protección contra:}

Coerción y compulsión

Una visión de la vida reduccionista

Control Social

Discriminación

Estigmatización

Tanto en la doctrina como en la jurisprudencia sobre la aplicación de pruebas biológicas, se ha argumentado que su uso ocasionaría la afectación de derechos fundamentales como la libertad personal o autodeterminación, la objeción de conciencia, la dignidad, la intimidad, la integridad, la igualdad, el

377 EGÚSQUIZA BALMASEDA, Ma. Ángeles; "El Papel jurídico de las pruebas biológicas yt la negativa a su sometimiento en la investigación de la paternidad” I; en Revista de Derecho y Genoma humano; Bilbao, Universidad de Deusto, 1994, No. 1, p. 207. 
honor, a no declarar contra sí mismo y hasta la primacía de la presunción de inocencia frente a la inspección corporal y el derecho a la tutela judicial efectiva.

El hecho está en que nadie puede ampararse en la ley ni refugiarse en sus derechos para negarse a rendir una prueba, si está de por medio un interés digno y un derecho superior como es el de la identidad de un menor. Éste ha sido el criterio unánime del Tribunal Constitucional Español, que en la sentencia de 19 de enero de 1994, determinó la prevalencia de los derechos del hijo frente a los del progenitor. ${ }^{378}$

\subsubsection{Principio de libertad de investigación de la paternidad}

Las pruebas biológicas no están prohibidas por la Constitución, sin embargo tampoco son reconocidas expresamente por la misma, como es el caso de otras Constituciones, al disponerlas implícitamente como una exigencia de aplicación en los procesos judiciales a fin de hacer factible el principio de libre investigación de la paternidad.

Como se ha indicado, tanto la Constitución española como la mexicana, han otorgado implícitamente el derecho a la libertad de la investigación de paternidad, en leyes ordinarias y apegadas a los tratados internacionales, aunque dándoles indirectamente vigor constitucional, con el apoyo de la jurisprudencia.

\footnotetext{
${ }^{378}$ LLEDO YAGÜE, Francisco; “La paternidad forzada: a propósito de la reciente sentencia del Tribunal constitucional del 19 de enero de 1994”, en Revista de Derecho y Genoma humano; Bilbao, Universidad de Deusto, 1994, No. 1, p. 207.
} 


\subsubsection{Efectividad de la prueba biológica}

Por motivos históricos o de desconocimiento se tiene la errónea idea de que la exclusión de la paternidad es una cuestión absoluta y clara, mientras que la prueba positiva se sumerge en el tenebroso mar de las probabilidades y se piensa que debe ser valorada con cautela.

Debe aclararse que tanto la prueba negativa como la positiva son igualmente seguras y sus resultados son incontrovertibles, pero, como toda prueba, poseen un margen de error que es calculable.

En este sentido, podemos ver que la legalidad y validez de las pruebas biológicas así como la valoración y aplicación de sus resultados en lo referente a este punto, no merecen mayor problema y no son contrarios a las normas constitucionales del debido proceso.

Dicho lo anterior; podemos decir que la filiación, identidad y paternidad no son conceptos exclusivos del Derecho civil, son también de interés constitucional al establecer vínculos jurídicos de protección al sujeto de derecho y, en especial a la niñez.

Los Códigos Civiles establecen que la determinación de la filiación se sustenta en presunciones expresas que permiten su investigación judicial, como supuestos cotidianos, estas presunciones no agotan todas las posibilidades en que se puede indagar el nexo parental, restringiendo el legítimo interés natural de actuar en defensa del reconocimiento de nuestro derecho a la identidad. Así, el sistema mexicano tiende al establecimiento de una filiación social antes que una filiación biológica; no así la legislación española, la cual le da el valor justo a la prueba biológica. 
De lo anterior, es claro que la ley mexicana no brinda una regulación adecuada a la filiación, ya que llega a contraponerse a los tratados internacionales, al aplicar conceptos que retienen el conocimiento de la verdad biológica y superior del menor. Sin embargo, la omisión o deficiencia de las normas no pueden dejar sin amparo jurídico al hijo cuando existen otros indicios suficientes para probar la paternidad.

\subsection{Naturaleza jurídica de las pruebas heredobiológicas}

Mucho se ha discutido acerca de la naturaleza jurídica de las pruebas biomédicas. Se ha alegado, por un lado, su característica pericial sui generis y, por otro, el modo de aplicación puramente técnica de la cual que las caracteriza.

La doctrina y la jurisprudencia española específicamente desde las sentencias del Tribunal Supremo de 5 de noviembre de 1987, 21 de abril de 1988, 2 de febrero de 1991, 26 de febrero de 1992, 8 de octubre de 1993, han señalado que este tipo de pruebas tienen un carácter pericial. En el caso español y por ende el mexicano, la pericia es un medio para la obtención de elementos probatorios que establezcan los hechos controvertidos en el juicio. El dictamen pericial en ningún momento podrá obligar al juez, quien está facultado a valorarlo de acuerdo con reglas de apreciación. De esta manera, la jurisprudencia española de las fechas antes citadas, ha determinado que el "juez posee plena libertad en la estimación de las pruebas periciales, de conformidad con los criterios que dictan las máximas de la experiencia y la sana crítica”379

\footnotetext{
${ }^{379}$ STS 07 de febrero de 1986 y 2 de enero de 1991, Cfr. EGUSQUIZA BALMASEDA, María Ángeles; "El papel jurídico de las pruebas biológicas y la negativa a su sometimiento en la investigación de la paternidad” en Revista de Derecho y Genoma-Humano, Bilbao, Universidad de Deusto No. 2, 1995, p. 49 nota 66 .
} 
La experiencia genética de investigación de paternidad no tiene un lugar específico dentro de la clasificación procesal de las pruebas, sin embargo mucho tiene que ver con la pericia por el hecho de ser realizada por terceros que gozan de conocimientos científicos, solvencia moral, ajenos al litigio y porque esclarecen al juzgador su razonamiento sobre puntos técnicos. Es por ello que “... las pruebas biológicas constituyen un medio de prueba legítimo en el proceso sobre la investigación de la paternidad", tal como se ha manifestado en la Sentencia del Tribunal Supremo de 18 de mayo de 1994, aplicándosele los principios periciales.

Ubicada la prueba heredobiológica dentro del ámbito pericial surge otro problema: la libre apreciación valorativa que hará el juez de ésta de acuerdo con su naturaleza. La afirmación que antecede no puede aplicarse con todo rigor a este tipo de pruebas biomédicas, ya que si bien los expertos (genetistas, hematólogos, biólogos, etcétera) no son quienes dirimirán el resultado de la controversia judicial con el informe que presente, éste deberá ser valorado jurídicamente de acuerdo con su carácter netamente científico y técnico, en concordancia con las demás pruebas actuadas. ${ }^{380}$

El juzgador no puede reemplazar al técnico especializado e incursionar en un terreno tan espinoso, como es la transmisibilidad de los marcadores genéticos de generación en generación, desestimando los principios biológicos en los cuales se sustenta el informe pericial. Sin duda alguna, la palabra del especialista que interviene en estas pruebas no puede ser considerada

\footnotetext{
${ }^{380}$ En la opinión de EGUSQUIZA BALMASEDA, “... las pruebas biológicas son un medio probatorio más, que el juez valorará a fin de alcanzar la convicción necesaria sobre la filiación que se cuestione. Sólo la contundencia técnica acerca de la verdad biológica le confiere a las pruebas biológicas su singular relevancia, por ello, aún siendo medios probatorios de igual entidad que los demás, su práctica reviste un especial interés ya portan datos insustituibles”, Op cit, p. 79
} 
absolutamente determinante, pero tampoco podemos negarle que en gran medida lo es. $^{381}$

FAIREN GUILLÉN ${ }^{382}$ considera el caso de la legislación alemana, en la cual los peritos que intervienen en estas pruebas constituyen un caso de representación del juez, quien no puede realizar las investigaciones por carecer de conocimientos técnicos y llegar a un resultado efectivo, por lo tanto, se trata de una relación entre la prueba pericial y la de reconocimiento judicial, ya que a pesar de la independencia del juez con respecto a los dictámenes periciales, no es factible que a través de comparaciones llevadas a cabo por él o en vista de resultados parciales del referido dictamen, llegue a una conclusión global opuesta a la de los peritos.

Por otro lado, menciona que el perito constituye un auxiliar del juez que suministra a aquél un dictamen científicamente razonado, con un índice de certeza en la exclusión de la paternidad al 100\% y de fiabilidad sobre ésta del 99.99\%. Estas razones conducen a que sea forzoso ligar al juez o por lo menos impedirle que extraiga fundamentos parciales del dictamen o consecuencias distintas de aquéllas a las que el perito llegó ${ }^{383}$.

Efectivamente, la técnica genética se convierte en una prueba de indiscutible valor en la decisión judicial, con ella se demuestra de manera biológica quién es el padre o, en su caso, quién no puede serlo; lo que producirá

\footnotetext{
${ }^{381}$ Con criterio igual NOGUEIRA, Paulo, nos dice que la prueba hematológica, cuando excluye el vínculo, tiene valor perentorio y absoluto, no pudiendo el juez decidir contra ella, fijando su decisión vinculada a la pericia, dispensando la actuación de pruebas en la audiencia y juzgando anticipadamente.

${ }^{382}$ FAIREN GUILLEN, Víctor; "La investigación biológica de la paternidad y su valor desde el punto de vista procesal”, en Anuario de Derecho Civil, Madrid, Ministerio de Justicia e Interior, julio - septiembre 1950, tomo III, fasc. III, p. 647

${ }^{383}$ FAIREN GUILLEN, Víctor; Op cit, p. 654
} 
de inmediato una valoración absoluta del resultado, determinante al momento de expedir sentencia. $^{384}$

Jurídicamente, resulta forzada la valoración y vinculación judicial de la prueba genética en los juicios de investigación paternal. Debemos considerar las leyes biológicas y principios genéticos en los cuales se sustenta la prueba heredobiológica de paternidad y relacionarlos con lo poco coherente que resulta la valoración subjetiva que otorga nuestra ley procesal a las pericias en general, sin hacer la distinción o clasificación que requieren estos tipos de investigación técnico científicas.

Con ello, la función judicial no verá mermada su participación directa en la valoración y apreciación de la prueba, muy por el contrario, esto significará desechar esa probanza judicial en los resultados de las pruebas heredobiológicas, suministrando una excelente arma probatoria en los controvertidos juicios de filiación.

Es necesario otorgar a la prueba biogenética de paternidad una regulación acorde con sus características, a fin de contar con un medio de prueba eficaz para resolver los problemas de paternidad discutida.

Dada la eficacia en sus resultados, y a sus especiales características, se llegó a determinar que la prueba hereditaria de paternidad era atípica, es decir, estando considerada expresamente en la legislación procesal civil, debía ser aplicada de manera especial, pero ello no es así, pues el medio probatorio atípico

\footnotetext{
${ }^{384}$ En estos casos, el juez tiene mayor deber de precisión para valorar libre y ampliamente los medios de prueba, independientemente de su valor probatorio, el criterio dictaminador del juez se ceñirá a la certeza y eficacia de la prueba, pero será él quien juzgue conveniente según su correcto y leal entender, el resultado obtenido, para ello no sólo será exiguo mencionar la existencia de una novísima prueba, sino que será necesario agotar jurídica y técnicamente su esencia con el objetivo de obtener la comprobación judicial deseada.
} 
es el que sirve para lograr la finalidad de los medios probatorios a través de auxilios técnicos o científicos. En este sentido no es una prueba atípica, en todo caso lo sería el informe que un tercero realice sobre la prueba en sí, analizando su resultado o comparándola con los principios científicos.

\subsubsection{Prueba ordinaria}

Concretamente, las pruebas biopaternales son de aplicación ordinaria o común, es decir, no son obligatorias ${ }^{385}$, su utilización no es necesaria, exclusiva o preferente, podemos prescindir de ellas ${ }^{386}$, pues la investigación filial implica un análisis amplio de todas las pruebas existentes, agotándose los medios necesarios.

La biologización judicial de la paternidad no debe tomarse como premisa fundamental ni única. Por sobre todo, estas pruebas deben orientarse, y así utilizarse, al hecho principal.

\footnotetext{
385 "Solo cuando las mismas no entrañen riesgo o quebranto para la salud del sujeto o bien no quepa extraerse evidencias de paternidad mediante otros medios probatorios, la práctica de la prueba biológica resultará obligatoria, así ha sido establecido por la STC 7/1994, de 17 de enero: -Una vez decidido por el juzgado que es preciso realizar la prueba biológica porque no puede obtenerse la evidencia de la paternidad a través de otros medios probatorios, el afectado está obligado a posibilitar su práctica. No sólo por deberes elementales de buena fe y de lealtad procesal, y de prestar la colaboración requerida por los Tribunales en el curso del proceso, (art. $118 \mathrm{CE}$ ), sino por el deber que impone la Constitución a todos los ciudadanos de velar por sus hijos menores, sean procreados dentro o fuera del matrimonio (art. 39.3 CE) deber que puede verse defraudado cuando se niega la paternidad sin razón, con el sólo objeto de eludir las responsabilidades y obligaciones derivadas de la misma”. Cfr. EGÚZQUIZA BALMASEDA, María Ángeles, Op. Cit., P. 46 nota 57.

386 "Sólo en el caso de que el juez tenga el convencimiento acreditado por otros medios probatorios de la paternidad, podrá prescindirse de ese tipo probatorio (...) se intenta que el juez adquiera la convicción más plena sobre la veracidad de la paternidad, en la que los criterios objetivos proporcionados por las pruebas biológicas pueden resultar en todo punto fundamentales” STS 7/1994 de 17 de enero.
} 


\subsubsection{Prueba extraordinaria}

La jurisprudencia italiana ${ }^{387}$ ha determinado que la prueba bioparental tiene carácter extraordinario, en otras palabras, es practicable sólo cuando el juez no puede alcanzar de otro medio su convencimiento directo. En todo caso, se presenta como excepcional. Este criterio es limitativo, ya que restringe a los tribunales de una de las herramientas de convicción más certeras en la determinación de la paternidad.

Debemos aclarar que la utilización de este tipo de pruebas es especial, lo que implicaría que éstas no deben ser llevadas a cabo en forma indiscriminada. Su admisibilidad depende de la cautela integral de los derechos que corresponden a los sujetos intervinientes.

Será esencial recurrir a las biopruebas en los supuestos en los que exista prueba preliminar o suficiente (principio de prueba) para admitir la demanda, pero será insuficiente por sí sola para acreditar la paternidad. ${ }^{388}$

Esto ha sido consagrado en el caso argentino, en la Ley 23.511 denominada Ley de Banco de Datos Genéticos, que en su artículo 4 expresa que cuando fuese necesario determinar en juicio de filiación de una persona y la pretensión apareciese como verosímil o razonable se practicará el examen genético.

\footnotetext{
${ }^{387}$ Sentencia de la Corte di Cassazione, 2 de marzo de 1976 y 4 de marzo de 1960, Crf. LLEDÓ YAGÜE, Francisco, "Las pruebas biológicas en los procesos de paternidad" en La Ley, Buenos Aires, 1986, p. 1075 notas 2 y 4

${ }^{388}$ En tal sentido la STC 7/1994 de 17 de enero nos dice que: "En estos casos supuestos intermedios, en donde la pretensión de reconocimiento de la filiación resulta probada por otros medios, ni parce huérfana de toda verosimilitud, es donde la práctica de la prueba biológica resulta esencial. En esta hipótesis, constatada judicialmente al acordar la práctica del reconocimiento biológico en la fase probatoria del proceso, no es ilícito, desde la perspectiva del art. 24.1, 14 y 39 de la Constitución Española, que la negativa de una persona a que se extraigan unos centímetros cúbicos de sangre deje sin la prueba más fiable a la decisión judicial que debe declarar la filiación de un hijo no matrimonial, y deje sin una prueba decisiva a quien insta de buena fe el reconocimiento de la filiación”.
} 
Esto serviría como un medio de salvaguardar el derecho de todo ciudadano a no verse sometido a reconocimientos de carácter biológico a causa de demandas frívolas o torticeras. ${ }^{389}$

Lo anteriormente dicho nos lleva directamente al principio de la prueba, y el cual se sustenta en que, a fin de solicitar o aplicar las pruebas biológicas de paternidad, se requiera una base, un sustento, una motivación que nos lleve a pensar acerca de la existencia de un probable lazo familiar. ${ }^{390}$

Esto obviamente, ha ido desarrollándose de acuerdo con el criterio de discrecionalidad judicial ${ }^{391}$, sin embargo las decisiones de los tribunales al respecto no han sido unánimes. ${ }^{392}$

El hecho de que se fomente la bioinvestigación de la paternidad no implica que se vulneren las relaciones sociales existentes, de ahí la exigencia de

\footnotetext{
${ }^{389}$ En este mismo sentido la anteriormente referida STC 7/1994 de 17 de enero, reconoce varias cautelas a fin de evitar reconocimientos de carácter biológico en caso de demandas frívolas, la segunda, y decisiva, se sitúa en el acto mismo de decidir la realización de las pruebas biológicas. Estas solo proceden si no son impertinentes o inútiles (art. 566 LEC). Criterio legal, que unido a la trascendencia de este tipo de prueba y a la posibilidad que tiene el órgano judicial de decidir sobre su práctica al final del período probatorio, o incluso después, mediante diligencias para mejor proveer (arts. 569 y 340.3 LEC), conduce a que la autoridad judicial solo disponga la realización de pruebas biológicas, cuando a la vista de los elementos de convicción obrantes en el proceso, resulte del todo necesario para esclarecer una paternidad posible, no meramente inventada por quien formula la acción de filiación, como la ha declarado la Sentencia del tribunal de casación de fecha 24 de mayo de 1989.

390 DOMINGUEZ PLATAS, indica que este criterio de principio de prueba servirá como medio para "cernir aquellas demandas que infundadamente pudieran alterar, incluso temerariamente, determinadas situaciones de paz familiar”, op cit. p. 440 nota 10.

${ }^{391}$ En el caso Porter del distrito de Columbia, Estados Unidos de Norteamérica, el juez Kennedy pudo presenciar, durante 20 días, diversas declaraciones de ocho peritos, admitió más de 110 pruebas instrumentales y recibió más de 1.300 páginas de informes. A continuación el juez resolvió no haber lugar a la admisión de la prueba del ADN, decisión ésta que fundamentó en 93 páginas de exhaustivos análisis. Cfr. LAPIEZA SPOTA. Ángel Hernán: "La real doctrina de la prueba del ADN en la jurisprudencia norteamericana", en La Ley, tomo 1996-A p. 906.

${ }^{392}$ En el caso de España, la STS de 3 de junio de 1988 considera suficiente en el escrito inicial la alegación de pruebas que puedan ser corroboradas en la etapa probatoria. En la STS del 3 de diciembre de 1991, ni siquiera se considera necesario que el principio de la prueba tenga que plasmarse en algún documento adjunto, sino que basta que en la demanda conste la oferta de practicar determinadas pruebas en el momento adecuado, y así poder llevar un control de la razonabilidad de la demanda.
} 
un principio de prueba con el fin de vincular el principio de veracidad (que corresponde el demandante) con el de seguridad jurídica y estabilidad que subyace en el proceso). Con esta orientación MÉNDEZ COSTA argumenta que no podría exigirse la prueba hematológica si antes no se ha demostrado por cualquier medio que el hecho de la filiación demandada es posible”. 393

La utilidad y aplicación de las pruebas en el campo de la indagación paternal es indiscutida. Abogados, fiscales y jueces han llegado a la convicción de su valor demostrativo y fehaciente como prueba de descarte y determinación de paternidad, así como elemento importante de la contradicción de las presunciones legales del nexo parental ${ }^{394}$.

Día a día el desarrollo biotécnico de estas pruebas ha ido alcanzando grados de eficacia cada vez mayores y determinantes en la investigación de la filiación, llegando a considerarse como la única prueba de certidumbre capaz de decidir categóricamente el problema del parentesco consanguíneo. Esto no es una cuestión teórica, como se ha analizado capítulos anteriores citándose autores como de SIMONÍN y GROSMAN, quienes así lo corroboraron; sin embargo, el avance biomédico en esta materia es incesante.

\footnotetext{
${ }^{393}$ Cit. Por GROSMAN, Cecilia P. y ARIANNA, Carlos; "Los efectos de la negativa a someterse a los exámenes biológicos en los juicios de filiación paterna extramatrimonial”, en La Ley Buenos Aires, 1992, p. 1194.

394 “... la práctica de una prueba biológica tiene aptitud para destruir una presunción”, como se plantea en la Sentencia del Tribunal Supremo de 17 de marzo de 1995; en el mismo sentido la Sentencia del Tribunal Supremo de 07 de diciembre de 2005, apegándose en un criterio homologo a la anterior, ha manifestado que “... la negativa a la prueba biológica no constituye un elemento probatorio equiparable a los demás en cuanto a su grado de eficacia presuntiva, sino que desempeña un papel especialmente relevante, como se deduce de la afirmación reiterada en nuestras sentencias, especialmente en las más recientes, en el sentido de que dicha negativa constituye un indicio «valioso» o «muy cualificado», sintagma este último que se invoca y reproduce literalmente en la sentencia constitucional a que venimos refiriéndonos, la cual, en suma, perfila el marco constitucional dentro de cuyos límites ha de manifestarse con sentido propio nuestro poder de juzgar y nuestra función de fijar la orientación jurisprudencial que debe presidir la aplicación de la ley por los tribunales civiles”.
} 
Hoy podemos decir, con toda certidumbre y basados en principios científicos plenamente válidos, que la determinación biológica de la paternidad a través de los marcadores genéticos no es una esperanza futura sino una realidad. Tanto como el sistema de histocompatibilidad, los polimorfismos cromosómicos y el perfil de ADN se llega a precisar positivamente la relación de consanguinidad.

En el caso argentino, Aída Kemelmajer sustenta el hecho de que tanto la prueba de HLA como el ADN son aceptadas por la comunidad jurídica como métodos confiables que integran la categoría de las llamadas pruebas estadísticas. ${ }^{395}$

Más aún, en el caso de la prueba del perfil de ADN que, basada en la transmisibilidad de las características del genoma entre los procreantes y el procreado, se presenta como incontrovertible y con alto grado de efectividad en la determinación de la paternidad. Esto se basa en el hecho de que la posibilidad de que dos individuos sin vínculo biológico entre si compartan un mismo patrón de bandas es menor a la relación de 1 a 1.000.000.000.000, por eso los índices de inclusión o de exclusión que brindan, complementados con otros estudios, llegan a alcanzar una certidumbre virtual del 100\%. ${ }^{396}$

Es en la investigación positiva del nexo parental que el derecho debe tomar conciencia y regular su aplicación en beneficio y resguardo de la institución familiar. El sustento jurídico de su aplicación tomará como base los

\footnotetext{
${ }^{395}$ KEMELMAJER DE CARLUCCI, Aída "El valor de la prueba genética en el derecho argentino”, en El derecho ante el proyecto de genoma. Madrid, Fundación BBV, vol. IV, 1994, p. 175.

${ }^{396}$ LEONARDI, Danilo "El ADN puede colaborar con la administración de justicia”, en La Ley, Buenos Aires, 1990, Cit. ZANNONI, Eduardo, "Identidad personal y pruebas biológicas”, en op. Cit. P. 164.

En el caso español EGÚSQUIZA BALMASEDA señala que: "La exclusión de la paternidad, si se desprende del peritaje correspondiente, es aceptada y dictaminada como hecho objetivo de plena contundencia. La prueba biológica positiva de paternidad, se evalúa de acuerdo con los criterios de verosimilitud recogidos en las tablas de probabilidades de Hummel, así como las circunstancias que rodean el caso”. EGÚSQUIZA BALMASEDA, María Ángeles; op cit. P. 49
} 
principios genéticos y biológicos técnicamente comprobados que le otorgan la certeza, eficacia y seguridad para su aplicación. Es más, las pericias genéticas servirán para acelerar o aligerar los juicios al contarse con herramientas eficaces para indagar la veracidad de los hechos alegados. ${ }^{397}$

\subsection{La admisibilidad de las pruebas genéticas}

En lo referente a la admisibilidad jurídico procesal de las pruebas genéticas deben considerarse las tendencias relativas al valor probatorio que representan.

Los informes periciales heredobiológicos en el Derecho comparado están orientados en tres tendencias:

- Objetiva.- El informe pericial obliga al juez y sus conclusiones no pueden ser debatidas por el tribunal que conoce la causa. En estos sistemas la admisibilidad de las pruebas genéticas se realiza restringidamente, ya que la solución jurídica de la filiación se sustenta, si bien no en la opinión del perito, en consideraciones extrasociales, es decir, técnicas

- Subjetiva.- La opinión pericial sólo tiene un carácter informativo e ilustrativo para el juez, quien procederá a valorar la experticia de acuerdo con su libre apreciación y criterio en concurrencia de las demás pruebas aportadas en el proceso.

\footnotetext{
${ }^{397}$ LEONARDI, Danilo en su artículo "El ADN puede colaborar con la administración de justicia”, op cit, ha indicado que en Estados Unidos se observó que cada vez que se recurre a este tipo de pericia, el jurado tiende a deliberar en menos tiempo de lo usual (en Dallas, el jurado pronunció su veredicto de culpabilidad contra un violador en 22 minutos).
} 
- Mixta.- El juez considera la validez científica de las pruebas genéticas tanto de descarte y de determinación de paternidad como corroboradoras indispensables de las pruebas actuadas en los juicios de filiación. En este caso, el informe investigatorio de paternidad, presentado y sustentado por los técnicos, tiene un carácter científico y obligará al juzgador a la valoración conjunta de todas las pruebas actuadas.

La tendencia mixta, es la más difundida, se aplica en la actualidad en países como Alemania, Canadá, Estados Unidos y Francia.

\section{En el caso español ${ }^{398}$ y mexicano tienen valor tanto subjetivo como}

mixto ya que no se le ha otorgado a las pruebas heredobiológicas una libre y exclusiva apreciación, dado que no puede ser la única ofrecida, sino que debe estar vinculada con algún otro medio de prueba, además de que el juez se

\footnotetext{
398 La STS de 22 de noviembre de 2005, citando la similar de fecha 5 de abril de 1990, ha considerado que "Tras la reforma de los preceptos del Código Civil relativos a la filiación por la Ley de 13 de mayo de 1981 y en fiel concordancia de los principios sentados al efecto por la vigente Constitución Española, se ha consolidado ya una línea jurisprudencial, claramente superadora de actitudes restrictivas y formalistas, que proclama con acentuada unanimidad que los actuales arts. 127 y 135 del Código Civil establecen y propician una amplia gama de procedimientos para llegar a conocer la realidad genética, permitiendo que los Tribunales utilicen al efecto cualquier sistema de los previstos por la razón humana, en consonancia con la realidad sociológica y la época en que aquellas relaciones se produjeron, así como con la realidad social en que han de ser aplicadas esas normas de tan amplio espectro inquisitivo, atendiendo, fundamentalmente, al espíritu y finalidad de éstas, que no es otro que la defensa de los intereses prioritarios de los hijos. Tal principio de libertad en la práctica de las pruebas y de razonable apreciación y valoración de las mismas por el Juzgador tiende, en definitiva, a buscar el principio de verdad material en el proceso, para lo cual resulta decisivo el último inciso del citado art. 135, que alude a "otros hechos de los que se infiera la filiación, de modo análogo"; frase que, sin duda, remite a pruebas indirectas que son de especial significación cuando no se dan los hechos base que específicamente menciona a aquel precepto: (reconocimiento expreso o tácito, posesión de estado y convivencia con la madre en la época de la concepción)"

En el mismo sentido se manifiesta la STS de 26 de septiembre de 1998 : "el referido artículo 135 , que hay que poner en relación con el 127, presenta un notorio carácter procesal, ya que autoriza a aportar medios probatorios adecuados, al poner a disposición de los juzgadores con plena libertad cuantas pruebas legales procedan ( sentencias de 18 de febrero de 1992 ), a fin de que con base a las mismas puedan decidir sobre la filiación que se reclama", y continúa: "El precepto establece dos clases de pruebas, las directas, entre las que cabe incluir, si se presenta contundente, la heredobiológica, y las indirectas o presuntivas respecto a haber mediado relaciones sexuales entre los litigantes determinantes de la generación" (sentencias de 29 de marzo y 20 de octubre de 1993, 16 de junio y 28 de julio de 1995, 7 de octubre de 1995 y 4 de julio de 1996 ).
} 
encuentra en la libertad de apreciarla a su mejor leal saber; pero sin embargo, de la misma forma nos damos cuenta que la pericial en ADN en la filiación es una forma indispensable de corroboración del hecho en disputa.

Sin embargo, la efectividad de las pruebas genéticas ha llevado a sustentar que la convicción del juez no puede agregar ni quitar nada a las conclusiones periciales, situación ésta que implicaría que los problemas de filiación sean resueltos por los laboratorios y no por el Poder judicial. Más que cualquier resultado parental genésico el juez debe seguir siendo el señor de las pruebas. $^{399}$

Existen límites al principio de discrecionalidad frente a la valoración de la prueba, como lo establecen WAGNER y ABALLE ${ }^{400}$, quienes citan que la jurisprudencia de los últimos años ha establecido que:

- Para poder apartarse de las conclusiones allegadas por el técnico el juzgador debe dar razones muy fundadas.

- Si bien las normas procesales no acuerdan a la prueba técnica el carácter de prueba legal y le permiten al magistrado formar su propia convicción al respecto, para desvirtuarla es imprescindible valorar elementos que permitan advertir fehacientemente el error o la incorrecta aplicación de los procesos científicos.

\footnotetext{
399 "Los laboratorios, por muy buenos que sean, no bastan para decidir los procesos judiciales". Esta posición es apoyada por Guillermo FREIRE Falcao de Olivera quien asimismo. Cita el caso de O.J. Simpson en el que el laboratorio determinó que la sangre encontrada en un guante en el lugar del crimen pertenecía al reo, pero se suscitó la duda de que la misma hubiese sido recogida en otra circunstancia, conservada y colocada en el lugar del homicidio para la correspondiente incriminación vid. FREIRE FALCAO DE OLIVEIRA, Guillermo, "Implicancias jurídicas del conocimiento del genoma" en Revista de Derecho y Genoma Humano, Bilbao, Universidad de Deusto No. 6, 1997, pp. 57-58, nota 12.

${ }^{400}$ WAGNER, Horacio y ABALLE, Rubén. "Límites a la libre valoración de las pruebas científicas", en La Ley, tomo 1996-A, p. 1138.
} 
- Cuando el peritaje aparece fundado en principios técnicos inobjetables y no existe otra prueba de parejo tenor que lo desvirtúe, la sana crítica aconseja, frente a la imposibilidad de oponer argumentos científicos de mayor peso, aceptar las conclusiones de aquél.

Toda prueba debe tener vinculación con los hechos alegados y producir certeza en el juez respecto de los puntos controvertidos, a fin de que sea de utilidad para fundamentar sus decisiones. En tal sentido, el juez puede negarse a admitir una prueba si la considera improcedente o ilegal.

Por el contrario, está obligado a su admisión cuando se refiera a los hechos controvertidos y a la costumbre, cuando esta última sustente la pretensión con una obligatoriedad judicial. ${ }^{401}$

Dentro del Derecho procesal civil mexicano podemos observar que el juez si bien tiene la libertad de admitir todas las pruebas planteadas por las partes, estas de igual forma deben estar vinculadas con los hechos controvertidos, pudiendo desechar aquellas que considere no tengan relación con ellos, pero todo lo anterior en búsqueda de la verdad del hecho, sin poder ir, ni buscar más allá de lo expuesto y ofrecido por los litigantes.

\footnotetext{
${ }^{401}$ En especial sobre este punto EGÚSQUIZA BALMASEDA menciona que "la obligación de alcanzar un grado de certidumbre adecuado, respecto de la paternidad que se pretende, llevó a la doctrina y la jurisprudencia reconocieran la facultad del juez para acordar la práctica de pruebas biológicas de oficio" Op Cit., p. 47.
} 


\subsection{Las partes y la prueba biológica}

La aplicación de la prueba genética suscita cuestiones de carácter procesal, sea en lo referente a su admisibilidad, eficacia y obligatoriedad a su sometimiento. Es en este último aspecto que las implicaciones directas con el órgano jurisdiccional que conoce la causa y con las partes que discuten el nexo biológico determinan efectos jurídicos trascendentales.

La obligatoriedad de las partes al sometimiento a este medio de prueba es el punto de mayor importancia en la aplicación judicial de las pruebas biológicas. El sometimiento de las partes a las experticias en estudio motiva innumerables problemas de orden jurídico, que van desde los derechos y garantías constitucionales hasta la valoración de la negativa de parte para esclarecer el nexo biológico.

Respecto de la obligación de las partes a someterse al examen heredobiológico, existen tres teorías doctrinales, muy bien definidas, que tratan sobre la relación jurídica de la conducta de parte frente al valor justicia para investigar la paternidad: la teoría de la potestad de la prueba, la teoría del fin supremo de la justicia y la teoría de los derechos de la persona.

\subsubsection{Teoría de la potestad de la prueba}

Se apoya en el principio procesal de que ningún litigante debe ser obligado a proporcionar medios de prueba a la contraparte (derecho a la tutela efectiva)

En este caso, sustentan la validez de negarse al sometimiento de la pericia genética para investigar la paternidad, ya que ello sólo beneficiará a su 
adversario (nemo tenetur edere contra se, nadie está obligado a ir contra sí suministrando prueba al contrario).

Sobre este punto cabe mencionar que las legislaciones favorecidas con la investigación biológica de la filiación no verán restringida su facultad de pedir el sometimiento al examen hematológico a la contraparte, ya que debemos estimar que en estos casos, no hay porqué temer violada la máxima nemo tenetur edere contra se, pues la creación de la relación jurídica procesal determina, para las partes, el deber de decir la verdad y la obligación de comportarse lealmente en el juicio. ${ }^{402}$

El sustento de esta teoría no ha tenido mayor connotación jurídica, pues la prueba sirve para determinar y comprobar lo alegado por las partes, independientemente del modo y técnica utilizada.

\subsubsection{Teoría del fin supremo justicia}

La obligación de participar activamente y colaborar en el proceso judicial es un acto inherente a toda persona, por la razón de vivir en un Estado de derecho y con sujeción a las normas del orden jurídico. Es principio elemental el establecimiento de la verdad, por lo que los litigantes deben contribuir personalmente en su descubrimiento. Esta cooperación al sistema judicial es uno de los deberes fundamentales del ciudadano y se cumple mediante la participación para descubrir la verdad con relación a las controversias que han sido expuestas en el litigio. ${ }^{403}$

\footnotetext{
${ }^{402}$ DÍAZ DE GUIJARRO, Enrique, "Valoración probatoria de la negativa a someterse a la investigación de los grupos sanguíneos” en Jurisprudencia Argentina, buenos Aires, julio 1987 p. 217.

403 Ésta es la posición indicada por la Cámara 1ª Civil y Comercial de Bahía Blanca, Argentina en el sentido de que "...el sometimiento a las pruebas viene a constituir para el demandado no sólo un
} 
El sometimiento a las pruebas genéticas ordenadas por el juzgador para investigar la paternidad es una "colaboración obligatoria” y que de ningún modo atenta contra la libertad individual, en razón de que las técnicas de paternidad son sencillas y no implican una violación a los derechos. Quien alegue tal restricción estaría cometiendo un abuso de derecho.

El demandado no está obligado a prestar su cuerpo, pero sí tiene la carga de hacerlo porque si no lo hace su negativa constituirá una de las pautas para juzgador circunstancialmente la situación de hecho. ${ }^{404}$

Por sobre todo está el valor justicia y el esclarecimiento de los hechos, más aún tratándose de indagar una filiación que es el sustento de un derecho subjetivo, conocer quién es nuestro padre biológico. En todos estos procesos, lo que se busca no es la defensa de los progenitores sino el reconocimiento de los derechos del hijo.

En este sentido, la Suprema Corte de Justicia de la Nación de México, ha emitido el criterio jurisprudencial en el sentido de que el artículo 5, apartado B), inciso III, de la Ley de los Derechos de las Niñas y Niños en el Distrito Federal, que establece que las niñas y niños tienen el derecho a la identidad, certeza jurídica y familia, y a solicitar y recibir información sobre su origen, sobre la identidad de sus padres y a conocer su origen genético, se traduce en el derecho de los menores a solicitar en juicio, la prueba pericial en genética molecular del ácido desoxirribonucleico (ADN), de sus presuntos progenitores. Lo anterior no viola la garantía de audiencia, puesto que la misma se encuentra

imperativo ético y legal, en cuanto le compete colaborar con lealtad al juzgador, sino - y aun más. Una carga ineludible en su propio interés”. Ct. Revista de Derecho Privado y Comercial No. 5, p. 337; en el mismo sentido el Artículo 118 de la Constitución Española.

${ }^{404}$ ZANONI, Eduardo, Op Cit. P. 170 
debidamente protegida por el artículo 298 del Código de Procedimientos Civiles para el Distrito Federal, por virtud del cual existe la posibilidad de impugnar mediante el recurso de apelación en el efecto devolutivo, la admisión de una prueba por parte de quien pudiera resultar afectado por la propia admisión. ${ }^{405}$

Dentro de esta teoría se considera necesario el establecimiento legal de la obligatoriedad al análisis biológico, con el fin de que el juez tenga la facultad y el marco jurídico adecuado para deducir de la negativa conclusiones en contra de quien se resiste.

Oponerse, indica acertadamente EGÚSQUIZA BALMASEDA “a la práctica de una prueba de ese tipo revela una falta de solidaridad y colaboración a la administración de justicia para determinar derechos a terceros, (...) ciertamente lamentable si se tiene en cuenta el elevadísimo índice de fiabilidad respecto a la determinación positiva de la paternidad en cada caso concreto”, según lo establecido por la sentencia del tribunal supremo de 6 de junio de $1991 .{ }^{406}$

En sentido similar, la jurisprudencia argentina ha indicado que la actitud renuente del demandado en el juicio de filiación a someterse a la prueba biológica es un elemento sustancial para presumir la paternidad que se indaga, salvo supuestos excepcionales, cuando se discute el estado de familia de una persona no es admisible la actitud omisiva de esa índole, la que sólo puede

\footnotetext{
405 Registro No. 176171; Localización: Novena Época; Instancia: Primera Sala; Fuente: Semanario Judicial de la Federación y su Gaceta; XXIII, Enero de 2006; Página: 737 Tesis: 1a. CCXVIII/2005; Tesis Aislada; Materia(s): Constitucional, Civil PRUEBA PERICIAL EN GENTICA MOLECULAR DEL ÁCIDO DESOXIRRIBONUCLEICO (ADN). EL ARTÍCULO 5, APARTADO B), INCISO III, DE LA LEY DE LOS DERECHOS DE LAS NIÑAS Y NIÑOS EN EL DISTRITO FEDERAL, NO VIOLA LA GARANTÍA DE AUDIENCIA. Amparo en revisión 1166/2005. José Martín Roiz Rodríguez. 16 de noviembre de 2005. Cinco votos. Ponente: Sergio A. Valls Hernández. Secretario: Joaquín Cisneros Sánchez.

${ }^{406}$ EGÚSQUIZA BALMASEDA, María Ángeles, op. cit. P. 55
} 
responder al deseo de privar al juez de un elemento de convicción sobre hechos sucedidos $^{407}$

Una forma indirecta de que la prueba biológica de paternidad sea obligatoria es el establecimiento de una presunción en caso exista una negativa a su sometimiento. Indiscutiblemente, un gran sector de la población - pro defensa de la niñez y de la familia - alega vivamente la obligatoriedad legal a los exámenes biológicos, es decir, propugnan una forma directa y expresa, reconocidas por la ley, para que las pruebas de paternidad tengan el carácter de obligatorias.

\subsubsection{Teoría de los derechos de la persona}

Sostiene que a nadie puede obligársele y menos aún en forma compulsiva a un examen biocorporal, en razón de la existencia de derechos personales. ${ }^{408} \mathrm{Y}$ es que la voluntad es decisiva en la práctica de las pruebas biológicas. Lo contrario implicaría, en inicio, la transgresión de los derechos de la persona, por ello podemos negarnos al sometimiento de los exámenes in corporis manu militari ya que importaría un menoscabo de nuestros derechos fundamentales.

Si bien estos planteamientos benefician a los litigantes de mala fe, que ocultan y resguardan su responsabilidad paternal en los principios constitucionales de libertad humana y de la inviolabilidad de la persona, debe

\footnotetext{
${ }^{407}$ Cámara Nacional Civil, Sala F, 24-8-92, Cit. Revista de Derecho Privado y Comunitario, Santa Fe, Rubinzal Culzoni, No. 3, p. 391

${ }^{408}$ Estos derechos son sagrados, no surgen ni provienen de una ley escrita: jus hominis in se ipsum o potestas in se ipsum, jura personarum (Cfr. GATTI, Hugo; "Los grupos sanguíneos y la prueba de la filiación natural”, en Revista de Jurisprudencia Peruana, Lima, Ed. Revista de jurisprudencia Peruana, julio 1954, año XII No. 126 p. 798).
} 


\title{
considerarse que el impedimento para actuar la pericia reside en la coacción o
} compulsión al sometimiento de ésta.

\author{
Sin embargo, los argumentos antes mencionados no son del todo \\ válidos al estar de por medio un interés de carácter preferente, cual es que todo \\ sujeto tiene derecho a conocer quién es su padre. ${ }^{409}$
}

\begin{abstract}
${ }^{409}$ En tal sentido, se recoge la argumentación vertida por la STC de 17 de enero de 1994, en que se dispone que la resolución judicial que, en el curso de un pleito de filiación ordena llevar a cabo un reconocimiento hematológico de alguna de las partes no vulnera los derechos del afectado a su intimidad y a su integridad, cuando reúne los requisitos delineados por nuestra jurisprudencia al interpretar los artículos 18.1 y 15 de la CE:
\end{abstract}

A) Primero, consistir en una intromisión en el ámbito de protegido del ciudadano que no es, por si sola inaceptable (STS 37/1989, FJ $7^{\circ}$ y $8^{\circ}$, in fine), es indudable que no puede considerarse degradante, ni contraria a la dignidad de la persona, la verificación de un examen hematológico por parte de un profesional de la medicina, en circunstancias adecuadas. Un examen de sangre no constituye per se una injerencia prohibida (STC 103/1985, FJ 3º) y la extracción de unas gotas de sanfre, de acuerdo con la STS de 14 de noviembre de 1987, no constituye, según un sano criterio, violación del pudor o recato de una persona. (ATC 221/1990, FJ 3²)

B) En segundo lugar, debe existir una causa prevista por la ley que justifique la medida judicial de injerencia. En este caso, no solamente el artículo 127 del Código Civil da cobertura legal explícita a las pruebas biológicas de investigación de la paternidad e inscribe esta prescripción en la idea de protección integral de los hijos, iguales éstos ante la ley con independencia de su filiación. Lo cual conecta directamente con el artículo 14, en cuanto prohíbe que prevalezca discriminación alguna por razón de nacimiento. Y, la constitución establece directamente un deber, los padres deben presentar asistencia de todo orden que permite la práctica de las pruebas biológicas no es otra que la defensa, en primer lugar, de los intereses de los hijos, tanto en el orden material como en el moral, y destaca como doctrina del Tribunal Supremo. Así pues, las resoluciones judiciales que disponen la investigación de la filiación sirven directamente fines constitucionales; y la interpretación de las leyes que rigen esta materia debe realizarse en el sentido que mejor procure el cumplimiento por los padres de sus deberes respecto a sus hijos menores, para lo cual aparece como instrumento imprescindible la investigación de la paternidad cuando ésta es desconocida.

C) En tercer lugar, las pruebas biológicas en la medida en que conllevan la práctica de una intervención corporal tan solo se justifican cuando sean indispensables para alcanzar los fines constitucionalmente protegidos, de tal suerte que, cuando la evidencia sobre la paternidad pueda obtenerse a través de otros medios probatorios menos lesivos para la integridad física, no está autorizado el órgano judicial a disponer la práctica obligatoria de los análisis sanguíneos.

D) En ningún caso puede disponerse por el juez la práctica de una intervención corporal destinada a la investigación de la paternidad cuando pueda suponer para quien tenga la obligación de soportaría un grave riesgo o quebranto para su salud. En cualquier caso, la ejecución de tales intervenciones corporales debe efectuarse por personal sanitario y en centros hospitalarios públicos.

E) Por último, la medida judicial que ordena realizar las pruebas biológicas debe guardar una adecuada proporción entre la intromisión que conlleva la intimidad y la integridad física o moral 
Los derechos de la persona se ven afectados por el propio acto de intervención, no importando el resultado que éste arroje. Sea negativo o positivo, el daño a los derechos está dado, pero se toma en cuenta el interés superior del niño, esto de acuerdo al artículo VIII del Código de los Niños y Adolescentes o dicho de otra forma el mejor interés del niño. ${ }^{410}$

En la fase probatoria del proceso, los derechos de las partes pueden verse seriamente afectados por una acción de investigación de la paternidad, es más, cualquier acto realizado contra la voluntad humana atentaría contra sus facultades inherentes que serían:

\section{Derecho a la integridad}

La integridad es la característica propia, el contexto corporal y funcional que como sujeto de derecho le corresponde al ser humano. Su finalidad es proteger al hombre como un todo.

Mediante este derecho se determina la protección de la estructura corporal (integridad física), psicológica (integridad psíquica) y social (integridad moral) de la persona humana, de allí que sean contrarios todos aquellos actos tendientes a la vulneración de la corporeidad lato sensu.

del afectado por ellas, y la finalidad a la que sirve (STC 37/1989, FJ 7º, 3 y 8, párr.. 3 a 5) ponderación que debe plasmarse en la motivación de la necesidad de la medida que ha de razonarse en la decisión judicial”.

${ }^{410}$ Es interesante la posición de la constitución colombiana al establecer en su artículo 44, que "Los derechos de los niños prevalecen sobre los derechos de los demás” 
Existen casos en los que la integridad cede al frente a casos concretos como son los actos de libre disposición del cuerpo humano y exámenes médicos o quirúrgicos. ${ }^{411}$

Por criterio discrecional, se carece de una norma que obligue manu militari la práctica de pruebas biológicas para indagar la paternidad, de manera tal que la obligatoriedad es meramente enunciativa, es decir, no puede ser conminada su ejecución. ${ }^{412}$

La Comisión Europea de Derechos Humanos por decisión del 13 de octubre de 1989 indicó que "una intervención tan banal como un examen de sangre no constituye injerencia prohibida por el artículo 2.1 del Convenio Europeo". En tal caso, no es dable considerarlo como un ataque al derecho de la integridad; de serlo, la repercusión sería mínima pues, al ejercerse cierto grado de violencia para obtener muestras o fluidos corpóreos, la repercusión es ínfima en comparación con los intereses superiores que emanan de la determinación del origen y de la identidad. ${ }^{413}$ Es más, la extracción de dicha muestra no genera daños ni físicos ni moral alguno. ${ }^{414}$

\footnotetext{
411 "Toda persona puede rehusar someterse a examen o tratamiento médico o quirúrgico, salvo disposición legal o judicial que establezca su obligatoriedad por razones de orden público, dentro de los límites del respeto a la persona humana”, encabezado del artículo 11 de Código Civil Peruano de acuerdo a la Propuesta de la Comisión Revisora.

${ }^{412}$ En el caso español existen decisiones judiciales en el sentido de la no obligatoriedad, como la STS de 21 de mayo de 1988, STS de 27 de junio de 1987, 23 de septiembre y 3 de diciembre de 1988 y 18 de mayo de 1990.

${ }^{413}$ La profesora KEMELMAJER alude a “... la prioridad que la mayoría de los tribunales constitucionales dan al derecho a la propia identidad sobre el derecho del presunto padre de no prestar su propio cuerpo para practicar la prueba biológica”, para sustentar esta posición menciona sus pronunciamientos como juez de la sala I de la Suprema Corte de justicia de la provincia de Mendoza, en sentencia del 29/08/1995 CLM publicada en La Ley 1996-B-547, con nota de Jorge A. Mazzinghi: "Negativa a colaborar con la investigación de la paternidad y la indignidad sucesoria", en Revista del Foro, Lima Perú. Octubre de 1997.

${ }^{414}$ La STS del 3 de diciembre de 1988, ha descartado que la extracción de sangre pueda comportar una agresión contra la integridad física o moral de aquél contra quien se dirigen los medios de prueba.
} 
Por así referirlo, estos tipos de exámenes equivalen a un análisis común de laboratorio que nada tiene de humillante o degradante, por el contrario, nadie duda de que la extracción mínima de sangre es un proceso inocuo, indoloro y no traumático, por tanto legalmente admisible.

Por otro lado, y como es conocido, la recogida de material genético con las modernas pruebas de paternidad no requieren necesariamente la extracción de sangre, pueden realizarse con salivas o específicamente con las células epiteliales de la boca, raíz de cabello o con fragmentos de uña, siendo éstos lógicamente los menos ofensivos. ${ }^{415}$

A pesar de ello, existen casos en que prima la integridad, por lo que el derecho del hijo a conocer su origen biológico cede justificadamente ante la del padre.

Estudio especial, en materia del derecho a la integridad, ha merecido en la doctrina la valoración jurídica de la inspectio corporis (análisis corporal) y su relación con el jus in se ipsum (derecho sobre si mismo) en el sentido de que, al ser el hombre dueño y ejercer dominio sobre su cuerpo, no cabría la ejecución de prácticas que alteren dicho señorío corpóreo si es que no se cuenta con la autorización respectiva. Como tal, el jus in se ipsum es el derecho personalísimo que tiene una persona para disponer de su propio cuerpo, impidiendo, en razón de objeción de conciencia, pudor, prejuicios, sensibilidad o cualquier otra justificación, un menoscabo de su intimidad personal.

\footnotetext{
${ }^{415}$ FREIRE FALCAO DE OLIVERA indica que en "el derecho inglés y el derecho australiano del estado de Victoria, consagran la distinción entre las partes del cuerpo estrictamente personales (taxativamente mencionadas, entre las que se encuentra la sangre) y no estrictamente personales. No pudiendo realizarse una recogida forzada en las primeras, pero sí en las segundas (que parecen ser, por exclusión, los cabellos y las uñas) Cfr. "Implicancias jurídicas del conocimiento del genoma”, op cit p. 59 nota 15
} 
No obstante, para fines de la averiguación filial se ha tendido una corriente que declara la inspectio corporis necessarie, facilitando y admitiendo la realización de los exámenes sanguíneos.

\section{Derecho a la libertad}

La libertad es la "facultad natural que tiene el hombre de obrar de una manera o de otra, y de no obrar, por lo que es responsable de sus actos” ${ }^{416}$. Sin embargo, jurídicamente la libertad se vincula con el derecho a la autodeterminación y con el derecho a decidir libremente.

Se ha determinado, casi unánimemente, que el derecho que más resulta lesionando con la aplicación de las pruebas biológicas es la libertad personal, en el sentido de que a toda persona le corresponde la facultad de oponerse a la ejecución de aquello que sea impuesto sin fundamento legal.

La jurisprudencia española tanto del Tribunal Supremo como del Tribunal Constitucional se ha manifestado contraria a la imposición coercitiva de la prueba, defendiendo extensamente la libertad individual La obtención de una prueba contra la voluntad del sujeto implica una violencia, una fuerza para lograr las muestras necesarias, las vis absoluta califican primariamente esta prueba como ineficaz por la forma a su sometimiento. ${ }^{417}$ Es por ende bien sabido que si bien la voluntad y el consentimiento son la esencia para la validez de una prueba, es preciso valorar la conducta del sujeto a efectos de proteger los derechos que

\footnotetext{
${ }^{416}$ Real Academia Española Op. Cit. P. 1252

417 ZANNONI Eduardo, ha vertido la opinión de que "por respeto a la libertad individual, se ha afirmado el criterio según el cual no cabe ejercer compulsión física sobre la parte que se niega a someterse a tales pericias... no obstante, la negativa es uniformemente considerada presunción en contra de la tesis que en autos sostiene la persona que se niega a los estudios y pruebas científicas” en: Derecho de Familia op cit. Tomo II p. 460
} 
están en juego, en este caso, la libertad personal y el derecho a conocer la identidad de su progenitor.

\section{Derecho a la intimidad}

La vida del ser humano es reservada. En ella se reúnen diversos aspectos (personal, familiar y laboral entre otros) que, dado su contenido, pertenecen exclusivamente a su titular. Por ello, nadie tiene facultad alguna de conocerlos ni divulgarlos, por lo reservado de éstos. Esta prerrogativa es el derecho a la intimidad.

Como derecho permite la reserva, el secreto, propiamente a nuestras cosas consideradas como íntimas, tiene ámbitos de aplicación como la vida interna es decir, pensamientos, creencias o ideas; de relación, como familia, compañías, círculos frecuentados; los de comunicación como la correspondencia o memorias y las de representación como imagen y voz.

Actualmente ese mundo interno del hombre merece una cautela y seguridad especiales con respecto a la información contenida en su código genético y en sus genes ya que por ejemplo:

a) la forma como ha sido procreado,

b) su estructura genética,

c) los resultados que se obtengan de los análisis realizados, y

d) las prácticas médicas a las que se ha sometido no pueden ser revelados, y es que, justamente, el derecho a la intimidad protege consideraciones que le interesan a un solo sujeto y a nadie más. 
La intimidad es otro de los derechos recurridos para justificar la negativa a los exámenes biocorporales de paternidad, pues se vulnera a través de los actos de indagación (intromisión) y puesta en conocimiento público (divulgación). El patrimonio personal del sujeto se ve afectado al descubrir sus datos biológicos o de herencia genética (intimidad genética) ${ }^{418}$

La gran mayoría de pronunciamientos del Tribunal Supremo de España, se inclinan por la inafectación al derecho a la intimidad, incluso no puede considerarse inconstitucional, como hemos analizado en párrafos anteriores.

Sin embargo, en caso contrario la Suprema Corte de Justicia de la Nación, en criterio jurisprudencial, ha dicho que tratándose de la investigación de la paternidad legal para esclarecer lo planteado en un asunto de desconocimiento o reconocimiento de paternidad, debe prevalecer esa prerrogativa en orden con la de intimidad o privacía, en razón a que en un conflicto de esa naturaleza sustantiva, el conocimiento o averiguación dirigida a saber quién es el progenitor deviene predominante al derivar del supremo derecho del menor a obtener, entre otros, su identidad y filiación, alimentos, casa, educación, vestido, atención médica, etcétera, así como la obligación común de ambos padres de proporcionar los medios económicos y condiciones de vida necesarios para el pleno y armonioso desarrollo intelectual y físico de un menor. Además, si bien es exacto que la protección a la intimidad se puede afectar con el desahogo de la prueba pericial en genética, que es la idónea para demostrar científica y biológicamente la relación paterno filial, e implica la práctica de estudios químicos y exámenes

\footnotetext{
${ }^{418}$ La base que justifica este planteamiento ha sido el reconocimiento jurisprudencial que dentro del ámbito de la intimidad debía ser incluida la protección de datos o aspectos personales que no son vida o vivencia personal, pero que indudablemente pertenecen al mas estricto ámbito personal del sujeto. En este sentido, la STS de 13 de marzo de 1989, en la que se debatía la difusión a través de una agencia de noticias la conformación cromosómica de una atleta que afectaba su femineidad, sostuvo que el patrimonio que comprende la identidad personal se encuentra también integrado por los aspectos caracterobiológicos o biológicos que comprende el ser de una persona
} 
de laboratorio traducidos en la toma de muestras de tejidos sanguíneos u orgánicos que podrían poner al descubierto otras características genéticas, como diversos aspectos patológicos o de conducta que nada tengan que ver con la paternidad que se busca dilucidar, no menos verídico resulta que para preservar tal derecho a la intimidad el desahogo de dicha probanza se debe limitar mediante niveles de control y acceso a esa información confidencial, esto es, que el juzgador ha de velar porque en la práctica dicha pericial se lleve a cabo con las medidas de discreción, de reserva y sanitarias para salvaguardar el estado de salud de los progenitores y del propio menor. Incluso es patente que la información que se obtenga de dicho procedimiento científico será concreta y objetiva, sólo para resolver la cuestión controvertida. Por consiguiente, en tales casos indiscutiblemente deviene preponderante el derecho de investigación sobre la identidad de la paternidad en el juicio de desconocimiento o reconocimiento de la misma, en relación con la filiación en cuanto al progenitor, frente a una invasión a la intimidad o privacía individual. ${ }^{419}$

Como aclara GUZMÁN ZAPATER ${ }^{420}$, la investigación de la paternidad puede atentar contra el derecho a la intimidad de las personas y familias afectadas con la indagación. Si bien es cierto que el derecho a la intimidad se extiende también a "determinados aspectos de la vida de otras personas con las que se guarde una especial y estrecha vinculación” ${ }^{421}$, y que también constituye una intromisión en la intimidad personal desvelar el origen adoptivo de una persona como se refiere en la STC 197/1991, la respuesta más

${ }^{419}$ Registro No. 176668; Localización: Novena Época; Instancia: Tribunales Colegiados de Circuito; Fuente: Semanario Judicial de la Federación y su Gaceta XXII, Noviembre de 2005; Página: 911; Tesis: II.2o.C.501 C; Tesis Aislada; Materia(s): Civil

PERICIAL EN GENÉTICA. SU DESAHOGO ES PREPONDERANTE EN UN JUICIO DE DESCONOCIMIENTO O RECONOCIMIENTO DE PATERNIDAD, CON INDEPENDENCIA DEL DERECHO A LA PRIVACÍA O INTIMIDAD; SEGUNDO TRIBUNAL COLEGIADO EN MATERIA CIVIL DEL SEGUNDO CIRCUITO.

${ }^{420}$ Op Cit. pp. 96 - 97

${ }^{421}$ En España, en el mismo sentido, el TC en su sentencia 231/1988 referida a la penosa divulgación de las últimas imágenes de la vida del torero Paquirri en la plaza de toros de Pozoblanco y el derecho a la intimidad de su viuda. 
contundente la dio el pronunciamiento del ATC 221/1990 al contraponer el “interés social y de orden público que subyace en las declaraciones de paternidad... que trasciende a un derecho de naturaleza estrictamente individual, como es el de la intimidad personal, cuando está en juego además la certeza de un pronunciamiento judicial”; asimismo la STC 103/1990, en la que se afirma que la tutela del derecho fundamental a la intimidad no puede convertirse en un "límite infranqueable a la actividad probatoria y a la investigación judicial de la realidad subyacente en el litigio planteado”.

Indiscutiblemente, hablaríamos de una lesión a la intimidad si las muestras se obtienen sin el consentimiento, autorización o conocimiento ${ }^{422}$ del interesado.

Los engaños y argucias para el sometimiento, así como el ocultamiento o divulgación de los resultados de las pruebas, le restringen efectivamente y dejan libre la esfera del sujeto analizando para hablar de un atentado directo contra sus derechos, en especial la intimidad. ${ }^{423}$

\footnotetext{
${ }^{422}$ En el caso español, fundamentalmente en los autos número 103/1990 y 221/1990 del Tribunal Constitucional , se ha determinado que “... la práctica de las pruebas genéticas en la identificación de la persona no puede decirse que ataque la intimidad de ésta, ya que si bien es cierto que es posible realizar intromisiones legítimas en la esfera de la intimidad y que puede admitirse una prueba, como la biológica, que afecte a tal derecho, sin embargo, con arreglo al principio de proporcionalidad de sacrificios, es proceso que existan otras pruebas e indicios que justifiquen una intromisión en la intimidad para obtener una prueba adicional. No se puede acordar una prueba que representa una intromisión en la intimidad como prueba única, tampoco se puede compeler a la práctica de dicha prueba, sino mediante la advertencia expresa de las consecuencias que pueden seguirse de su negativa o de la valoración que de ésta pueda hacerse con los indicios ya existentes". (vid. Fundamentalmente los autos 103/1990 y 221/1990 del Tribunal Constitucional)

${ }^{423}$ LLEDO YAGÜE; Francisco; "La identificación de la persona mediante pruebas genéticas y sus implicaciones jurídicas", en El derecho ante el proyecto genoma humano, Madrid; Fundación BBV, 1994, vol. IV, p. 37
} 


\section{Derecho al honor}

El honor es un crédito moral que se configura a través del cumplimiento de nuestros deberes. Es, en pocas palabras lo que permite la sociabilización de la persona. Su vulneración se da, en nuestro estudio, por la exigencia al sometimiento a las pruebas biológicas, la repercusión que genera la información obtenida o el uso indebido de ésta. De manera tal que los efectos repercuten contra el sentimiento propio y estado de honestidad, la reserva debida y el reconocimiento social de la persona intervenida ${ }^{424}$. Éste es el argumento esgrimido en defensa del derecho al honor frente a la investigación de la paternidad.

Por su parte se alega que el probable atentado irrogado a este derecho está dado básicamente en el entorno social, al ponerse al descubierto relaciones sexuales extramatrimoniales y el nacimiento de un hijo como consecuencia de éstas. Los efectos son mayores si la persona a la cual se indagó biológicamente es casada o es personaje público.

\section{Derecho a la igualdad.}

Este derecho está relacionado con la libertad y contrapuesto con la discriminación. Su fundamento se circunscribe en la prohibición que el derecho impone frente a las diferencias existentes entre y hacia las personas.

\footnotetext{
${ }^{424}$ EGÚSQUIZA BALMASEDA, María Ángeles, op.cit p. 61, abunda sobre el tema del pudor y el recato, haciendo referencia a la STC de 17 de enero de 1994, la cual expresa que: "no puede considerarse degradante, ni contraria a la dignidad de la persona, la verificación de un examen hematológico por parte de un profesional de la medicina, en circunstancias adecuadas (...) la extracción de unas gotas de sangre, de acuerdo con la Sentencia del Tribunal Supremo de 14 de noviembre de 1987, no constituye según un sano criterio, violación del pudor o recato de una persona".
} 
El análisis correspondiente a la investigación paternal y este derecho debemos realizarlo alegando que si bien existe una igualdad entre los hijos, ésta es limitada pues en temas como la determinación parental no se da. Así, tenemos que los matrimoniales gozan de una presunción legal pater est, mientras que los extramatrimoniales carecen de relación preestablecida, por lo que extraer una aproximación a la vinculación filial frente a la negativa al sometimiento de la prueba biológica es tender al fortalecimiento del derecho a la igualdad entre los hijos.

\section{Derecho a la tutela judicial efectiva.}

Este derecho se vincula con la administración de justicia y la facultad que tiene la persona de gozar de una adecuada solución jurisprudencial frente a sus problemas, partiendo del principio de que las partes tienen el deber de colaborar y actuar de buena fe, así como el juez encargarse adecuadamente del proceso.

Los argumentos en pro de este derecho han sido de los más variados, tenemos algunos por citar:

- El derecho que asiste a todo sujeto de no declarar contra sí mismo (principio de no autoinculpación). ${ }^{425}$ En los procesos judiciales, las partes no son sólo titulares de derechos sino también sujetos de obligaciones y cargas. ${ }^{426}$

\footnotetext{
${ }^{425}$ Germán BIDART CAMPOS en su artículo "La negatoria a someterse a pruebas biológicas en el juicio de filiación”, en Diálogo con la jurisprudencia. Revista de crítica y análisis jurisprudencial. Lima: Gaceta Jurídica Editores, año III No. 5; adelantando la sociedad de su posición constitucional, establece:

- No estar obligado a declarar contra sí mismo es un derecho constitucional que significa también no estar obligado a prestar su propio cuerpo.

- $\quad$ Prestar el cuerpo requiere inexorablemente el consentimiento con plena voluntad y libertad.

- Al no poderse obligar al sometimiento de la prueba, tampoco puede constitucionalmente ordenarse vía judicial que ser practique contra la voluntad y mucho menos coactivamente.
} 
- La negativa puede implicar un fraude de ley. ${ }^{427}$

- Es un abuso de derecho.

- Es una falta de colaboración con la administración de justicia.

- La negativa a la práctica de pruebas biológicas no supone, $a b$ inittio, una ficta confessio ni será una ficta pericia.

En particular, el derecho a la tutela judicial efectiva puede verse afectado de diversas maneras de acuerdo con los intereses de las partes, teniendo que:

- En el demandante, si no procede investigar la verdad biológica a partir de medios de prueba indirectos y tiene lugar la negativa de la parte demandada a la prueba biológica, obstaculizándose la continuación del proceso. ${ }^{428}$

- En el demandado, si es sometido en forma obligatoria exámenes biológicos.

Del análisis de estos derechos de la persona vemos que en contraposición, o como defensa de la filiación, están implicados otros derechos como son el derecho a la identidad, el derecho a conocer el propio origen

- La negativa al sometimiento no puede ser usada como un reconocimiento ficto de la filiación, ni como presunción en contra de quien rehusó la prueba, ni como elemento adicional a acumularse indiciariamente con otras pruebas rendidas en juicio.

${ }^{426}$ En tal sentido la STS de 15 de marzo de 1989, que recoge doctrina ya asentada en la del 14 de julio de 1988, plantea que no hay que olvidar que si la persona de la que se postula el reconocimiento de la paternidad es sujeto del proceso es, a su vez, el objeto del proceso y, en última instancia, el cuerpo humano pasa a ser objeto de la prueba pericial sobre la que ha de operar la obtención de las pruebas biológicas y antropológicas, cuya negativa por parte del sujeto de someterse a ellas conculcarían la declaración programática del artículo 39.2 in fine de la Constitución.

427 "Mantener a ultranza el derecho individualista a negarse a las pruebas biológicas supone un fraude a la vez y un ejercicio antisocial del derecho”. Fallo cit. por GROSMAN, Cecilia y ARIANNA, Carlos; "Los efectos de la negativa a someterse a ellas conculcaría la declaración paterna extramatrimonial”, en La Ley, Buenos Aires, 1992-B-1193.

${ }^{428}$ Es el motivo básico de recurso ante el Tribunal Constitucional español de una sentencia de la Sala de lo Civil del Tribunal Supremo, que dio lugar a la importante Sentencia del Tribunal Constitucional 7/1994 que se ha venido analizando a lo largo del presente trabajo; y por vulneración del derecho a la tutela efectiva; en el mismo sentido el Acuerdo del Tribunal Constitucional 221/1990. 
biológico, la dignidad, el derecho a la investigación de la paternidad, a ser procreado y nacer dentro de una familia, el reconocimiento especial a la individualidad biológica y el derecho a la salud psíquica y social.

$\mathrm{Y}$ es que en el Derecho de familia se “... exige desplazar, si fuese necesario, el interés del individuo frente al del grupo familiar, núcleo básico de la sociedad”429. Es más, en la filiación subyace, prevalece y está en juego el interés social dominante que implica, a través de las pretensiones correspondientes, atribuir un nombre, asegurar un vínculo sucesorio y, por sobre todo, consolidar la obligación alimentaria.

Debe aplicarse, entonces, criterios de proporcionalidad o la denominada teoría de ponderación de intereses, a efectos de salvaguardar el derecho de mayor relevancia, que en este caso es, sin duda, la identidad. En definitiva, la colisión entre el principio de la verdad biológica y cualquiera de estos derechos enunciados potencialmente afectados ha de resolverse conforme al método de ponderación triple, esto es: respecto al contenido esencial del derecho fundamental, legitimidad y proporcionalidad de la medida.

En muchos casos, la defensa de los derechos fundamentales va a ser alegada o utilizada con una finalidad contraria a su esencia a efectos de desvirtuar la pretensión principal, cual es la determinación de la paternidad. En estos casos es necesario entablar una correcta relación entre la pretensión, el medio de prueba ofrecido y los intereses en juego.

\footnotetext{
${ }^{429}$ KEMELMAJER DE CARLUCCI, Aída. "Derechos humanos, derecho comunitario, derecho constitucional y familia”, en op. cit, aclara, asimismo, que demostrativa de la aplicación de esta pauta”... fue la legislación civil que vedó la investigación de la maternidad si la finalidad de la acción era atribuir un hijo extramatrimonial a una mujer casada, la conciencia social de entonces imponía que era preferible mantener la paz de la familia, legítima aunque un menor quedase sin filiación reconocida"
} 
Esta evaluación entre la pretensión y la alegación de parte en defensa de sus derechos debe venir motivada y, en cada caso, basada en el principio de proporcionalidad, entre la intromisión y agresión y la necesidad y finalidad perseguida con ella, respetando siempre el contenido esencial del derecho fundamental afectado.

Así lo ha entendido la legislación francesa que desde su Proyecto de ley relativo al cuerpo humano ha establecido que en materia civil la identificación de una persona no puede ser objeto de investigación, sino en casos de resolución motivada por el juez orientada a establecer o contestar la filiación, sea para la obtención o supresión de subsidios, todo ello con acuerdo expreso del interesado ${ }^{430}$.

Así mismo, en su Ley número 94-653, relativa al respeto del cuerpo humano, mediante la cual los franceses incluyen un capítulo a su Código Civil denominándolo del "estudio genético de las características de una persona y de la identificación de una persona por sus huellas genéticas”, considerando que la identificación de las personas por sus huellas genéticas no puede ser realizada más que en el marco de medidas de investigación o de instrucción dirigida en un procedimiento judicial o para fines médicos o de investigación científica. En materia civil, esta identificación no puede realizarse más que en el caso de una medida de instrucción ordenada por el juez en un proceso en el que se pretenda el establecimiento o a la contestación del vínculo filiatorio, o bien la supresión de las obligaciones correspondientes. El consentimiento del interesado debe estar consignado expresamente. ${ }^{431}$

\footnotetext{
${ }^{430}$ Esta disposición se encuentra establecido en el artículo 27, del proyecto francés Núm.. 66 del Senado presentado en sesión ordinaria de 1992 - 1993.

${ }^{431}$ Ley número 94-653, París de 29 de julio de 1994, relativa al respeto del cuerpo humano (traducida por Natalia Sandoval Peña, 28/10/1994).
} 
Es de considerarse que la intervención del juez ordenando la prueba, así como su práctica, es la base para el respeto y defensa de los derechos de la persona. Más que un mero formulismo, la garantía en el decreto y ejecución de la prueba de identificación genética es fundamental.

Por su parte, la jurisprudencia española nos indica que en los procesos de investigación de la paternidad se ha producido un tránsito del principio de la verdad formal al principio de la verdad material ${ }^{432}$, que al afectar el interés social y el orden público se sigue en ellos un principio inquisitivo ${ }^{433}$, en el que la articulación de un sistema probatorio libre y ponderado determina que la prueba sea apreciada por el tribunal. ${ }^{434}$

Esta libre evaluación del juzgador y el amplio sistema de pruebas asumido, fijan los parámetros sobre los que se permite afirmar la filiación sólo a partir de medios de prueba indirectos, cuando la conducta obstruccionista del demandado impide la práctica de pruebas directas más concluyentes. ${ }^{435}$

\subsection{Los terceros y la prueba biológica}

Si bien son las partes las que se encuentran vinculadas con el proceso y es a través de ellas que se obtienen elementos para el esclarecimiento de los hechos en discusión, en casos especiales se requiere la intervención y participación de terceros (ajenos al litigio). En los juicios de filiación, los presuntos abuelos, hermanos, tíos, primos, pueden aportar elementos biológicos básicos para sentenciar correctamente.

\footnotetext{
432 STS de 15 de marzo y 5 de mayo de 1989.

${ }^{433}$ STS de 3 de diciembre de 1988 y de 5 de mayo de 1989

${ }^{434}$ STS de 3 de diciembre de 1988

${ }^{435}$ STS de 28 de noviembre de 1995
} 
La intervención de terceros puede facilitar la investigación del nexo filial en discusión. Como hemos determinado, las pruebas heredobiológicas tienen como sustento la transmisibilidad de los marcadores genéticos de generación en generación, individualizándose cada vez más conforme se vaya estrechando un vínculo biológico entre los parientes consanguíneos.

Siendo esto así, en determinados casos como la desaparición, la ausencia o investigación de paternidad post mortem, aparición de caracteres genéticos ex novo, existencia de genes silentes, es necesaria la participación de los terceros familiares en la investigación biológica de la paternidad, para poder afianzar la transmisibilidad hereditaria de los caracteres biológicos en estudio. ${ }^{436}$

Un caso bastante singular sería aquél en el que se investigue la vinculación filial realizando el examen genético entre los hermanos y madre, determinando de manera efectiva el parentesco correspondiente.

Esto lo analiza Enrique VARSI ROSPIGLIOSI ${ }^{437}$, al exponer el siguiente cuadro seguida de la explicación:

\footnotetext{
${ }^{436}$ En Alemania, Austria y Rusia, se establece que cada vez que sea necesario se procederá a la investigación racial, hereditaria y sanguínea de los abuelos, interesados y testigos. En el caso especial de los abuelos, la doctrina y jurisprudencia argentina ha establecido que "Algunas sentencias destacan que la prueba es relevante aunque se haya practicado en los presuntos abuelos y no en el padre, sobre todo si los primeros no tuvieron otros hijos varones y el niño acusa la posible herencia de antígenos presentes en la abuela, lo que descarta que sea hijo del abuelo" (especial mención en la nota a pie de página no.9 remite al Voto de ZANNONI, Cám. Nac. Sala A 25/11/1986 ED 123-107 o en la Ley 1987-C-69) Cfr. KEMELMAJER DE CARLUCCI, Aída R. "El valor de la prueba genética en el derecho argentino”, en El derecho ante el proyecto genoma humano, Madrid, fundación BBV, 1994, vol IV p. 176.

${ }^{437}$ VARSI ROSPIGLIOSI, Enrique, Derecho, ADN y Genética; Universidad de Lima; Cfr. "A mediados del mes instalan equipos para análisis de ADN”, enn El Comercio, Lima, 31 de enero de 1997, sección A, p. 20
} 


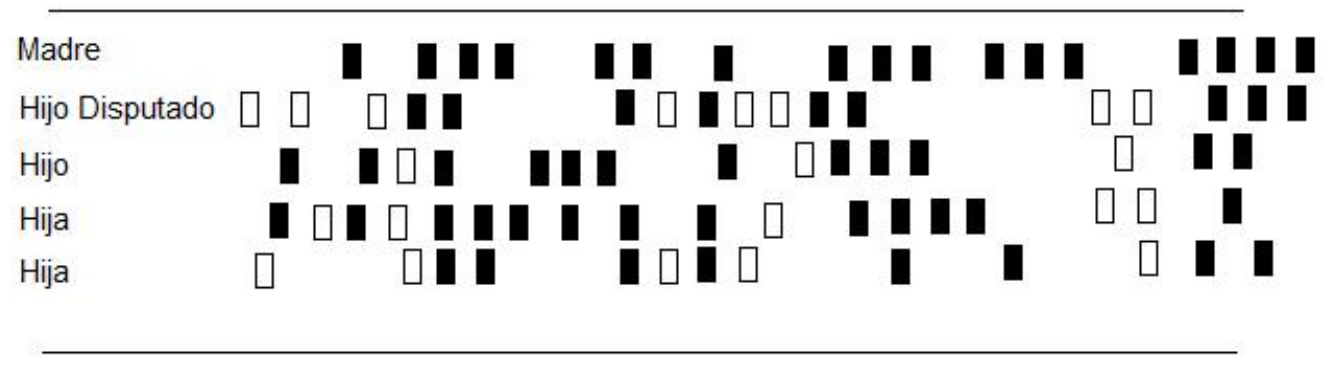

Este cuadro es el resultado de un análisis de ADN. Las barras negras en la primera fila son segmentos o huellas genéticos del ADN de la madre. Las barras blancas son las huellas genéticas del padre ausente. La segunda fila contiene las huellas genéticas del hijo en disputa y las restantes, de los hijos reconocidos. Puede verse que caras de las huellas genéticas (barras negras y blancas) que el hijo disputado heredó de su padre y su madre, también están presentes, con la misma ubicación, en uno o más de sus hermanos. La presencia y la igual ubicación, de las "huellas genéticas" permiten individualizar a los hermanos.

En nuestro medio no existe amparo legal para que los terceros ajenos al litigio como lo es el abuelo, hermano, tío, etcétera, se sometan al examen heredobiológico para investigar en sus marcadores genéticos la transmisibilidad de la huella familiar en relación con las partes litigantes (padre e hijo). Incluso, para estos terceros ajenos al litigio no rige el deber de declarar o el de sometimiento establecido para el caso de los testigos. 


\subsection{La negativa a someterse a la prueba biológica}

Entendida la tendencia doctrinal a la obligatoriedad de la parte a colaborar con la prueba heredobiológica y descartada la compulsión o ejecución forzada de la misma, ${ }^{438}$ es necesario estudiar los efectos jurídicos que surgirían de la resistencia a su sometimiento.

Con relación a ello, las tendencias legislativas otorgan una solución vía apremios, presunciones o de tenerse por ciertos los hechos alegados respecto a quien se niega. Este punto es el de principal preocupación, pues la doctrina y jurisprudencia comparada lo han tratado de una manera amplia y por demás dispar.

\subsubsection{Elementos}

Para que la negativa pueda implicar una valoración jurídica de aproximación al fallo, deberá cumplir con los siguientes elementos, conforme lo señala la jurisprudencia española ${ }^{439}$ :

\section{- Ser seria}

\footnotetext{
${ }^{438}$ En Alemania, Austria y algunos estados americanos el examen biológico puede llegarse a cumplir coactivamente. Así tenemos que, "en la República Alemana cabe la práctica forzosa en virtud del principio 'Duldingspflich' (deber de sometimiento), que obliga a las partes y terceros a soportar todos los exámenes susceptibles de conducir al descubrimiento de la verdad biológica. (art. $372 \mathrm{ZPO}$ ), siempre que existan repetidamente negativas injustificadas" (vid. RIVERO HERNANDEZ, "Comentario a la sentencia de 17 de julio de 1987”, en Cuadernos Civitas de jurisprudencia Civil 1987, pp. 4,839 y ss), en el mismo sentido manu militari, se obliga al desarrollo de pruebas biológicas, si media oposición improcedente, en las legislaciones de Dinamarca, Austria y algunos estados de Norteamérica. En los Estados Unidos de Norteamérica, el tribunal puede pedir de oficio o a instancia de parte el blood test, con las secuelas, para las partes que se oponen de la posible decisión en su contra (uniform Act on Paternity 1973 - y Uniform Act on Blood Test Determine Patternity -1963), el Código suizo tras las reformas de 1976, establece la obligación de que las partes y los terceros presten su colaboración a la práctica de las pruebas necesarias para aclarar la filiación correspondiente, siempre que ello no entrañe un peligro para la salud.

${ }_{439}$ Como se ha manifestado en las Sentencias del Tribunal Supremo de 29 de marzo de 1993, 14 de julio y 23 de septiembre de 1988 y 15 de marzo de 1989.
} 
- Injustificada

- Manifestada personalmente por el interesado

- Ser obstruccionista

- Reveladora de un expreso propósito de no comparecer al juzgado o ante los peritos para someterse a las pruebas biológicas.

\subsubsection{Clases}

En los juicios donde se invoque la prueba heredobiológica, el sujeto pasivo siempre tendrá el derecho a poder negarse a prestar su cuerpo para la práctica de la misma, siempre teniendo una razón, y los diferentes criterios jurisprudenciales le han ido dando un tratamiento diverso.

\section{A) Justificada}

Hay casos en que la negativa del sujeto pasivo a prestar su cuerpo para la práctica de dicha probanza puede estar justificada. En estas situaciones los argumentos que se esgriman debe ser razonables y estar debidamente probados, de esta manera, sólo la existencia de causas muy cualificadas, y debidamente justificadas, podrían legitimar la negativa al sometimiento de la prueba biológica.

En las pretensiones de filiación prevalece "el interés social y de orden público, connatural a toda declaración de paternidad, y base fundamental de los demás derechos correspondientes a la filiación, al proteger a esta tanto dentro como fuera del matrimonio”. Así pues la negativa del demandado que no vaya 
acompañada de la irresponsabilidad, respecto de la aceptación de las cargas y deberes directamente derivados de unos posibles vínculos familiares. ${ }^{440}$

Entre algunos casos de especial consideración tenemos:

- Razones de salud física, como ser hemofílico o padecer otra enfermedad; o bien salud psíquica ${ }^{441}$.

También se ha resuelto en un caso particular de estudio, que no cabe extraer consecuencias de la negativa si el demandado es un anciano de más de ochenta años, que padece arteriosclerosis avanzada, con hipertensión y esclerosis coronaria con broncoefisema pulmonar, edad y padecimientos que algunos meses después le produjeron la muerte ${ }^{442}$.

- Motivos religiosos ${ }^{443}$ o de credo, así como otras causas relevantes vinculadas a la libertad religiosa.

\footnotetext{
${ }^{440}$ Anuario de Derecho Civil, Madrid, ministerio de Justicia e interior, Abril - junio MCMXCVI, tomo XLIX, fasc. II p. 1027

441 “Así, un Tribunal alemán, el OLG Koblenz en sentencia de 19 de septiembre de 1975; (cfr. NJW, 1976, p. 379) estimó como argumento valido, en un proceso de impugnación de paternidad matrimonial, para negarse la madre al sometimiento de la prueba hematológica, los importantes daños psíquicos que de ello se podrían derivar dado su gran temor al pinchazo en la extracción de sangre. El tribunal concluyó que, puesto que había sido probado, que la señora efectivamente padecía una "Spritzen - Phobie", y que ésta podía ser tratada y curada, si no era posible decidir sobre la filiación mediante las restantes pruebas. Cabía postergar la práctica de esa prueba a un momento posterior". Cfr. RIVERO HERNÁNDEZ. "Las pruebas biológicas...” cit. pp. 74-75. Citado además por EGÚSQUIZA BALMASEDAS, María Ángeles. Op Cit. p. 59 nota 85.

${ }^{442}$ STS español 14de mayo de 1991, comentada por José Luis de los Mozos y José María de la Cuesta en Revista de Derecho Privado de Madrid, dic, 1991, p. 1057".

${ }^{443}$ En la STS español del 3 de diciembre 1991, descartó la negativa fundada en razones religiosas, el rechazo estuvo motivado en que estas razones se esgrimieron por primera vez en la instancia de la casación y no estaban probadas. Cfr. Cuadernos Civitas de Jurisprudencia Civil , número 28, p. 29, especial comentario de Francisco Rivera Hernández. El autor recuerda la sentencia del 14 de noviembre de 1987 en la que el Tribunal estimó irrelevante ser miembro de la secta religiosa denominada Testigos de Jehová porque el representante de la asociación que los reúne testimonió que esa religión no prohíbe la extracción sanguínea con el fin de practicar un análisis, dejándose su ejecución a la conciencia de cada uno.
} 
- Cuando el imputado como padre demuestre su imposibilidad física de haber cohabitado con la madre, estar de viaje, en etapa de convalecencia o en prisión.

- Cuando se demuestre efectivamente la infertilidad o impotencia. Así también sería alegable la negativa de un menor de 16 años, tomando en consideración que el reconocimiento en nuestro sistema se realiza a partir de esa edad (principio de economía básico)

- Error en la identidad del demandado ${ }^{444}$.

Los casos mencionados forman parte de lo que se conoce como las probabilidades a priori contingentes, en la investigación de la paternidad, es decir, aquellas situaciones analizadas con anterioridad al examen biológico. En otras palabras, sin circunstancias preliminares que rodean el evento, como tales, deberán ser estudiados con sumo detenimiento.

La negativa infundamentada de un sujeto a someterse a la prueba biológica es por demás sospechosa y obstruccionista, mereciendo el calificativo de ilegítima por falta de justificación, lo que implicará la sanción valorativa del juez.

\footnotetext{
444 "En el caso se consideró acreditado que la madre del menor en la época de la concepción se desempeñaba como doméstica con cama adentro en el domicilio del presunto padre. A su vez, éste no había acreditado que la madre tuviera en aquel tiempo relaciones sexuales con otros hombres. Por otra parte, el demandado no concurrió a someterse a los estudios biológicos, declarando ante el juez que los mismos no dan seguridad y que era mellizo gemelo con otra persona. En relación a ello, el tribunal entendió que al contestar la demanda no se había dicho nada respecto del hermano, ni solicitado que se integrara la litis con él, ni acompañado oportunamente certificados de nacimiento y mucho menos ofrecido la prueba biológica para acreditar la gemelidad. Finalmente se afirmó que cuando los presuntos padres son mellizos, pueden ser dicigótico o monocigótico" Revista de Derecho Privado y Comunitario. Santa Fe; Rubinzal Culzoni No. 8 p. 426.
} 
Respecto de ello, se ha hablado que dicha resistencia genera un reconocimiento tácito de lo que se discute, pues si nada se arguye como justificación resulta ilógico disculpar o no considerar dicha actitud. ${ }^{445}$

Otros casos que, en cierta manera, justificarían la negativa y que se han presentado en la jurisprudencia comparada son:

- La inexistencia evidente de indicios serios de la conducta que se le atribuye al demandado.

- La absoluta falta de necesidad de la misma al existir otros medios probatorios, fácilmente utilizables, que pueden conducir a la determinación de la paternidad.

\section{b) Injustificada}

No serán considerados como motivos justos:

- El daño a la integridad física (la tipificación de los estudios de ADN no requiere sangre sino que se realizan con cualquier otro fluido corporal).

- El riesgo económico (el demandado asume el costo de la prueba si resulta positivo).

- La deshonra social (que sea un personaje público o por notoriedad de la persona).

\footnotetext{
${ }^{445}$ El silencio de la legislación mexicana, así como la española, no impediría atribuir a la negativa y el reconocimiento del valor probatorio de una manifestación de que se tuvo relaciones sexuales en condiciones que habían posible la generación, porque sólo el temor de que se descubra la verdad biológica, que el sujeto previamente conoce, explica su rechazo a facilitar la práctica de una prueba que le ofrece la oportunidad de desvirtuar la demanda, como se ha indicado en la sentencia del Tribunal Supremo de 6 de junio de 1991, y las de 8 de julio de 1991, 4 de abril y 19 de junio de 1986.
} 
- La vulneración a la integridad familiar (causal de divorcio por adulterio, injuria grave).

- El desmedro profesional (profesional exitoso).

- Un posible contagio de enfermedades infecciosas.

- El hecho punible como consecuencia de la negativa (delito contra la administración de justicia o ser acusado de violación al comprobarse la compatibilidad genética).

Todo ello será apreciado por el juez de acuerdo con su poder discrecional, considerando que la negativa injustificada al sometimiento de la bioprueba no se dirige a la protección del cuerpo humano sino a obstaculizar una investigación filial. En estos casos, la negativa se presenta como realmente injustificada, lo que releva de toda entidad esas objeciones.

La negativa puede derivarse del padre, de la madre o del hijo e indiscutiblemente los efectos jurídicos que produzca serán disímiles con relación a la persona de quien provenga.

El Superior Tribunal de Justicia de Entre Ríos, Argentina ha resuelto por mayoría que no se puede atribuir el mismo efecto si el renuente a la prueba biológica es el pretenso padre, o si lo es un descendiente, colateral o ascendiente en una acción de filiación post mortem. ${ }^{446}$

Por tanto tenemos que:

- Cuando es la madre o el hijo quien de modo injustificado se niega a someterse al examen genético, deducimos que de dicha actitud se

\footnotetext{
446 Cámara $1^{\text {a }}$. Civil y Comercial de San Nicolás, 22-12-1994, Cit. Revista de Derecho Privado y Comunitario. Santa Fe; Rubinzal Culsoni, No. 11, p. 338
} 
desprende un temor a que sea descubierto el verdadero nexo biológico, quedando desestimada la demanda interpuesta por aquellos. Igualmente, que sea considerado como una causa fehaciente de no paternidad cuando la prueba biológica haya sido ofrecida por el padre como medio de prueba. $^{447}$

En este caso, el juez considerará una presunción de incompatibilidad de marcadores genéticos desfavorable a la madre o el hijo que afirmó el vínculo en su demanda, independientemente de quién presentó la prueba de paternidad biológica.

- Cuando es el padre quien se resiste al sometimiento de la experticia biomédica, tanto la doctrina como la jurisprudencia comparada no son uniformes. En este caso el criterio determinador común y lógico es que el juez apreciará la negativa del supuesto padre como una conducta encubridora de la relación filial demandada, ya que si el imputado como progenitor no lo fuera realmente no evadiría una prueba que tiene por objeto poner de manifiesto la existencia o imposibilidad del vínculo parental. $^{448}$

\footnotetext{
${ }^{447}$ Impugnación de paternidad y negativa de la madre: “... la negativa al sometimiento fue incoada como elemento coadyuvante para acoger la demanda de impugnación de la paternidad iniciada por el marido de la madre. En el caso, el hijo había nacido dos años después de la separación de hecho seguida de una declaración o manifestación efectuada ante una defensoría en que se dejó constancias de esa situación. La madre, demandada conjuntamente con el hijo, se opuso tenazmente a esta prueba, elemento que fue valorado por el tribunal para acoger la demanda de impugnación” op cit. Revista de Derecho Privado y Comunitario. P. 327

${ }^{448}$ De esta manera, en España el Tribunal Constitucional Español, dictaminó al declarar la paternidad del famoso torero "El Cordobés" a favor de Manuel Benitez Velasco, hijo de Aline Elizabeth Velasco (otrora modelo y amante del demandado). La Alta Corte basó su sentencia en que "El Cordobés" se negó siempre a hacerse las pruebas de paternidad. El Tribunal Español consideró que tal negativa "constituye base suficiente para que el Tribunal esclarezca el nexo causal preciso para llegar a una conclusión sobre la paternidad reclamada”. Con el fallo del Tribunal Constitucional se confirmó en definitiva la paternidad del demandado quien no podrá recurrir de nuevo a la sentencia. (vid. Semana, Canarias, España, Ed. Rivadeneyra, S.A., de 28 de marzo de 1990, No. 2615
} 
- Hecho singular se presentaría si es un tercero el que se niega a someterse a la prueba biológica (abuelo que se rehúsa al examen para investigar la paternidad de un supuesto nieto) o autorizar su aplicación en una persona bajo su dependencia (adoptante que niega la investigación biológica de su hijo legal). En estos casos no podemos deducir ningún tipo de supuesto relacional de filiación.

En la línea seguida por los dos primeros puntos ha decidido la jurisprudencia española que la negativa a someterse a las pruebas biológicas debe ser evaluada caso por caso, pero de la negativa, en general, debe extraerse la presunción de lo afirmado por la otra parte. Todo lo contrario, es decir, aceptar o reconocer la negativa injustificada al sometimiento de la prueba de paternidad, sería un acto directamente lesivo contra los derechos del recurrente en filiación, así como una violación al ordenamiento jurídico. ${ }^{449}$

Es de ocasión asumir el criterio de CROSMAN y ARIANNA, quienes alegan respecto del significado de la obligatoriedad de los bioexámenes, que extraer de la negativa una presunción que son ciertas las afirmaciones de la contraparte, si bien permiten la declaración filial, ésta adolece de una deficiencia ética, ya que se está reemplazando la posibilidad de obtener un alto grado de probabilidad de paternidad, por una presunción de paternidad nacida de un acto de inconducta procesal. Con esto se está sustituyendo el derecho del hijo a ser declarado como tal sobre la base de pruebas eficientes, por una filiación fruto de un reconocimiento ficto. Por otro lado, es de reconocer, y así valorar los efectos, que desde la posición del demandado, es menos comprometedor perder un juicio

\footnotetext{
${ }^{449}$ En esta orientación, la resolución de la Corte suprema argentina no. 4/12/95-HCS y otro "admitir la negativa a su cumplimiento importaría tanto como desconocer lo estipulado en la Convención sobre los Derechos del Niño - específicamente en su artículo 8 - ; circunstancia ésta que podría ocasionar la responsabilidad del estadio por incumplimiento de los compromisos internacionales asumidos. Cit. CIFUENTES, Santos. "Difícil y necesario equilibrio entre los intereses públicos y los derechos personalísimos (La inspectio corporis Forzada)", en Dialogo con la jurisprudencia, revista crítica y análisis jurisprudencial. Lima, Gaceta jurídica 1997, año III No. 6 p. 313 punto 14.
} 
como resultado de una ficción que como consecuencia de la comprobación de una verdad negada. De esta manera se deja latente la duda, cosa que por consiguiente se le atribuirá la paternidad a un sujeto del cual deberá existir la certeza jurídica que en verdad lo sea, y por consiguiente podemos afirmar que el derecho del menor a poder saber sus orígenes no se puede encontrar satisfecho con esa presunción, la cual ni siquiera podría entrar ya en la posibilidad de iuris tantum.

\subsubsection{Valoración de la negativa}

En un primer momento la negativa al sometimiento a las biopruebas de paternidad fue considerada como un indicio de valor a efectos de declarar el vínculo filial, criterio este asumido por los primeros fallos españoles, así como, de una manera poco más cautelosa, por el Código civil de Colombia en el cual se encuentra establecido en la Ley No. 75 de 4 de diciembre de 1968, complementaria del Código Civil. Se establece en esta última norma que la renuencia de los interesados a la práctica de tales exámenes será apreciada por el juez como indicio. Venezuela en su Código Civil dispone en su artículo 210 que la negativa del padre a someterse a la prueba genética se considerará como una presunción en contra. En Argentina se encuentra regulado en la Ley de banco de datos genéticos y en la cual se afirma que la negativa a someterse a los exámenes y análisis necesarios constituirá un indicio en contrario a la posición sustentada por el renuente.

En el caso mexicano no se encuentra regulado en ley alguna, sino que ha sido considerado por la jurisprudencia la cual ha señalado en forma imperativa que: "Conforme a los artículos 4o. de la Constitución Política de los Estados Unidos Mexicanos; 3o., 6o., 7o. y 8o. de la Convención sobre los Derechos del Niño; y 22 de la Ley para la Protección de los Derechos de Niñas, Niños y 
Adolescentes, los menores tienen derecho a conocer su identidad, y la importancia de ese derecho fundamental no sólo radica en la posibilidad de que conozcan su origen biológico (ascendencia), sino en que de ese conocimiento deriva el derecho del menor, constitucionalmente establecido, de que sus ascendientes satisfagan sus necesidades de alimentación, salud, educación y sano esparcimiento, para su desarrollo integral, además de que puede implicar el derecho a una nacionalidad determinada.

Por otra parte, los Códigos de Procedimientos Civiles del Estado de Nuevo León y del Estado de México establecen medidas de apremio a través de las cuales los Jueces y Magistrados pueden lograr que sus determinaciones se cumplan. Así, cuando en un juicio de paternidad se ordena el desahogo de la prueba pericial en materia de genética (ADN) y el presunto ascendiente se niega a que se le practique, es constitucional que se le apliquen dichas medidas para que se cumpla la determinación del juzgador, pero si a pesar de esas medidas no se logra vencer la negativa del demandado para la realización de la prueba, esto no significa que se deje a merced de la voluntad del presunto ascendiente el interés superior del menor, y que dicha negativa u oposición para la práctica de la prueba quede sin consecuencia alguna, ya que en todo caso debe operar la presunción de la filiación controvertida porque, por una parte, el artículo 190 bis V del Código de Procedimientos Civiles de Nuevo León así lo señala expresamente y, por otra, aunque la legislación del Estado de México no precisa esa circunstancia en una norma expresa, atendiendo al interés superior del niño y de una interpretación extensiva y analógica de los artículos 1.287 y 2.44 del Código Procesal Civil de esa entidad federativa, que establecen los supuestos de confesión ficta y reconocimiento de documentos, se concluye que ante la negativa del presunto ascendiente a practicarse la mencionada prueba, debe operar la presunción de la filiación, salvo prueba en contrario, pues como se ha dicho, considerarlo de otra manera llevaría a dejar el interés superior del niño a 
merced de la voluntad del presunto progenitor y no se respetaría su derecho fundamental a conocer su identidad”450

Al respecto el máximo tribunal mexicano, ha emitido un voto en particular respecto de esta resolución en contradicción de tesis, el cual por considerarse relevante en el tema en el sistema por ser lo más nuevo existente en México puede consultarse en el anexo que se acompaña a esta investigación.

La doctrina del Tribunal Supremo español ante la negativa de la prueba biológica es reiterada en el sentido de que no estimaba como ficta confessio, per así como dato indudable valor, que unido al resto de las pruebas, permitía dar lugar a la acción de filiación y declarar la paternidad. En caso de no haber más pruebas, se tendría que desestimar la demanda, pero si existe alguna indiciaria, esta es suficiente para que combinada con la negativa a la prueba biológica, se pueda estimar la demanda, doctrina que ha sido sostenida en la sentencia de 30 de octubre de 1993 (A.C. 228/94) en los siguientes términos, del final del párrafo primero del fundamento 1.- "La negativa a someterse a las pruebas biológicas no implica, ni supone, desde luego, una ficta confessio, si supone un valioso indicio, puesto en relación con los demás medios probatorios aportados, revelador de una falta de solidaridad y colaboración a la administración de justicia para determinar derechos de terceros cual es el hijo cuya filiación se reclama”.

450 Registro No. 172993; Localización: Novena Época Instancia: Primera Sala Fuente: Semanario Judicial de la Federación y su Gaceta XXV, Marzo de 2007; Página: 111; Tesis: 1a./J. 101/2006; Jurisprudencia; Materia(s): Civil

JUICIOS DE PATERNIDAD. EN LOS CASOS EN QUE A PESAR DE LA IMPOSICIÓN DE MEDIDAS DE APREMIO LOS PRESUNTOS ASCENDIENTES SE NIEGAN A PRACTICARSE LA PRUEBA PERICIAL EN MATERIA DE GENÉTICA (ADN), OPERA LA PRESUNCIÓN DE LA FILIACIÓN CONTROVERTIDA (LEGISLACIONES DE NUEVO LEÓN Y DEL ESTADO DE MÉXICO).

Contradicción de tesis 154/2005-PS. Entre las sustentadas por el Tercer Tribunal Colegiado en Materia Civil del Cuarto Circuito y el Tercer Tribunal Colegiado en Materia Civil del Segundo Circuito. 18 de octubre de 2006. Mayoría de tres votos. Disidentes: José de Jesús Gudiño Pelayo y Juan N. Silva Meza. Ponente: José Ramón Cossío Díaz. Secretario: Fernando A. Casasola Mendoza. 
Ante la negativa a la práctica de la prueba biológica y por falta de otros medios de prueba, se ha desestimado la demanda, fracasando la pretensión de filiación. En los siguientes casos resueltos por las sentencias de 12 de abril de 1988 que en su fundamento 3 contiene la expresión de que "pues dicha conducta no puede originar una presunción favorable a la paternidad”; la sentencia de 24 de mayo de 1989 que destaca que la negativa no la expresó el propio demandado, sino su representante procesal; la de 18 de mayo de 1990, que insiste en que la negativa es un simple indicio que carece de valor probatorio si no va acompañado de otras pruebas; la de 20 de julio de 1990 al expresar que ante la negativa, no declara una paternidad que no cabe ser deducida de situaciones meramente dudosas. Todo esto, ya que resulta lógico presumir que quien no quiere develar la verdad, algo tiene que ocultar.

Actualmente, existe una clara y ya definida posición que lleva a otorgarle validez a dicha negativa sólo en los casos en que ésta es valorada con otras pruebas actuadas en el proceso. Esto quiere decir que, únicamente o de manera individual, la referida resistencia a la bioinvestigación carece de efectos jurídicos y, por el contrario, es importante cuando genera una relación implícita con otros hechos que deberán acreditar la pretensión filial

Frente a esta conducta procesal se valorará el conjunto, no la individualidad, pues el sustrato de esta última es una presunción.

A partir de ello, las pruebas que se ofrezcan así como las obtenidas serán valoradas a partir de tal indicio. Las biopruebas servirán de elementos de convicción al juez para reforzar los supuestos. La idea es sumar indicios al de la negativa a fin de llegar a una conclusión clara, no por ello apresurada. Es en este sentido que "la no comparecencia o bien la negativa a la práctica de las pruebas 
constituye un dato de gran valor cuando va unida a otras pruebas o indicios que revelen la razonable posibilidad de la unión carnal, sobre la que no debe esperarse una prueba plena y directa...”. ${ }^{451}$ Esto sí implicaría un acercamiento a la determinación del vínculo filial. ${ }^{452}$

En otros términos, y aproximando la práctica judicial a la hipótesis de esta teoría, se dirá que para declararse la paternidad por esta vía presuncional debemos interrelacionar los hechos ocurridos, demostrables a través de un escrito indubitado, posesión de estado, relación amorosa estrecha o estado de enamorados, concubinato, entre otros), con la prueba biológica. Alegaremos, con más seguridad, que ese "indicio probatorio (...) ha de estar acompañado en forma incontrovertible de otras pruebas absolutamente definidas, que conduzcan derechamente al juzgador al convencimiento de la paternidad". ${ }^{453}$ Por ello, la negativa se considerará como presunción de paternidad o un indicio muy cualificado $^{454}$ que, corroborada con otras pruebas, permitirá declarar la paternidad.

De la misma manera ha sido entendido por el Superior Tribunal de Justicia de Entre Ríos, Argentina, al haber resuelto que si se acepta que la mera negativa a someterse a las pruebas biológicas no es suficiente para tener por acreditada la paternidad, pero que es necesaria muy poca prueba más para ello,

\footnotetext{
${ }^{451}$ En este sentido la jurisprudencia española se ha pronunciado en las siguientes sentencias: STS 28 de junio de 1991, 5 y 17 de marzo de 1992, 17 de junio de 1992, 26 de enero de 1993.

${ }_{452}$ La jurisprudencia brasileña ha sostenido que la renuencia del padre a someterse al examen hematológico, al lado de otros elementos seguros de convicción existentes en autos, equivalen al verdadero reconocimiento de paternidad. (TJSP, $2^{\text {a }}$ cámara Civ. J-18-8-1981, RT, 559:113) Cfr. NOGUEIRA, Paulo Lúcio; Op Cit., p. 72. Asimismo, la jurisprudencia uruguaya revocó el pronunciamiento que admitía la demanda de filiación, sosteniendo que la sola negativa a pasar la prueba biológica, si bien es un indicio grave con un peso específico muy elevado, es insuficiente para constituir, por sí sola, el fundamento de una sentencia favorable al reclamo filiatorio, siendo necesarios otros medios de prueba para formar convicción

${ }^{453}$ En este sentido la jurisprudencia española: STS de 30 de abril de 1992, 26 de junio, 20 de julio y 26 de noviembre de 1990; 2 de enero, 6 de febrero, 25 de abril 14 de mayo, 28 de junio y 11 de julio de 1991.

${ }^{454}$ STS de 21 de octubre de 1994. Cit. Anuario de Derecho Civil, Madrid, Ministerio de Justicia e Interior, Octubre - diciembre de 1996, Tomo XLIX, fasc. IV, p. 1834
} 
debe analizarse la restante para conducir si es o no procedente la demanda de filiación. Aplicado este principio al caso en examen, se concluyó que si la negativa a la prueba biológica del demandado, médico, que por ende conoce los avances científicos, se suma que se probaron encuentros entre las partes, paseos en autos, salidas, inexplicables en el contexto de la errada negativa del demandado a la existencia de toda relación no profesional, rumores en el barrio sobre el noviazgo, y a ello se agrega la negativa del demandado a presentar la historia clínica de la actora, su paciente, así como el notable parecido físico del menor con el demandado, negar la procedencia de la filiación sería arbitrario ante la afirmación de que la negativa es indicio y se requiere de muy poca prueba más. ${ }^{455}$

Si el resistente ilegítimo es el demandado, o sea, el padre, nace en su contra una presunción grave de que es verdad lo que afirma el acto, o bien, el hijo, y que está tan seguro de su paternidad que teme el nacimiento de un mero indicio que coadyuve con otras pruebas a su demostración. La deducción es producto de una simple lógica, valorar el hecho de que las partes implicadas en el proceso temen su práctica por la cercanía a la verdad.

La jurisprudencia argentina ha determinado respecto de los efectos de la negativa al examen, que en este sentido, existe coincidencia entre la jurisprudencia de ese país y el criterio del Tribunal Supremo español al afirmar que si bien la negativa del demandado no comporta una ficta confessio, es un

\footnotetext{
455 STJ de la sala Civil y Comercial 29-4-94, y sobre el punto DIAZ DE GUIJARRO, Enrique, se pronuncia en el sentido de que “... la presunción de la conducta procesal de quien se resistió a la investigación de su grupo sanguíneo, es insuficiente para acreditar la filiación, si bien influirá en el examen conjunto de la prueba y, armonizándose con los demás elementos que la integren, conducirán al juez al convencimiento necesario para declarar la filiación. Ha de tomarse en cuenta, pues, como uno de los medios congruentes para la demostración del nexo biológico” op cit p. 219
} 
indicio revelador de un afán obstruccionista y denota hasta un fraude a la ley y un ejercicio antisocial del derecho. ${ }^{456}$

En otros términos la STS de 6 de febrero de 1991, ha dicho que la negativa a la práctica de la prueba biológica merece ser seriamente ponderada en el conjunto de los elementos fácticos y probatorios del caso, no cabe soslayar que en los procesos de filiación, en que al interés privado se une la trascendencia social y pública de la filiación, al carácter dispositivo del proceso civil se impregna de tintes inquisitivos que exigen una profundización más aguda de las reglas procesales, tales como la buena fe de las partes o en deberes de rango constitucional, como prestar la colaboración requerida por los tribunales en el curso del proceso. ${ }^{457}$

La posición asumida por EGÚSQUIZA BALMASEDA, quien ha dicho que, como prueba indirecta o presuntiva en materia de pruebas biológicas, se ha hablado del indicio que entraña la negativa a someterse a las pruebas biológicas. En estos casos en los que el convencimiento del juez sobre la cuestión no puede adverarlo como una prueba tan contundente como la biología, se acude al resto probatorio y se valora presuntivamente esa negativa de singular entidad. Se trata de una presunción de hecho que será valorada por el juez, según las reglas del criterio humano. Por ello el Tribunal Supremo ha considerado que el indicio que proporciona la negativa a someterse a un análisis de sangre cabía ser adscrito a un tercer género de pruebas, que sin las representadas por aquel conjunto de circunstancias fácticas y objetivas que tal y como se producen y por las consecuencias que originan bien pudieran ser calificadas de cuasi directas o

\footnotetext{
${ }^{456}$ STS de 14 de julio de 1988.

${ }^{457}$ En el mismo sentido la STS de 3 de diciembre de 1991.
} 
presuntivas. ${ }^{458}$ Esto tal como ha sido establecido por la STS de 2 de abril de 1991. 459

Sobre este punto, pudiera parecer que se ha introducido la ficta confessio, es decir, el reconocimiento de culpabilidad cuando el sujeto se niega a someterse a la prueba, sin embargo tal conclusión resulta inaceptable en el Derecho español, pudiendo mejor decir que la negativa al sometimiento a la prueba biológica será apreciada por el juez de acuerdo a la calidad de quien se resiste y a las demás pruebas aportadas en el proceso. Así el juez podrá deducir, según las circunstancias del caso, las consecuencias, pero sin necesariamente perjudicar a quien se resiste, si su actitud se basa en motivos diferentes al de sustraerse de la acción de la justicia.

\subsubsection{Efectos de la negativa}

La negativa a someterse a la bioprueba de paternidad puede darse ante varios supuestos o situaciones, que deberán ser apreciadas por el juez al momento de resolver dada la singularidad de cada una de ellas; en esta caso se puede presentar lo siguiente:

- Cuando el único elemento del juicio es la negativa del demandado.

\footnotetext{
${ }^{458}$ EGUSQUIZA BALMASEDA, María Ángeles; op cit p. 92.

${ }^{459}$ En opinión de BUJOSA VADELL, Lorenzo M; sería mejor que el legislador estableciera medidas de vis compulsiva para que, garantizando el cumplimiento de las obligaciones procesales, quedaran subsistentes los intereses públicos y los derechos fundamentales de los ciudadanos, con proporcionalidad de los instrumentos o sanciones al fin pretendido, teniendo en la práctica una finalidad disuasoria de actitudes incialmente contrarias al sometimiento a la extracción de sangre, con lo cual la mera amenaza de coerción facilitaría un mayor cumplimiento voluntario de esta obligación. BUJOSA VADELL, Lorenzo Mateo; "El alcance de la obligación de sometimiento a las pruebas biológicas en los procesos de filiación” Revista General de Derecho; núm. 616 - 617; 1996.
} 
Éste es el caso más delicado pues el juez sólo cuenta con un elemento referencial de paternidad: la presunción surgida de la negativa a sometimiento a la prueba de paternidad. En este caso no hay más que lleve al juez a pensar acerca de una paternidad.

- Cuando existen otros elementos de prueba.

La presunción originada de la negativa robustecerá las pruebas existentes, de manera tal que analizará el plexo probatorio.

- Cuando existen elementos probatorios que demuestran fehacientemente la ausencia de nexo biológico.

En este caso la presunción que surge de la negativa no deberá ser tomada en cuenta, ya que existen situaciones que la desvirtúan.

La identificación personal a través del ADN es el principal avance científico en el área de la medicina legal y la biología forense. Su campo de aplicación es amplio, pudiendo conseguirse resultados efectivos para diversos tipos de procedimientos tales como la determinación de culpabilidad, análisis de vestigios biológicos en el lugar del crimen, casos de migración ilegal y la investigación de la paternidad.

El hecho es que debemos esperar que en un futuro las prácticas e investigaciones biológicas tengan una mayor utilización ante los tribunales de justicia para ofrecer una mejor resolución a las causas en litigios. Por ahora, es nuestra tarea establecer la aplicación judicial de las pruebas heredobiológicas para así lograr una visión total de estas técnicas en análisis. 
Entre los contextos jurídicos en los cuales son de utilidad estas pruebas, según el criterio de las partes que las pueden ofrecer, tenemos:

\section{Por el padre}

- Para desvirtuar o contradecir las presunciones de paternidad $^{460}$.

- Reclamación de la relación parental con un niño

- Anulación de reconocimientos realizados por vicios en el consentimiento o cuando no hubo intervención directa del padre. ${ }^{461}$

- Para desconocer la paternidad. ${ }^{462}$

- Para impugnar la propia paternidad

- Indagación de la paternidad del hijo póstumo

- Para probar el adulterio. ${ }^{463}$

- Para declarar la desestimación de la pretensión alimentaria del menor no reconocido ni declarado judicialmente como tal, por existir un descarte de paternidad.

\footnotetext{
${ }^{460}$ En un punto, que podríamos llamar presunciones contra la prueba biológica, se ha señalado acertadamente que el aporte de las nuevas pruebas y exámenes biológicos relativos a la determinación de la paternidad hacen perder relevancia a la prueba de relaciones sexuales entre el presunto padre y la madre en el período legal de la concepción. Esta prueba es hoy sustituible por la de las pruebas biológicas Cfr. KEMELMAJER DE CARLUCCI, Aída R. "El valor de la prueba genética en el derecho argentino", op cit. p. 176

${ }^{461}$ El demandante solicita la aplicación de la prueba negativa de los grupos sanguíneos en una nulidad de reconocimiento por simulación absoluta.

${ }^{462}$ En este caso podemos citar el Código Civil boliviano, el cual admite como forma de exclusión de la paternidad cualquier medio de prueba incluso el examen o procedimiento médico científico para demostrar que no puede ser el padre del hijo. Artículo 209; Código Civil de Bolivia.

${ }^{463}$ En el Derecho comparado existe discrepancia doctrinal y jurisprudencial en cuanto a la fundamentación de la demanda de adulterio en la prueba hematológica que sirva para demostrar y alegar la inexistencia de vínculo biológico entre el hijo concebido en el matrimonio y el marido. Quienes niegan su procedencia se basan en la prohibición de la investigación de la paternidad del hijo adulterino, ya que ello atentaría contra la familia legítima y el orden social. Ello es corroborado en gran parte por los hermanos MAZEAD. Lecciones de Derecho Civil; Buenos Aires; Ed. Jurídicas Europa - América, parte I, vol. III, 1959, p. 502.
} 
- Cuando una mujer que ha cohabitado con varios hombres le imputa la paternidad a quien más le conviene (exceptio plurium concubentium)

\section{Por la madre}

- Negación de su maternidad

- Reclamación de paternidad

- Negación de la relación parental de quien no reconoció a su hijo

- Maternidad dubitada. En los casos de suposición o simulación de embarazo o parto, sirviendo como prueba corroboradora a las huellas del parto reciente.

- Sustitución accidental o dolosa de niños en la maternidad

- Violación o si se alega la existencia de relaciones sexuales con varios hombres.

- Como dispensa del plazo de viudedad, cuando llegue a determinarse la imposibilidad de paternidad del marido difunto, en el caso de la viuda, de la mujer divorciada o cuyo matrimonio ha sido invalidado y quiera contraer nuevas nupcias antes de los 300 días de la muerte de su marido.

\section{Por el hijo}

- Negación de paternidad

- Para aclarar la pluralidad de reconocimientos

- Acción de reclamación de la filiación 


\section{Contra terceros y otros casos especiales}

- En reclamaciones de herencia por herederos falsos

- Para determinar el vínculo filial de los niños abandonados, fetos abortados o personas desaparecidas

- En el esclarecimiento del vínculo biológico para determinar la consanguinidad entre el sujeto activo y pasivo de los delitos de infanticidio, parricidio o incesto.

- Para investigar el verdadero nexo biológico producto de la biotecnología de la reproducción ${ }^{464}$ tales como: la fecundación asistida, utilización del útero y en la reproducción asexual mediante la partogénesis y reproducción clónica.

- Para la identificación de personas desaparecidas o de cadáveres. ${ }^{465}$

- En la determinación de los abuelos, los derechos de herencia, reclamaciones de seguros o beneficios de la seguridad social.

- En el establecimiento de los derechos de un sujeto nativo de un país determinado.

- En la averiguación del carácter de gemelos respecto a varios hermanos.

En este último punto, por citar algunos, tendríamos los controvertidos casos de: fecundación heteróloga de la mujer casada, en mujer sola, en viuda con semen del marido prefallecido, la transferencia del embrión en mujer portadora y

\footnotetext{
${ }^{464}$ Con una lógica clara Juan CRUZ CRUZ, nos explica que la biotecnología de la reproducción con sus técnicas heterólogas, así como la selección de los caracteres en el futuro hijo, implican la anulación de la paternidad, pues "ese padre no quiere ya el hijo por sí mismo, por su naturalidad espontánea, sino meramente por satisfacer un deseo (...) su hijo será su deseo, serpa la repetición de sí mismo, la reproducción de su yo" Persona y bioética, Universidad de La Sabana; año 2, no. 2, octubre - enero de 1998;

${ }^{465}$ Las biopruebas podrían ser utilizadas por el Registro del Estado Civil, como se viene haciendo en algunos estados norteamericanos.
} 
la oposición del marido a la transferencia a su ex esposa de embriones crioconservados de ambos.

Habiendo analizado la efectividad positiva de la prueba de paternidad y reconocido el campo de aplicación en la negación de la misma, debemos establecer que estas pruebas genéticas pueden ser utilizadas, según la función que cumplen, tanto como prueba de cargo o de descargo por el padre, la madre o el hijo para investigar la verdadera relación paterno - filial.

Establecido el grado de validez científica, si es que el demandante que desea probar un vínculo filial ofrecer la prueba genética, ésta no deberá ser rechazada ya que es una prueba idónea y, por tanto, admisible debido a los efectos positivos que produce, los cuales servirán de asidero biotécnico al juez para la valoración conjunta de las demás pruebas presentadas en la controversia.

Las investigaciones científicas han avanzado hoy en día permitiéndole al juez tomar plena conciencia de la realidad del nexo biológico que podemos afirmar el salto ineludible e impostergable de la época del trauma a la época de la verdad, de la paternidad probable a la paternidad segura, de la incertidumbre a la determinación.

En el caso en México, podemos decir que la falta de una regulación específica sobre la aplicación de la prueba de marcadores genéticos puede ocasionar un uso inadecuado de ésta, lo cual atentaría seriamente contra los principios de seguridad jurídica e integridad familiar. Antes que ello, estas experticias deberán servir para cautelar y contener la armonía familiar, dando una alternativa eficaz como medio probatorio, sirviendo de elemento robustecedor a la institución de la paternidad responsable de manera tal que se eviten en gran 
parte y de manera indirecta, algunas consecuencias eventuales de la promiscuidad y del trato sexual indiscriminado. 


\section{CONCLUSIONES}

1. El ser humano por su naturaleza social, se va uniendo a otros, creando con ello a la institución familiar y ésta considerada el núcleo de la sociedad, la cual es una institución social y jurídica, dentro en la que se satisfacen las primeras necesidades de la persona y por ende, es la base parental y la forma más generalizada de perpetuar la especie; de aquí debemos entender a la filiación como el vínculo de mayor importancia para la conexión de estos lazos familiares, ya que se generan los derechos y deberes de asistencia mutua y desarrollo personal entre los padres e hijos principalmente.

2. La filiación es un derecho de identidad, con el cual nace todo ser humano, y como derecho fundamental requiere una protección y determinación, como sería lo relativo a la individualidad biológica, el derecho a la investigación de la paternidad y el derecho a conocer el propio origen biológico, por contar cada individuo con una sola filiación llamada biológica, surgida de la concepción generada por sus progenitores, y por ende de la aportación de material genético de dos personas y la cual debe estar debidamente determinada para surtir sus efectos legales.

3. Los términos "paternidad" y "filiación" expresan calidades correlativas, esto es la calidad de padre y la calidad de hijo; pero evidentemente la filiación es un concepto más extenso, ya que reposa no solo en la paternidad, sino igualmente en la maternidad; esto de manera tal que el título de adquisición del estado de hijo tiene su causa en la procreación, 
constituyendo el presupuesto biológico fundamental en la relación jurídica paternal; sin embargo, esta relación igual puede constituirse sin hecho biológico o existir un hecho biológico sin filiación, o no existir una procreación propiamente dicha y una filiación por determinarse.

4. El problema de la filiación surge al correlacionar el vínculo biológico con el jurídico, ya que mientras el primero es natural, ilimitado y reservado en su determinación, el jurídico es creado, limitado y concreto en su establecimiento, contraponiéndose en ocasiones. De ahí que se pueda hablar de dos cuestiones fundamentales en la filiación que son el hecho biológico de la procreación y el acto jurídico de su prueba; sentando sus bases en las ciencias biológicas, las que tienen como regla el hecho de que el hijo necesariamente tiene un padre que inició la fecundación y una madre que lo alumbró. Pero para el Derecho puede carecerse de uno de ellos o de los dos porque la procreación es un hecho productor de efectos jurídicos, pero entre éstos no está necesariamente la atribución de un estado de filiación; no existiendo siempre una correlación exacta entre la paternidad jurídica y la biológica, aun cuando el Derecho trate de apoyar la primera en la segunda, esforzándose porque ambos conceptos concuerden, aunque la afirmación jurídica de la filiación es una realidad biológica presuntiva.

5. Tender a la verdad biológica, dejando de lado la social, es tanto como la realidad actual de admitir la prueba biológica sin brindarle una adecuada regulación jurídica, reafirmando el principio natural de que la filiación tiene su causa iuris en la concepción. Así, en los sistemas filiales cerrados, la investigación paternal se tolera siempre que existan elementos básicos que predeterminen un estado de familia, o bien de otra forma, que exista un principio de los hechos en que se funde que permitan la admisibilidad de la demanda; estos elementos son las presunciones que se 
fundamentan en indicios, reflejando casos sociales que lleven a suponer que una persona es padre de otra porque existen hechos ocurridos, conductas asumidas o situaciones por comprobar que así lo permitan presumir.

6. La presunción de la filiación se da por la imposibilidad biológica de probar el nexo filial, de aquí que se tomen de referencia en la indagación de la paternidad, con todas las limitaciones e inseguridades que se genera, caso específico de México, en que se ha buscado en la presunción el origen genético de la filiación. La presunción simplemente es un acto que ha permitido fundar la determinación de la paternidad, pero en ningún momento puede asegurar la certeza de la misma, ya que todas admiten prueba de descargo, por tanto el presunto padre puede probar por los medios legales de que disponga la no paternidad. En consecuencia, en nuestra opinión las presunciones deben tener como características: en primer lugar, la no determinación automática de la paternidad y, en segundo lugar, ser presupuesto para la indagación de la misma, servir de elemento que complementa la valoración del material probatorio y admitir prueba en contrario, debiendo perder de este modo toda eficacia directa sobre la determinación de un hecho biológico.

7. Es necesario un cambio que permita la amplia investigación de la paternidad tendiendo a fomentarla a través de principios como la igualdad de los hijos, la permisibilidad de la investigación de la paternidad, la admisibilidad de la prueba biológica y el fomento de la paternidad responsable. Las pretensiones de filiación son de estado, siendo su objetivo el establecer el verdadero estado filial y tienen como características el ser imprescriptibles, inalienables, personales, intrans- 
misibles, irrenunciables y de eficacia erga omnes. Se dirigen a la determinación biológico del vínculo filial.

8. La investigación de la paternidad ha sido preocupación de todos los tiempos, el ser humano ha tratado de encontrar la huella imperecedera y precisa que permita establecer la real y verdadera vinculación biológica con quienes le dieron el ser y la vida; de aquí se deriva el hecho de que la investigación biológica de la paternidad debe contar con medios de prueba exactos y científicos, con el empleo de técnicas que arrojen resultados precisos e indudables, ya que una de las mayores ambiciones legales es el hacer coincidir la relación biológica con la legal, lograr que la condición de hijo legal corresponda genéticamente a la de hijo biológico. Para el Derecho como para la sociedad ello se ha presentado como una finalidad necesaria pero que, debido a consideraciones de orden meramente técnico, no se podía lograr; sin embargo, las biopruebas de paternidad al sustentarse en marcadores genéticos presentes en el organismo de los padres y los hijos, lo pueden lograr

9. Un examen hematológico para investigar la paternidad debe comportar el estudio de la mayor cantidad de grupos sanguíneos de manera tal que se alcance un alto grado de certeza en la negación de la paternidad, permitiendo un acercamiento a la determinación de la paternidad cuando el examen hematológico unido con otras pruebas puede inferir una relación parental. Los principios genéticos de la investigación de la paternidad, presentan en la actualidad dificultades en el campo jurídico, por el desconocimiento y falta de actualización de los jueces y abogados, por lo cual se ha restringido su aplicación en la práctica, sin embargo es necesario que se legisle sobre la prueba heredobiológica, por su propia naturaleza y efectividad, y no solo en materia civil, si no en las demás 
materias jurídicas que sea necesario, a fin de tener una figura especial para su ejecución y valoración por el juez. Así se ha hecho en algunos ordenamientos, pero otros como el mexicano se encuentra rezagado en esta materia.

10. Es necesario el estudio de las pruebas heredobiológicas con el fin de destruir las peligrosas presunciones, poniendo el derecho superior del niño a conocer su origen biológico frente al derecho a la intimidad del padre, y así hacer una vinculación efectiva. Apoyamos el carácter obligatorio del sometimiento a la experticia biológica para que el juez pueda extraer y determinar un lazo filial cierto y efectivo y así una resistencia valida a la resistencia del padre. Y no debe limitarse al uso de las pruebas heredobiológicas a aquellos casos de indagación del nexo filial producto de una relación extramatrimonial. La aplicación jurídica de las mismas debe estar orientada, conjuntamente en beneficio de los hijos nacidos dentro o fuera del matrimonio, ya que en ambos casos el fenómeno de la procreación posee las mismas características, por tanto, la calidad de padre debe ser investigada con igual trascendencia.

11. La Constitución en México, no contiene una norma expresa que fomente la investigación de la paternidad, como sí lo hacen otras constituciones que se orientan hacia el descubrimiento de la verdad filial, a través de todos los medios posibles, como lo es el caso de la española. Las disposiciones igualmente contenidas en el Código Civil de México no brindan aún una regulación cabal y justa en el ámbito paterno filial en beneficio de los hijos y de los padres, por lo cual debe adecuar sus normas en defensa del principio de legalidad y de protección de los menores carentes de lazos parentales. 
12. Es importante compatibilizar los tratados internacionales sobre derechos humanos, Constitución, leyes de protección de niños y adolescentes y los códigos civiles y familiares del mundo, de manera tal que en los distintos ordenamientos se reconozca el derecho fundamental de toda persona para reclamar su filiación sobre la base de la probanza del nexo biológico, en virtud de que la investigación de la paternidad es un derecho inherente de la persona cuyo objetivo es indagar, adecuar y establecer la verdad biológica con la relación jurídica de la filiación. Por ende, como derecho, protege y encauza el interés privado de la persona por hallar sus orígenes familiares a través de los medios jurisdiccionales correspondientes.

13. El derecho de la identidad se ha especializado con la identidad genética y ha aparecido como un nuevo derecho, el de conocer el propio origen biológico y su garantía, cual es la promoción constitucional de la investigación de paternidad. El derecho a conocer el origen biológico es una facultad propia y natural del ser humano y le permite el ejercicio de averiguar quién es su progenitor que, por distintas causas, puede ser desconocido, estar discutido o ser debatible. En doctrina como en la jurisprudencia se ha argumentado que la aplicación de pruebas biogenéticas ocasionaría la afectación de derechos fundamentales como la libertad, la objeción de conciencia, la dignidad, la intimidad, la integridad, la igualdad, el honor, a no declarar contra sí mismo y hasta la primacía de la presunción de inocencia frente a la inspectio corporis y el derecho a la tutela judicial efectiva. 


\section{BIBLIOGRAFIA}

ACERO GALLEGO, Beatriz Helena y GARCÍA BERNAL Juan Carlos; La prueba en la filiación, Pontifica Universidad Javeriana, Bogotá, 1984.

ALBALADEJO, Manuel; Manual de Derecho de Familia y Sucesiones, Ed. Bosch, España; 1984

ALTERINI, Atilio Aníbal “Cuerpo humano, persona y familia” en Libro homenaje a la doctora María Josefa Méndez Costa, Santa Fe, 1990.

ALVA RODRÍGUEZ Mario; “El ADN su caracterización y utilidad en la investigación Criminalística y médico forense”. Criminalia; México; Ed. Porrúa Año LVII, No. 1-12 Enero - diciembre de 1991.

ÁLVAREZ VELEZ, María Isabel, La Protección de los Derechos del niño. En el Marco de las Naciones Unidas y en el Derecho Constitucional Español, Publicaciones de la Universidad Pontificia comillas, España, 1994.

BAQUEIRO ROJAS, Edgar y Rosalía BUENROSTRO BÁEZ, Derecho de Familia; Ed. Harla, México, 2005

BARBERO, Doménico: Sistema del Derecho privado, Buenos Aires, EJEA, 1967. 
BASILE, Alejandro y David WAISMAN; Fundamento de Medicina Legal; Ed. El Ateneo, Argentina, 1989.

BARRERA, Cristiani, María Fernando; "Presunción de paternidad y tutela judicial efectiva”. Revista de Investigaciones Jurídicas, México, 1996.

BECERRA, Bautista, José; Cientificidad de la Prueba en relación con los dictámenes procesales y la Apreciación del Juzgador; Ediciones de la Universidad de Yucatán, México 1971

BECKER, Gary; Tratado sobre la Familia; Trad. Por Carlos Peraita de Grado, Ed. Alianza, España, 1981.

BELLUSCIO, Augusto Cesar, Manual de Derecho de Familia Tomos I y II, $3^{\text {a }}$ ed., Ediciones de Palma, Argentina, 1983.

Benthan, Jeremías; Tratado de las Pruebas Judiciales; Trad. Por Manuel Manuel Ossorio Florit, Ediciones Jurídicas Europa América, Argentina, 1959

BERCOVITZ y RODRÍGUEZ-CANO, Rodrigo; "La filiación inducida y las clasificaciones legales”, II Congreso mundial vasco, la filiación a finales del siglo XX, Problemática planteada por los avances científicos en materia de reproducción humana, Ed. Trivium, S.A., Madrid, 1988.

BERNAL DE AFANADOR, Silvia Y BUITRAGO, Margarita, Impugnación de la paternidad legítima, Pontifica Universidad Javeriana, Bogotá, 1988. 
BIDART CAMPOS, Germán; "La negatoria a someterse a pruebas biológicas en el juicio de filiación”, en Diálogo con la jurisprudencia. Revista de crítica y análisis jurisprudencial. Lima: Gaceta Jurídica Editores, año III No. 5

BONNIER, Eduardo. Tratado teórico y práctico de las pruebas en el Derecho Civil y en Derecho Penal. Madrid; Reus Editores, 1913.

BOSSERT, Gustavo y Eduardo ZANNONI; Régimen Legal de filiación y Patria Potestad; Ed, Aestrea, Argentina, 1987.

BUENO RINCON, Enrique Fabio; La investigación de la filiación y las pruebas biológicas; $2^{\mathrm{a}}$ edición; Ediciones jurídicas Gustavo Ibáñez; Santafé Bogota; Ed. Gustavo Ibáñez, 1996

BUJOSA VADELL, Lorenzo Mateo; "El alcance de la obligación de sometimiento a las pruebas biológicas en los procesos de filiación” Revista General de Derecho; núm. 616 - 617; 1996.

BUSTAMANTE MONTORO, Juan Carlos; "Estudio médico - legal de los marcadores genéticos empleados en la investigación de la paternidad y criminalística", Tesis doctoral, Madrid, Universidad Complutense de Madrid, Facultad de Medicina, Departamento de Toxicología y Legislación Sanitaria, 1993.

CABAÑAS GARCÍA, Juan Carlos; La Valoración de las Pruebas y su Control en el Proceso Civil, Ed. Trivium, España, 1992. 
CARBAJO GONZÁLEZ, Julio; Las acciones de reclamación de la filiación, Ed. Bosch, Barcelona, 1989.

CARBAJO GONZÁLEZ, Julio, en SERRANO ALONSO, Eduardo (compilador), Manual de derecho de familia, Edisofer, Madrid, 2000, p. 335

CARBONNIER, Jean; Derecho Civil. Situaciones Familiares y CuasiFamiliares. Trad. Por Manuel María Zorilla Ruiz, Ed. Bosch, España, 1961.

CARLOTA, Eugenio O., "Determinación de la Paternidad por el sistema HLA, o complejo mayor de Histocompatibilidad”, en La Ley; Buenos Aires; 1985-A-472.

CARNELLI, Lorenzo; La investigación técnica de paternidad y su aplicación en el derecho. Buenos Aires, Antología jurídica, 1988, tomo I

CARNELUTTI, Francesco; La Prueba civil Traducido por Niceto Alcala Zamora y Castillo; 2da ed., ediciones Depalma, Argentina; 1982; p. 38

CASINI, Carlo, "Informe sobe la fecundación artificial in vivo e in vitro" Parlamento Europeo, Problemas éticos y jurídicos de la manipulación genética y de la fecundación humana, Comisión de Asuntos Jurídicos y de Derecho de los Ciudadanos, Oficina de Publicaciones Oficiales de las Comunidades Europeas, Bruselas, 1990. 
CASTAN TOBEÑAS, José; Derecho Civil Español, Común y Foral. Derecho de Familia (Relaciones paternofiliales y tutelares) 6a edición; Ed. Reus; España; 1944.

CICU, Antonio: La filiación, 1ra. edición, Madrid, Revista de Derecho privado, 1930.

CHAVEZ ASENCIO, Manuel F., La familia en el derecho. Relaciones jurídicas paterno filiales. Ed. Porrúa, México, 1987.

CIFUENTES, Santos. Derechos Personalísimos. 2ª Edición; Buenos Aires; Astrea, 1995.

CORNEJO CHÁVEZ, Héctor; Derecho Familiar peruano; 6ª edición; Lima; Librería Studium; tomo II, 1987.

CORTÉS DOMÍNGUEZ, Valentín, Derecho Procesal Civil, Valencia: Ed. Tirant to blanc, 1993.

COSTAS LUGO, Carolyn; "Las pruebas del ADN y su justo valor probatorio”; Revista de Derecho Puertorriqueño; Puerto Rico, Publicación de la Facultad de Derecho de la Pontificia Universidad Católica de Puerto Rico; Vol. 37 No. 2 y 3, mayo - diciembre de 1998.

COUTURE, Eduardo; Estudios de Derecho Procesal Civil; Pruebas en Materia Civil, T. II; Editar Editores; Argentina; 1949.

DE IBARROLA, Antonio; Derecho de Familia; Ed. Porrúa, México; 1978. 
DELlePAine, Antonio; Nueva Teoría de la Prueba; 9a ed., Ed. Themis, Colombia; 2000.

DE PINA RAFAEL, Tratado de las pruebas civiles; $3^{\mathrm{a}}$ ed., Ed. Porrúa; México; 1981;

DEVIS ECHANDIA; Hernando; Teoría General de la Prueba Judicial, Tomos I y II, $5^{a}$ Ed.; Víctor P. de Zavalía editor; Argentina; 1981.

DI LELLA, Pedro; Paternidad y Pruebas Biológicas, Ed. Depalma, Argentina, 1997.

DÍAZ DE GUIJARRO, Enrique, "Valoración probatoria de la negativa a someterse a la investigación de los grupos sanguíneos" en Jurisprudencia Argentina, buenos Aires, julio 1987 p. 217.

DIEZ-PICAZO, LUIS y GULLÓN; ANTONIO; Sistema de Derecho Civil, Madrid, Ed. Tecnos, Tomo IV; Derecho de Familia; 1992.

DÖHRING, Erich; La prueba, su práctica y apreciación Trad. Por Tomás A. Banzhaf, Ediciones Jurídicas Europa-América, Argentina, 1981

DOMÍNGUEZ PLATAS, Jesús; "Las acciones de filiación, Encudramiento general y funciones de la posesión de estado"; en Revista de Derecho Privado, Madrid. Ed. Revista de Derecho Privado, 1996, Tomo LXXX enero - diciembre. 
EGUSQUIZA BALMASEDA, María Ángeles; “EL papel jurídico de las pruebas biológicas y la negativa a su sometimiento en la investigación de la paternidad” en Revista de Derecho y Genoma-Humano, Bilbao, Universidad de Deusto No. 2, 1995.

EISNER, ISIDORO; La prueba en el proceso civil; $2^{\mathrm{a}}$ ed, Ed. Abeledo - Perrot; Argentina; 1992.

ENGELS, Federico; El Origen de la familia, la propiedad privada y el Estado, Ed. Porrua, 1990.

ENNECCERUS, Ludwing; Tratado de Derecho Civil, T. IV, Vol. I, Ed. Bosch, España, 1979.

ESCRICHE, Joaquín, Diccionario razonado de legislación y jurisprudencia, Ed. Porrua, México. 1994; y París, Librería de Ch. Bouret, 1884, p.203.

ESPIN CANOVAS, Diego: Manual de Derecho civil español, 7a. edición, Madrid, Ed. Revista de Derecho Privado, 1982, vol. IV.

ESTRADA ALONSO Eduardo; Las Uniones Extramatrimoniales en el Derecho Civil Español; 2a. Ed., Ed. Civitas; España; 1991.

ETXEBERRÍA Guridi, José Francisco; Los Análisis de ADN y su Aplicación al Proceso Penal; Ed. Comares; España; 2000

ETXEBERRÍA Guridi, José Francisco; Las intervenciones corporales: su práctica y valoración como prueba en el proceso penal : inspecciones, 
registros y extracción de muestras corporales”; Ed. Trivium, España; 1999

FÁBREGAS RUIZ, Cristóbal Francisco; Biología y filiación. Aproximación al estudio jurídico de las pruebas biológicas de la paternidad y de las técnicas de reproducción asistida, Ed. Comares, Granada, 1999.

FAIREN GUILLÉN, Víctor. "La investigación biológica de la paternidad y su valor desde el punto de vista procesal”, en Anuario de Derecho Civil. Madrid. Ministerio de Justicia e Interior, Julio-Septiembre 1950, tomo III, fascículo III.

FERNÁNDEZ CLÉRIGO, Luis. El derecho de familia en la legislación comparada, México, Ed. Hispano Americana, 1987.

FERNANDEZ GONZÁLEZ, Ma. Begoña; El reconocimiento de los hijos no matrimoniales, Dykinson, Madrid, 1998,

FERNÁNDEZ SESSAREGO, Carlos; Derecho a la identidad personal. Buenos Aires; Astrea, 1992.

FLORES ÁVALOS, Elvia. "Protección Legal a la persona en la práctica del diagnóstico genético" Tesis de licenciatura, México, Facultad de Derecho de la UNAM; 1997;

FREIRE FALCAO DE OLIVEIRA, Guillermo, "Implicancias jurídicas del conocimiento del genoma” en Revista de Derecho y Genoma Humano, Bilbao, Universidad de Deusto No. 6, 1997, pp. 57-58. 
FURNO, Carlo; Teoría de la Prueba Legal, Ed. Obregón y Heredia; México; 1983.

GALINDO GARFIAS, Ignacio, Derecho Civil; Primer Curso, Parte General, Personas y familia, Editorial Porrúa; México, 1993.

GALVAN RIVERA, Flavio; El concubinato en el vigente Derecho Mexicano; Ed. Porrúa; México; 2003.

GATTI, Hugo; “Los grupos sanguíneos y la prueba de la filiación natural”, en Revista de jurisprudencia Peruana; Lima, año XII, julio 1954, no. 156

GESCHE MÜLLER, Bernardo; Investigación de la Paternidad Ilegítima Publicación del Instituto de Ciencias jurídicas y Sociales de Chile, Chile, 1967.

GIL RODRÍGUEZ, Jacinto, "La reproducción humana asistida como acto médico y el fundamento del anonimato", Boletín de información del Ministerio de Justicia, año XLV, núm, 1593, Madrid, España, 15 de marzo de 1991.

GIRALDO; Cesar Augusto; Medicina Forense; 6a ed; Ed. Publicación de la Universidad de Antioquia, Colombia, 1991.

GÓMEZ BENGOECHEA, Blanca; "Derecho a la Identidad y Filiación”; I. Persona y familia; Colección Monografías de Derecho Civil; Ed. Dykinson; Madrid; 2007 
GÓMEZ DE LIAÑo GONZALEZ, Fernando; El Proceso Civil; ed. Forum; 1993; España

GORAN, Morris, Biología experimental para todos; Ed. Ramón Sopena, S.A., Barcelona; 1967.

GROSMAN, Cecilia; Acción de Impugnación de la Paternidad del Marido, ed. Ábaco de Rodolfo de Palma, Argentina, 1982.

GROSMAN, Cecilia P. y ARIANNA, Carlos. Los efectos de la negativa a someterse a los exámenes biológicos en los juicios de filiación paterna extramatrimonial, en La Ley, Buenos Aires, 1992.

GUITRON FUENTEVILLA, Julián; Qué es el Derecho de Familia, Vol. II, Ed. Porrúa; México; 1992.

GUZMÁN ÁVALOS, Aníbal, La filiación en los albores del siglo XXI; Ed. Porrúa; México; 2005.

GUZMÁN ZAPATER, Mónica; El derecho a la investigación de la paternidad (en el proceso con elemento extranjero) Madrid, Ed. Civitas, S.A., 1996.

HADDAD, Gérard. Lefant ilegitime. Surces talmudiques de la psychanalyse. París, Hachete, 1981,

HERRERA CAMPOS, Ramón, La investigación de la paternidad y la filiación no matrimonial, Publicaciones de la Universidad de Granada, España, 1987. 
HERÓDOTO, Los nueve libros de la historia (traducción de María Rosa Lida de Malkiel), en Clásicos Jackson, W.M. Jackson, 1956, vol. XXII, Melpómene, Buenos Aires, 1980.

HIRSZFELD, LUWIK; Les groupes sanguins. Leer aplication a la biologie, a la medicine et au droit, París, 1938.

HUERTAS MARTíN; M. Isabel; El sujeto Pasivo del Proceso Penal como Objeto de la Prueba; Ed. Bosch; Barcelona; 1999.

KEMELMAJER DE CARLUCCI, Aída "El valor de la prueba genética en el derecho argentino", en El derecho ante el proyecto de genoma. Madrid, Fundación BBV, vol. IV, 1994.

KOZICKI, Enrique, “La filiación, el HLA, el DNA, La ciencia y el derecho”. La Ley, tomo 1990-D

LACRUZ, BERDEJO, José Luis y SANCHO REBULLIDA, Francisco de Asís; Derecho de familia, tomo I, $3^{\text {a }}$ edición; Ed. Bosch, Barcelona, España; 1982 ,

LAFAILLE, Héctor; Derecho de Familia; Buenos Aires; Biblioteca Jurídica Argentina; 1930.

LAPIEZA SPOTA. Ángel Hernán: "La real doctrina de la prueba del ADN en la jurisprudencia norteamericana”, en La ley, tomo 1996-A p. 906.

LEÑERO OTERO, Luis; Investigación de la Familia en México, Publicación del Instituto Mexicano de Estudios Sociales, Ed. Edicol, México, 1976. 
LEONARDI, Danilo "El ADN puede colaborar con la administración de justicia”, en La Ley, Buenos Aires, 1990.

LÓPEZ DEL CARRIL, Julio; Legitimación de Hijos Extramatrimoniales; Ed. Depalma, Argentina, Argentina; 1960

LÓPEZ FAUGIER, Irene; La prueba científica de la filiación; Ed. Porrúa; México; 2005.

LLEDO YAGÜE; Francisco; “Acciones de Filiación”; La Ley; España.

LLEDÓ YAGUE, Francisco; Director; CUADERNOS DE DERECHO JUDICIAL; "La Filiación; su Régimen Jurídico e Incidencia de la Genética en la Determinación de la Filiación”; Consejo General del Poder Judicial; Madrid; 1994.

LLEDO YAGÜE; Francisco; "La identificación de la persona mediante pruebas genéticas y sus implicaciones jurídicas”, en El derecho ante el proyecto genoma humano, Madrid; Fundación BBV, 1994, vol. IV, p. 37

LLEDO YAGÜE, Francisco; "La paternidad forzada: a propósito de la reciente sentencia del Tribunal constitucional del 19 de enero de 1994", en Revista de Derecho y Genoma humano; Bilbao, Universidad de Deusto, 1994, No. 1, p. 207. 
MANFREDI, Marcos; Compendio de Derecho Romano comparado con el Derecho civil Italiano, Publicación de los Talleres de la Ciencia Jurídica, México, 1981.

MARTÍNEZ MURILLO, Salvador; Medicina Legal, 16 ed; Méndez editores, México; 1998.

MASSIP, Jacques, La preuve scientifique de la filiation et la practique judiciare, en Droit de la filiation et progres scientifiques, Económica, París, 1982.

MATEOS ALARCÓN, Manuel; Las Pruebas en Materia Civil, Mercantil y Federal, 3ª ed., Cárdenas Editor y Distribuidor, México, 1988.

MAZEAUD, Henri; Lecciones de Derecho civil. La familia, Constitución de la familia, Trad. Por Luis Alcalá Zamoda y Castillo, Parte Primera, V. III, Ediciones jurídicas Europa - América, Argentina, 1959,

MAZZINGHI, Jorge Adolfo; Derecho de Familia, Tomo IV; 3ª ed., Ed. Abaco de Rodolfo Depalma, Argentina, 1995.

MENDEZ COSTA, María Josefa: La filiación, Santa Fe, Rubinzal y Culzoni SCC., 1986.

MESSINEO, Francesco; Manual de Derecho Civil y comercial. Derechos de la Personalidad, Derechos de la Familia y Derechos Reales, Tomo III $8^{\mathrm{a}}$ ed., Ediciones jurídicas Europa - América, Argentina, 1954, 
METER, Tak; "Le test ADN et la procédure pénale en Europe” Revue de Science Criminelle et de Droit Pénal Comparé, France, Ed Virrey No. 4, Trimestrielle, Octubre - Décembre, 1993.

MIRÓ QUESADA, Antonio; La investigación de la paternidad, en Anales de la Universidad Mayor de San Marcos de Lima, Imprenta Liberal, tomo XXV, Lima. 1988.

MOJER, Mario; La ley de las doce tablas, Publicación de la Universidad Nacional de la Plata Facultad de Ciencias Jurpidicas y Sociales, Argentina, 1994.

MONTES PENADES, Vicente; "Las características negociales de las técnicas de reproducción asistida", Actualidad Civil, Revista Semanal técnica jurídica de derecho privado, 1994-4, Actualidad Editorial, S.A., Madrid, España, 1994.

MORO ALMARAZ y SÁNCHEZ Cid; Lecciones de Derecho de familia, Universidad de Salamanca y Ed. Colex, Madrid, 2002.

MOSSET ITURRASPE, Jorge; "Los nuevos derechos: ¿meras declaraciones o derechos operativos?, en Revista de Derecho Privado y _Comunitario (derecho privado en la reforma constitucional); Santa Fe, Rubinzal Culzoni, No. 7.

MULDWORF, Bernard; La Paternidad, Ediciones Guadarrama, España, 1973. 
NOVOA MONREAL, Eduardo; Derecho a la Vida Privada y Libertad de Información. Un conflicto de Derechos, Ed. Siglo Veintiuno, México, 1989.

O’CALLAGHAN. Xavier, Investigación de la paternidad; acciones de filiación, investigación de la paternidad, prueba biológica. Madrid, Actualidad Editorial, 1994.

OCAÑA RODRÍGUEZ, Antonio; La filiación en España, Jurisprudencia y Doctrina, Ed. Comares, España, 1991.

OSSIO, Juan; La estructura social de las comunicaciones andinas, Perú, Ed. Mejía Baca, 1982, tomo III.

OVALLE FAVELA, José; Derecho Procesal Civil, 2ª ed. Ed. Oxford University Press; México; 2008;

PARRA QUIJANO, Jairo; Manual de Derecho Probatorio; 15ª ed., Ed. Librería Ediciones del profesional ltda., Bogota, Colombia; 2006

PASCUAL FRANQUESA, Ernesto; La impugnación de la filiación matrimonial Vol. II; Bolsa de investigación; Consejo General del Poder Judicial Fundación Wellington; Madrid; 2008.

PATITO, José Ángel; Medicina Legal; 2ª ed; Ediciones Centro y Norte; Argentina; 2001. p. 297 
PÉREZ LUÑO, Antonio enrique, Las generaciones de derechos humanos, en Revista del Centro de Estudios Constitucionales; núm. 10; 1991; Madrid, España.

PÉREZ PALMA, Rafael; Guía de Derecho Procesal Civil, Tomo I, 9a ed., Cárdenas Editor Distribuidor, México 2001.

PLANIOL, MARCEL y RIPERT, GEORGES; Tratado de Derecho Civil, Ed. Harla; México; 2005.

POZO VILCHES, Juan; El Reconocimiento de la Filiación. Sus requisitos complementarios. Ed. Trivium, Madrid, 1993.

PRIMAROSA, CHIERI Y ZANNONI, Eduardo, La prueba de ADN, Ed. Astrea; Argentina; 1999,

QUEZADA GONZÁLEZ, "El derecho (¿Constitucional?) a conocer el propio origen biológico", en Anuario de Derecho Civil, Madrid: Ministerio de justicia e interior, tomo XLVII, fasc. II, abril-junio, 1994.

QUICIOS MOLINA, María Susana, Determinación de la Filiación no Matrimonial por Reconocimiento; Ed. Bosch; España; 1997.

QUIROZ CUARON, Alfonso; Medicina forense, 8ª ed.; Ed. Porrúa, México; 2006.

REAL ACADEMIA DE LA HISTORIA, Las Siete Partidas del Rey Don Alfonso El Sabio; T. II, Imprenta Real, España, 1972 
REAL ACADEMIA DE LA LENGUA ESPAÑOLA, Diccionario de la Real Academia Española de la Lengua; 22ª . Ed. Editorial Espasa-Calpe; España; 2005.

RIVERO HERNÁNDEZ, Francisco; Las Acciones de Filiación en el Código de Familia Catalán; Ed. Atelier; 2001

RIVERO HERNÁNDEZ, Francisco; "La investigación de la mera relación biológica en la filiación derivada de la fecundación artificial” Ponencia en el II Congreso Mundial Vasco, "La Filiación a finales del siglo XX”.

ROJAS GOMEZ, Miguel Enrique: El proceso de Investigación de la Paternidad; Universidad Externado de Colombia No. 3, Colombia; 2001.

ROJINA VIILlEGAS, Rafael; Compendio de Derecho Civil, Introducción, Personas y Familia, 29a ed., Ed. Porrúa, México, 2000.

ROMEO CASABONA, Carlos María y María Casado; Derecho Biomédico y Bioética, Ed. Comares, España; 1998.

ROMO PIZARRO, Osvaldo, Medicina Legal; Elementos de Ciencias Forenses. Ed. Jurídica Chile; Chile; 1998.

RUGGERIO, Roberto, Instituciones de Derecho Civil, trad. Ramón Serrano Suñer y José Santa Cruz Tejeiro, vol. II, Reus, Madrid, 1931

SÁNCHEZ MEDAL, Ramón; Los Grandes Cambios en el Derecho de Familia de México, 2a ed., Ed. Porrúa; México; 2001 
SANTIAGO TIANA Sócrates; Diccionario de Derecho Romano; Ed. Sista; México; 2006.

SENTIS MELENDO, Santiago; La Prueba, Los Grandes Temas del Derecho Probatorio, Ediciones Jurídicas Europa - América, Argentina; 1979.

SERNA MEROÑO, Encarnación; La Reforma de la filiación; Ed. Montecorvo; España; 1985.

SILVA Cruz, Pedro; "El derecho de familia y la inseminación artificial -in vitro“, en Revista de Derecho Privado, Madrid; Ed. Derecho Reunidas, 1987; enero - diciembre, tomo LXXI.

SOTO LAMADRID, Miguel Angel; Biogenética, filiación y delito, Buenos Aires, Astrea, 1990.

TAMBURRINO, Giuseppe, La filiazone, Utet, Torino, 1984.

TEJADA, José Francisco; "Nuevos medios de prueba de la paternidad” Boletín Mexicano de Derecho Comparado, México, enero - agosto, 1978, No. 31-32.

THEODORO JUNIOR, Humberto: Alguns impactos da nova ordem constitucional sobre o direito civil, en: Revista dos tribunais, Sao Paulo, Ed. Revista dos tribunais, 1990,

TORRES RIVERO, Arturo Luis; Pruebas de Estado (Derecho de Familia Parte General) Publicación de la Universidad Central de Venezuela, Venezuela, 1980. 
VALVERDE Y VALVERDE, Calixto; Tratado de Derecho Civil Español, Derecho de Familia, $3^{\circ}$ ed., Publicaciones de los Talleres Tipográficos Cuesta, España, 1926.

VARGAS ALVARADO, Eduardo; Medicina Legal, Ed. Trillas, México, 1996.

VARSI ROSPIGLOSI, Enrique; Filiación, Derecho y manipulación genética; Lima; Universidad de Lima, 1996.

VARSI ROSPIGLIOSI, Enrique; Evolución Jurídico Médica de la prueba filial; Universidad de Lima, 2004.

VARSI Rospigliosi, Enrique ; Filiación, Derecho y Genética; Fondo de Cultura Económica, Universidad de Lima; Perú, México, 1999.

VARSI ROSPIGLIOSI, Enrique, "La ley de las XII tablas (su vigencia con el Código Civil Peruano en 1984”, en Revista Jurídica del Perú, Trujillo, Ed. Normas Legales S.A., año XLVII No. 12; Lima, Perú; 1997

VERDERA SERVER, Rafael, Determinación y Acreditación de la Filiación, Bosch, Barcelona, España; 1993.

VERRUNO, Luis y otros; Manual para la investigación de la filiación actualización médico - legal; Ed. Ebeledo - Perrot, Argentina, 1985.

VIDAL MARTÍNEZ, Jaime; Las Nuevas Formas de Reproducción Humana Ed. Civitas, España, 1988. 
VILA-CORO BORRACHINA, María Dolores; Huérfanos Biológicos; Madrid, España; 1997

VILA-CORO BARRACHINA, María Dolores: Introducción a la biojurídica, Madrid, Universidad Complutense de Madrid, 1995.

VILA-CORO BARRACHINA, María Dolores; “Los límites de la bioética”, en Biotecnología y Futuro del Hombre: la respuesta bioética; Madrid, Eduema S.A., diciembre de 1992.

WAGNER, Horacio y ABALLE, Rubén. "Límites a la libre valoración de las pruebas científicas”, en La Ley, España.

WIKLER, Daniel; “El Derecho ante el Proyecto Genoma Humano” Vol. I, Publicación de la Fundación BBV y Diputación foral de Biskaia, España, 1993.

WITTHAUS, Rodolfo; Prueba Pericial; Ed. Universidad, Argentina; 1991.

YUNIS T., Emilio José y Juan; El ADN en la identificación Humana, ed. Temis, Colombia, 2002.

ZANNONI, Eduardo: "Identidad personal y pruebas biológicas", en: Revista de Derecho Privado y Comunitario, Derecho privado en la reforma constitucional, Santa Fe, Rubinzal y Culzoni, 1997, No.13.

ZANNONI, Eduardo: Inseminación Artificial y Fecundación Extrauterina, Ed. Astrea, Argentina, 1978. 
ZAVALA DE GONZÁLEZ, Matilde, Derecho a la Intimidad; Ed. AbeledoPerrot, Argentina, 1982.

ZICARELLI, Filho, "La prueba en la acción de la investigación de paternidad", en Revista Mexicana de Derecho Penal; mayo - junio No. 3; México; 1970. 


\section{LEGISLACIÓN}

CÓDIGO CIVIL ESPAÑOL.

CÓDIGO CIVIL FEDERAL MÉXICO.

CÓDIGO FAMILIAR DEL ESTADO DE MICHOACÁN.

CÓDIGO FAMILIAR DEL ESTADO DE ZACATECAS.

CÓDIGO DE LOS NIÑOS Y ADOLESCENTES.

COMPILACIÓN DE LEGISLACIÓN DE DERECHOS DEL NIÑO. ONU, Conferencia de la Haya, Derecho Internacional humanitario, Consejo de Europa, Unión Europea, Organización de Estados Americanos y Organización para la Unidad Africada; Ed. Mc Graw Hill, España, 1998

CONSTITUCIÓN DE COLOMBIA.

CONSTITUCIÓN ESPAÑOLA.

CONSTITUCIÓN POLÍTICA DE LOS ESTADOS UNIDOS MEXICANOS.

CONVENCIÓN SOBRE LOS DERECHOS DEL NIÑO. 
CONVENCIONES INTERNACIONALES CELEBRADAS Y RATIFICADAS POR MÉXICO.

SEMANARIO JUDICIAL DE LA FEDERACIÓN Y SU GACETA, NOVENA ÉPOCA, MÉXICO, 2005

DECLARACIÓN UNIVERSAL DE LOS DERECHOS HUMANOS;

LEY DE LOS DERECHOS DE LAS NIÑAS Y LOS NIÑOS FEDERAL;

LEY DEL NOTARIADO FEDERAL;

LEY DEL NOTARIADO DEL ESTADO DE HIDALGO;

LEY FAMILIAR PARA EL ESTADO DE HIDALGO; 


\section{JURISPRUDENCIA}

\section{Española}

Sentencias del Tribunal Supremo

- $\quad 14$ de octubre de 1985

- 7 de febrero de 1986

- 10 de febrero de 1986

- 8 de julio de 1986

- 19 de junio de 1986

- 10 de noviembre de 1986

- 27 de junio de 1987

- 5 de noviembre de 1987

- 10 de noviembre de 1987

- 12 de noviembre de 1987

- 14 de noviembre de 1987

- 21 de abril de 1988

- 21 de mayo de 1988

- 14 de julio de 1988

- 23 de septiembre de 1988

- 3 de diciembre de 1988

- 15 de marzo de 1989

- 17 de marzo de 1989

- 5 de mayo de 1989

- 5 de abril de 1990 
- 18 de mayo de 1990

- 26 de junio de 1990

- 20 de julio de 1990

- 6 de noviembre de 1990

- 2 de enero de 1991

- 2 de febrero de 1991

- 6 de febrero de 1991

- 25 de abril de 1991

- 14 de mayo de 1991

- 6 de junio de 1991

- 28 de junio de 1991

- 8 de julio de 1991

- $\quad 11$ de julio de 1991

- 3 de diciembre de 1991

- 18 de febrero de 1992

- 26 de febrero de 1992

- 5 de marzo de 1992

- 17 de marzo de 1992

- 2 de abril de 1992

- 30 de abril de 1992

- 17 de junio de 1992

- 5 de octubre de 1992

- 26 de enero de 1993

- 29 de marzo de 1993

- 20 de octubre de 1993

- 21 de octubre de 1994

- 17 de marzo de 1995

- 16 de junio de 1995

- 28 de julio de 1995 
- 7 de octubre de 1995

- 28 de noviembre de 1995

- 4 de julio de 1996

- 26 de septiembre de 1998

- 07 de diciembre de 2005

- 22 de noviembre de 2005

Sentencias del Tribunal Constitucional

7/1994, de 17 de enero

\section{Mexicana}

Registro No. 168288

Localización: Novena Época; Instancia: Tribunales Colegiados de Circuito; Fuente: Semanario Judicial de la Federación y su Gaceta; XXVIII, Diciembre de 2008; Página: 1067; Tesis: VI.2o.C.647 C; Tesis Aislada; Materia(s): Civil

PRUEBA PERICIAL EN GENÉTICA. ES ILEGAL SU DESECHAMIENTO POR NO CUMPLIR CON LAS FORMALIDADES EXIGIDAS POR LA LEY PARA SU OFRECIMIENTO, EN JUICIOS RELACIONADOS CON LA PATERNIDAD O MATERNIDAD (LEGISLACIÓN DEL ESTADO DE PUEBLA). 
Registro No. 169819

Localización: Novena Época; Instancia: Tribunales Colegiados de Circuito; Fuente: Semanario Judicial de la Federación y su Gaceta; XXVII, Abril de 2008;

Página: 2409

Tesis: XVI.2o.C.T.48 C; Tesis Aislada; Materia(s): Civil

RECONOCIMIENTO DE LA PATERNIDAD. PARA QUE SE COLME LA EXIGENCIA LEGAL RELATIVA AL PRINCIPIO DE PRUEBA, CONTRA EL PRETENDIDO PADRE, BASTA CON QUE EN EL ESCRITO DE DEMANDA SE IMPUTE AL DEMANDADO UNA SITUACIÓN OBJETIVA SUSCEPTIBLE DE SER PROBADA (LEGISLACIÓN DEL ESTADO DE GUANAJUATO).

Registro No. 170275

Localización: Novena Época; Instancia: Tribunales Colegiados de Circuito; Fuente: Semanario Judicial de la Federación y su Gaceta; XXVII, Febrero de 2008; Página: 2313

Tesis: VII.2o.C.111 C; Tesis Aislada; Materia(s): Civil

JUICIOS DE PATERNIDAD. EN LOS CASOS EN QUE A PESAR DE LA IMPOSICIÓN DE MEDIDAS DE APREMIO LOS PRESUNTOS ASCENDIENTES SE NIEGAN A PRACTICARSE LA PRUEBA PERICIAL EN MATERIA DE GENÉTICA (ADN), OPERA LA PRESUNCIÓN DE LA FILIACIÓN CONTROVERTIDA, SALVO PRUEBA EN CONTRARIO (LEGISLACIÓN DEL ESTADO DE VERACRUZ). 
Registro No. 172985

Localización: 9a. Época; 1a. Sala; S.J.F. y su Gaceta; XXV, Marzo de 2007; Pág. 150; [J];

MEDIDAS DE APREMIO. SU APLICACIÓN ES CONSTITUCIONAL EN LOS JUICIOS DE PATERNIDAD CUANDO LOS PRESUNTOS ASCENDIENTES SE NIEGAN A PRACTICARSE LA PRUEBA PERICIAL EN MATERIA DE GENÉTICA (ADN) (LEGISLACIONES DE NUEVO LEÓN Y DEL ESTADO DE MÉXICO).

Registro No. 172988

Localización: 9a. Época; 1a. Sala; S.J.F. y su Gaceta; XXV, Marzo de 2007; Pág. 149; [J];

MEDIDAS DE APREMIO. ALCANCE DEL USO DE LA FUERZA PÚBLICA TRATÁNDOSE DE JUICIOS DE PATERNIDAD EN LOS QUE SE OFRECE LA PRUEBA EN GENÉTICA MOLECULAR (ADN).

Registro No. 173072

Localización: 9a. Época; 1a. Sala; S.J.F. y su Gaceta; XXV, Marzo de 2007; Pág. 258; [T.A.];

CONOCIMIENTOS CIENTÍFICOS. CARACTERÍSTICAS QUE DEBEN TENER PARA QUE PUEDAN SER TOMADOS EN CUENTA POR EL JUZGADOR AL MOMENTO DE EMITIR SU FALLO. 
Registro No. 173491

Localización: Novena Época; Instancia: Tribunales Colegiados de Circuito; Fuente: Semanario Judicial de la Federación y su Gaceta; XXV, Enero de 2007; Página: 2306; Tesis: I.3o.C.576 C; Tesis Aislada; Materia(s): Civil

PRUEBA PERICIAL EN GENÉTICA MOLECULAR. CUANDO SE OFRECE EN EL JUICIO DE DESCONOCIMIENTO DE PATERNIDAD Y EL MENOR SE NIEGA A QUE SE LE PRACTIQUEN LOS EXÁMENES CORRESPONDIENTES, DEBEN TENERSE POR CIERTOS LOS HECHOS NARRADOS POR SU CONTRAPARTE, SALVO PRUEBA EN CONTRARIO.

Registro No. 173477

Localización: Novena Época; Instancia: Tribunales Colegiados de Circuito; Fuente: Semanario Judicial de la Federación y su Gaceta; XXV, Enero de 2007; Página: 2316; Tesis: XX.2o.38 C; Tesis Aislada; Materia(s): Civil

RECONOCIMIENTO DE PATERNIDAD. SI EL SUJETO DE LA PRUEBA PERICIAL EN GENÉTICA MOLECULAR SE NIEGA A SU DESAHOGO, DEBE TENERSE COMO VERDADERO QUE EL RENUENTE ES PROGENITOR DEL MENOR INVOLUCRADO (LEGISLACIÓN DEL ESTADO DE CHIAPAS).

Registro No. 174388

Localización: Novena Época; Instancia: Tribunales Colegiados de Circuito; Fuente: Semanario Judicial de la Federación y su Gaceta; XXIV, Agosto de 2006; Página: 2317; Tesis: VI.10.C.88 C; Tesis Aislada; Materia(s): Civil 
PRUEBA PERICIAL EN GENÉTICA. LAS PARTES QUE SE SOMETAN A ELLA DEBEN TENER CONOCIMIENTO DESDE UN INICIO DEL LABORATORIO Y DE LA PERSONA QUE TOMARÁ LAS MUESTRAS, PUES SI SE DESARROLLA EN FORMA IRREGULAR, NO SERVIRÁ COMO MEDIO FEHACIENTE DE CONVICCIÓN, ANTE EL JUEZ QUE CONOCE DEL ASUNTO.

Registro No. 176172

Localización: Novena Época; Instancia: Primera Sala; Fuente: Semanario Judicial de la Federación y su Gaceta; XXIII, Enero de 2006; Página: 736; Tesis: 1a. CCXVII/2005; Tesis Aislada; Materia(s): Civil

PRUEBA PERICIAL EN GENÉTICA MOLECULAR DEL ÁCIDO DESOXIRRIBONUCLEICO (ADN). ANTE LA POSIBILIDAD DE LOS PRESUNTOS PADRES DE NEGARSE AL DESAHOGO DE DICHA PROBANZA, SE PRESUMIRÁ SU PATERNIDAD SALVO PRUEBA EN CONTRARIO (ARTÍCULO 5, APARTADO B), INCISO III, DE LA LEY DE LOS DERECHOS DE LAS NIÑAS Y NIÑOS EN EL DISTRITO FEDERAL).

Registro No. 176171

Localización: Novena Época; Instancia: Primera Sala; Fuente: Semanario Judicial de la Federación y su Gaceta; XXIII, Enero de 2006; Página: 737; Tesis: 1a. CCXVIII/2005; Tesis Aislada; Materia(s): Constitucional, Civil

PRUEBA PERICIAL EN GENÉTICA MOLECULAR DEL ÁCIDO DESOXIRRIBONUCLEICO (ADN). EL ARTÍCULO 5, APARTADO B), INCISO III, DE LA LEY DE LOS DERECHOS DE LAS NIÑAS Y NIÑOS 
EN EL DISTRITO FEDERAL, NO VIOLA LA GARANTÍA DE AUDIENCIA.

Registro No. 176668

Localización: Novena Época; Instancia: Tribunales Colegiados de Circuito; Fuente: Semanario Judicial de la Federación y su Gaceta; XXII, Noviembre de 2005; Página: 911; Tesis: II.2o.C.501 C; Tesis Aislada; Materia(s): Civil

PERICIAL EN GENÉTICA. SU DESAHOGO ES PREPONDERANTE EN UN JUICIO DE DESCONOCIMIENTO O RECONOCIMIENTO DE PATERNIDAD, CON INDEPENDENCIA DEL DERECHO A LA PRIVACÍA O INTIMIDAD.

Registro No. 183442

Localización: Novena Época; Instancia: Tribunales Colegiados de Circuito; Fuente: Semanario Judicial de la Federación y su Gaceta; XVIII, Agosto de 2003; Página: 1806; Tesis: III.5o.C.48 C; Tesis Aislada; Materia(s): Civil

PRUEBA PERICIAL EN GENÉTICA. PARA SU DESAHOGO NO SE REQUIERE EL CONSENTIMIENTO DEL DEMANDADO.

Registro No. 184431

Localización: Novena Época; Instancia: Primera Sala; Fuente: Semanario Judicial de la Federación y su Gaceta; XVII, Abril de 2003; Página: 88; Tesis: 1a./J. 17/2003; Jurisprudencia; Materia(s): Civil 
PRUEBA PERICIAL EN GENÉTICA. SU ADMISIÓN Y DESAHOGO TIENEN UNA EJECUCIÓN DE IMPOSIBLE REPARACIÓN SUSCEPTIBLE DE AFECTAR DERECHOS SUSTANTIVOS DE LA PERSONA.

Registro No. 189232

Localización: Novena Época; Instancia: Tribunales Colegiados de Circuito; Fuente: Semanario Judicial de la Federación y su Gaceta; XIV, Agosto de 2001; Página: 1169; Tesis: II.2o.C.286 C; Tesis Aislada; Materia(s): Civil

\section{ADULTERIO COMO CAUSAL DE DIVORCIO. DEBE SER DEBIDAMENTE COMPROBADA (LEGISLACIÓN DEL ESTADO DE MÉXICO).}

Registro No. 192806

Localización:

Novena Época; Instancia: Tribunales Colegiados de Circuito; Fuente: Semanario Judicial de la Federación y su Gaceta; X, Diciembre de 1999; Página: 751; Tesis: I.6o.C.189 C; Tesis Aislada; Materia(s): Civil.

PATERNIDAD. RECONOCIMIENTO DE HIJO NACIDO FUERA DE MATRIMONIO.

Registro No. 204077; Localización: Novena Época; Instancia: Tribunales Colegiados de Circuito; Fuente: Semanario Judicial de la Federación y su Gaceta II, Octubre de 1995; Página: 590; Tesis: I.3o.C.50 C; Tesis Aislada; Materia(s): Civil 
PATERNIDAD INVESTIGACION DE LA. PRUEBAS APTAS EN EL EJERCICIO DE ESA ACCION. 


\section{$\underline{\text { Anexos }}$}

\section{ANEXO I \\ VOTO PARTICULAR EN LA DISCUSIÓN EN LA SUPREMA CORTE DE JUSTICIA DE MEXICO RESPECTO A LA NEGATIVA DE PRÁCTICA DE LA PRUEBA PERICIAL EN GENETICA}

\section{Ejecutoria:}

Asunto: CONTRADICCIÓN DE TESIS 154/2005-PS.

Promovente: ENTRE LAS SUSTENTADAS POR EL TERCER TRIBUNAL COLEGIADO EN MATERIA CIVIL DEL CUARTO CIRCUITO Y EL TERCER TRIBUNAL COLEGIADO EN MATERIA CIVIL DEL SEGUNDO CIRCUITO.

Localización: 9a. Época; 1a. Sala; S.J.F. y su Gaceta; XXV, Marzo de 2007; Pág. 112;

Registro No. 20018

Localización:

Novena Época

Instancia: Primera Sala

Fuente: Semanario Judicial de la Federación y su Gaceta

Tomo: XXV, Marzo de 2007

Página: 112

Tema: JUICIOS DE PATERNIDAD. EN LOS CASOS EN QUE A PESAR DE LA IMPOSICIÓN DE MEDIDAS DE APREMIO LOS PRESUNTOS ASCENDIENTES SE NIEGAN A PRACTICARSE LA PRUEBA PERICIAL EN MATERIA DE 
GENÉTICA (ADN), OPERA LA PRESUNCIÓN DE LA FILIACIÓN CONTROVERTIDA (LEGISLACIONES DE NUEVO LEÓN Y DEL ESTADO DE MÉXICO).

MEDIDAS DE APREMIO. ALCANCE DEL USO DE LA FUERZA PÚBLICA TRATÁNDOSE DE JUICIOS DE PATERNIDAD EN LOS QUE SE OFRECE LA PRUEBA EN GENÉTICA MOLECULAR (ADN).

MEDIDAS DE APREMIO. SU APLICACIÓN ES CONSTITUCIONAL EN LOS JUICIOS DE PATERNIDAD CUANDO LOS PRESUNTOS ASCENDIENTES SE NIEGAN A PRACTICARSE LA PRUEBA PERICIAL EN MATERIA DE GENÉTICA (ADN) (LEGISLACIONES DE NUEVO LEÓN Y DEL ESTADO DE MÉXICO).

CONOCIMIENTOS CIENTÍFICOS. CARACTERÍSTICAS QUE DEBEN TENER PARA QUE PUEDAN SER TOMADOS EN CUENTA POR EL JUZGADOR AL MOMENTO DE EMITIR SU FALLO.

CONTRADICCIÓN DE TESIS 154/2005-PS. ENTRE LAS SUSTENTADAS POR EL TERCER TRIBUNAL COLEGIADO EN MATERIA CIVIL DEL CUARTO CIRCUITO Y EL TERCER TRIBUNAL COLEGIADO EN MATERIA CIVIL DEL SEGUNDO

CIRCUITO.

CONSIDERANDO:

PRIMERO. Competencia.

Esta Primera Sala de la Suprema Corte de Justicia de la Nación es competente para conocer y resolver sobre la presente denuncia de contradicción de tesis, de conformidad con lo dispuesto por los artículos 107, fracción XIII, párrafo primero, de la Constitución Política de los Estados Unidos Mexicanos; 197-A de la Ley de Amparo; y 21, fracción VIII, de la Ley Orgánica del Poder Judicial de la Federación, en relación con los puntos 
segundo y cuarto del Acuerdo General 5/2001 y punto segundo del diverso Acuerdo 4/2002 del Tribunal Pleno de esta Suprema Corte de Justicia de la Nación, en virtud de que se trata de una denuncia de contradicción de tesis suscitada entre criterios de Tribunales Colegiados de Circuito en un tema que, por su naturaleza civil, corresponde a la materia de la especialidad de la Primera Sala.

SEGUNDO. Legitimación del denunciante.

La denuncia de contradicción de tesis proviene de parte legítima, de conformidad con lo previsto por los artículos 107, fracción XIII, segundo párrafo, constitucional y 197, párrafo primero, de la Ley de Amparo pues, en el caso, la contradicción de tesis fue denunciada por el Magistrado presidente del Tercer Tribunal Colegiado en Materia Civil del Segundo Circuito, por lo que formalmente se actualiza el supuesto de legitimación a que aluden los referidos preceptos.

TERCERO. Ejecutorias que participan en la contradicción.

En primer lugar, debe determinarse si en el caso existe contradicción de criterios, para lo cual es necesario analizar las ejecutorias que participan en la misma.

I. Tercer Tribunal Colegiado en Materia Civil del Segundo Circuito.

Este tribunal conoció de un asunto en el que se demandó el reconocimiento de paternidad y para tal efecto se ofreció como prueba la pericial en genética, consistente básicamente en el análisis del ADN del demandado para compararlo con el del menor cuya paternidad se le imputaba, misma que fue admitida y se dio vista al demandado para que designara perito de su parte. El Juez de la causa señaló diversas fechas para el desahogo de esa prueba, la cual no se pudo llevar a cabo pues en una ocasión no compareció el demandado y en las otras se opuso a la toma de muestras, por lo que se le apercibió que en caso de negarse se le impondría una multa hasta por cien días de salario mínimo vigente en el Estado de México. En contra de esa resolución el 
demandado promovió juicio de amparo indirecto en el que se le negó el amparo solicitado. Inconforme con esa resolución, interpuso recurso de revisión ante el mencionado Tribunal Colegiado el cual revocó la sentencia recurrida y concedió el amparo al quejoso.

Las consideraciones en las que se apoyó el Tribunal Colegiado para dictar su resolución fueron, en síntesis, las siguientes:

Los artículos 3o., 7o., 9o., 10, 12, 18, 19, 20 y 27 de la Convención sobre los Derechos del Niño (ratificada por el Estado mexicano el veintiuno de septiembre de de mil novecientos noventa, por lo que de acuerdo al artículo 133 constitucional, sus normas se consideran como parte del sistema jurídico nacional), establecen que los tribunales judiciales deben velar por el interés superior del niño.

Por su parte, el artículo 4o. constitucional establece como garantía individual de los niños el derecho a la satisfacción de sus necesidades de alimentación, salud, educación y sano esparcimiento.

Por lo anterior, no cabe duda de que el niño tiene derecho a conocer su filiación, porque de ello deriva su derecho a obtener entre otros, alimento, vestido, educación, etcétera.

Sin embargo, con el fin de armonizar los precisados derechos del niño con los derechos constitucionales de la persona a quien se le atribuye la paternidad del citado infante, debe mencionarse que el derecho a la intimidad es la facultad que le reconoce el Estado al hombre, de mantener reservada la información que considere no comunicable.

En concordancia con lo antedicho, cabe acotar que el caso en estudio, específicamente la prueba pericial en materia de genética, implica la práctica de estudios químicos y exámenes de laboratorio de donde habrán de tomarse los elementos necesarios para contestar el cuestionario conforme al cual deben ser rendidos los dictámenes periciales correspondientes. De esa manera, la forma y términos en que habrá de desahogarse la 
aludida prueba pericial, se traduce necesariamente, en la toma de muestras de sangre, con objeto de determinar la correspondencia de ADN a fin de establecer, mediante el procedimiento científico, los caracteres hereditarios que a su vez permitirán determinar si existe o no un vínculo de parentesco por consanguinidad, y así poder dilucidar la acción de reconocimiento de paternidad.

Sin embargo, debe ponerse de manifiesto que por medio de la prueba química para determinar la huella genética, no solamente es posible poner al descubierto las características idóneas para dilucidar problemas de reconocimiento de hijos, puesto también lo es que dicha prueba puede poner en evidencia otras características o condiciones genéticas relacionadas con aspectos patológicos hereditarios o algunas tendencias o proclividad a determinadas conductas que pertenecen a la más absoluta intimidad del ser humano; por tanto, permitir la práctica de la prueba pericial genética, podría traducirse en una invasión a la intimidad del ser humano, una intromisión a su individualidad, poniendo al descubierto aspectos o características genéticas que no tengan nada que ver con la litis sobre los derechos de paternidad que en su caso se ventile, pero que puedan quedar de manifiesto a través de los dictámenes periciales que en su momento se rindan, y obrar en autos en donde todo aquel que tenga acceso al expediente podrá imponerse de su contenido, con lo cual se vería burlado el derecho a la intimidad y, en alguna medida, el derecho a la libertad y a la integridad física.

Por tanto, se estiman sustancialmente fundados los argumentos en donde el recurrente aduce que el Juez constitucional no observó que la determinación que le obliga por la fuerza a tomar las muestras para el desahogo de la prueba pericial en materia de genética $\mathrm{ADN}$, contraviene lo dispuesto en los artículos 14 y 16 constitucionales, esencialmente porque el desahogo de la citada probanza no está reglamentado en el Código Civil ni en el Código Procesal Civil de esta entidad, además de que la toma de muestras le ocasiona una lesión irreparable y, por ello, se le lesionan sus derechos fundamentales como es el relativo a someterse o no a dicha prueba. Lo dicho es así, pues en el actual Código de Procedimientos Civiles para el Estado de México, no se encuentra expresamente regulado lo relativo a que ante la ausencia de la voluntad del 
demandado para aportar las muestras médicas necesarias para el desahogo de la prueba pericial en genética ADN, éstas puedan obtenerse de manera coercitiva, es decir, a través de la aplicación de los medios de apremio. Así entonces, dicha laguna de la ley, no podía ser cubierta con la facultad que tiene el juzgador para hacer cumplir sus determinaciones aplicando las medidas de apremio previstas en el artículo 1.124 del citado código adjetivo, pues, ciertamente, el Juez natural para hacer cumplir sus determinaciones tiene a su alcance esas medidas coercitivas, pero no se puede soslayar que las mismas forman parte de un sistema jurídico y, por ello, no pueden rebasar lo expresamente estatuido en los artículos 14 y 16 de la Carta Magna, los cuales consagran los principios de legalidad y seguridad jurídica.

De lo anterior deriva, que aun ante la evidente contumacia del demandado, en el sentido de negarse a proporcionar las muestras médicas necesarias para el desahogo de la prueba pericial de ADN, jurídicamente no era factible quebrantar su libertad con el fin de obtener las aludidas muestras médicas necesarias a través de la aplicación de las medidas de apremio legalmente establecidas, en razón de que también está en juego el derecho a la intimidad del demandado.

Con base en los precisados razonamientos, debe concluirse que en el caso, ante la conducta adoptada por el enjuiciado en el sentido de que no es su voluntad proporcionar las muestras médicas para el desahogo de la prueba pericial en genética, si bien no era posible la aplicación de los medios de apremio establecidos por la ley para vencer la contumacia del demandado, atendiendo a los principios generales del derecho resultaba procedente aplicar por analogía lo previsto por los artículos 1.287 y 2.44 del actual Código de Procedimientos Civiles para el Estado de México, que se refieren a la confesión ficta y al reconocimiento de documentos, era posible apercibir al demandado de que en caso de oponerse al desahogo de la mencionada prueba pericial se tendrían por ciertos los hechos que se pretendían probar a través de ese medio de prueba, salvo prueba en contrario, dado que esto resulta una consecuencia de la conducta adoptada por el enjuiciado al rehusarse a proporcionar las aludidas muestras médicas.\} 


\section{Tercer Tribunal Colegiado en Materia Civil del Cuarto Circuito.}

Este tribunal conoció de un asunto en el que se demandó el reconocimiento de paternidad del demandado respecto de un menor de edad en el que se ofreció como prueba para acreditar tal acción la prueba pericial en genética molecular ADN. El desahogo de dicha probanza se ordenó en la segunda instancia ya que no fue posible realizarlo en la primera. Al proveerse sobre el desahogo de esa prueba, el Magistrado a cargo del asunto señaló día y hora para ese efecto y apercibió al demandado, para el caso de que no asistiera, de que se le aplicarían los medios de apremio que para tal efecto prescribe el artículo 42 del Código de Procedimientos Civiles para el Estado de Nuevo León.

Posteriormente, se volvió a señalar día y hora para el desahogo de esa probanza, apercibiendo al demandado en el sentido de que, para el caso de que dejare de comparecer sin justa causa, se le aplicaría un arresto de hasta treinta y seis horas, de conformidad con lo dispuesto por la fracción II del artículo 42 antes citado. El demandado no compareció a la diligencia de desahogo, por lo que se le hizo efectivo el apercibimiento y se decretó el arresto hasta por treinta y seis horas.

En contra de esa resolución, se promovió un juicio de amparo indirecto, en el cual, el Juez de Distrito negó el amparo solicitado por el quejoso. Inconforme con ese fallo, el demandado interpuso recurso de revisión, el cual correspondió conocer al Tribunal Colegiado que nos ocupa, quedando registrado con el número 358/2004/3; al resolver ese recurso, se confirmó la sentencia recurrida y se negó el amparo al quejoso.

Las consideraciones en que se apoyó dicho Tribunal Colegiado al dictar su resolución fueron, en esencia, las siguientes:

Por un lado, el apercibimiento decretado contra el quejoso de aplicarle el arresto hasta por treinta y seis horas en caso de que no compareciera al desahogo de la extracción 
sanguínea de su cuerpo, no puede catalogarse como una pena infamante, pues ésta ha sido interpretada por la Suprema Corte de Justicia de la Nación, como aquella que implica una deshonra del gobernado imborrable y permanente frente a terceros. En el caso de la ejecución de la medida de apremio ordenada por el Magistrado responsable, no generará tal agravio, ya que en el juicio de origen sólo tienen injerencia tanto la parte actora como demandada, en la medida que dicho arresto en su caso, sólo constituirá una sanción por no comparecer al cumplimiento de un requerimiento que el agraviado estima ilegal porque se afecta su persona desde el punto de vista psico-físico; lo que significa que ante terceros el quejoso sólo aparecerá como una persona que en juicio se niega a acatar una orden judicial, por tener la convicción de que es justificada esa negativa a la luz de sus garantías que prevé la Constitución General; de manera que es evidente que desde el punto de vista de la posición del reo, no se ocasionará ningún descrédito o deshonra con la aplicación del medio coercitivo aludido.

En otro aspecto, el apercibimiento y arresto decretado por el tribunal de apelación contra del quejoso no pueden clasificarse tampoco como una sanción que se traduzca en palos, azotes o mutilación, pues de los actos impugnados no se advierte que se haya ordenado golpear o maltratar de alguna manera al quejoso, ya que no debe desatenderse que dicha medida de apremio se aplicó porque éste no compareció voluntariamente a aportar una toma de muestra del líquido hemático de su cuerpo, sin que la Sala responsable haya ordenado que se hiciera comparecer al desahogo de la prueba con auxilio de la fuerza pública y con la utilización de palos o azotes y menos a través de una mutilación del organismo del quejoso.

Tampoco es posible otorgarle al apercibimiento y arresto a que se refieren los actos reclamados la calidad de una pena trascendental, en razón a que la ejecución de tal medida correctiva está dirigida sólo contra el agraviado sin afectar a terceras personas que tienen relación con él, según el concepto de "pena inusitada" acuñado por la Suprema Corte de Justicia de la Nación, quien la ha definido como aquella que se caracteriza porque sus efectos no recaen exclusivamente sobre la esfera jurídica del condenado, sino que van más allá, afectando a sus parientes o allegados; de ahí que se 
insiste, en la especie no se individualiza alguna pena trascendental a que alude el artículo 22 constitucional.

En otro punto, en lo concerniente a que la negativa del quejoso a asistir a la materialización de la prueba pericial indicada haya sido fundada en que, de haber compareciendo a la extracción sanguínea de su cuerpo, implicaba una medida que involucraba un acto cruel, inhumano o excesivo para estimarla como una pena inusitada, o bien, que trajera como consecuencia un tormento o cualquier marca en la persona del demandado, debe decirse que en el caso no se individualizarían las penas citadas que recoge el artículo 22 de la Constitución General, en razón a que, aplicando una interpretación valorativa de las normas jurídicas que permean el asunto a resolver, se llega a la conclusión que el desahogo de dicha prueba que lleva consigo la comparecencia del agraviado para que voluntariamente aportara una muestra de su sangre, nace de un derecho legítimo del menor de edad que por conducto de su madre reclama del quejoso el reconocimiento de su paternidad.

Por lo anterior, este Tribunal Colegiado estima que en la escala de valores en conflicto, debe prevalecer el de mayor jerarquía como es el derecho del menor a conocer su identidad frente al derecho de su progenitor de negarse a proporcionar de manera voluntaria una muestra de líquido hemático para que, con base en la prueba científica conocida como ácido desoxirribonucleico ADN, puedan aportarse datos que revelen esa identidad, porque si bien, efectivamente, es un hecho conocido por todos que la extracción de sangre a una persona le representa un dolor mínimo, también lo es que ese procedimiento actualmente se practica con facilidad en los hospitales y centros de salud dispersados por todo el territorio nacional.

En tal tesitura, aunque la extracción de sangre constituye un método invasivo, no puede anteponerse en su caso a las obligaciones que tiene el ser humano que reconozca la paternidad del ser que procreó, pues ese reconocimiento implica no sólo poner en evidencia la identidad del menor, sino su protección que es de interés público y la sociedad está interesada en que se respeten tales derechos, como se ve en los artículos 
1o. (sic) de la Ley para la Protección de los Niños, Niñas y Adolescentes, la cual a su vez tiene su fundamento en el párrafo sexto del artículo 4o. de la Constitución General.

Por consiguiente, colocando en la escala de valores jurídicos la oposición del agraviado a la toma de muestra de material orgánico de su cuerpo, frente al derecho del menor de edad que le reclama su reconocimiento como hijo de aquél, este Tribunal Colegiado, consciente de la situación y riesgos que ello implica, estima que el apercibimiento y arresto decretado contra el agraviado por no haber comparecido al desahogo de la prueba pericial ofrecida por la actora en el juicio natural, a fin de que aportara voluntariamente la muestra de su sangre, no es inconstitucional, pues no transgrede el artículo 22 de la Constitución Política de los Estados Unidos Mexicanos.

Sobre este mismo punto, tampoco se puede concebir la idea que son inconstitucionales los actos reclamados con base en los artículos 14 y 16 de la Carta Magna, en la posible afectación al derecho personal de integridad física del quejoso, en caso de que compareciera al desahogo de la prueba en cuestión, ya que si bien es cierto que podrá darse esa afectación, como se indicó, la misma es de menor valor que el interés del infante que reclama ser reconocido como hijo al enjuiciado.

CUARTO. Existencia de la contradicción.

Para que haya materia a dilucidar respecto de cuál criterio es el que debe prevalecer, es necesario que:

a) $\mathrm{Al}$ resolver los negocios se examinen cuestiones jurídicas esencialmente iguales y se adopten posiciones o criterios jurídicos discrepantes;

b) La diferencia de criterios se presente en las consideraciones, razonamientos o interpretaciones jurídicas de las sentencias respectivas, y 
c) Los diferentes criterios provengan del examen de los mismos elementos.

Al respecto, es aplicable la jurisprudencia 26/2001, emitida por el Pleno de la Suprema Corte de Justicia de la Nación de rubro: "CONTRADICCIÓN DE TESIS DE TRIBUNALES COLEGIADOS DE CIRCUITO. REQUISITOS PARA SU EXISTENCIA."(1)

Cabe señalar que, aun cuando los criterios sustentados por los tribunales contendientes no constituyen jurisprudencia debidamente integrada, ello no es requisito indispensable para proceder a su análisis y establecer si existe la contradicción planteada y, en su caso, cuál es el criterio que debe prevalecer, siendo aplicable la tesis L/94, de rubro: "CONTRADICCIÓN DE TESIS. PARA SU INTEGRACIÓN NO ES NECESARIO QUE SE TRATE DE JURISPRUDENCIAS.", emitida por el Pleno de la Suprema Corte de Justicia de la Nación.

Establecido lo anterior, es procedente examinar si en la especie se da o no la contradicción de criterios.

De la confrontación de las consideraciones emitidas en las resoluciones de los tribunales contendientes, se llega a la conclusión de que sí existe la contradicción de criterios, pues en los negocios resueltos se examinaron cuestiones jurídicas esencialmente iguales y se adoptaron posiciones o criterios jurídicos discrepantes, obteniéndose diferencia de criterios en los razonamientos, proviniendo del análisis de los mismos elementos, lo cual se demuestra con los razonamientos siguientes:

En los criterios discordantes se realizó el examen de los mismos elementos, pues ambos tribunales abordaron el estudio de casos en los que se ofreció como prueba para demostrar la paternidad del demandado respecto de un menor, la prueba pericial en genética, consistente en la toma de muestras de ADN y el demandado se negó a practicarse dicha prueba (por inasistencia a la diligencia respectiva y por oposición 
directa) y, en consecuencia, los juzgadores le impusieron como medida de apremio por esa actitud, en un caso una multa y, en el otro, un arresto, con base en las legislaciones procesales civiles de cada entidad (Estado de México y Nuevo León).

Ambos tribunales realizaron el análisis de una misma cuestión de derecho. En este aspecto, los dos órganos jurisdiccionales contendientes resolvieron, a la luz de los artículos 14 y 16 de nuestra Carta Magna, si era o no constitucional el apercibimiento que tiene como finalidad, a través de la aplicación de los aludidos medios de apremio, proporcionar las muestras médicas necesarias para el desahogo de la prueba pericial ofrecida.

Sin embargo, el criterio que cada uno de los tribunales adoptó al resolver el problema planteado fue diferente. En efecto, el Tercer Tribunal Colegiado en Materia Civil del Segundo Circuito consideró que el apercibimiento que se le realiza al demandado consistente en que de no acudir a desahogar la prueba pericial en materia de genética se le hará efectiva la aplicación de alguno de los medios de apremio establecidos por la ley, era violatorio de garantías individuales, por lo que no se le puede obligar a tomarse dichas muestras; no obstante, al tomar en cuenta los derechos fundamentales del menor, la solución que dio es que ante la negativa del demandado a someterse a dicha prueba pericial, no es correcto que se le aperciba con los medios de apremio ordenados por la ley, sino en el sentido de que si no comparece o se opone a la realización de dicho examen, se presumirán ciertos los hechos que se pretenden probar con tal probanza.

Por su parte, el Tercer Tribunal Colegiado en Materia Civil del Cuarto Circuito consideró que dicho apercibimiento (arresto hasta por treinta y seis horas), al ser su causa el conocer la filiación e identidad del infante, no constituía violación de garantías constitucionales, puesto estimó que, atendiendo a la escala de valores, debe prevalecer el derecho del menor a conocer su identidad frente al derecho de quien se le acusa la paternidad del niño, por lo que es correcto que se hayan aplicado esas medidas de apremio. 
Así, se llega a la conclusión de que ambos tribunales realizaron el examen de los mismos elementos: casos en que se demandó el reconocimiento de paternidad, se ofreció una prueba pericial en genética de ADN, y en los que el demandado se negó o se opuso a realizarla y, por ello, se impusieron medidas de apremio consistentes en multa y arresto; sobre una misma cuestión jurídica: si es o no violatorio de garantías el apercibimiento que se realiza al demandado, consistente en que de no acudir a desahogar la prueba pericial en materia de genética, se le hará efectiva la aplicación de alguno de los medios de apremio establecidos por la ley, a fin de conocer la identidad del menor; pero las decisiones a las que llegaron fueron divergentes: por un lado, se sostuvo que la imposición de las medidas de apremio antes referidas es violatoria de garantías, y que el apercibimiento debía ser en el sentido de que se presumirían ciertos los hechos que se pretenden acreditar con esa probanza; y, por otro lado, que dicha resolución no era violatoria de garantías, en razón de que debe prevalecer el derecho del menor frente al derecho del enjuiciado.

El problema de la presente contradicción, toda vez que se ha declarado existente, es el siguiente: En los casos en que se ofrece una prueba pericial en materia de genética ADN y el demandado se niega o se opone a realizarla ¿Es constitucional o no la aplicación de las medidas de apremio en los casos en los que el demandado se niega o se opone a que se le practique la prueba pericial en genética? Una vez determinado lo anterior, subsiste otro problema: ¿Cómo puede el Juez garantizar el derecho del menor a la filiación ante la negativa del demandado para realizar la prueba de ADN?

QUINTO. Determinación del criterio a prevalecer.

Esta Primera Sala de la Suprema Corte de Justicia de la Nación considera que debe prevalecer, con el carácter de jurisprudencia, el criterio que se sustenta en el presente fallo, de conformidad con los siguientes razonamientos.

El análisis de la presente contradicción se realizará a través de las siguientes etapas: 
I. En primer lugar, toda vez que en el presente asunto se aborda un tema que tiene íntima relación con los derechos de los menores, pues se refiere a casos de juicios de reconocimiento de paternidad en los que se ofrece la prueba pericial en genética de ADN y el demandado se niega o se opone a la realización de dicha prueba, se establecerá el derecho de los menores a conocer su identidad.

II. Posteriormente, se hablará de la posibilidad legal de que los menores demanden de sus presuntos ascendientes el reconocimiento de la relación paterno-filial.

III. En tercer lugar, se hará un estudio general de la prueba pericial de ADN.

IV. En cuarto lugar, se analizará si es o no inconstitucional la aplicación de las medidas de apremio en los casos en que el presunto ascendiente se niega a la práctica de la prueba.

V. Finalmente, se determinará qué es lo que debe hacer el Juez ante la imposibilidad de utilizar las medidas de apremio señaladas en la legislación procesal civil.

I. El derecho de los menores a la identidad.

El artículo 4o. de la Constitución Política de los Estados Unidos Mexicanos establece, en lo conducente, lo siguiente:

"Artículo 4o.

$" \ldots$

"Los niños y las niñas tienen derecho a la satisfacción de sus necesidades de alimentación, salud, educación y sano esparcimiento para su desarrollo integral.

"Los ascendientes, tutores y custodios tienen el deber de preservar estos derechos. El 
Estado proveerá lo necesario para propiciar el respeto a la dignidad de la niñez y el ejercicio pleno de sus derechos.

"El Estado otorgará facilidades a los particulares para que coadyuven al cumplimiento de los derechos de la niñez."

Por su parte, la Convención sobre los Derechos del Niño, la cual fue suscrita y ratificada por el Estado mexicano (por lo que en términos del artículo 133 constitucional forma parte de nuestro sistema jurídico como una norma de derecho positivo vigente), establece que las autoridades administrativas, los tribunales o los órganos legislativos en todas las medidas que tomen concernientes a los niños, se atenderá primordialmente el interés superior del niño(3) (artículo 3o.); asimismo, dicha convención estipula que tendrá derecho desde que nace a un nombre, a adquirir una nacionalidad y, en la medida de lo posible, a conocer a sus padres (artículo 7o.); que los Estados partes se comprometen a respetar el derecho del niño a preservar su identidad, incluidos la nacionalidad, el nombre y las relaciones familiares de conformidad con la ley, sin injerencias ilícitas; finalmente, agrega que cuando un niño sea privado ilegalmente de alguno de los elementos de su identidad o de todos ellos, los Estados partes deberán prestar la asistencia y protección debidas con miras a reestablecer rápidamente su identidad (artículo 8o.)

En concordancia con lo anterior, la Ley para la Protección de los Niños, Niñas y Adolescentes, la cual es de orden público, de interés social y de observancia obligatoria en toda la República (artículo primero), establece en su artículo 22, incisos a) y c), que el derecho a la identidad está compuesto por tener un nombre y los apellidos de los padres desde que nazca y conocer su filiación y su origen, salvo en el caso que las leyes lo prohíban.

De esta manera, se tiene que el estado civil comporta un atributo propio de la persona, inherente y consustancial al derecho de la personalidad jurídica y al nombre que, en el caso de los menores, reviste el carácter de derecho fundamental. Por ello, el hecho de 
que el menor tenga la certeza de quién es su progenitor constituye un principio de orden público y hace parte del núcleo esencial del derecho fundamental a la personalidad jurídica.

La importancia de ese derecho fundamental a la identidad no sólo radica en la posibilidad de conocer el nombre y el origen biológico (ascendencia), sino que, a partir de ese conocimiento, puede derivarse en primer lugar, el derecho del menor a tener una nacionalidad y, por otra parte, el derecho del menor, constitucionalmente establecido (artículo 4o.), de que sus ascendientes satisfagan sus necesidades de alimentación, salud, educación y sano esparcimiento, para su desarrollo integral.

Este derecho a la obtención de los satisfactores básicos para lograr el desarrollo es una extensión del derecho a la vida, pues éste implica que las condiciones de vida deben ser lo suficientemente buenas para que el menor crezca sana y armoniosamente, garantizándose su pleno desarrollo.(4)

Todo lo anterior permite concluir que no únicamente en nuestra Ley Fundamental, sino que en diversas normas internacionales y otras de derecho interno que la desarrollan, se consagra el principio del "interés superior de la niñez", y es innegable que debe garantizarse el derecho del menor a conocer su filiación, esto es, la identidad de sus ascendientes, toda vez que de esta circunstancia se deriva el derecho del infante a percibir de sus ascendientes la satisfacción de sus necesidades y a obtener así una vida digna que permita su desarrollo.

II. Juicios de paternidad.

Precisamente por lo expuesto en los párrafos precedentes, las dos legislaciones en las que se basaron los tribunales contendientes (Estado de México y Nuevo León) establecen la posibilidad de que los menores demanden el reconocimiento de la paternidad. 
En efecto, el artículo 4.175 del Código Civil mexiquense establece:

"Artículo 4.175. La investigación de la paternidad de los hijos, está permitida:

"I. En los casos de rapto, estupro o violación;

"II. Cuando se encuentre en posesión de estado de hijo;

"III. Cuando haya sido concebido durante el tiempo en que la madre hizo vida marital con el presunto padre;

"IV. Cuando el hijo tenga a su favor un principio de prueba contra el presunto padre."

Por su parte, el Código de Procedimientos Civiles para el Estado de Nuevo León establece:

"Artículo 190 Bis. Este acto tendrá por objeto preparar la acción correspondiente a la investigación de la filiación a fin de determinar la paternidad o la maternidad, mediante el estudio del ADN, la prueba biológica molecular de la caracterización del ácido desoxirribonucleico de sus células, en la que deberán utilizarse las pruebas de mayor avance científico, en los casos en que determina este código."

"Artículo 190 Bis VI. La acción correspondiente deberá intentarse por parte del solicitante dentro del término de treinta días, una vez recibido el dictamen con resultado positivo o generada la presunción de filiación; apercibido de que en caso de no hacerlo así, quedarán sin materia los beneficios obtenidos en este procedimiento."

Los derechos de los niños que se especificaron en los párrafos precedentes, dentro de los cuales se incluye el derecho a su identidad, implican que éstos pueden demandar la paternidad y ofrecer en el procedimiento cualquier medio de prueba que produzca 
convicción en el juzgador, entre los cuales se encuentra la prueba pericial en genética de sus supuestos progenitores.

\section{La prueba pericial de ADN.(5)}

Los tribunales cada vez con mayor frecuencia requieren allegarse de evidencia científica para la resolución de los asuntos que son sometidos a su conocimiento, debido a los avances de los últimos tiempos en el campo de la ciencia y a las repercusiones que esos hallazgos pueden representar para el derecho. De esta forma, en muchas ocasiones los juzgadores requieren contar con la opinión de expertos en esas materias para proferir sus fallos de una manera informada y evitar incurrir en especulaciones en torno a ámbitos del conocimiento que van más allá del conocimiento del derecho que el juzgador debe tener.

$\mathrm{Al}$ respecto, debe tenerse presente que el derecho y la ciencia son dos de las fuentes de autoridad más importantes para los gobiernos modernos, aun cuando tienen origen, fundamentos y alcances diversos. Los productos de ambas ramas del conocimiento se presumen imparciales, ajenos a intereses particulares y válidos sin importar el contexto inmediato de su generación; de ahí que frecuentemente orienten las políticas públicas y sirvan de fundamento para evaluar la racionalidad de las decisiones políticas. Juntos, el derecho y la ciencia, constituyen un medio para asegurar la legitimidad de las decisiones gubernamentales, ello a partir de las diversas modalidades de relación que entre ambos se generan.

Precisamente por ello, en la decisión jurisdiccional sobre la acción de paternidad, los avances de la ciencia son indispensables para auxiliar al juzgador a tomar sus decisiones. La propia ley lo reconoce así al permitir que de diversas maneras se utilicen como medios de prueba diversos elementos aportados por la ciencia y la tecnología. En esos casos, debido a la naturaleza de las cuestiones que serán materia de la prueba, al requerirse conocimientos científicos y tecnológicos, se utiliza la prueba pericial, mediante la cual un especialista presta auxilio al juzgador en un área en la que éste no es 
un experto. Lo anterior encuentra fundamento en los artículos 1.265, fracciones III y VI y 1.304 del Código de Procedimientos Civiles del Estado de México y 239, fracción VII y 309 del Código de Procedimientos Civiles de Nuevo León.(6)

Ante esto, es menester preguntarnos qué tipo de hallazgos científicos pueden y deben ser admitidos para orientar la toma de decisiones jurisdiccionales y permitir con ello que los tribunales impartan justicia, al hacer que los juzgadores profieran sus fallos de una manera más informada cuando se enfrentan a ámbitos del conocimiento que, como ya se anotó, van más allá del conocimiento ordinario del derecho.

En todo caso, para que un órgano jurisdiccional pueda apoyarse válidamente en una opinión de algún experto en una rama de la ciencia, es necesario que esa opinión tenga las siguientes características:

1. Que la evidencia científica sea relevante para el caso concreto en estudio, es decir, que a través de la misma pueda efectivamente conocerse la verdad de los hechos sujetos a prueba, $\mathrm{y}$

2. Que la evidencia científica sea fidedigna, esto es, que se haya arribado a ella a través del método científico, para lo cual se requiere, generalmente, que la teoría o técnica científica de que se trate:

a. Haya sido sujeta a pruebas empíricas, o sea, que la misma haya sido sujeta a pruebas de refutabilidad;

b. Haya sido sujeta a la opinión, revisión y aceptación de la comunidad científica;

c. Se conozca su margen de error potencial, y

d. Existan estándares que controlen su aplicación. 
Partiendo de estos criterios, a juicio de esta Primera Sala la realización de las pruebas de ADN satisface los lineamientos anteriores.

Aun cuando la realización de la prueba general de ADN puede hacerse con diversos elementos propios de un cuerpo, en el caso concreto, la prueba de ADN se realiza a partir de la extracción de muestras de sangre o saliva tanto del presunto padre como del presunto hijo, para compararlas y determinar así las relaciones de filiación.

El ácido desoxirribonucleico es el material genético de los organismos vivos y es el componente primario de los cromosomas y el material del cual los genes están formados. Se encuentra en el interior del núcleo de todas las células del organismo. La unidad estructural y funcional básica de los seres humanos, como la de cualquier ser vivo, es la célula. Cada una de las células de un organismo humano consta de un núcleo en el cual se encuentra la cromatina. La cromatina se organiza en pequeños cuerpos llamados cromosomas, y la base de cada cromosoma es una molécula larga de ADN formada por dos cadenas que imparten las instrucciones específicas de cada célula en el desarrollo o en el mantenimiento de las funciones del cuerpo. La cadena de ADN contiene muchos genes y esos genes son necesarios para construir y hacer funcionar a cada uno de los órganos del cuerpo humano. Este ADN es prácticamente el mismo en cada una de las células del cuerpo humano.

La reproducción sexual lleva el ADN de los dos progenitores para crear una combinación única de material genético en una nueva célula, de forma tal que el material genético de un individuo es derivado del material genético de sus padres. La combinación mencionada estará presente en todas las células del nuevo ser humano.

Cada célula humana tiene cuarenta y seis cromosomas, salvo en el caso de las células reproductoras tanto del hombre como de la mujer, caso en el que tienen veintitrés cromosomas. Por ello existen cuarenta y seis cromosomas en cada célula, porque se recibe la mitad de cada una de las células de los progenitores. Precisamente porque el 
hijo tiene una combinación genética de cada uno de sus padres es factible que a través de diversos métodos científicos, al realizar las pruebas de ADN puedan determinarse sus relaciones de filiación.

De los cuarenta y seis cromosomas, cuarenta y cuatro (veintidós pares) están presentes tanto en las células femeninas como en las masculinas. El otro par tiene que ver principalmente con las características del desarrollo sexual y son diferentes según se trate de una mujer o de un varón. En las mujeres el complemento cromosómico sexual es XX, mientras que en el varón este complemento es XY.

Ahora bien, el procedimiento que se sigue al realizarse una prueba pericial en genética y así determinar la relación de paternidad o maternidad respecto de una persona es el siguiente:

Las cadenas de ADN están compuestas de cuatro moléculas diferentes: a) adenina (A), b) timina (T), c) citosina (C); y d) guanina (G). Esos elementos se agrupan a manera de una escalera que se entrelaza, está extremadamente condensada y contiene una cantidad enorme de información genética, pues se compone de secuencias muy largas de agrupación de los cuatro elementos mencionados. Las dos cadenas son complementarias, ya que existe un apareamiento específico entre las bases nitrogenadas, de tal suerte que la adenina se une a la timina y la guanina lo hace a la citosina. Por esta razón la secuencia de una cadena automáticamente determina la secuencia de la cadena complementaria. Por ejemplo, un segmento de cada una de las cadenas mencionadas sería TAGTAC en una cadena y ATCATG en otra, y la secuencia de ADN es la combinación de esas cadenas. Así, la secuencia de esos elementos y sus combinaciones determinan genéticamente las funciones y características de los seres humanos.

La posibilidad de conseguir la identificación de un individuo mediante el estudio del ADN se basa en el hecho de que su cadena está compuesta por los elementos mencionados. La unión de esos cuatro elementos o bases da lugar a largas secuencias con combinaciones variables, y tienen la particularidad adicional de presentar 
repeticiones del número variable en regiones del genoma. Estas secuencias de bases repetidas del número variable (UNTR) difieren de un ser a otro, pero se identifican en el caso de la filiación. Así, el ADN se da por secuencias de bases que constituyen unidades de repetición, las cuales se caracterizan porque en su zona central existen varias bases de ADN que apenas muestran variaciones entre las diferentes unidades. En los lugares extremos de cada unidad de repetición pueden ocurrir cambios de bases, pero entre las diversas unidades de repetición es casi totalmente constante la secuencia de las bases. Esas variaciones se denominan marcadores.

Al realizarse una prueba de ADN para determinar las relaciones de filiación, las cadenas de aquél son divididas en secuencias específicas de patrones de herencia, esto es, en marcadores. La mejor manera de establecer la identidad de un individuo a través del $\mathrm{ADN}$ es conocer la secuencia en un número lo suficientemente representativo de estos marcadores, como para poder individualizar las variantes específicas presentes en la secuencia, siendo importante en el caso de la determinación de la filiación padre-hijo (varón), es estudiar los marcadores del cromosoma "Y" o masculino.

El ADN de cada ser humano contiene dos copias de los marcadores, una heredada del ADN del padre y otra del de la madre. Así, aunque los hijos heredan de los padres la mitad del ADN de cada uno de éstos, el ADN de aquéllos es diferente. En otras palabras, los marcadores del ADN de cada persona difieren, ya sea en lo largo o en la secuencia y la razón para que exista esa diferencia es precisamente la diferencia de los marcadores heredados de los padres.

Entonces, los marcadores del ADN de cada persona se diferencian, pero conservan diversos patrones repetitivos heredados de cada uno de los progenitores (huellas del ADN). La combinación del tamaño de los marcadores encontrados en cada persona da como resultado su perfil genético. De la comparación del perfil genético del hijo con el del padre o madre pueden determinarse las relaciones de parentesco consanguíneo, pues los perfiles son comparados para ver si el perfil del niño tiene marcadores que son coincidentes con el padre y la madre que se someten a prueba y esa comparación de 
secuencias de ADN de un individuo respecto de otra de alguien diverso puede demostrar si una de ellas fue o no derivada de la otra.

El informe de prueba de paternidad determina los perfiles genéticos de la persona que participa en la prueba y el tamaño de los diferentes marcadores sometidos a prueba, es decir, establece una huella genética que contiene únicamente las informaciones sobre las secuencias de los marcadores; también se determina el llamado "índice de paternidad", que consiste en una medida estadística de qué tan fuertemente una coincidencia entre los marcadores del presunto padre y del presunto hijo indica paternidad: si los marcadores de ADN que se comparan no coinciden, entonces el presunto padre es excluido en un cien por ciento de la posibilidad de ser el ascendiente, pero si coinciden, se puede calcular una probabilidad que alcanza más del 99.99\% de certeza.

Por ese grado de certeza, una prueba de ADN bien realizada es considerada como el método más preciso, confiable y contundente para establecer relaciones de paternidadfiliación, porque está basada en un análisis exacto de los perfiles genéticos (huellas genéticas) del padre o madre y del hijo.

Debe señalarse que en este tipo de pruebas únicamente se analiza la huella genética y no la totalidad de la información que podría desprenderse del ADN del sujeto a prueba. En efecto, a través del mapa genético puede obtenerse información de diversa índole, pero en el análisis de paternidad por ADN únicamente se obtiene la llamada huella genética, la cual no incluye toda la información incorporada al mapa genético, sino sólo la correspondiente a determinados segmentos de $\mathrm{ADN}$, los cuales se toman en cuenta exclusivamente en lo relativo a la longitud de su secuencia repetitiva y a la frecuencia de la misma.

IV. Análisis de la constitucionalidad de la aplicación de las medidas de apremio en el caso a estudio.

Una vez determinada la validez científica de la prueba de ADN y su grado de certeza, es 
necesario establecer si en los casos en que el presunto padre se niega a realizarse la prueba de ADN, es constitucional que el Juez haga uso de las medidas de apremio que tiene a su disposición para hacer cumplir sus determinaciones. En otras palabras, debe determinarse si el Juez puede coaccionar al presunto padre a que acuda a la realización de la prueba pericial genética.

Los Códigos de Procedimientos Civiles de Nuevo León y del Estado de México establecen las medidas de apremio en las cuales los Jueces o Magistrados pueden apoyarse para que sus determinaciones sean cumplidas, de la siguiente manera:

Código de Procedimientos Civiles para el Estado de Nuevo León

"Artículo 42. Los Magistrados y los Jueces para hacer cumplir sus determinaciones, pueden emplear cualesquiera de los siguientes medios de apremio:

"I. Multa hasta por las cantidades a que se refiere el artículo 27 de éste código, que se duplicará en caso de reincidencia;

"II. Auxilio de la fuerza pública;

"III. Cateo por orden escrita;

"IV. Arresto hasta por treinta y seis horas.

"Si el caso exigiere mayor pena, se consignará al Ministerio Público para los efectos legales."

Código de Procedimientos Civiles para el Estado de México

"Artículo 1.124. Los Jueces para hacer cumplir sus determinaciones, siempre que no 
existan otros específicos determinados por la ley, pueden emplear indistintamente, los siguientes medios de apremio:

"I. Multa hasta de cien días de salario mínimo vigente en la región de su actuación, que podrá duplicarse en caso de reincidencia;

"II. Uso de la fuerza pública;

"III. Rompimiento de cerraduras;

"IV. Cateo por orden escrita;

"V. Arresto hasta por treinta y seis horas."

Ahora bien, estas medidas no son suficientes, en muchos casos, para vencer la resistencia de una de las partes para cumplir con las determinaciones del Juez, por lo que es necesario inclusive, en estos casos, dar vista al agente del Ministerio Público por la probable comisión de un delito, que en los casos de las legislaciones que nos ocupan, es el de desobediencia.(7) Sin embargo, ocurre también, a veces, que ni aun en el caso de que se iniciara una averiguación previa por la probable comisión de este delito, se lograría vencer la resistencia de la parte renuente a cumplir con lo ordenado por el juzgador. En estos casos extremos, la determinación del Juez quedaría sin cumplimiento a pesar de que se hubieran agotado las medidas antes aludidas en perjuicio de la contraparte de la contumaz y entonces, habría que establecer qué debe hacer el Juez para salvaguardar el derecho de la parte afectada.

De acuerdo con lo anterior, interpretando literalmente la ley, se llega a la conclusión de que las medidas de apremio son legalmente aplicables para el caso de que el presunto ascendiente se niegue u oponga a realizarse la prueba de ADN, pues los artículos transcritos señalan que los Magistrados y los Jueces pueden hacer uso de cualquiera de los medios de apremio para hacer cumplir sus determinaciones. Así, cuando el Juez 
admite la prueba pericial genética y ordena su desahogo, esa cuestión constituye una determinación que encajaría en el supuesto de las normas mencionadas y, entonces, legalmente tendría la posibilidad de hacer uso de las medidas de apremio.

No pasa inadvertido para esta Sala que entre las medidas de apremio que pueden utilizar los Jueces se encuentra el uso de la fuerza pública; sin embargo, se considera que esta medida de apremio debe utilizarse sólo para presentar al demandado al lugar en el que se debe realizar la prueba, mas no para obtener la muestra necesaria haciendo uso de tal medio, de conformidad con las razones que se dan más adelante, las cuales carecerían de razón si se obtuviera de esa manera la muestra para la realización de la prueba genética de ADN.

No es obstáculo para lo anterior, la problemática planteada en los amparos de los cuales provienen las ejecutorias que se enfrentan en la presente contradicción. En ellas, los presuntos padres hacían valer que el desahogo de la prueba pericial en genética violaba las garantías establecidas en el artículo 22 constitucional, su derecho a la intimidad y su derecho a la integridad física, por lo que las medidas de apremio que se dictaran para el caso de negativa del presunto ascendiente era inconstitucional. Separemos los problemas para su mejor comprensión.

En cuanto al derecho a la intimidad genética, el cual incluye también la autodeterminación de la información correspondiente, ese derecho no se viola, por lo siguiente:

El mapa genético, como ya se señaló, contiene mucha información de diversa índole, como las características propias de la personalidad y tendencias patológicas. La titularidad de la información de ese mapa corresponde únicamente a su propietario y éste tiene derecho, en principio, a mantenerla bajo privacidad; sin embargo, en los análisis de paternidad por ADN (en los cuales únicamente se obtiene la llamada huella genética), como ya se dijo, no se incluyen los contenidos de toda esa información, sino 
sólo lo que corresponde a determinados segmentos de ADN, los cuales se toman en cuenta exclusivamente en lo relativo a la longitud de su secuencia repetitiva y a la frecuencia de la misma.

Entonces, la práctica de una prueba pericial que versará sobre la información genética del presunto padre, únicamente para verificar si sus marcadores son coincidentes con los del actor (presunto hijo) no constituye una violación a la intimidad, porque las enfermedades, tendencias y demás información genética no se analizarán en la prueba, sino que ésta únicamente consistirá en establecer si los marcadores del hijo son o no iguales a los del padre, lo cual en manera alguna viola el derecho a la intimidad, pues precisamente el hijo tiene derecho a conocer su origen biológico y al ofrecer esta prueba esa es la única información que será rendida por los peritos correspondientes. Cuando se analiza una huella genética para determinar la paternidad es como si se analizara una huella dactilar.

En este aspecto, la legislación de Nuevo León es bastante clara al señalar, en el artículo 190 Bis IV del Código de Procedimientos Civiles, que:

"El dictamen remitido a la autoridad judicial versará únicamente sobre los datos relativos a la filiación, conservándose en la confidencialidad los demás datos o características genéticas que pudiera arrojar la misma, a fin de preservar los derechos que en cuanto a su intimidad le asisten a la persona."

Por otra parte, la acción de paternidad, en todo caso, únicamente versará sobre esa cuestión, por lo que en todo caso la solicitud de desahogo de la prueba pericial en genética a cargo del presunto padre no puede ofrecerse para que se conozcan otras características genéticas de él.

La posibilidad de que se conozca la información de la huella genética está perfectamente justificada si se toma en cuenta que existe el interés del actor para 
conocer su identidad genética y la realización de la prueba puede dar con bastante certeza los datos necesarios para determinar ello, como también ha quedado expuesto.

Por las mismas razones, tampoco existe una violación de garantías respecto de la autodeterminación informativa, pues el hecho de que las partes y el Juez puedan conocer la información que se desprenderá del análisis de paternidad tiene una justificación en tanto que únicamente versará sobre la filiación y no sobre otras cuestiones.

Lo anterior encuentra apoyo en la resolución del amparo en revisión 1166/2005, emitida por unanimidad de votos de los integrantes de esta Primera Sala, de la cual se derivó la siguiente tesis:

"PRUEBA PERICIAL EN GENÉTICA MOLECULAR DEL ÁCIDO DESOXIRRIBONUCLEICO (ADN). EL ARTÍCULO 5o., APARTADO B), INCISO III, DE LA LEY DE LOS DERECHOS DE LAS NIÑAS Y NIÑOS EN EL DISTRITO FEDERAL, NO VIOLA LA GARANTÍA DE AUDIENCIA. El artículo 5o., apartado B), inciso III, de la Ley de los Derechos de las Niñas y Niños en el Distrito Federal, que establece que las niñas y niños tienen el derecho a la identidad, certeza jurídica y familia, y a solicitar y recibir información sobre su origen, sobre la identidad de sus padres y a conocer su origen genético, se traduce en el derecho de los menores a solicitar en juicio, la prueba pericial en genética molecular del ácido desoxirribonucleico (ADN), de sus presuntos progenitores. Lo anterior no viola la garantía de audiencia, puesto que la misma se encuentra debidamente protegida por el artículo 298 del Código de Procedimientos Civiles para el Distrito Federal, por virtud del cual existe la posibilidad de impugnar mediante el recurso de apelación en el efecto devolutivo, la admisión de una prueba por parte de quien pudiera resultar afectado por la propia admisión."(8)

Igualmente esta Primera Sala reitera el criterio mencionado en el párrafo anterior en el sentido de que la realización de la prueba pericial en genética no viola las disposiciones 
del artículo 22 constitucional porque dicho artículo se refiere a las sanciones que se imponen a los individuos cuya responsabilidad está plenamente demostrada, previo el desahogo de un proceso legal, mientras que la prueba pericial sólo implica la práctica de estudios de laboratorio para determinar la correspondencia del ADN y no puede considerarse una pena. Así, precisamente porque no constituye una pena o sanción, no se encuentra en los supuestos del artículo 22 constitucional, en cuanto prohíbe toda pena infamante, inusitada $\mathrm{y}$ trascendental.

Debe señalarse que aunque esta Primera Sala ya ha determinado que con el desahogo de la prueba pericial en genética no se violan los derechos a la intimidad ni las garantías establecidas en el artículo 22 constitucional, no quiere decir que no pueda impugnarse la constitucionalidad de esa prueba en circunstancias en que se acredite que por la forma en que se ordena y desahoga, la prueba pueda violar el derecho a la intimidad, a la integridad personal o a la salud del presunto ascendiente, lo cual sucedería en el supuesto de que se admitiera una pericial de una institución no reconocida para ese efecto, si se ordenara para que se obtuviera otra información diferente a la huella genética o si estuviera en riesgo la salud del sujeto a prueba. En todo caso, esta Primera Sala que considera dichos actos serían de imposible reparación y serían impugnables en amparo indirecto, tal como lo señaló al resolver la contradicción de tesis 81/2002, de la que derivó la jurisprudencia 17/2003, la cual es del tenor literal siguiente:

\section{"PRUEBA PERICIAL EN GENÉTICA. SU ADMISIÓN Y DESAHOGO TIENEN UNA EJECUCIÓN DE IMPOSIBLE REPARACIÓN SUSCEPTIBLE DE AFECTAR} DERECHOS SUSTANTIVOS DE LA PERSONA. Cuando en un juicio ordinario civil en el que se ventilan cuestiones relacionadas con la paternidad, se dicta un auto por el que se admite y ordena el desahogo de la prueba pericial para determinar la huella genética, con el objeto de acreditar si existe o no vínculo de parentesco por consanguinidad, dicho proveído debe ser considerado como un acto de imposible reparación, que puede afectar los derechos fundamentales del individuo, por lo que debe ser sujeto a un inmediato análisis constitucional, a través del juicio de amparo indirecto, en términos de los artículos 107, fracción III, inciso b), de la Constitución Política de 
los Estados Unidos Mexicanos y 114, fracción IV, de la Ley de Amparo. Lo anterior es así, por la especial naturaleza de la prueba, ya que para desahogarla es necesario la toma de muestras de tejido celular, por lo general de sangre, a partir del cual, mediante un procedimiento científico, es posible determinar la correspondencia del ADN (ácido desoxirribonucleico), es decir, la huella de identificación genética, lo cual permitirá establecer no sólo la existencia de un vínculo de parentesco, sino también otras características genéticas inherentes a la persona que se somete a ese estudio, pero que nada tengan que ver con la litis que se busca dilucidar y, no obstante, puedan poner al descubierto, contra la voluntad del afectado, otro tipo de condición genética hereditaria, relacionada por ejemplo con aspectos patológicos o de conducta del individuo, que pertenezcan a la más absoluta intimidad del ser humano."(9)

De acuerdo con lo anterior, queda claro que el uso de medidas de apremio por parte del Juez está plenamente justificado en tanto que el presunto ascendiente tiene la obligación de practicarse la prueba sin poder poner como excusa que pudiera violarse su intimidad, o su privacidad genética, o que ello implicaría una pena inusitada, infamante o trascendental. Entonces, se concluye que tratándose de la prueba en genética molecular del ADN, las medidas de apremio establecidas en la ley y su aplicación para lograr que el demandado se someta a la misma, son constitucionales.

No obstante lo anterior, nos enfrentamos a un problema práctico que el Juez debe resolver: ¿Qué debe hacer el Juez si, a pesar de la aplicación de estas medidas de apremio, el demandado continúa negándose a someterse a la mencionada prueba?

Los artículos 14 y 16 constitucionales garantizan con amplitud la vida privada del individuo, su familia, su domicilio y sus posesiones, como un límite no sólo frente a otro derecho sino también frente a la autoridad, por constituir tales aspectos valores esenciales de respeto entre gobierno-gobernado, de tal forma que la libertad de las personas para decidir lo relativo a su cuerpo y a su integridad personal se encuentra, en todo momento, guarecida por el Estado, aun cuando existen casos en que el Estado puede justificar la limitación de estos derechos.(10) 
Así las cosas, sin perjuicio de lo expuesto en los párrafos anteriores, para el caso de los juicios civiles de paternidad, el presunto padre tiene derecho a disponer de su propio cuerpo frente a injerencias de los particulares o del Estado y la propia norma constitucional lo protege para no sufrir invasiones a su integridad física y personal. En el ejercicio de ese derecho, sólo por lo que se refiere a los juicios civiles de paternidad, puede negarse, a pesar de la imposición de las medidas de apremio, a la práctica y desahogo de la prueba pericial de $\mathrm{ADN}$, pues en este tipo de casos efectivamente tiene el derecho a decidir sobre su libertad de movimiento y sobre su integridad personal.

Entonces, hay casos en los que, aún con esas medidas, no se lograría vencer la negativa del demandado para la realización de esa prueba y de cualquier manera el resultado de la acción del presunto descendiente quedaría a merced de que el demandado aceptara practicarse el examen. En estos casos, esas medidas de apremio no tendrían un resultado eficaz, como se ha dicho, pues aunque se arrestara a la persona, la prueba seguiría sin realizarse, e incluso ante la posible comisión del delito de desobediencia ésta podría seguir oponiéndose y cumplir con la pena correspondiente, pero la prueba no se desahogaría y, así, el derecho del menor quedaría en entredicho.

Ahora bien, el hecho de que el demandado se niegue reiteradamente y a pesar de la aplicación de las medidas de apremio a practicarse la prueba de ADN no implica, por otra parte, que se deje el interés superior del niño al arbitrio del presunto padre, porque de cualquier manera esa negativa u oposición tendría una consecuencia jurídica que resguarda los derechos del menor que busca conocer su identidad.

V. Consecuencias de la negativa del presunto ascendiente para la práctica de la prueba de ADN.

Como ya se señaló, no pasa desapercibido a esta Primera Sala que ante esa decisión podría pensarse que, sin poder obligar al presunto padre a acudir a realizarse una prueba que tiene un porcentaje altísimo de certeza respecto de la acción del menor, se dejaría a 
merced de la voluntad del presunto progenitor el interés superior del niño, pues al ascendiente que en verdad lo fuera, le bastaría con no someterse a la referida prueba genética para impedir que se le declarara progenitor del menor y, en su caso, asumiera sus obligaciones como padre.

No obstante, las propias legislaciones contendientes proporcionan una solución a dicho problema, pues el hecho de que las medidas de apremio no sean aplicables no implica que la negativa u oposición del presunto ascendiente queden sin consecuencia jurídica alguna.

Así, cuando el demandado se niega o se opone a la realización de la prueba pericial en genética, atendiendo "el interés superior del niño" y su derecho de conocer la identidad de sus progenitores, ante la ineficacia de los medios de apremio referidos por las causas apuntadas, es menester que los juzgadores se conduzcan conforme lo previsto en el artículo 14 de la Constitución Política de los Estados Unidos Mexicanos, el cual establece que "... En los juicios del orden civil, la sentencia definitiva deberá ser conforme a la letra o a la interpretación jurídica de la ley, y a falta de ésta se fundará en los principios generales del derecho".

De acuerdo con lo anteriormente transcrito, los órganos jurisdiccionales, al resolver la cuestión jurídica de naturaleza civil lato sensu (entre la que se encuentra la ley procesal civil), deberán hacerlo conforme a la letra o a la interpretación jurídica de la ley y, a falta de ésta, fundándose en los principios generales del derecho.

Así, existe la posibilidad de que los juzgadores apliquen diversos medios de interpretación, pero existe un orden metodológico en cuanto a los sistemas interpretativos, según el cual siempre debe acudirse primero a la interpretación gramatical o literal de la ley y buscar la solución del problema jurídico sometido a la consideración del Juez tomando en cuenta en primer lugar lo dispuesto expresamente en 
el ordenamiento jurídico correspondiente y únicamente en el caso de que éste sea confuso, oscuro o deficiente puede acudirse a otros métodos, el primero de los cuales debe ser el método de interpretación sistemático que consiste en desentrañar el sentido de una norma a través de la interpretación conjunta con el resto de las disposiciones de un ordenamiento. Si aún ante la interpretación sistemática existe confusión respecto del sentido de la ley, debe acudirse a otros métodos para desentrañar su sentido, como lo son la búsqueda de la intención del legislador, el fin que se pretende con la ley o la integración a través de la analogía.(11) Entonces, sólo por excepción el intérprete tiene el derecho y el deber de apartarse del sentido literal de la ley.(12)

Así las cosas, debe atenderse a las consecuencias que las leyes de los tribunales contendientes prevén para el caso de la negativa del demandado a practicarse la prueba genética.

De esta manera, el artículo 190 Bis V del Código de Procedimientos Civiles de Nuevo León, que no da lugar a dudas respecto de su contenido, establece expresamente que si el presunto ascendiente se niega o se opone a la realización de la prueba, se presumirá la filiación que se le atribuye, en los siguientes términos:

"Artículo 190 Bis V. Si la persona que deba practicarse la prueba, no asistiere a la misma o se negare a proporcionar la muestra necesaria, hará presumir la filiación que se le atribuye en los términos del Código Civil."

Por su parte, la legislación del Estado de México, si bien no lo precisa mediante una norma expresa, debe recordarse que, como ya se señaló, los Jueces se encuentran facultados para disipar toda disputa, amén de manifestarse silencio, oscuridad o insuficiencia de ley, con la aplicación debida de los principios generales del derecho, toda vez que bajo ninguna circunstancia podrán dejar de resolver ninguna controversia suscitada y tampoco podrían permitir que los derechos del menor a conocer su identidad quedaran al arbitrio de la contraparte para asistir o no a la prueba pericial de ADN que, en ocasiones, puede ser el medio de convicción más importante del procedimiento. 
Así, prevaleciendo en igualdad de circunstancias, tanto los derechos fundamentales del infante como los del demandado y, sin interesar el hecho de presenciarse una laguna de ley respecto del desahogo de la prueba pericial en materia de genética ADN en la legislación del Estado de México, debe resolverse la cuestión relativa a la negativa del demandado, atendiendo a la interpretación extensiva y analógica de la ley, atendiendo a los fines de la institución de que se trata, o sea, a los fines que se persiguen con la referida prueba, como ha quedado expuesto con anterioridad.

De esta manera, esta Primera Sala considera que para resolver esa laguna legal, se deben aplicar, por analogía, las disposiciones concernientes a los principios reguladores de la confesión ficta y del reconocimiento de documentos, en su caso, las cuales se contienen en los artículos 1.287 y 2.44 del Código de Procedimientos Civiles del Estado de México (confesión ficta y reconocimiento de documentos).

De acuerdo con estos preceptos, se tendrá por confesa a la parte citada a absolver posiciones cuando se niegue a declarar o no comparezca a la diligencia sin justa causa. Asimismo, cuando se cite a una persona a reconocer un documento y no comparece, se le tendrá por reconocido.

Estas disposiciones son aplicables, por analogía como se ha dicho, en el caso que nos ocupa, ya que ante la negativa u oposición del demandado para realizarse el estudio genético, se tendrán por ciertos los hechos que se pretendían probar por conducto del aludido medio probatorio, pues como se ha dicho, lo contrario llevaría a dejar el interés superior del niño a merced de la voluntad del presunto progenitor. Esto es así, pues ante la negativa del demandado para someterse a dicha prueba y atendiendo al interés superior del niño y a su derecho fundamental de conocer su origen, lo procedente es apercibir al demandado en el sentido de que en caso de oposición o de que se niegue a realizar el estudio genético correspondiente, se tendrán por ciertos los hechos que se pretendían acreditar con ese medio de convicción, salvo prueba en contrario, es decir, la 
conducta omisa del demandado generaría una presunción juris tantum respecto de la paternidad del actor, presunción que, por tanto, admitiría prueba en contrario.(13)

Esto implica que el juzgador deberá considerar, en estos casos, esa prueba como si se tratara de una confesión ficta y como tal, deberá valorarla al momento de dictar la resolución correspondiente.

Debe quedar claro que, como sucede con cualquier prueba ficta, esta presunción derivada de la omisión del demandado de realizarse la prueba de ADN debe estar adminiculada con otros medios de prueba para que éstas, en su conjunto, tengan eficacia para acreditar la paternidad. De otra manera, si no existiera alguna prueba que robusteciera la pericial en comento, o hubiera alguna en contrario, la presunción mencionada no sería suficiente para tener por cierta la relación paterno-filial.

Además de todo lo mencionado, precisamente por el grado de certeza de la prueba de que se habla (que como ya se señaló alcanza un 99.99\% respecto de la paternidad), es justificable que se genere esa presunción de filiación que servirá como un indicio de que existe la relación de parentesco entre el actor y el demandado, ante la negativa de éste para practicarse la prueba.

Entonces, tanto en el caso de la legislación del Estado de México como en la de Nuevo León, ante la negativa u oposición del presunto padre para practicarse la prueba pericial de $\mathrm{ADN}$, la consecuencia jurídica será que se presumirá la relación paterno-filial, salvo prueba en contrario.

De acuerdo con la exposición precedente, debe prevalecer con carácter de jurisprudencia, en términos del artículo 192 de la Ley de Amparo, el criterio que sustenta la Primera Sala de la Suprema Corte de Justicia de la Nación a través de las siguientes tesis: 
MEDIDAS DE APREMIO. SU APLICACIÓN ES CONSTITUCIONAL EN LOS JUICIOS DE PATERNIDAD CUANDO LOS PRESUNTOS ASCENDIENTES SE NIEGAN A PRACTICARSE LA PRUEBA PERICIAL EN MATERIA DE GENÉTICA (ADN) (LEGISLACIONES DE NUEVO LEÓN Y DEL ESTADO DE MÉXICO). Los Códigos de Procedimientos Civiles del Estado de Nuevo León y del Estado de México establecen medidas de apremio a través de las cuales los Jueces y Magistrados pueden lograr que sus determinaciones se cumplan. Así, cuando el Juez en un juicio de paternidad ordena el desahogo de la prueba pericial en materia de genética (ADN) y el presunto ascendiente se niega a que se le practique, esa conducta encaja en los supuestos de aplicación de las medidas de apremio para que se cumpla la determinación del juzgador. Con la aplicación de estas medidas, no se viola el derecho a la intimidad genética del presunto padre, pues en los análisis de paternidad por ADN únicamente se obtiene la llamada huella genética, la cual no incluye el contenido de toda la información genética, sino sólo lo que corresponde a determinados segmentos del ADN para verificar si los marcadores del presunto padre son coincidentes con los del presunto hijo, y así establecer si existe o no relación de filiación entre ellos. Por esas mismas razones, no existe violación de garantías respecto de la autodeterminación informativa, pues el análisis de paternidad tiene una justificación en tanto que únicamente versará sobre la filiación y no sobre otras cuestiones. De igual manera, la realización de la mencionada prueba no viola las garantías establecidas en el artículo 22 constitucional porque dicho artículo se refiere a las sanciones que se imponen a los individuos cuya responsabilidad está plenamente demostrada, previo desahogo de un proceso legal, y la práctica de la prueba genética no puede considerarse una pena; por ello, al no constituir una pena o sanción, no se encuentra en los supuestos del artículo 22 constitucional. Por lo anterior, se concluye que el uso de las medidas de seguridad está plenamente justificado en tanto que el presunto ascendiente tiene la obligación de practicarse dicha prueba atendiendo al interés superior del menor y a su derecho de conocer su origen biológico y la identidad de sus progenitores.

MEDIDAS DE APREMIO. ALCANCE DEL USO DE LA FUERZA PÚBLICA 
TRATÁNDOSE DE JUICIOS DE PATERNIDAD EN LOS QUE SE OFRECE LA PRUEBA EN GENÉTICA MOLECULAR (ADN). Esta Primera Sala ha establecido que tratándose de los juicios de paternidad en los que se ofrece la prueba en genética molecular (ADN), es constitucional que el Juez haga uso de las medidas de apremio previstas en la ley para lograr que el demandado se someta a dicha prueba. Asimismo, se determinó que si a pesar de la imposición de dichas medidas de apremio no se logra vencer la negativa del demandado para realizarse la prueba, la consecuencia de esa conducta será que opere la presunción de la filiación, salvo prueba en contrario. Ahora bien, dentro de las medidas de apremio establecidas por la ley se encuentra el uso de la fuerza pública, pero esta medida debe utilizarse sólo para presentar al demandado al lugar donde deba tomarse la muestra genética, pero de ninguna manera para que con esta medida se obtenga dicha muestra, pues de considerar que con tal providencia se pudiera forzar al presunto padre para obtener la mencionada muestra, ninguna razón de ser tendría haber establecido que en caso de que persistiera la negativa para realizarse esa prueba, se tendrían por presuntamente probados los hechos que se pretendían acreditar.

JUICIOS DE PATERNIDAD. EN LOS CASOS EN QUE A PESAR DE LA IMPOSICIÓN DE MEDIDAS DE APREMIO LOS PRESUNTOS ASCENDIENTES SE NIEGAN A PRACTICARSE LA PRUEBA PERICIAL EN MATERIA DE GENÉTICA (ADN), OPERA LA PRESUNCIÓN DE LA FILIACIÓN CONTROVERTIDA (LEGISLACIONES DE NUEVO LEÓN Y DEL ESTADO DE MÉXICO). Conforme a los artículos 4o. de la Constitución Política de los Estados Unidos Mexicanos; 3o., 6o., 7o. y 8o. de la Convención sobre los Derechos del Niño; y 22 de la Ley para la Protección de los Derechos de Niñas, Niños y Adolescentes, los menores tienen derecho a conocer su identidad, y la importancia de ese derecho fundamental no sólo radica en la posibilidad de que conozcan su origen biológico (ascendencia), sino en que de ese conocimiento deriva el derecho del menor, constitucionalmente establecido, de que sus ascendientes satisfagan sus necesidades de alimentación, salud, educación y sano esparcimiento, para su desarrollo integral, además de que puede implicar el derecho a una nacionalidad determinada. Por otra parte, los 
Códigos de Procedimientos Civiles del Estado de Nuevo León y del Estado de México establecen medidas de apremio a través de las cuales los Jueces y Magistrados pueden lograr que sus determinaciones se cumplan. Así, cuando en un juicio de paternidad se ordena el desahogo de la prueba pericial en materia de genética (ADN) y el presunto ascendiente se niega a que se le practique, es constitucional que se le apliquen dichas medidas para que se cumpla la determinación del juzgador, pero si a pesar de esas medidas no se logra vencer la negativa del demandado para la realización de la prueba, esto no significa que se deje a merced de la voluntad del presunto ascendiente el interés superior del menor, y que dicha negativa u oposición para la práctica de la prueba quede sin consecuencia alguna, ya que en todo caso debe operar la presunción de la filiación controvertida porque, por una parte, el artículo 190 Bis V del Código de Procedimientos Civiles de Nuevo León así lo señala expresamente y, por otra, aunque la legislación del Estado de México no precisa esa circunstancia en una norma expresa, atendiendo al interés superior del niño y de una interpretación extensiva y analógica de los artículos 1.287 y 2.44 del Código Procesal Civil de esa entidad federativa, que establecen los supuestos de confesión ficta y reconocimiento de documentos, se concluye que ante la negativa del presunto ascendiente a practicarse la mencionada prueba, debe operar la presunción de la filiación, salvo prueba en contrario, pues como se ha dicho, considerarlo de otra manera llevaría a dejar el interés superior del niño a merced de la voluntad del presunto progenitor y no se respetaría su derecho fundamental a conocer su identidad.

Por lo expuesto y fundado, se resuelve:

PRIMERO. Sí existe la contradicción de tesis a que este expediente se refiere, en los términos del considerando cuarto de esta resolución.

SEGUNDO. Debe prevalecer, con carácter de jurisprudencia, el criterio sustentado por esta Primera Sala, en los términos de las tesis redactadas en el último considerando del presente fallo. 
TERCERO. Dése publicidad a las tesis jurisprudenciales que se sustentan en la presente resolución, en términos del artículo 195 de la Ley de Amparo.

Notifíquese y, en su oportunidad, archívese el expediente como asunto concluido.

Así lo resolvió la Primera Sala de la Suprema Corte de Justicia de la Nación, por mayoría de tres votos de los señores Ministros: Sergio A. Valls Hernández, Olga Sánchez Cordero de García Villegas y presidente José Ramón Cossío Díaz (ponente). En contra de los emitidos por los señores Ministros Juan N. Silva Meza y José de Jesús Gudiño Pelayo, quienes formularán voto de minoría.

1. Publicada en el Semanario Judicial de la Federación y su Gaceta, Novena Época, tomo XIII, abril de 2001, página 76.

2. Ibid, Octava Época, tomo 83, noviembre de 1994, página 35.

3. El concepto de interés superior del niño ha sido interpretado por la Corte Interamericana de Derechos Humanos (cuya competencia aceptó el Estado mexicano el veinticuatro de marzo de mil novecientos ochenta y uno al ratificar la Convención Interamericana de Derechos Humanos y cuyos criterios, por tanto, son obligatorios) de la siguiente manera: "... la expresión 'interés superior del niño’, consagrada en el artículo 3o. de la Convención sobre los Derechos del Niño, implica que el desarrollo de éste y el ejercicio pleno de sus derechos deben ser considerados como criterios rectores para la elaboración de normas y la aplicación de éstas en todos los órdenes relativos a la vida del niño." Opinión Consultiva 17/2002, página 65, párrafo final.

4. La Corte Interamericana de Derechos Humanos así lo estableció en la sentencia dictada al resolver el caso Villagrán Morales y otros contra Guatemala, el diecinueve de noviembre de mil novecientos noventa y nueve, de la siguiente manera: "El derecho a la 
vida es un derecho humano fundamental, cuyo goce es un prerrequisito para el disfrute de todos los demás derechos humanos. De no ser respetado, todos los derechos carecen de sentido. En razón del carácter fundamental del derecho a la vida, no son admisibles enfoques restrictivos del mismo. En esencia, el derecho fundamental a la vida comprende, no sólo el derecho de todo ser humano de no ser privado de la vida arbitrariamente, sino también el derecho a que no se le impida el acceso a las condiciones que le garanticen una existencia digna. Los Estados tienen la obligación de garantizar la creación de las condiciones que se requieran para que no se produzcan violaciones de ese derecho básico y, en particular, el deber de impedir que sus agentes atenten contra él." (sentencia, página 39, parágrafo 144).

5. Para lo expuesto en este apartado, se utilizó información de diversas fuentes. Entre las principales se destacan las siguientes: Identificación genética y pruebas de paternidad. Raúl Aguirre ... (et al) Ed. Lucía Cifuentes. Santiago de Chile, Universidad de Chile. 1996. 169 p. Identificación por ADN. Guillermo Cejas Mazzotta. 2a. ed. corr. y amp. Mendoza, Argentina. Ediciones Jurídicas Cuyo. 2000. 340 p.; Paternity Testing. A. Medical Dictionary, Bibliography, and Annotated Research Guide to Internet References. Icon Health Publications MB, 100 p. y Genetic Ties and the Family. The Impact of Paternity Testing on Parents and Children. Rothstein, Mark A. Ed. Johns Hopkins University Press. 2005. 230 p.

6. "Artículo 1.265. Se reconocen como medio de prueba: ... III. Dictámenes periciales; ... VI. Fotografías, copias fotostáticas, registros dactiloscópicos, cualquier grabación de imágenes y sonidos y, en general, todos aquellos elementos aportados por la ciencia y la tecnología."

"Artículo 1.304. La prueba pericial será ofrecida y admitida cuando la naturaleza de las cuestiones materia de la misma requieran conocimientos científicos o tecnológicos o bien experiencia práctica en el ejercicio de un servicio u oficio, con la finalidad de prestar auxilio al juzgador." 
"Artículo 239. La ley reconoce como medios de prueba: ... VII. Fotografías, copias fotostáticas, cintas de video, dispositivos de archivos electrónicos o magnéticos, registros dactiloscópicos, electrónicos y, en general, todos aquellos elementos derivados de los avances de la ciencia y de la tecnología."

7. Previstos en los artículos 180, 181, 184 y 185 del Código Penal de Nuevo León y 117, 118 y 119 del Código Penal del Estado de México.

8. Tesis 1a. CCXVIII/2005, publicada en el Semanario Judicial de la Federación y su Gaceta, Novena Época, Tomo XXIII, enero de 2006, página 737.

9. Ibid, Novena Época, Tomo XVII, abril de 2003, página 88.

10. Entre estos casos podríamos mencionar causas penales, como investigación de una violación o de un homicidio, por mencionar sólo algunos ejemplos. Existen países como Alemania o Suecia en los que esta prueba es obligatoria en todos los casos, es decir, siempre que se admita se debe hacer forzosamente, incluso con auxilio de la fuerza pública.

11. Esto encuentra apoyo en la tesis LXXII/2004, emitida por la Primera Sala, la cual señala: "INTERPRETACIÓN DE LA LEY. SI SU TEXTO ES OSCURO O INCOMPLETO Y NO BASTA EL EXAMEN GRAMATICAL. EL JUZGADOR PODRÁ UTILIZAR EL MÉTODO QUE CONFORME A SU CRITERIO SEA EL MÁS ADECUADO PARA RESOLVER EL CASO CONCRETO. De acuerdo con el cuarto párrafo del artículo 14 de la Constitución Política de los Estados Unidos Mexicanos, el órgano jurisdiccional, al resolver la cuestión jurídica que se le plantee, deberá hacerlo conforme a la letra o a la interpretación jurídica de la ley y, a falta de ésta, se fundará en los principios generales del derecho. En este sentido, los juzgadores no están obligados a aplicar un método de interpretación específico, por lo que válidamente pueden utilizar el que acorde con su criterio sea el más adecuado para 
resolver el caso concreto. Sin embargo, en principio deberá utilizarse el literal, pues como lo establece el propio precepto constitucional, los fallos judiciales deberán dictarse 'conforme a la letra o a la interpretación jurídica de la ley.', con lo que se constriñe al juzgador a buscar la solución del problema que se le presente, considerando en primer lugar lo dispuesto expresamente en el ordenamiento jurídico correspondiente." Dicha tesis fue publicada en el Semanario Judicial de la Federación y su Gaceta, Tomo XIX, junio de 2004, página 234. El precedente es: Amparo directo en revisión 1886/2003. Miguel Armando Oleta Montalvo. 31 de marzo de 2004. Unanimidad de cuatro votos. Ausente: Humberto Román Palacios. Ponente: Olga Sánchez Cordero de García Villegas. Secretaria: Leticia Flores Díaz.

12. Así se establece en la tesis de Primera Sala de texto y rubro: "LEY INTERPRETACIÓN DE LA.-De acuerdo con Baudry Lacantinerie, la primera de las reglas de la interpretación de la ley crea la exigencia de que aquélla esta regida, en primer lugar, por la interpretación gramatical del texto, ya que sólo cuando la redacción del precepto que el operador del derecho se ve constreñido a verificar, es oscuro y dudoso, atenderá para su interpretación a los principios de la lógica y en último extremo, a los principios generales del derecho. De ahí que el mejor medio es el de atenerse a la idea que el texto expresa claramente; pues sólo por excepción, el interprete tiene el derecho y el deber de apartarse del sentido literal de la ley; y es cuando se demuestra claramente que el legislador ha dicho una cosa distinta de la que quiere decir, ya que como consecuencia del carácter imperativo de la ley, debe interpretarse según la voluntad que ha precedido a su origen." Esa tesis fue publicada en el Semanario Judicial de la Federación, Quinta Época, Tomo CXI, página 2244. El precedente es el siguiente: Amparo penal directo 4973/51. Pulgarín Domingo y coag. 31 de marzo de 1952. Unanimidad de cuatro votos. Ausente: Fernando de la Fuente. La publicación no menciona el nombre del ponente.

13. En casos parecidos, existen algunos países que han adoptado el criterio de que ante la negativa a someterse a la prueba genética de paternidad, la consecuencia es la 
declaración de la paternidad. Contrario a este tratamiento y acorde con la solución que se plantea en el presente asunto, existen muchos países, tales como España (Ley 1/2000 de Enjuiciamiento Civil, artículo 767.4), Argentina (Ley 23.511, artículo 4o.), Inglaterra, Francia, Estados Unidos de Norteamérica (en Nevada, Texas y California), entre otros, en donde se le da un valor de indicio probatorio (presunción iuris tantum) a esa prueba, la cual debe estar fortalecida con otros medios de convicción, para poder declarar la paternidad del demandado. 
ANEXO II

DIAGRAMAS 


\section{FILIACION EXTRAMATRIMONIAL}

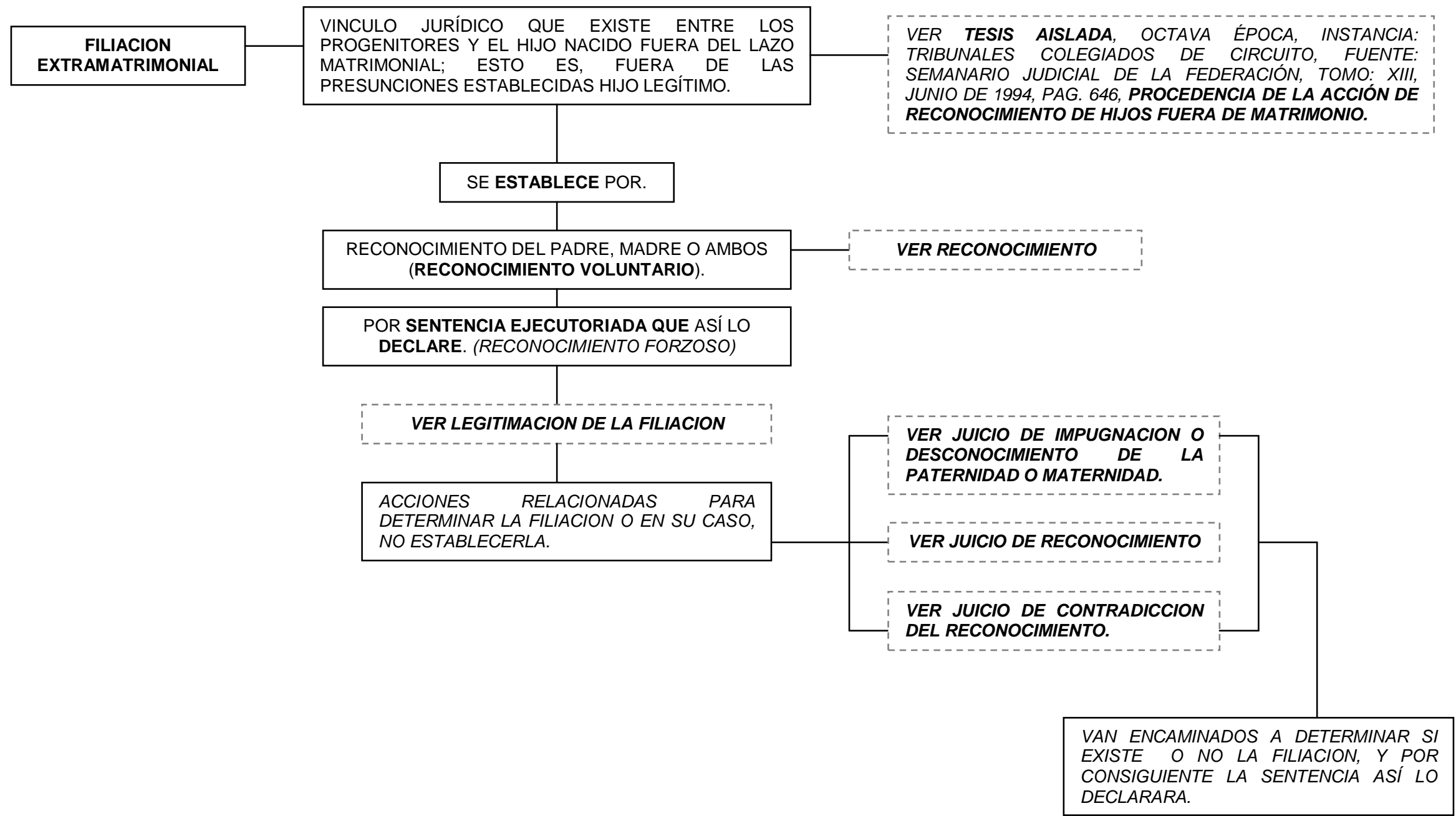




\section{FILIACION MATRIMONIAL}

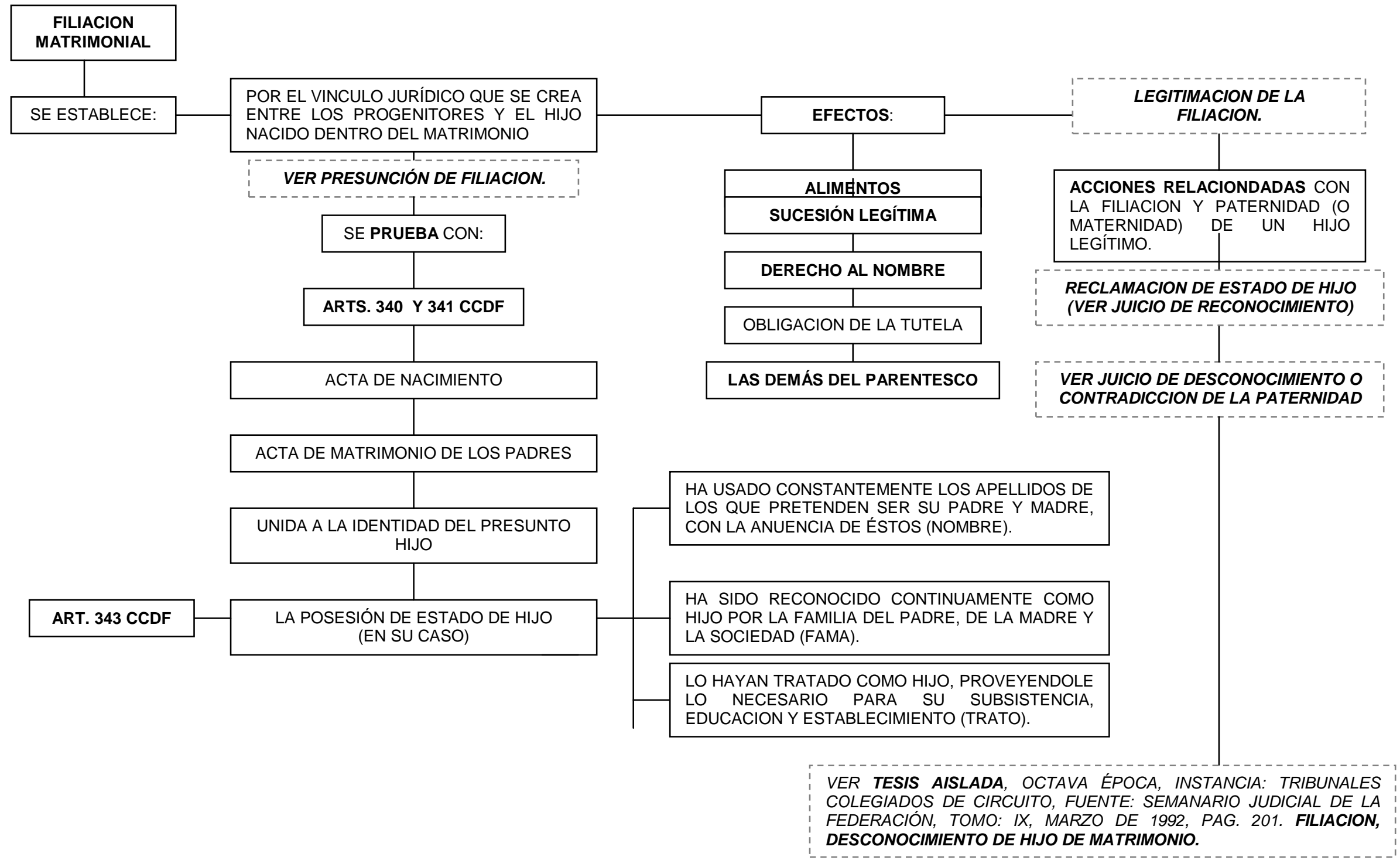


JUICIO DE CONTRADICCION DE LA PATERNIDAD

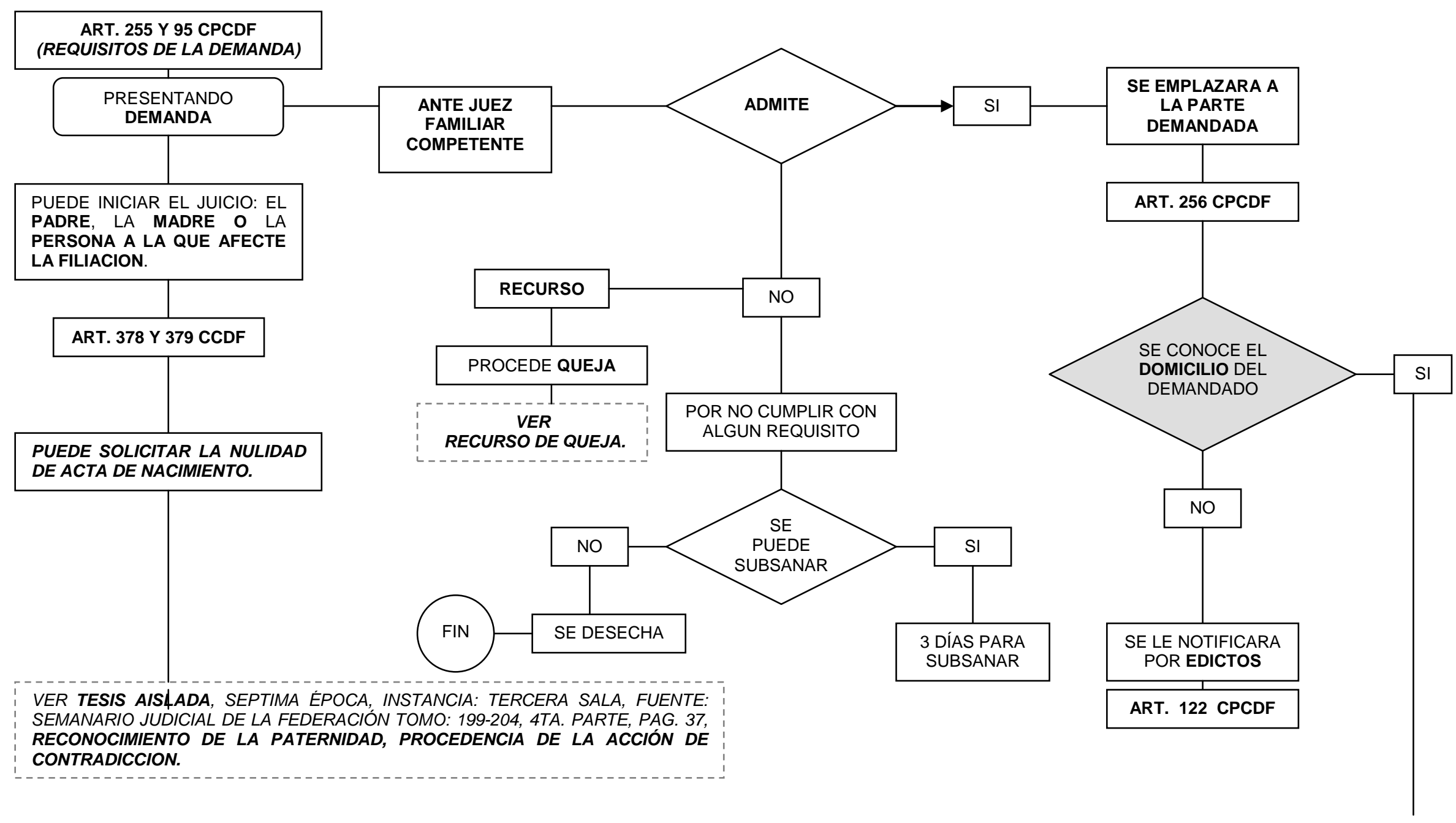




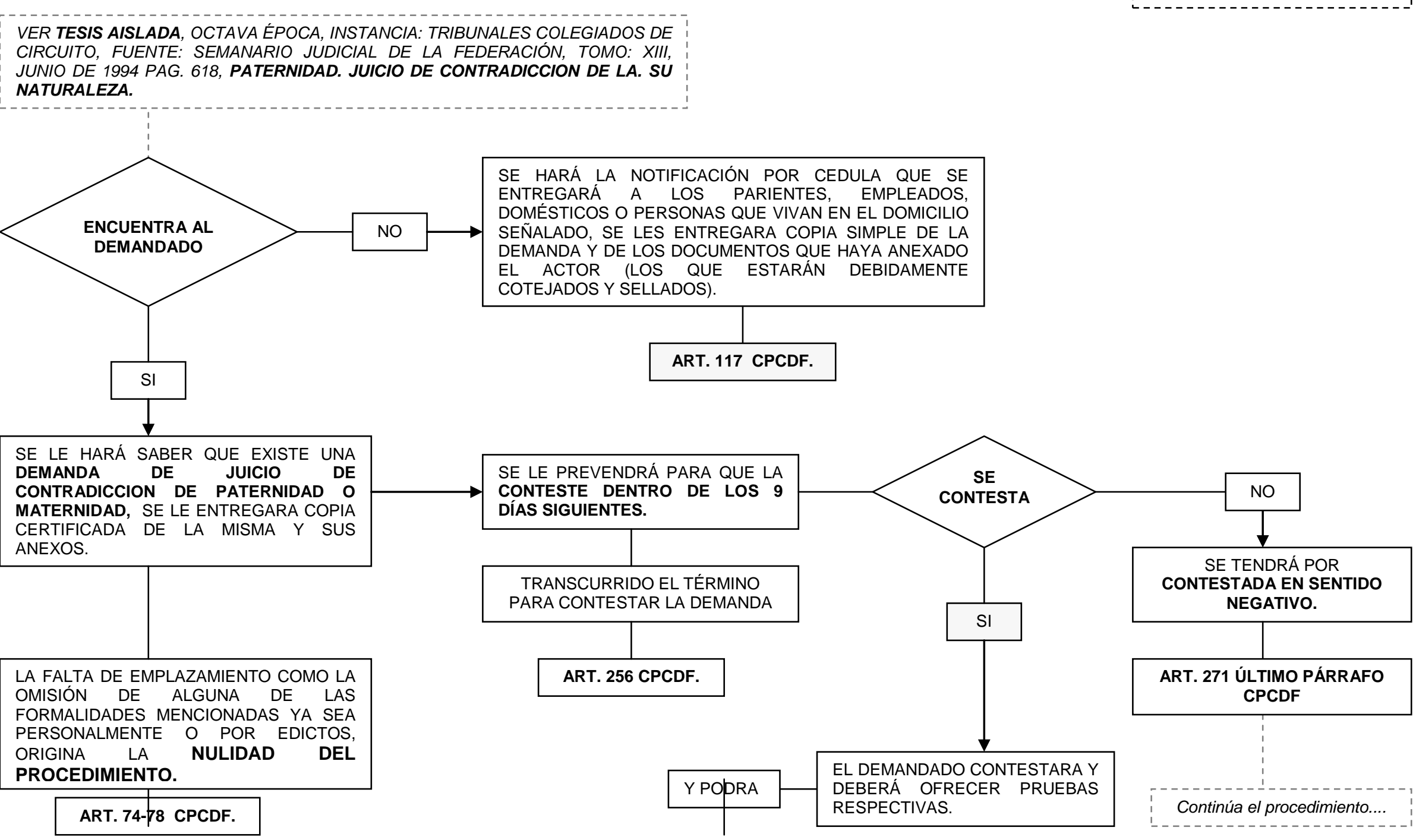




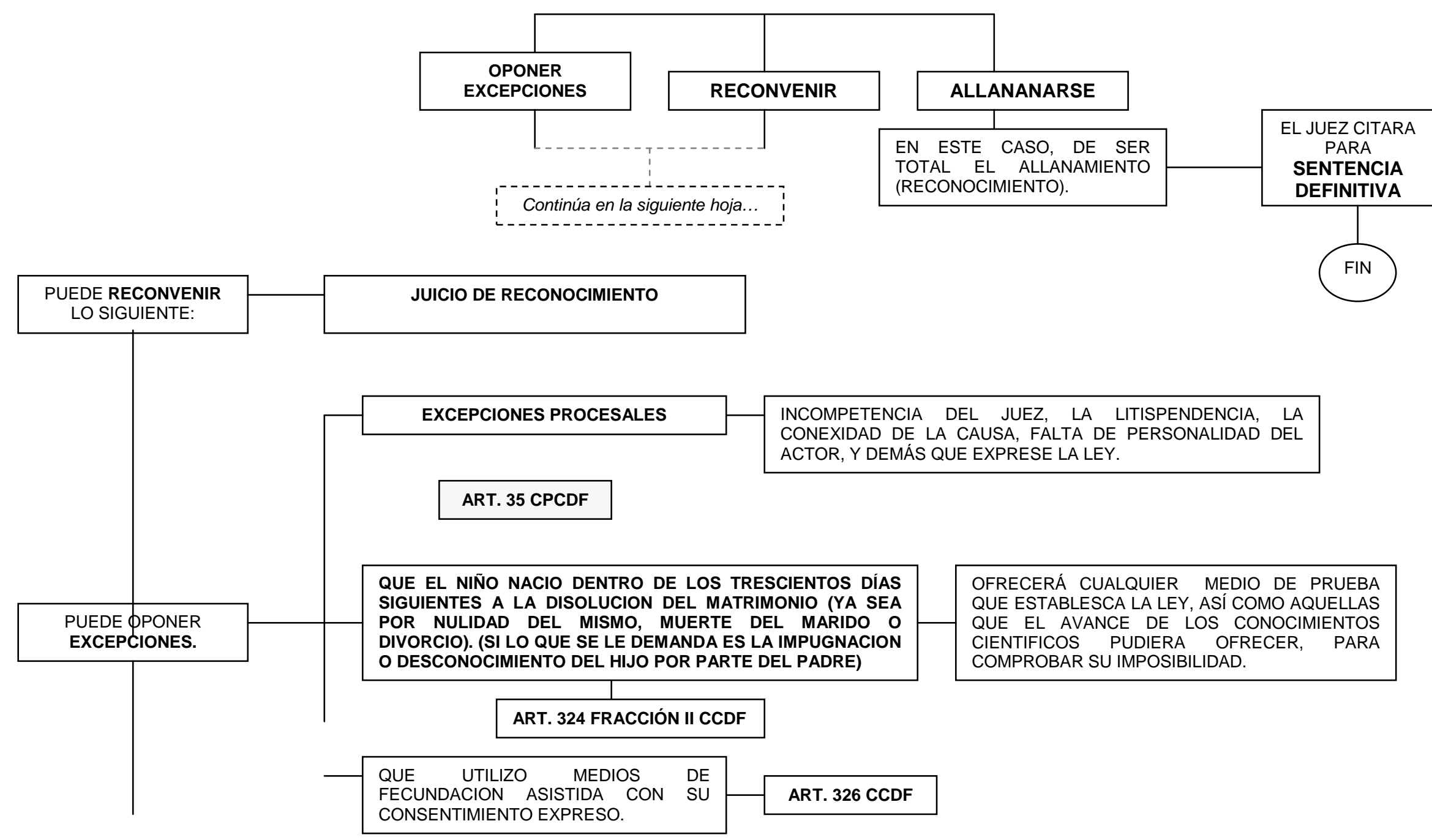


SE DICTARA EL AUTO QUE LA TIENE POR CONTESTADA
Y SEGÚN SEA EL CASO, SE TENGAN POR OPUESTAS LAS EXCEPCIONES Y DEFENSAS, O EN SU CASO LA RECONVENCION, Y SE LE CORRA TRASLADO AL ACTOR PARA QUE CONTESTE.

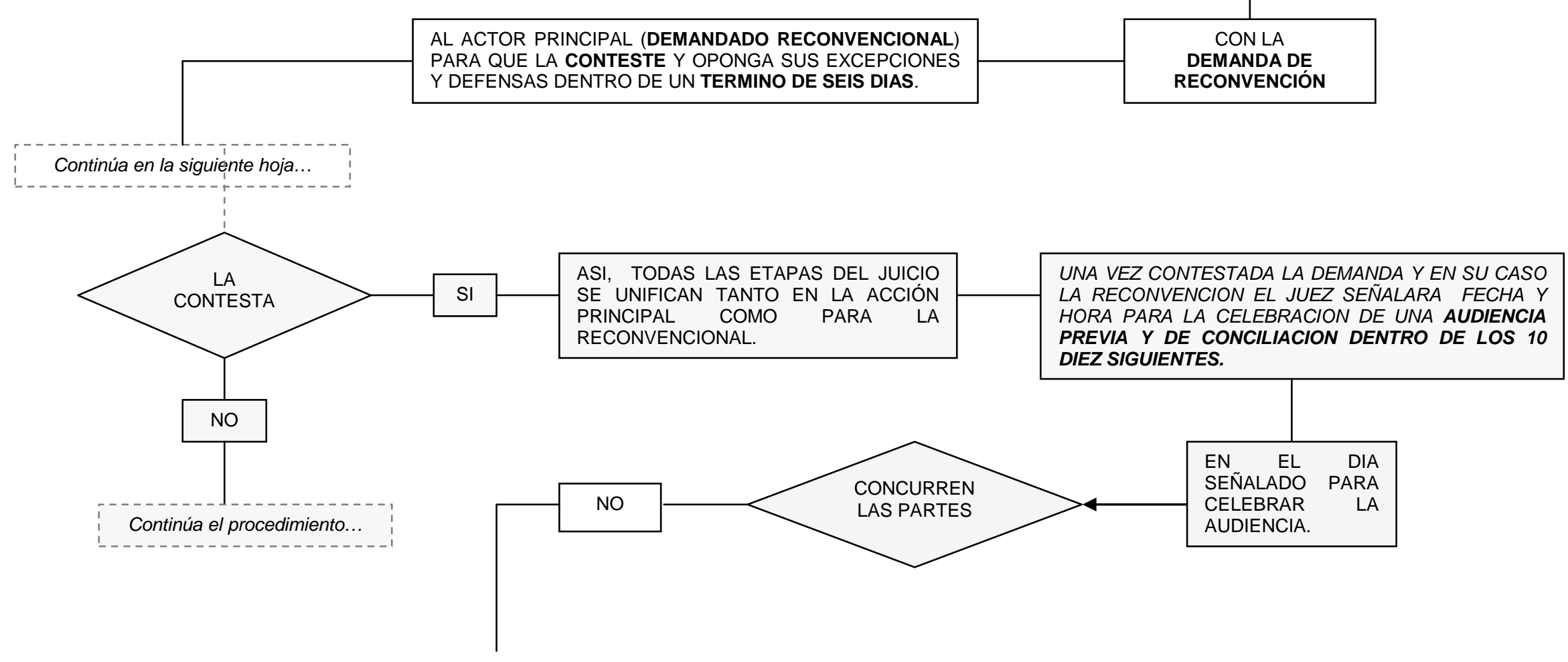




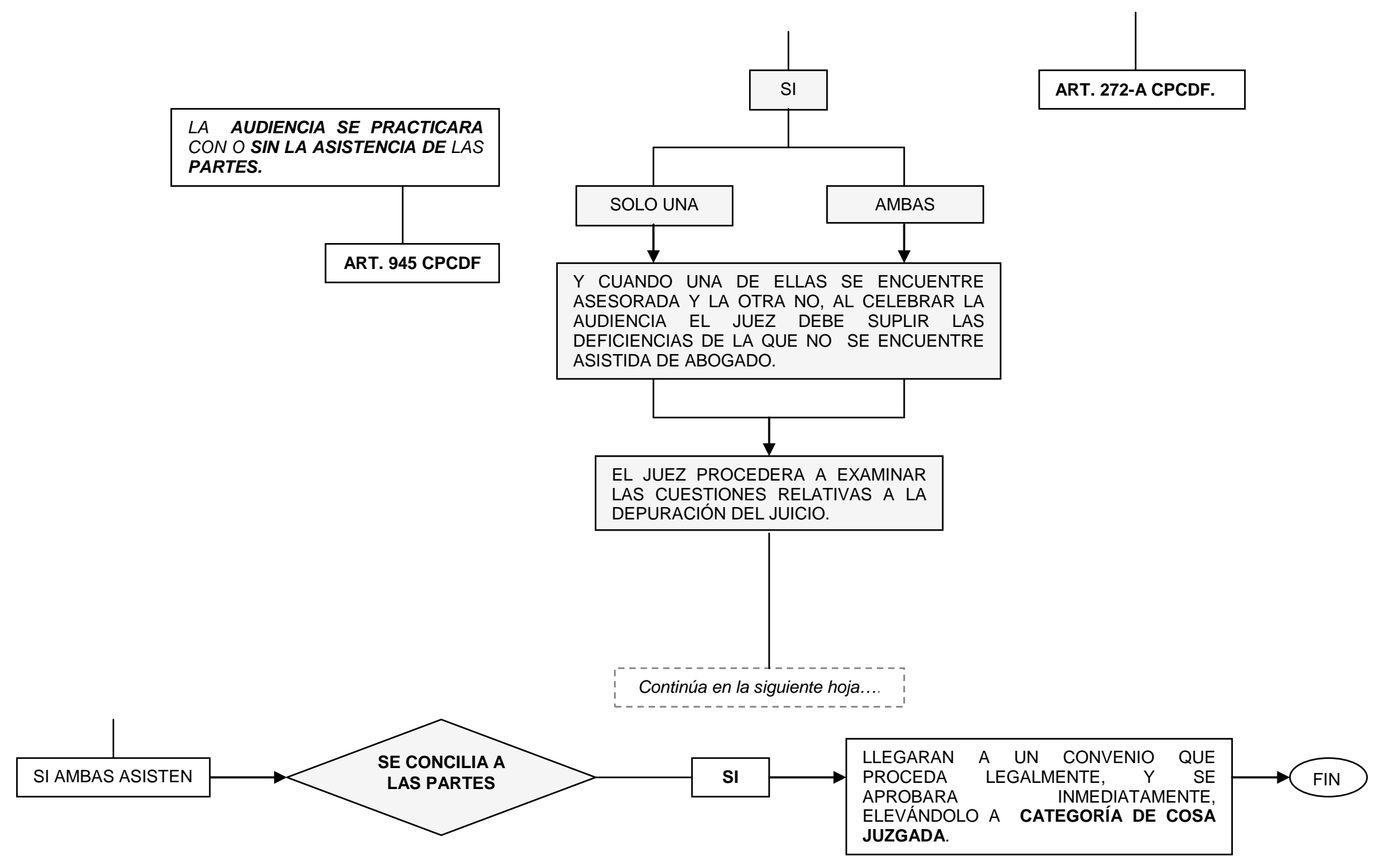




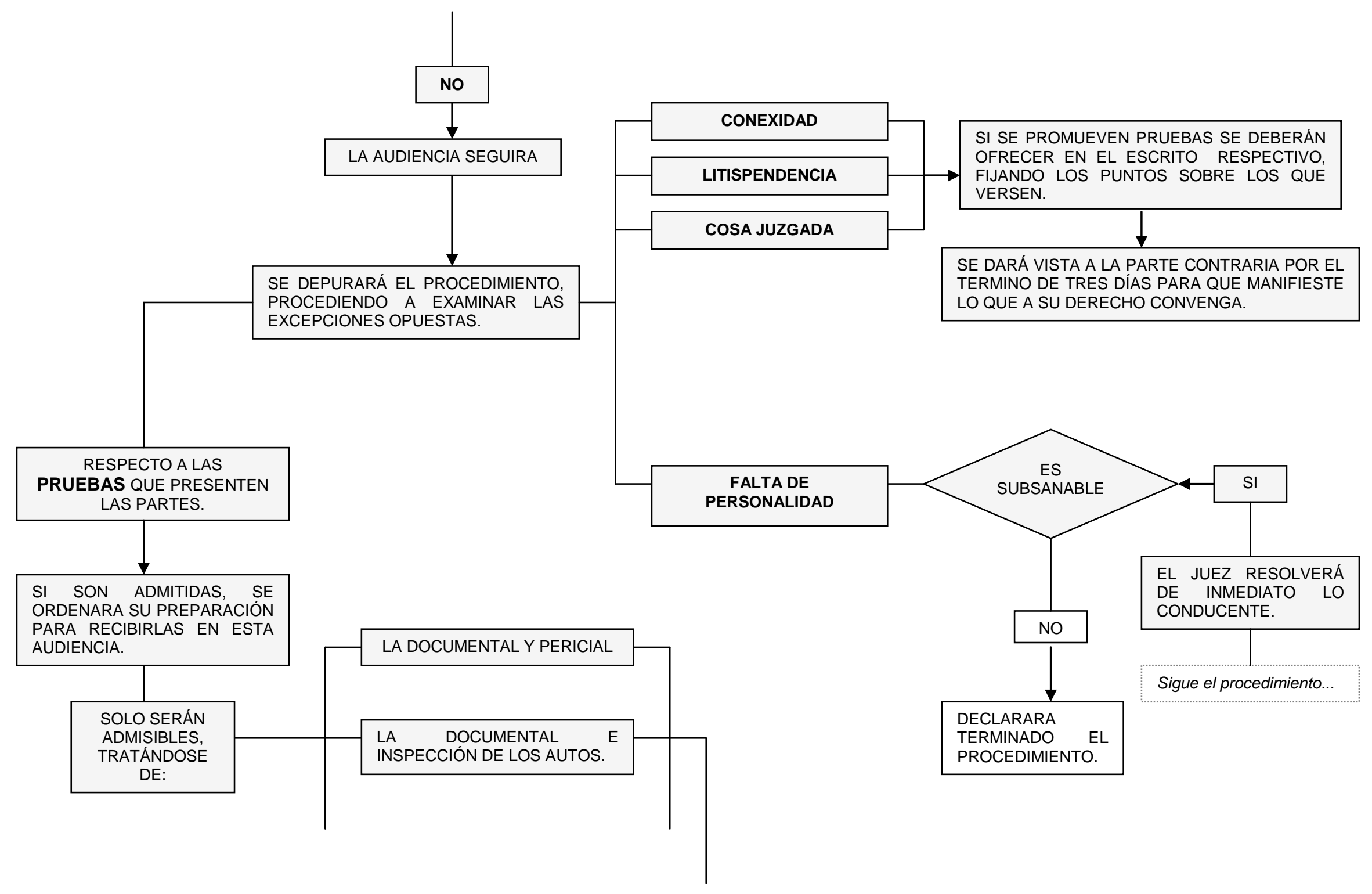




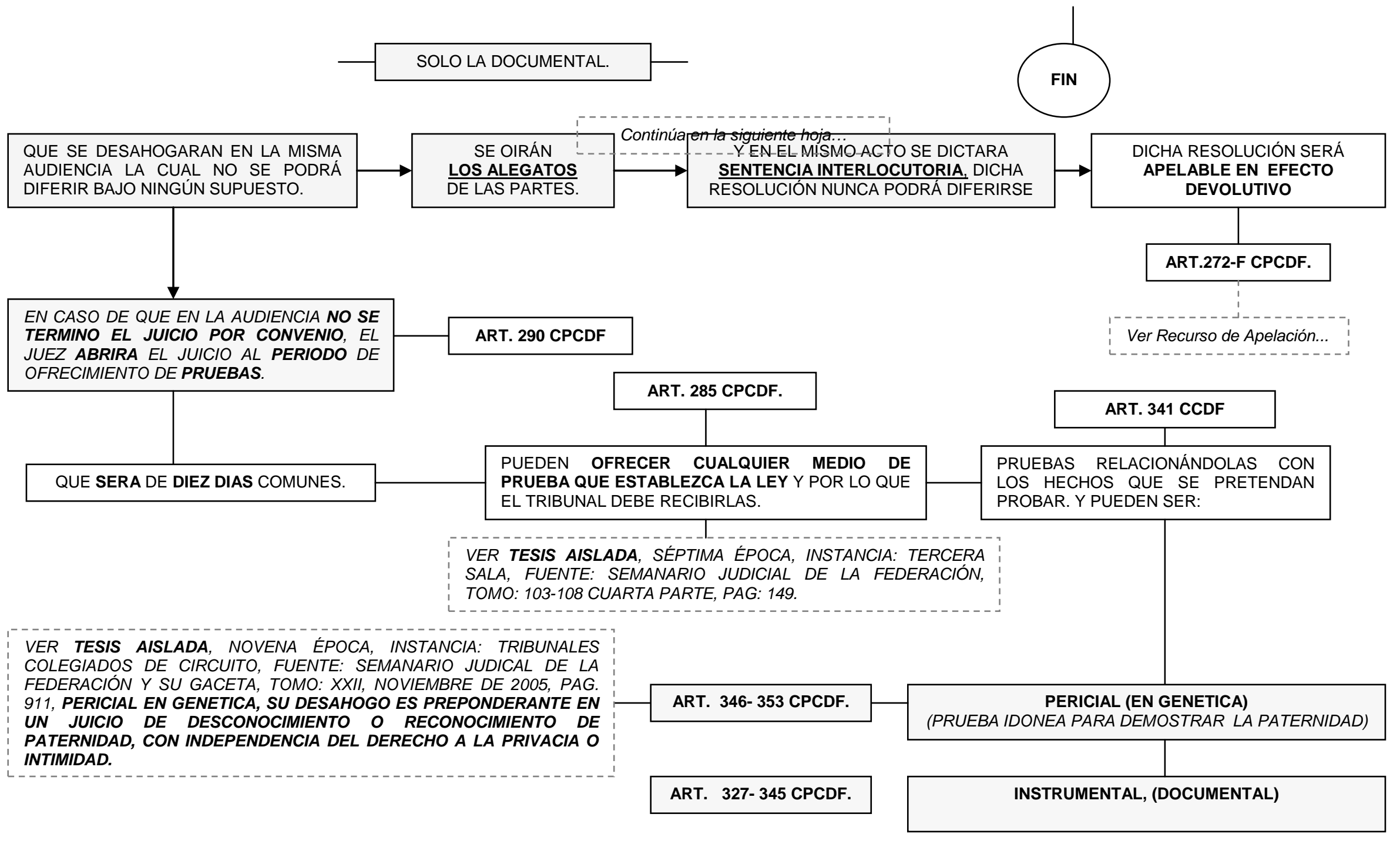


VER TESIS AISLADA, NOVENA ÉPOCA, INSTANCIA: TRIBUNALES COLEGIADOS DE CIRCUITO, FUENTE: SEMANARIO JUDICIAL DE LA FECERACION Y SU GACETA TOMO: II, OCTUBRE DE 1995, PAG. 590

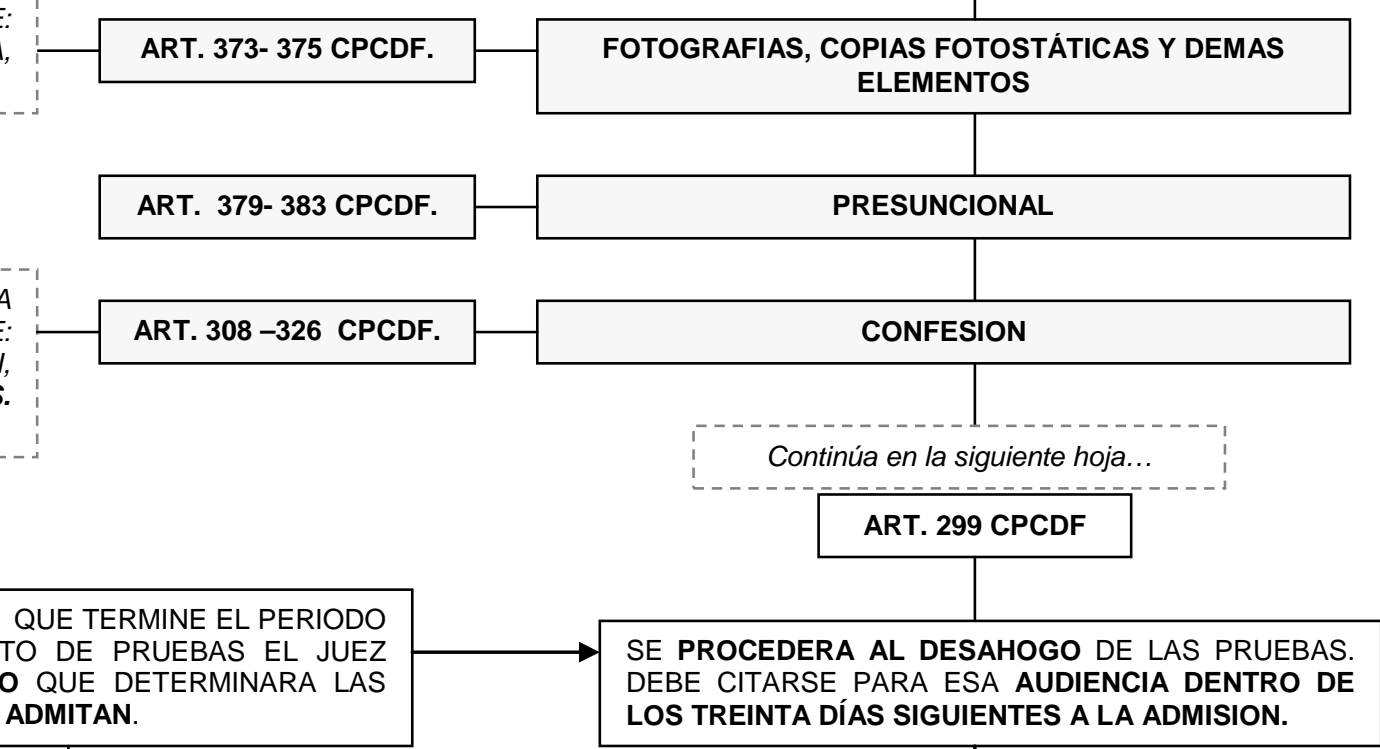

PRESENTANDO LAS

PARTES SU ESCRITO DE

PRUEBAS.

VER TESIS AISLADA OCTAVA ÉPOCA INSTANCI TRIBUNALES COLEGIADOS DE CIRCUITO, FUENTE: TRINALES COLEGIADOS DE CIRCUITO, FUENTE: SEMANARIO JUDICIAL DE LA FEDERACION, TOMO. VII, REQUISITOS DE LA CONFESIÓN PARA CONSTITUIRLO.

\begin{tabular}{|l|l|l|}
\hline ART. 373- 375 CPCDF. & \multicolumn{3}{|c|}{ FOTOGRAFIAS, COPIAS FOTOSTÁTICAS Y DEMAS } \\
ELEMENTOS
\end{tabular}
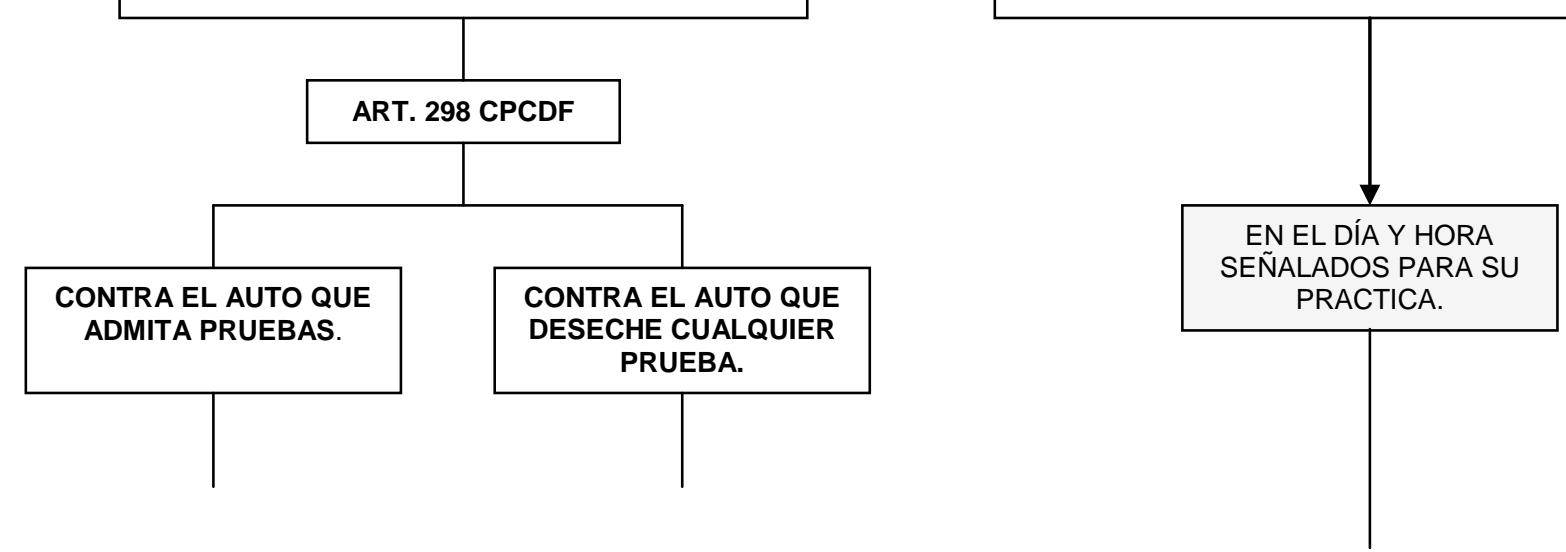
QUE SE ENCUENTREN EN ALGUNAS DE

LAS PROHIBICIONES QUE SEÑALA LA

LEY, PROCEDE LA APELACION EN

SE ADMITIRA LA APELACION EN

EFECTO DEVOLUTIVO CONTRA

EL AUTO QUE DESECHE

EFECTO DEVOLUTIVO.

CUALQUIER PRUEBA.

EN LA AUDIENCIA

PÚBLICA
LOS PERITOS DETERMINARAN POR DE LAS PARTES Y EL PERITO TERCERO EN DISCORDIA SI LO HUBIERE.

SE RELATARAN LOS DOCUMENTOS
PRESENTADOS EN LA DEMANDA Y
CONTESTACIÓN RESPECTIVAMENTE.
CONTESTACIÓN RESPECTIVAMENTE.

LA PERICIAL

SE RECIBIRÁ ASENTANDO LAS CONTESTACIONES EN QUE VAYA IMPLÍCITA LA PREGUNTA, SIN NECESIDAD DE ASENTAR ESTA.

LA CONFESIÓN

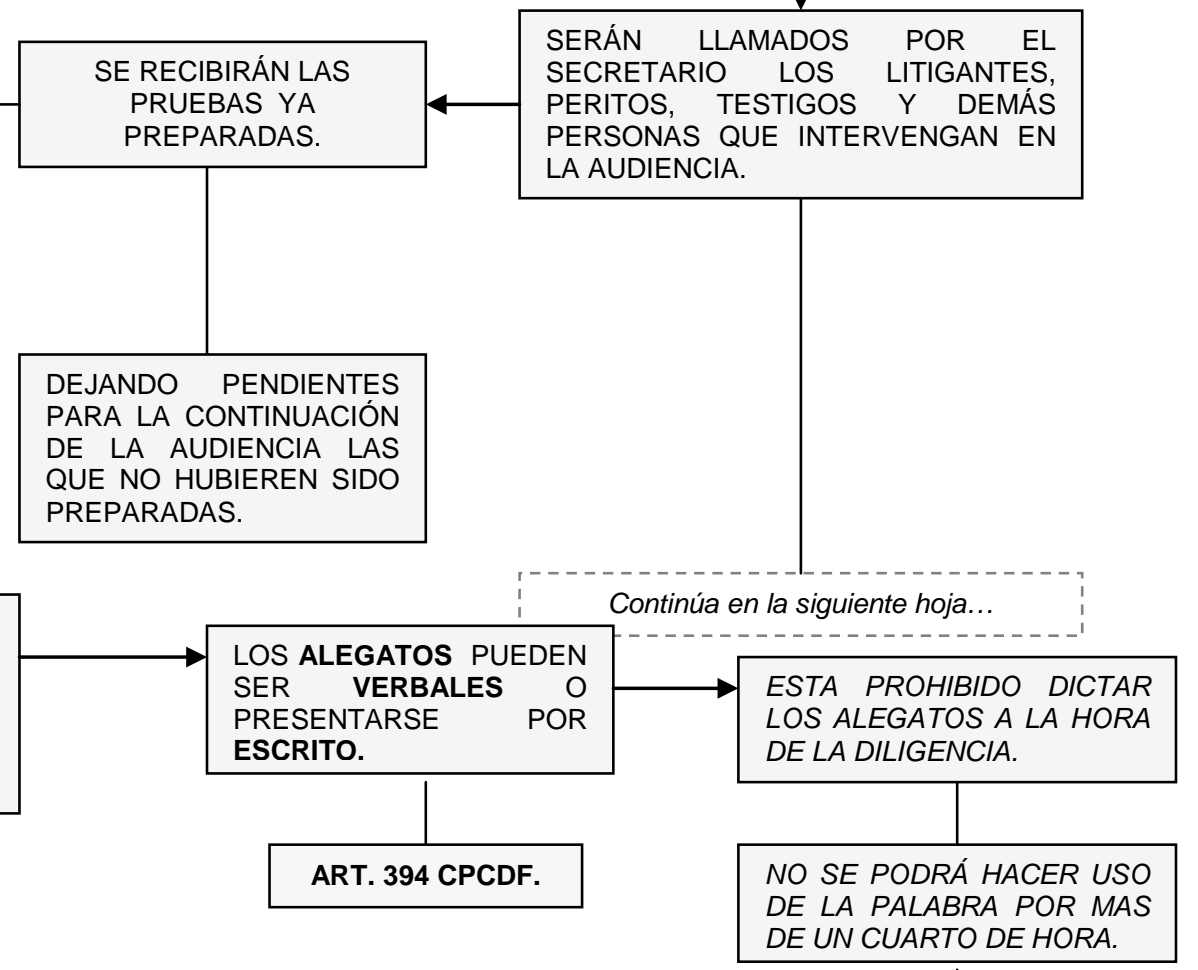




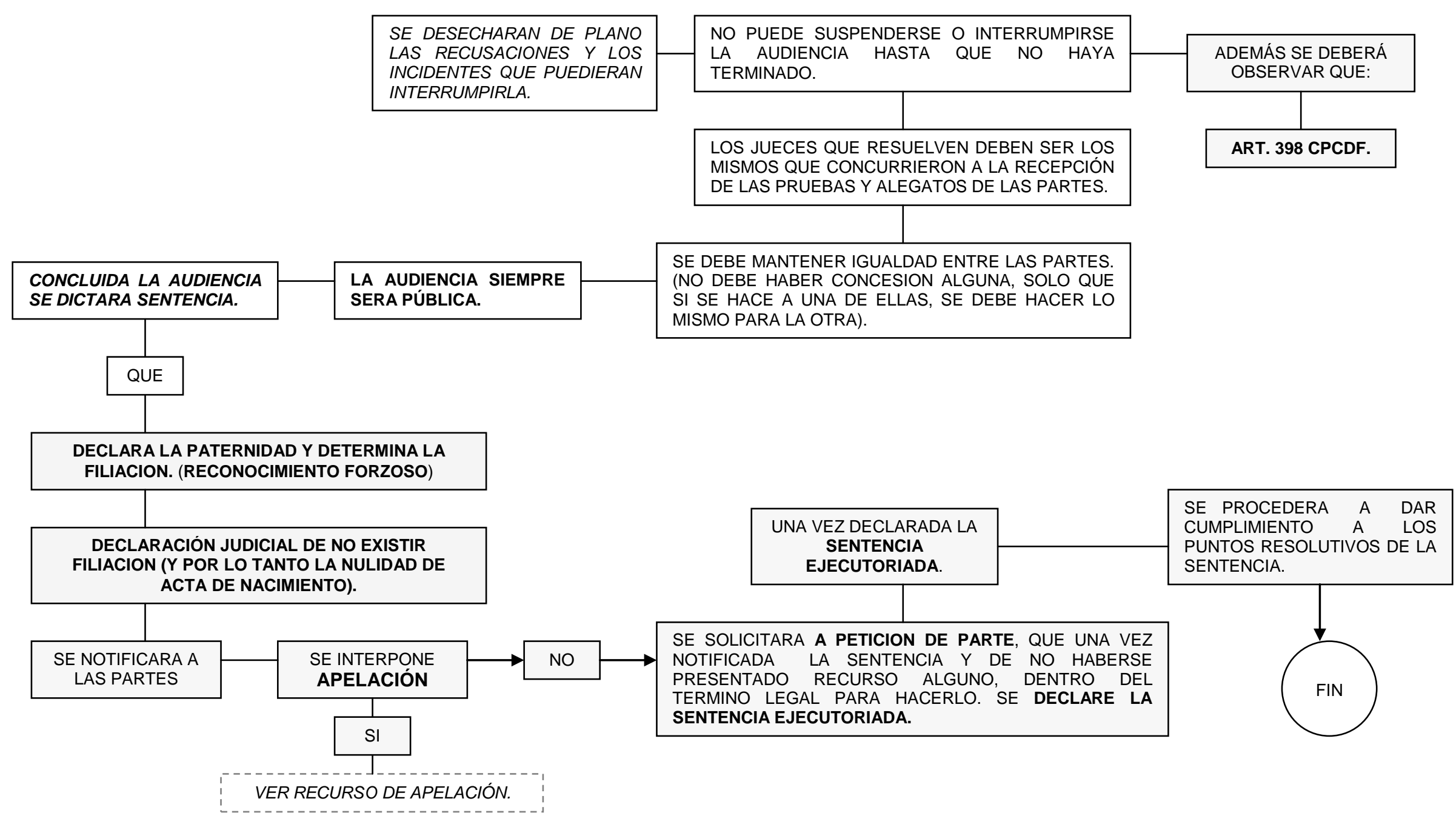




\section{JUICIO DE IMPUGNACION O DESCONOCIMIENTO}

\section{DE LA PATERNIDAD}

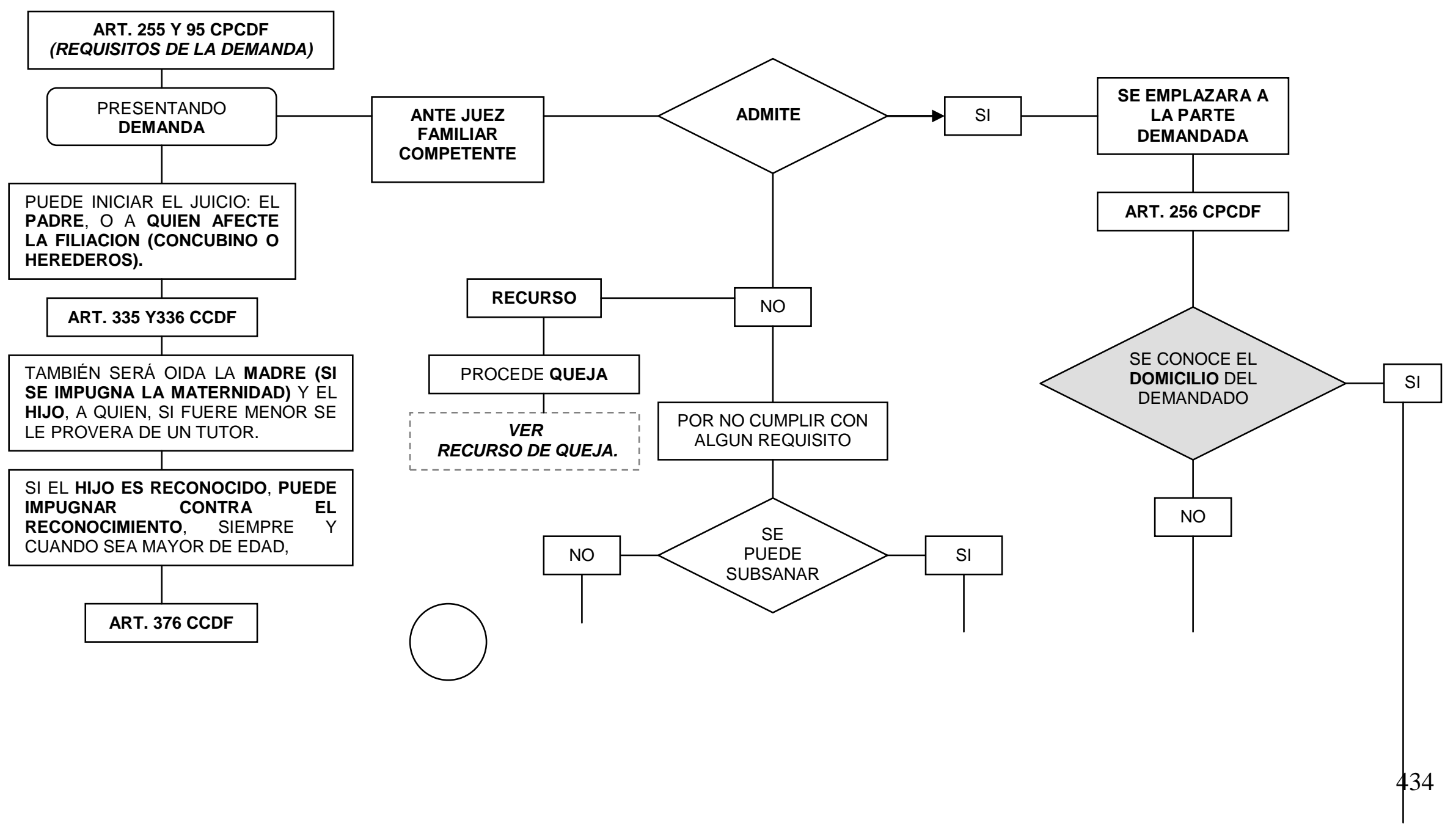




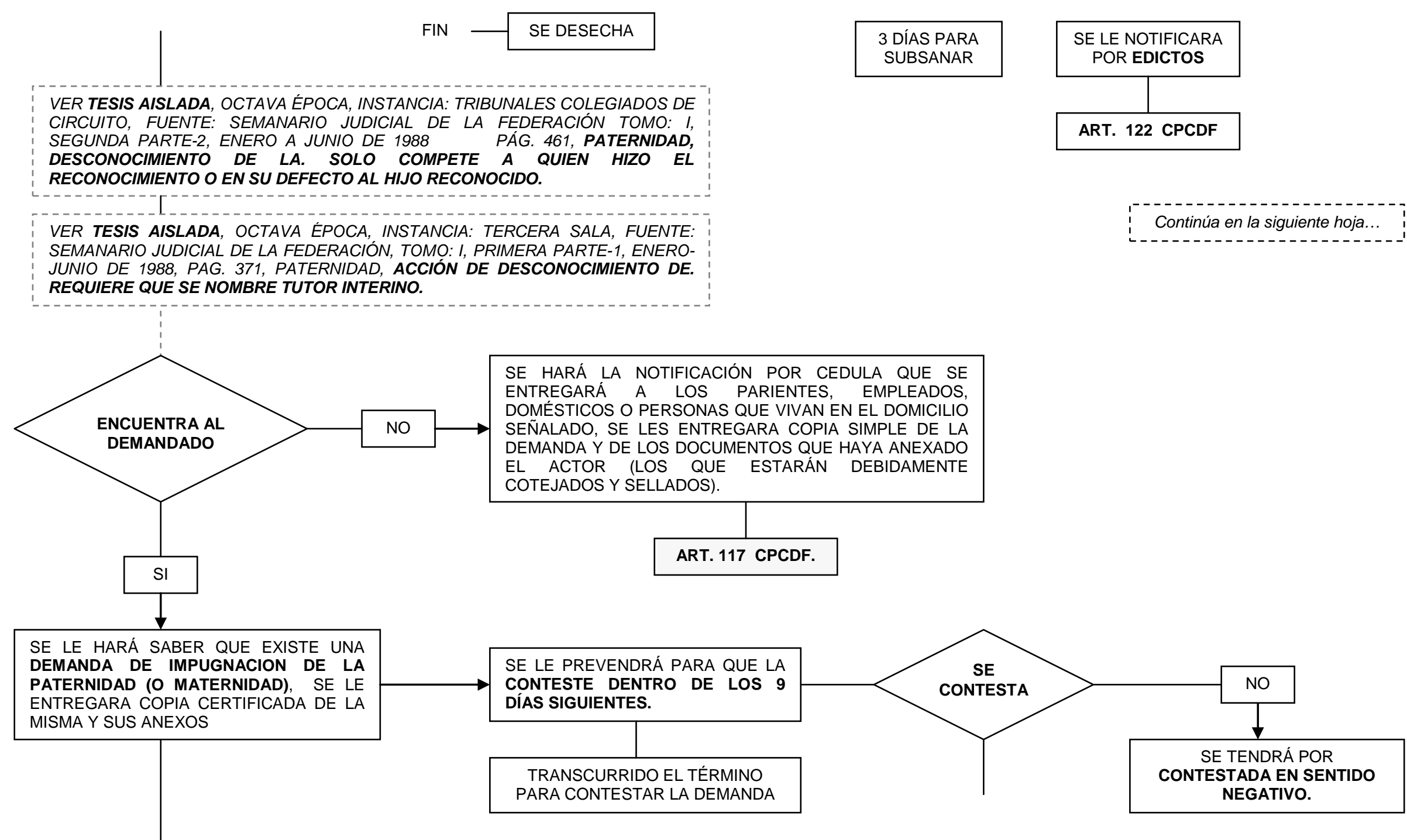


OMISIÓN DE ALGUNA DE LAS

FORMALIDADES MENCIONADAS YA SEA

PERSONALMENTE O POR EDICTOS,
NULIDAD
DEL

PROCEDIMIENTO.

PROCEDIMIENTO.
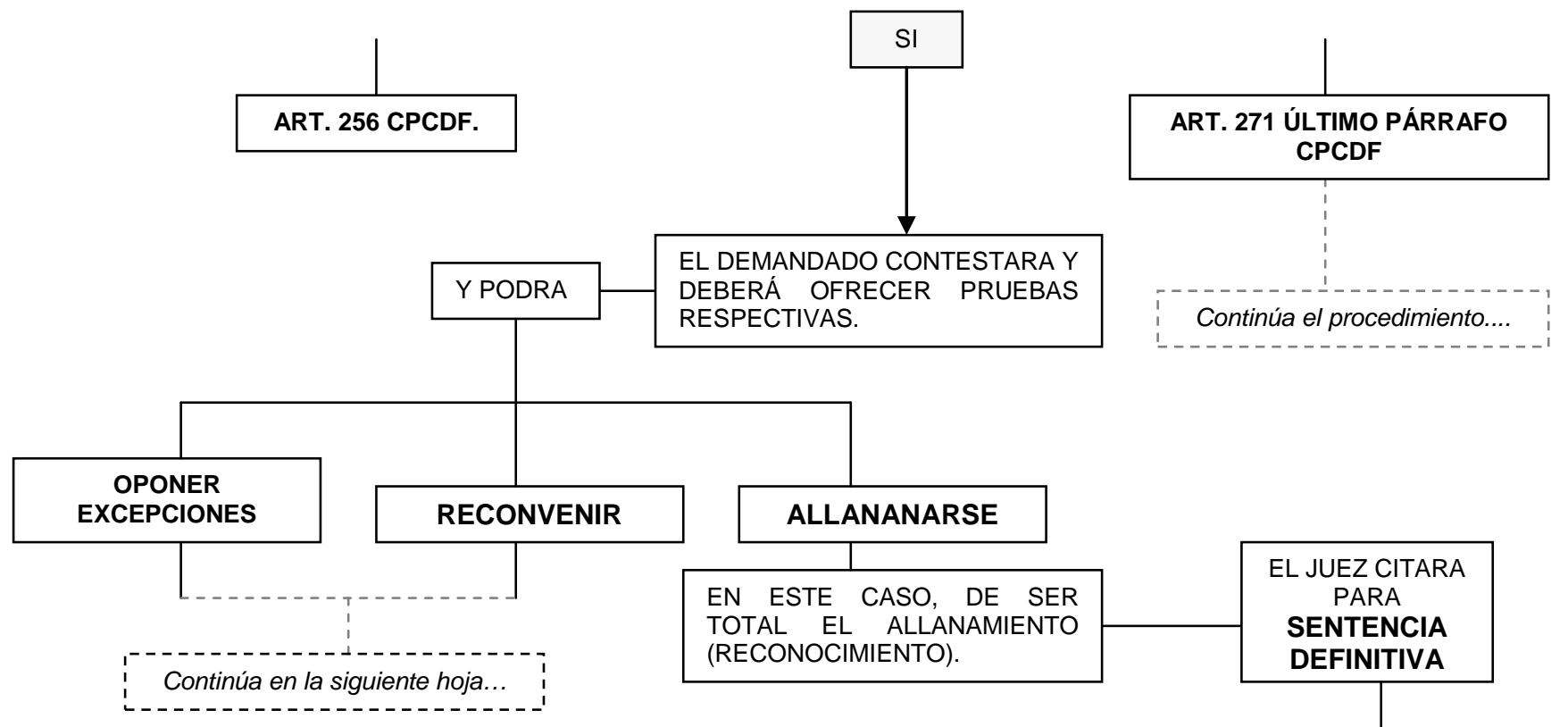

ART. 74-78 CPCDF.

(RECONOCIMIENTO). 


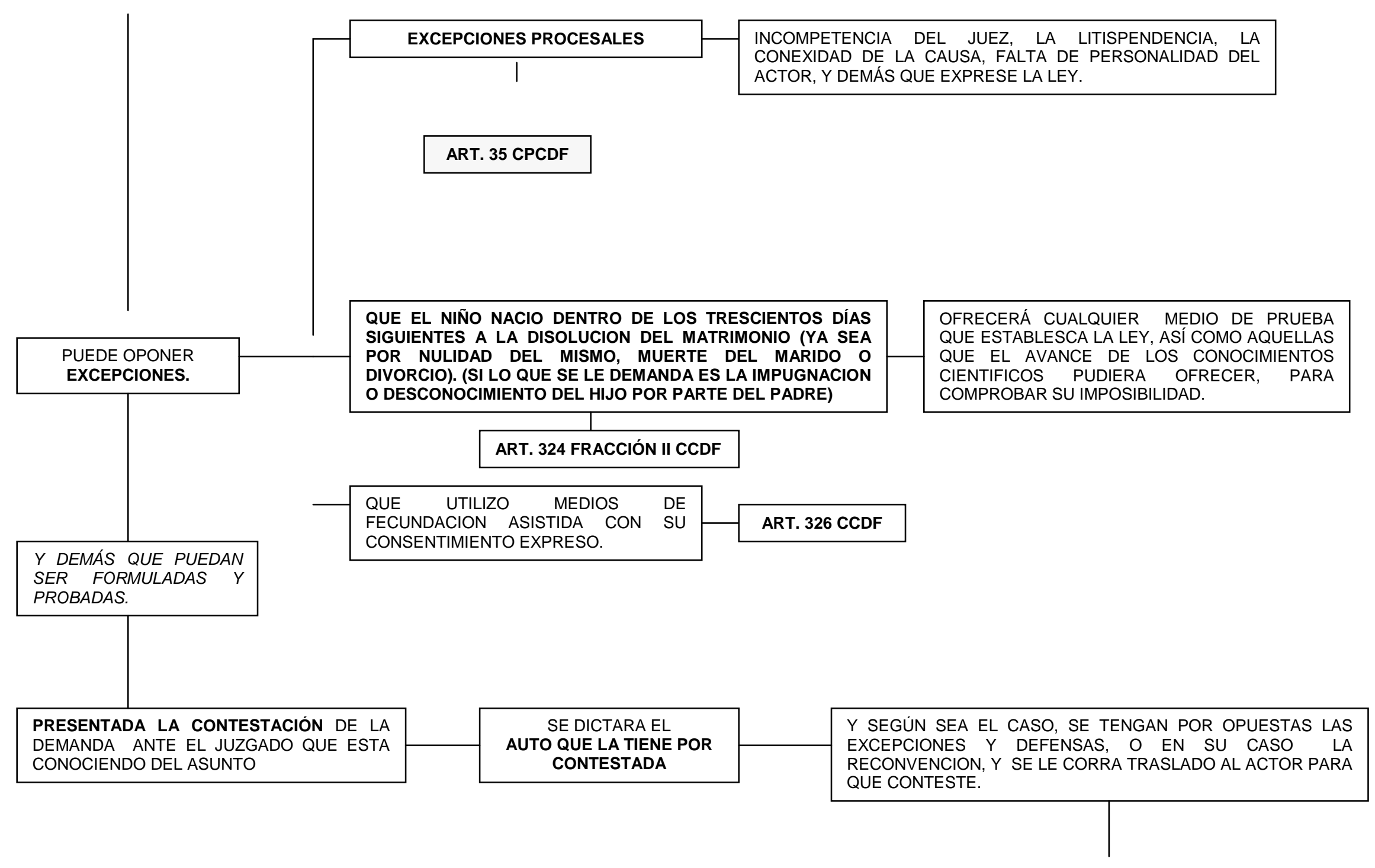




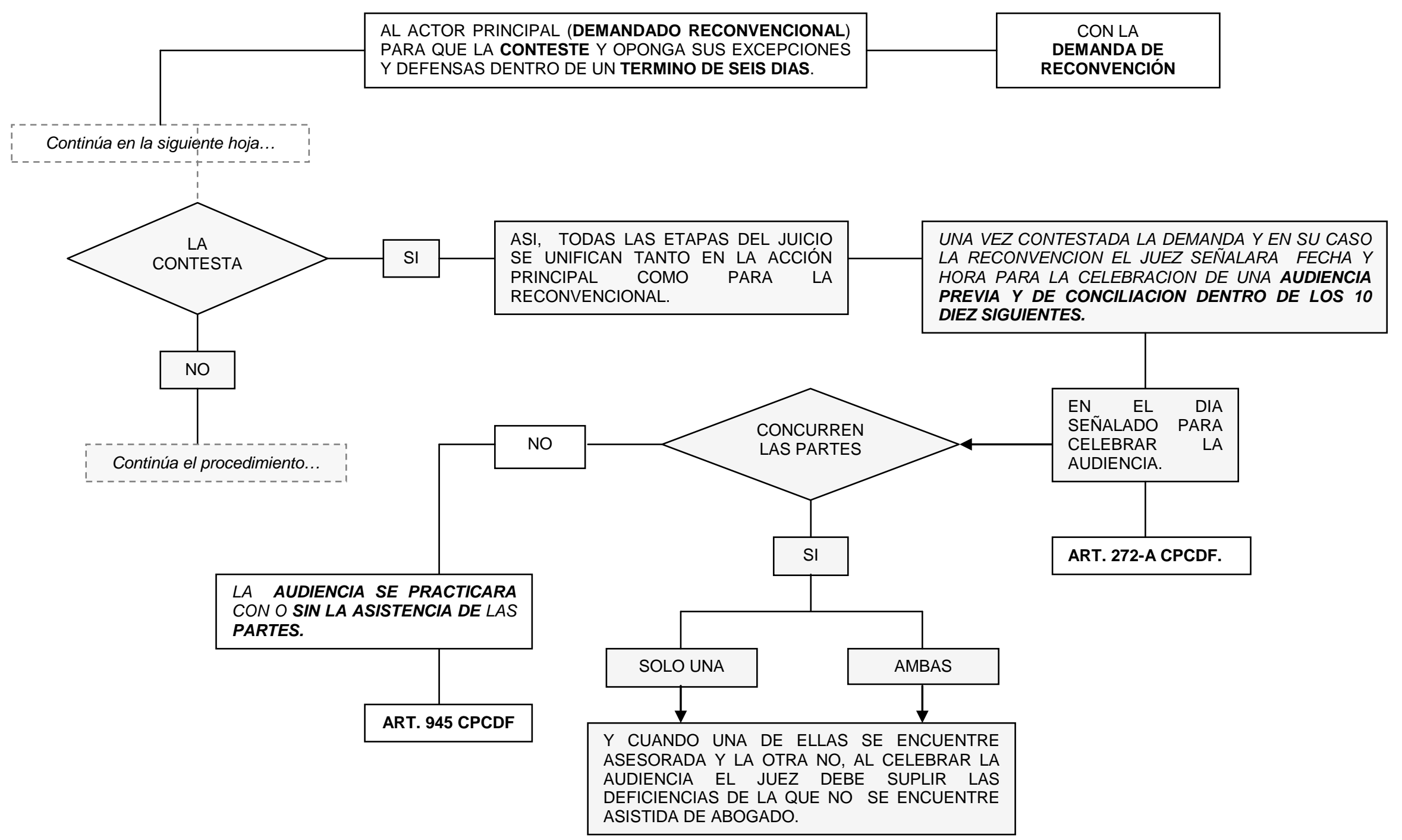




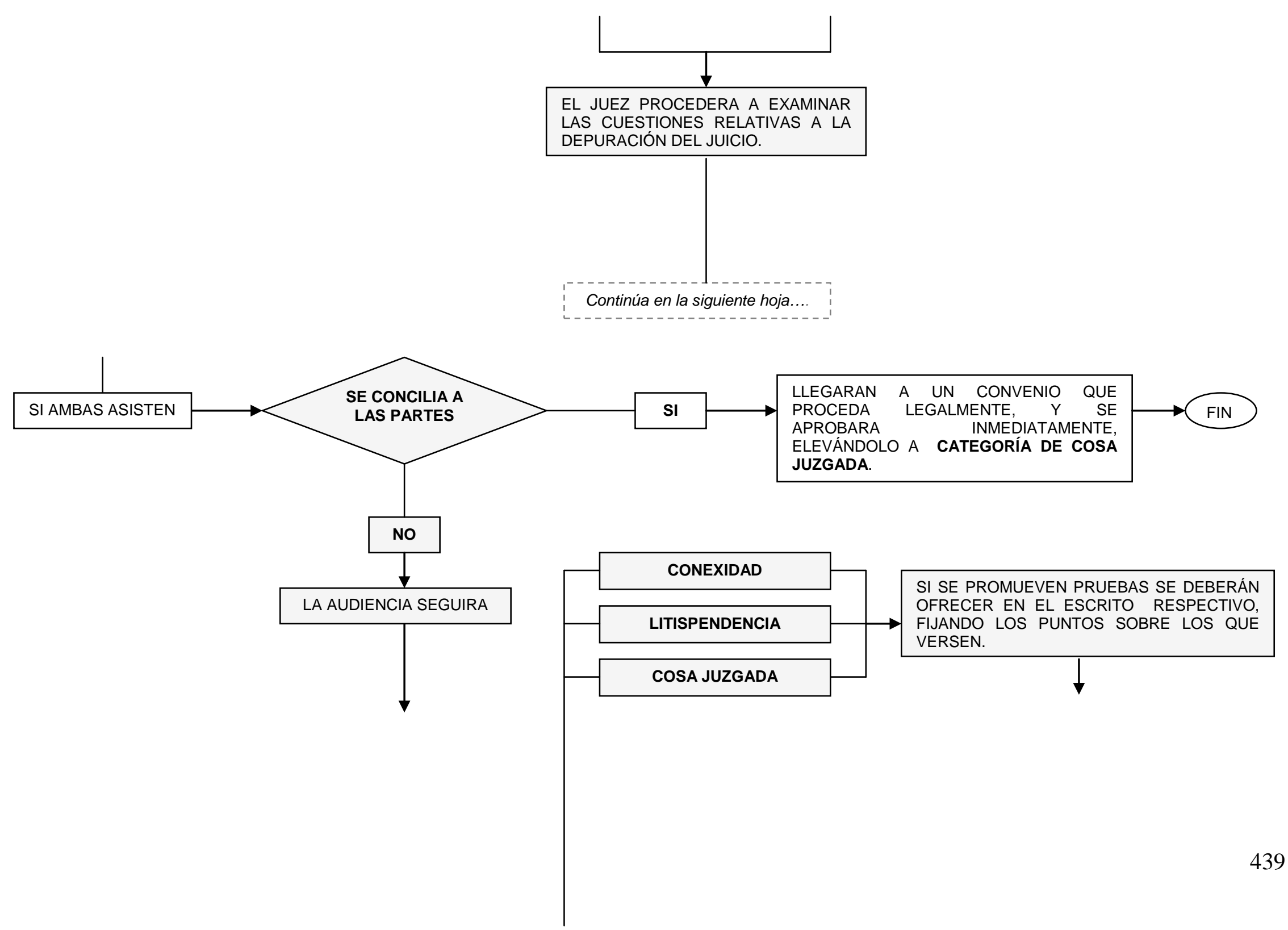




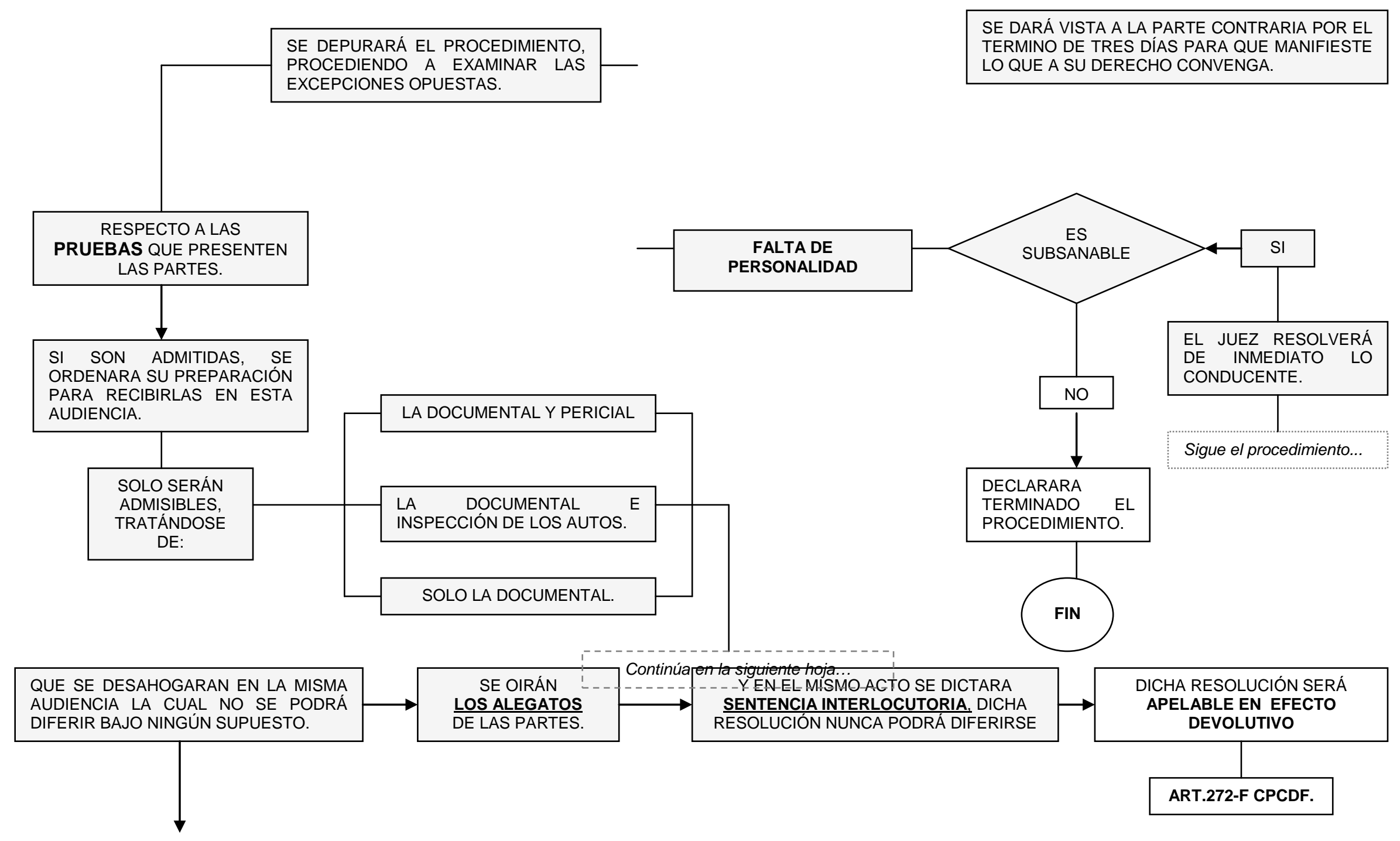




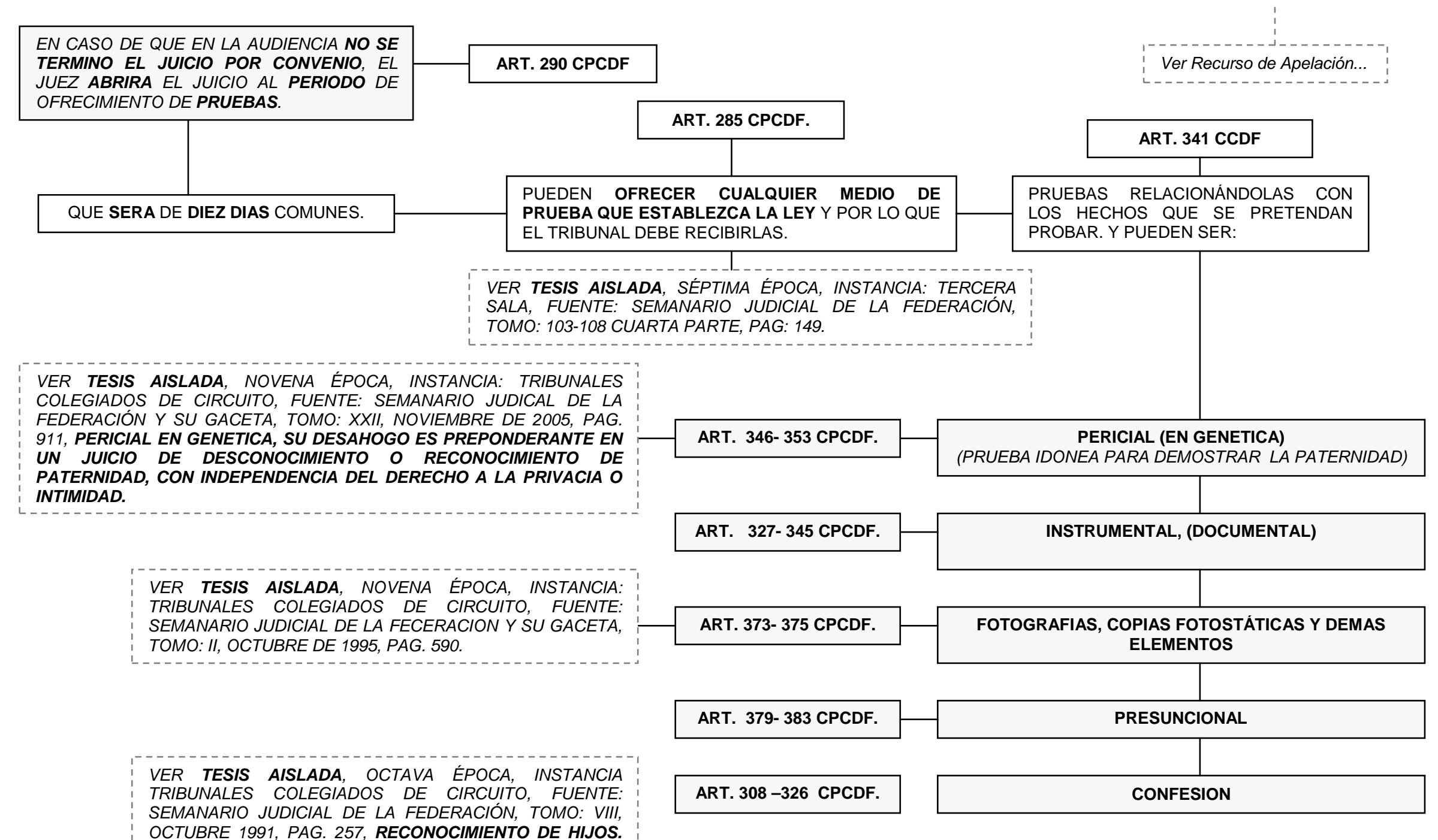




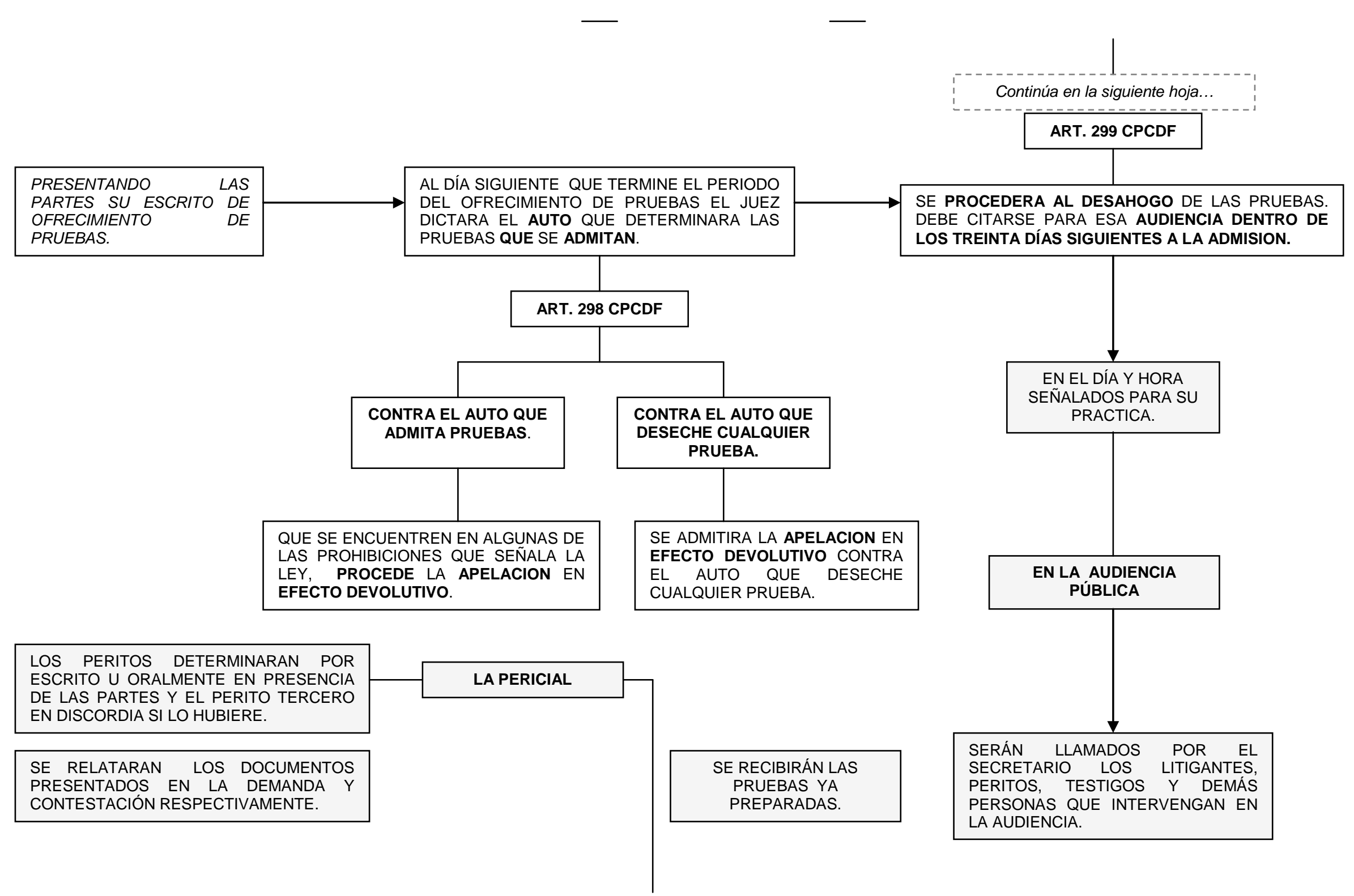




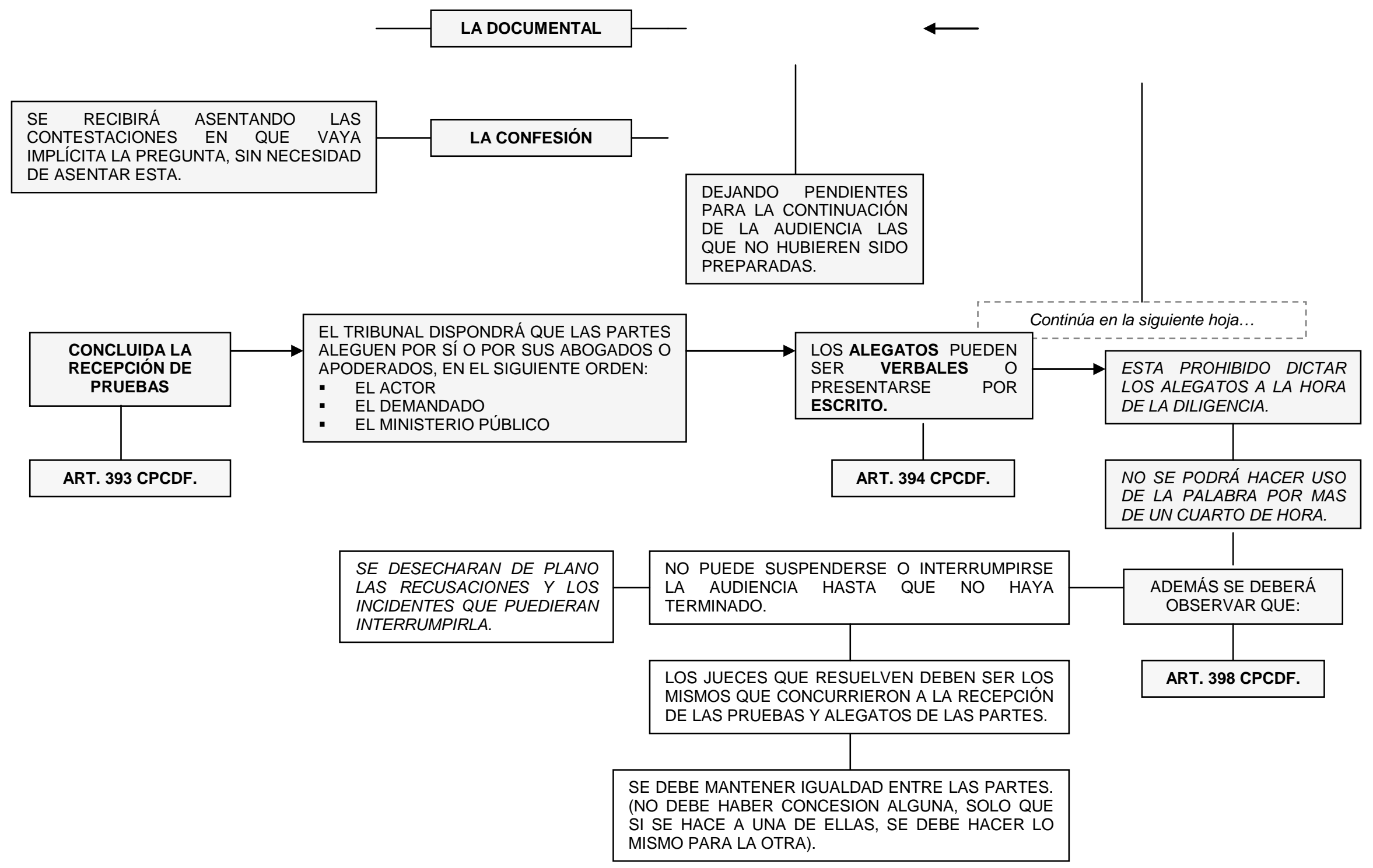




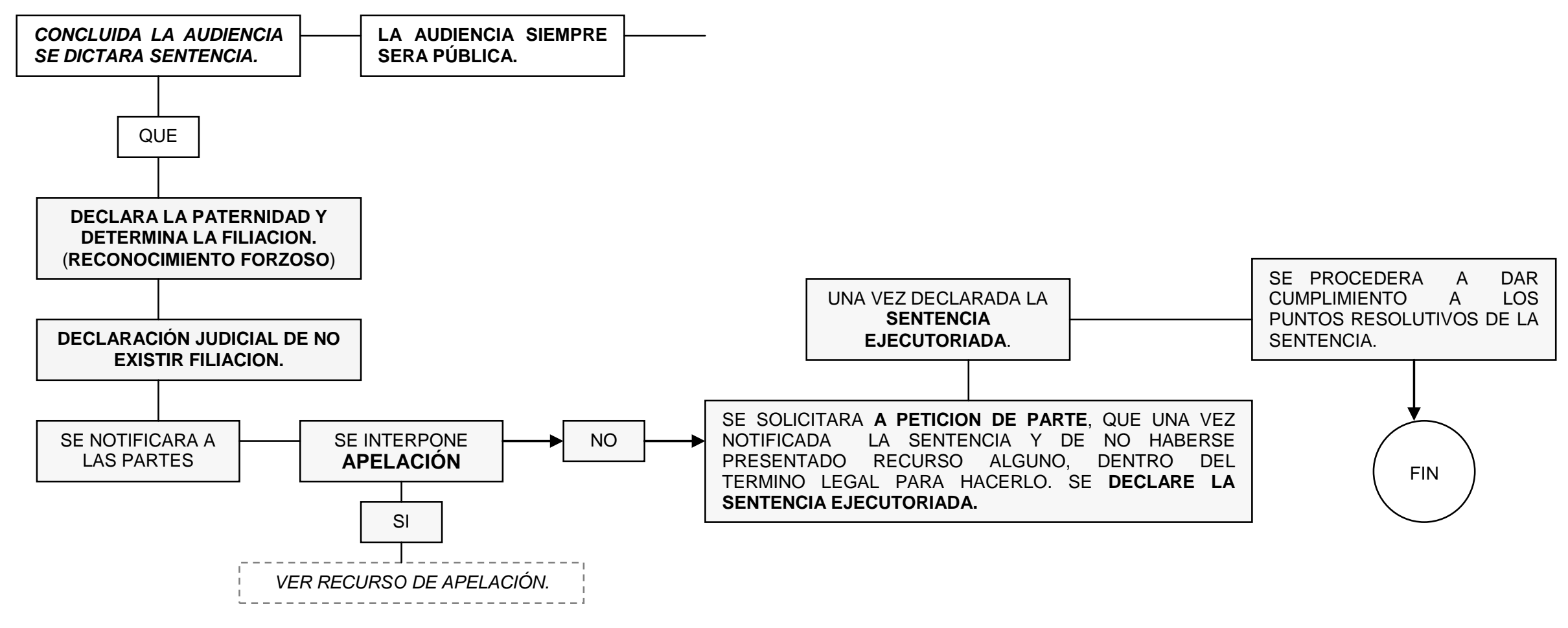


JUICIO DE INVESTIGACION DE LA PATERNIDAD

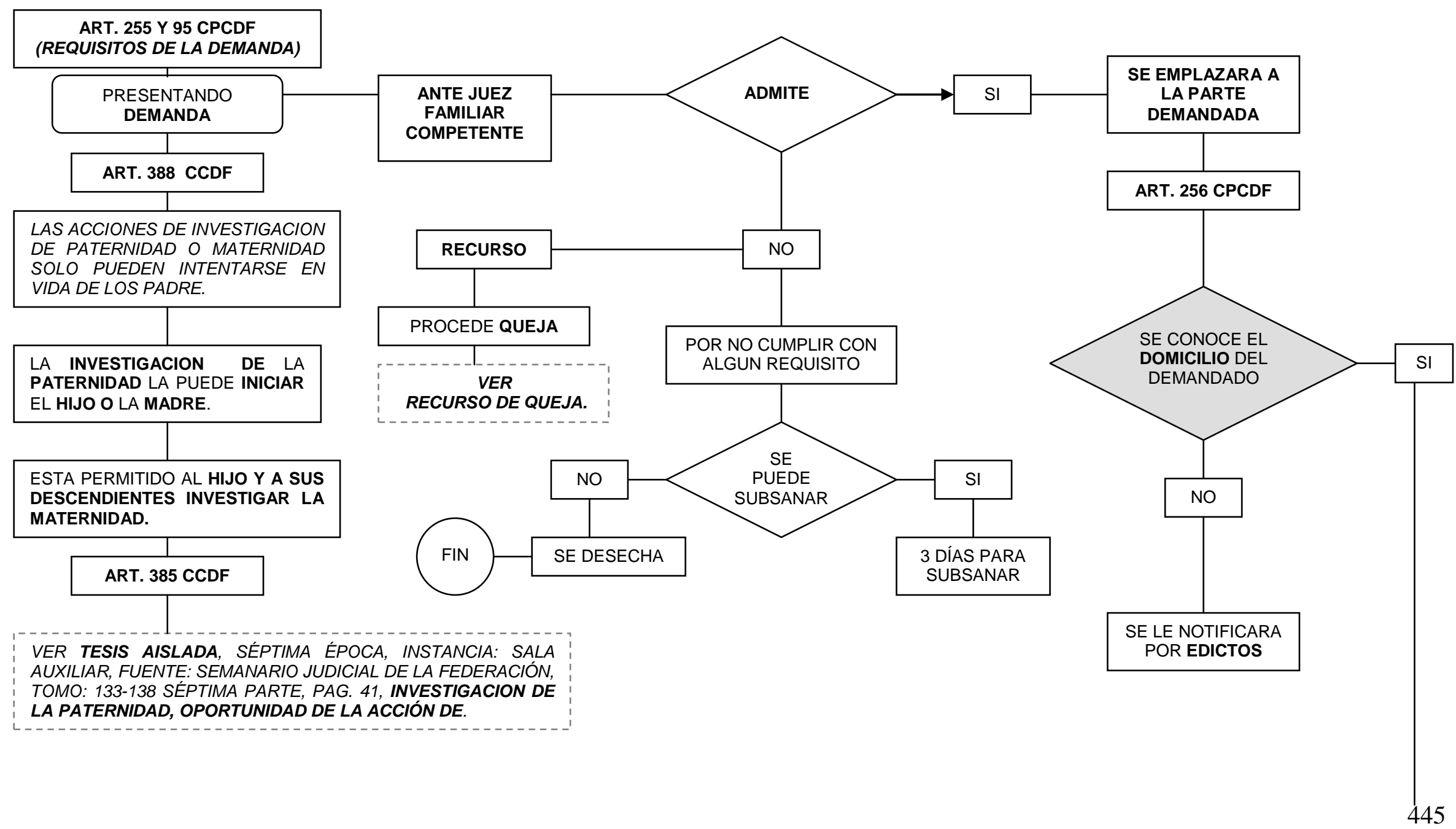


TESIS AISLADA NOVENA ÉPOCA, INSTANCIA. TRIBUNALES COLGISDOA, NOVENA EPOCA, INSTANCIA. TRIBUNALES COLEGIADOS DE CIRCUITO, FUENTE. SEMANARIO JUDICIAL DE LA FEDERACION Y SU GACETA, TOMO II, OCTUBRE DE 1995, PAG: 590. PATERNIDAD INVESTIGACION DE LA. LA VÍA ORDINARIA CIVIL SEGUIDA AL EFECTO NO IMPIDE APLICAR LAS NORMAS QUE RIGEN PARA LAS CONTROVERSIAS DE ORDEN FAMILIAR.

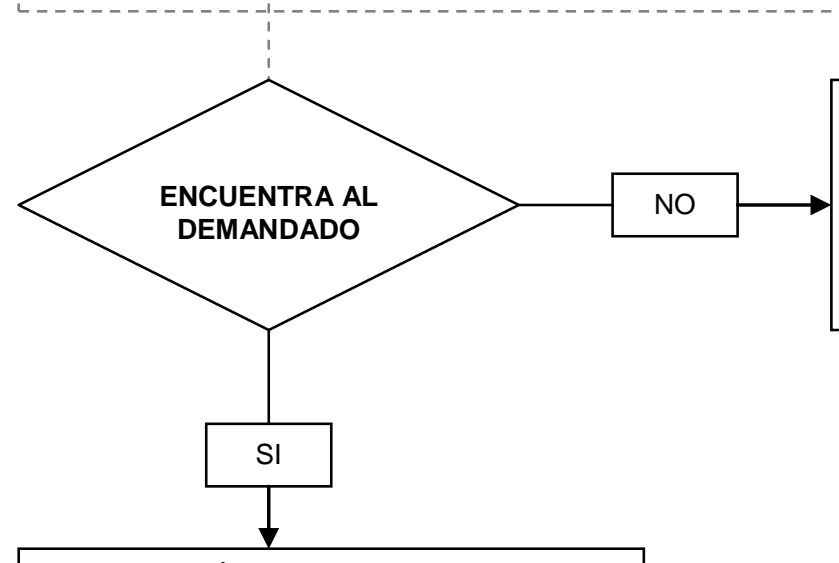

SE LE HARÁ SABER QUE EXISTE UNA DEMANDA DE INVESTIGACION DE LA PATERNIDAD O MATERNIDAD DE, SE LE ENTREGARA COPIA CERTIFICADA DE LA MISMA Y SUS ANEXOS

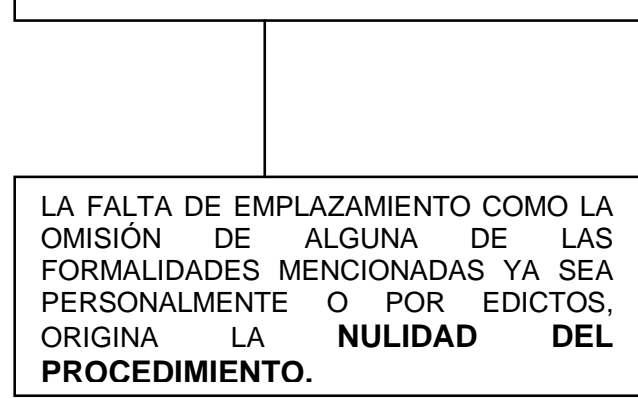
TERCERA SALA, FUENTE: SEMANIARIO JUDICIAL DE LA FEDERACION, TOMO: 61 CUARTA PARTE, PAG. 37 PATERNIDAD, INVESTIGACION DE LA, CUANDO SE TRATA DE POSESIÓN DE ESTADO DE HIJO DEL PRESUNTO PADRE.

SE HARÁ LA NOTIFICACIÓN POR CEDULA QUE SE ENTREGARÁ A LOS PARIENTES, EMPLEADOS, DOMÉSTICOS O PERSONAS QUE VIVAN EN EL DOMICILIO SENTALADO, SE LES ENTREGARA COPIA SIMPLE DE LA DEMANDA Y DE LOS DOCUMENTOS QUE HAYA ANEXADO COTEJADOS Y SELLADOS).

\section{ART. 117 CPCDF.}

SE LE PREVENDRÁ PARA QUE LA CONTESTE DENTRO DE LOS 9 DÍAS SIGUIENTES.

TRANSCURRIDO EL TÉRMINO PARA CONTESTAR LA DEMANDA

ART. 256 CPCDF

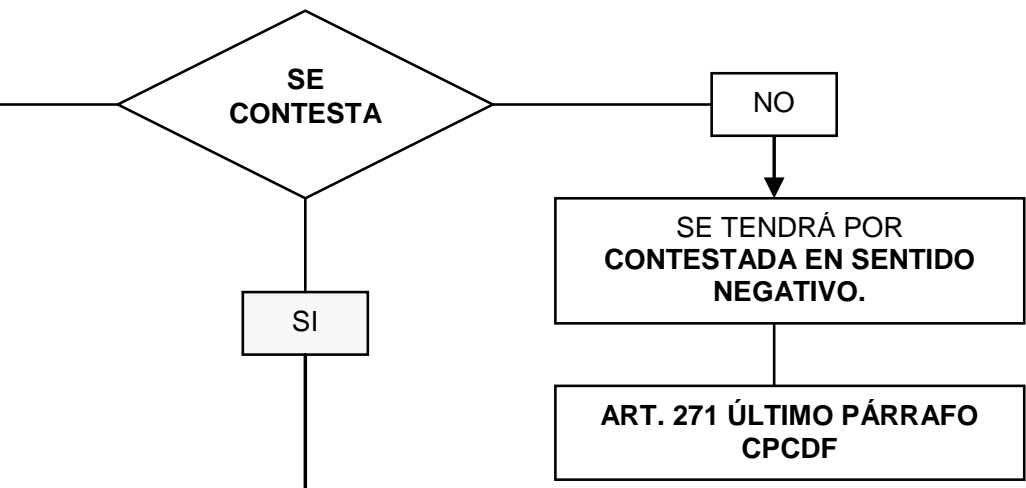


ART. 74-78 CPCDF.

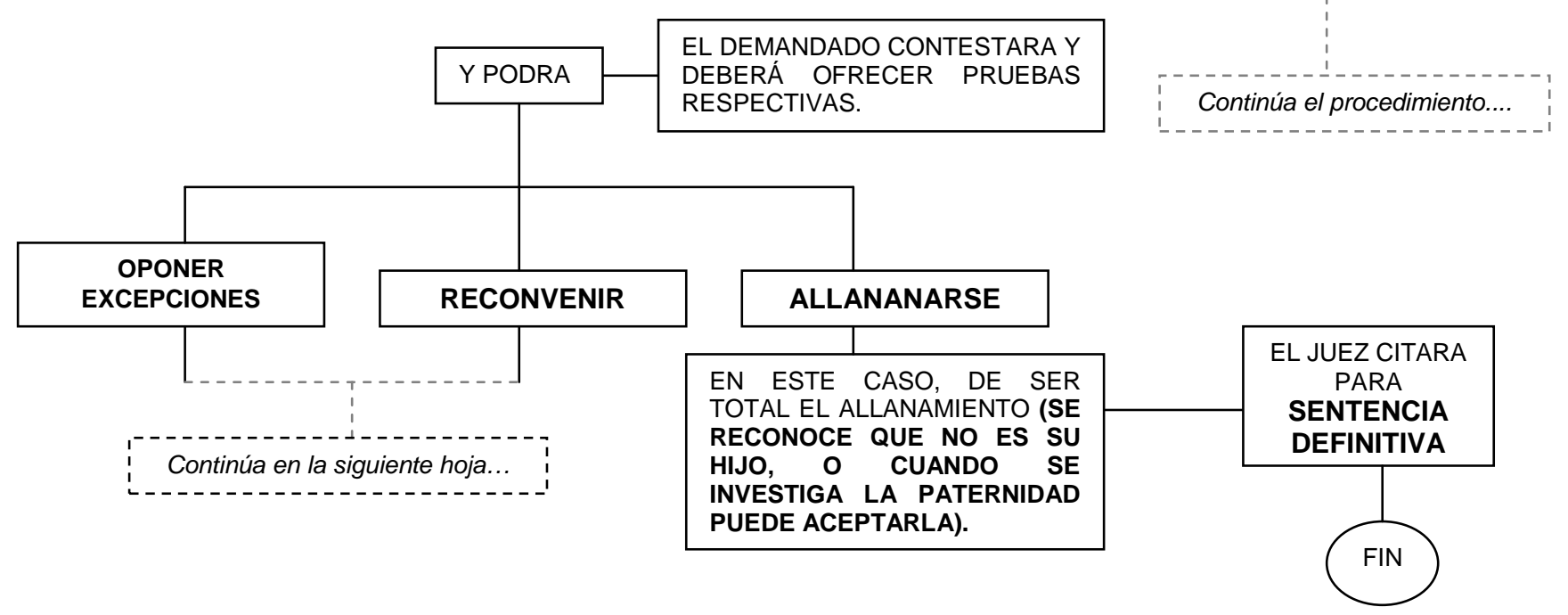




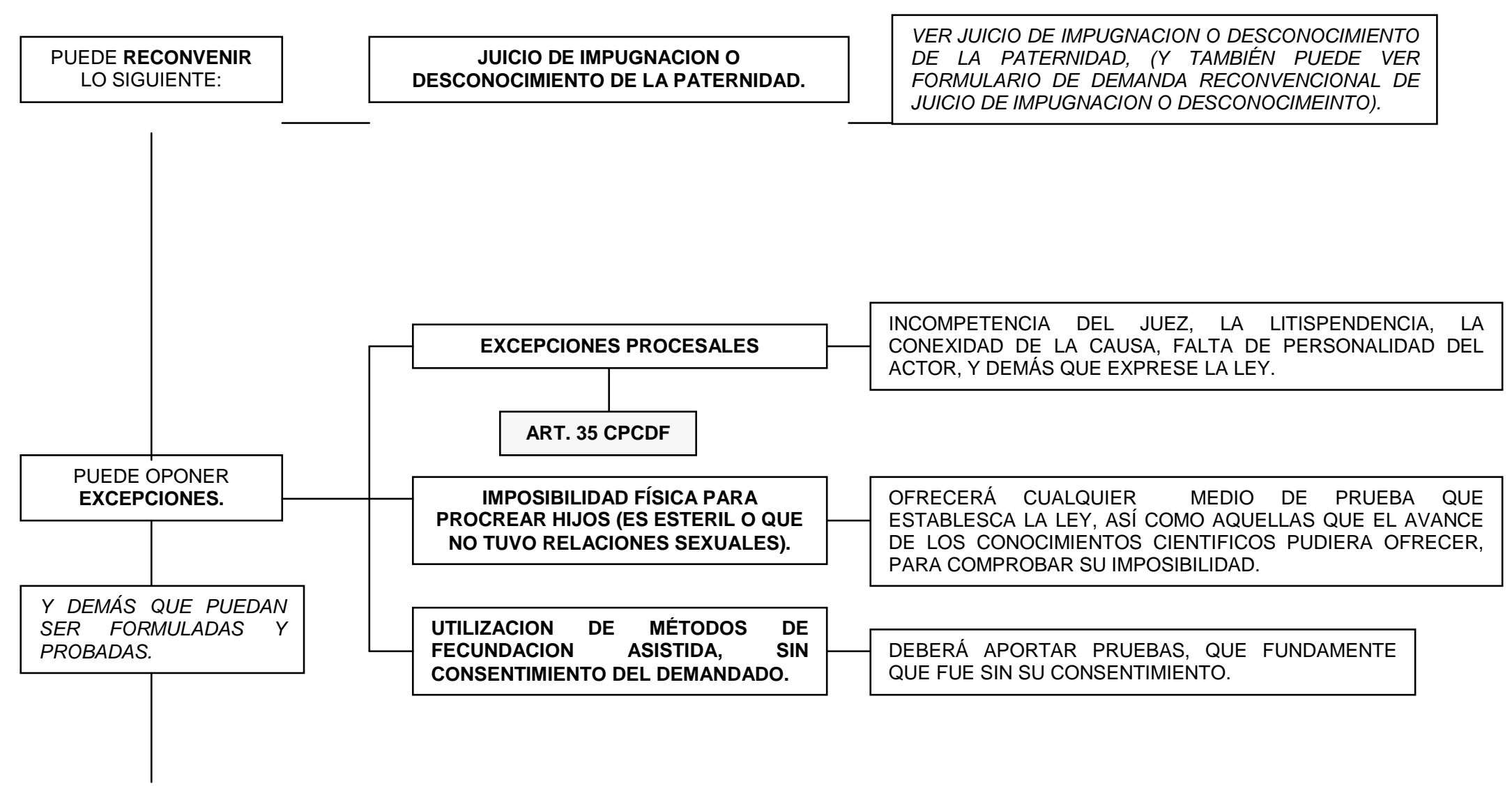


PRESENTADA LA CONTESTACIÓN DE LA CONOCIENDO DEL ASUNTO
SE DICTARA EL

AUTO QUE LA TIENE POR

CONTESTADA
Y SEGÚN SEA EL CASO, SE TENGAN POR OPUESTAS LAS EXCEPCIONES Y DEFENSAS, O EN SU CASO LA RECONVENCION, Y SE LE CORRA TRASLADO AL ACTOR PARA QUE CONTESTE.

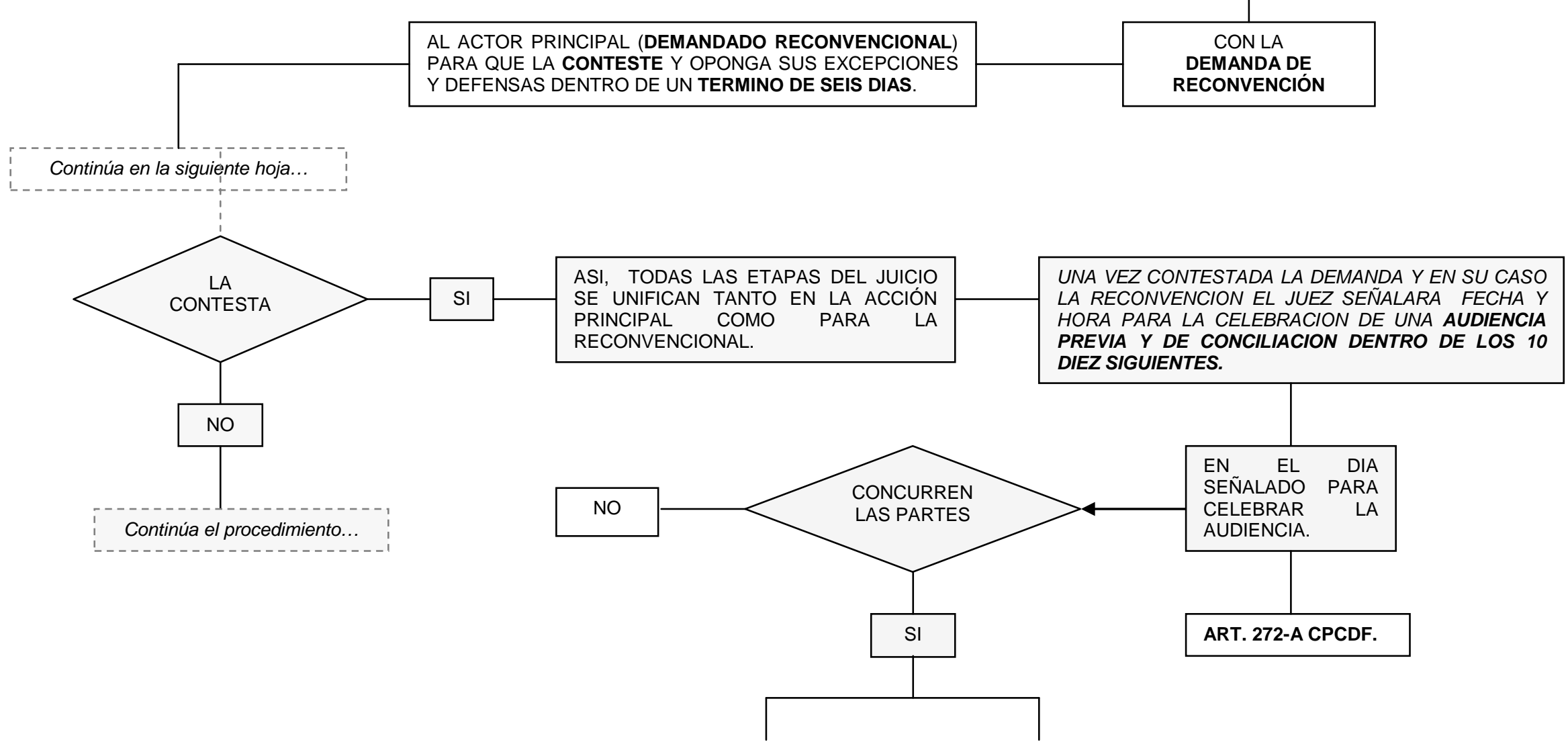




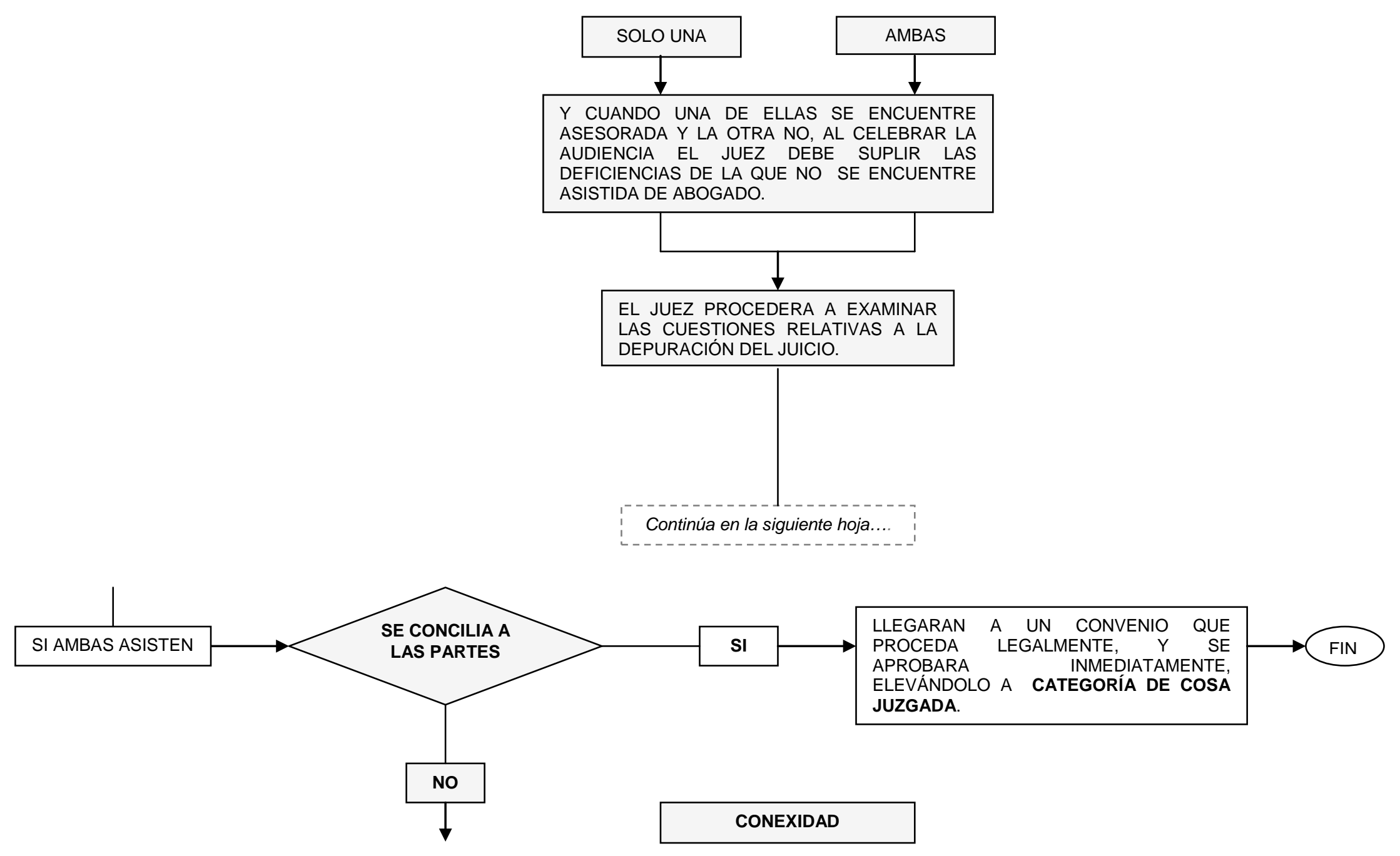




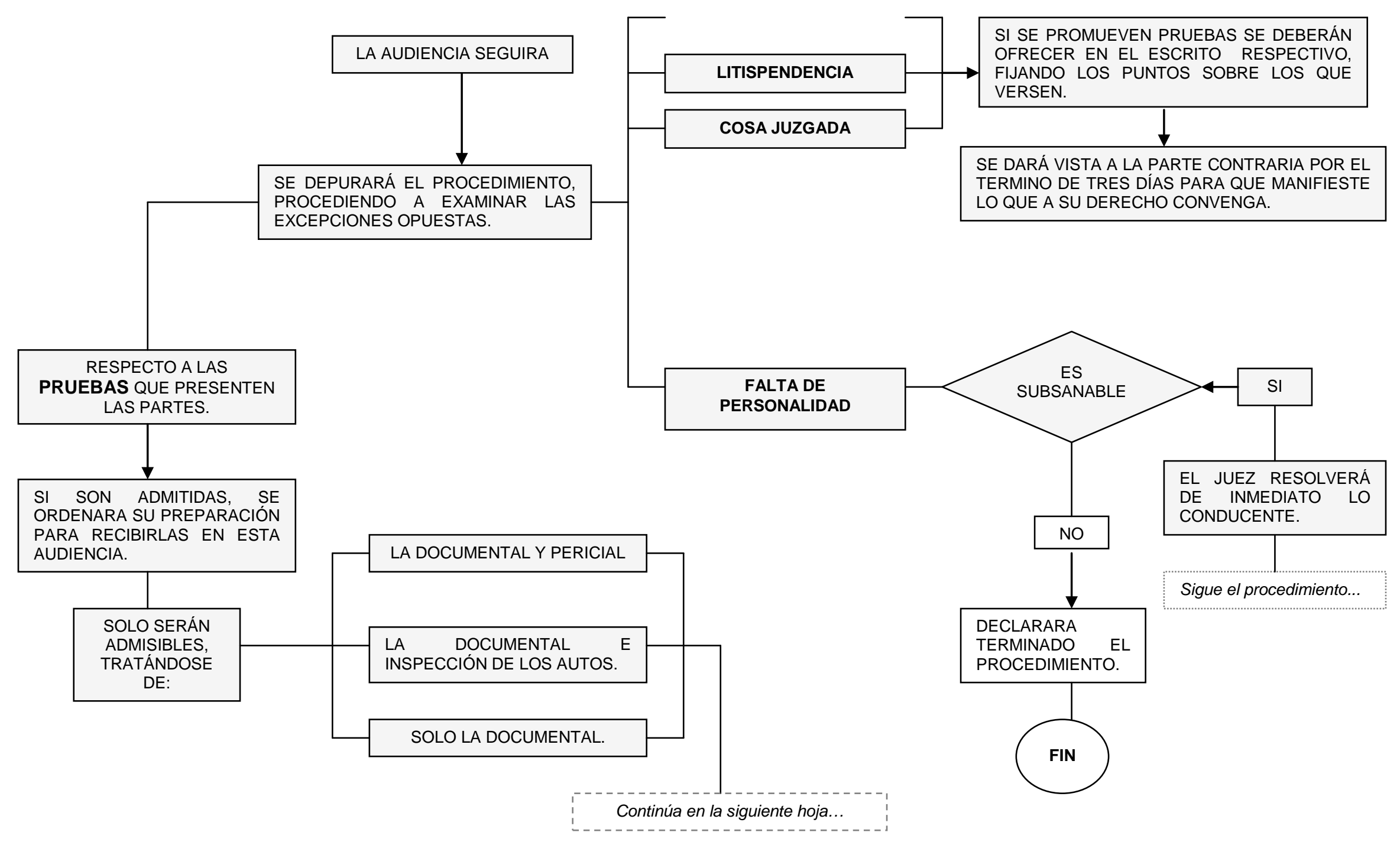




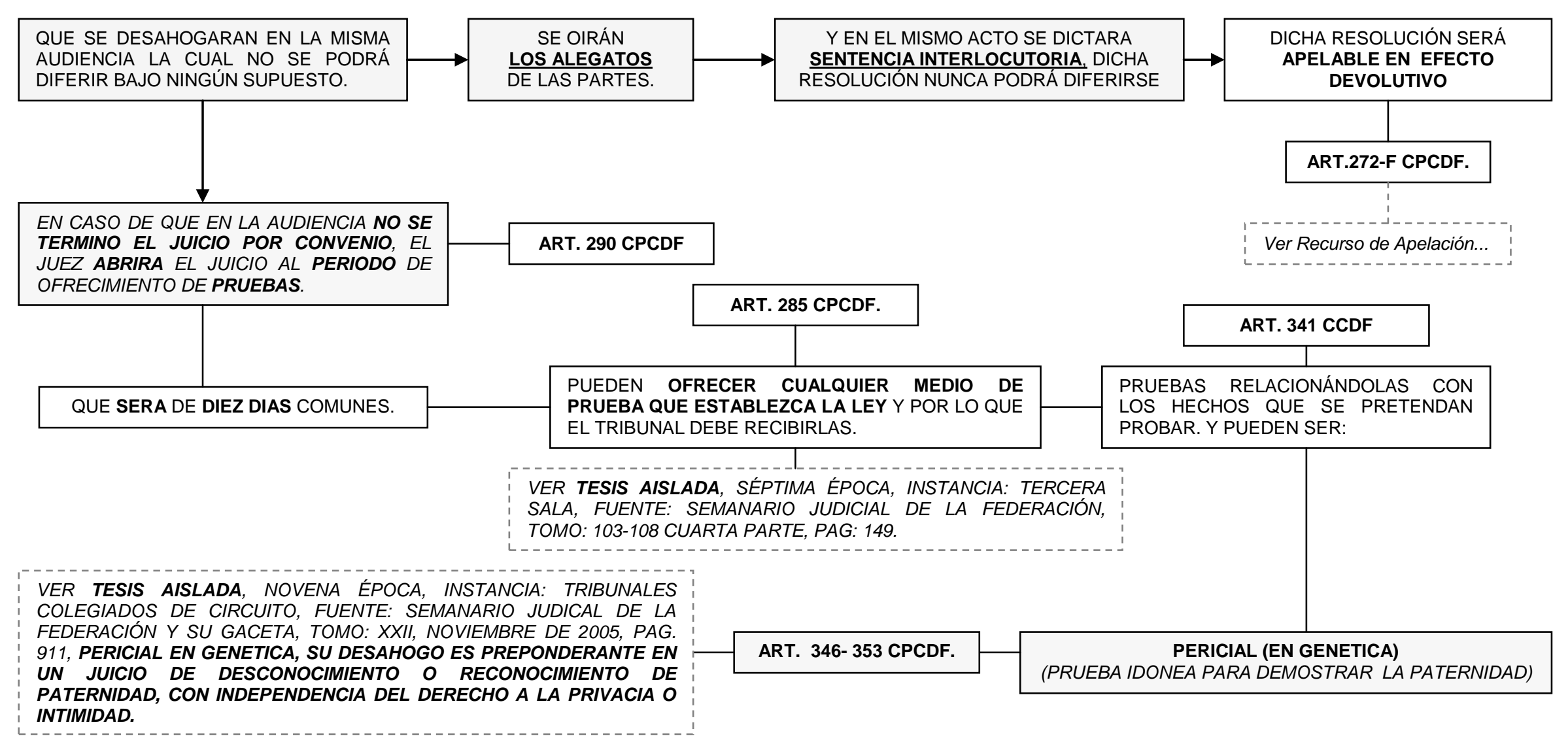


VER TESIS AISLADA, NOVENA ÉPOCA, INSTANCIA: TRIBUNALES COLEGIADOS DE CIRCUITO, FUENTE: SEMANARIO JUDICIAL DE LA FECERACION Y SU GACETA, TOMO: II, OCTUBRE DE 1995, PAG 590 PATERNIDAD INVESTIGACION DE LA PRUEBAS APTAS EN EJERCICIO DE ESA ACCIÓN.

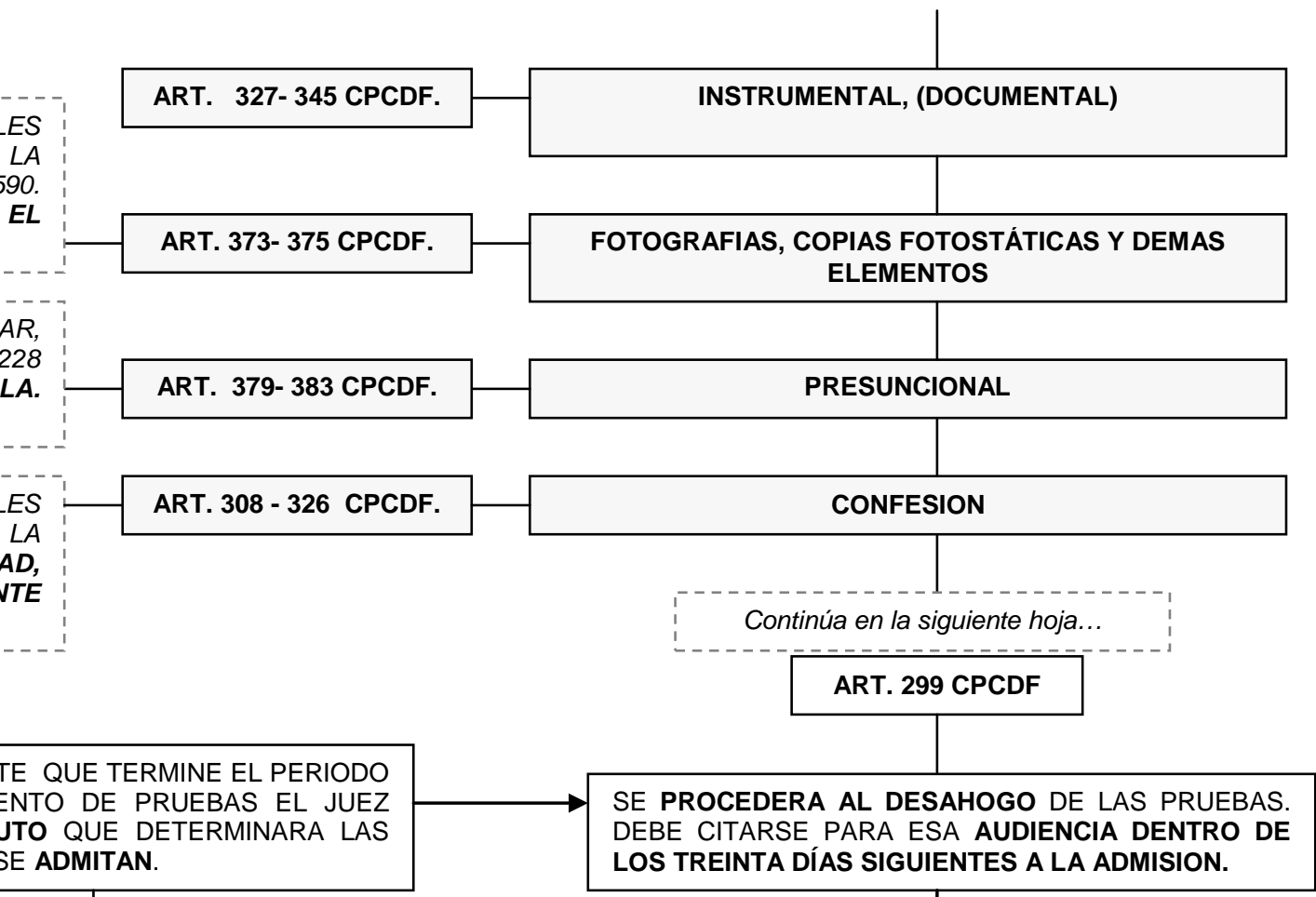

PRESENTANDO LAS

PARTES SU ESCRITO DE

OFRECIMIENTO
AL DÍA SIGUIENTE QUE TERMINE EL PERIODO DEL OFRECIMIENTO DE PRUEBAS EL JUEZ DICTARA EL AUTO QUE DETERMINARA LAS PRUEBAS QUE SE ADMITAN.

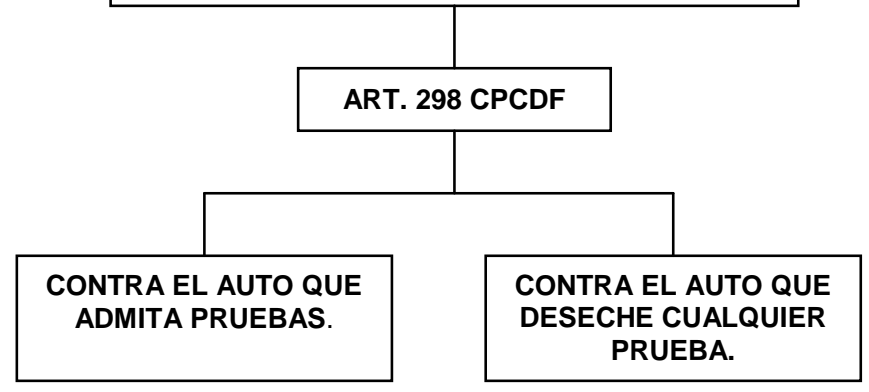
LOS TREINTA DÍAS SIGUIENTES A LA ADMISION. 


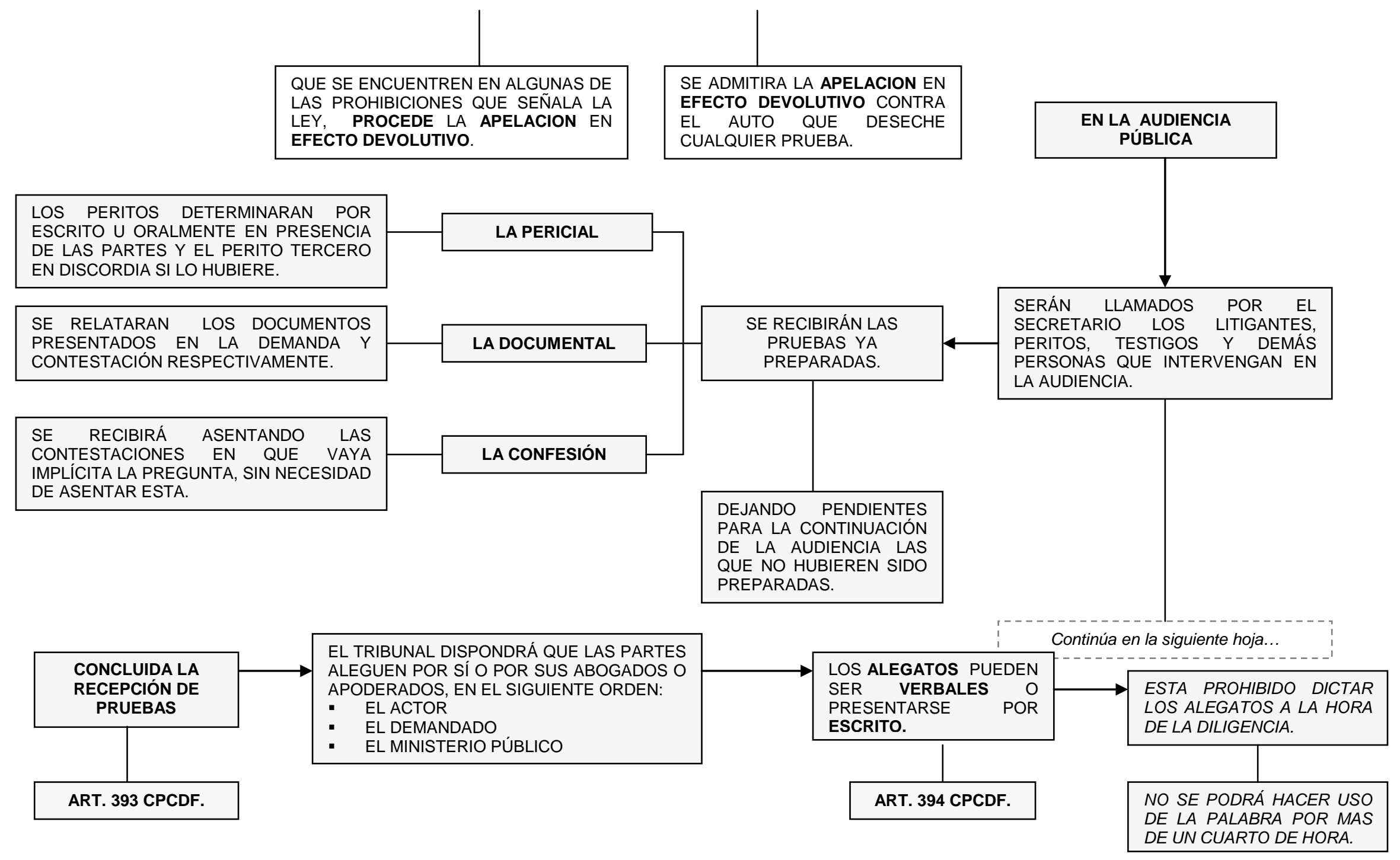




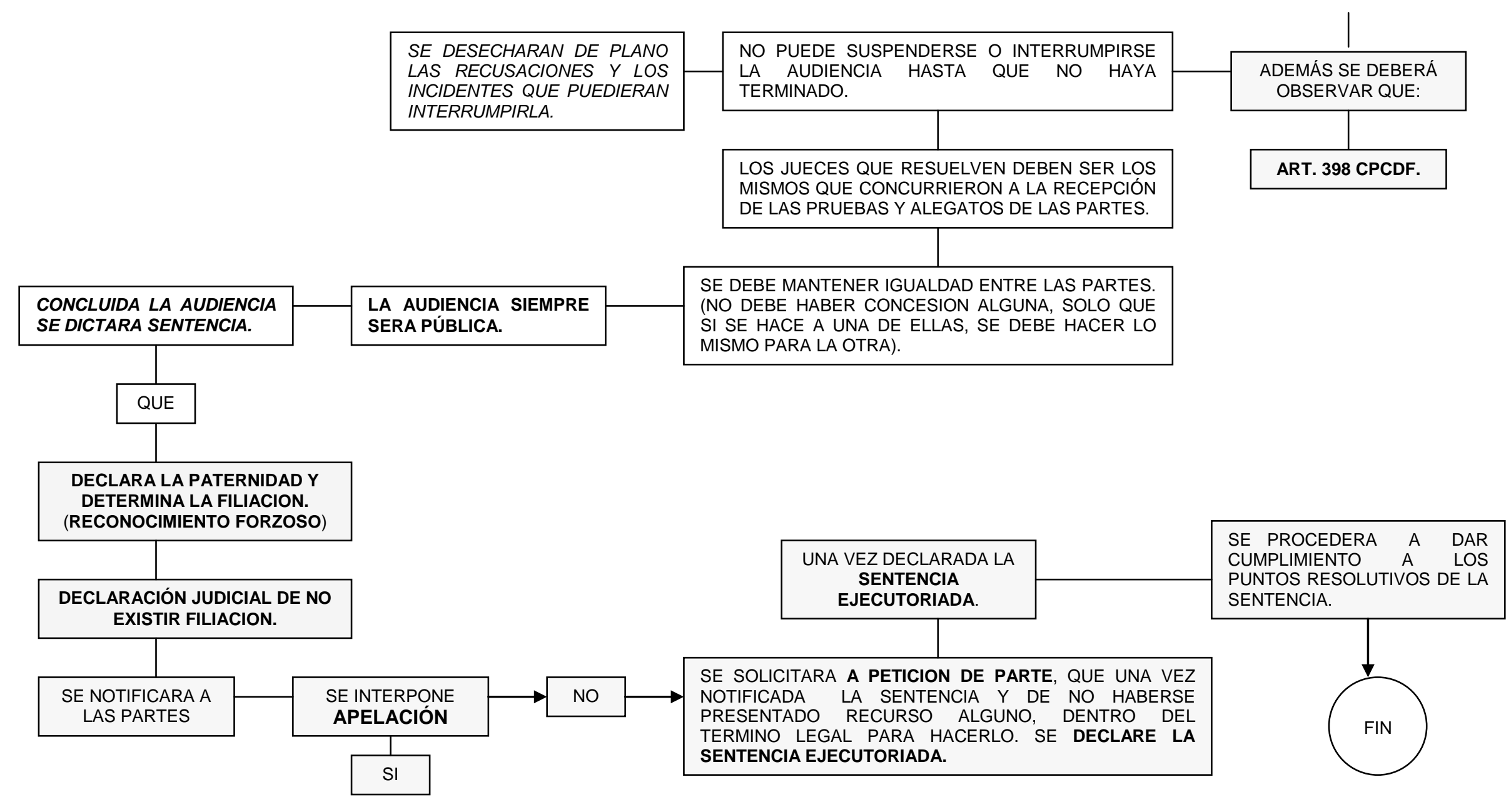




\section{JUICIO DE RECONOCIMIENTO DE LA PATERNIDAD}

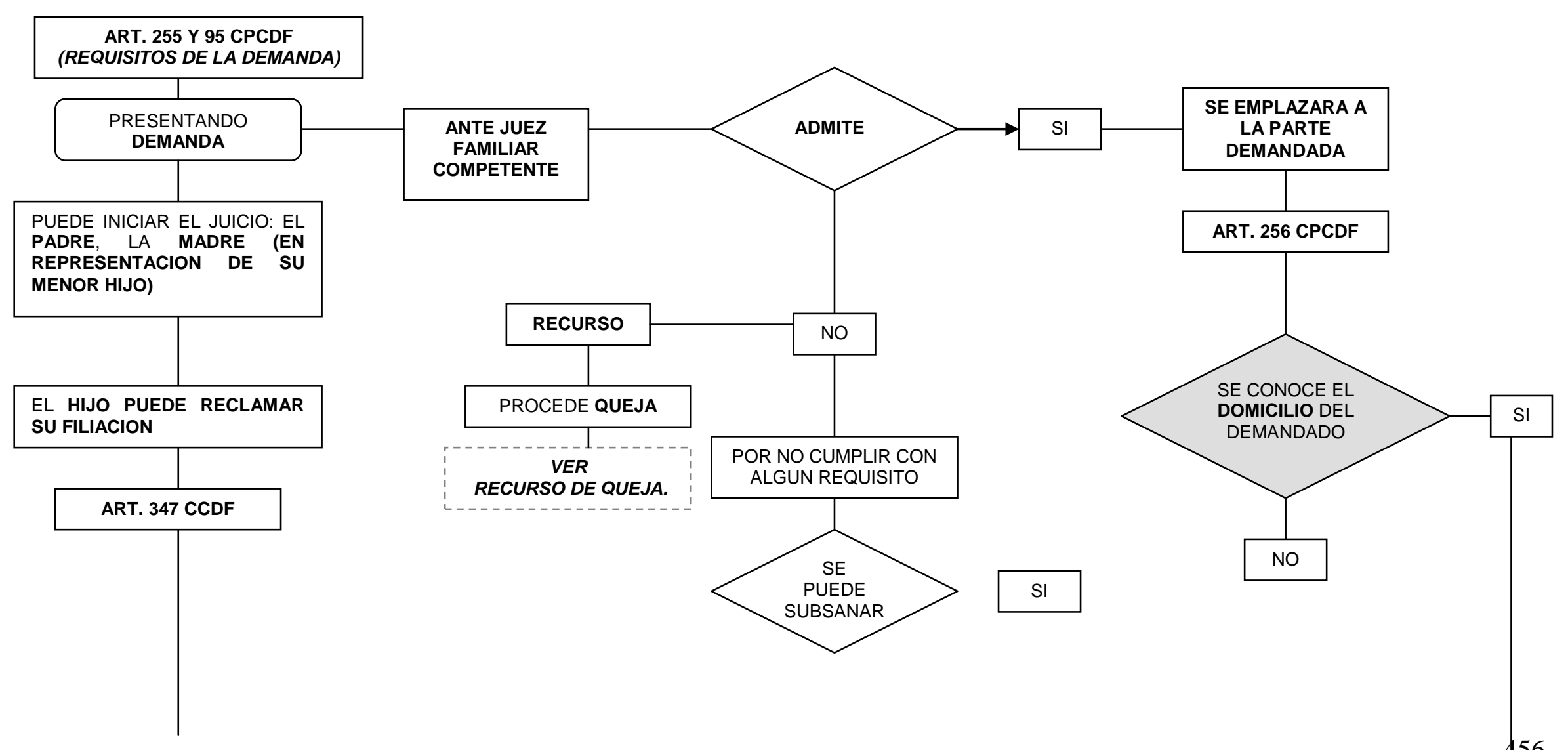



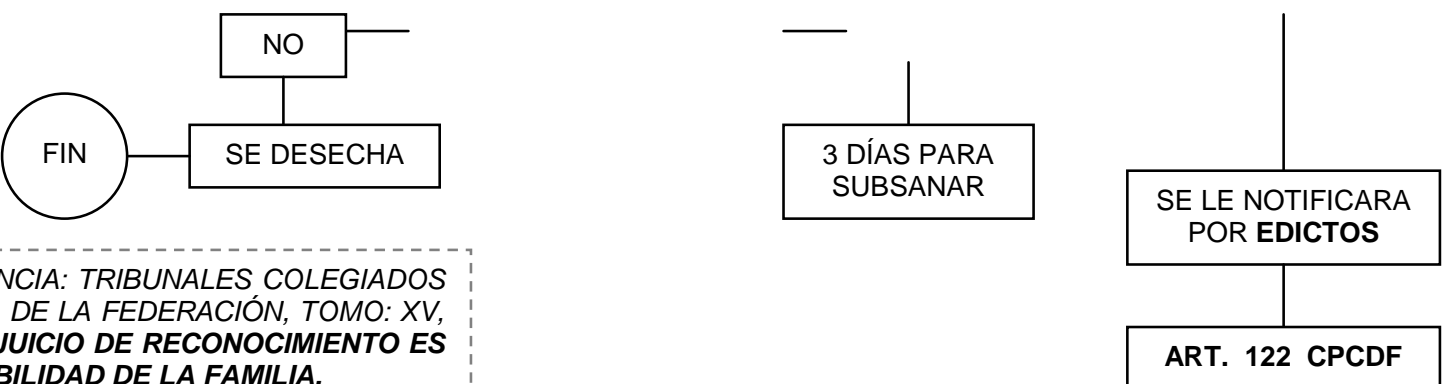

VER TESIS AISLADA OCTAVA ÉPOCA INSTANCIA. TRIBUNALES COLEGIADOS DE CIRCUITO, FUENTE: SEMANARIO JUDICIAL DE LA FEDERACIÓN, TOMO: XV ENERO DE 1995, PAG. 279. PATERNIDAD. EL JUICIO DE RECONOCIMIENTO ES UNA CUESTIÓN RELATIVA AL ORDEN Y ESTABILIDAD DE LA FAMILIA.

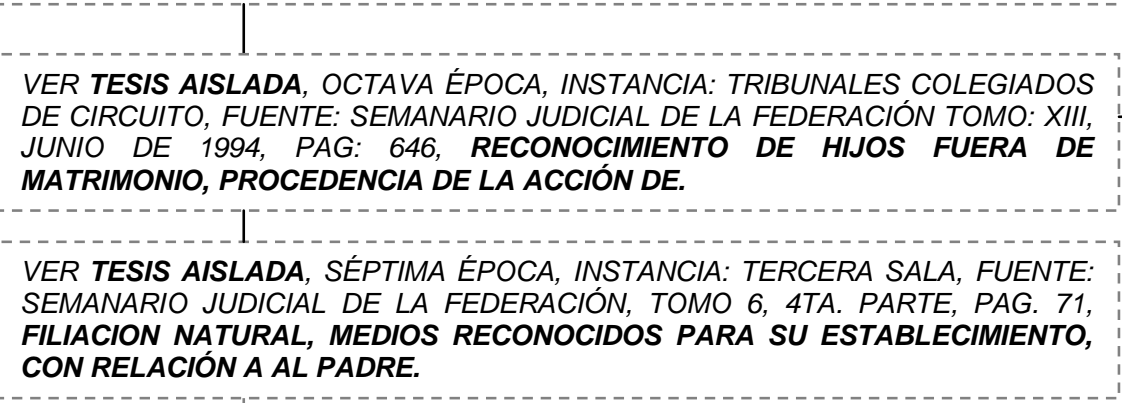

VER TESIS AISLADA SÉPTIMA ÉPOCA, INSTANCIA: TERCERA SALA FUENTE SEMANARIO JUDICIAL DE TERCERA SALA, FUENTE SEMANARIO JUDICIAL DE
LA FEDERACIÓN, TOMO: 205-216 4TA. PARTE, PAG. 128. PATERNIDAD. DEBE ACREDITARSE CON PLENITUD.

-

\section{CON RELACIÓN A AL PADRE.}

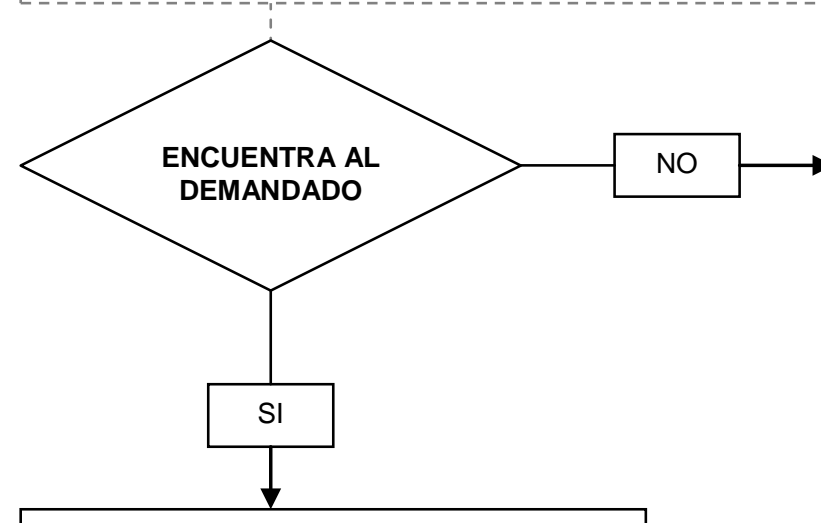

SE HARÁ LA NOTIFICACIÓN POR CEDULA QUE SE SE HARA LA NOTIFICACION POR CEDULA QUE SE
ENTREGARÁ A LOS PARIENTES, EMPLEADOS, EOMÉSTICOS O PERSONAS OUE VIVAN EN EL DOMICILIO

SEÑALADO, SE LES ENTREGARA COPIA SIMPLE DE LA SENALADO, SE LES ENTREGARA COPIA SIMPLE DE LA EL ACTOR (LOS QUE ESTARÁN DEBIDAMENTE COTEJADOS Y SELLADOS).

ART. 117 CPCDF.

SE LE HARÁ SABER QUE EXISTE UNA DEMANDA DE RECONOCIMIENTO DE HIJO, SE LE ENTREGARA COPIA

ANEXOS

SE LE PREVENDRÁ PARA QUE LA DÍAS SIGUIENTES

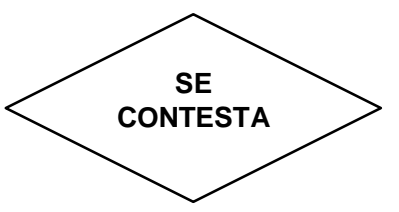




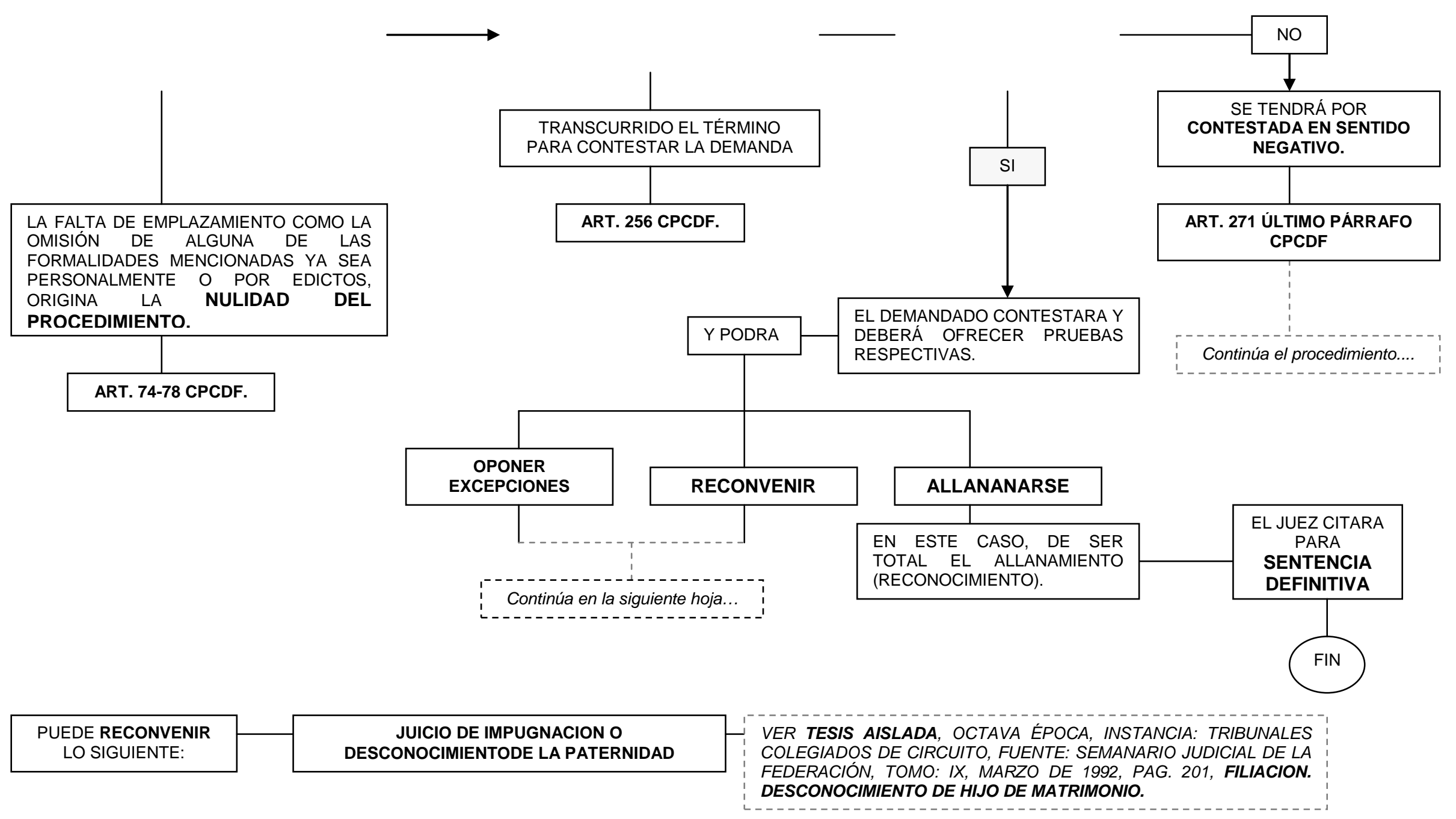




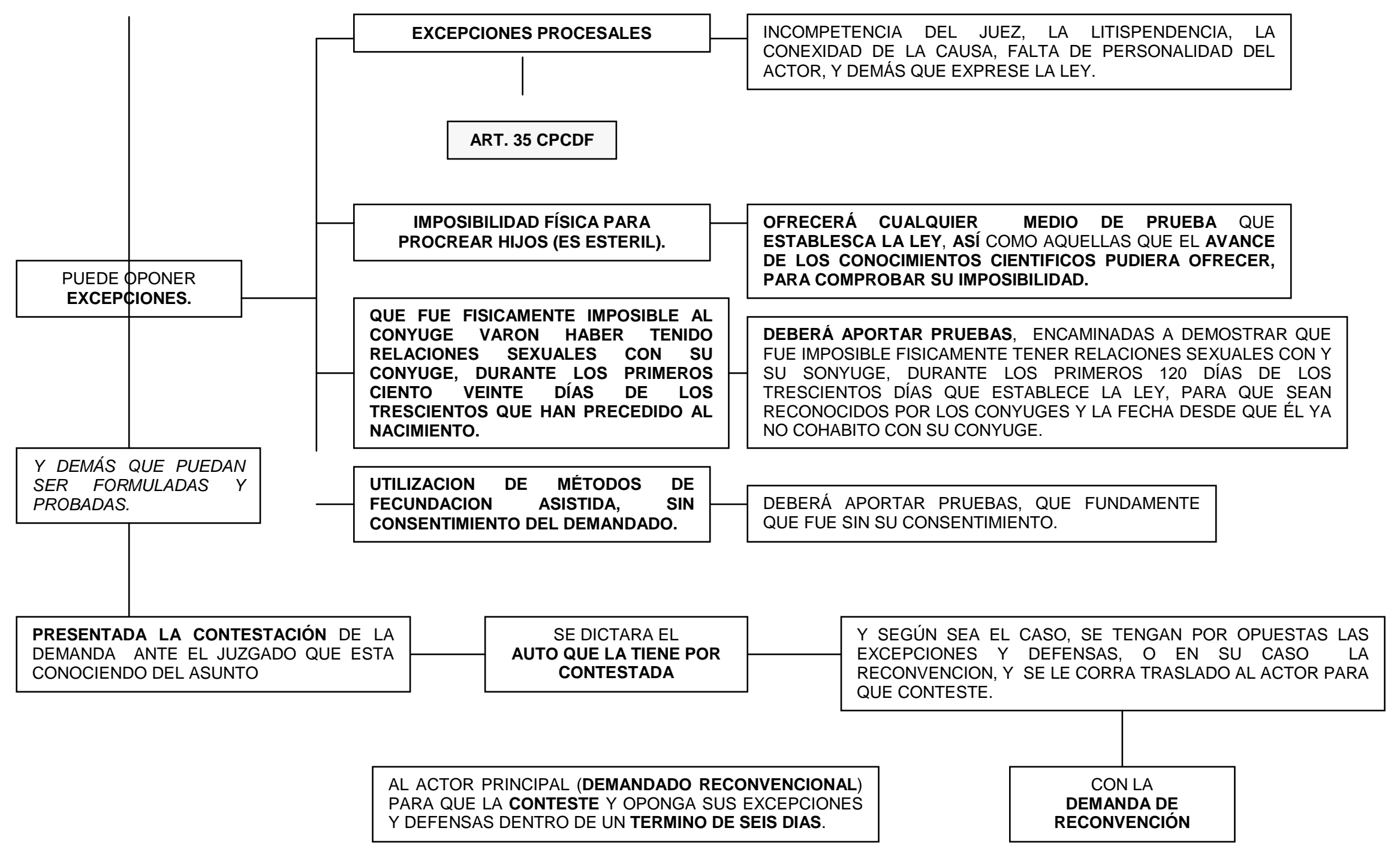




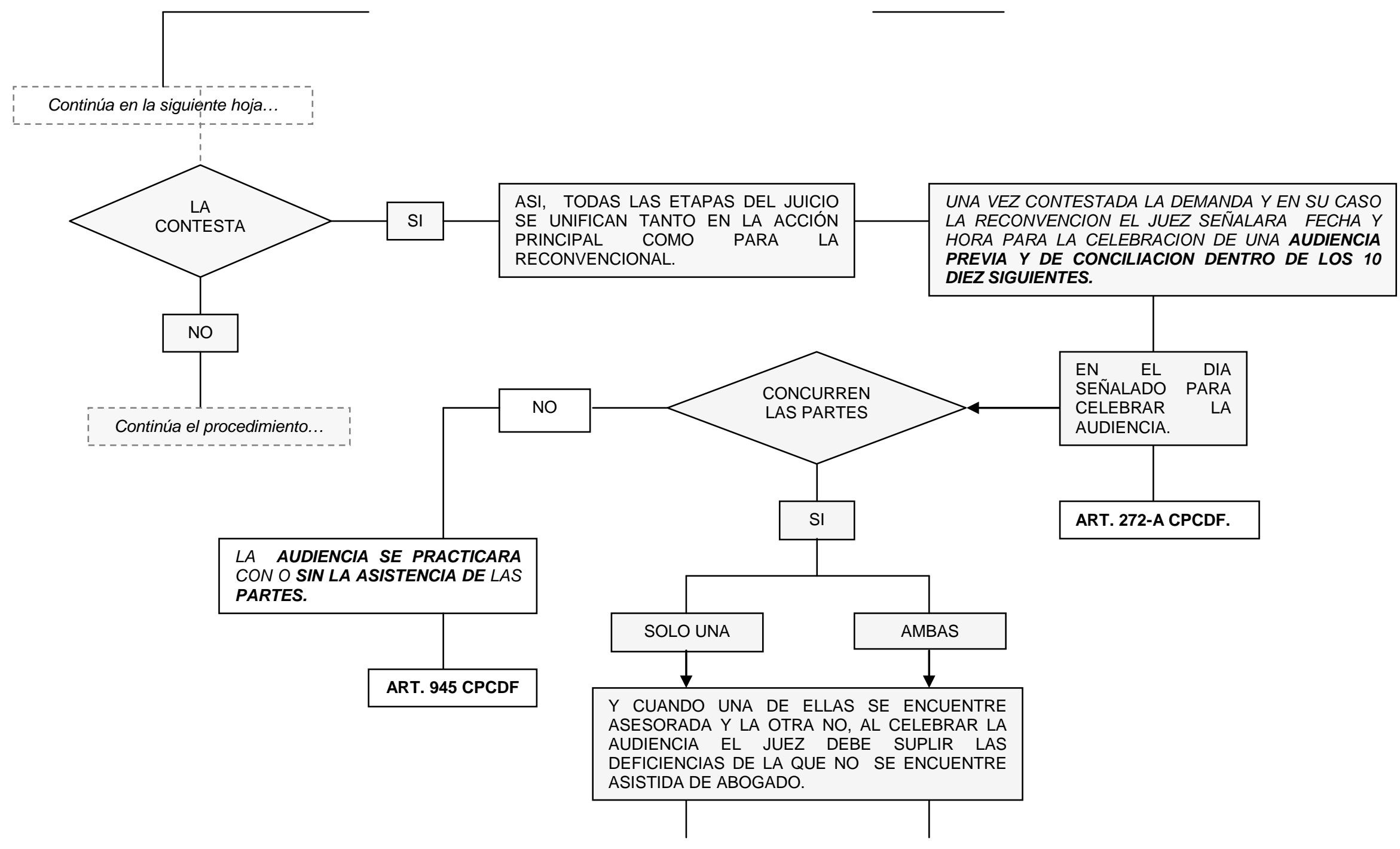




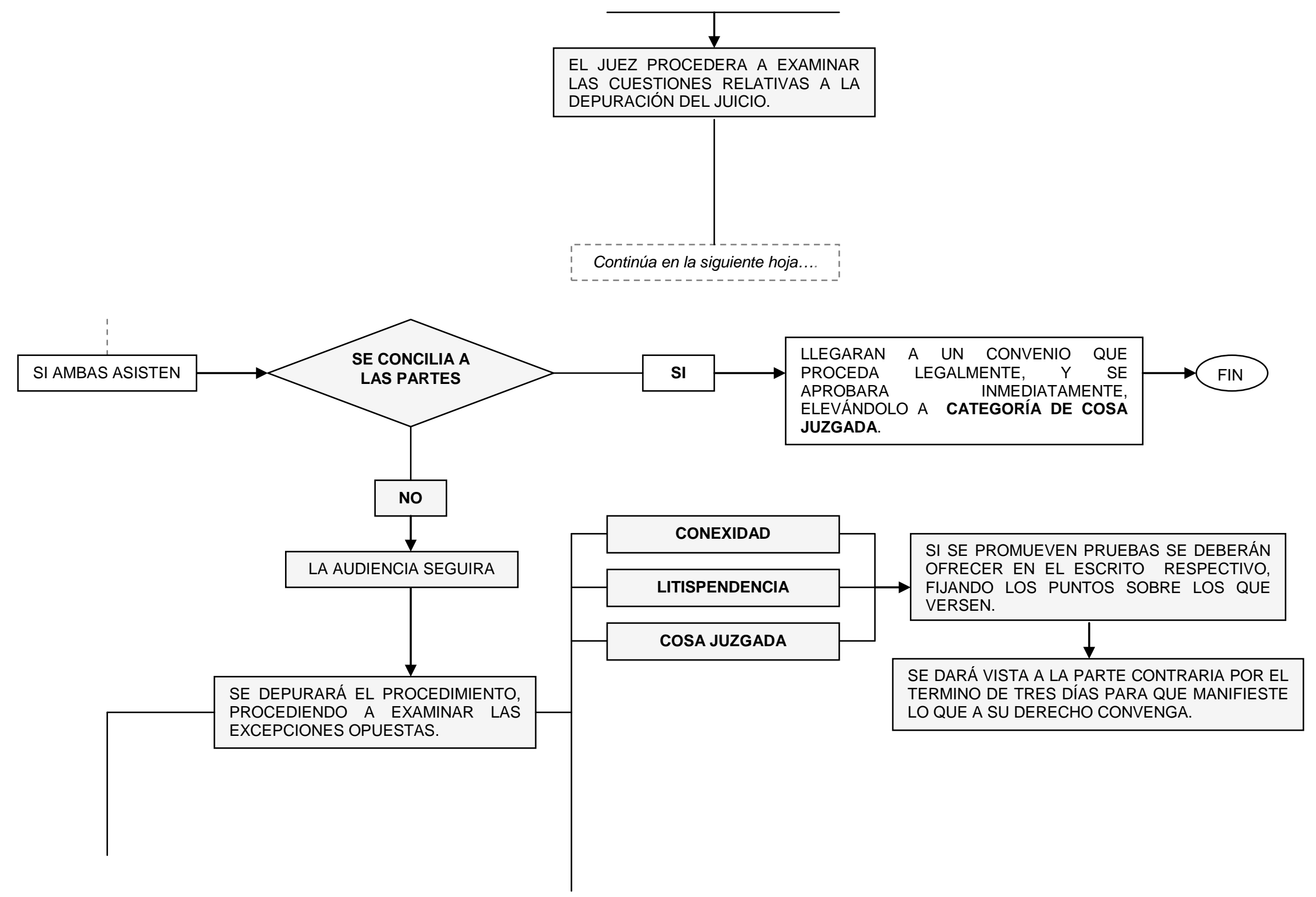


RESPECTO A LAS

PRUEBAS QUE PRESENTEN LAS PARTES.

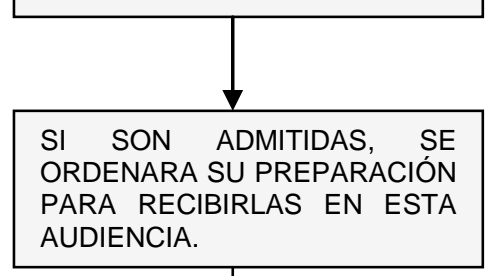

ATIENCIA.

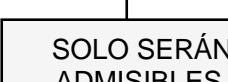

ADMISIBLES,

TRATÁNDOSE

DE:
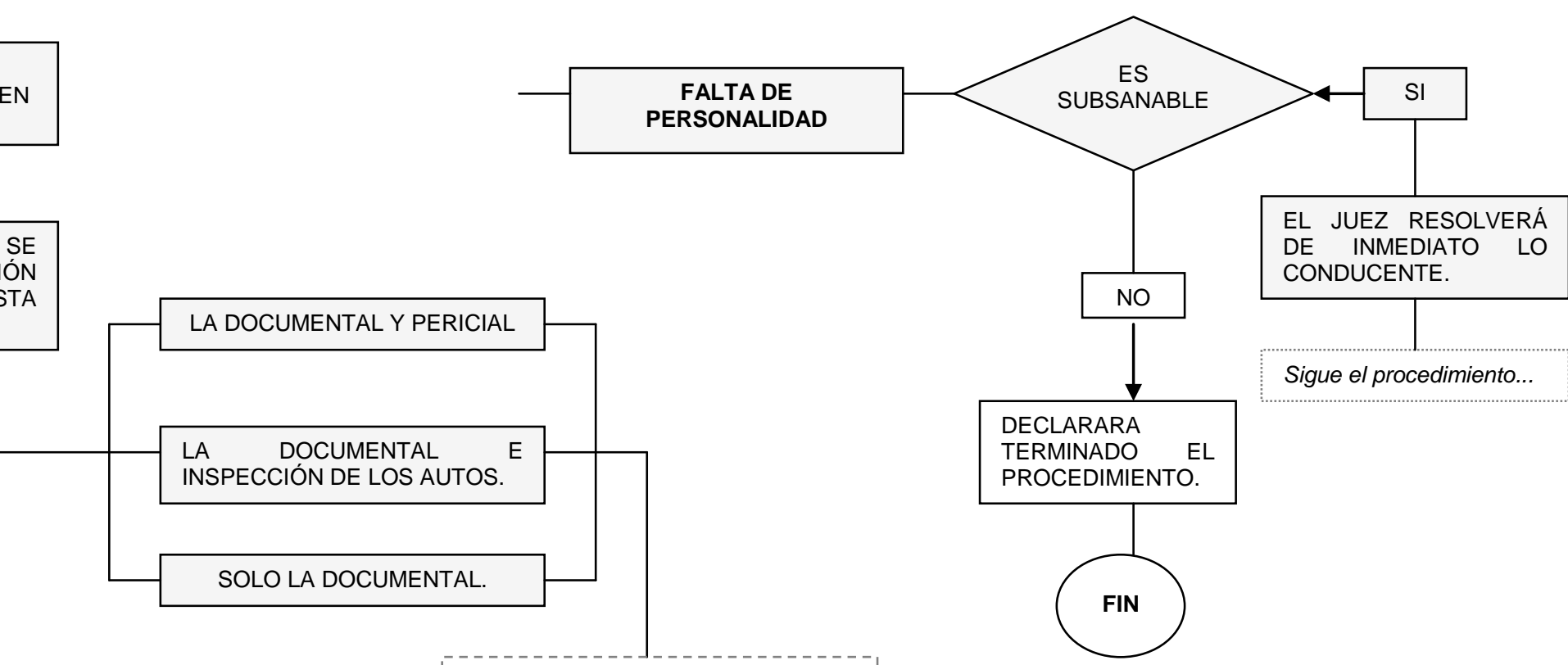

QUE SE DESAHOGARAN EN LA MISMA
AUDIENCIA LA CUAL NO SE PODRÁ

SE OIRÁN

(1)

DICHA RESOLUCIÓN SERÁ LOS ALEGATOS

Continúa sigutiente MISMOA-ACTO SE DICTARA

DIFERIR BAJO NINGÚN SUPUESTO.

DE LAS PARTES.

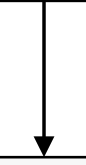

EN CASO DE QUE EN LA AUDIENCIA NO SE TERMINO EL JUICIO POR CONVENIO, EL

JUEZ ABRIRA EL JUICIO AL PERIODO DE

OFRECIMIENTO DE PRUEBAS

ART. 290 CPCDF

ART.272-F CPCDF.

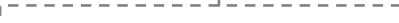

Ver Recurso de Apelación...

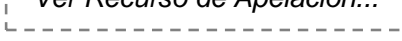




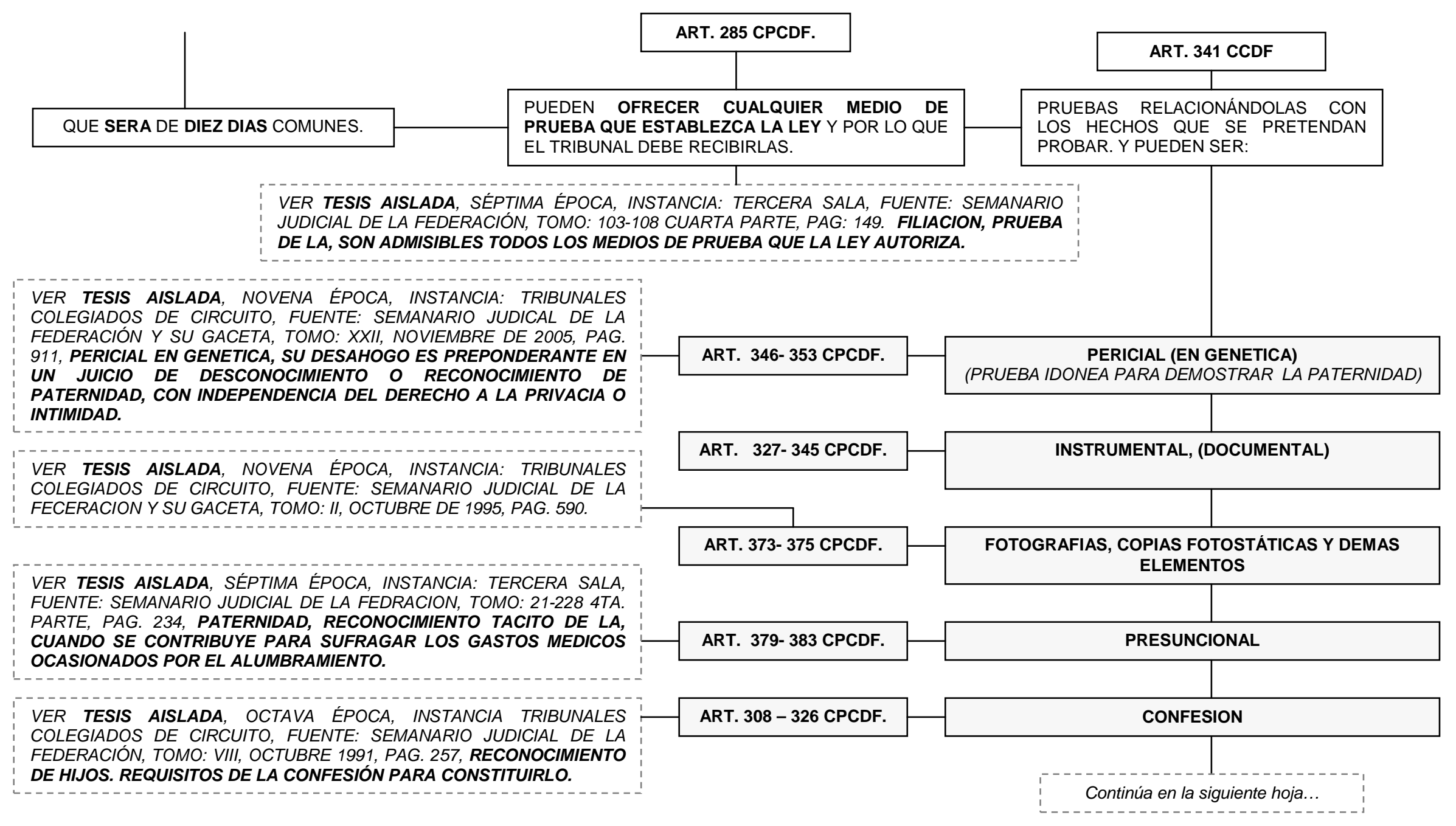




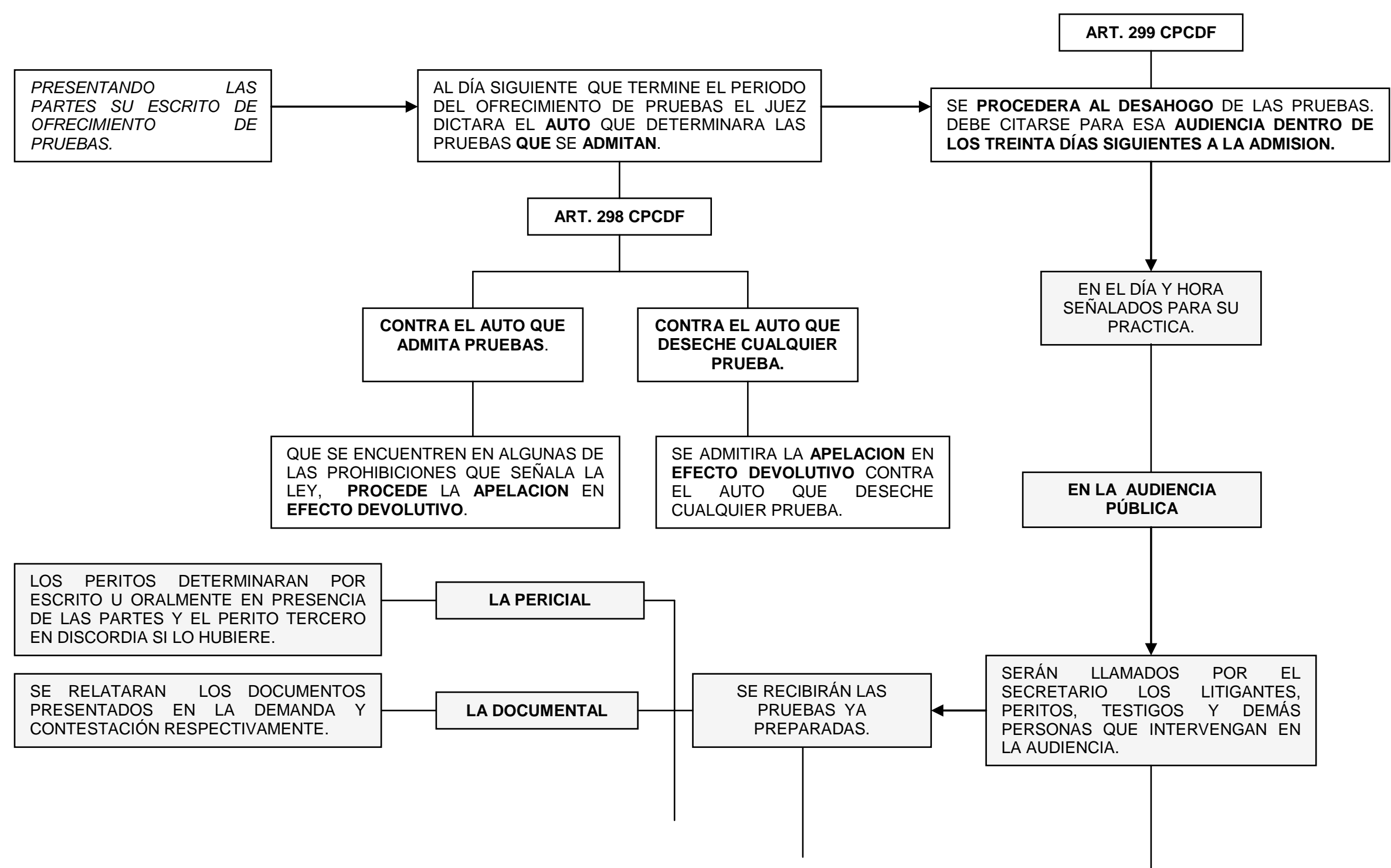




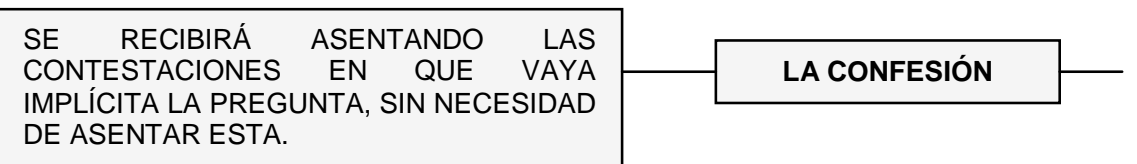
DE ASENTAR ESTA.

DEJANDO PENDIENTES PARA LA CONTINUACIÓN DE LA AUDIENCIA LAS QUE NO HUBIEREN SIDO PREPARADAS.

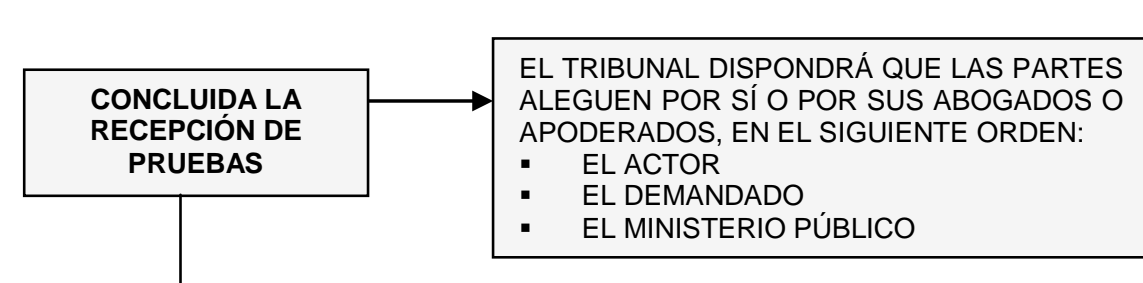

ART. 393 CPCDF

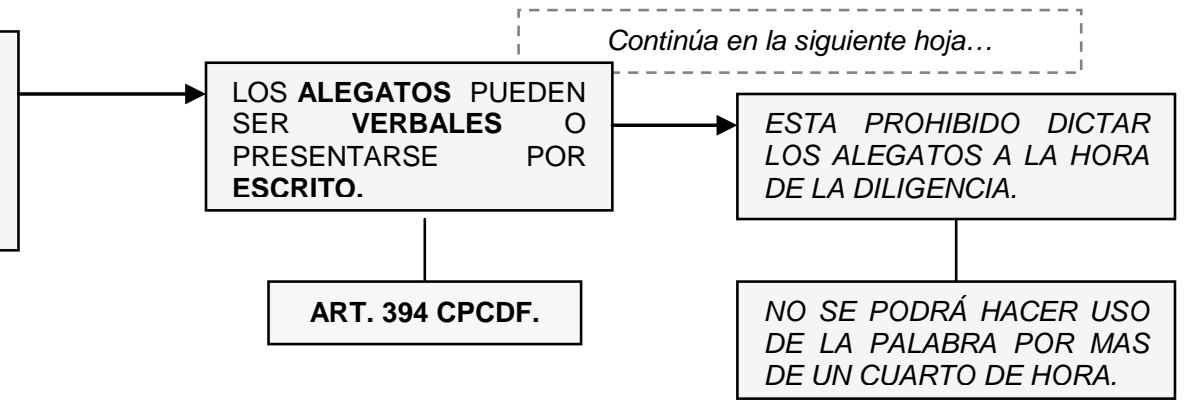

SE DESECHARAN DE PLANO LAS RECUSACIONES Y LOS INCIDENTES QUE PUEDIERAN INTERRUMPIRLA

NO PUEDE SUSPENDERSE O INTERRUMPIRSE LA AUDIENCIA HASTA QUE NO HAYA

UARTO DE HORA.

TERMINADO.

LOS JUECES QUE RESUELVEN DEBEN SER LOS MISMOS QUE CONCURRIERON A LA RECEPCIÓN DE LAS PRUEBAS Y ALEGATOS DE LAS PARTES.

SE DEBE MANTENER IGUALDAD ENTRE LAS PARTES. (NO DEBE HABER CONCESION ALGUNA, SOLO QUE SI SE HACE A UNA DE ELLAS, SE DEBE HACER LO MISMO PARA LA OTRA). 
DECLARAR LA PATERNIDAD Y

DETERMINA LA FILIACION.

(RECONOCIMIENTO FORZOSO)

O DECLARACIÓN JUDICIAL DE NO EXISTIR FILIACION.

SE NOTIFICARA A LAS PARTES

\section{SE INTERPONE}

APELACIÓN

* LEGITIMACION DE LA ACCIÓN DE FILIACION.

HIJO

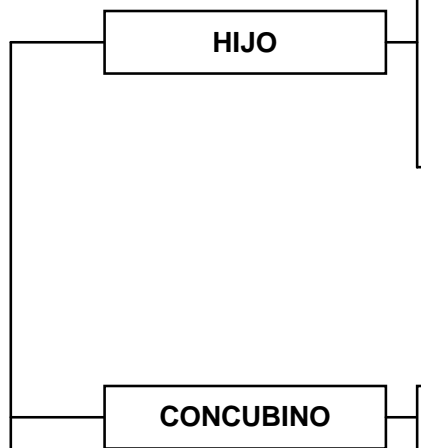

CUANDO ALEGA OUE EL HIJO NACIO DESPUES DE LOS TRESCIENTOS DÍAS SIGUIENTES EN

QUE CESO LA VÍDA EN COMUN SENTENCIA EJECUTORIADA.

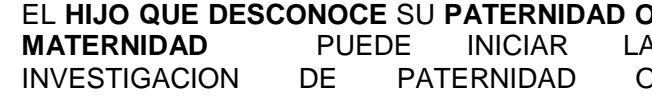
MATERNIDAD.

EN CASO DE IMPUGNAR LA PATERNIDAD, SI ES RECONOCIDO PUEDE RECLAMAR CONTRA EL RECONOCIMIENTO, CUANDO LLEGUE A LA MAYORÍA DE EDAD.

ART. 376 CCDF

SE PROCEDERA A DAR CUMPLIMIENTO A LAS PUNTOS RESOLUTIVOS DE LA SENTENCIA.

SE SOLICITARA A PETICION DE PARTE, QUE UNA VEZ NOTIFICADA LA SENTENCIA Y DE NO HABERSE PRESENTADO RECURSO ALGUNO, DENTRO DEL TERMINO LEGAL PARA HACERLO. SE DECLARE LA

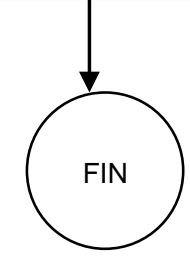

SALVO LO DISPUESTO POR EL ART. 385 CCDF.

\begin{tabular}{|c|c|c|}
\hline \multicolumn{3}{|c|}{ ART. 377 CCDF } \\
\hline \multicolumn{3}{|c|}{$\begin{array}{l}\text { EL TERMINO PARA ESTA ACCIÓN SERÁ DE DOS } \\
\text { ANNOS, QUE COMENZARA DESPUES DE QUE EL } \\
\text { HIJO SEA MAYOR DE EDAD. }\end{array}$} \\
\hline $\begin{array}{l}\text { SI ANTES } \\
\text { RECONOC } \\
\text { FECHA EN }\end{array}$ & $\begin{array}{l}\text { DE SERLO TUV } \\
\text { MIENTO; Y SI NO LA } \\
\text { QUE LA ADQUIRIO. }\end{array}$ & $\begin{array}{l}\text { O NOTICIA DEL } \\
\text { TENIA, DESDE LA }\end{array}$ \\
\hline $\begin{array}{l}\text { PUEDE } \\
\text { NULIDAD }\end{array}$ & $\begin{array}{l}\text { ESCONOCERLO, } \\
\text { EL ACTA DE NACIMI }\end{array}$ & $\begin{array}{l}\text { Y PEDIR LA } \\
\text { ENTO. }\end{array}$ \\
\hline
\end{tabular}




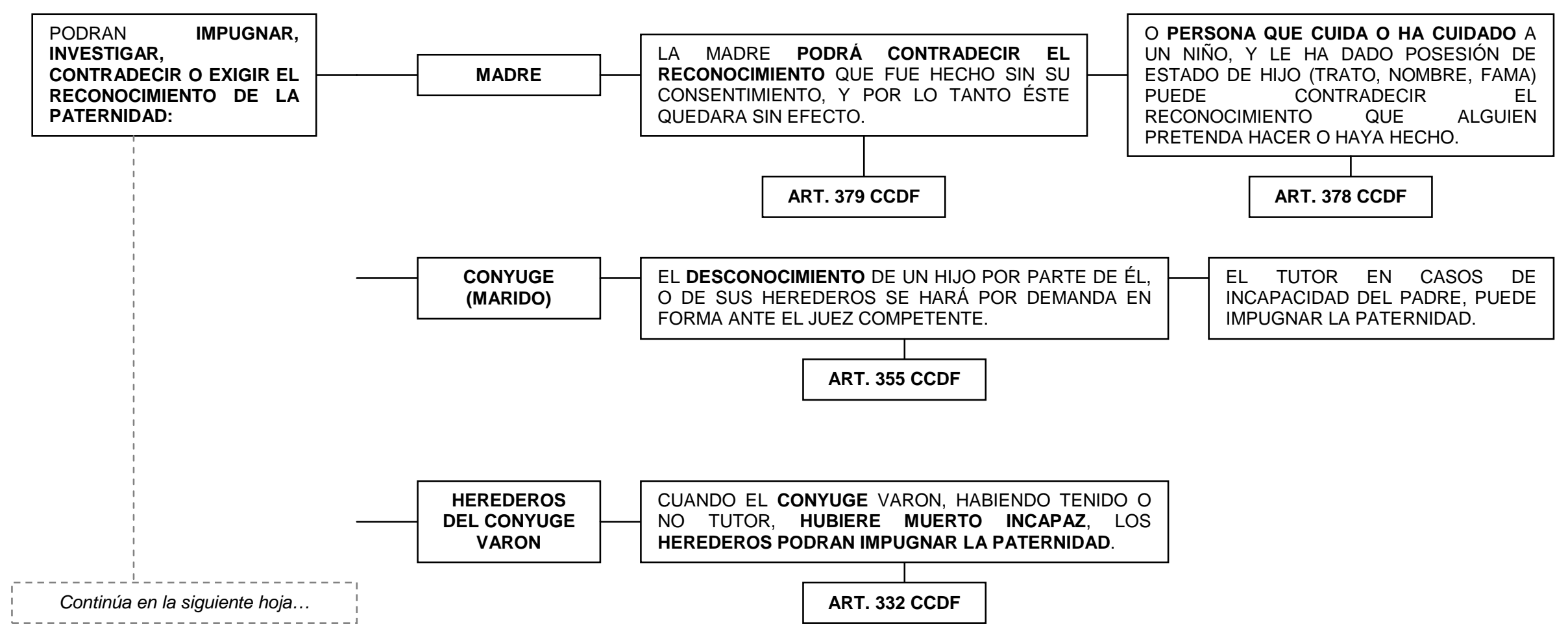




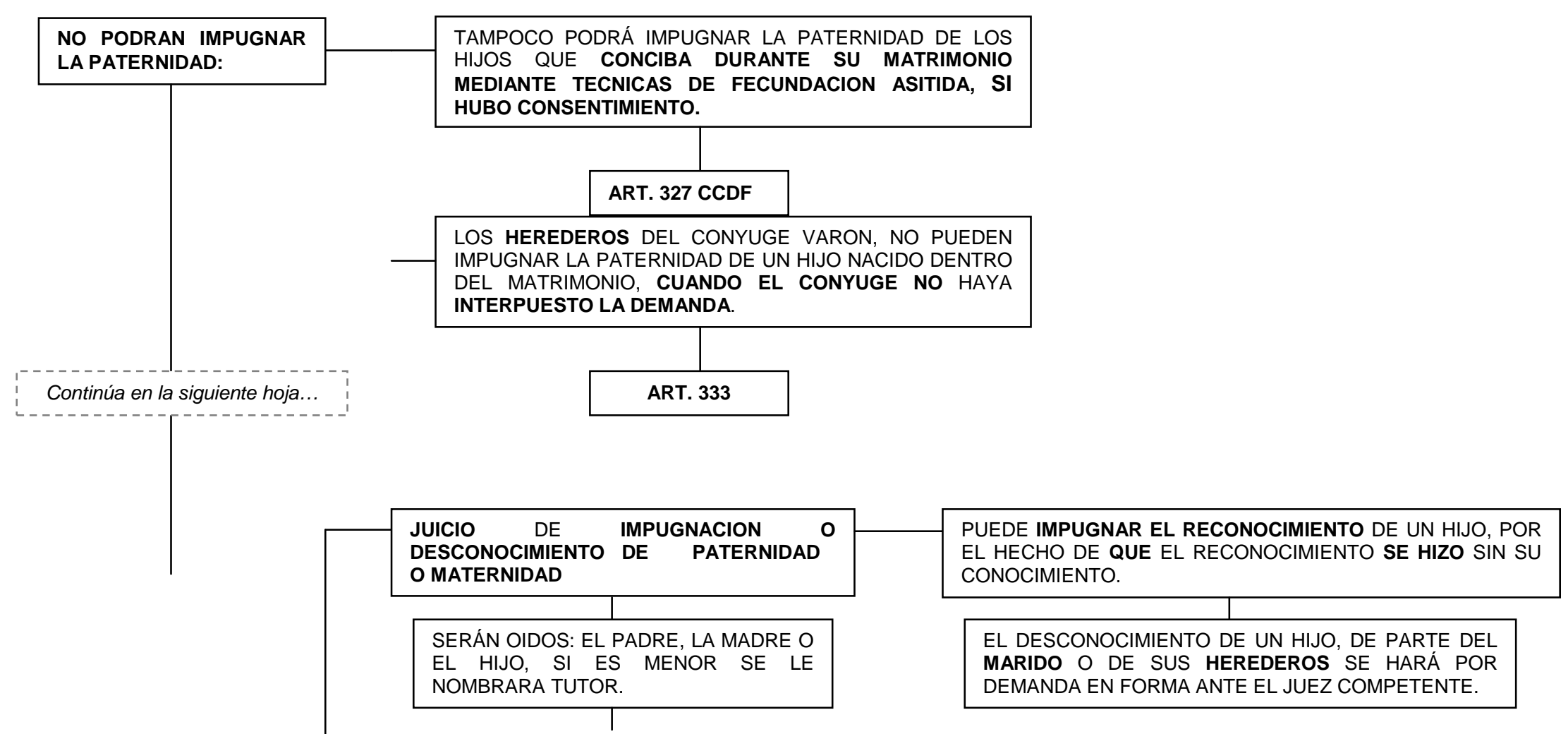




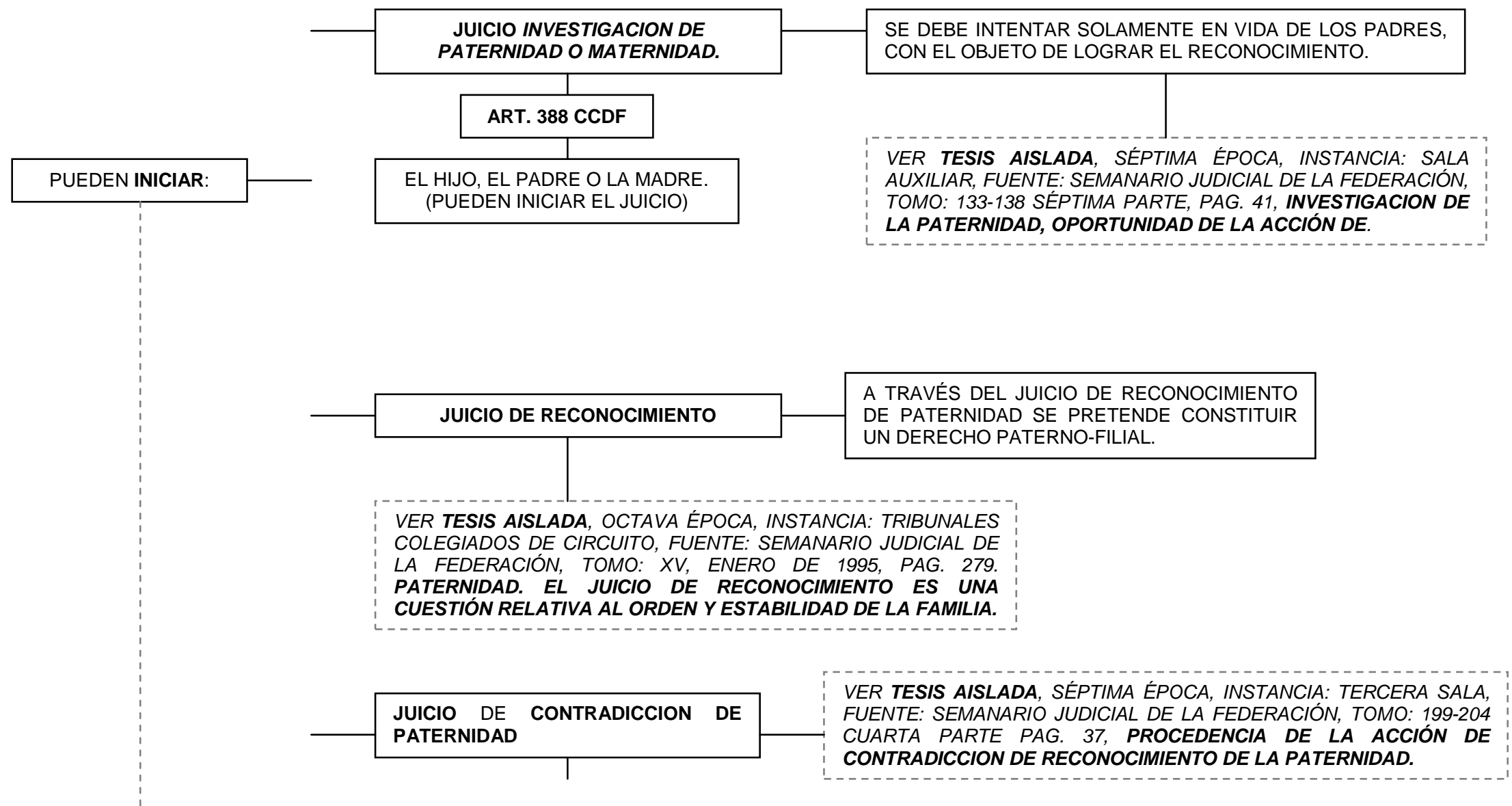




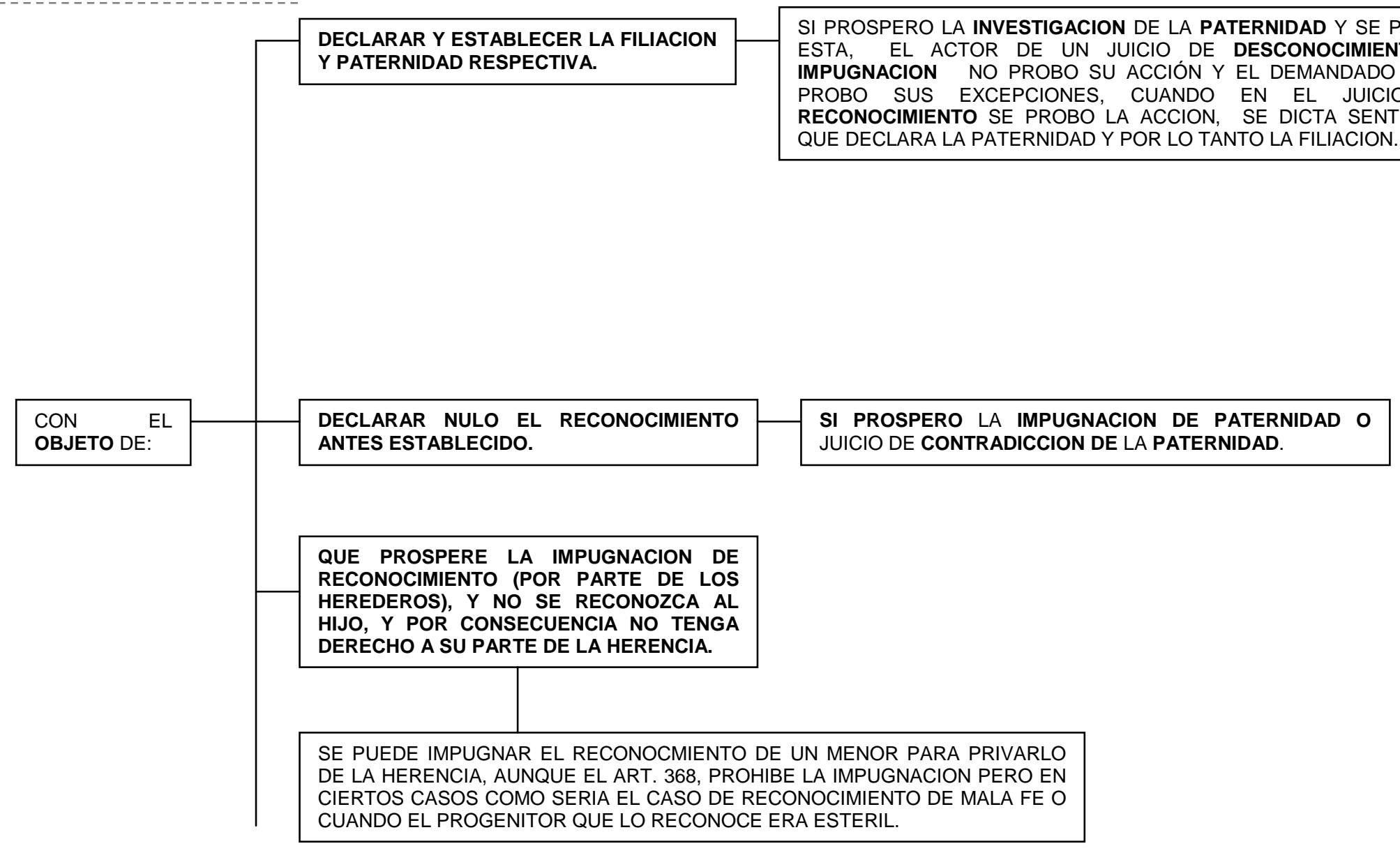




\section{* MOMENTO PARA EJERCITAR LA ACCIÓN.}

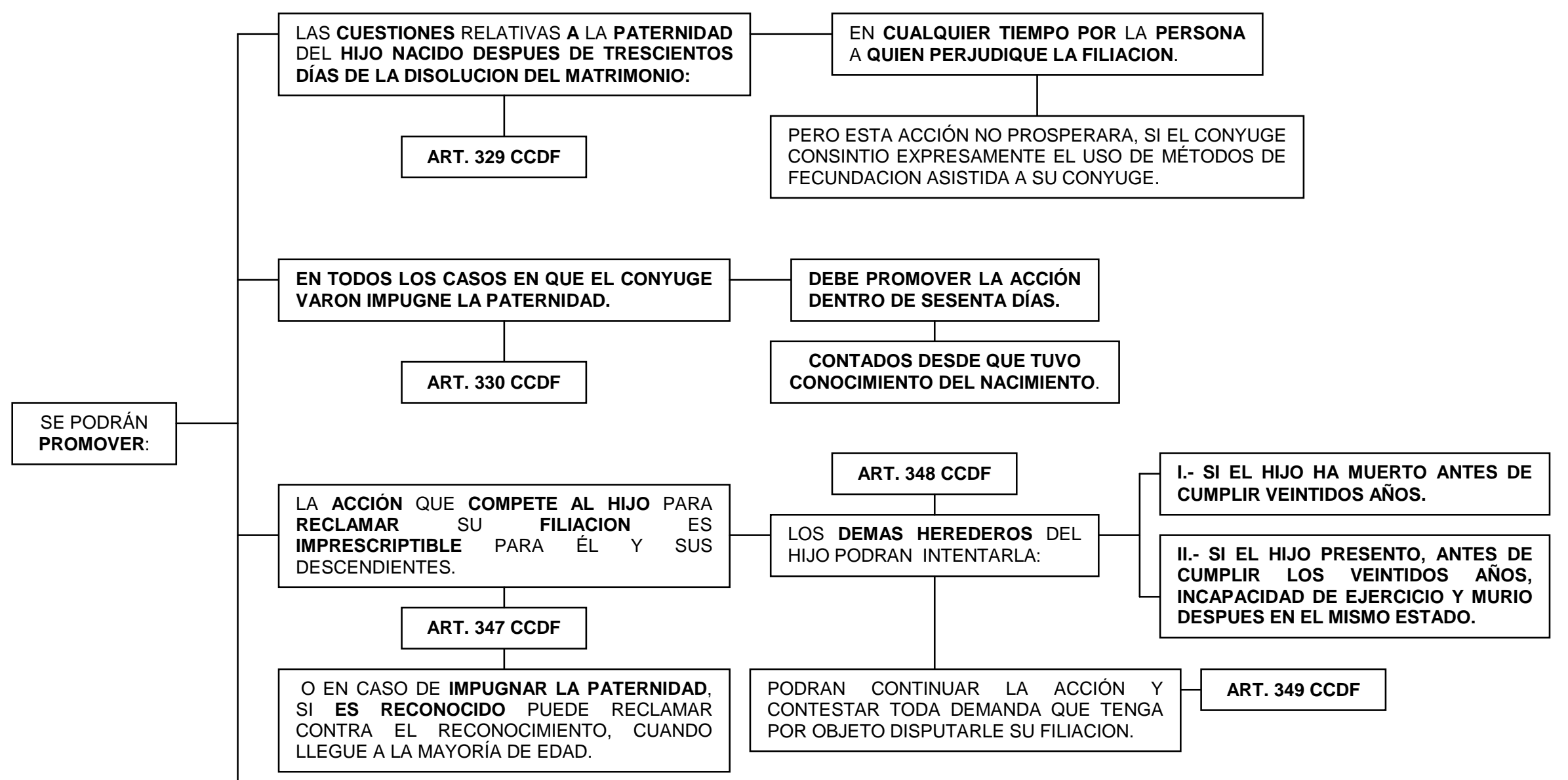


EL TERMINO PARA ESTA ACCIÓN SERÁ DE DOS AÑOS, QUE COMENZARA DESPUES DE QUE EL HIJO SEA MAYOR DE EDAD.

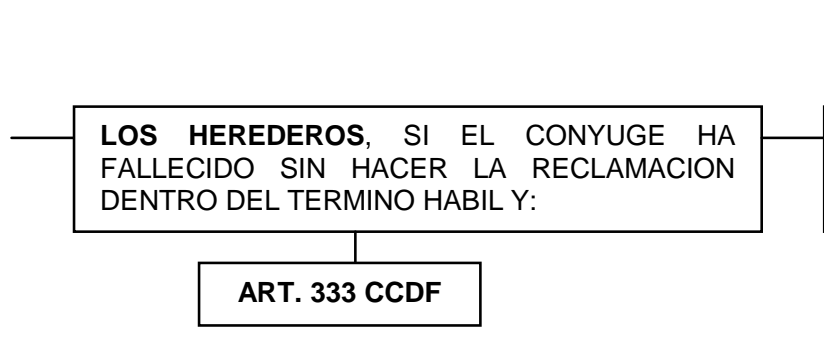
SU ACCIÓN PRESCRIBIRÁ A LOS CUATRO AÑOS, CONTADOS DESDE EL FALLECIMIENTO DEL HIJO.

ART. 351 CCDF

QUE EL HIJO HAYA SIDO PUESTO EN POSESIÓN DE LOS BIENES DEL PADRE

PODRAN INTERPONER LA DEMANDA DENTRO DE SESENTA DÍAS A PARTIR:

O DESDE QUE LOS HEREDEROS SE VEAN PERTURBADOS POR EL HIJO EN LA POSESIÓN DE LA HERENCIA.

\section{FILIACION}

— PRESUNCIÓN DE FILIACION.

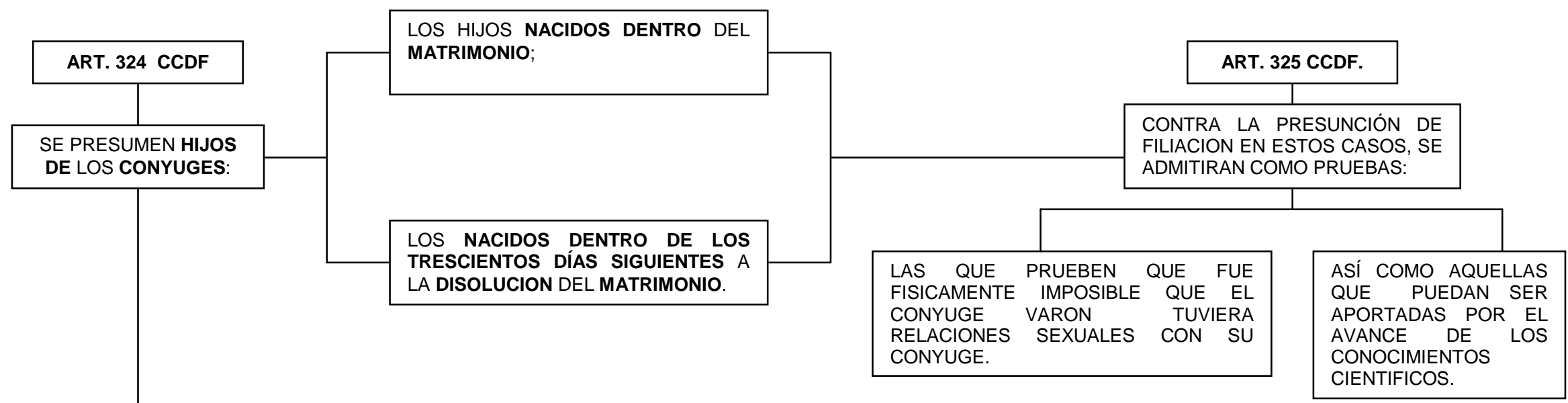




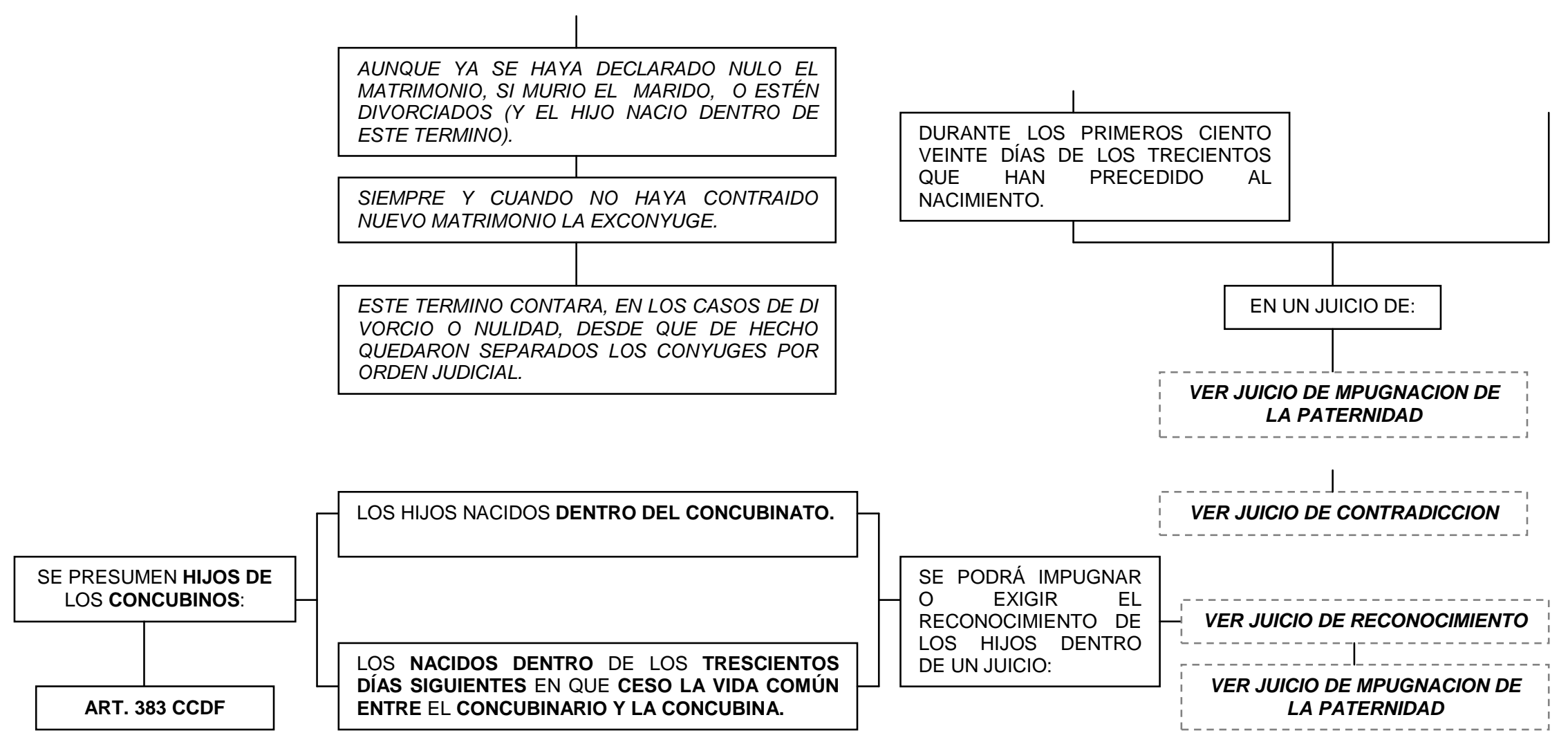




\section{RECONOCIMIENTO DE LA FILIACIÒN}

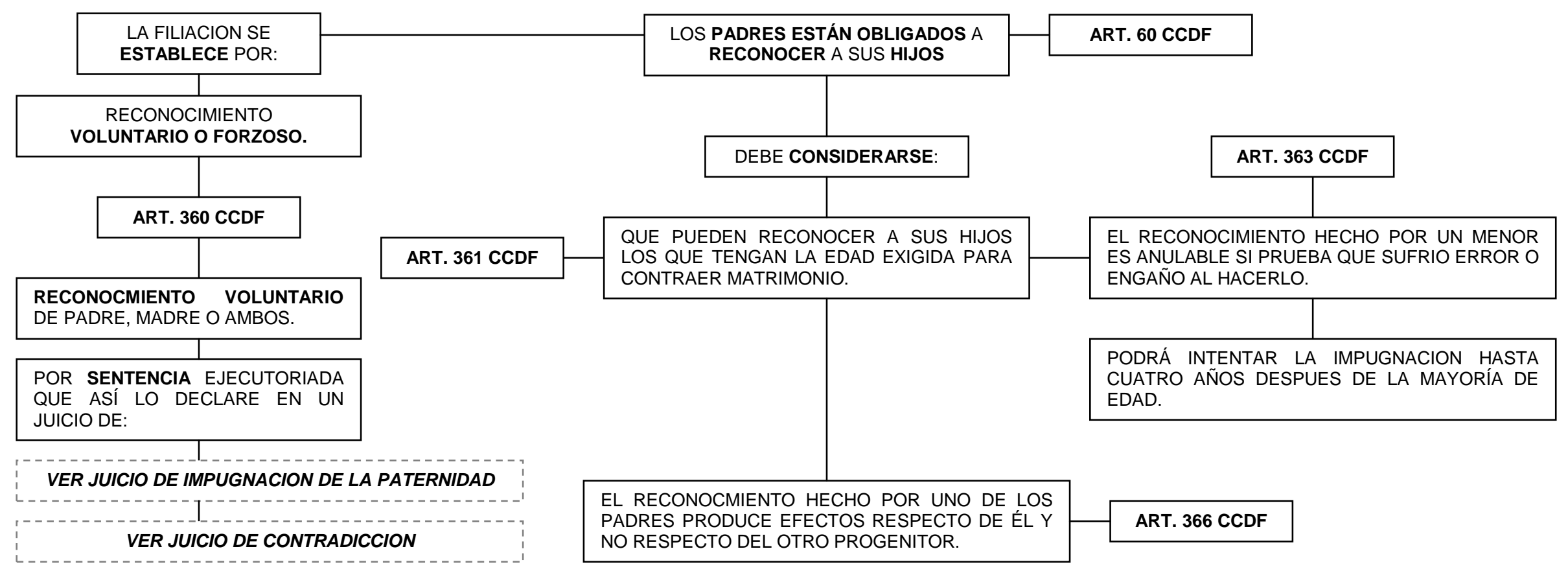




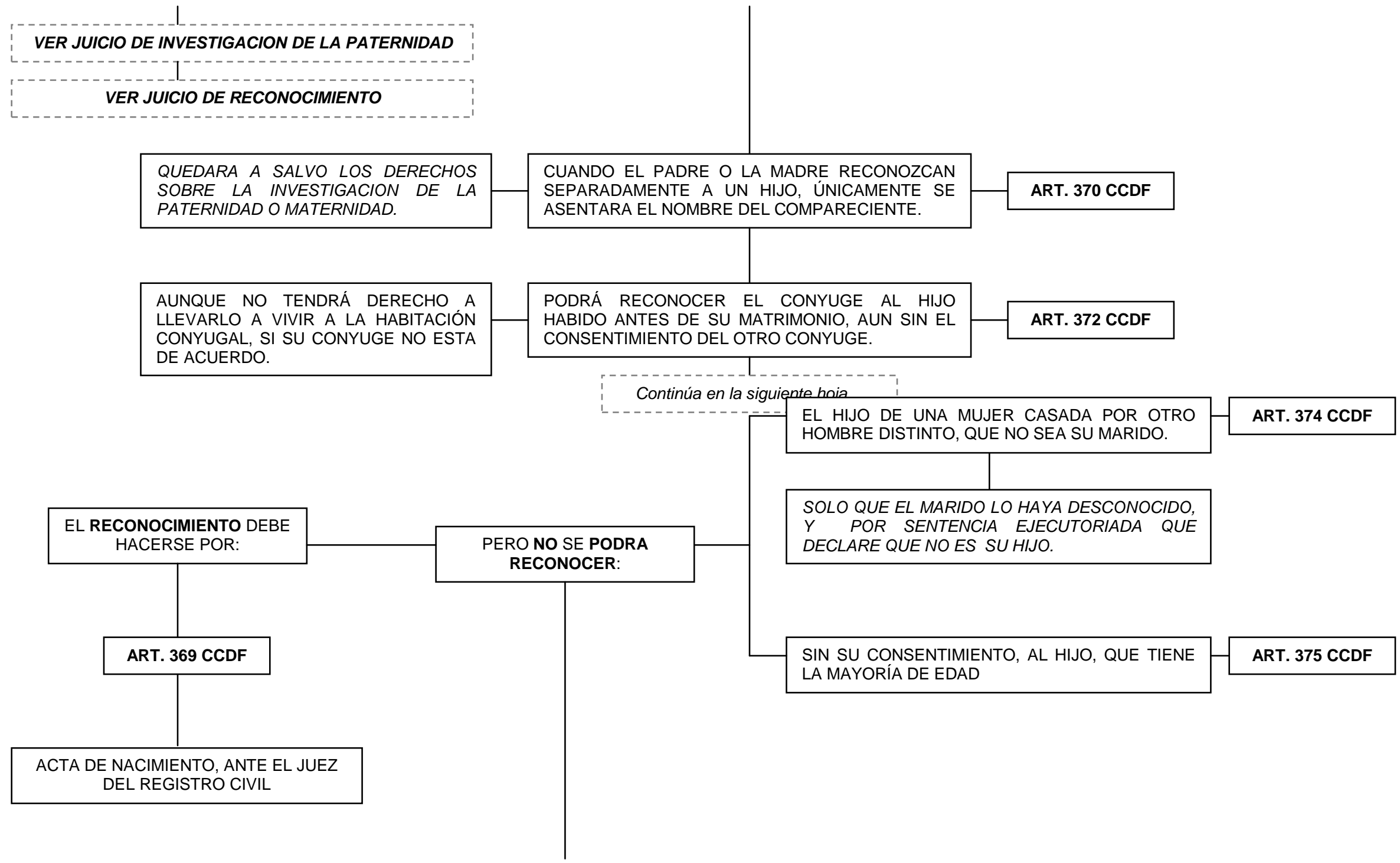



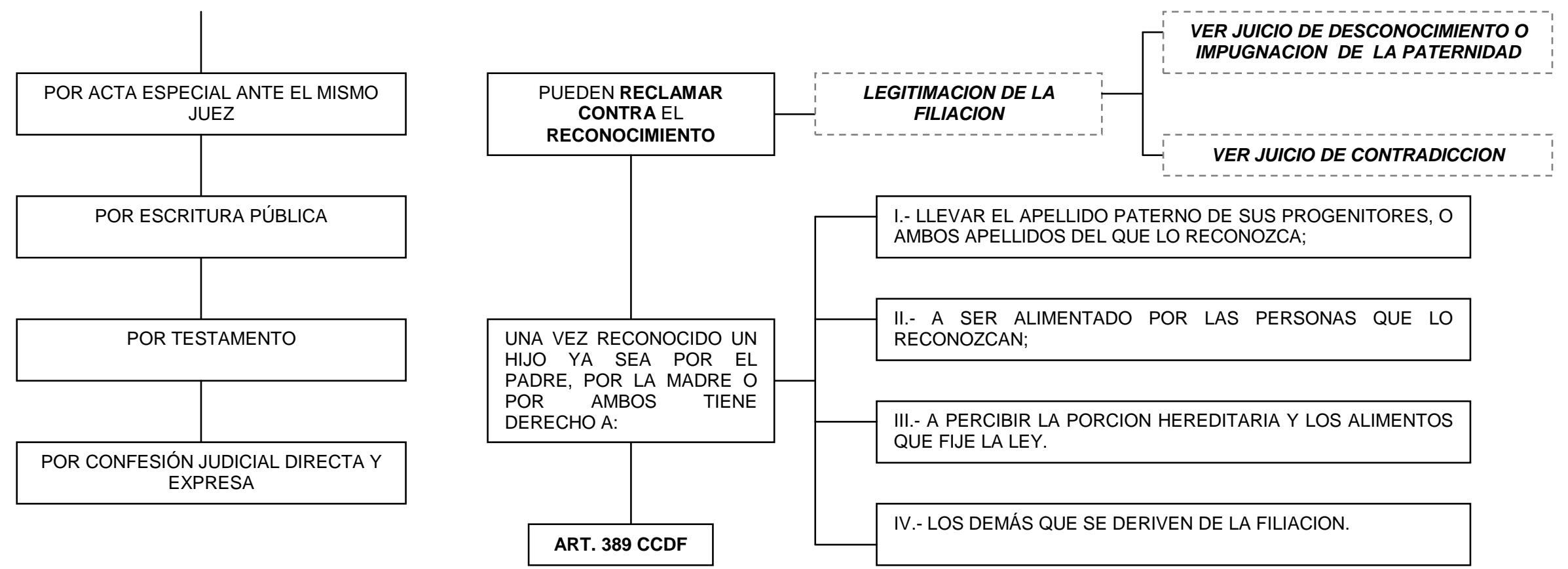